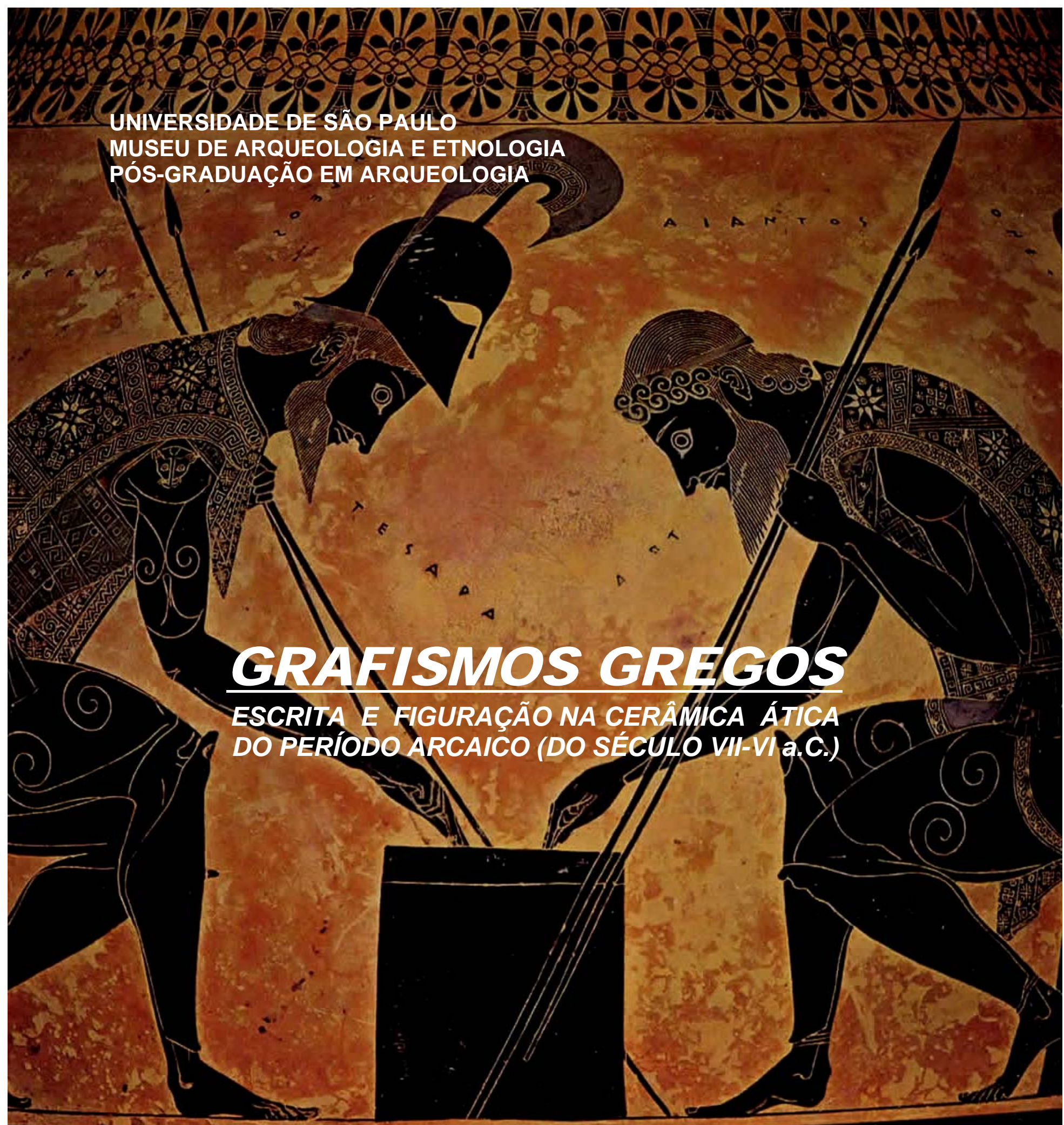

DISSERTAÇÃO DE MESTRADO

AUTOR: GILBERTO DA SILVA FRANCISCO

ORIENTADORA: Prof ${ }^{a}$ Dr $^{a}$ HAIGANUCH SARIAN

SÃO PAULO

2007

FRANCISCO, G. da S. 
UNIVERSIDADE DE SÃO PAULO

Museu de Arqueologia e Etnologia

PROGRAMA DE PÓS-GRADUAÇÃO EM ARQUEOLOGIA

\section{GRAFISMOS GREGOS}

ESCRITA E FIGURAÇÃO NA CERÂMICA ÁTICA DO PERÍODO ARCAICO (DO SÉCULO VII-VI a.C.)

Gilberto da Silva Francisco

Dissertação apresentada ao Programa de PósGraduação em Arqueologia, do Museu de Arqueologia e Etnologia da Universidade de São Paulo, para a obtenção do título de Mestre em Arqueologia.

Orientadora: Prof ${ }^{a}$. Dra. Haiganuch Sarian 
A Elzira, Manoel e Norma, e Bruno Meu ontem, meu hoje e meu amanhã... Meu sempre. 


\section{AGRADECIMENTOS}

Agradeço, inicialmente, ao CNPq (Conselho Nacional de Desenvolvimento Científico e Tecnológico), pelo apoio referente ao custeio de bolsa de estudo durante dois anos. Aos funcionários do MAE-USP (Museu de Arqueologia e Etnologia da Universidade de São Paulo), pela disposição e viabilização de atividades acadêmicas essenciais das quais tomei parte ao longo desta pesquisa; bem como aos professores da instituição (e outras unidades da Universidade de São Paulo) com quem tive algum contato que se converte, sempre, em contribuição preciosa. Agradeço, ainda, à Escola Francesa de Atenas (École Française d'Athènes), pela disponibilização de sua estrutura favorecendo, em grande medida, pesquisas arqueológicas das quais participei nos anos de 2004 e 2006.

Aos amigos de longa data: Mojana, Lília, Daniella, Karina, Caio, Billi, Leandro, Alessandro; aos colegas do Museu e de Universidade: Camila Zanon, Leilane, Tatiana, Pedro, Carol, José Geraldo, Maria Fernanda, Paula, Camila Diogo (obrigado pelas sugestões quanto ao abstract), Regina, Carlos, Fábio, e a outros que me desculparão o esquecimento; pelas inúmeras conversas, desabafos, e momentos em que dividimos conhecimento e amizade.

Aos professores François Lissarrague, Alan H. Shapiro, Jan Bažant e Georges Rougemont, pela apreciação do projeto de pesquisa (formulação bastante inicial da pesquisa); bem como aos membros da banca de qualificação desta dissertação, o Professor Dr. Álvaro Hashizume Allegrette e o Professor Dr. Pedro P. A. Funari, pelo interesse, leitura crítica e direcionamento dos rumos desta pesquisa.

Imensamente, agradeço à professora Haiganuch Sarian, orientadora desta dissertação de mestrado, modelo de pesquisadora e intelectual, pelo interesse e constante ajuda nos anos em que me guiou nas veredas dos Estudos Clássicos.

Por fim, aos principais responsáveis pelo êxito até agora alcançado neste trabalho, na vida acadêmica... em toda a minha vida: a minha família. Minha avó Elzira, meus pais Norma e Manoel, meus irmãos Gilson e Gisele, minha tia Vera, e ao queridíssimo sobrinho Bruno (colaborador deste trabalho - quem alcançar o capítulo 3, e observar a figura 2, saberá do que digo). Agradeço pelo apoio incondicional, pela contribuição efetiva na minha formação como ser humano, por tudo isso e outras coisas que eu não conseguiria enumerar ou descrever... Obrigado! Este trabalho é tanto meu quanto de vocês. 


\section{RESUMO}

Esta dissertação trata da interação entre linguagem escrita e figurativa, aproveitando um debate geral, mas concentra-se na experiência grega sobre o tema. Assim, partindo da compreensão antiga dessa aproximação, serão perseguidos os aspectos gráficos (que integravam conceitualmente escrita e desenho - como indica o verbo graphêin), presentes na cerâmica ática ornamentada do período arcaico. Questões sobre a articulação de fontes escritas e materiais na pesquisa arqueológica também serão tratadas.

Estruturalmente, este texto se divide em questões teórico-metodológicas relativas à natureza da documentação e seu tratamento no campo da Arqueologia Histórica e Epigrafia; e as justificativas das delimitações espaço-temporais. Depois, uma discussão sobre o gráfico, de forma geral, caminhando para o caso grego. Por fim, a apresentação de questões gráficas e relacionadas, próprias da documentação selecionada; bem como um estudo de caso: as ânforas panatenaicas

Palavras-chave: Grafismo, Escrita, Imagem figurativa, Arqueologia Clássica, Epigrafia Grega.

\section{ABSTRACT}

This work deals with the interaction between written and figurative languages in the general debate, but concentrates in the Greek experience about this subject. Therefore, we will begin with the ancient understanding of this approach; the graphical aspects present at Attic decorated ceramics of the archaic period will be pursued (due to the fact that these graphical aspects conceptually included writing and drawing, as it is indicated by the verb graphêin). Questions about the relationship between written and material sources in the archaeological research will be also considered.

Structurally, this text is divided in theoretical-methodological questions about the nature of the documentation discussed in the field of Historical Archaeology and Greek Epigraphy and the justifications of time and space limits. After that, it is also included a general debate over the graphic, restricting to the Greek example. Finally, there will be a presentation of graphical questions and the ones related to the chosen documentation, as well as a case study: the panathenaic amphorae.

Key words: Graphism, Writing, Figurative Image, Classical Archaeology, Greek Epigraphy. 


\section{ÍNDICE}

Nota sobre a citação das sentenças gregas..........................................p. 8

Introdução

p. 9

\section{Capítulo 1. Aspectos teórico-metodológicos}

1.1. Fontes escritas e materiais: as múltiplas relações. p. 32

1.2. Relação temática, material e conceitual............................................................p. 36

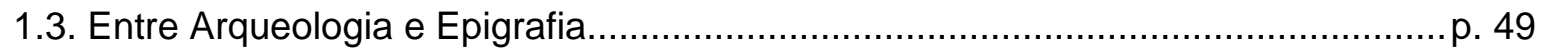

1.3.1. A fonte epigráfica como arqueológica....................................................... 50

1.3.2. Contexto e trajetória................................................................................. 53

\section{Capítulo 2. Balizas espaço-temporais}

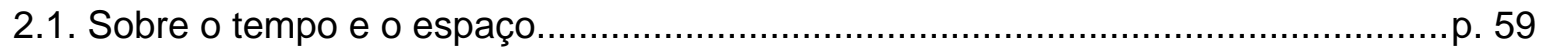

2.1.1. A cronologia: recorte e justificativas................................................................ 59

2.1.2. A espacialização: recorte e justificativas........................................................... 72

\section{Capítulo 3. Os grafismos, da origem às especificidades gregas}

3.1. O gráfico, o escrito e o figurativo: uma apreensão geral..................................... p. 79

3.2. Os grafismos gregos até o período arcaico.................................................. p. 92

3.3. Período arcaico. Memória, grafismos e oralidade............................................. p. 99

3.4. Espaço, inscrições e composição figurativa.................................................... p. 110

\section{Capítulo 4. Sobre a documentação}

4.1. Fonte material, fonte textual e a noção de documento........................................p. 142

4.2. Limites e possibilidades da documentação....................................................... p. 150

4.3. Algumas características dos grafismos............................................................. p. 163

4.3.1. Os cenários: produção, difusão, consumo e deposição/rejeição.......................p. 164

4.3.2. Tipos de imagens, de inscrições e de articulações gráficas............................... p. 173

4.3.3. Suporte e ornamentação: questões de limites e comunicação..........................p. 181

\section{Capítulo 5. Um estudo de caso: as ânforas panatenaicas}

5.1. Caracterizando a ânfora panatenaica. 
5.2. Uma observação interna: a relação escrito-figurativa..........................................p. 207

5.3. Uma observação contextual: historicidade e contexto arqueológico......................p. 212

5.4. Os múltiplos contextos e os múltiplos significados........................................... p. 218

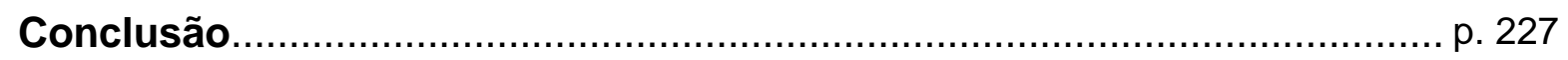

\section{Bibliografia/citações}

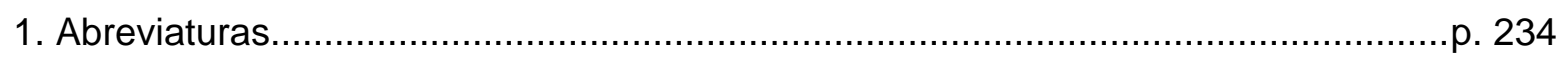

2. Texto original das citações traduzidas............................................................p. 235

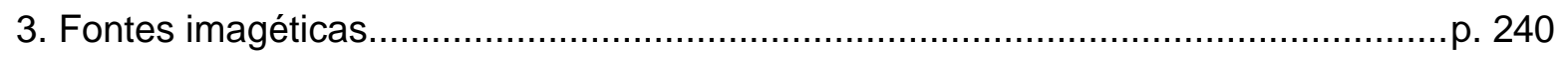

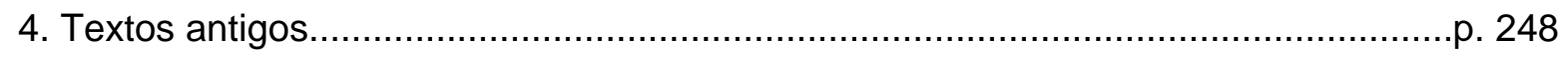

5. Obras de referência e dicionários............................................................. p. 249

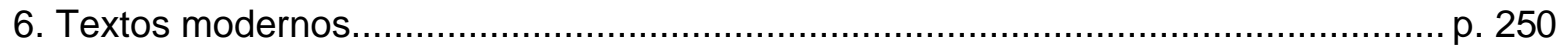

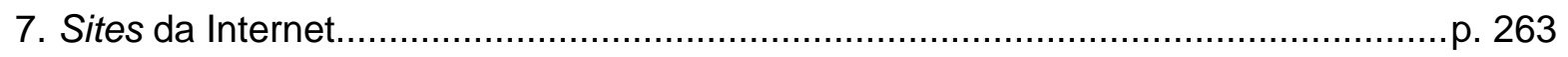




\section{Nota sobre a citação das sentenças gregas}

As citações em grego serão apresentadas seguindo as especificidades das fontes aqui utilizadas; dessa forma:

- para as fontes literárias e palavras gregas que não sejam provenientes de inscrições, seguir-se-ão as regras de citação das obras consultadas com original em grego, ressaltando-se que haverá certa normatização quanto às notações gráficas;

- para as fontes epigráficas (as inscrições sobre os vasos, sobretudo), a transcrição será sempre em letras gregas maiúsculas; sem acentuação, e respeitando a separação ou falta dela, na inscrição original. Ainda, as reconstituições no caso de inscrições fragmentárias, serão feitas seguindo as regras de escrita do grego acadêmico (conforme ponto acima).

No caso de aproveitamento de traduções para o português, sua referência bibliográfica será imediatamente citada. Ainda, quanto aos nomes de vaso e à toponímia, a dificuldade de normatização em língua portuguesa expressará certa variedade no seu tratamento.

\section{Sinais epigráficos:}

$\Gamma$ O ponto abaixo da letra indica que ela é incerta na reconstituição da inscrição, ou fragmentária.

$$
\leftarrow
$$

Orientação da escrita: da direita para esquerda; da esquerda para a direita.

()

Letra omitida em erro.

\{\}

Letra incluída em erro.
[ ]

Letra ou segmento restaurado.

$[---]$

Número de letras perdidas desconhecida.

$?$

Segue reconstituição duvidosa de sentença.

। Indicação de separação física em inscrições, geralmente, os três pontos verticais que marcavam a separação de palavras em algumas inscrições. 
INTRODUCÃ̃O 
O resultado do jogo é quatro $(\mathrm{TE} \Sigma \mathrm{APA} \rightarrow)$ a três $(\mathrm{TP}[1] \mathrm{A} \leftarrow)$; é o que dizem Aquiles $(\mathrm{AXI} \Lambda \mathrm{EO} \Sigma \leftarrow$ ), o mais favorecido, e Ájax (AIANTO $\Sigma \rightarrow$ ); seguindo uma interpretação mais imediata da cena da face de uma ânfora de Exéquias; ${ }^{1}$ autoria indicada pela inscrição $\mathrm{EX} \Sigma \mathrm{EKIA} \Sigma \mathrm{E} \Pi \mathrm{OIE} \Sigma \mathrm{EN} \rightarrow$ (Exéquias fez; horizontal, logo atrás da cabeça e as lanças de Aquiles). A caracterização das personagens, da cena, e da autoria; tudo isso, é rapidamente compreendido dadas as informações escritas. Assim, as figuras dizem certas coisas, elas são personagens bem definidas, e foram produzidas por um artesão determinado.

Essa ânfora de Exéquias, uma "epígrafe" extremamente adequada (a imagem, em detalhe, na capa), apresenta uma variedade de possibilidades bastante seguras de interpretação. Mas, mais que isso, é importante saber que são essas as perguntas feitas há muito tempo às inscrições que convivem com as imagens desse vaso, e também para inúmeros outros. Quem são as personagens? O que elas dizem? E, quem as fez? Mas, pode-se perguntar ainda: o que significa, materialmente falando, "falar" (conferir voz a determinada figura), nomeá-la (determinar quem ela é ou não é), e quais as implicações materiais das inscrições de autoria? Questões que geralmente não são feitas, mas que têm tanta pertinência quanto as primeiras. As questões antigas são importantes, mas podem, em certa medida, ser aferidas por essas últimas. Assim, é entre a tradicional observação dessas imagens e inscrições e "novas" questões que esta dissertação se desenvolverá. "Novas" questões que já foram por vezes esboçadas, mas que podem ser mais bem desenvolvidas.

O estudo das interações num mesmo suporte entre o campo da linguagem escrita e figurativa entre os gregos na Antigüidade está longe de ser definido consistentemente por reflexões teóricas; mas vem sendo paulatinamente alvo da abordagem de especialistas interessados nas possibilidades num campo de estudos que consolidou um tipo de olhar sobre as complexas e dinâmicas aproximações entre informações literárias e visuais para a constituição de um discurso sobre o passado grego.

Essa falta de um "chão" bem assentado, impele, então, à organização de alguns instrumentos que auxiliem a análise dessas questões no campo dos Estudos Clássicos. Um

\footnotetext{
${ }^{1}$ c. 530 a.C., Vaticano, Museu do Vaticano.
} 
caminho viável, então, é remeter a outras experiências similares, buscando os pontos de junções no que se refere à experiência grega.

(...) Com efeito, se a arte figurativa e a escrita foram já objeto de inúmeros estudos, as relações de interligação dos dois domínios são geralmente mal definidas e parece que seria proveitosa a sua pesquisa numa perspectiva geral. (Leroi-Gourhan, 1990a, p. 187)

Do geral ao específico, da constatação de Leroi-Gourhan à formulação discursiva antiga sobre o tema, então, é que este estudo se desenvolverá. É claro, a demanda que coloca Leroi-Gourhan estará longe de ser bem definida aqui, visto que ela é, em certa medida, auxiliar; mas a dimensão do todo, do mais amplo, de perspectivas universais serão buscadas para estruturar bem o quadro das questões bastante específicas; o que não é, diga-se de passagem, uma proposta absolutamente nova. ${ }^{2}$

O ponto inicial, seguindo em certa medida aspectos discursivos antigos, é a constatação da intimidade entre o escrever e o desenhar. ${ }^{3} \mathrm{O}$ verbo $\gamma \rho \alpha \varphi \tilde{\varepsilon} \imath$, amplamente presente nas inscrições de assinaturas da cerâmica ornamentada grega, indica, já na Antigüidade, um sentido polissêmico de seu uso: referia-se tanto ao universo da escrita, como o da produção de imagens desenhadas. ${ }^{4}$ Se Homero em uma das únicas referências à escrita utilizou-se do termo $\gamma \rho \alpha ́$ q $\alpha \varsigma$ (Ilíada, canto VI, 168), já no século VI a.C. começa a aparecer nas assinaturas sobre a cerâmica a palavra $\gamma \rho \alpha \varphi \tilde{\varepsilon} v v$, referindo-se à autoria de ornamentação de vasos; ${ }^{5}$ e nos séculos VII, VI e V a.C., além da permanência nas assinaturas, o sentido polissêmico é registrado em inúmeras obras literárias (ver nota 4). Nesse sentido, o ponto de partida é a acepção antiga do termo, baseada num registro mais abrangente. Entretanto

\footnotetext{
${ }^{2}$ Um dos mais tradicionais estudos sobre os artesãos ceramistas produzido por J. D. Beazley, Potter and painter in ancient Athens (1944), já apresentava algo parecido; ou seja, um esforço com as questões específicas, mas também a abertura para "duas outras fontes, a serem usadas com cuidado: nosso conhecimento da natureza humana; e analogias criadas a partir do que é conhecido sobre outros artesãos em outras épocas." (Beazley, 1949 , p. 5)

3 "Escrita e desenho, no código visual grego, são (...) estreitamente ligados (...). A língua grega possui um termo que designa as duas atividades escrever e desenhar numa mesma palavra: graphêin." (Lissarrague, 1992, p. 191)

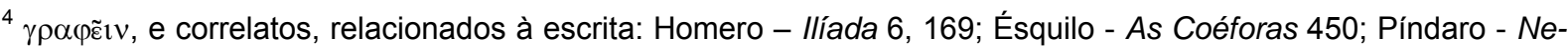
méias 6, 5; Sófocles - Trácios 683; Fragmento 694; Édipo Rei 411; Filoctete 1325; Tucídides - 1, 128; Xenofonte - Helênicas 1, 7, 34; 3, 3, 10; 4, 1, 39; Ciropedia 4, 3, 21; 8, 2, 9; Cinegética 13, 2; Memoráveis de Sócrates 1, 2, 42; 4, 4, 13; Platão - A República 377d; Fédon 274b; 276c; Eutídeme 2e; 279e; As Leis 754fim; 788b; 850b; 923c; 929d; 929e; 934c; 956c; Eutífrom 2b; 3b; Protágoras 326d; Teétete 142e; Cratile 428b; Heródoto - 1, 125;

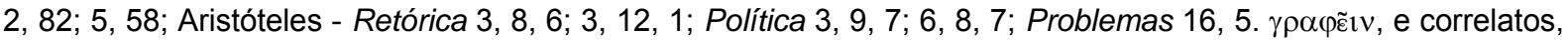
relacionados à imagem visual: Homero - Ilíada 17, 599; Ésquilo - Agamêmnon 241; 1329; As Eumênides 50; Sófocles - Édipo Rei 411; Xenofonte - Memoráveis de Sócrates 3, 10, 1; Platão - Timeu 19b; A Política 277c; O Banquete 193a; Gorgias 450c; 453c; Teétete 144e; 210d; Philebe 39b; Heródoto - 2, 73; 3, 24; 4, 36; 4, 88; 4, 91; Aristóteles - Poética 6; Retórica 1, 11, 3 (ver Bailly, verbetes: $\gamma \rho \alpha \varphi \varepsilon \tilde{o} o v, \gamma \rho \alpha \varphi \varepsilon u ́ c, \gamma \rho \alpha \varphi \eta ́, ~ \gamma \rho \alpha \varphi i ́ \delta ı v ~ e ~ \gamma \rho \alpha \varphi ı \tilde{\omega} \varsigma)$.

${ }^{5}$ Segundo o estágio atual do conhecimento, na cerâmica ática, Sófilo é o primeiro a assinar como grafista. Antes disso, na região, apenas um grafite de Himeto ([- - ]HОГПЕР ЕГРАП ЕN $\leftarrow)$, sobre fragmento de vaso de cerâmica do início do século VII a.C. (Immerwahr, 1990, p. 12).
} 
esse é apenas o início do caminho, e ele deve considerar as leituras posteriores; ou seja, como a ampla bibliografia que tratou da cerâmica grega, especialmente a ática, observou, direta ou indiretamente, tal situação. Um discurso mais articulado sobre as características gráficas da ornamentação da cerâmica ática é recente, sobretudo o que baseia a discussão na acepção antiga acima indicada; mas alguns indícios da observação desse universo gráfico já podem ser observados muito antes disso.

Como ponto de partida para a compreensão gráfica da ornamentação da cerâmica, François Lissarrague (1992, p. 189) indica o pioneiro estudo de Michel Butor (1969). ${ }^{6}$ Além de referenciar Butor, Lissarrague (Idem) utiliza-se como epígrafe uma citação de Paul Klee "Escrever e desenhar são idênticos na sua essência", indicando essa observação no cenário das artes plásticas contemporâneo, como uma viável base para a compreensão do problema na Antigüidade Clássica. François Lissarrague é o autor que trata mais sistematicamente a questão da articulação gráfica entre os gregos (Lissarrague, 1988; 1990a; 1998; destacando-se o artigo Graphêin: écrire et dessiner, 1992); mas vale a pena citar alguns outros esforços de análise nesse sentido: há um número da revista Métis (volume XIII, 1998) que trata especialmente das aproximações entre inscrições e figurações na cerâmica grega; mas a apreensão bibliográfica de tal temática é marcada por uma dispersão grande, ou seja, artigos publicados em inúmeros periódicos, dos quais se pode destacar um artigo de Holtzmann (Le graphisme dans l'art grec, 1993), que discute a arte grega a partir da acepção gráfica; e um capítulo de Snodgrass em Homero e os artistas. Texto e pintura na arte grega antiga $(2004)^{7}$ intitulado "A imagem com inscrição" (p. 151-84). ${ }^{8}$

Mas algumas considerações acerca desse pioneirismo devem ser feitas. Em Les mots dans la peinture, Michel Butor comenta variadas aproximações entre formas do discurso verbal e pinturas. São dimensões múltiplas dessa coexistência: a palavra escrita numa pintura, a aproximação entre quadro e legenda, o discurso da crítica artística sobre alguma pintura etc. Para indicar como essa aproximação pode mudar significativamente a compreensão da mensagem da pintura, ele mostra, por exemplo, como o título Paisagem com queda de Ícaro dado por Bruegel a uma pintura, muda em grande medida as atenções para os elementos da pintura, e que há uma concentração em um detalhe (duas pernas emersas, indicando ser aquele Ícaro afogando-se) - Butor, 1969, p. 13-4.

Seria, então, esse debate em desenvolvimento sobre as artes plásticas moderna e contemporânea (época tratada por Butor), que daria início ao interesse dessa dimensão em

\footnotetext{
6 "A relação da letra e da imagem foi freqüentemente estudada a partir do texto inaugural de M. Butor, Les mots dans la peinture (1969)." (Lissarrague, 1992, p. 189). Ver também Coüelle, 1998, p. 135.

${ }^{7}$ Publicado originalmente em 1998.

${ }^{8}$ Nesse caso, o interesse é específico: Snodgrass concentra-se nas figurações com inscrições que tenham alguma relação com o Ciclo Troiano, e a interpretação gira em torno da verificação das constantes filiações de algumas figuras à poesia homérica feitas pela erudição acadêmica.
} 
outras áreas como os Estudos Clássicos; já que, nesse campo, a aproximação preponderante entre linguagem verbal e não verbal (visual, no caso), dava-se sobretudo no cotejamento de fontes literárias e iconográficas. Nesse sentido, a inspiração é externa e afeta paulatinamente os Estudos Clássicos, área constantemente acusada de práticas e leituras bastante tradicionais.

Os comentários de Butor são abrangentes, e não apresentam uma abordagem física/material de forma mais profunda. A discussão gráfica, então, bastante própria da observação da cerâmica grega, como indica a acepção antiga do termo, é pouco desenvolvida. Entretanto a mudança de sensibilidade no que se refere a aproximação do discurso verbal e não-verbal já é bastante importante. Mas, pode-se mesmo, para suprir essas ausências, ampliar a observação a outros campos de estudo, e ponderar sobre as possibilidades de análise nos Estudos Clássicos. Nesse sentido, a observação do desenvolvimento gráfico na "Pré-História", e mesmo nos estudos pedagógicos sobre o desenvolvimento gráfico em crianças em processo de alfabetização (áreas que por vezes andam de mãos dadas - ver Clark, 1985, p. 38-9), é bastante fecundo.

Em síntese, tem-se que a preocupação propriamente gráfica é recente nos Estudos Clássicos, sobretudo influenciada pela História da Arte, mas que a observação da aptidão gráfica do ser humano, tanto na "Pré-História" como no processo de aprendizado infantil, pode ampliar as possibilidades da observação dessa dimensão gráfica entre os gregos. ${ }^{9}$

Mas, mesmo antes disso, deve ter-se em vista a discussão que se estabeleceu durante muito tempo no seio dos Estudos Clássicos. Lissarrague indica que alguns estudos bem anteriores com preocupações similares; por exemplo, Paul Jacobsthal (Zur kunstgeschichte der griechischen inschriften, 1911; e Ornamente grieschischer vasen, 1927) já discutia a função ornamental das inscrições gregas (Lissarrague, 1998, p. 123).

Uma visão atenta, pode indicar que indiretamente aspectos gráficos podiam ser observados; ou seja, mesmo quando o interesse prioritário era a compreensão da caracterização iconográfica de determinadas figuras (sobretudo mitológicas), situação inúmeras vezes auxiliada por inscrições, o debate gráfico não se perdia completamente. Em outras palavras, em vários casos, enquanto se preocupava em estabelecer quem era tal e qual figura mitológica, a compreensão gráfica da imagem figurativa, da inscrição e de sua articulação era essencial.

O termo "gráfico" já vem sendo utilizado há algum tempo no campo dos estudos arqueológicos da Antigüidade grega, e pode-se indicar o filólogo alemão, Carl Robert (Bild und

\footnotetext{
${ }^{9}$ Deve-se ainda destacar também os esforços, relativamente recentes, da intitulada Arqueologia Medieval, que também se depara com questões parecidas, depois de lidar durante muito tempo (não como Arqueologia, mas como História da Arte), com paralelos constantes entre fontes literárias e materiais.
} 
Lied, Apud Dugas, 1960, p. 59), como um dos pioneiros. ${ }^{10}$ É bastante emblemático que o confronto, ou melhor dizendo, o estabelecimento de paralelos entre "tradição literária" e tradição gráfica", tenha sido iniciado por ele; já que essa prática retoma a comum entonação até então dos Estudos Clássicos, a de utilizar as fontes materiais como subsidiária ao estudo dos textos por excelência. Já Ch. Dugas (Tradition littéraire et tradition graphique dans l'Antiquité grecque), observa uma efetiva possibilidade de independência entre uma tradição e outra, situação que destoava então da comum aproximação pouco autônoma da fonte iconográfica frente à literária. Afora a proposta de independência entre fontes, ou da falta dela, é importante destacar um traço indireto que permeia a caracterização de Dugas: a informação escrita não é absolutamente legada ao campo da tradição literária, isso, pois as inscrições presentes nos vasos, aquelas que compunham junto das imagens figurativas formas do mito, eram peculiares da tradição gráfica.

É claro que essa é uma caracterização indireta (Dugas não comenta claramente tal característica), mas a forma com que organiza as fontes, e sua interpretação, indica uma divisão aguda entre informações literárias de um lado (aquelas próprias da "grande literatura", como a poesia); e, do outro, aquelas presentes em vasos (sem fazer qualquer distinção entre figura e inscrição). Nessa linha, é permitido pensar o problema da escrita (a dimensão da tradição gráfica que interessa aqui), extrapolando a proposta original do autor, numa perspectiva tanto literária como gráfica (ver esquema 1).

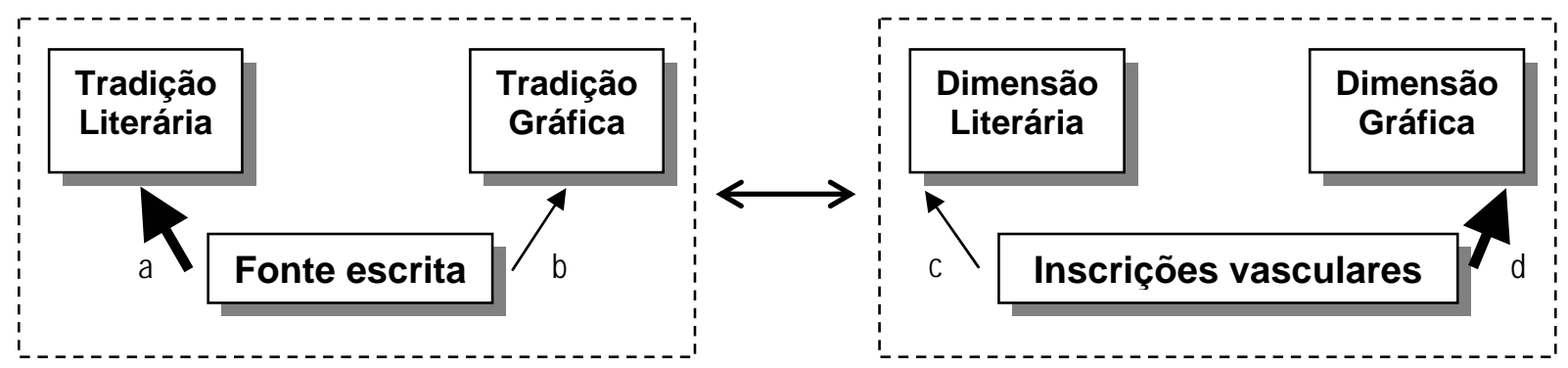

Esquema 1. Informações escritas relacionadas à "tradição literária" (própria da formulação literária do mito - textos antigos e oralidade) e "tradição gráfica" (própria da formulação visual do mito - figuras e inscrições relacionadas). Por extensão, concebem-se uma "dimensão literária" (própria dos estudos literários e filológicos [conteúdo, estilo literário etc.[), e uma "dimensão gráfica" (própria dos estudos epigráficos [estilo da escrita, cronologia etc.]), relacionadas às inscrições.

\footnotetext{
${ }^{10}$ O termo gráfico, e relacionados, não segue uma conseqüente caracterização das figuras como grafismos. Ch. Dugas (1932), quando se refere à tradição gráfica, utiliza largamente os termos pintor/pintar/pintura, e não grafista/grafar/grafismo ou mesmo desenhista/desenhar/desenho; mas P. Devambez, em La peinture e les arts graphiques (In: Le style grec. Paris: Librairie Larousse, 1944), já operava numa distinção entre aspectos gráficos e de pintura; enquanto boa parte da bibliografia clássica sobre a Ceramologia, Arqueologia e História da Arte gregas, apresenta tradicionalmente a idéia de pintura como preponderante (alguns títulos da ceramologia grega indicam tal situação, como, por exemplo, Attic black-figure vase-painters e Potter and painter in ancient Athens, de J. D. Beazley, e Greek painted pottery, de R. M. Cook, reforçam essa idéia), a despeito das imprecisões de compreensão da atividade ceramista que tal termo pode influenciar.
} 
Por extensão, pode-se pensar que a escrita estaria ligada tanto a uma tradição literária (a), mas também ao campo da tradição gráfica (b); e, ainda, que essas inscrições sobre os vasos de cerâmica podem ser observados do ponto de vista de sua "dimensão gráfica" (d); mas que sua dimensão literária não deve ser esquecida. Assim, é seguindo a pista dessas possibilidades amplas de análise, considerando a dimensão gráfica e literária das inscrições presentes nos vasos que se operará a interpretação da documentação selecionada. $O$ desnivelamento relacional entre $a$ e $b$, e $c$ e $d$, apresentado no esquema com as setas diferentes, indica um descompasso na percepção dessas estruturas na compreensão acadêmica. Encarar a inscrição como elemento gráfico, já em autores como Dugas, não significa atribuir-Ihe um natural grau de independência; já que, se por um lado amplia-se a perspectiva de observação do que foi registrado pela escrita; de outro, a inscrição é vista comumente como elemento subsidiário da figuração nesse quadro de caracterização gráfica (ela pertence a uma tradição gráfica, mais pela sua contribuição na compreensão da composição das figuras e narrativas iconográficas do mito, que pela constituição gráfica que tem). ${ }^{11}$

No campo que trata da tradição literária, essas inscrições geralmente são desprezadas, pois em sua maioria são curtas, e não chegam a constituir textos propriamente ditos. Já no campo que trata sobretudo das inscrições, nomes de divindades, então, a partir de seu conteúdo, indicaram-se ou se reforçaram, ao longo do tempo, inúmeras caracterizações de figuras mitológicas. É do ponto de vista do conteúdo, e não da formas materiais que se aproximou constantemente inscrições e imagens figurativas. Do ponto de vista de seu conteúdo, também foram observadas, freqüentemente, as inscrições de autoria ( $\varepsilon \pi \circ \varepsilon \varepsilon \sigma \varepsilon v$ [fez], $\varepsilon \gamma \rho \alpha \psi \varepsilon v$ [desenhou]); buscando-se informações quanto à composição do trabalho em oficinas ceramistas; e do ponto de vista da aproximação entre escrita e figuração, elas indicariam em alguns casos os nomes de autores da ornamentação de grupos de vasos. Assim, por exemplo, Beazley (1949) atuou na caracterização de vários vasos de alguns "pintores", mesmo aqueles que não eram assinados.

De forma indireta, novamente, é possível observar que nesses estudos que constantemente privilegiaram a dimensão literária das inscrições, a despeito de suas características gráficas, a importância da discussão de cunho gráfico nem sempre se perde; e em alguns casos ela é central. O exemplo de uma antiga série de propostas de caracterização de uma figura, frente a uma inscrição, indica bem isso. Trata-se de um fragmento de uma cratera protoática, encontrada em Egina, possuindo imagem e inscrição fragmentárias (ver esque-

\footnotetext{
${ }^{11}$ As relações entre Arqueologia e Filologia aqui indicadas (a fonte material como auxiliar em face às informações próprias da linguagem verbal) não resumem, em absoluto, as profundas interações entre esses dois campos; mas estruturam o discurso base do interesse específico. Vale lembrar que a Filologia serviu durante muito tempo como paradigma, não apenas dessas disposições metodológicas, mas como central referência teórica na interpretação arqueológica; ou seja, a crença na constituição entre paralelos entre a "evolução", "desenvolvimento", coesão "racial" ou "cultural" próprios da língua para a interpretação da cultura material (para um arrazoado histórico e situação da discussão, ver Funari, 1999).
} 
ma 2). Beazley retoma um debate já presente em Otto Benndorf (Griechische und sicilische Vasenbilder, 1883; Apud ABF, p. 1); que seria desenvolvido mais tarde (já na década de 1930, e retomado por Immewahr [1990] e Jeffery [1990] ${ }^{12}$ ). O interesse prioritário era o de identificar a figura; e, a partir do fragmento de inscrição, as propostas foram variadas (ver esquema 2). ${ }^{13}$ Mas, se se quis saber, desde o final do século XIX, quem era tal figura, resvalou-se inúmeras vezes na necessidade de entender graficamente a relação escritofigurativa. Entender quais as possibilidades de reconstituição da inscrição (se o alfa é seguido de um gama ático, um lâmbda egineta ou um nu ático) só as características gráficas podem responder (ver esquema 2). A discussão gráfica, nesse caso, indica também que existem características comuns entre essas três letras no período tratado (o gama, o lâmbda e o $n u)$, a ponto de haver uma dificuldade de restauração da letra, da inscrição e da caracterização da figura ao lado, o objetivo principal dos autores que trataram desse fragmento; mesmo que boa parte da letra tenha sido preservada.
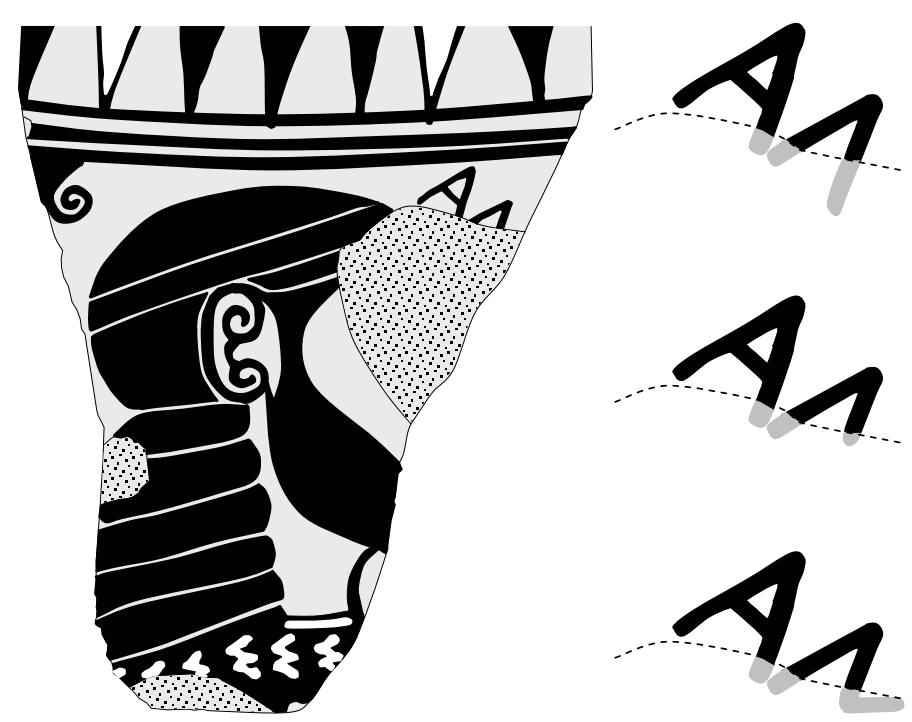

Esquema 2. Fragmento de cratera protoática (detaIhe), Pintor de Berlim A 34, c. 650-625 a.C. Atenas, Museu Nacional. Três propostas de reconstituição da inscrição:

1. $\mathrm{A} \Gamma[\alpha \mu \varepsilon \mu \nu \mathrm{ov}]$

2. $\mathrm{A} \Lambda[\varepsilon \chi \sigma \alpha \nu \delta \rho \circ \varsigma]$

3. AN $[\tau \varepsilon v o \rho]$

Coloca-se, ainda, outra questão central: o que significa, materialmente falando, nomear determinada figura? A caracterização poderia ser feita apenas a partir de atributos iconográficos, mas nem sempre isso é possível, e uma inscrição relacionada, ou seja, próxima fisicamente, poderia corroborar nessa caracterização. Entretanto, tal aproximação era estabelecida a partir de certa lógica de articulação; e, nesse caso, um homem com barba e cabelo longo poderia ser Agamêmnon, Alexandros ou Antenor, e essa logicidade está claramente relacionada com as propostas de reconstituição da inscrição, pois $\mathrm{A} \Gamma, \mathrm{A} \Lambda$ e $\mathrm{AN}$ po-

\footnotetext{
12 Publicado originalmente em 1961.

${ }^{13}$ A proposta de reconstituição como Agamêmnon ou Alexandros já era presente em $A B F$ (p. 1); a adição de Antenor como possibilidade surge depois (ver verbete "Agamemenon", de Touchefeu, O e Krauskopf, I, LIMC $1)$.
} 
deria iniciar uma gama grande de palavras, mas a lógica gráfica (o tipo de figura e sua aproximação a outras produções da mesma época) influencia claramente a delimitação nominativa das propostas de reconstituição da inscrição. As três possibilidades remetem a personagens do Ciclo Troiano: Agamêmnon, o comandante do exército aqueu; Alexandros (Páris), o príncipe troiano; e Antenor, o ancião troiano companheiro de Príamo. No bojo dessas caracterizações, é importante saber que a mais difundida delas (Agamêmnon), era defendida por Beazley (1935, p. 475), aproximando-a da inscrição MENE $\Lambda$ A $\Sigma$ (Menelau) presente numa base de cratera protoática. ${ }^{14}$ Ainda, o nome Antenor também surge como possibilidade de restauração de inscrição num fragmento de vaso do século VIII a.C. ([A?]NTE[vop?]); ${ }^{15}$

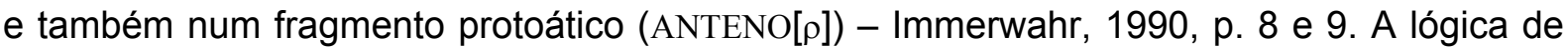
conteúdo e gráfica, como visto, andam juntas.

A discussão gráfica é essencial no que tange a Epigrafia grega, sobretudo quanto ao estudo das inscrições mais antigas. Trata-se, nesse plano, tanto das características formais quanto as lingüísticas, e a apresentação de tabelas com a partir de referências culturais (por cidade) e cronológicas, indica isso (ver Immerwhar 1990, p. xxii-xxiii e 131-69; Jeffery, 1990 [várias, ao longo da obra - ver última página para uma tabela comparativa], e Boardman, 1995, p. 202). A abordagem gráfica fica clara nesse campo, quando se observa que a caracterização cultural passa pela formal (estilística) das letras. Assim, fala-se em "iota dobrado", "barra oblíqua", "lados curvados" etc.; todas, formas de caracterizar várias letras gregas. Ora, se a letra é a redução mais drástica da língua, ela ainda pode ser "atomizada" no que se referem aos seus aspectos gráficos. Por exemplo, a reunião de duas linhas oblíquas unidas pelo vértice na sua parte superior, articuladas a outra, horizontal, em altura média, é a própria caracterização da letra alfa, que pode sofrer variações. ${ }^{16} \mathrm{O}$ que interessa aqui é que esse debate pode começar mesmo antes da articulação de palavras numa oração, ou de seu significado, aproveitando-se questões sobre a mais profunda redução que tal sistema de escrita poderia sofrer: a gráfica; já que a desarticulação das linhas oblíquas e a horizontal que caracterizam o alfa, já não responderiam à estrutura de uma letra, e por conseqüência, da linguagem verbal. Essa caracterização é importante, pois, essa forma de grafar o alfa já no final do período arcaico, início do clássico, pode ser distinguida da forma peculiarmente

\footnotetext{
14 “(...) sobre o corpo, está a cabeça e o pescoço de um homem, e o início de um inscrição, A $\gamma . .$. Professor Karo recentemente publicou fragmentos de um outro grande vaso ático encontrado em Egina, uma base de cratera um pouco mais antiga que a nossa ( $26^{\text {tes }}$ Hallisches Winckelmannsprogramm, pl. 1 e p. 10-4): ela é decorada com

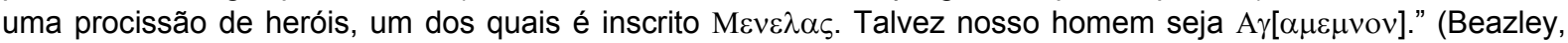
1935, p. 475) Entretanto, a interpretação da inscrição MENE $\Lambda$ A $\Sigma$, como nominativa da figura ao seu lado, é polêmica, e vem sendo reavaliada (ver Ferrari, 1987).

${ }^{15}$ A reconstituição dessa inscrição, bastante fragmentária, também passa por considerações gráficas precedentes, conforme indica Immerwahr, 1990, p. 8.

${ }^{16}$ A caracterização dessas linhas como oblíquas e horizontais leva em conta a orientação da escrita que, no caso do grego, é linear (o $\ell$ no esquema 3 ).
} 
arcaica, pois esta tem freqüentemente o traço intermediário também oblíquo (ver esquema 3).

Esses exemplos mostram que a discussão gráfica, apesar de nem sempre apresentada, é feita, mesmo que de forma insuficiente, e que ela é importante passo para a caracterização mais profunda dos significados dos grafismos, convertidos, por exemplo, em compreensão de figuras mitológicas no campo da iconografia clássica. O gráfico, então, é uma dimensão já anunciada na Antigüidade para a caracterização de certo tipo de produção, um discurso próprio (antigo e específico, ou seja, apresentado também pelo próprio artesão, como se observa em algumas assinaturas de autoria); e também como característica própria do debate acadêmico contemporâneo.

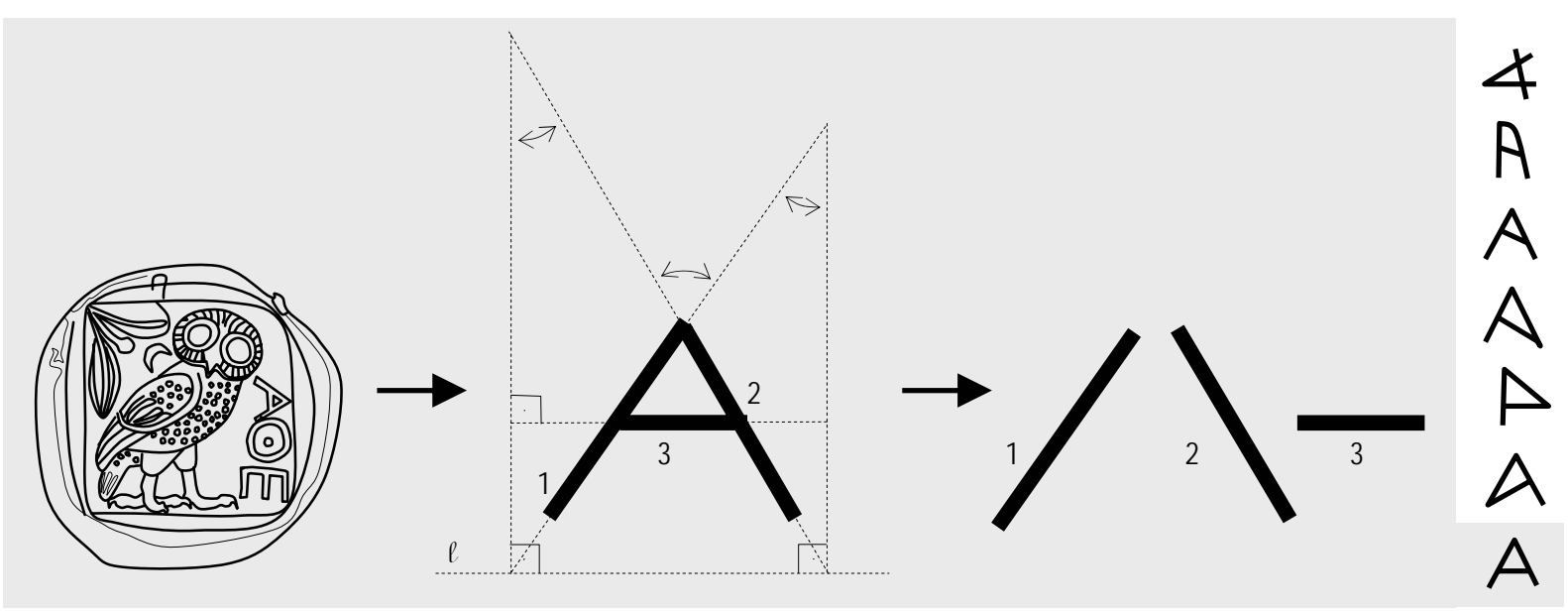

Esquema 3. Em destaque: (à esquerda) Moeda de prata de Atenas (tretradracma) com inscrição A@E, início do séc. V a.C.; (meio) Alfa isolado: apresentação esquemática; (à direita) Desarticulação gráfica da letra alfa. Ao lado, formas do alfa em inscrições áticas do período arcaico (Jeffery, 1990, p. 66, fig. 26).

A proposta desta pesquisa, então, justifica-se pela própria vivacidade do tema. Ora, esse discurso que aproxima linguagem escrita e figurativa, verbal e não verbal, presente nas fontes literárias e materiais, é amplamente encontrado na contemporaneidade em campos variados. Freud, por exemplo, mostra como o processo de alfabetização pode guardar paralelos interessantes com a própria dimensão fisiológica do homem; assim, as diferenças entre letras $(M$ e $N$ ) podem ser aproximadas às diferenças de cunho biológico (ver capítulo 1 , item 1.1). Mas esses paralelos podem ser estendidos a grande parte do mundo sensível:

(...) Uma vez que aprendeu a ler (...) se distraía da história, embriagado, quase à beira das lágrimas, pela beleza do alfabeto, com seus sutis e ricos sons e formas: embevecido e perplexo pela complexa amplitude de um $a$, o zumbido sexo, lenhoso do $r$, o mimado $E$ maiúsculo, parecido com um rastelo; o q como um girino que nadava na infância salina e úmida da evolução; o $b$ com suas bravatas e brusquidões; o $H$ maiúsculo, com seus pilares grandes e eclesiásticos, inquieto na aparência, mas de som muito duvidoso, uma fraca exalação, silen- 
ciosa como o sopro de Deus no rosto de Adão, como o resfolegar de um cavalo, $h$ de hora, de herói, de hecatombe. (...) (Fernanda Eberstadt, Los demonios de Isaac, Barcelona: EMECÉ, 1993)

Constantemente, paralelos entre figuração a escrita colocam como referência formas ideográficas de escrita; mas, mais que isso, a experiência figurativa num sistema de escrita que perdeu essa dimensão num drástico processo de abstração: é a cabeça de boi, própria da caracterização do alef semítico, mas resistente no alfa grego (ver capítulo 3, nota 4 ) e o a latino. Não por acaso, há inúmeras caracterizações de tipos alfabéticos que extrapolaram o traço simples, buscando organizações que, em certa medida, dialogam com essa experiência figurativa milenar da escrita (ver fig. 1).

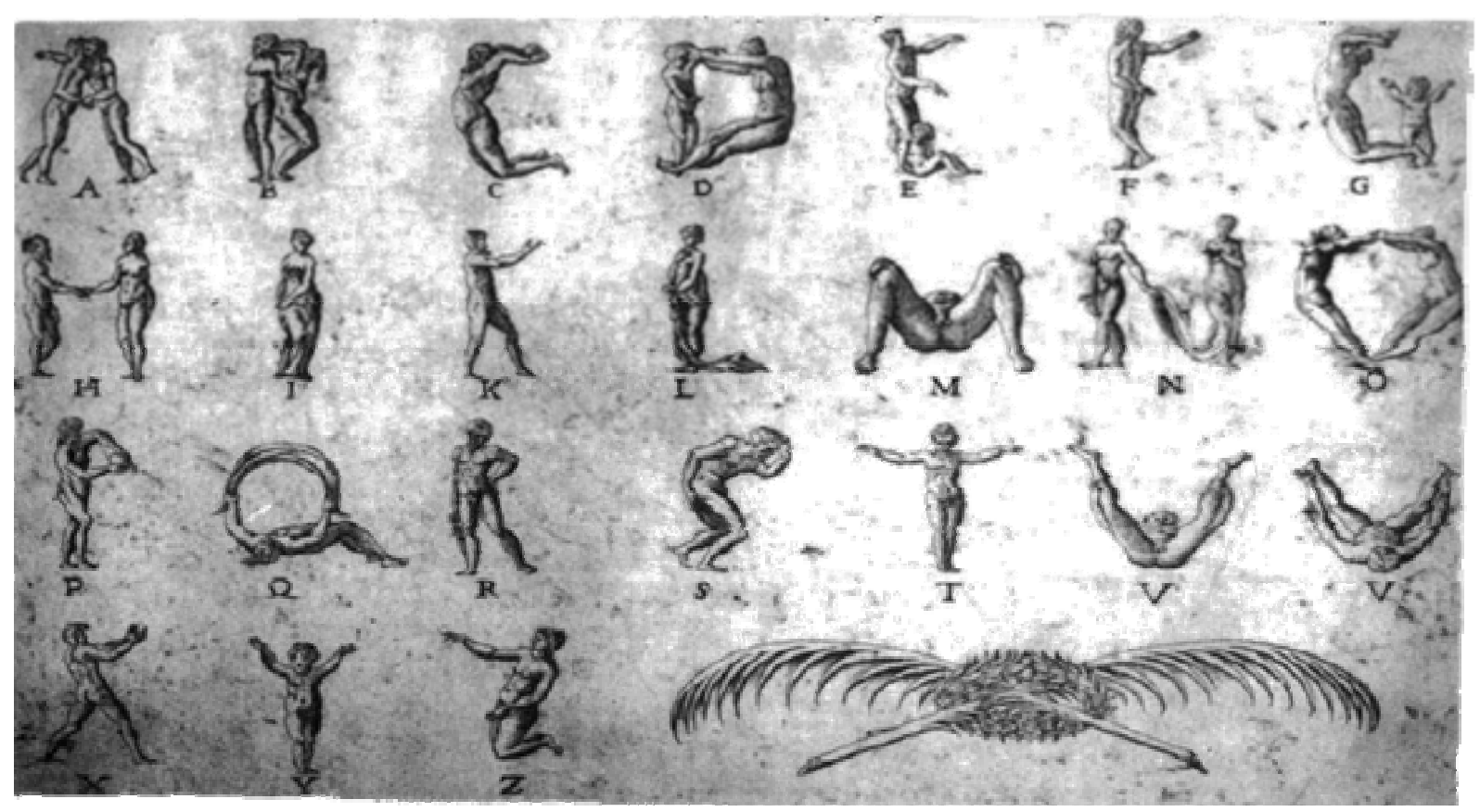

Fig. 1. Alfabeto Figurativo, Peter Flotner, 1534.

Mas, mais que uma compreensão abstrata da profunda aproximação entre escrita e figuração, esse foi um traço constantemente retomado em projetos de alfabetização de massas no mundo contemporâneo. A organização de cartilhas mostrou, em inúmeros casos, a crença numa eficiência da alfabetização que considere seriamente os paralelismos com a imagem visual. Nesse sentido, optou-se, durante muito tempo, na rede pública de ensino básico no estado de São Paulo, pela utilização de uma cartilha bastante conhecida: Caminho suave. Alfabetização pela imagem. E não seria nenhuma surpresa, assim, observar que a segunda lição ali proposta "Eu vejo a barriga do bebê", trouxesse a caracterização da letra $b$ como o tronco e a barriga da figura do bebê (ver fig. 2). ${ }^{17}$

\footnotetext{
17 Teoriza-se, desde a "Idade Média", sobre a viabilidade do uso didático das imagens visuais para a difusão de conteúdos propriamente literários. Georges Duby, diz que "Em sua maioria, (...) [as] imagens serviam também de
} 


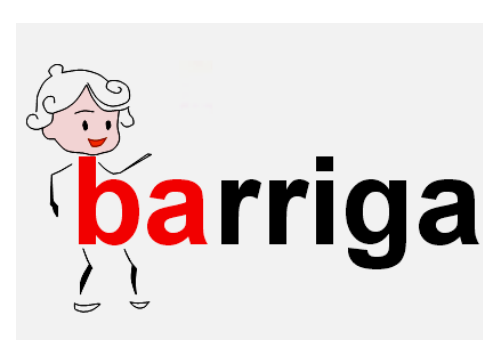

Eu vejo a barriga do bebê.

Fig. 2. Trecho da segunda lição da cartilha Caminho Suave. Alfabetização pela imagem. Branca Alves de Lima, São Paulo: Caminho Suave Edições, 2005; Fig. 3. Neues Nationen-Alphabet, Leporello, 1835; Nr. 97. Titelblatt. Lição das letras $A$ (Americaner) e $B$ (Berber).
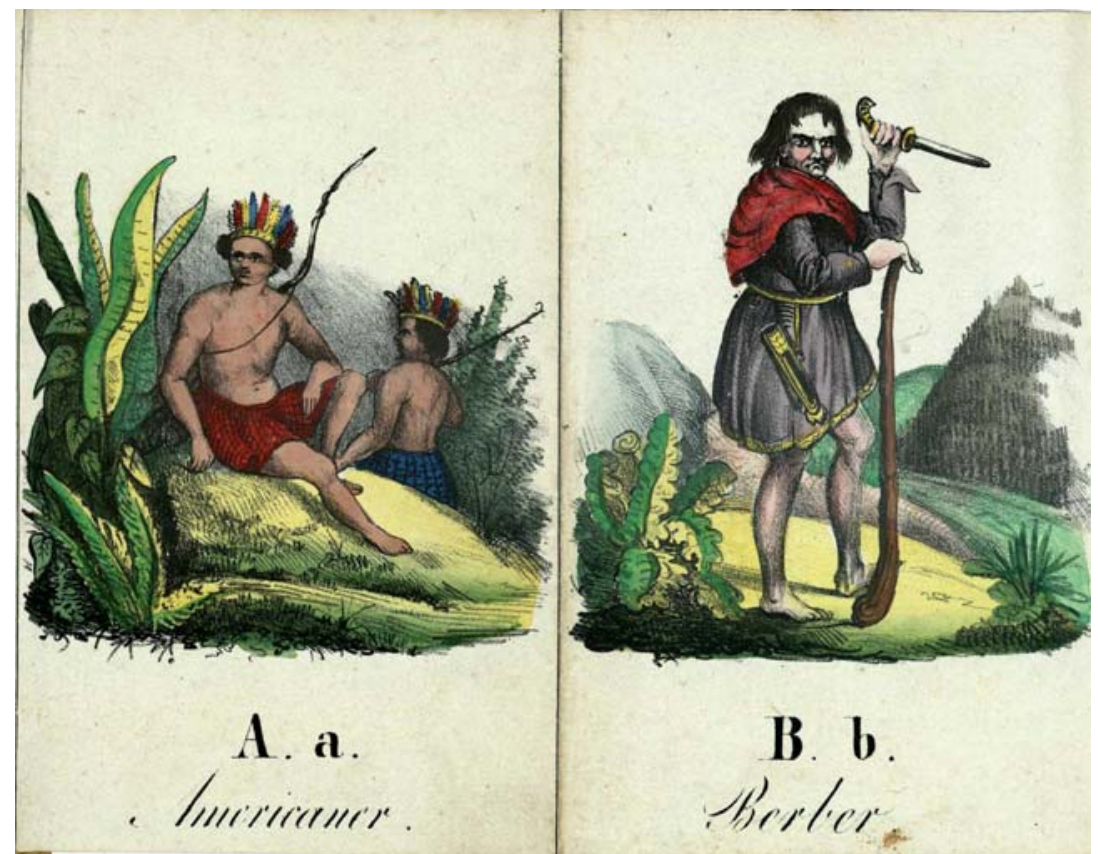

Essa experiência gráfica peculiar das sociedades ocidentais contemporâneas apresenta o interesse e a viabilidade de compreender um problema bastante pertinente entre os gregos, "civilização" constantemente concebida como modelo de origem. Entretanto é preciso situar bem o problema entre os gregos, e identificar o que é anseio contemporâneo e questões propriamente históricas. Tratar da aproximação entre escrita e figuração não significa identificar, necessariamente, uma letra-figura; e as questões, como o arrazoado de discussões gráficas acima propostas, são de outra ordem. É claro que, seguindo a própria caracterização próxima entre escrita e figuração, através da idéia do gráfico, pode-se perceber certo grau de abstração que a escrita sofre, chegando a haver casos de uma letra que deixa de ser pura letra, ou seja, partícula atômica da língua, ou melhor, de um sistema de escrita, e passa a comunicar ganhando outro significado. Esse é, por exemplo, o caso de um alfa apresentado sobre um escudo de uma figura que disputa uma corrida, a pé e com armas (o primeiro concorrente porta o escudo com um grande alfa, ou seja, o ganhador [ver Olmos, 1993, fig. 52 e p. 132, para outra interpretação] - ver fig. 4). A letra, ali, tem um significado diverso do usual: ela é uma figura indicadora dos rumos da narrativa da cena (tem valor iconográfico), mas também mostra que a letra alfa isoladamente poderia comunicar. Ela signifi-

mediadores, favorecendo a comunicação com o outro mundo, um outro mundo de que pretendiam ser um reflexo, uma aproximação. (...) Os homens de saber, condescendentes, atribuíam-lhes além disso uma função pedagógica mais vulgar, encarregando-os de mostrar aos analfabetos aquilo em que deviam acreditar. Em 1205, o sínodo de Arras autorizou a pintura de imagem para ensinar os ignorantes. Cem anos mais tarde, Bernardo de Claraval (cuja sensibilidade não era todavia visual, pois convidava seus irmãos a fiarem, na escuridão da noite, à escuta do icogniscível: 'Por que esforçamo-nos em ver? É preciso ouvir.') exortava os bispos a 'exercitar por meio de imagem sensíveis a devoção carnal do povo, quando não pudessem fazê-lo por meio de imagens espirituais'." (História artística da Europa. Rio de Janeiro: Paz e Terra, 2002, p. 16). Ainda, vale dizer, desde os mais antigos esforços contemporâneos preocupados com a alfabetização (inicialmente mais restritos; e, depois, dedicados às massas) o paralelo entre letras, textos e figuras são constantes (ver fig. 3). 
ca também o primeiro, situação endossada pelo uso das letras em sistemas numéricos entre os gregos (tanto o acrofônico, como o alfabético - ver B. F. Cook, As inscrições gregas. In: Hooker, 1990, p. 328-9), e mesmo a caracterização em alguns vasos do que se chama de abecedaria, ou seja, das letras do alfabeto, uma após a outra, indicando que já em tempos antigos havia a estruturação desse sistema de escrita que hoje, em certa medida, organiza grande parte do conhecimento. ${ }^{18}$

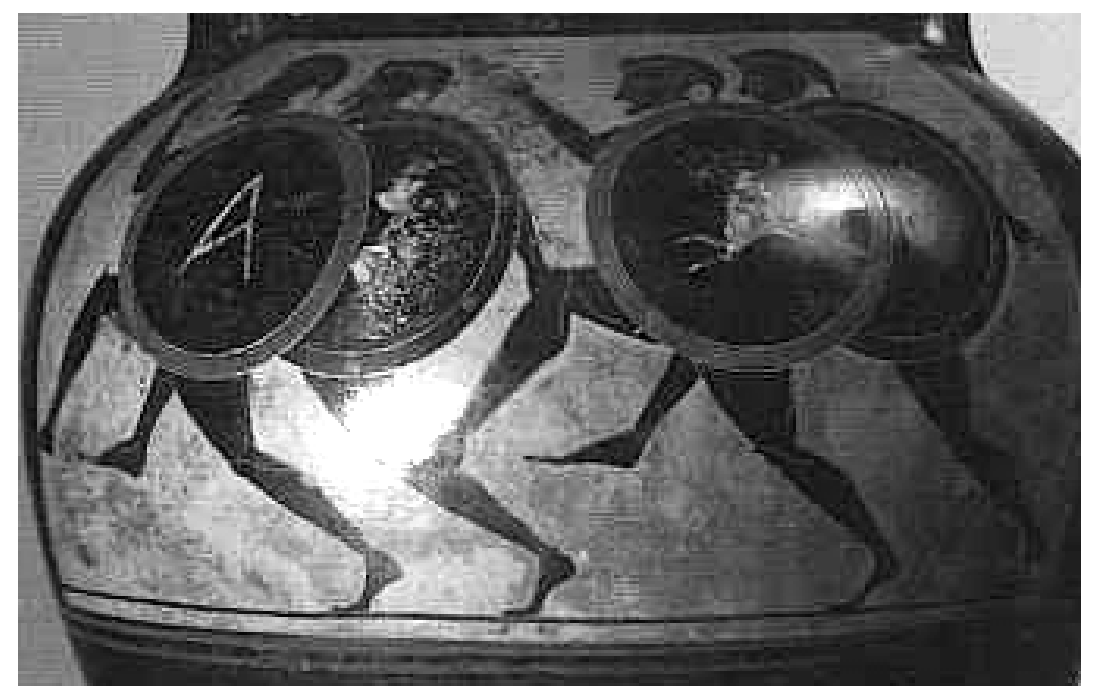

Fig. 4. Face de ânfora panatenaica (detalhe): corredores a pé e com escudos, o primeiro colocado carrega um escudo com uma grande letra alfa.

A partir disso, mostra-se bastante viável discutir as disposições materiais, entre os gregos, da linguagem escrita e figurativa; e, constatada a viabilidade do problema histórico, mostra-se imperativo indicar as justificativas que endossam a pertinência da seleção das fontes aqui tratadas: os vasos de cerâmica ornamentados produzidos nas oficinas áticas do período arcaico, onde exista escrita e figuração coexistam.

A bibliografia em geral indica a cerâmica como a documentação mais viável, pois são desse tipo de suporte os exemplares mais antigos, e que constituem com maior densidade uma série. Nesse sentido, a cerâmica ática constitui o grupo mais coeso e com maior permanência, a despeito dos exemplares coríntios com organização gráfica escrito-figurativa mesmo antes dessa prática disseminada na Ática; entretanto, é na Ática que tal prática se estende com grande força em todo o período arcaico, produzindo um modelo de extrapolação desse período, mas guardando a relação escrito-figurativa própria dessa época: é o caso das ânforas panatenaicas (matéria do capítulo 5), que conserva formas da organização gráfica arcaica na cerâmica até o período romano. E mais, é sobre a cerâmica que se constitui uma caracterização mais clara e definida das duas linguagens aproximadas conceitual-

\footnotetext{
18 Dicionários e enciclopédias, por exemplo, são formas de organização do conhecimento subordinando-o à estrutura seqüencial básica do sistema de escrita.
} 
mente, conforme indica a utilização do verbo $\gamma \rho \alpha \varphi \tilde{e} 1 v$ nas assinaturas de autoria. Assim, como a entonação principal deste estudo pauta-se nos grafismos sobre a cerâmica, cabe, ao menos resumidamente, comentar um pouco da articulação escrito-figurativa em outros contextos.

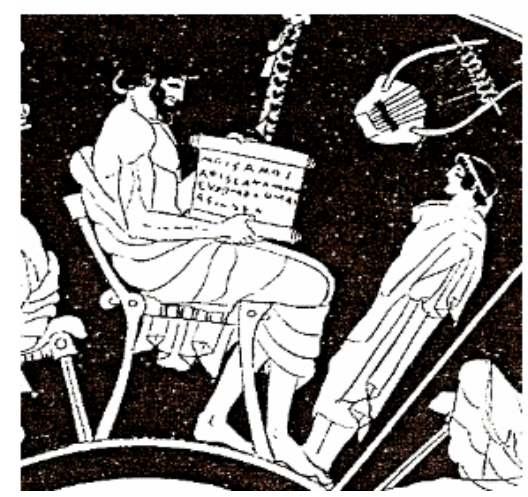

Fig. 5. Taça ática de figuras vermelhas, Pintor Douris, c. 485 a.C., Berlin, Staatliche Museen; Fig. 6. Lécito ático de fundo branco, Inscription Painter, c. 475-450, Atenas, Museu Nacional (Inv. 1958); Fig. 7. Lécito ático de figuras vermelhas, Klügmann Painter, c. 435-425 a.C., Paris, Museu do Louvre.
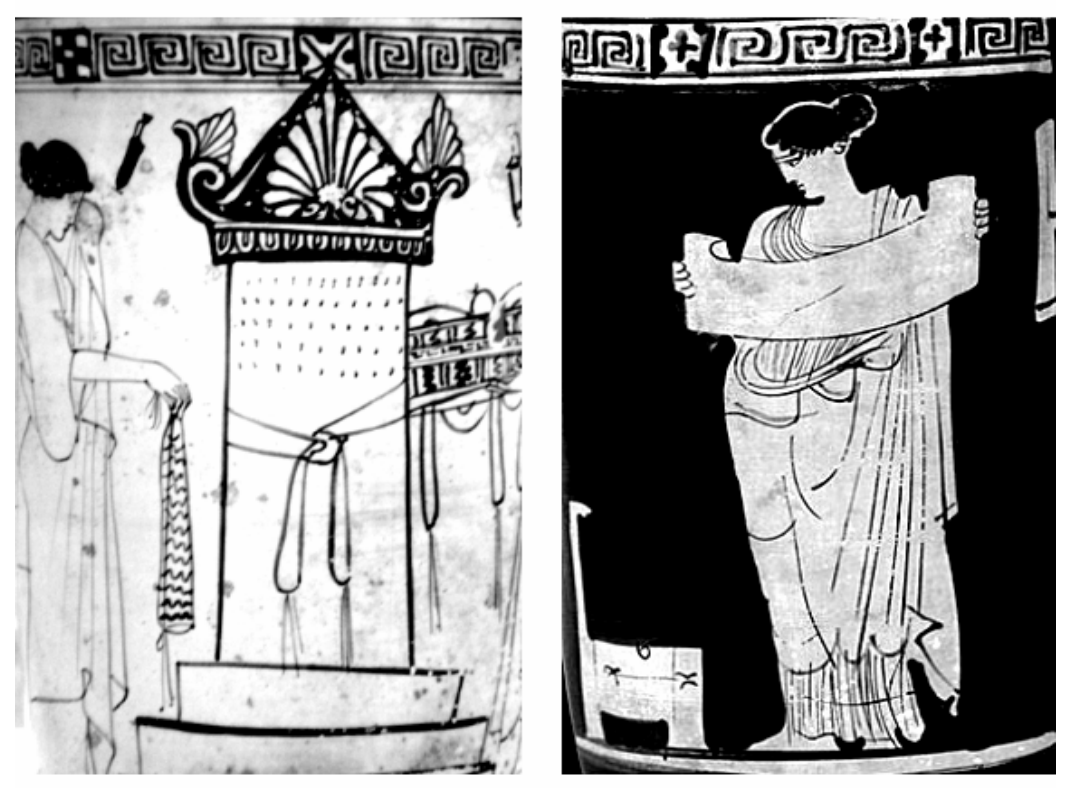

Avançar, e tratar das dinâmicas escrito-figurativas na cerâmica própria do período clássico e posterior, significaria abordar novas estratégias metodológicas e mesmo deparar com uma situação de desenvolvimento dos paralelos entre escrita e figuração bastante incomuns no período arcaico. Por exemplo, a escrita (como texto) apresentada iconograficamente. É o caso das figuras de papiros (ver fig. 5 e 7), tabletes ou de estelas funerárias (ver fig. 6). A escrita como componente da figuração não apenas para indicar uma personagem ou informar a autoria ou homenagem; mas a escrita como figura; indo da apresentação textual de uma informação, ${ }^{19}$ passando pela imitação da escrita (ver fig. 6), chegando até a sua abstração quase total (ela nem precisaria aparecer) - ver fig. 7. Assim, uma experiência bastante diferente daquela da escrita como elemento que compunha os esquemas figurativos no período arcaico.

Quanto a abordagem de outros suportes, as questões específicas colocam caminhos próprios de análise, que, é claro, podem ser observados em conjunto; como, por exemplo, na observação de duas esculturas do século VII a.C. (do grupo dos mais antigos exemplares do gênero - ver fig. 8 e 9).

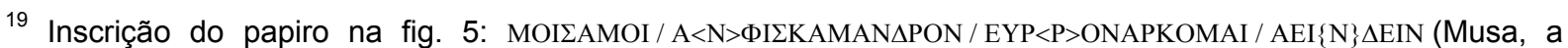
mim... e, sobre os rios abundantes do Escamandro, eu começo a cantar); ilegível na imagem (tradução e proposta de correções baseadas em Hurwit, 1990, p. 197).
} 

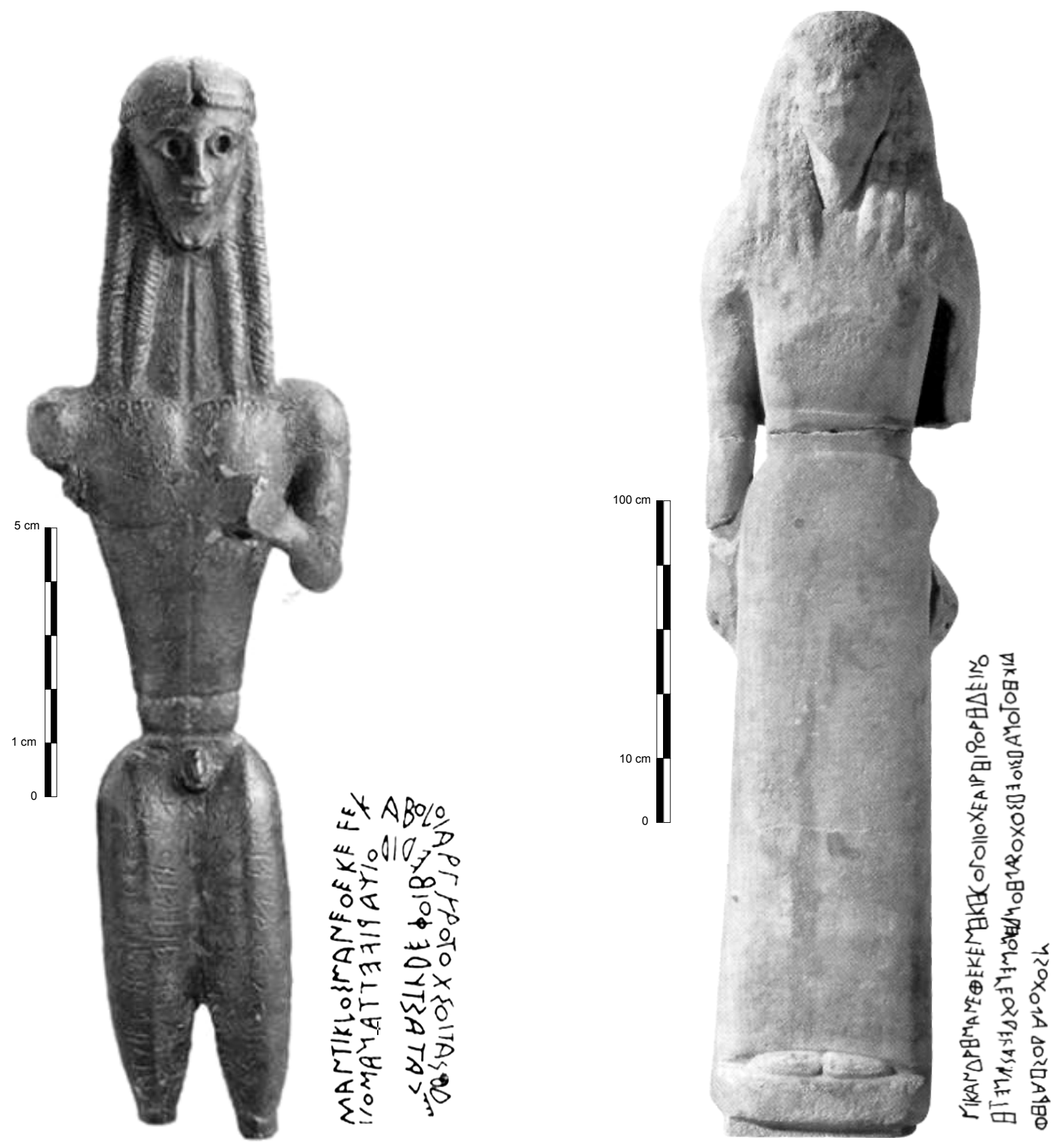

Fig. 8. (à esquerda) Kouros de Mânticlo, procedente da Beócia, c. 700-675 a.C., Boston, Museum of Fine Arts (alt.: 20,3 cm). Inscrição em boustrophedon, ao longo das pernas da estátua:

MANTIK $\Lambda$ O $\Sigma$ MANETEKEFEKABO $\Lambda$ OIAPГYPOTO $\Xi \Sigma O I T A \Sigma\{\Delta\} \Delta$ EKATA $\Sigma T Y \Delta E \Phi O I B E \Delta I \Delta O I X A P I F E T T A N A M O I B Q[A N]$

(Mânticlo dedicou-me ao que fere de longe, ao senhor do arco de prata. Pela oferenda, que Febo te dê boa recompensa)

Fig. 9. (à direita) Koré de Nicandra, procedente de Delos, c. 650 a.C.; Atenas, Museu Nacional (alt.: $175 \mathrm{~cm})$. Inscrição em boustrophedon, na lateral esquerda (abaixo da mão, e estende-se até o final da vestimenta) da estátua:

NIKAN $\triangle$ PEMANETEKENH $<$ E $>$ KHBO $\Lambda$ OIIOXEAIPHI

$\Delta \mathrm{IKEOTONAH} \Sigma \mathrm{IOEH} \Sigma \mathrm{OXO} \Sigma \mathrm{A} \Lambda \mathrm{HON} \Delta \mathrm{EINOMENEO} \Sigma \Delta$ EKA $\Sigma \mathrm{I} \Gamma \mathrm{NETH}$

ФHPAH $\Sigma \mathrm{O} \triangle \mathrm{A} \Lambda \mathrm{OXO} \Sigma \mathrm{N}<\mathrm{YN} ?>$

(Nicandra me dedicou ao que lança as flechas ao longe,

a distinta filha de Deinodikes de Naxos,

irmã de Deinomenes, esposa de Phraxos) 
As dimensões e o tipo de material são bem diferentes: uma é de bronze e a outra de pedra; ou seja, a primeira, de um material que chegou menos aos dias atuais (sobretudo os exemplares em grandes dimensões), e a outra compõe um grupo mais consistente. São duas esculturas onde a inscrição relativamente longa teve que se adaptar ao espaço figurativo. A escrita ocorre sobre a figura que é também seu suporte. Assim, enquanto na cerâmica a articulação escrito-figurativa ocorre em suporte comum (o vaso), essas esculturas indicam caminhos diferentes - a escultura é o suporte da escrita, e a figura é seu próprio suporte.

Essa distinção é importante, pois parece que é na produção escultórica que a aproximação entre escrita e figuração segue com mais proximidade os modelos orientais e egípcios; enquanto na produção cerâmica, as formas são constituídas, sobretudo, a partir de questões específicas (ver capítulo 3, item 3.3). Por exemplo, a prática de inscrever sobre a escultura já era bem organizada anteriormente; ou seja, adaptar as informações escritas ao espaço fornecido pela figura tridimensional era bastante observável em modelos egípcios. ${ }^{20}$

Ambas apresentam uma fórmula de escrita muito comum na arte grega do período, trata-se da inscrição que dá "voz" ao objeto, ou seja, ele mesmo se apresenta. ${ }^{21}$ No caso dessas esculturas tal característica é indicada pela fórmula $\mu^{\prime} \alpha \nu \varepsilon \tau \varepsilon \kappa \varepsilon v$ (me dedicou); e na cerâmica pintada nas inscrições de autoria ( $\mu^{\prime} \varepsilon \gamma \rho \alpha \psi \varepsilon v$ [me desenhou] e $\mu^{\prime} \varepsilon \pi 01 \varepsilon \sigma \varepsilon v$ [me fez]), e cabe dizer, a inscrição de autoria mais antiga num vaso de cerâmica, já apresentava tal fórmula (ver capítulo 2, fig. 7, p. 64). ${ }^{22}$ Essa característica comum coloca uma questão interessante para a interpretação dessas esculturas, em perspectiva comparativa. Eric Havelock (1996, p. 203), sobre a estátua dedicada por Mânticlo, diz que

As letras se imprimem no objeto como que intimamente, e se conformam à convenção de que a inscrição registre, mais uma vez, em pronunciamento do objeto. (...) Era impossível colocar essas palavras perto da boca, como se faria numa pintura cerâmica. Mas quando a estátua se dirige a Febo, nós percebemos que é o próprio doador quem está a falar. De fato, a inscrição traz sua assinatura, sua reivindicação de crédito, sua expectativa de recompensa. Por que, então, a comunicação indireta?

\footnotetext{
${ }^{20}$ Hurwit (1990, p. 181) apresenta estrutura similar em estátuas de Ramsés II, no Egito, onde as letras ocupam as pernas; isso, em época coincidente de tal prática na Grécia (início do século VI a.C.).

${ }^{21}$ Tais inscrições de objetos "falantes" (parlantes) são chamadas de "egocêntricas", segundo J. Svembro (J'écris, donc je m'efface. L'énonciation dans les premières inscriptions grecques, In: Detienne, 1992, p. 463), pois elas assumem o ego da enunciação, e apresentam os objetos que as portam, em primeira pessoa; colocando o dedicador como ausente.

${ }^{22}$ O grupo dessas inscrições é grande. Além das tratadas, pode-se, ainda, citar "Eu sou o cálice de Korakos (...)"; "Eumares me erigiu como monumento (...)"; "Eu sou o mnèma de Glaukos (...)" (Svembro, op. cit.). Ainda, outros paralelos entre produção grega e oriental: Hurwit (op. cit.) observa em retratos e estátuas da Gudéia de Lagash, textos inscritos em estrutura bem similar.
} 
Ora, a perspectiva de interpretação é específica (a lógica interativa entre a natureza da inscrição [seu conteúdo e posição] e seu suporte), mas também relacional (quando aproximado das formas peculiares de inscrições em vasos de cerâmica); e é essa que interessa aqui. Havelock caracteriza bem o enunciador da mensagem como o próprio dedicador Mânticlo, e não a estátua; e, dessa forma, não haveria por que aproximar a fala-inscrição da boca-física da escultura. Nos vasos de cerâmica, ao contrário do que diz Havelock, inscrições do tipo dedicatória, geralmente inseridas fora de contexto original de produção dos vasos, não seguiam necessariamente a lógica figurativa; assim, as mensagens não sairiam das bocas das figuras. Esse tipo de recurso (a inscrição "balão") era geralmente usado quando a informação escrita tinha relação mais direta com a lógica figurativa. Ao contrário, as dedicatórias apresentam o objeto como intermediário, revelando o interesse do dedicante, e não um necessário anseio da personagem figurada. Assim, são figuras ou objetos que "falam"? ${ }^{23}$ As esculturas, suporte e figura ao mesmo tempo, estão no mesmo plano dos vasos e placas votivas, objetos que também levavam mensagens dedicatórias, e eram claros intermediários nessa relação entre dedicante e dedicado?

A resposta passaria pela compreensão das especificidades desses objetos que estavam inseridos num mesmo contexto; mas que integravam também setores específicos da sociedade em certos estágios dessa vida social: os produtores e consumidores, por exemplo, poderiam ser muito diferentes. Dessa forma, a escolha da observação sistemática de um aspecto dessa dinâmica ampla, deu-se seguindo as limitações da pesquisa em época atual, tanto no que se refere à oferta das fontes, mas também as especificidades que deveriam ser tratadas. É sobretudo por isso que se escolheu a cerâmica como documento privilegiado para a observação da relação escrito-figurativa, a despeito das esculturas, relevos moedas, placas em madeira, e outros materiais; ou seja, um grande arsenal de documentos que permitiriam uma observação mais complexa e ampla da questão colocada. Entretanto, a observação sistemática de um aspecto da interação escrito-figurativa pode ser bastante fecundo.

Quanto às fontes literárias, ou seja, textos que comentem ou indiquem, mesmo indiretamente, algo dessa relação na Antigüidade, elas são raras. A longa descrição do escudo de Aquiles na Ilíada (canto XVIII) - 131 versos -, por exemplo, privilegia a apresentação de cenas, e não uma descrição material no detalhe, que pode ser observada, mais consistentemente, na seqüência da disposição das personagens e grupos, e nada sobre a presença

\footnotetext{
${ }^{23}$ Sobre a escultura dedicada por Mânticlo, P. Pucci (Inscriptions archaïques sur les statues des dieux, In: Detienne, 1992, p. 487) comenta a dificuldade de interpretação: seria a estátua uma oferenda pura e simples ou um "duplo" do deus Apolo (o dedicado). Nesse sentido, o "eu" presente na inscrição da estátua de Mânticlo não é esclarecedor, pelo menos não absolutamente. Esse é um bom exemplo de como a conjunção entre imagem figurativa e inscrição não significa diretamente que a imagem ganha "voz", que "fale" espontaneamente.
} 
de inscrições. Quanto à escrita, o interesse de Homero é pequeno (canto VI, 168-70 e 178, somente). ${ }^{24}$ Aqui, os versos mais importantes são os 167-70:

À Lícia o manda, com mensagem

Que grafara - funestos signos - em tabuinhas

Fechadas, para o sogro (os sinais insinuavam

Que fosse executado)

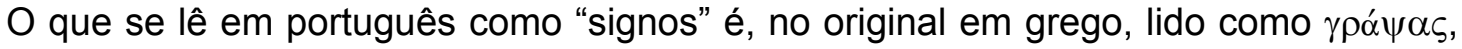
correspondente ao verbo $\gamma \rho \alpha \phi \tilde{\varepsilon} 1 v$; e ainda há a indicação do suporte da escrita: "tábuas fechadas" ( $\left.\pi^{\prime} v \alpha \kappa \imath ~ \pi \tau v \kappa \tau \tilde{\omega}\right)$. De início, algumas informações sobre a escrita ficam claras: a que se refere Homero, tem caráter privado (ela é transportada fechada do remetente ao destinatário); além disso, o conteúdo do que é escrito é passível de qualificação, ou seja, é chamado de "funesto". Em síntese, em Homero, nada da aproximação mais íntima entre escrita e figuração.

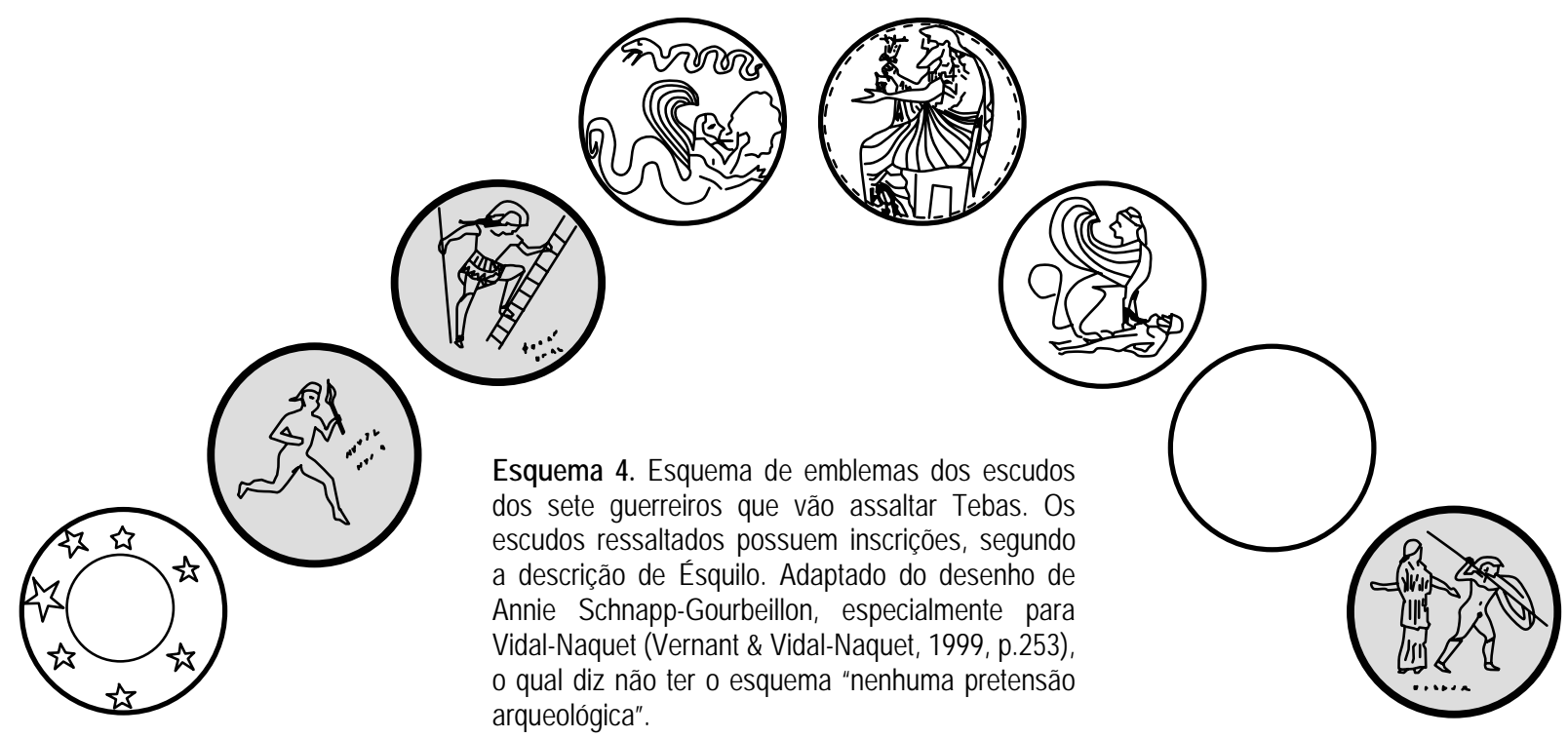

Uma referência mais adequada, ou seja, que indica algo sobre a relação entre escrita e figuração, encontra-se em Ésquilo, quando este, nos Sete contra Tebas, apresenta uma breve descrição dos escudos dos invasores. Três deles possuem imagens figurativas aproximadas de inscrições: trata-se do segundo, terceiro e do oitavo escudos (ver esquema 4). A caracterização dos escudos é bastante variada, indo desde o simples lábaro de estrelas, até

\footnotetext{
${ }^{24}$ Ver Snodgrass, 2004, p. 84; e llíada (Loeb Classical Library, vol. I, p. 274 [nota do tradutor A. T. Murray]).
} 
figuras aproximadas de inscrições, havendo, mesmo, um escudo sem ornamentação figurativa nenhuma. Quanto aos escudos com informações escritas e figurativas (destacados no esquema 4), eles são estruturalmente similares: todas as inscrições são do tipo "balão", ou seja, aquelas que indicam a fala da personagem. No segundo, o escudo

\author{
... Tem por emblema \\ um herói despido com uma tocha. Assim armado, \\ agita o fogo com as mãos. Vê-se um dístico em \\ letras de ouro: arrasarei a cidade. (vv 431-434)
}

No terceiro,

... O escudo esquematiza

façanha ousada: um soldado, um hoplita,

escala a muralha para tomar uma torre.

Uma inscrição soletra-lhe o grito:

Nem Ares me derrubará da torre. (vv 465-469)

Por fim, no oitavo

Porta um recém forjado escudo circular, provido de emblema duplo, trabalhado com arte.

Exibe um homem talhado em ouro, armado, conduzido por uma mulher serena.

Ela se apresenta como a própria justiça, a crer no que diz a legenda: Restaurei este homem, ele recuperará a cidade e o palácio de seus pais. (vv 642-648) $)^{25}$

Algumas informações materiais são oferecidas, como as letras de ouro no segundo escudo. Entretanto, o maior interesse é no que as informações oferecidas pelas inscrições poderia complementar as figuras: homens bradando e a proposta intervenção da Justiça. $A$ inscrição é sobretudo um complemento no que se refere ao tema. Letras de ouro poderiam causar impacto visual, mas é apenas esse elemento da materialidade que Ésquilo oferece, ou melhor, com que se preocupa. Elas poderiam até dar um grau mais consistente ao que se dizia, mas ainda aí a preocupação é temática.

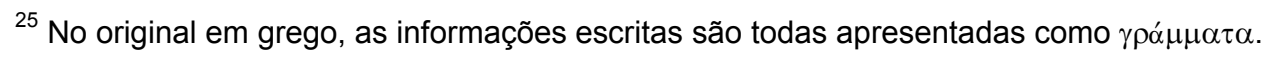


As caracterizações sobre a aproximação entre informação escrita e figurativa, assim, mostra-se bastante esparsa e irregular. Não chegou aos dias atuais algum texto que indicasse uma reflexão teórica mais aprofundada sobre a articulação desses dois domínios de linguagem. Outras informações são bem tardias, como as de Plínio, e mesmo de Zenóbio (séc. II d.C.), que chega a comentar um exemplo específico, nos Provérbios (IV, 28), a inscrição "Boútes" ao lado de um combatente num afresco.

É da mesma época o que se tornou um dos mais conhecidos exemplos de caracterização literária de um objeto na História da Arte da Antigüidade: trata-se da descrição da Arca de Cípselo feita por Pausânias (Descrição da Grécia, V, 17-9). Os estudos que se interessam pela articulação entre inscrições e imagens figurativas geralmente tratam com bastante interesse dessa descrição (ver Snodgrass, 2004, p. 162-5 e Hurwit, 1990, p. 181). A descrição é longa, e apresenta variados níveis da aproximação entre informação escrita e figurativa na constituição de uma descrição das figuras, mais a partir de suas referências míticas, que da caracterização material mais aprofundada; tanto que as tentativas de reconstituição de tal arca buscam paralelos na arte grega do período arcaico, época geralmente legada à produção da arca; cronologia que confia em grande medida nas informações que Pausânias dá sobre ela.

Essa coletânea de informações mostra a dificuldade de verificação da articulação da linguagem escrita e figurativa de forma coesa nas fontes literárias (é preciso, para um levantamento consistente, ir de Homero a Pausânias, o que apresenta alguns problemas históricos de cunho cultural e temporal. Os relatos são bastante distantes temporalmente, e comentam tal interação em suportes diversos. Com isso, observa-se que tal questão, como tema literário, tinha relevância pequena na Antigüidade, e que as reflexões sobre a aproximação entre escrita e figuração restringem-se mais à constatação imediata (sua verificação em descrição), que uma abordagem filosófica do tema.

Observados os contornos da temática proposta, e as justificativas da seleção documental, cabe apresentar resumidamente a estrutura da dissertação; ou seja, os caminhos tomados para o tratamento da articulação gráfica entre escrita e figuração nos vasos gregos (áticos) do período arcaico. Como visto, a abordagem transita entre o geral e o específico; tentando observar, a partir de contribuições variadas, as especificidades gregas.

O primeiro capítulo (Aspectos teórico-metodológicos) apresenta concentradamente as questões de cunho teórico e metodológico concernentes à analise proposta, mas não esgota absolutamente tal tratamento, que será cotizado ao longo da dissertação. Dar-se-á, então, com maior interesse uma discussão sobre os contornos múltiplos das relações entre escrita e figuração (fonte escrita e fonte material, tradição escrita e tradição visual [gráfica], cultura material e cultura do texto), buscando compreender suas interações e distanciamen- 
tos, tanto no que se refere às dinâmicas próprias da Antigüidade, como o tratamento do problema na bibliografia.

Tal cenário será observado sob a ótica das perspectivas arqueológicas (sobretudo as da Arqueologia Histórica); bem como da Epigrafia grega (o estudo das inscrições, seu conteúdo e materialidade [estilo e suporte]). Nesse ponto, será apresentada a idéia de observação da trajetória dos objetos; ferramenta metodológica que acompanhará em grande medida as análises e interpretações.

O capítulo 2 (As balizas espaço-temporais) tratará da construção dos limites temporais e geográficos utilizados aqui. De início, cabe dizer, as tradicionais balizas "período arcaico" e "Atenas", "Ática", "Grécia" e "Mundo grego", são insuficientes em si, e sua adequação deve ser discutida. Para isso, os contornos da documentação tratada ajudará em grande medida.

Após essas discussões, o gráfico como problema antropológico e histórico será tratado; bem como as formas gráficas e não gráficas de articulação entre escrita e figuração; de início, de forma generalista, mas posteriormente, buscando passo a passo a compreensão desse cenário no Mediterrâneo, numa perspectiva histórica. Esta é a temática do capítulo 3 (O gráfico, da origem às especificidades gregas), que inicia com um breve tratamento abstrato sobre o gráfico (a organização a partir da linha e do contraste), e como isso pode proporcionar, desde tempos "pré-históricos", comunicação como estrutura rítmica. Serão tratadas questões próprias da história da escrita e seus pontos de união com a imagem figurativa, explorando desde formas pictográficas de escrita, até a redução abstrata de alguns sistemas de escrita, como o alfabeto.

A interação entre escrita e arte figurativa em várias culturas do Mediterrâneo será tratada, concentrando-se na experiência do cuneiforme e dos hieróglifos. Disso, partir-se-á para a Península Balcânica, e como se organiza na região escrita e figuração, tendo sempre no horizonte o problema da aproximação dos dois sistemas de linguagem. Assim, concentrar-se-á brevemente sobre os hieróglifos cretenses, o Linear A, o Linear B, e o desaparecimento, na região, da experiência da escrita e da arte figurativa.

Por fim, já no exemplo grego, serão tratadas questões próprias da organização da articulação gráfica no seio das oficinas ceramistas. Assim, as contribuições externas e internas serão avaliadas na análise das estratégias de articulação gráfica na Ática do período arcaico; bem como o espaço como elemento definidor de aspectos das mudanças e permanências na produção gráfica.

O capítulo 4 (Sobre a documentação), tratará de questões próprias da documentação selecionada. Entretanto, longe de uma apresentação em forma de catálogo, serão perseguidos aspectos pertinentes para a análise gráfica dos grafismos sobre a cerâmica. $O$ tratamento específico da documentação será precedido de duas discussões de caráter mais am- 
plo, mas de grande aproveitamento para a compreensão específica: trata-se da própria noção de documento relacionada ao tipo de material aqui analisado, bem como as limitações concernentes ao acesso da documentação.

A documentação é formada por vasos de cerâmica áticos; sobre os quais, aqui, será lançada uma observação de um aspecto: a relação escrito-figurativa. Assim, como a compreensão dos grafismos depende da compreensão do seu suporte, e de como este se inseria socialmente, três pontos, nessa linha, serão apresentados: questões sobre a trajetória ampla desses vasos; uma caracterização das formas gráficas e a lógica da interação ornamentação-suporte.

Por fim, o capítulo 5 (Um estudo de caso: as ânforas panatenaicas), reunirá grande parte das questões apresentadas ao longo da dissertação para a compreensão da inserção social de um tipo específico de vaso: as ânforas panatenaicas. Assim, a ambientação histórica e a caracterização material, auxiliarão a compreensão de um tipo de vaso excepcional por vários motivos: era um tipo de premiação num evento especial, havendo quem os trate como "vasos públicos". Ainda, tinham ornamentação tradicional, cunhada no período arcaico, mas que alcança o período romano (há indícios de sua continuidade até o século IV d.C.).

Esses vasos, assim, fornecem um arsenal de informações que permitem mapear com certa clareza as trajetórias amplas, e, nesse cenário, buscar-se-á compreender a interação escrito-figurativa, e o valor que poderia assumir no contexto original (sua produção nas oficinas áticas e premiação nos jogos panatenaicos), e em outros vários contextos em que foram utilizados.

A conclusão, voltando-se aos resultados interpretativos, buscará organizar as contribuições que esta discussão sobre a interação gráfica (escrito-figurativa) pode oferecer para a narrativa da Antigüidade grega. Retomando a hipótese inicial de que a proposta gráfica que unifica escrita e figuração, não o faz absolutamente. Assim, questões específicas formais e contextuais serão observadas para avaliar o grau de proximidade e distanciamento. 


\subsection{Fontes escritas e materiais: as múltiplas relações}

Uma imagem vale mais que mil palavras.

(Domínio público)

Não é recente a tentativa de encarar de forma opositiva, ou havendo distâncias abismais, palavras e imagens. Elas se confundem, e apenas uma caracterização mais específica pode (ou tenta) separá-las. Vistas de forma abrangente, palavras (ditas, escritas etc.) formam imagens, e a própria caracterização das letras que formam as palavras escritas são imagens. Mesmo a abordagem restritiva não as separa absolutamente; entretanto há domínios próprios.

Se o potencial das palavras não comporta uma imagem visual, se não se pode descrever de forma integral imagens com palavras como sugere a epígrafe, o inverso parece verificar-se. Isso, pois a imagem quando intenta fazer a vez de palavra usa recursos próprios (seja uma pintura abstrata ou um instantâneo fotográfico), convertendo-se em nova informação, e algo das palavras acaba perdendo-se. Porém isso não indica um compromisso maior com a realidade por parte de uma ou outra. Configura-se oposição? Mais coerente é pensar em complementaridade com campos de autonomia e sem hierarquias naturais; dessa forma, cabe entender que quando as hierarquias existem, são socialmente estabelecidas.

Somos herdeiros de uma cultura que muitas vezes distanciou aspectos da escrita e visualidade (ou da cultura material, de forma mais ampla), constantemente vistas como opositivos. Jean J. Rosseau, em 1781, nas Confessions (1765 seq.) ${ }^{1}$ diz:

ignoro o que fiz até os cinco ou seis anos, não sei como aprendi a ler, só me lembro das minhas leituras e do efeito que sobre mim produziram: é o tempo a que faço rememorar, sem interrupções, a consciência de mim próprio.

Vê-se, em Rosseau, que é o processo de letramento (a tradição do texto) que compõe de forma substancial a "sua história", e é também o filtro para rememorá-la. Entretanto, em uma época posterior, Marcel Proust (1871-1922) apresenta outra forma de conceber o passado, a partir da materialidade das coisas, como no conhecido caso da petite madeleine, são despertadas sensações que remontam ao passado, processo "(...) diferente do que nos apresenta a memória da inteligência sobre a requisição de nossa vontade".2

\footnotetext{
${ }^{1}$ Apud Cazade, E. \& Thomas, C. Alfabeto. In: ENCICLOPÉDIA Einaudi, 1987, p. 178.

${ }^{2}$ Proust, M. La petite Madeleine. In: À la recherche du temps perdu. Galimard, Vol. I, p. 701.
} 
Afora as questões da "racionalidade" (no caso de Rosseau) e do "instinto" (no caso de Proust), o passado, ou melhor, a memória é concebida a partir de objetos diferentes, o textual e o material. Essa delimitação apresenta de forma metafórica a própria discussão que, nas Ciências Humanas, trata (desde o século XVIII) da viabilidade das fontes escritas e materiais como instrumento para o estudo de sociedades passadas; questão inquietante e ainda atual. Essa delimitação baseou a atividade dos estudos históricos e arqueológicos e de outras áreas, e mesmo a aproximação dos objetos propôs, em vários casos, hierarquias entre ramos de estudos e mesmo entre fontes. Sobre a utilização de fontes "artísticas" e literárias ${ }^{3}$ para a compreensão do passado Oscar Wilde chega a dizer:

Você acredita que a mulher ateniense era como as imponentes e dignificadas figuras dos frisos do Pártenon, ou aquelas maravilhosas deusas que permaneciam sentadas nos frontões triangulares de alguns templos? Se você julga através da arte, elas certamente eram assim. Mas leia uma autoridade, como Aristófanes, por exemplo. Você irá descobrir que as damas atenienses eram (...) como qualquer criatura de bom gosto ou frívola de nossos próprios dias. O fato é que nós olhamos o passado inteiramente através da arte, e arte, muito afortunadamente, nunca, por uma só vez, contou-nos a verdade. (Wilde, O. The decay of lying. An observation. 1891. Apud Bazant, 1981, p. 13)

Emblemática, é a caracterização de períodos da História humana na qual a escrita ocupa papel central (balizador): antes dela, a "pré-história", e após seu desenvolvimento, o período "histórico" propriamente dito. Essa caracterização serviu a um discurso imperialista europeu que propunha "civilizar" populações de locais onde ainda se vivia uma "préhistória", ou melhor, um estado de "barbárie"; e nesse contexto chama a atenção casos como o da Austrália, onde ainda não se havia desenvolvido a escrita até a chegada dos europeus, e nessa linha de raciocínio, vivia sua "pré-história" até o final do século XVIII. ${ }^{4}$ Eric Havelock (1996, p. 101) chega a dizer que "tornou-se moda nos países industrializados considerar as culturas não-letradas como não-culturas"; pois muito se utilizou a dicotomia não letrado:letrado como equivalente a barbarismo:civilização e primitivo:avançado (Funari, Hall \& Jones, 1999, p. 3 e 5); havendo, inclusive, criação de categorias para indicar o afastamento da civilização: E. B. Tyler, que influenciou fortemente vários arqueólogos ingleses no século XIX, no seu ensaio Researches into the Early History of Mankind (1865), chegou a ca-

\footnotetext{
${ }^{3}$ Compreende-se, aqui, por "fontes literárias", aqueles registros humanos de formulação verbal, desde o discurso oralmente articulado, até o texto escrito; e não o estilo ou campo intelectual relacionado à produção escrita que se convencionou chamar de Literatura, Estudos literários etc.

4 “As fontes históricas convencionais só começam com o nascimento do documento escrito, que se produziu na Ásia Ocidental em 3000 a.C. aproximadamente, e bastante mais tarde em outras partes do mundo (na Austrália, por exemplo, não existiu até 1788 d.C.). Por esta razão, é bastante comum a distinção que se faz entre préhistória - o período anterior à escrita - e história no sentido estrito, que supõe o estudo do passado através da evidência escrita." Bahn \& Renfrew, 1993, p. 10.
} 
racterizar o Paleolítico como equivalente ao estado de selvageria, e o Neolítico como estado de barbárie, "sendo a categoria civilização reservada às sociedades organizadas em alguma forma de Estado e que praticavam, pelo menos, um certo grau de escrita" (Clark, 1985, p. 61). Nesse sentido, mais sofisticado foi o antropólogo norte-americano, Lewis H. Morgan, que subdividiu tais estágios da seguinte forma: ${ }^{5}$

\begin{tabular}{cl}
\multicolumn{1}{c}{ Estágios sociais } & \multicolumn{1}{c}{ Indicadores materiais } \\
\hline \hline VII Civilização & Inscrições \\
VI Barbárie Superior & Ferro \\
V Barbárie Média & Animais e plantas domésticos \\
IV Barbárie Inferior & Cerâmica \\
\hline
\end{tabular}

\begin{tabular}{cll}
\multicolumn{1}{c}{ Estágios sociais } & \multicolumn{1}{c}{ Indicadores materiais } \\
\hline \hline III Selvagismo Superior & Arco e flecha \\
II Selvagismo Médio & Pesca, fogo \\
I Selvagismo Inferior & - \\
\hline
\end{tabular}

Tabela 1. Estágios na evolução social da humanidade, segundo L. H. Morgan.

Essa visão, há algum tempo, vem sendo relativizada; por exemplo, um ciclo de conferências intitulado Religions des peuples sans écriture ${ }^{6}$ dirigido por C. Lévi-Strauss desde 1951 (quando substituiu M. Leenhardt), teve na sua origem (em 1888, e até 1954) o nome Religions des peuples non civilisés (Lévi-Strauss, 1997, p. 77-8 - grifos meus). Essa mudança buscou justamente discutir de forma mais crítica o binômio escrita-civilização.

No caso dos estudos sobre a Grécia Antiga, muito se utilizaram as fontes materiais, pois boa parte da documentação escrita é irregular, fragmentária e chegou até a atualidade através de interpretações de copistas; sem contar as traduções que, como se sabe, são, em certa medida, "recriações". ${ }^{7}$ Ora, nesse caso, então, a fonte material mostra-se bastante viável. Entretanto, pode legar-se esse papel de preenchimento de lacunas à cultura material? Quando isso é feito incorre-se em erro, pois se deve lembrar que a relação entre o homem e cultura material é bastante antiga e constante. Desde tempos "pré-históricos" o homem apropria-se das matérias naturais para seu uso, dessa forma, talha, pinta, faz incisões, arrasta coisas de um espaço para outro, cobre-se quando sente frio, dentre várias outras ações, que não devem ser interpretadas sob o ponto de vista puramente utilitário: elas se inserem em esferas mais amplas, e, dessa forma, informam mais que o puro uso ou técnica de produção.

\footnotetext{
${ }^{5}$ Ancient society or researches in the lines of human progress from savagery to civilization, 1877. Apud Clark, op. cit.

${ }^{6}$ C.N.R.S., publicado pela seção de Ciências Religiosas na ocasião do centenário da École Pratique de Hautes Études, sob o título Problèmes et méthodes d'histoire des religion. Paris: Presses Universitaires de France, 1968.

7 Quanto à documentação material, o acesso também é, em grande parte, indireto (como a experiência deste pesquisador nesta dissertação): reproduções fotográficas que privilegiam posições específicas, apresentação de detalhes, ou então desenhos, esquemas etc.; no caso das fotografias em cores, para além dos contrastes bem revelados, as gamas tonais são variadas (qual a verdadeira cor da grande ânfora do Pintor de Nessos? Tive acesso, pelo menos, a quatro imagens que apresentavam tons bem diferentes), o que coloca certos limites para a análise gráfica. No entanto, para além desses limites, existe a possibilidade de lidar com o original, em alguma exposição ou reserva técnica de museus ou coleções particulares (o original ainda existe!); situação impossível no caso de grande parte dos originais dos textos antigos, irremediavelmente perdidos. (Para maior detalhamento das questões sobre tais limites, ver capítulo 4, item 4.2).
} 
A ocorrência da escrita, de uma cultura literária e do letramento é bastante recente se se levar em consideração a ampla experiência humana (desde o Homo sapiens); LéviStrauss, adverte que o alfabeto (técnica em torno da qual se desenvolveu em grande parte o conhecimento ocidental), corresponderia a apenas $0,35 \%$ da experiência humana. ${ }^{8}$ Assim, relegar à cultura material um papel secundário é subestimar essa permanente experiência entre as sociedades. Deve-se ainda lembrar que nas mais variadas épocas passadas, como ainda hoje, a totalidade da população humana relaciona-se diretamente em algum nível de sua vida com a cultura material, coisa que não acontece com a cultura letrada ${ }^{9}$; e mesmo a escrita pode ser vista a partir de sua materialidade, e assim se explorar inúmeras questões, dentre elas o estilo de letra, seu suporte, processos editoriais, instrumentos de escrita, circulação de livros, processo de letramento. Sobre o último, Sigmund Freud, submetendo em certo grau essa prática ao filtro da sexualidade humana, dá um interessante exemplo, sobre o processo de aprendizado de um jovem, frente ao problema da distinção fonética das letras $m$ e $n$ :

A tia faz-Ihe notar que a letra $m$ tem uma perna a mais que a letra $n$. Não haveria qualquer razão para contestar a autenticidade desta recordação de infância; mas o significado da recordação só se revelou mais tarde, quando se verificou que era possível interpretá-la como uma representação (substitutiva) simbólica de outra curiosidade da criança. Porque, tal como pretendia saber nessa altura a diferença entre $m$ e $n$, procurou mais tarde conhecer a diferença entre menino e menina, e teria gostado de ser instruído dessa maneira pela tia em questão. Acabou por descobrir que a diferença entre menino e menina é a mesma que entre $m$ e $n$, ou seja, que o menino tem qualquer coisa mais que a menina, e foi na época em que adquiriu esse conhecimento que nele despertou a recordação da lição do alfabeto. (Freud, S. Lembranças da infância e lembranças encobridoras. Apud Cazade \& Thomas, op. cit., p. 180)

A partir dessa narrativa, Freud acaba mostrando a importância da dimensão material, nesse caso analógica, na compreensão de certos traços do universo da escrita. Assim, é comparando com um paralelo biológico que se fixa a diferença entre as duas letras, ou seja, nesse episódio é a forma material que distingue, mais adequadamente que a fala.

Realçar a importância da cultura material não significa dizer que a cultura literária é hierarquicamente inferior àquela nos procedimentos analíticos do passado e do presente, mas de relativizar a exacerbada importância dada ao texto como explicador e vetor da ação

\footnotetext{
8 "(...) a agricultura nasceu no curso de uma fase recente correspondente a $2 \%$ dessa duração, a metalurgia a 0,7\%, o alfabeto a 0,35\%, a física galileana a 0,035\% e o darwinismo a 0,009\%" (Lévi-Strauss, op. cit., p. 408; baseado em Leslie A. White, The science of culture, p. 356).

${ }^{9}$ Fala-se aqui de um acesso direto, já que mesmo sem dominar a escrita, ela pode ser usada como mediadora, socialmente falando. É comum, por exemplo, que analfabetos possuam carteira de identidade, com números e palavras que o individualizam no seu grupo.
} 
humana no planeta, uma "tirania do texto", nos termos de David B. Small. ${ }^{10}$ (É bastante indicativo disso, que o primeiro número da Revista Annales d'Histoire Économique et Sociale, que propunha "novos ares" na discussão histórica, que ainda tinha um ranço positivista nas primeiras décadas do século $\mathrm{XX}$, apresentou como primeiro artigo na sua primeira publicação um estudo de Gustave Glotz, em que se discute, em bases economicistas, um suporte da escrita na Grécia antiga ${ }^{11}$ ). Assim, distante da universalização do texto como fonte, mesmo quando a informação escrita abunda, é importante que se lance mão da fonte material.

As relações entre fonte material e escrita podem ser observadas de três diferentes formas, que não são necessariamente excludentes entre si:

1) Fonte material frente à fonte escrita - relativo à viabilidade do uso e ao estatuto da fonte material numa situação que privilegia o texto escrito como fonte;

2) Fonte material cruzada com a fonte escrita - o que propõe a discussão da natureza e especificidade de cada fonte, para que o cruzamento seja bem sucedido;

3) Fonte material e fonte escrita como uma só fonte - o caso dos documentos estudados pela Epigrafia, Papirologia, Paleografia, Diplomática e áreas afins.

O primeiro ponto já foi tratado brevemente. A seqüência deste capítulo tratará dos dois últimos pontos, tendo em vista que a entonação principal deste estudo concentra-se no último ponto, que resume os problemas centrais desta redação.

\subsection{Relação temática, material e conceitual}

Uma das características da cerâmica grega produzida na Antigüidade é sua ornamentação ${ }^{12}$ em torno da qual se desenvolveu, ao longo do tempo, inúmeros ramos de pes-

\footnotetext{
${ }^{10}$ Small, D. B. The tyranny of the text: lost social strategies in current historical period archaeology in the classical Mediterranean. In: Funari, Hall \& Jones, 1999, p. 122-36. Esse pesquisador diz que, em alguns casos (como as modificações materiais no cemitério do Cerâmico e da Syndagma Square, que ele analisa), para além da comum utilização dos textos escritos junto à pesquisa arqueológica, uma abordagem etnoarqueológica (a comparação com um cemitério em Nashville, EUA) seria mais fecunda.

${ }^{11} \mathrm{O}$ artigo em questão é Le prix du papyrus dans l'Antiquité grecque. Annales d'Histoire Économique et Sociale. Tomo Primeiro, Paris, 1929, p. 3-12.

${ }^{12}$ A ornamentação a que se faz referência é bastante ampla; trata-se da técnica de figuras negras: a aplicação de verniz e desenho sobre ele com estilete; e ainda, por vezes, a aplicação de tinta branca e rubra em alguns
} 
quisa visando a compreensão da cultura, sociedade, política, economia etc., dos gregos antigos. Além da chamativa decoração figurativa (que privilegiou freqüentemente a figuração do ser humano, mas não somente dele), havia inscrições que conviviam com essas imagens. A região da Ática, liderada por Atenas, teve uma grande participação nesse processo, o que promoveu um amplo acervo documental. Para o início da análise dessas formas de linguagem (inscrição e imagem figurativa na cerâmica ática), é necessário antes o entendimento da natureza dessa interação escrito-figurativa. ${ }^{13}$ Relacionar tradição escrita e imagética para a compreensão de estruturas da Antigüidade não é novidade; porém nem sempre essa aproximação pode ser vista de forma homogênea: há variantes.

A primeira está vinculada à aproximação bastante comum entre fontes visuais e literárias feita por estudiosos contemporaneamente. Nessa situação, as imagens de vasos, esculturas, relevos etc., produzidos nas sociedades antigas, são interpretadas juntamente a textos antigos, que formaram documentação privilegiada para o estudo da História das sociedades antigas durante muito tempo. Para entender, por exemplo, como era vista determinada divindade, os dois tipos de fontes são articuladas, propondo possíveis explicações. Vale atentar que essa aproximação atende, principalmente, as necessidades da pesquisa acadêmica desde a modernidade. ${ }^{14}$

Quando o autor da literatura antiga se referia a uma determinada divindade, quando a caracterizava, não havia necessariamente ligação direta com alguma imagem figurada relativa ao mesmo tema; e o artesão-artista quando criava suas imagens, baseava-se também num repertório oral que the fornecia modelos; assim, não se tratava de uma resposta imediata aos textos de Homero ou Hesíodo, um exemplo para se fixar no período arcaico. ${ }^{15}$ Aproxima-se, desde a modernidade - pelo esforço acadêmico que visava (e visa) entender o passado -, criações independentes que não tinham relação imediata na Antigüidade, por mais que falassem de um mesmo tema. Portanto, uma relação temática.

Diferentes disso, as fontes epigráficas apresentam uma outra forma de ver essa relação. Elas compõem importante categoria de documento arqueológico, já que têm seu con-

detalhes. As formas são geométricas e orgânicas; desde a delimitação de espaços até cenas figurativas (homens, animais etc.).

13 Aqui, a formulação da entidade "escrita e imagem" é dada, de início, a partir da sua coexistência num mesmo suporte. Materialmente falando, essa é a aproximação mais básica entre inscrição e figuração, o que não permite, ainda, visualizar a sua dinâmica e uma articulação mais profunda.

14 "Modernidade" é um termo assaz amplo. Interessa aqui o impulso que se deu na Europa, por volta dos séc. XIV e seguintes, caracterizado em boa parte pelo interesse sobre a Antigüidade clássica.

${ }^{15}$ Para uma discussão da complexidade da relação entre relatos orais, escritos e a produção de imagens visuais, relacionados ao Ciclo Troiano, ver Snodgrass, 2004. Ainda, vale a pena citar Dugas (1937, p. 59); que, ao discutir os paralelos entre a poesia e a imagística na pintura de vasos gregos, denunciada por Carl Robert, diz: "Eu gostaria (...) de mostrar que existe uma tradição gráfica autônoma, independente da tradição literária. A maior parte das vezes a tradição gráfica é paralela à tradição literária, ela a duplica, a completa em derivação evidentemente da mesma forma poética dos temas. Mas em outros casos, ela não é somente independente da tradição literária, ela é oposta, e ela nos dá uma variante da lenda incompatível com a variante conservada pelos textos". 
texto (lugar de achado, suporte físico, forma etc.) assegurado, ao contrário da tradição literária que guarda conteúdo e forma literária do que foi escrito, chegando aos dias atuais indiretamente. Além disso, as informações epigráficas aparecem articuladas a imagens figuradas em vários casos. A aproximação entre escrita e figuração num mesmo suporte é antiga nessas condições; pensada e criada em sociedades passadas; com isso, não apenas a inscrição e a imagem figurada são objetos de estudo, mas também a sua própria relação antiga (ou seja, contextual): uma relação material.

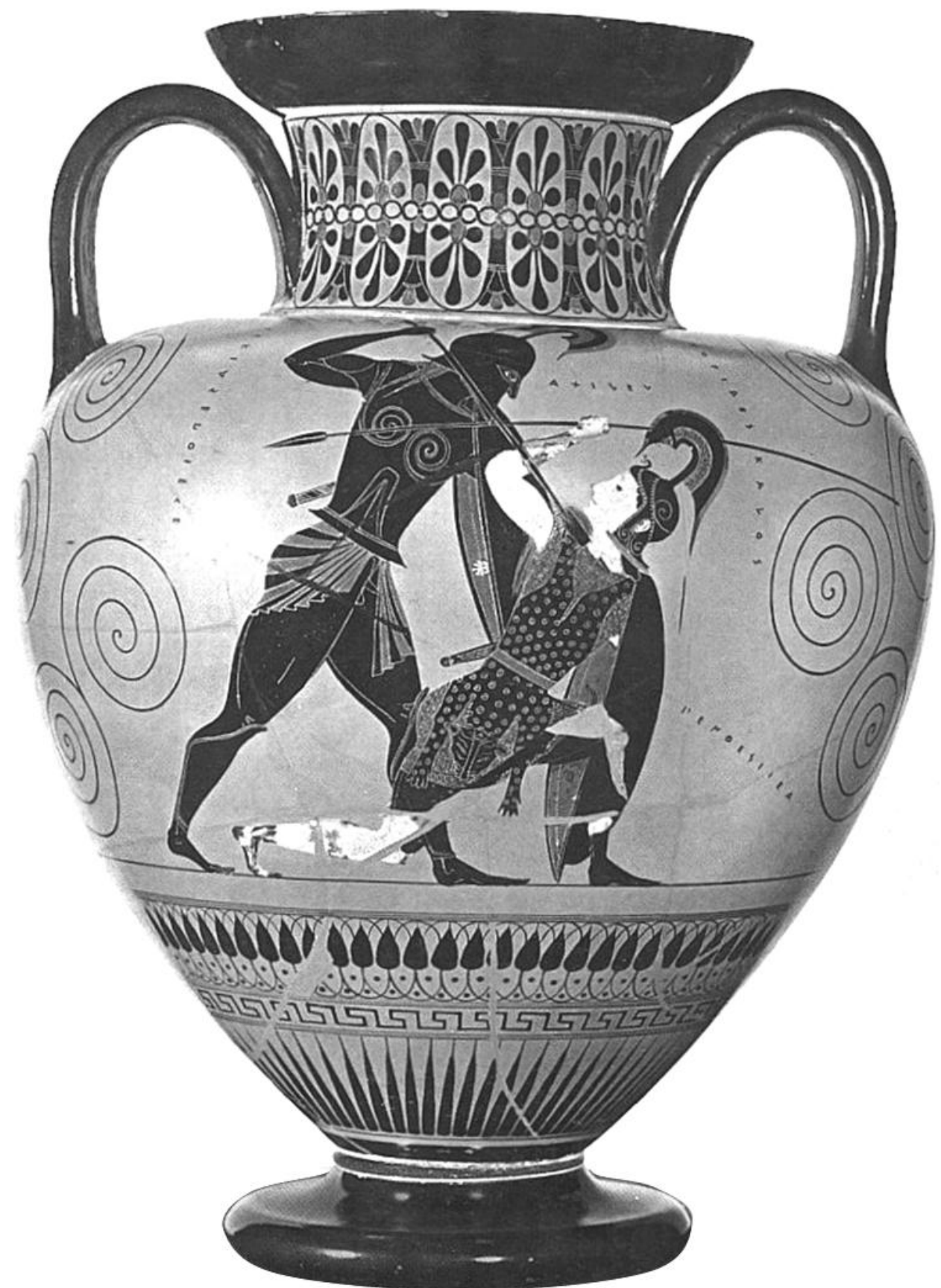

Fig. 1. Face de ânfora executada por Exéquias: Cena de luta entre Aquiles e Pentesiléia, c. 530 a.C. Londres, Museu Britânico (alt:: $41,6 \mathrm{~cm}$ ). 
As relações materiais e temáticas podem parecer essencialmente contrastantes, mas nem sempre isso é verdade, já que uma relação temática pode inserir-se numa material. Uma ânfora ática do período arcaico, confeccionada por Exéquias, apresenta isso em parte de sua figuração (ver fig. 1). Ao lado das personagens Aquiles e Pentesiléia há inscrições que as identificam; ou seja, uma relação temática antiga concernente a uma material (também antiga, por definição). Mesmo nos casos de aproximação entre tradição escrita e imagética, encontram-se pontos de articulação material antiga. Nesse mesmo vaso, além das inscrições que nomeiam Aquiles e Pentesiléia, há outras: de autoria e de homenagem. Ainda, na outra face observa-se a mesma estrutura: inscrições denominam duas figuras mitológicas e há uma inscrição de autoria. ${ }^{16}$

Esse breve exemplo mostra que a análise do relacionamento escrito-figurativo deve preocupar-se com a variedade dessa aproximação. Nesse sentido, uma lição dada pela matemática pode elucidar a compreensão desse comportamento: trata-se do princípio de fórmula, numa acepção próxima da utilizada pelas ciências naturais. De início é necessário dizer que tal termo é presente na bibliografia que trata a relação escrito-figurativa (e afim). Por exemplo, Charles Dugas (1924, p. 37) usou-o para designar a interação das inscrições de autoria; e François Lissarrague (1990, p. 15 e 16), que freqüentemente discute a relação escrito-figurativa, utiliza-o também, assim como o termo equação.

O dicionário Houaiss registra para a palavra fórmula, dentre vários significados, a rubrica na área da matemática como "expressão que define com rigor tanto as relações fundamentais entre os termos que entram na composição de um todo, como as regras estabelecidas por tipo de operação". Na Matemática, Física e Química (“linguagens formalizadas” ou "línguas artificiais") ${ }^{17}$, uma fórmula, basicamente, constitui-se de partes autônomas, independentes, que se inter-relacionam e produzem algo diferente $(x-y=z, x+y . z=w$ etc. $)$, mesmo que a natureza quantitativa seja equivalente (por exemplo, $1 \times 1=1$; entretanto cada parte tem significado diferente na fórmula). A lógica da organização matemática dos numerais, e sua múltipla articulação, pode ajudar a entender a natureza da relação escrito-figurativa num mesmo suporte. Um exemplo, a articulação de dois numerais diferentes como o "1" (um) e o "2" (dois). Sua justaposição simples indica dupla informação: o numeral "12", ou invertido "21", que na compreensão dos números aplica resultado bem diferente (uma dezena e duas unidades, e duas dezenas e uma unidade, respectivamente). A sua justaposição e a inser-

\footnotetext{
${ }^{16}$ Para uma visão mais aprofundada sobre os grafismos desse vaso (ver capítulo 3, item 3.4). Ainda, vale dizer que tal vaso será retomado em momentos variados deste estudo, dado que, foi a partir dele que surgiu meu interesse sobre a questão da articulação entre escrita e figuração. O primeiro exercício, pouco desenvolvido, de interpretação deu-se na apresentação de um seminário no curso de "História social da arte", ministrado pelo professor Ulpiano Toledo Bezerra de Meneses, no Departamento de História da FFLCH-USP, no segundo semestre de 2003.

${ }^{17}$ Eco, U. (1971) A estrutura ausente. Introdução à pesquisa semiológica. (trad.: Pérola de Carvalho), São Paulo: EDUSP, Ed. Perspectiva, 1971. p. 401.
} 
ção de outros sinais gráficos, que a matemática utiliza, apresenta resultados ainda mais di-

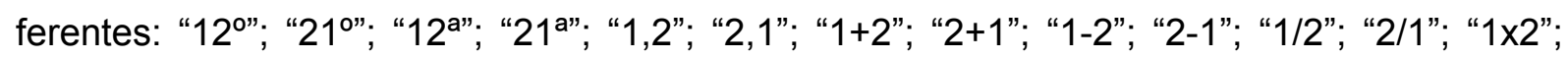
"2x1"; "12"; "21"; e muitos outros possíveis. Os resultados são variados: "décimo segundo"; "vigésimo primeiro"; "décima segunda"; "vigésima primeira" (note-se a diferença localizada na idéia de gênero); "um inteiro e dois décimos"; "dois inteiros e um décimo"; “3"; "3"; “-1"; “1"; “0,5"; “2”; “2”; “2"; “1”; "2"; respectivamente. ${ }^{18}$

A aproximação entre imagem figurativa e inscrição pode ser equacionada da seguinte forma: [imagem] e [inscrição] = [resultado variado]. Dependendo do tipo de inscrição e de imagem visual, pode obter-se uma especificação da identidade da figuração e (ou) a composição de um esquema visual, dentre muitas outras possibilidades. Percebe-se, dessa forma, que identificar apenas uma combinação simples leva a uma compreensão pobre da relação entre escrita e figuração, já que é necessária a compreensão das suas múltiplas articulações, permitindo identificar vários resultados (significados diversos dessa relação escrito-figurativa). Claramente não é sempre o caso de uma soma simples que se deve procurar, e a própria idéia de relação, amplamente utilizada aqui, deve ser relativizada, pois se liga a um tipo de operação fundamental específica. Essa abordagem torna-se fundamental, pois se pode identificar várias formas de escrita e imagem figurada na cerâmica ática (falar em escrita e figuração, no singular, pode levar a ignorar sua variedade). Aqui, sempre que se falar em escrita e figuração, buscar-se-á uma acepção abrangente; assim, desde fórmulas mais simples até as mais complexas.

No cerne da relação escrito-figurativa localiza-se a tradição oral que basearia a criação escrita e imagética em grande parte; entretanto, mesmo com isso, a trajetória da escrita e da imagística são diferentes, ainda que paralelas. Ambas reapareceriam na Grécia no início do período arcaico, mas em contextos próprios. Ainda, a trajetória de determinadas palavras (resgatadas pelo estudo etimológico) é bastante específica; bem como o percurso da formulação visual de muitas figuras humanas ou humanizadas. Não é sempre que ocorre comprovada influência entre fonte imagética e literária, situação clara em textos como os de Pausânias, na sua Descrição da Grécia. ${ }^{19} \mathrm{Em}$ alguns vasos, mesmo quando essa aproxi-

\footnotetext{
${ }^{18}$ Ainda, as fórmulas não indicam apenas a logicidade da relação entre números puros, mas muitas vezes correspondências entre medidas de natureza muito diferente. No campo da física, por exemplo, isso é bem explicitado: medidas de extensão lineares $\left(m\right.$, metro), de área $\left(\mathrm{m}^{2}\right.$, metro quadrado), de volume $\left(\mathrm{m}^{3}\right.$, metro cúbico) de tempo, ( $h$, hora; s., segundo), de peso ( $N$, Newton), de massa ( $g$, grama) etc., podem ser articuladas e a expressão final apresenta algo que não se restringe a uma delas, mas a novas dimensões não correspondentes, em seu significado, a nenhuma das partes originais. Têm-se então, $\mathrm{m} / \mathrm{s}^{2}, \mathrm{Km} / \mathrm{h}, \mathrm{m} / \mathrm{s}$ etc.

${ }^{19}$ Um outro exemplo bastante claro de uma relação direta entre texto escrito e fonte material. De forma breve, Eurípides, em Íon (183 e seq.), descreve imagens:

"- Não é só na sacrossanta Atenas que os deuses têm templos de belas colunas e se pratica o culto do Agieu: também junto de Lóxias, filho de Leto, existe a visão luminosa, deslumbrante, de um templo de duplo frontão.

- Olha! Vem ver isto: o filho de Zeus a matar a hidra de Lerna com setas de ouro! Vê-me isto, querida, com olhos de ver!
} 
mação é antiga, nota-se que além das inscrições que têm conteúdo ligado diretamente às imagens, existem outras que são completamente desconectadas delas no que se refere ao significado mais imediato (num mesmo vaso podem ocorrer inscrições de autoria, homenagens, legendas etc.), ou mesmo inscrições sem sentido algum.

Porém, se escrita e imagem têm particularidades na sua formulação, o ato de desenhar e de escrever, já na Grécia arcaica tinha uma única caracterização, ou seja, no grego antigo, o verbo graphêin indicava o ato de escrever e produzir alguns tipos de imagens (Lissarrague, 1992 e Holtzmann, 1993. Ver também Sarian, 1987, p. 17; Vernant, 1990, p. 399 e Funari, 2003, p. 85). Tanto a ornamentação em figuras negras e as inscrições, que têm procedimentos criativos diferentes, podem ser chamados de grafismos, tendo como base uma acepção antiga do termo que aproxima escrita e desenho conceitualmente. Dessa forma, há uma relação conceitual entre as duas atividades.

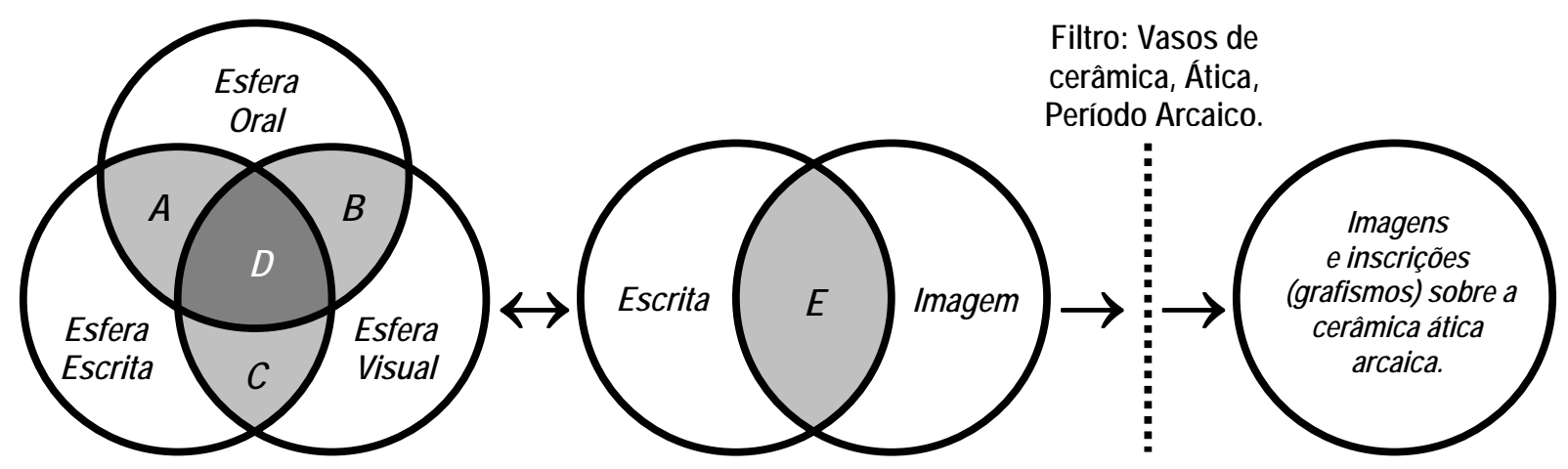

Esquema 1 - A. Relação entre Esfera Oral e Escrita - exemplo: registros escritos de narrativas mitológicas (llíada, Odisséia, Teogonia etc.); B. Relação entre Esfera Oral e Visual - exemplo: imagística (criação de imagens - pinturas, esculturas, relevos, bronzes, moedas etc.) a partir de referências orais; $\boldsymbol{C}$. Relação entre Esfera Escrita e Visual - exemplo: relatos escritos de fontes materiais como a Descrição da Grécia, de Pausânias; ou imagens comprovadamente criadas a partir de referências de textos escritos; $\boldsymbol{D}$. Relação entre Esfera Oral, Escrita e Visual - exemplo: coexistência entre escrita e imagem num mesmo objeto, de onde uma, ou ambas estruturas sejam influenciadas pela tradição oral; $\boldsymbol{E}$. Relação entre escrita e imagem - ela se expressa de duas formas principais: de forma temática (relação entre texto e imagem a partir do assunto de ambos) e (ou) material (articulação entre escrita e imagem num mesmo suporte: objetos de cerâmica, pedra, metais etc.). Dessa forma, relação temática e relação material.

A compreensão da relação entre escrita e imagem figurativa impele a uma visão mais ampla das estruturas da sociedade ática arcaica, e não apenas uma restrição ao universo da escrita e da imagística (ver esquema 1). É importante notar nesse diagrama a possibilidade de identificação de "espaços" interativos entre a linguagem escrita e visual (espe-

- Estou a ver. E mesmo ao pé dele outro herói qualquer está a levantar uma tocha em brasa ardente. Não será aquele cuja História é narrada pelos fios da minha tapeçaria, Iolau, o portador de escudo, que ao agüentar os mesmos trabalhos, sofre juntamente com o filho de Zeus?

- Olha para este, montado num cavalo alado! Está a matar aquela força bruta de triplo corpo, a que tem sopro de fogo.

- Não paro de correr por toda a parte de trás do meu olhar! Repara no combate de Gigantes nas paredes de mármore!

- Queridas, olhemos agora para aqui.

- Vê-la brandir contra Encélado o escudo de ferocíssimo aspecto...?

- Vejo Palas, a minha deusa.

- Então será que vês, nas mãos de Zeus que acertaram ao longe, o poderoso raio de pontas flamejantes?

- Vejo: reduz a cinzas com sua incandescência o feroz Mimas.

- E Brômio com seus tirsos de hera não-violentos - o Bacante abate outro dos filhos da Terra". 
cificamente, as inscrições e as imagens figurativas presentes em vasos de cerâmica), e mesmo numa perspectiva mais abrangente, das esferas oral, escrita e visual da cultura. Entretanto, essa interação não deve disfarçar as áreas independentes, e de coexistência restrita, pois é justamente aí que se identificam as especificidades de cada estrutura, tarefa essencial para ver com mais profundidade e clareza suas relações e seus limites interativos; ou seja, as prováveis aproximações e distanciamentos. Com isso, não se propõem oposições, como a erudição acadêmica muitas vezes fez, e faz; mas, ao contrário, complementaridades (guardando certa independência).

Outro ponto importante é a articulação entre o escrito e o figurativo, que poderia parecer apenas um cruzamento entre cultura visual e escrita; mas, como o esquema 1 mostra, ela deve considerar também a esfera oral da cultura; o que leva a concluir que os "espaços" interativos entre o escrito e o figurativo resultam de uma (ou estão inseridos em uma) articulação entre as esferas escrita, visual e oral. As imagens e inscrições sobre os vasos áticos compõem um grupo que é desenvolvido a partir de um caminho complexo, e não simplesmente linear como pode parecer. É cabível, dessa forma, fazer o caminho inverso (a partir desses grafismos até as estruturas mais complexas em que estão inseridos) sabendo que é uma vereda tortuosa, mas se bem trilhada, poderá informar a real importância desses grafismos na sociedade em que estavam inseridos. Restituir os quadros da cultura dos quais eles fazem parte permite não apenas uma compreensão da cultura como estrutura, mas de aspectos mais amplos. Sabe-se que há uma interação entre esferas como a política, cultura, sociedade, cotidiano etc., e que uma definição completamente purista de cada uma delas nunca é possível. Se a perspectiva liberal propõe a divisão mais aguda dessas estruturas, não se pode dizer que os gregos antigos procediam da mesma forma; e essa é uma chave importante para se desvendar os possíveis alcances, em campos variados, dos grafismos aqui tratados.

Como visto, a análise das informações escritas e figurativas, mesmo relacionadas num mesmo suporte, deve preocupar-se também com a dimensão independente de cada linguagem. De fato, esse é um problema complexo, e insere-se numa discussão atual mais ampla no ramo da Arqueologia Histórica: a necessidade de articular registros escritos e materiais de forma precisa, debate que auxiliará a pesquisa aqui proposta. O ponto de partida é que se é necessário cruzar essas fontes de natureza diversa em certa medida, como fazêlo? Pois uma apreensão simplista da questão não suportaria a amplitude dos processos produtivos e cognitivos envolvidos em cada uma dessas fontes. Nesse sentido

O confronto que nos últimos anos opôs a documentação textual (...) à documentação material (...) desviou a atenção a um fato capital: são dois sistemas documentais de natureza radicalmente diversa e, portanto, de objetivos e aproveitamentos diversos; podem fertilizar-se um ao 
outro, mas é impossível cruzá-los automaticamente. (...) Sobrepor uma evidência à outra é comprometer o que se pode extrair de um ou de outro sistema de fontes. ${ }^{20}$

Entretanto, essa discussão não deve encobrir o fato de que se existem problemas em cruzar fontes escritas e materiais, a dificuldade persiste quando se cruzam fontes materiais entre si, e o mesmo vale para as fontes escritas. O que se chama de "fonte material" na verdade abarca uma gama extremamente complexa e variada da ação humana. Quanto à cultura grega, pode exemplificar-se bem isso, e dar-se-á seqüência aqui a uma breve caracterização desse universo variado de fontes no que se refere à composição de uma temática mitológica que assumiu papel importante no período clássico: os Gigantes; cuja composição visual deu-se no período arcaico, e é esse fenômeno que se acompanhará agora.

Vale dizer que a caracterização desse mito, inicialmente, era imprecisa e vaga. $A$ oralidade, observada indiretamente pelo conteúdo das poesias homéricas, indica como referência algumas poucas informações soltas. Primeiro, o termo Gigante aparece associado à figura de Eurimedonte, "dotado de espírito grande, que entre os Gigantes altivos reinou nas idades passadas" (Odisséia, VII, 58-59); e ainda há a caracterização dos Ciclopes (VII, 204206) e dos Lestrigões (X, 119-121) como Gigantes. Uma referência mais precisa (porém também breve) seria feita por Hesíodo, na sua Teogonia: os Gigantes eram uma geração específica, criada a partir do sangue do pênis de Urano (o Céu) que jazia no Oceano, decepado por Cronos. Dessa forma, apenas esses seres, na tradição que Hesíodo remete, podem ser caracterizados como Gigantes; seriam eles "rútilos nas armas com longas lanças nas mãos" (Teogonia, 185-186). Como é possível observar, a caracterização de tal figura, que serve bem a narrativa literária, é bastante sumária (pode-se mesmo reduzi-la a uma excelência no combate).

Adiante, tratar-se-á da caracterização dessa mesma figura em composição material, tanto de forma escultórica, como gráfica, iniciando pela escultura, pois a primeira provável figuração de Gigantes deu-se em escultura quase plena, em pedra: o exemplar em questão é uma figura do frontão do templo de Ártemis em Corfou (ver fig. 2). ${ }^{21}$ No canto direito do frontão, em situação de combate com uma figura, provavelmente Zeus (pelo raio que segura), há um homem com um dos joelhos no chão, um braço atrás do oponente, e o outro

\footnotetext{
${ }^{20}$ Meneses, U. T. B. A fundação de cidades e o imaginário de Tito Lívio. Classica, 1989, São Paulo, v.1, p. 144. Ver também Sarian, 1999b, p. 69-84. Além dessas referências que tratam de forma breve a questão do cotejamento das fontes escritas e materiais, vale ver Funari, Hall e Jones 1999; onde as diferentes opiniões sobre o tratamento teórico dessa relação texto-fonte material são apresentadas, num balizamento que a compreende desde "o caso da abordagem de Small, onde ele enfatiza que as evidências material e escrita constituem independentes setores de dados, produzidos por diferentes processos sociais, e o argumento de Johnson, que elas são um produto do mesmo processo social" (Small, in: Funari, Hall \& Jones, 1999, p. 10).

${ }^{21}$ A interpretação não é segura, já que se pode tratar também do episódio da Titanomaquia, temática menos comum que a Gigantomaquia. Isso, que poderia indicar uma tendência a favor da interpretação da Gigantomaquia deve considerar que mesmo a figuração da Gigantomaquia era, nessa época (início do século VI a.C.), pouco comum.
} 
prostrado à frente de seu próprio dorso, com a mão na região do peito. A caracterização é de "estilo arcaico", e segue alguns dos cânones como o sorriso (perceptível, apesar da face fragmentada) e mesmo a estrutura do cabelo.
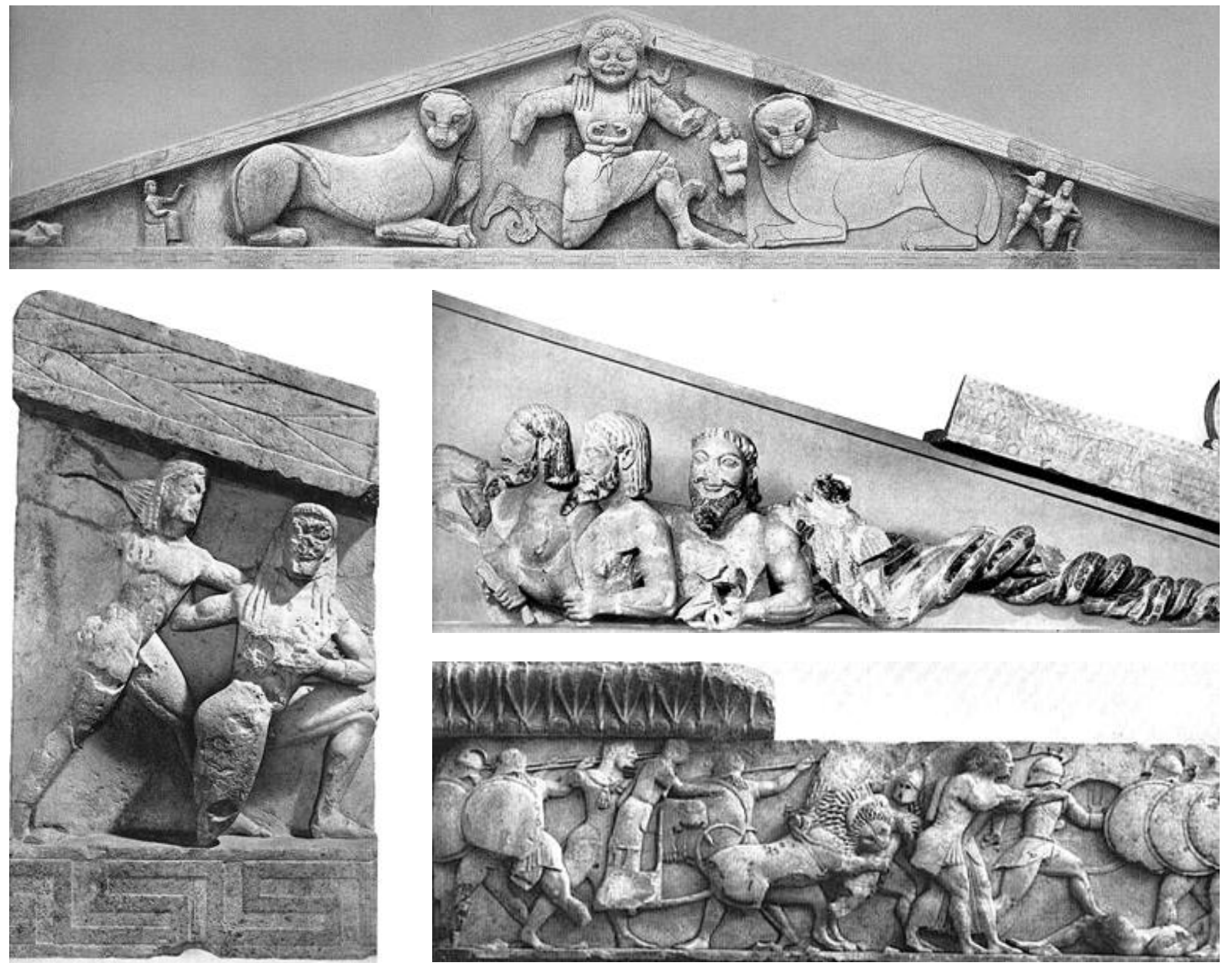

Fig. 2. (Acima e abaixo, à esquerda) Zeus fulminado gigante, ou titã. Frontão (e detalhe) do Templo de Ártemis, início do séc. VI a.C., Corfou, Museu de Corfou. Fig. 3. (à direita, meio) Elemento de templo arcaico da Acrópole (pedra calcária), c. 550-540 a.C., Atenas, Museu da Acrópole; Fig. 4. (à direita, abaixo) Detalhe do friso norte do Tesouro de Sifnos, c. 525 a.C.- Delfos, Museu de Delfos.

Deve chamar-se a atenção a alguns detalhes: o primeiro deles é a compleição física do provável Gigante, frente a Zeus. Dizer que esse é um traço característico de tal figura mitológica é proceder de forma ansiosa, pois se pode tratar apenas de uma adaptação ao esquema triangular do frontão. É comum nesses frontões esse tipo de organização das figuras, promovendo diversas proporções dos corpos, ou adequações ao espaço (figuras ajoeIhadas, deitadas ou com segmentos corporais que se encaixam nesses espaços). Os frontões do Pártenon, por exemplo, apresentam, no conjunto central, figuras em pé e, ladeandoas, figuras sentadas em cadeiras, no próprio "chão", algumas deitadas no canto, e, associadas a elas, há figuras em pé, em proporção corporal menor.

A luta entre Héracles e um Tritão, e mesmo o mostro com rabo de serpente e três corpos de um templo arcaico da Acrópole de Atenas, aparecem deitados, e acompanham 
todo o comprimento final do triângulo até seu vértice, estendendo os afilados rabos de serpente (ver fig. 3). Assim, a posição do provável Gigante no frontão de Corfou não é seguramente um signo de maior compleição física, já que nesse frontão, a partir de seus elementos remanescentes, é possível notar uma variedade de proporção corporal das figuras, seguindo, em parte, adaptações ao arranjo triangular.

Se parece distante o ponto inicial desta discussão, deve ter-se em mente que esses são problemas enfrentados pelo produtor dessas imagens. Caracterizar um Gigante em escultura apresenta uma série de problemas e busca de soluções materiais completamente ausentes no campo da literatura. O escultor, frente à pedra, provavelmente conhecia uma tradição que Ihe contava algo sobre esses seres (Gigantes ou Titãs), mas ela não poderia ajudá-lo precisamente na execução de alguns detalhes próprios da ação criativa da escultura e da arquitetura.

Rumando para uma caracterização mais segura da figura dos Gigantes, tratar-se-á agora de uma outra, em pedra, a Gigantomaquia do friso norte do Tesouro de Sifnos (ver fig. 4). A técnica é o relevo, e a apresentação da cena é bastante diversa da anterior: um grupo de deuses lutando contra um grupo de Gigantes, havendo figuras como leões nesse combate. A interpretação segura deve-se à recente descoberta de vestígios de inscrições pintadas associadas às figuras citadas. O combate, nesse contexto, é apresentado num esquema de fileira, bastante comum na imagística grega da época em vários suportes, o que já apresenta uma diversidade no processo criativo, se se relacionar ao exemplo de Corfu. Os problemas criativos estão ligados à técnica do relevo e a adaptação à faixa é bastante diferente do esquema triangular do frontão. Para isso, basta dizer que a estatura física dos deuses e Gigantes é a mesma.

A versão literária parece comunicar-se de forma mais próxima com esse exemplar, pois os Gigantes, portadores de armas, guardam alguns paralelos. A questão é a seguinte: como apresentar um guerreiro competente nas armas; basta munir essas figuras de armamentos como os capacetes, lanças e escudos? O importante é que o artista para formular tal idéia aproxima a figura dos Gigantes à do guerreiro grego por excelência, vale dizer, uma nova compreensão do homem no combate, distante da moralidade heróica - trata-se do hoplita.

É claro que, apesar da comunicação temática, cada criação (a literária, a escultura no frontão, e o relevo do tesouro sifniano) tem sua especificidade criativa, que também deve ser levada em conta, já que se trata da apresentação do mito, numa acepção geral, mas também de processos cognitivos diversos.

A caracterização dos Gigantes sobre a cerâmica pintada com a técnica de figuras negras também apresenta uma outra vereda criativa. As imagens sobre dois vasos que aqui se toma como exemplares indicam isso com clareza (ver fig. 5). O esquema iconográfico é 
em faixa, os Gigantes caracterizados como hoplitas, e além das lanças e escudos, carregam pedras, o que lhes dá um caráter mais selvagem. ${ }^{22}$ Ainda, a organização espacial propõe diferentes proporções corporais entre os Gigantes (que aparecem capitulando, portanto ajoelhados) e os deuses. Se as questões visuais parecem as mesmas, a especificidade nesse caso reside na própria natureza da criação gráfica, ou seja, não é da reflexão do artesão sobre formas tridimensionais que a composição da figura nasce, mas a partir de linhas incisas, e pouquíssima variação de cores, sobre um suporte curvilíneo de dimensões bem menores.
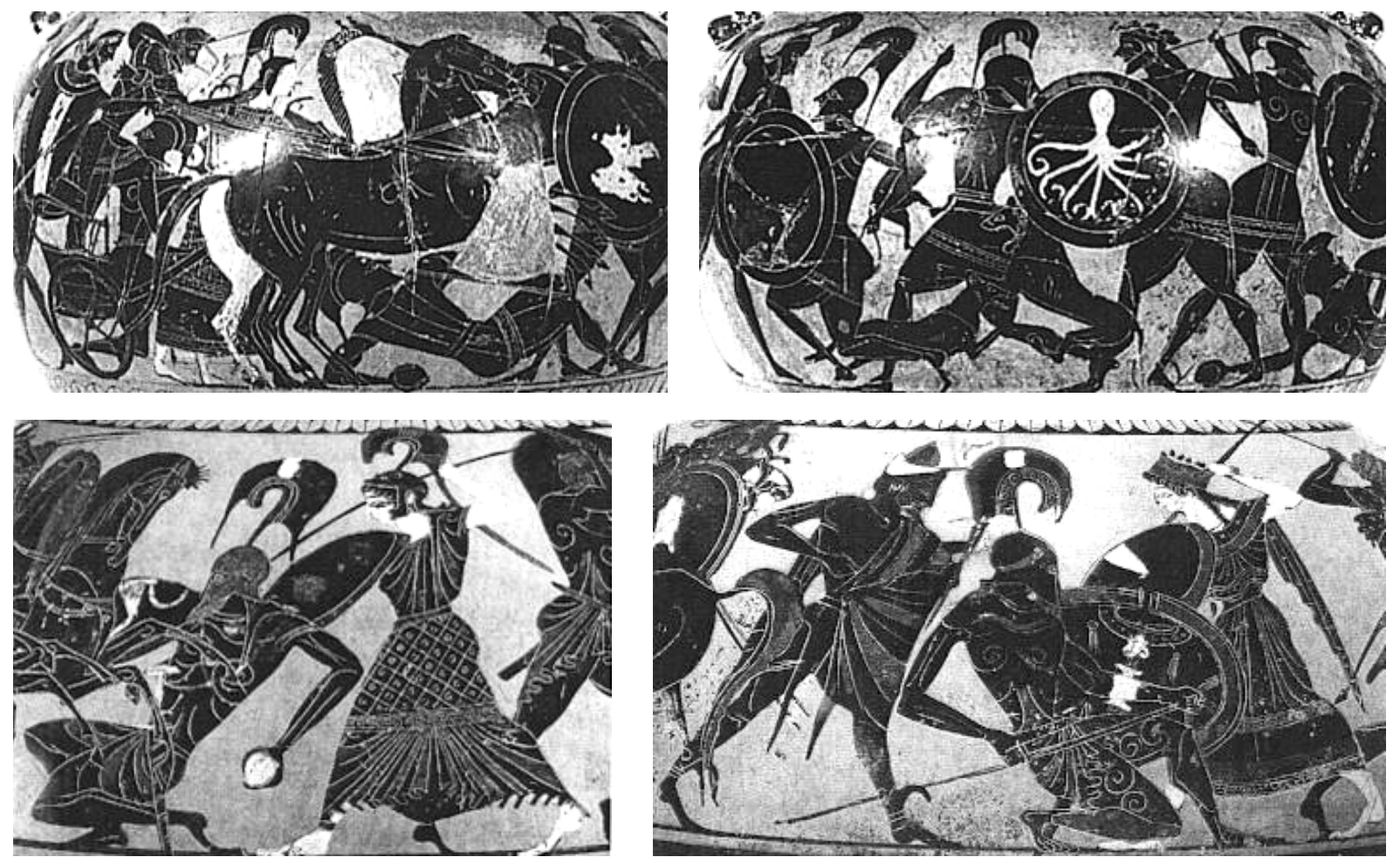

Fig. 5. (Acima) detalhes de ânfora ática, Tarquínia, Museu Nacional; (abaixo) detalhes de psykter ático, 530-520 a.C., Texas, Rice Museum.

Esse cotejamento de informações não se deve concentrar somente no ato da criação, mas o consumo visual, ou seja, a fruição deve também ser considerada. Claramente a difusão literária do mito é diferente da visual. Sobre a primeira, no período arcaico, persiste com maior freqüência a difusão oral do conteúdo mítico (se comparada ao registro escrito), pois apesar de já estar disponível o alfabeto grego ${ }^{23}$ no século VIII a.C., ainda não havia

\footnotetext{
${ }^{22}$ A iconografia vascular dos Gigantes assume essa conotação no período clássico, havendo caracterizações dessas personagens carregando pedras e vestindo pele de animal não tratada; ou seja, uma aproximação do mundo selvagem. Reforçam isso caracterizações como a do altar de Pérgamo (já no período helenístico) nas quais os Gigantes "ganham" pernas que são serpentes (anguípede), tradição também observada em Apolodoro (Biblioteca mitológica, 1, 6, 1).

${ }^{23}$ Falar em "alfabeto grego", sobretudo no período arcaico, deve sempre, cogitar um cenário variado, ou seja, onde não havia uma sistematização universal, a que, hoje, chama-se de gramática. Não se pode falar numa
} 
propriamente uma sociedade letrada, ou seja, com aptidão para falar, ler e escrever numa língua. ${ }^{24}$ Tratava-se do domínio de uma série de regras lógicas e formais na articulação do discurso (como morfologia, sintaxe, métrica etc.). Elas explicitam-se pela articulação dos signos alfabéticos (o registro escrito) ou pelo aparelho fonador (na verdade, "manipulação combinada da laringe, língua, dentes e palato" - Havelock, 1996, p. 131), no caso da apresentação rapsódica; e assim se pode pensar, por exemplo, em situações como a entonação da voz e gestual, na sua comunicação com o público ouvinte. Quanto à escrita, além da especificidade do suporte, que indicaria algo da difusão da mensagem, o receptor deveria ter habilidades para a leitura (o que não era algo generalizado na época tratada, como indicam as fontes literárias e materiais); havendo situações de leitura pública do que foi anteriormente escrito. Sobre as imagens visuais, deve distinguir-se em dois campos para o breve exame de sua difusão: trata-se da noção de imóvel e móvel.

A difusão do teor das imagens visuais nessas variadas fontes materiais é diversa. Num primeiro grupo é possível observar a figuração arquitetônica, escultural, que se pauta pela imobilidade, ou seja, o interessado deve dirigir-se até o edifício ou outro espaço em que as imagens residem. Uma extensão disso pode ser observada em situações de descrição do que foi visto, e nesse caso deve levar-se em conta que a descrição está ligada à visão de mundo, filtros culturais, etc. de quem a faz. A descrição de Eurípides em Íon (ver nota 19), é exemplar, bem como as executadas por Pausânias. ${ }^{25}$

Num segundo grupo estão as imagens "móveis", pois figuram sobre suporte móvel: tal é a situação da cerâmica. Nesse caso, essas imagens podem alcançar distâncias muito grandes, e ser observadas por "fruidores" completamente alheios à sua significação original. São vários os casos de iconografia grega que chega a outros povos do Mediterrâneo, via comércio, havendo inclusive possíveis adaptações da compreensão das imagens a um conjunto de referências locais.

A própria relação física homem-imagem é diferente. No caso das imagens esculturais, elas compõem algo que está fora, em certa medida, da dimensão do corpo humano (podem estar dispostas em partes altas de templos, ou mesmo ter dimensões monumentais). Já as imagens vasculares podem ser carregadas, o vaso poderia ser manipulado para uma atenta observação. E mais, a presença desses vasos na vida cotidiana é mais dinâmi-

ação gramatical da língua grega antes dos esforços helenísticos de organização e imposição de um sistema padronizado. Isso não quer dizer que, antes disso, houvesse uma ausência de regras. Havia, sim, formas dialetais peculiares que distinguiam a língua e a escrita de algumas cidades, o que não impedia a comunicação interna. Por exemplo, em determinadas situações, em Atenas, cujo dialeto padrão era o ático, utilizava-se o dialeto dórico (Ferrari, 1988, p. 180-1).

${ }^{24}$ A discussão sobre a oralidade, escrita e letramento será retomada no capítulo 3 , mas de antemão vale a indicação de Havelock, 1996.

${ }^{25}$ Para as descrições de Pausânias sobre as apresentações visuais da Gigantomaquia, ver: Livro I, 25, 2; II, 27 , 3 e VI, $19,13$. 
ca, sendo eles usados nas tarefas mais variadas da vida do cidadão comum, e não somente dele. Entretanto, essa delimitação entre os dois grupos não é absolutamente severa, pois tais vasos poderiam ser oferecidos como oferenda votiva, e tornar-se um "bem imóvel"; ou então, como butim de guerra, por exemplo, esculturas ou monumentos poderiam ser deslocados para outro espaço.

Essa pequena coletânea de informações e reflexões sobre os problemas da articulação das informações literárias e materiais, e internamente no universo destas, apresentam uma boa justificativa para a concentração da análise num único suporte. Tratar da natureza da articulação escrito-figurativa de forma geral, extrapolando os limites da produção ceramista e da composição gráfica impostos aqui, significaria abarcar uma grandíssima gama de informações e relações complexas, o que a dinâmica da pesquisa em tempos atuais não permite. Porém, vale dizer, a perseguição de uma única entonação da relação escritofigurativa na Ática arcaica propõe, como visto, uma ampliação de significados além da própria materialidade do objeto.

Um exemplo disso é a discussão das competências verbais e não-verbais do cérebro humano. No caso da interação escrito-figurativa, existe uma aproximação desses universos por várias características. Isso, pois as imagens moldam-se em relação a um universo verbal (freqüentemente oral, mas como visto, também escrito), e vice-versa, como será possível observar em alguns estudos de caso, a escrita nesses vasos de cerâmica (as inscrições) também desempenha amplo papel visual. Assim, escrita, oralidade e figuração, competências que se distinguem por sua natureza verbal, para as primeiras, e não-verbal, para a última, interagem de tal forma a ser quase impossível corroborar uma cisão absoluta entre esses campos cognitivos; entretanto não se deve ignorar essa delimitação que existe. A neurociência apresenta uma distinção desses processos já na apreensão cerebral:

Particularmente relevante para a reflexão sobre a dicotomia verbal/não-verbal é a questão da especialização dos hemisférios cerebrais, que parece ser um princípio extremamente importante na organização funcional do cérebro (Luria, 1973). Um dos hemisférios cerebrais vem a ser o hemisfério chamado dominante e o outro o secundário, ou não-dominante. O dominante tende a ser o hemisfério esquerdo, mas pode também ser o direito, especialmente em pessoas canhotas (Eccles, 1979; Mecacci, 1987). O hemisfério dominante é responsável pelas funções da fala e pelas atividades relacionadas à linguagem, como memória verbal, pensamento lógico, organização da percepção em esquemas lógicos, e por tarefas de natureza computacional. Ele funciona de modo analítico, seqüencial. O hemisfério não-dominante, geralmente direito, é não-verbal, realizando funções relacionadas a habilidades espaciais, visuais e musicais e operando de modo holístico e sintético. (Oliveira, 1992-1993, p. 54, n. 16) 
Essas distinções não implicam em uma absoluta e irresoluta separação entre essas capacidades do ser humano. Há, sim, uma organização de natureza diferente, conquista do processo de desenvolvimento biológico do homem, mas que são intercambiáveis, comunicativas. A própria discussão científica indica isso, pois

a especialização hemisférica não é universal (certas investigações indicam que em alguns indivíduos os dois tipos de funções são representadas em ambos os hemisférios), nem estabelecida desde o nascimento (a lateralização das funções aumenta com o desenvolvimento do indivíduo, isto é, é menor em crianças pequenas), nem irreversível (em caso de lesões cerebrais num dos hemisférios o outro pode assumir as funções prejudicadas, dependendo da idade em que a lesão ocorra). (Idem)

Porém, se o cérebro distingue (não completamente, como visto), a cultura também incide sobre tais competências cognitivas, promovendo as interações citadas no caso da relação escrito-figurativa na cerâmica ática. Não há na cultura objeto ou ação destituída completamente de significado comunicativo. Uma cadeira, uma mesa, ou outro mobiliário qualquer, que tem sua função prática básica, assumem significados exteriores (objetos de status, presentes [dons], indicam posição privilegiada ou comum etc.); ou então uma pintura, uma obra de arte, absolutamente branca, para além do monocromatismo, pode indicar uma discussão sobre as cores-pigmento no campo das artes plásticas, e mesmo uma pintura totalmente vermelha, o erotismo.

Buscar-se-á aqui, perseguindo as especificidades da cerâmica ática arcaica, caminhar entre as características gerais, peculiares do homem (pode dizer-se comportamentos biologicamente orientados), mas, sobretudo, as específicas condições sociais da Grécia arcaica, numa perspectiva histórica.

\subsection{Entre Arqueologia e Epigrafia}

Minimamente tratadas das questões sobre a as linguagens verbal e não verbal, e sua dimensão documental (as fontes literárias [no caso, textuais] e materiais), bem como de seus campos de interação e disrupção, cabe, na seqüência, caracterizar a discussão no âmbito da pesquisa arqueológica e epigráfica, buscando no debate interno instrumentos que auxiliarão a pesquisa aqui proposta. 


\subsubsection{A fonte epigráfica como arqueológica}

O termo "epigrafia", estruturalmente, apresenta duas partículas que auxiliam em grande medida a compreensão da natureza e vocação dessa disciplina. O prefixo ep(i)- (sobre) remete à idéia de suporte; já o radical -graf(ia), como já visto, ao ato de escrever e a própria escrita. Ora, tem-se então um resumo da matéria desse campo de estudo: escritos antigos, mas aqueles que tenham sobrevivido materialmente; assim, inscrições que podem ser observadas de forma variada, mas não apenas isso. Existe um "sobre o qual", ou seja, um suporte a se considerar. Nesse sentido, inscrições sobre determinado tipo de suporte. Entretanto, de início, é importante dizer que frequentemente as questões de suporte são subexploradas, privilegiando-se o conteúdo e materialidade (estilo) das inscrições; ou então, privilegiam-se alguns tipos de suporte, como a pedra. Por exemplo, encontra-se no dicionário Houaiss da Língua Portuguesa uma caracterização da palavra Epigrafia que transita de uma apreensão generalista do termo: "Estudo da composição de epígrafes, de inscrições"; até uma mais restrita: "paleografia: ciência que estuda as inscrições lapidares dos monumentos antigos", delimitando o suporte; como também acontece na caracterização da palavra epígrafo, "Entre os antigos atenienses, o encarregado da escrituração das contribuições"; o que também restringe seu significado (a uma produção exclusiva por atenienses, e ainda, à pedra, já que se sabe que a "escrituração das contribuições" era feita sobre esse suporte). De fato, a pedra como suporte foi (e ainda é) bastante privilegiada nos estudos epigráficos. ${ }^{26}$ Basta consultar obras de levantamento das inscrições mais conhecidas que se nota essa entonação. Entretanto essa não é a única possibilidade de estudo epigráfico, e a própria caracterização do dicionário Houaiss apresenta uma certa amplitude de possibilidades da Epigrafia. É justamente essa a linha que se perseguirá aqui.

É importante dizer que algumas inscrições vasculares, como a da enócoa do Dípilo (ver cap. 2, fig. 1, p. 60) e da kotyle de Nestor (ver cap. 2, fig. 8, p. 66), constam em importantes levantamentos básicos aos estudiosos de Epigrafia, nos quais se reúnem inscrições gregas, como o Inscriptiones Graecae (IG i ${ }^{2}$ 919, para a inscrição da enócoa) e o Supplementum Epigraphicum Graecum (SEG 14, 604, para a inscrição da kotyle); pois são bastante antigas e relativamente longas. Esse não é o caso da grande parte das inscrições vasculares: geralmente são simples nomes de divindade, ou mesmo, como no caso do vaso François, além das inscrições referentes a várias divindades e a autoria, nomes de alguns obje-

\footnotetext{
${ }^{26}$ Por exemplo, o Oxford dictionary of the classical world, apresenta o verbete epigrafia grega da seguinte forma: "o estudo das inscrições gravadas sobre a pedra ou metal em letras gregas" (Roberts, 2005, p. 263). Uma certa abrangência de sentido pode ser observada no verbete seguinte, epigrafia latina: "o estudo dos textos latinos inscritos sobre objetos duráveis, usualmente de pedra ou bronze" (Idem, p. 264).
} 
tos. ${ }^{27}$ Dessa forma, não se constituíram grandes corpora documentais sobre essas inscrições vasculares, havendo uma pequena amostra delas em alguns trabalhos como o de Immerwahr (1990) e Jeffery (1990). ${ }^{28}$

Foi vista acima uma definição bastante básica de Epigrafia; cabe, agora, entender como ela é tratada por alguns especialistas que utilizam essas inscrições: os próprios epigrafistas, mas também arqueólogos e historiadores. Essa caracterização é importante, pois sua compreensão não é unitária; e, dessa forma, é necessário apresentar um breve quadro dessa discussão, bem como o posicionamento aqui tomado.

Dominique Mulliez trata a Epigrafia como o estudo de inscrições, qualquer que seja seu suporte; ${ }^{29}$ como Georges Rougemont, dizendo que "a Epigrafia grega é o estudo das inscrições gregas antigas", sem especificações de suporte ou de outra natureza (Rougemont, 1996-1997, p. 265). De início, apreende-se que o estudo epigráfico trata de suportes variados, não é restrito, por mais que a ação dos especialistas volte-se para as inscrições em pedra, sobretudo num esforço esclarecedor da História política e econômica da Antigüidade. Entretanto, nessa linha, o "documento epigráfico" é, por vezes, analisado de forma conteudista, desprezando-se as suas informações contextuais. Neste ponto cabe a questão: a que serve a Epigrafia, qual a sua vocação? Sobre isso, Rougemont (Idem, p. 266) diz:

(...) a Epigrafia grega é, portanto, uma disciplina auxiliar da História, como a papirologia ou a numismática. O epigrafista é um historiador, especializado no estudo de uma categoria de documentos (no caso, as inscrições) graças aos quais escreve-se a História do mundo antigo.

A visão de uma atividade epigráfica mais próxima da História, como auxiliar, é dividida com M. I. Finley, que, ao discutir os limites e interações entre Arqueologia e História, acaba por dizer que "papiros, inscrições, rolos de couros - derivados de escavações" não são "evidências arqueológicas" (Finley, 1994b, p. 90); propondo uma ênfase na natureza documental (são fontes textuais), conteudista, e desprezando as informações contextuais, caracterizando-as como pouco explicativas - um claro discernimento entre fonte arqueológica e epigráfica.

Numa outra perspectiva Philippe Bruneau (1974, p. 1) caracteriza a Epigrafia como

\footnotetext{
${ }^{27}$ Sobre o Vaso François, foram feitos alguns levantamentos epigráficos, já que é um vaso possuidor de um grande número de inscrições de natureza variada. Para tanto, ver Minto, 1960; Cristofani, 1980; Wachter, 1991.

${ }^{28}$ Há, também, nos Beazley Archives, um grande levantamento de inscrições vasculares; e ainda um proposto levantamento de inscrições vasculares gregas, ainda em curso, por François Lissarrague, citado nos artigos Paroles d'images, in: Christin, A.M. Ecritures 2, 1985, 71 sqq.; e Lissarrague, 1992.

${ }^{29}$ Baseado em anotações do curso "Epigrafia grega e as inscrições de Delfos" de 11 a 27 de maio de 2005 no MAE-USP.
} 
ponto de encontro da Filologia e Arqueologia (...) [pois] a pedra inscrita possui ao mesmo tempo as características de um objeto arqueológico, porque tem um local de achado, uma forma particular, eventuais funções arquitetônicas ou outras, numa palavra, por sua unicidade e por sua materialidade das quais resulta a própria escrita, às vezes esclarecendo mais que o texto.

O debate abrange a própria natureza da fonte epigráfica e os domínios epistemológicos a que ela melhor se adapta; e acaba por inserir a contenda entre Arqueologia e História. Finley, ao não aceitar a caracterização da fonte epigráfica como arqueológica, diminui as possibilidades interpretativas e analíticas a partir da fonte material, opondo-as em campos distintos, submetendo a fonte material a uma "obrigação" do texto escrito para uma melhor interpretação. Como salienta Bruneau, acima, a fonte epigráfica não se resume ao conteúdo. As informações contextuais são importantíssimas, e a combinação de conteúdo com as características materiais da inscrição e seu suporte parece bastante proveitoso.

Por exemplo, um estudo que levasse em conta apenas, ou principalmente, o tema das inscrições vasculares esqueceria uma dimensão básica de seu recorrente comportamento no período arcaico grego: sua coexistência com imagens figuradas; ou seja, este é traço bastante comum na produção artesanal ática arcaica. A inscrição AXI $\mathrm{EYY}$ (Aquiles) sobre um vaso, vista de forma isolada, no que se refere ao conteúdo, diz pouco; entretanto, a problemática de sua relação com a imagem figurada pode propor uma série de questões importantes, como será visto na interpretação de uma ânfora de Exéquias (ver capítulo 3 , item 3.4).

Aqui, a relação entre fonte material e escrita será observada do ponto de vista de sua unicidade, ou seja, os dois registros como uma só fonte. Essa linha propõe uma análise epigráfica ampla, que se preocupa com características além da técnica, estilo e conteúdo da inscrição; o suporte como um todo, ou pelo menos de forma bastante abrangente, deve ser considerado, bem como questões sobre sua produção e uso, além de, é claro, seu contexto arqueológico. Assim, colocam-se aqui três pontos para a análise epigráfica:

1) Conteúdo: É de grande importância entender o que foi escrito, qual a mensagem, os atores envolvidos, o estilo literário empregado, estrutura do texto etc. Cabe lembrar que essa é a conotação mais comum dos estudos literários, que dão ênfase ao conjunto de referências dos escritos, procurando observá-los do ponto de vista da crítica genética, da psicologia, semiótica etc.

2) Contexto histórico: Além da mensagem, deve-se compreender o ambiente em que ela foi produzida, difundida e recepcionada, mas é preciso observar esses momentos 
com potenciais diferentes do ponto de vista histórico: o momento de produção é geralmente único ${ }^{30}$ e pode ser cronologicamente estabelecido por seu conteúdo, características formais literárias, materialidade do suporte etc. Entretanto, os momentos da difusão e da recepção da mensagem podem ser contemporâneos à produção ou posteriroes. E, nesse sentido, as questões históricas que envolvem o tripé produção-difusão-recepção podem ser situadas pontualmente ou então num processo com certa duração.

3) Materialidade: Aliadas às características acima indicadas, a dimensão da materialidade da mensagem e do suporte são essenciais. Assim, o estilo da letra, sua técnica de produção, bem como as características do suporte e o contexto arqueológico, indicam mais informações sobre a situação do que foi escrito, sobre sua produção (emissor) e recepção.

\subsubsection{Contexto e trajetória}

De um campo onde a escrita como característica documental não existe, surge um interessante ponto de vista metodológico, no qual, com certas adaptações, pode aplicar-se à análise gráfica com fecundidade: trata-se do conceito de cadeias operatórias utilizado amplamente em recentes pesquisas no ramo da "pré-história" ${ }^{31}$ :

a cadeia operatória visa descrever e compreender todas as transformações culturais que uma matéria-prima específica teve de forma completa. É uma segmentação cronológica da ação e processo mental, requeridos na manufatura de um artefato e em sua manutenção até o sistema técnico de um grupo pré-histórico. O estágio inicial de uma cadeia é a procura de matéria-prima, e o estágio final é o descarte do artefato. (Sellet, p. 106)

A análise que busca a compreensão do utensílio, e da ação humana relacionada a ele, ganha muitas novas possibilidades, como a questão da espacialidade. Não se trata apenas de registrar o local onde foi encontrado o material lítico, mas de estabelecer relações

\footnotetext{
${ }^{30}$ Deve-se, aqui, lembrar que existem longas produções escritas, levando cerca de anos, decadas; entretanto, esse é o caso mais relacionado a obras de literatura (histórias, biografias, contos etc.). Quanto às fontes epigráficas, o período de produção é bastante menor, circunscrito a cerca de minutos, horas, dias, semanas; dependendo do tipo de suporte e texto a ser gravado; variando desde uma breve inscrição pintada ou riscada num vaso de cerâmica, até constantes adições ao longo do tempo como o caso do muro poligonal que sustenta o templo de Apolo no santuário do mesmo deus em Delfos.

${ }^{31}$ O termo cadeia operatória já era aplicado, com conotação diversa do uso recente em autores como LeroiGourhan, desde 1943, "para indicar método de estruturação de atos técnicos (...), [e] foi adaptado pelos préhistoriadores aos estudos de indústrias pré-históricas” (Vialou, 2004, p. 422).
} 
entre o local de captura de matéria-prima, local de produção (oficina) e de retoque, e de utilização ostensiva. Esses locais podem ser o mesmo, ou então muito diferentes, o que propõe uma discussão sobre compreensão do espaço e sua variada apropriação pelo homem "pré-histórico". Ainda, questões relacionadas à economia (como eram tratadas as matériasprimas líticas, a que necessidades respondiam, se eram abundantes etc.), à memória e repetição (como, por exemplo, a transmissão da técnica de talhamento, lascamento, polimento etc.), ao desenvolvimento mental etc. Dessa forma

[a] utilização [do conceito de cadeias operatórias] permite definir estratégias de produção lítica em meio a contextos sócio-econômicos aos quais concernentes aos períodos da préHistória (Perlès 1991). Essa noção de cadeia operatória tem progressivamente conduzido ao desenvolvimento de uma noção mais ampla que o próprio processo de realização. (...) A noção de sistema técnico designa nesse caso o quadro sócio-econômico geral das operações técnicas. (Geneste, 1991, p. 9)

Tem-se, nesse sentido, contato com uma organização das sociedades pré-históricas de forma mais abrangente. A lógica do utensílio, da matéria-prima, da tecnologia convertemse em informações que ampliam os significados do material, propiciando uma maior compreensão dos grupos humanos relacionados a eles.

O recorte da aplicação de tal ferramenta metodológica é bastante específico (a experiência com os materiais líticos na "pré-história"), entretanto há algo que se pode tomar de empréstimo, sem grandes distorções à aplicação original: trata-se do acompanhamento amplo do objeto, desde sua produção até seu descarte, o que no caso desta pesquisa incitam interessantes problemas de espacialização, que serão discutidos em breve, mas, de antemão, é viável indicar que não será restrito ao local de produção; assim, não apenas a lógica da produção artesanal (especificamente, produção gráfica) será tratada; mas também o amplo caminho que esses grafismos percorrem, incitando questões como a difusão comercial dos vasos áticos, e a conseqüente recepção deles em contextos variados; ou seja, diversos espaços e diversos processos cognitivos.

Meneses (2002, p. 148) apresenta bem essa abordagem metodológica, já aplicada no campo do estudo das imagens:

Trabalhar historicamente com imagens obriga a percorrer o ciclo completo de sua produção, circulação, consumo e ação. (...) Seja como for, não é possível continuar privilegiando o estudo da imagem em si, distinta de sua biografia, sua carreira, sua trajetória.

Se as diferenças parecem residir na delimitação, muitas vezes arbitrária e discutível, entre História e "Pré-história", a abordagem que amplia as possibilidades de interpretação 
do objeto (seja a pedra lascada ou uma fotografia do século $X X$ ), unem-se, buscando uma visão que compreenda não apenas um estudo sistemático do objeto, mas de sua inserção em contextos diversos, observados a partir da complexidade de sua trajetória.

As questões sobre suporte, neste estudo, passarão preponderantemente pela observação da trajetória complexa dos objetos. Nesse sentido, cabe discuti-lo desde as questões próprias das técnicas de produção, e não concentradas unicamente no objeto como "meio" de comunicação entre emissor e receptor. Isso, pois aqui se acredita que o suporte como meio físico complexo (meio eletrônico, elétrico, transmissão de ondas e dados [ver McLuhan 1972 e 1974]) são muito peculiares das sociedades contemporâneas, e a própria noção de produção do suporte da mensagem é diferente. Com relação à Antiguidade, a situação é completamente diversa e menos difusa. Dessa forma, é viável lidar com o suporte nesse âmbito mais amplo. Nesse contexto, por exemplo, em muitos casos o "emissor" é o próprio produtor do objeto. Um pintor de vasos na Ática poderia ser responsável pela articulação de uma mensagem e pela execução material (nesse caso, o "emissor" tem condições de controlar o suporte, já que sua produção depende dele). A experiência contemporânea, apesar de ainda registrar esse tipo de situação, abrange questões de ampla desconexão entre o ambiente produtor do suporte de comunicação e do emissor de determinada mensagem.

Ainda, outro recurso que auxiliará a abordagem da análise gráfica, consoante aos anteriores, é a utilização da abordagem histórica, presente na linha contextualista da Arqueologia. O princípio de contexto na Arqueologia é variado, transitando entre a "ambientação" histórica de determinado objeto, ação, pensamento etc. (contexto histórico); até a disposição física dos objetos relacionados às ocupações evidenciadas pelo estudo estratigráfico (contexto arqueológico). A Arqueologia Contextualista é uma linha que reabilita a interpretação histórica no seio da discussão arqueológica (após críticas oriundas da "Nova Arqueologia"), que busca compreender o objeto material a partir das suas relações dinâmicas na sociedade em que se insere; ${ }^{32}$ entretanto, conforme salienta Michael Shanks, o objeto não deve ser tratado como refém do contexto. ${ }^{33}$ Novamente então, uma comunicação entre o objeto e estruturas mais amplas com as quais ele interage.

\footnotetext{
32 "Uma tese básica do contextualismo é a afirmação de Hodder, etnograficamente muito bem documentada, de que a cultura material não é mero reflexo da adaptação ecológica ou da organização sóciopolítica; também constitui um elemento ativo nas relações entre grupos, elemento que tanto pode ser usado para disfarçar relações sociais como para as refletir" (Trigger, 2004, p. 338).

33 "O contexto foi durante muito tempo tido como vital no estabelecimento do significado do artefato. Foi certamente reforçado que o contexto deve ser considerado para se referir não somente à data, espaço e posição, mas também ao contexto social. A "Arqueologia contextual" (Hodder 1987, 1991) faz muitas associações, sustentando que o significado das coisas pode apenas ser verificado se os contextos de uso são considerados. Eu argumento que essas possíveis dimensões do contexto devem ser, de fato, notadas, mas não definidas a priori. O artefato, como produto deve definir seu próprio contexto através da busca interpretativa (Shanks \& Hodder, 1995, p. 1417)" (Shanks, 1999, p. 28). Ainda, Vernat (2002, p. 54) dizia "Penso, com efeito, que não podemos falar dos homens fora dos grupos nos quais esses homens estão inseridos, fora de seu contexto social preciso; mas, in-
} 
Todos esses instrumentos, desde o uso distorcido da idéia de cadeia operatória, até a Arqueologia Contextualista, propõem interpretações do objeto material que extrapolem a sua materialidade, buscando, por exemplo, seus significados simbólicos. Ver, sob este ponto de vista, a aproximação entre inscrição e imagem figurativa na cerâmica ática é essencial, pois, rompendo uma tendência que não se preocupa com essa coexistência relativa, podese alcançar significados mais amplos desse traço cultural de uma sociedade que "reaprendia" a escrever e figurar.

A proposta, aqui, é afastar-se de qualquer monolitismo que identifique a produção escrita a uma classe (geralmente uma elite) e das coisas materiais a outras (freqüentemente, as "classes baixas"). Ora, além de esses paralelismos não se sustentarem absolutamen$t^{34}$, a análise ampla, levando em conta uma experiência escrita e material, para além das questões de produção e do universo cognitivo de um grupo materializados nas suas respectivas produções, possibilita uma visão mais dinâmica dessas estruturas, no seio de qualquer sociedade; assim, mesmo um grupo que não esteja envolvido diretamente na produção escrita envolve-se profundamente, em vários casos com esta produção.

John Moreland (2001, p. 89) mostra que numa revolta de camponeses ingleses "analfabetos", no século XIV, a escrita funcionou amplamente como mediador entre os revoltosos e a classe dominante. ${ }^{35}$ Ainda, pode-se notar, no Brasil contemporâneo que, apesar de um grande número de analfabetos e analfabetos funcionais, ${ }^{36}$ oficialmente o Estado comunica-se com sua população através da escrita; por exemplo, a publicação em diário oficial equivale à publicação "ao saber de todos", e a própria integração e regulação do indivíduo no grupo "nação", passa, invariavelmente pelo registro escrito, como o caso dos documen-

versamente, não existe contexto social que não possua uma dimensão 'humana', ou seja, mental (...)", e, pode acrescentar-se, material.

34 "Enquanto técnica a escrita esteve, durante dois milênios, ao serviço do poder, e este serviço assumiu duas formas, uma directa, imediata, a outra indirecta, mediata. Na civilização suméria, os escribas pertenciam às famílias mais ricas; o escribariato (que excluía as mulheres) era um ofício muito considerado: alguns escribas tornavam-se reis; a escrita, instrumento directo de poder, era de certo modo a via selectiva disso. Entre os Etruscos, em que a escrita parece ter tido um valor mais religioso do que oficioso, estava confinada à classe sacerdotal (aristocrática), a dos sacerdotes, dos arúspices. No outro extremo, mas com a mesma finalidade política, em Roma, a escrita era servil; o homem livre não escrevia, ditava a um escravo ou, pelo menos, (sabemo-lo através do exemplo de Cícero), dava-Ihe imediatamente o apressado rascunho para copiar; a escrita incorporada no escravo pertencia ao dono." (Barthes \& Muriès, 1987, p. 152)

${ }^{35}$ Moreland (2001), sob a perspectiva contextualista da Arqueologia, opõe-se a visões de especialistas em teoria da linguagem como Jack Goody e Walter Ong, que concentram a técnica da escrita essencialmente como estrutura de poder. Ele argumenta que muito dos traços culturais conseqüentes da "revolução" da escrita, pode também ser observado em sociedades não-letradas (p. 86), e que a escrita deve ser vista de forma mais ampla: não uma técnica simplesmente, mesmo que revolucionária, mas uma prática social.

${ }^{36} \mathrm{O}$ IBGE (Instituto Brasileiro de Geografia e Estatística) informa que a taxa de analfabetismo no Brasil é de $11,8 \%$ (medida em 2002), num decréscimo contínuo e significativo (em 1970, por exemplo, essa taxa era de $33,60 \%$ ). Entretanto, deve-se lembrar do analfabetismo funcional ("o analfabeto funcional é a pessoa que possui menos de quatro anos de estudos completos", ou seja, alfabetização ainda não completada), que tem números bem mais alarmantes: $26 \%$ da população brasileira de 15 anos ou mais idade, havendo distinções marcantes entre as regiões do Brasil: Norte - 24,7\%, Nordeste - 40,8\%, Sudeste - 19,6\%, Sul - 19,7\% e Centro-Oeste 23,8\%. Fonte dos dados: http://www.ibge.gov.br, consultado em junho de 2005. 
tos pessoais. Sobre isso, basta dizer que sem possuir a Certidão de Nascimento (um dos primeiros registros escritos que conferem a existência legal ao indivíduo), a criança não pode ser matriculada em qualquer escola pública ou outro sistema de ensino básico.

Da mesma forma, não se pode restringir a criação material a um esforço de linguagem atrelado àqueles que não sabem ler e escrever. É claro que as relações são complexas, e qualquer redução esquemática compromete a observação da trajetória dessas linguagens (verbal e não-verbal) no seio de um grupo. Deve indicar-se que existe uma polêmica no que tange aos domínios da escrita e da cultura material (Funari, Hall \& Jones, 1999, p. 10) aproximando-os de anseios e interesses de determinados grupos, entretanto, a observação contextual, que não privilegie apenas o estágio produtivo, aquele de organização original, não pode tomar essas conexões estanques como princípio fundamental, preocupando-se com a análise do detalhe, da especificidade de um caso. 


\subsection{Sobre o tempo e o espaço}

Mesmo que a coesão interna do arranjo escrito-figurativo de um vaso ofereça importantes informações, elas são limitadas a resultados ensimesmados, e apenas uma abordagem levando em conta também as informações espaço-temporais (dados históricos, contextualistas) poderão indicar de forma mais precisa a inserção desses vasos no quadro da cultura ática arcaica e as possíveis inserções no quadro regional (Grécia, Mar Egeu e áreas de colonização).

As informações arqueológicas no que se refere à relação escrito-figurativa sustentarão uma discussão sobre as balizas temporais; ou seja, o período arcaico como recorte é insuficiente como delimitação; pois, a despeito das acepções ideológicas, tal termo carrega uma construção conceitual (ver capítulo 3 , item 3.3) que não corresponde à especificidade da discussão aqui proposta. Nesse sentido é necessário construir os limites, e a documentação arqueológica será a sua base.

Quanto à espacialização, é necessário discutir significados dos termos Ática, Atenas, Grécia, Mundo grego e afins, pois o que se compreende como cultura grega não se restringiu na Antigüidade ao continente grego ou ao Mar Egeu, e como esta análise privilegiará uma compreensão contextual da criação gráfica e sua diversidade de inserção (de sua criação à sua fruição [consumo]) deve circunscrever-se com clareza os espaços dessas ações. Partir-se-á, para tanto, da própria acepção antiga dessas delimitações.

\subsubsection{Cronologia: recorte e justificativas}

Neste estudo busca-se a compreensão da origem substancial do ato de articular escrita e imagem figurativa na Ática. Se o espaço de produção parece bem definido, a cronologia merece atenção. Não se pode estabelecer balizas temporais artificiais, e é a própria documentação, a articulação dos grafismos sobre a cerâmica, que guiará um conseqüente estabelecimento dos limites temporais. Um ponto inicial seria a busca do primeiro vaso de cerâmica ática que contenha inscrições coexistindo com imagens. ${ }^{1}$ Tem-se notícia dele: é uma enócoa do Dípilo (c. 750-740 a.C.); um importante exemplar da cerâmica ática, já que ele contém a segunda inscrição mais antiga do alfabeto grego, ${ }^{2}$ a "mais antiga inscrição alfabética grega completa de alguma extensão" (Snodgrass, 2004, p. 87). Essa data marca-

\footnotetext{
${ }^{1}$ Dizer que esses objetos à disposição são "os primeiros", "os mais antigos", na verdade, relaciona-se à capacidade de encontrá-los em escavações arqueológicas ou mesmo ao acaso. Nem tudo será encontrado, e deve saber-se que, relativizando essas posições absolutas, eles são os "mais antigos" encontrados.

2 Para uma breve discussão sobre as inscrições alfabéticas gregas mais antigas, e a origem do alfabeto grego, ver Sarian, 1998-1999a.
} 
ria, então, o início do recorte cronológico; entretanto deve discutir-se mais essa proposta, caracterizando o próprio vaso e a natureza da articulação entre escrita e imagem figurativa nele.

É uma enócoa do final do período geométrico, do tipo LG Ib ${ }^{3}$ (fig. 1a). O bojo esférico tem sobre ele a aplicação de verniz escuro em linhas horizontais e paralelas, acompanhando o sentido das marcas do torno. ${ }^{4}$ Uma linha espessa intercalada de duas finas; essa repetição segue até a posição da altura pouco posterior à metade do corpo esférico. Acima disso, uma faixa horizontal em ziguezague (as linhas levemente arqueadas dão a impressão de pequenas meias folhas enfileiradas). Mais acima, há três linhas finas e uma grande faixa escura (na região do ombro, e vai até o pescoço), onde - na parte imediatamente baixa localiza-se uma inscrição (utilizando a divisão das faixas como linha): "Àquele que dentre todos os dançarinos dançar com mais graça" (fig. 1c). ${ }^{5}$

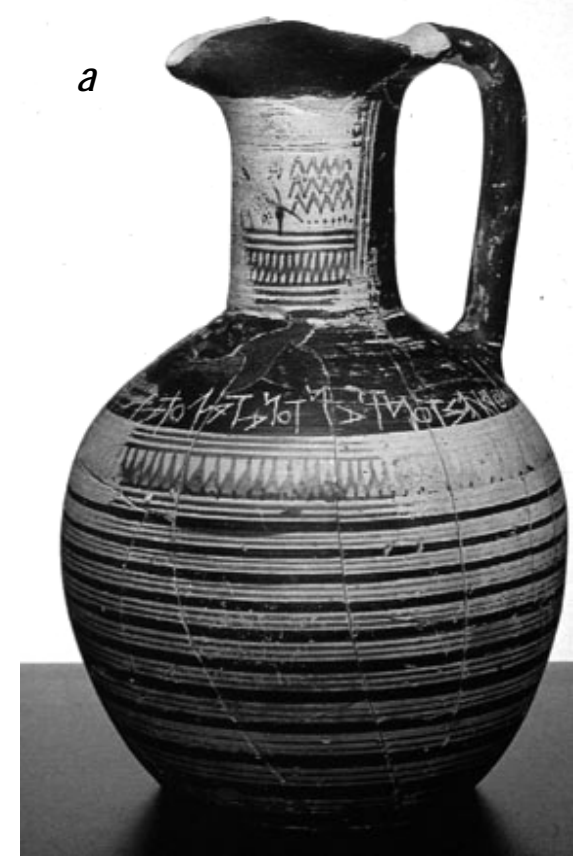

b

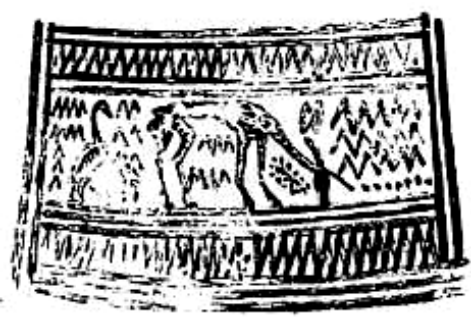

Fig. 1a, b e c. Enócoa do Dípilo, Ática, 750-740 a.C., Atenas, Museu Nacional (alt.: 23 cm).

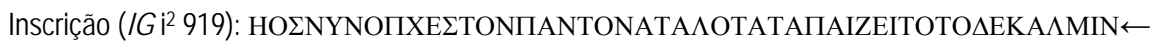

(Àquele que dentre todos os dançarinos dançar com mais graça. Tradução de Sarian, 1998-1999a, p. 162)

O pescoço é cilíndrico e estreito em relação ao bojo. Paralela a ele há uma alça em cordão que liga o ombro à boca que é trilobada. A coloração da alça e da boca é de verniz escuro. A alça indica a parte traseira do vaso, sendo a oposta, a dianteira. Nela há uma de-

\footnotetext{
${ }^{3}$ Segundo Coldstream (1979, p. 298), os vasos produzidos de 750 a 735 a.C.

${ }^{4}$ Anéis concêntricos de influência cipriota, segundo Young (1939, p. 228).

${ }^{5}$ Para uma discussão sobre a reconstituição e interpretação dessa inscrição ver Langdon, 1975 e Powell, 1988.
} 
coração figurativa, num painel delimitado acima e abaixo pelos limites do pescoço, e lateralmente por linhas pintadas, e faixas em ziguezague. No centro do painel há um cervídeo pastando (ele é pintado em silhueta, como a caracterização humana nos vasos funerários do Dípilo), e a cabeça abaixada em relação ao corpo, dá a idéia dessa atividade da pastagem. À sua esquerda, há uma ave, também pintada em silhueta. É importante notar o preenchimento do espaço com elementos geométricos (ziguezagues, pontos enfileirados). Poder-se-ia especular, dizendo que eles formam a grama da qual o animal se serve; porém esse era um elemento comum na ornamentação desses vasos figurações bem diferentes, o que não permite, com segurança, tal inferência (fig. 1b).

Esse vaso é amplamente referenciado em estudos diversos sobre a Antigüidade grega, pois apresenta uma inscrição relacionada a um concurso de dança, ou seja, refere-se ao amplamente comentado aspecto competitivo, estrutura bastante peculiar entre os gregos. Além dessa característica, que está ligada à interpretação do conteúdo da inscrição, indicase uma material e simbólica, ou seja, a utilização de vasos como prêmio, e o próprio estilo das letras da inscrição. Nesse quadro é viável ampliar a uma outra problemática de natureza material: a coexistência entre escrita e imagem figurativa nesse vaso, característica praticamente esquecida no que se refere aos estudos existentes sobre ele. Isso é importante, já que é possível discutir uma nova característica: uma sociedade que concebe a articulação entre duas linguagens diferentes, num mesmo suporte, desde o século VIII a.C. Ainda, levando em consideração a própria técnica gráfica, a análise do desenvolvimento de uma linguagem em relação à outra se mostra viável.

A imagem figurativa (o cervídeo pastando e a ave) não tem qualquer conexão temática com a inscrição, e se existe alguma aproximação, além do suporte comum, é a busca de espaços de boa visibilidade nesse vaso. A imagem figurativa está num painel, na área que se estende do meio à parte alta do pescoço; a inscrição, no ombro do vaso, aproveitando o contraste como o fundo escuro, e a delimitação dessa faixa escura (que é seu fundo) como linha que orienta a inscrição. A falta de conexão é reforçada pela própria estrutura do vaso que possui formas geométricas bem delimitadas, e a inscrição e a imagem, apesar de serem vistas ao mesmo tempo, estão localizadas em partes diferentes do vaso, claramente divididas. Ainda, a imagem pode ser vista com o vaso e "espectador" em repouso, já a inscrição impele o movimento: ou o "leitor" a rodeia, ou a gira em suas mãos. Vale lembrar que a imagem faz parte da composição original do artesão que produziu o vaso, é desenhada na mesma técnica do restante dos elementos ornamentais do vaso; enquanto a inscrição é um grafite, riscado posteriormente à concepção original do vaso, e não há elementos que comprovem a confecção de ambos pela mesma pessoa, e a datação antiga da inscrição dá-se pelo estilo das letras e da ornamentação do vaso (ver fig. 5). 


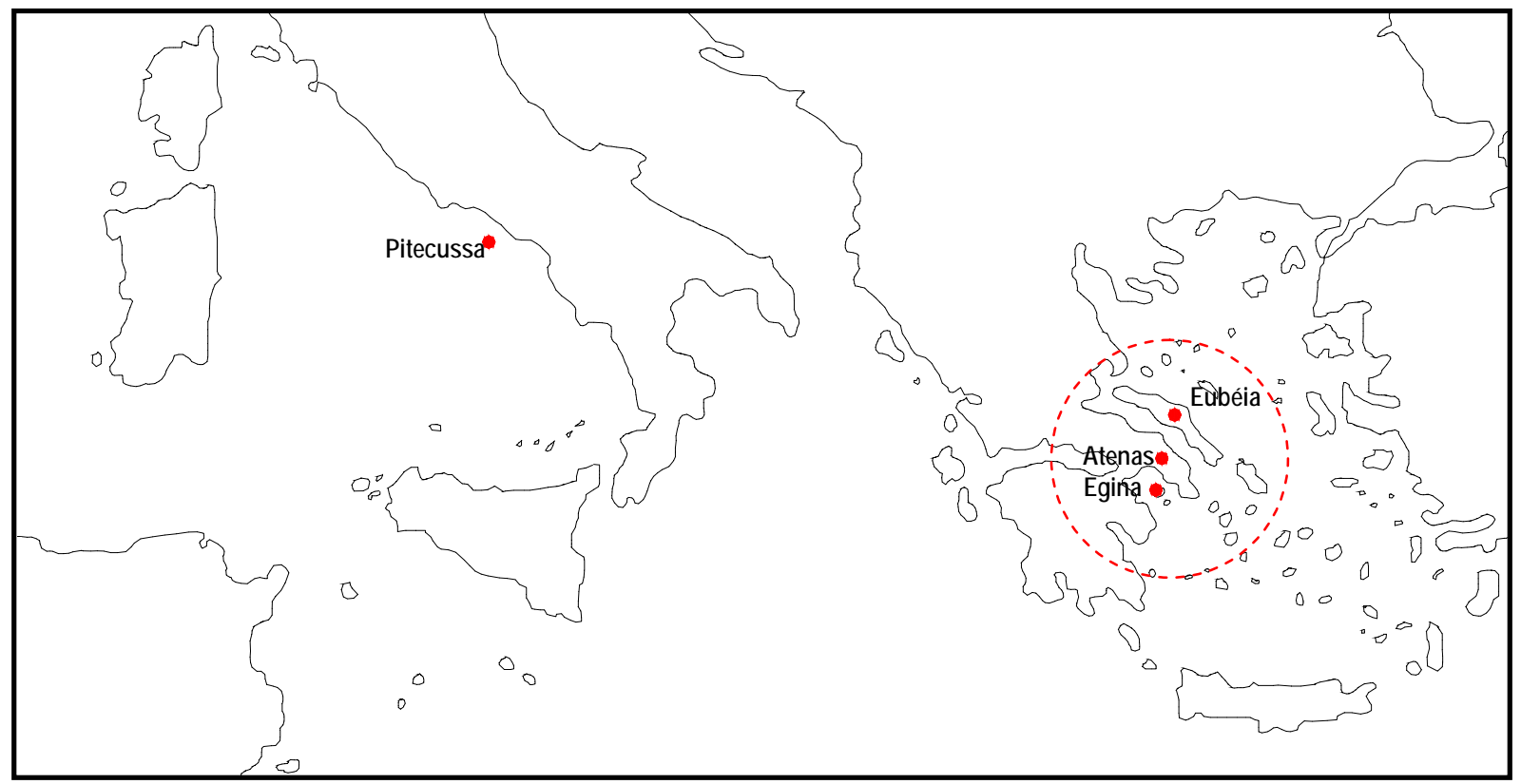

Croqui 1. Localização espacial: Pitecussa, Egina, Ática e Eubéia.

Apesar de ser amplamente aceita, a datação dessa inscrição sofre algumas críticas. Eric Havelock (1996, p. 22-3) rechaça a data de c. 740, pois acredita que ela é fundamentada em analogias e poucas informações contextuais. ${ }^{6}$ É certo que a determinação cronológica não é absolutamente verificável, e, para tanto, deve circunscrever-se seu campo de tolerância. A despeito das poucas informações contextuais (ver fig. 4, e comentário), o vaso tem datação segura (a partir do estilo ornamental), indicando um términus post quem para tal inscrição (ela seria de c. 740 ou depois disso). A baliza mais recente é menos segura, mas bastante provável (reside no estilo das letras). O alfa deitado, por exemplo, é inexistente em inscrições do século VII a.C., impelindo a um recuo temporal (anterior ao século VII a.C.), dada a semelhança com o fenício, ${ }^{7}$ uma das bases para a criação do alfabeto grego (o alfa deitado é pouco comum, e é verificável também num pequeno fragmento de Pitecussa Sarian, op. cit., p. 152 e 171) - ver croqui1 e fig. 3. Como há inscrições de c. 720 (por exemplo a da kotyle de Nestor, também de Pitecussa - ver fig. 8, p. 66) que registram o alfa

\footnotetext{
${ }^{6}$ Langdon (1975, p. 139), apesar de identificar a diversidade de opinião sobre a cronologia da enócoa do Dípilo, acredita na datação de 740-730 a.C., apoiando-se na bibliografia clássica sobre o tema.

${ }^{7} \mathrm{O}$ alfa, ou melhor, o Aleph deitado, é registrado no fenício desde o séc. X a.C. (inscrição de Shipitbaal, c. 925900 a.C., segundo Coldstream [op. cit., p. 297]); mas há também exemplares pouco anteriores com essa mesma característica (ver fig. 7). O aleph deitado era utilizado no moabita, hebraico e aramaico (Healey, J. F. O primeiro alfabeto. In: Hooker, 1996, p. 274). Cabe, ainda, lembrar que letras que assumem valor de vogal no alfabeto grego, como o alfa, não eram caracterizadas, por exemplo, no fenício, da mesma forma: sua utilização era "consonantal glotal" (Coldstream, Idem). Destaca-se, nesse sentido, a contribuição bastante provável da "estrutura silabária da escrita linear cretense, que persistiu, por empréstimo, em Chipre" (Sarian, 1998-1999a, p. 163). Barthes e Mauriès (1987, p. 149) dizem que "a origem do alfabeto coloca um duplo problema: em primeiro lugar, o aparecimento de um sistema simplesmente consonântico; depois, o da notação desse sistema [geralmente um conjunto em torno de vinte signos]". No caso do alfabeto grego, conforme os indícios acima citados, além dessas características básicas na constituição de um sistema alfabético, a introdução das vogais foi crucial.
} 
em pé (e seriam posteriores ao uso do alfa deitado). Na Ática, o alfa em pé ocorre apenas em c. 700 a.C. (Coldstream, op. cit., p. 299). A tolerância cronológica para o uso do alfa deitado fixar-se-ia, muito provavelmente, entre c. 740 e c. 700 a.C., reforçando a tese de que a inscrição da enócoa do Dípilo seja do século VIII a.C.
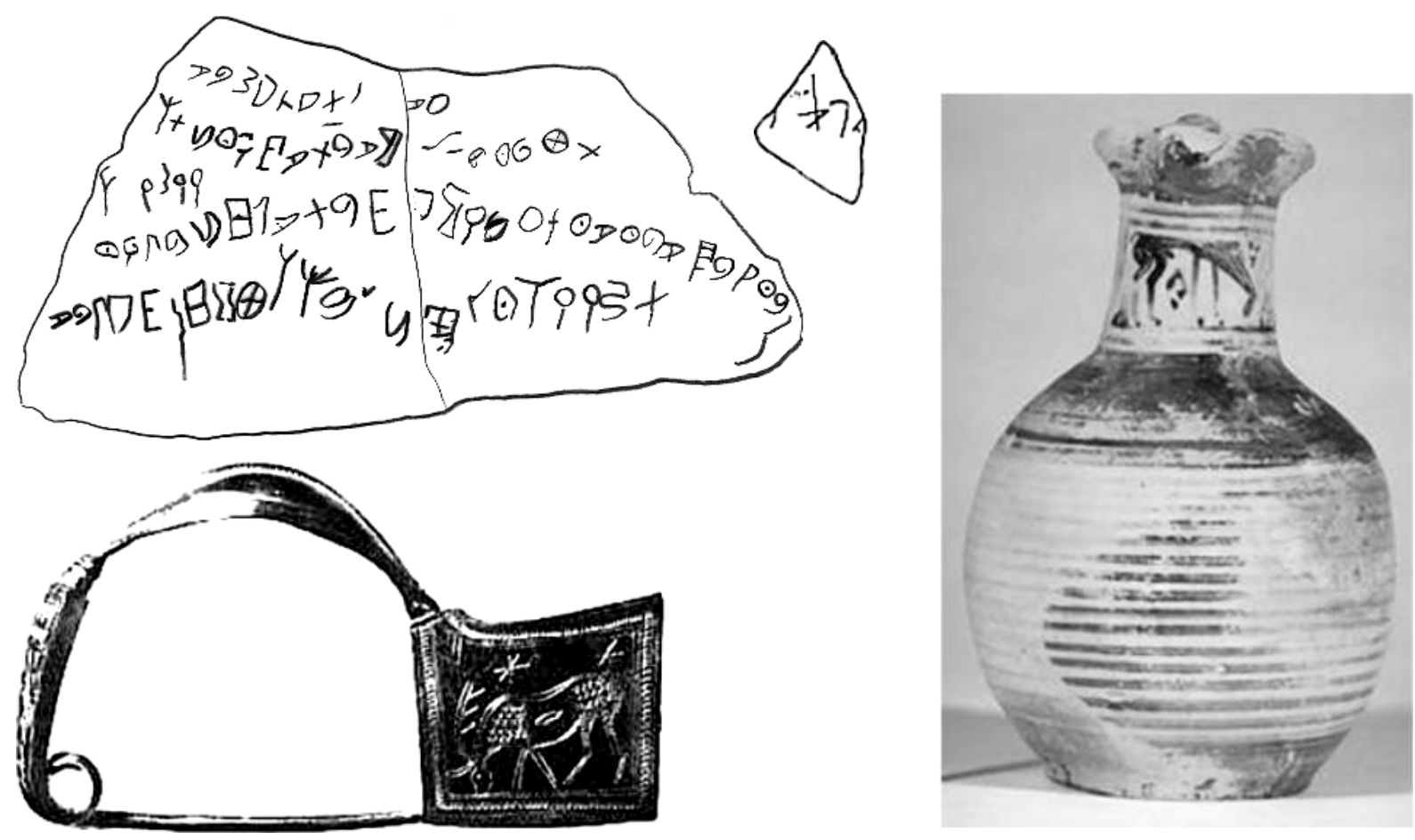

Fig. 2. (Acima, a esquerda) Inscrição de 'Izbet Sartah, c. séc. XI a.C. Fig. 3. (Meio) Inscrição sobre fragmento de cerâmica, Pitecussa. Fig. 4. (Abaixo) Fíbula de ouro, Londres, Museu Britânico (Coleção Elgin). (A enócoa do Dípilo "foi encontrada durante uma escavação irregular de tumbas em ou próximo do Cerâmico em 1871, e foi oferecida à Sociedade Arqueológica Grega com outro material, depois de ter sido dispersado; o resto do conteúdo da tumba que acompanhava essa enócoa, se ali havia algum, é por isso desconhecido" (Jeffery, 1990, p. 68). Entretanto, algumas características como o seu estilo decorativo e sua inscrição atestam sua datação. No tocante à decoração figurada é marcante a presença do cervídeo e do pássaro apresentados de forma geométrica em vários vasos e outros objetos como essa fíbula de ouro ática, na qual há a figuração do cervídeo geométrico.) Fig. 5. (À direita) Um exemplo: outra enócoa do grupo do Dípilo (LG IIb), estilo e forma similar. Não possui inscrição alguma. c. 725-700 a.C. Museu da Universidade de Melbourne (alt.: $21,5 \mathrm{~cm}$ ).

Contra isso, houve quem legasse a própria produção do vaso à data de 690 a.C. Young (1939, p. 228) argumenta que o estilo ornamental da enócoa do Dípilo (os anéis concêntricos e a figuração do cervídeo pastando e a ave) compõe um grupo de referências da decoração da cerâmica geométrica até o século VII a.C., conforme interpretação que o próprio autor faz a partir de vasos de forma e ornamentação similares (Idem, XIII 1, fig. 43, p. 68-9), sobretudo no que se refere aos anéis concêntricos (os mesmos da fig. 43 que apresenta [aqui, cap. 3, fig. 63, p. 121.]). Para a ornamentação figurativa, o autor comenta apenas que ela estende-se até o final do séc. VIII e início do VII a.C., sem mostrar nenhum exemplo. Há que se considerar que o motivo persiste, mas não exatamente da mesma forma, o que permite certas diferenciações cronológicas (Colstream [1979, p. 385], por exemplo, 
apresenta uma subdivisão específica para o Late Geometric: LG la, 760-50; LG Ib, 750-35; LG Ila, 735-20 e LG Ilb, 720-700; o que propõe, ao menos, considerar as diferenciações cronológicas, a partir de características estilísticas, nesse recorte temporal). Entretanto, Jeffery (1990, p. 16, n. 1; publicado originalmente em 1961) diz que, mais recentemente, Young penderia para a indicação cronológica "final do século VIII a.C." quanto à enócoa do Dípilo.

Além das características peculiares desse único vaso, para uma compreensão mais firme da sociedade que o produziu, é necessário inseri-lo numa série de vasos da mesma época e local.

Por sua ornamentação e forma, esses vasos são denominados de "estilo geométrico". ${ }^{8}$ Assim, recorrendo a outros exemplares desse estilo e forma, no qual está inserido a enócoa do Dípilo, percebe-se algumas semelhanças e diferenças: no que se refere à ornamentação e forma, essa enócoa é perfeitamente comum, e diferencia-se justamente por que possui uma inscrição, o que não é peculiar a outros dessa série (ver fig. 4 e 5). Nesse sentido ela é uma exceção.

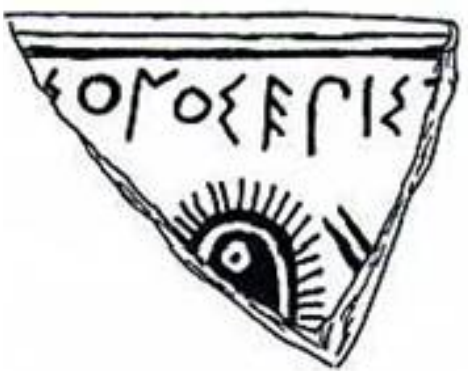

Fig. 6. Fragmento de placa votiva encontrada em Egina, c. 720710 a.C. Museu Nacional, Atenas.

Provável reconstituição da inscrição:

[- - - גụ́]

(Epstamon, filho de ...luson, dedicou... - Tradução minha, baseada na reconstituição por Jeffery, 1990, p. 403)

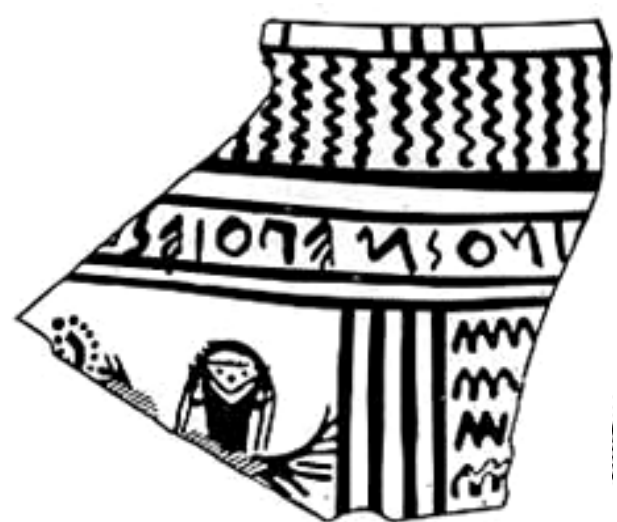

Fig. 7. Fragmento de cratera encontrada em Pitecussa, de tradição eubóica, último quartel do séc. VIII a.C. Museu Arqueológico de Pitecussa.

Inscrição: [- - -]INO $\Sigma$ MEПOIE $\Sigma E[$ [v?]

(...inos me fez. Tradução minha, baseada em Buchner, 1971, p. 67)

Uma outra série é a dos mais antigos exemplares sobre os quais foram articuladas escrita e imagem figurativa (séc. VIII a.C.). Na região da Ática, só se observam novos vestígios a partir do séc. VII a.C., e a enócoa do Dípilo é, até então, um testemunho isolado. Extrapolando essa região, nota-se uma pequena série na qual se insere essa enócoa: são ves-

\footnotetext{
${ }^{8}$ Dentro dessa categoria há várias divisões de acordo com grupos formais, estilísticos, e pelo tempo. A enócoa do Dípilo enquadra-se no grupo LG (Late Geometric).
} 
tígios cerâmicos encontrados em regiões diversas: Ática, Egina e Pitecussa, respectivamente (figs. 1, 6 e 7). Sua análise merece antes algumas considerações sobre os locais de achado e a natureza das inscrições.

A enócoa do Dípilo foi encontrada na região da Ática, nas imediações do Cerâmico, e possui nas suas inscrições peculiaridades que suscitam discussões sobre a origem de seu autor. J. N. Coldstream chega a dizer que o

(...) caso ateniense [a ocorrência do grafite nessa enócoa] é empalidecido por algumas evidências negativas: depois da enócoa do Dípilo, não há mais inscrições áticas conhecidas até os grafites do santuário de Himeto sobre vasos subgeométricos de cerca de 700 a.C., e isso parece inaugurar um novo início com o $\alpha$ vertical, ı reto, e o $\pi$ retilíneo; isso o levou a duvidar se a enócoa do Dípilo foi inscrita por um homem local. (Coldstream, op. cit., p. 299)

Já H. Immerwahr diz:

Jeffery tem feito várias diferenciações entre esta e as posteriores inscrições áticas; ela pensa que a inscrição não é ática, mas talvez próxima do alfabeto grego primitivo, que deriva de $\mathrm{Al}$ Mina (...). (Immerwahr, 1990, p. 7) ${ }^{9}$

Apesar de encontrar algumas semelhanças com inscrições áticas posteriores e certos distanciamentos da matriz fenícia; Jeffery, a "base" de vários desses estudos indicados, nota a excepcionalidade da inscrição sobre tal enócoa: "[o alfa deitado] é único (...), [o iota dobrado] é único (...) [e o seu lâmbda] ocorre apenas [nesta inscrição] e muito raramente depois (IG i ${ }^{2} 487$ )" (Jeffery, 1990, p. 66). ${ }^{10}$

Esse conjunto de informações permite apenas desconfiar da absoluta certeza de autoria ática da inscrição, mas não de afastá-la como vestígio, já que o vaso certamente é ático, e a dúvida persiste na autoria da inscrição.

O segundo testemunho é um fragmento de uma placa de cerâmica votiva (fig. 6), encontrada em Egina, nas cercanias do templo de Apolo. A escassez de documentação, a similaridade da técnica e a mesma matéria-prima impeliu a utilização dessa placa num conjunto de vasos (que muitas vezes também faziam às vezes de objetos votivos). Ela tem a ornamentação pintada (tanto a inscrição como a imagem figurada) e enquadra-se no estilo de "cabeças de guerreiros". ${ }^{11}$ Informação importante é a relação entre o local de achado e o

\footnotetext{
${ }^{9}$ No seio deste debate, sobre o fragmento de inscrição de Pitecussa com o alfa deitado (fig. 3), Jeffery (1984, p. 291) diz que a inscrição é fenícia; assim como McCarter, 1975, p. 140-1.

${ }^{10}$ Como visto, o alfa deitado ocorre também num fragmento de Pitecussa (ver nota acima). Para uma caracterização e comparandum mais amplos da inscrição da enócoa do Dípilo ver Guarducci, 1967, p. 133-6.

${ }^{11} \mathrm{O}$ que a data de c. 700 a.C., segundo Jeffery, Idem, p. 110.
} 
provável local de produção: Jeffery e Boardman acreditam que, mesmo sendo encontrado em Egina, esse fragmento, por suas características estilísticas (da inscrição e da imagem figurada) seja ático. ${ }^{12}$ Sua inscrição foi reconstituída, e parece ser um hexâmetro, como sugerem Jeffery (Idem, p. 403) e Powell (1990, p. 147): “Epistamon, filho de Luson, dedicou...”.

O último, um fragmento de uma cratera (séc. VIII a.C.) encontrado em Pitecussa (hoje denominada Ísquia), ilha no litoral centro-oeste da Itália, local que foi palco de colonização grega na Antigüidade. Outros achados importantes como a popular "kotyle de Nestor" (fig. 8) foram encontrados no mesmo local. O fragmento em questão tem uma inscrição de autoria: "(...)inos me fez" (fig. 7). Esse objeto é, ao mesmo tempo, suporte da mais antiga inscrição pintada e de autoria. Abaixo, separados por duas linhas, há uma imagem, interpretada comumente como uma esfinge, delimitada por parte de um painel com elementos geométricos. Cabe lembrar que Pitecussa foi colonizada por gregos vindos da Eubéia, e assim, esse fragmento apresenta os grafismos peculiares da tradição eubóica.

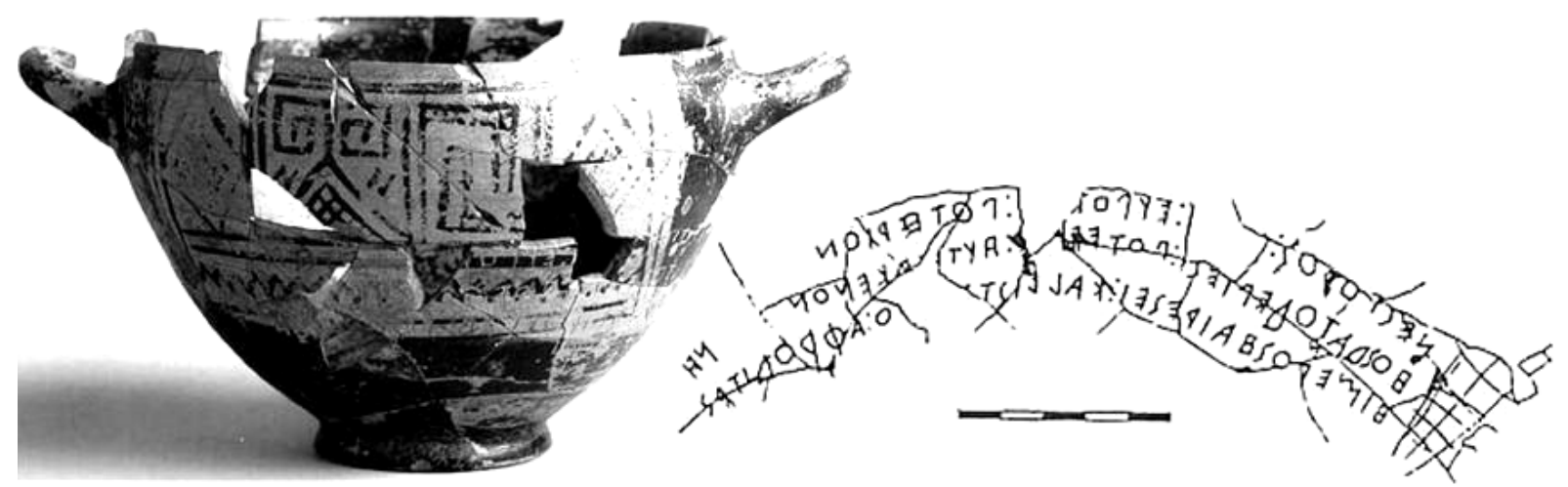

Fig. 8. Kotyle de Nestor, Pitecussa, 720-710 a.C., Museu Arqueológico de Pitecussa (alt.: 10,3 cm).

\section{Inscrição:}

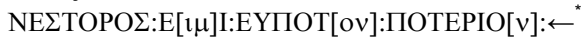

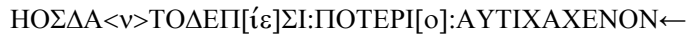

HIMEPO $\Sigma H A I P E \Sigma E I: X A \Lambda \Lambda I \Sigma T E[\varphi \alpha ́]$ NO:AФPO $\Delta \mathrm{ITE} \Sigma \leftarrow$

(Eu sou a taça de Nestor, quem beber desta taça, logo o tomará o desejo de Afrodite de bela coroa. Tradução minha, baseada em Havelock, 1996, p. 200).

* Existem alguns descompassos nas reconstituições das inscrições fragmentárias. No caso da inscrição da Kotyle de Nestor, vale a pena

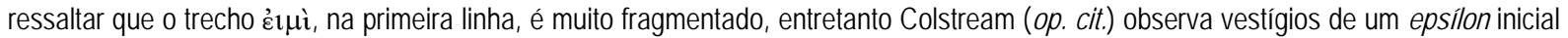
e um iota final. Já Copete (1999, p. 193) reconstitui de forma bastante diferente: não observa indícios do epsílon e iota, propondo o preenchimento da lacuna com a partícula $\mu \varepsilon ́ v$.

\footnotetext{
${ }^{12}$ Discussão citada por Jeffery, que inclusive baseia teses de relações comerciais entre Atenas e Egina. Ibidem.
} 
O primeiro grande contraste entre esses objetos é seu local de achado: se a região da Ática ficava próxima de Egina, e se inclusive essas cidades mantinham contatos comerciais, não se pode dizer o mesmo de Pitecussa (ver croqui1, p. 62). ${ }^{13}$ Essa diferença espacial insere o debate do difusionismo da cultura grega, ou das cidades gregas no âmbito do Mediterrâneo. Objetos de tradição grega são encontrados em várias regiões do Mediterrâneo, fugindo da Península Balcânica, inclusive materiais cerâmicos contendo inscrições e imagens. Qualquer estudo que se pretenda profundo sobre o desenvolvimento do alfabeto grego deve extrapolar as amarras da Grécia continental, do Mar Adriático e Egeu, e também rumar para oriente e ocidente. A inscrição alfabética grega mais antiga não foi encontrada na Grécia continental, mas na região da Itália. ${ }^{14}$ Ainda se deve destacar o papel da cerâmica como documento nos estudos do desenvolvimento do alfabeto grego. Esse suporte, por sua durabilidade material, apresenta várias dessas inscrições alfabéticas mais antigas. ${ }^{15}$

Como foi possível notar, os exemplares de Egina e Pitecussa apresentam uma articulação entre escrita e imagem figurativa que não pode ser notada no vaso ático: ambos, além de possuírem inscrição e imagem pintadas (articulados originalmente pelos artesãos que as produziram), têm escrita e imagem muito próximas, na mesma região do vaso; enquanto a enócoa do Dípilo tem inscrição e imagem figurada em técnicas diferentes (uma em grafite e a outra é pintada respectivamente), e são exibidos em espaços diferentes do vaso. Assim, se se percebe já uma relação original entre escrita e figuração nos exemplos da Egina e Pitecussa, no contexto da própria concepção artesanal, no caso ático só se pode identificar uma desconexão que só seria sanada posteriormente (no século VII a.C.); pois a relação entre os grafismos apresentada nele não revela uma atividade artesanal que articule originalmente as duas linguagens.

A temática é diversa: o vaso da Ática possui um grafite que o caracteriza como premiação num concurso de dança; o fragmento de Egina, uma dedicatória; já o exemplar de Pitecussa, uma inscrição de autoria. As imagens também não apresentam um conjunto coeso: o cervídeo e a ave, a "cabeça de guerreiro" e a provável esfinge.

Entretanto, se se tem em alguns casos relação original entre escrita e imagem na confecção artesanal, não se pode dizer o mesmo quanto à relação material-temática. Nesses exemplares nenhuma inscrição relaciona-se tematicamente com as imagens próximas;

\footnotetext{
${ }^{13}$ A caracterização dessa grande distância entre o eixo Atenas-Egina e Pitecussa atenua-se quando se traz a informação que a Eubéia, responsável pela colonização de Pitecussa, era uma grande ilha ao lado da Ática (ver croqui1). Essa proximidade pode parecer forçosa, mas é necessário considerar que muito da tradição cultural eubóica encontrava-se em Pitecussa.

${ }^{14}$ São elas "cinco letras gregas encontradas nas escavações de Osteria dell' Osa - Gabines, na Itália (região central do Tirreno): são as mais antigas e datam da primeira metade do séc. VIII a.C., mas elas são ilegíveis..." (Sarian, op. cit., p. 161).

${ }^{15}$ Além da inscrição de Osteria dell'Osa (ver nota acima), e da inscrição da enócoa do Dípilo, temos a inscrição ródia de Qoraqos, a extensa inscrição da kotyle (a "Taça de Nestor") e vários fragmentos de Pitecussa etc. (Idem) Todas essas inscrições ocorrem sobre o suporte cerâmico.
} 
mas essa pode ser uma informação parcialmente equivocada, pois a característica fragmentária dos exemplares de Pitecussa e Egina não permite a compreensão integral de sua concepção original.

Por fim, a inscrição de autoria do fragmento de Pitecussa distancia-se quanto à forma métrica das inscrições dos dois outros objetos: neles (no vaso ático e no fragmento egineta) há uma composição métrica idêntica: são hexâmetros (se a reconstituição de Jeffery for correta, como parece). ${ }^{16}$

Com isso, não se tem um grupo coeso, e o caráter de exceção do exemplar ático parece reforçar-se. ${ }^{17}$ Foram encontrados alguns paralelos entre a enócoa e os outros; mas não no que se refere à relação material entre inscrição e figuração. O que inferir a partir disso? Não se pode dizer que havia nessa época a preocupação maior em articular escrita e imagem na cerâmica na região da Ática no contexto da produção artesanal. Dessa forma, não se deve partir daí (do período geométrico) para este estudo, pois essa não era uma sociedade que aproximava essas linguagens de forma sistemática sobre os vasos de cerâmica. $O$ ponto inicial no que se refere à Ática deve ser mais recente, já no século VII a.C., quando surgem os primeiros exemplares de forma ostensiva (essa relação já pensada na própria confecção do vaso e em maior quantidade).

Como visto, buscar as origens dessa interação gráfica no século VIII a.C. não constitui um corpus documental denso. A partir do século VII a.C. encontra-se uma "forma", ou seja, o estilo das figuras negras sobre os vasos de cerâmica, e ela apresenta um conjunto que delimitará os nossos limites temporais (junto a alguns poucos exemplares do estilo protoático); e, para estipular um ponto final desse recorte, deve levar-se em consideração a época em que o estilo de figuras negras perde espaço para o de figuras vermelhas ${ }^{18}$, mas não por acaso. Esta análise tem como característica essencial a natureza dos grafismos produzidos sobre esses vasos. O universo tratado já apresenta uma variedade grande, unificada pela técnica e estilo (as figuras negras). Ora, avançar essa análise e tratar o estilo e a técnica das figuras vermelhas significa construir um outro arsenal teórico metodológico. Além disso, deve levar-se em conta o contexto em que se inserem esses grafismos: há grande modificação social, política, cultural etc., no "mundo grego", e especificamente na Ática. Assim, essas outras características específicas, abrem espaço para um novo estudo

\footnotetext{
${ }^{16}$ Jeffery, para essa reconstituição, leva em conta tanto o fragmento da inscrição original, como a natureza do suporte (uma placa de cerâmica utilizada para fins votivos), disso resulta a reconstituição bastante provável.

${ }^{17}$ Sobre as inscrições áticas no séc. VIII a.C., Immerwahr (op. cit., p. 8) diz: "O pequeno número de inscrições antes de 700 a.C. deve-se à relutância da Ática, mais que à oportunidade (...). Outras regiões fornecem melhores exemplos de escrita bastante antiga; (...) [note-se] especialmente as inscrições pintadas sobre um vaso local de Ítaca, e dois graffiti de um estilo desenvolvido (...) de Pitecussa, (...) de Corinto, todos três muito bem datados do final do século oitavo".

${ }^{18} \mathrm{O}$ estilo de figuras vermelhas baseia-se, resumidamente falando, na composição das formas a partir de linhas finas em verniz negro, a partir de pincéis, ressaltando-se assim a coloração alaranjada da cerâmica na figura; e o fundo é, geralmente, preenchido pelo mesmo verniz negro, o que caracteriza o contraste.
} 
Assim, essas outras características específicas, abrem espaço para um novo estudo além do proposto.

Essa discussão das fontes, e de sua inserção no tempo, no seu contexto, parece indicar que não se deve usar um recorte temporal tão específico, fechado em datas tão precisas. Toda a discussão sobre esses vasos, e sobre seus grafismos, leva em conta tolerâncias de datações, dada a dificuldade de uma precisão tão grande no que se refere às tendências dos grafismos em época tão recuada. Assim, se a proposta inicial de recorte temporal repousava em datas fechadas (630-525 a.C.), de forma mais tolerante, será utilizado um recorte que vai do séc. VII ao VI a.C., o que a discussão sobre as fontes sustenta com viabilidade.

O conjunto documental indica certa coesão, e a partir disso as balizas cronológicas aqui utilizadas são estabelecidas: um período que abrange, no mínimo, um século, o que incita uma discussão sobre as "durações" do tempo. As discussões sobre as temporalidades apresentadas por F. Braudel em $1958^{19}$, e até hoje discutidas, ajudarão neste ponto. Assim, haveria uma curta duração ("expressão dos acontecimentos", geralmente ligada ao ato político), a média duração (ligada aos ciclos econômicos, à conjuntura, tem fôlego médio), e a longa duração:

Os observadores do social entendem por estrutura uma organização, uma coerência, relações suficientemente fixas entre realidades e massas sociais. Para nós, historiadores, uma estrutura é, indubitavelmente, um agrupamento, uma arquitetura; mais ainda, uma realidade que o tempo demora imenso a desgastar e a transportar (Braudel, 1986, p. 14).

Entretanto, essas categorias temporais não são incomunicáveis, isoladas. Nesse sentido, Michel Vovelle apresenta uma "nova dialética do tempo curto e do tempo longo":

A noção de estrutura, como a manejam em campo os historiadores sociais e das mentalidades, perde toda rigidez e monolitismo, exprimindo um encontro de vestígios, que sem dúvida se organizam num sistema coerente, mas no âmbito de um equilíbrio sem cessar questionado e de uma respiração que é da História. (Vovelle, 1990, p. 89).

O estudo aqui proposto, apesar de notar a importância da dimensão da "curta duração" do tempo, e de lançar mão delas em alguns casos, pauta-se, sobretudo, numa apreensão que transita da "longa" à "média" duração. Isso, já que se tratarão de estruturas universais como a expressão gráfica (o ato de produzir grafismos, que remonta a comportamentos "pré-históricos"), porém concernentes a um caso específico. Assim, interessa mais a dimen-

\footnotetext{
${ }^{19}$ Histoire et sciences sociales: «la longue durée», Annales E. S. C., nº 4, Oct.-déc. 1958, Débats et Combats, pp. 725-753.
} 
são do fato (algo consolidado e seu comportamento ao longo do recorte temporal proposto); ou seja, o desenvolvimento dos grafismos em figuras negras, não como puro e simples indício de tendência gráfica, material, mas principalmente como vetor da ação de determinado grupo social.

Estruturas como a criação gráfica, que acompanham a história do homem desde tempos "pré-históricos", encontram certas especificidades espaço-temporais como as dos grafismos dos vasos áticos em técnica de figuras negras. Essa especificidade indica um diálogo entre uma longuíssima duração e uma média (já que tal estilo ornamental teve duração de pelo menos um centenário), e mesmo muitas ações políticas, no seio da História breve, interferiram frontalmente na dinâmica das ditas figuras negras. Isso tudo indica que essas temporalidades devem ser observadas a partir de sua comunicação. As características estruturais, no sentido de Braudel, encontram situações diversas na sua composição. O exemplo de Lévi-Strauss (que apresenta um outro tipo de estruturalismo, mas que pode ser observado sob a leitura braudeliana $)^{20}$, referente à idéia do incesto, mostra isso. Por mais que a explicação estrutural para a rejeição do incesto, ao longo do tempo e em inúmeras culturas, passe pela generalista estrutura de parentesco, (Lévi-Strauss, 1967, p. 64), ela encontra discursos afirmativos diversos, como nos dias atuais: além das antigas questões morais, as relacionadas ao discurso científico biológico, como a idéia de variabilidade genética, reafirmam a rejeição do incesto (Lévi-Strauss, 1982, p. 52-4).

A dinâmica da produção ceramista deve também ser observada levando-se em conta a variação da ornamentação, das formas e de seu uso, ao longo do tempo. No caso da produção, a substituição de uma geração por outra (ver esquema 1), aliada a outras questões de caráter político, comercial, cultural etc., apresenta alguns ciclos nos quais as mudanças são observadas. Como será visto, a relação entre escrita e figuração segue um caminho variado do século VII ao VI a.C. A corporeidade do estilo de figuras negras mantém-se, mas não de uma forma rígida. A concorrência entre oficinas, e a substituição de artesãos ao longo do tempo certamente estão relacionadas com essas mudanças.

Por fim, é importante dizer que as questões relacionadas à cronologia, lançadas neste item, não foram aqui esgotadas, e sempre que oportunamente uma discussão cronológica for necessária, ela será feita.

\footnotetext{
${ }^{20}$ Les structures élémentaires de la parenté, de Claude Lévi-Strauss, foi publicado originalmente em 1949, e citado várias vezes por Braudel em La longue durée..., bem como outras referências (Antropologia estrutural, Diogène couche, Les mathématiques et sciences sociales), o que confirma o diálogo na questão do estruturalismo.
} 
(a.C.)

630 P. of Berlin A 34

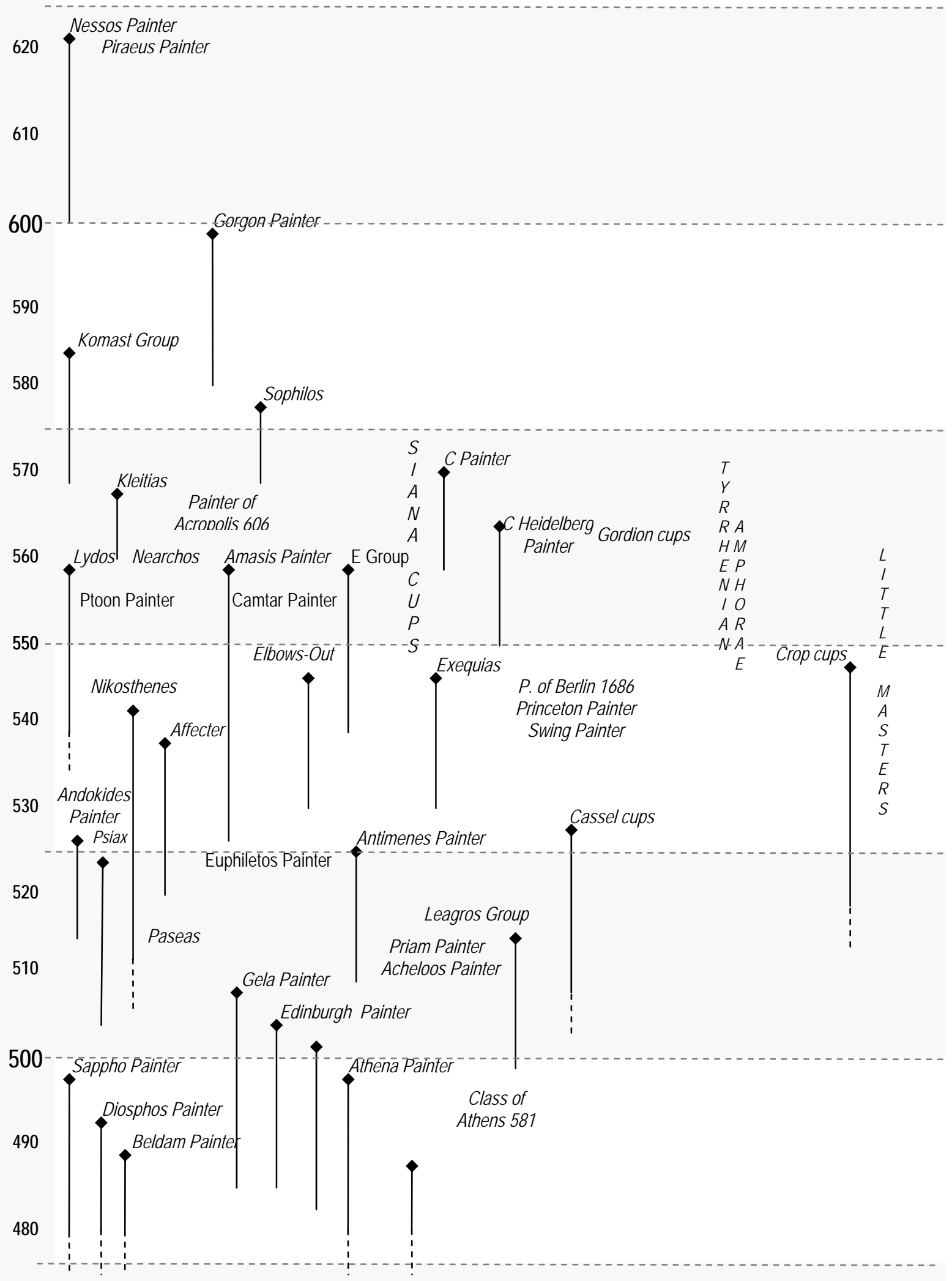

Esquema 1. Carta cronológica: oleiros, pintores e grupos estilísticos, de 630 a 480 a.C., atuantes na Ática (adaptado de Boardman, 1995. D. 234) 


\subsubsection{Espacialização: recorte e justificativas}

O termo "Grécia antiga" é consagrado no ramo dos estudos da Antigüidade. Totalizante, às vezes absoluto, esconde uma série de especificidades concernentes a essas sociedades (propositadamente colocadas no plural). Foi utilizado e utilizar-se-á tal termo aqui, já que há a facilidade de sua compreensão em vários meios; porém deve ser ressaltada a compreensão de sua relatividade, por vários motivos. De início, esse foi um nome dado pelos romanos (Graeci, para o local [Finley, 1988, p. 14], e graecus para seus habitantes). Vale lembrar que a denominação Hélade era mais comum na Antigüidade, não a única. Sabe-se que "heleno" era uma caracterização comum no período arcaico (pelo menos no século VI a.C.), junto a outras como

(...) quando se refere aos sitiadores de Tróia [os gregos], Homero emprega, diga-se, indistintamente, três nomes: aqueos, dánaos (descendentes de Dánao, um dos reis míticos que criaram a Grécia) e argivos. (Vidal-Naquet, 2001, p. 32) ${ }^{21}$

O termo "Grécia" sugere uma unidade e homogeneidade que não aconteceu na Antigüidade. ${ }^{22}$ Havia, isso sim, cidades-Estado autônomas, apesar de várias características afins, e mesmo de uma auto caracterização comum, que fica visível a partir de, por exemplo, um fragmento de texto do séc. VI a.C., intitulado Catálogo das mulheres: é reconstituída uma genealogia (ver esquema 2), a partir do herói tessálio Deucalião, pai de Heleno, ${ }^{23}$ que era pai de Doro, Eolo e Xuto. Este último era pai de Íon e Acaio; ou seja, clara referência a uma ancestralidade metafórica comum, com certas especificações. ${ }^{24}$ Além disso, mesmo na Antigüidade, houve projetos de unificação, como o denominado "imperialismo ateniense", que entusiasmou figuras como Heródoto, que, na sua História, propunha uma unificação grega, liderada por Atenas, frente ao perigo persa. Todavia, mesmo com esse tipo de pro-

\footnotetext{
${ }^{21}$ Ainda, Shapiro (1997, p. 2), ao comentar alguns aspectos do mito nos poemas homéricos diz: "Para eles [os gregos] não havia heróis 'gregos', mas heróis argivos, tebanos, atenienses, coríntos, cretenses (...)". Vale dizer que os nomes dánao, argivo e acaio, em Homero, aparecem de forma desigual, respectivamente em ordem quantitativa. Sobre esse traço, relacionado ao aparecimento desses qualificativos como epítetos ou isoladamente, ver Bandinelli, 1993a, p. 27-8.

${ }^{22}$ Essa discussão é em grande parte inspirada na experiência do curso de História Antiga II, ministrado pelo prof. Norberto Guarinello (DH-FFLCH-USP) em 2002; esboçada mais esquematicamente na sua apresentação da ANPUH (Por uma morfologia da História Antiga. Associação Nacional de História. XVII Encontro regional [São Paulo] de História, 6 a 10 de setembro de 2004). Um esboço bastante parcial de alguns pontos encontra-se em Guarinello, 2003.

${ }^{23}$ Essa personagem é apresentada como "Heleno" em Hall (2001, p. 218-9) e Vidal-Naquet (2002, p. 108); já na versão da LOEB Classical Library do Catálogo das mulheres, como "Hellen" (tradução em inglês do grego), e em Grimal (2000, p. 200) é registrado "Hélen", e "Heleno" como "filho de Príamo e Hécuba e irmão gêmeo de Cassandra". Manter-se-á aqui a terminologia "Heleno" para o herói tessálio; pois é a forma mais recorrene nas traduções em português.

${ }^{24}$ É importante notar que, apesar da idéia de ancestralidade comum, uma linhagem específica distingue os aqueus e jônios (representados por Aqueu e Íon) do quadro geral.
} 
posta de unificação, sobressaiu, até o avanço macedônico sobre a Grécia, a fragmentação com pontos de união, reforçada pelo sentimento panelênico. ${ }^{25}$

O termo "Antigüidade" também merece atenção. Ele compreende um recorte espaçotemporal muito grande (desde civilizações que desenvolveram a escrita, até a atuação romana imperial; e um espaço que abarca quase todo o Mediterrâneo, Médio Oriente e alhures). Compreendendo essa amplitude do termo, ele sempre será utilizado com certas restrições.

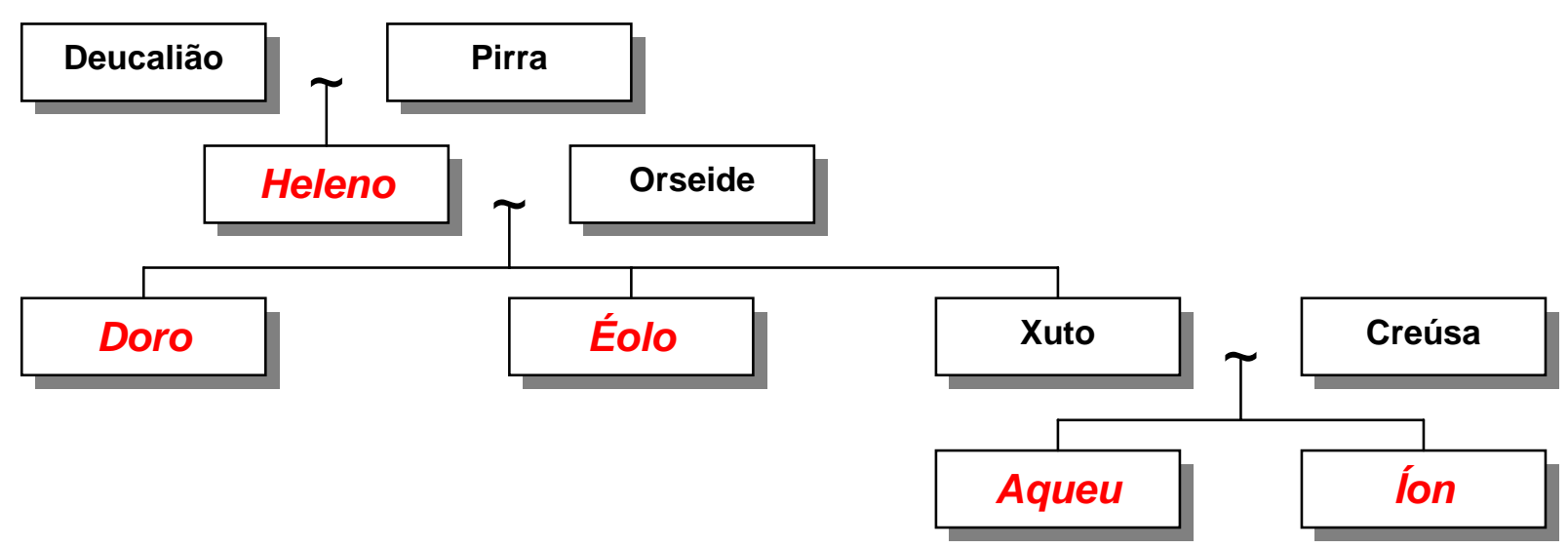

Esquema 2. Descendência de Deucalião e Pirra (para maior detalhamento, ver o quadro genealógico n. 8 em Grimal, 2000, p. 116).

Outra especificidade que deve ser feita, no quadro espaço-geográfico, se relaciona à problemática Ática-Atenas. Ou seja, podem ser usadas de forma unitária? Recorrendo à idéia dos conjuntos pode responder-se isso da seguinte forma: Atenas está contida na Ática (Atenas $\supset$ Ática), mas nem toda a Ática contém-se em Atenas. ${ }^{26}$ Parece, assim, que Atenas é uma parte da Ática, não sua totalidade. J. Boardman apresenta alguns pontos para esclarecer mais esse quadro: “(...) Atenas ou Ática? A comum prática de chamar de atenienses vasos áticos disfarça a possibilidade que havia na produção ceramista de vasos decorados em outro lugar da Ática além do bairro de oleiros de Atenas" (Boardman, 1995, p. 182). Mas esse é um esquema simples e não responde amplamente a questão colocada.

Como a concepção de pólis na Antigüidade não passava apenas pela questão territorial, mas também à bastante conhecida "comunidade de cidadãos", deve se ampliar o sentido, além da geografia, para compreender a relação Ática-Atenas. Para Boardman há uma distinção que deve ser feita entre uma e outra, inclusive para não sufocar tendências extra-

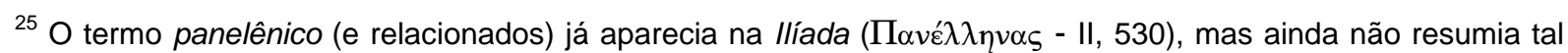
sensibilidade grupal observada desde o período arcaico; uma outra compreensão que nunca se baseou numa absoluta unificação entre as cidades gregas, mas sim num reconhecimento de traços comuns.

${ }^{26}$ A Ática "(...) era dividida, no período histórico, em 139 demói. Muitos deles eram distritos ou vizinhos da própria cidade, mas outros deles eram assentamentos separados distribuídos através do meio rural. Cada um deles tinha sua própria administração e organizações cívicas (...)" (Camp, 2001, p. 271).
} 
atenienses na Ática. Entretanto, havia o poder político ateniense sobre a região, e isso indica um outro problema: a posição de Atenas dentro da Ática, que não era equiparada aos demais demói, havia um desequilíbrio no jogo político. Com isso, a influência ateniense sobre esses outros espaços áticos é matéria que deve ser considerada nas questões espaciais.

Outro binômio, Atenas-Grécia, merece atenção: Sobre isso, Boardman ainda presta auxílio:

Atenas não é a Grécia. Há, por exemplo, uma rica e antiga série de cenas de mito na arte do Peloponeso sobre relevos de bronze e vasos de Corinto. Às vezes, o débito de Atenas a essa tradição pode ser traçado, às vezes sua independência dela. A influência estilística e técnica de artistas do Leste grego em Atenas no século sexto é clara, e nós podemos suspeitar de uma influência iconográfica também. (Idem, p. 215)

E finaliza:

não podemos tomar Atenas como o modelo de todo o comportamento e gosto gregos neste artesanato. (...) A influência de Atenas na Ática foi provavelmente a mais extensiva, mas havia Argos e a Argólida (...), Corinto com grande influência no Peloponeso noroeste (...). (Boardman, 2001, p. 24)

Novamente, Atenas insere-se na Grécia (Atenas $\supset$ Grécia), mas a Grécia não pode ser vista como correspondente a Atenas. É notório, que o interesse por Atenas ao longo do tempo, inclusive criando uma Atenas idealizada ("berço da democracia"), observada a partir de interesses posteriores, levou, por muitas vezes, dizer-se "arte grega", "cultura grega", "democracia grega" etc., quando se observava apenas Atenas. Os sistemas políticos, a criação cultural, as estruturas sociais, dentre outros, não tinham uma única entonação, e tomar Atenas por Grécia anula essa variedade e complexidade. Ainda, é importante saber que na História da Grécia antiga, Atenas posicionou-se de forma bastante privilegiada durante algum tempo, levando, com isso, muito de seu modo de ser para outros locais. Espaços como Delos, por exemplo, tiveram definitiva modificação no desenvolvimento de sua história dada a forte presença do poder ateniense.

Situar Atenas-Ática no plano espacial também é importante pois este era o pólo de produção dos grafismos aqui tratados. Porém, na linha de interpretação aqui proposta, esse é apenas um problema espacial a ser tratado, já que a análise da difusão dos grafismos impele a uma nova compreensão da lógica espacial, e é na relação entre Atenas-Ática e outros espaços que é possível compreender tal situação. Um bom começo é o próprio mo- 
vimento de difusionismo da cultura grega, desde o início do período arcaico, com o estabelecimento de um grande número de colônias espalhadas na região do Mediterrâneo. É certo que o movimento histórico chamado de colonização abrange situações desde a criação de entrepostos comerciais até a fixação de assentamentos mais desenvolvidos. Compreendendo toda essa abrangência, o cenário apresentado é de fixações gregas numa área de latitude e longitude bem amplas $\left(4^{\circ} \mathrm{O}\right.$ a $42^{\circ} \mathrm{L}$ e $32^{\circ} \mathrm{N}$ a $46^{\circ} \mathrm{N}$ ), com concentrações variadas (por exemplo, no Mar Egeu, na região da Sicília e Magna Grécia, as fixações de colônias são mais numerosas). Como a cerâmica ática arcaica não se restringia à sua região de produção, dada sua difusão através do comércio, o espaço a se considerar deve ser mais amplo. Mesmo o que é chamado de "Mundo grego" não restringia essa difusão comercial, de forma que se deve tratar da unidade espacial "Mediterrâneo".

O termo Mediterrâneo estrutura-se em torno de referências geográficas e culturais; dada a profunda comunicação entre populações (em grande parte calcada na dinâmica comercial), e a compreensão da formação de certas estruturas peculiares dessa região, levando em conta a experiência dos habitantes "originais"; mas sobretudo com a chegada de grupos indo-europeus, cujos traços culturais peculiares do Oriente são bastante claros na formação da cultura européia desde a antiguidade.

Já o termo "Mundo grego" compreende-se principalmente na idéia de cultura, pois o variado movimento de expansão (espacialmente e cronologicamente) e a própria estruturação das cidades-Estado na Grécia continental que dão certa coesão a tal termo. As contribuições entre os assentamentos da Ásia Menor e as culturas do Egeu (as do arquipélago egeano e as da Grécia continental) estão ainda sendo definidas por especialistas, inclusive no que se refere à cronologia: não se pode falar com segurança numa expansão unidirecional de influência do continente grego para a Ásia Menor, já que contribuições importantíssimas à cultura grega como a escrita alfabética ou a utilização de moedas foram moldadas no Mediterrâneo oriental, para depois se desenvolver no continente grego.

As relações entre o continente grego e outros espaços são mais amplas, e não se restringem às ligações entre metrópoles e colônias. Uma outra entonação pode ser observada na dinâmica comercial, e, nesse sentido, um bom recurso de verificação é distribuição dos vasos áticos na ampla região mediterrânica, até o Oriente Próximo. De início, vale dizer que a extensão dos locais de achado desses vasos é extremamente ampla e variada, atingindo distâncias que vão da Babilônia até a Península Ibérica, do Mar Negro a Luxor, como indica a relação dos locais de achado, apresentada no Beazley Archives (ver croqui 2, tabela 1, esquema 3).

Por fim, é necessário dizer que essas especificidades locais, notadas por meio de várias características, dentre elas os grafismos, permitem focalizar questões sobre esses grupos, e o papel dos grafismos tratados na organização desses limites que não são necessa- 
riamente espaciais; dito de outra forma, a utilização dos grafismos como instrumento para compreender questões da etnicidade ática arcaica. Entretanto isso não é tudo. A Ática, como espaço específico, contempla a produção e parte do mercado consumidor, mas há ainda, como visto, o mercado externo, que abarcava boa parte da bacia do Mediterrâneo, e ali haveria relação diferente com esses vasos, e conseqüentemente, também com seus grafismos; por exemplo, populações não-gregas, adquirindo vasos com "estranhas" temáticas mitológicas. Nesse sentido o recorte espacial não deve manter-se exclusivamente preso à Ática. Isso, não apenas pela abrangência do alcance dessa produção ceramista; ou seja, pela influência que os gregos exerceram no Mediterrâneo. Ora, as redes comerciais entre Grécia continental, Mar Egeu, Oriente Próximo e Egito, remontam dinâmicas comerciais desde a Idade do Bronze; assim, antes mesmo de estruturar-se qualquer traço autoconsciente de helenidade; e pensar na estruturação das póleis gregas no período arcaico leva constantemente a questões espaciais abrangentes.

a. Península lbérica b. Península Itálica e Região

\begin{tabular}{|c|c|c|c|c|c|c|c|c|c|}
\hline & \multicolumn{6}{|c|}{ D. Pelminsula Ilalica e Reglau } & \multicolumn{2}{|l|}{ C. Alpes e reglad } \\
\hline 1. Alcacer do Sal & 2 & 12. Tharros & 24 & 25. Gubbio & 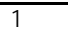 & 38. Paestum & 98 & 51. Bourges & 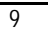 \\
\hline 2. Huelva & - & 13. Oristano & - & 26. Attiggio & 1 & 39. Altamura & 5 & 52. Vix & 5 \\
\hline 3. Baza & 5 & 14. Cagliari & - & 27. Chiusi & 463 & 40. Bari & 103 & 53. Courcelles & 1 \\
\hline 4. Toya & 22 & 15. Aleria & 78 & 28. Vulci & 482 & 41. Taranto & 724 & 54. Chatillon-sur-Glane & 10 \\
\hline 5. El Cigarrelejo & 3 & 16. Bologna & 435 & 29. Tarquinia & 645 & 42. Metapontum & 136 & 55. Heuneburg & 12 \\
\hline 6. Murcia & 3 & 17. Marzabotto & 28 & 30. Gravisca & 359 & 43. Locri Epizephyrii & - & 56. Hochdorf & 5 \\
\hline 7. Cabezo Lucero & 25 & 18. Florence & 1 & 31. Orvieto & 965 & 44. Megara Hyblaea & 132 & 57. Drouzkovice & 3 \\
\hline 8. Pozo Moro & 3 & 19. Arezzo & 9 & 32. Viterbo & 11 & 45. Syracuse & 13 & 58. Enserune & 330 \\
\hline 9. Los Villares & 4 & 20. Modena & 1 & 33. Cerveteri & 1192 & 46. Gela & 935 & 59. Beziers & 27 \\
\hline 10. Ampurias & 598 & 21. Adria & 629 & 34. Rome & - & 47. Agrigento & 407 & 60. La Monediere & 19 \\
\hline \multirow[t]{3}{*}{ 11. Ullastret } & 150 & 22. Spina & 485 & 35. Cumae & 258 & 48. Selinunte & 385 & 61. Marseille & 56 \\
\hline & & 23. Acquaviva & 9 & 36. Naples & 94 & 49. Segesta & 6 & & \\
\hline & & 24. Ancona & 4 & 37. Pontecagnano & 14 & 50. Palerma & 21 & & \\
\hline
\end{tabular}

d. Mar Negro e Oriente Próximo

\begin{tabular}{llll}
\hline 62. Zhurovka & - & 75. Ephesus & \\
63. Taganrog & 8 & 76. Tralleis & \\
64. Olbia & 155 & 77. Miletus & \\
65. Pantikapeion & 512 & 78. Bodrum & - \\
66. Pityus & - & 79. Episkopi & 2 \\
67. Odessos & 6 & 80. Kition & 80 \\
68. Apollonia Pontica & 64 & 81. Al Mina & \\
69. Istanbul & 2 & 82. Byblos & 3 \\
70. Heraclea Pontica & - & 83. Akko & 3 \\
71. Sinope & - & 84. Balatah & 17 \\
72. Troy & 4 & 85. Babylon & 3 \\
73. Old Esmyrna & 312 & 86. Dor & 14 \\
74. Clazomenae & 209 & 87. Atlit & 2 \\
\hline
\end{tabular}

e. Norte da África e Egito

$\begin{array}{llll}\text { 99. Utica } & 3 & \text { 112. Tell el-Herr } & - \\ \text { 100. Carthage } & 69 & \text { 113. Luxor } & 1 \\ \text { 101. Tunis } & 1 & \text { 114. Elephantine } & 1 \\ \text { 102. Sabratha } & 6 & & \\ \text { 103. Tripoli } & 1 & \\ \text { 104. Ptoemais } & 4 & \\ \text { 105. Benghazi } & 79 & & \\ \text { 106. Barka } & - & & \\ \text { 107. Cyrene } & 368 & & \\ \text { 108. Tocra } & 82 & & \\ \text { 109. Alexandria } & 15 & & \\ \text { 110. Naucratis } & 401 & & \\ \text { 111. Tell Defennen } & 62 & & \end{array}$

Tabela 1. Distribuição de vasos áticos no Mediterrâneo (do século VI ao IV a.C.), a partir de seus locais de achado, exceto a Grécia continental e Mar Egeu, segundo o Beazley Archives (consultado em janeiro de 2006). Apesar do importante levantamento, as informações desse site têm problemas. Por exemplo, alguns espaços indicados como findplaces (locais de achado) não apresentam nenhuma informação (o traço [-] na tabela acima), e certa desatualização de hiperlinks. (A grafia dos nomes dos sítios mantém-se fiel à apresentada no Beazley Archives).

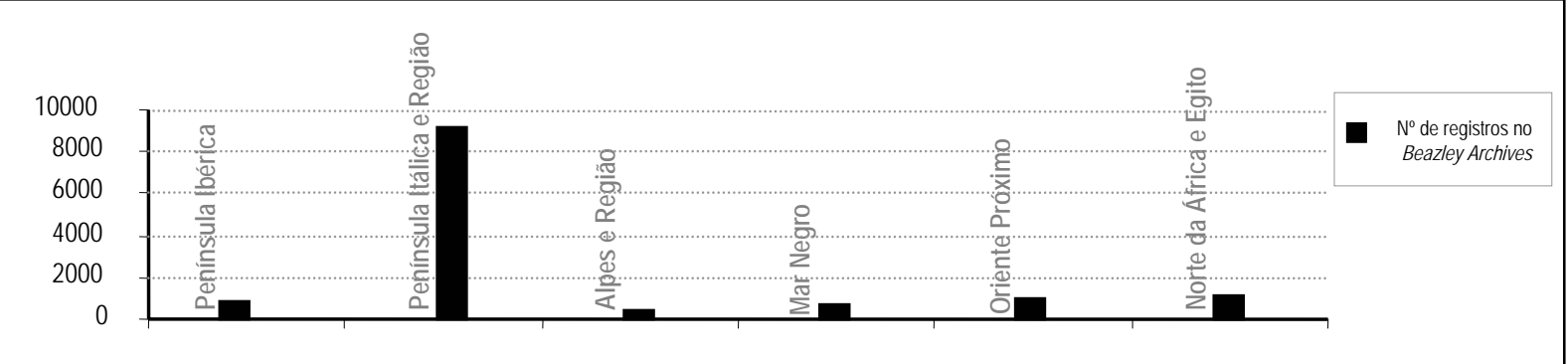

Esquema 3. Distribuição dos vasos áticos no Mediterrâneo (séc. VII-IV a.C.), a partir dos locais de achado. 


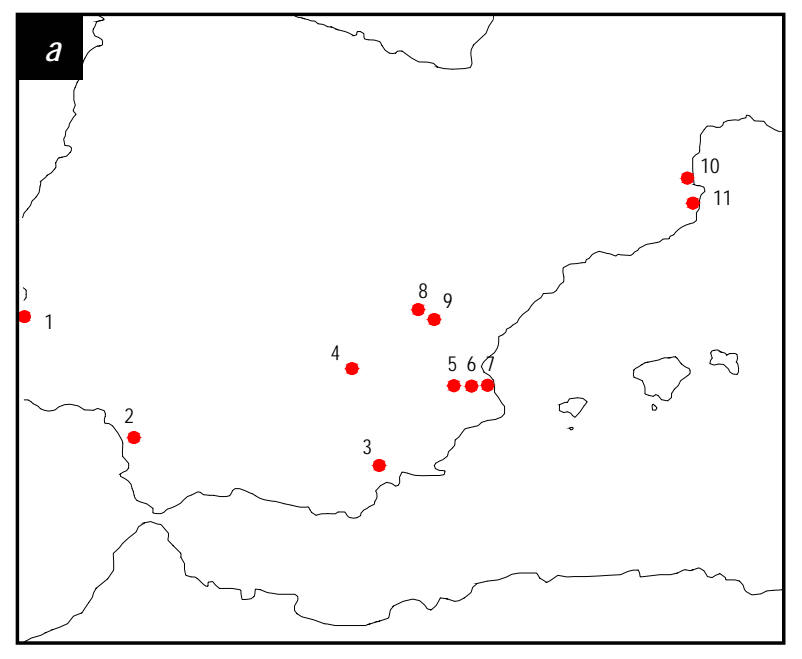

\section{b}
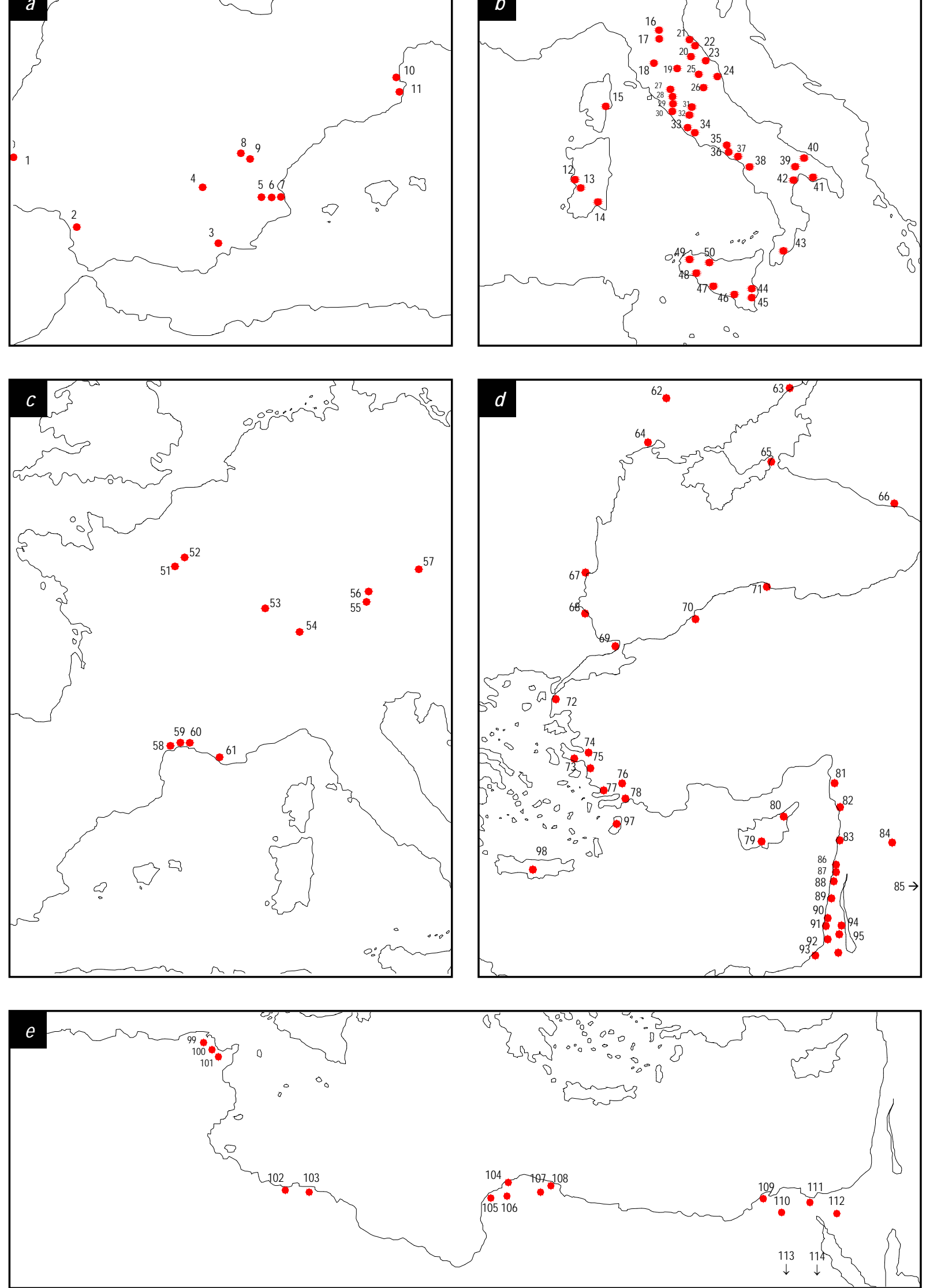

Croqui 2. Locais de achado de vasos áticos (exceto a Grécia continental): $\boldsymbol{a}$. Península Ibérica; $\boldsymbol{b}$. Península Itálica; $\boldsymbol{c}$. Alpes e Região; $\boldsymbol{d}$. Mar Negro e Oriente Próximo; e. Norte da África e Egito; segundo o site Beazley Archives. 
OS GRAFISMOS, DA ORIGEM ÀS ESPECIFICDADES GREGAS 


\subsection{O gráfico, o escrito e o figurativo: uma apreensão geral}

Se a conceituação grega sobre o gráfico abarcava tanto a dimensão da imagem visual quanto da escrita, sua utilização atual parece reservar paralelos com a caracterização antiga. O termo gráfico, e muitos outros co-relacionados, na acepção de dicionário, indica isso com clareza. Dentre várias designações, lê-se para gráfico "relativo ou destinado à representação da linguagem por sinais visuais desenhados ou gravados" e "relativo a qualquer tipo de grafismo produzido pela mão humana sobre uma superfície (pedra, barro, madeira, papiro, casca de árvore, pergaminho, papel, parede etc.)" (Dicionário Houaiss da Língua Portuguesa). A permanência do sentido, a despeito de sua ampliação em dias atuais, é inequívoca: mesmo a experiência de qualquer cidadão comum de nossa época inclui essa dupla informação no que se refere ao elemento gráfico: palavras como grafite (os desenhos nas paredes da cidade, ou o cilindro de carbono para desenhar ou escrever), autógrafo, caligrafia, dentre várias outras, estão incluídas no repertório corriqueiro.

O elemento gráfico insere-se no quadro das mais antigas criações humanas, e persiste, marcando uma experiência constante na história do homem desde épocas ditas "préhistóricas". Entretanto, antes de dar espaço ao desenvolvimento gráfico, numa perspectiva histórica, será feita uma breve explanação conceitual sobre o termo. Para tanto, serão perseguidas duas características essenciais: o contraste e a linha.

A etimologia do termo revela, como se observou antes, que ele já era registrado no grego antigo: o verbo graphêin; "remonta a um tema indo-europeu *gerbh que se encontra, por exemplo, no alemão kerben, e cujo primeiro sentido é esfolar, arranhar, entalhar" (Holtzmann, 1993, p. 3). Essa marca, mais especificamente um contraste, é notada a partir de diversas formas: claro e escuro, colorações ou mesmo tons diferentes de cores, por desníveis numa superfície etc. ${ }^{1}$ Elas geralmente têm uma organização passível de ser captada logicamente pelo cérebro, ou seja, a forma com que elas se dispõem indicam mais que simples riscos acidentais. Mesmo distante de uma organização seqüencial de caracteres gráficos, como a que se deu nos processos de desenvolvimento da escrita, essas marcas podem ser dispostas de tal forma que comuniquem algo, por exemplo, funções rítmicas (ver esquema 1): a forma está intimamente ligada ao conteúdo.

\footnotetext{
${ }^{1}$ Nota-se, nos mais antigos exemplares da cerâmica ornamentada, a ação gráfica a partir desses dois recursos: a linha pintada, contrastando com a coloração do suporte, e a incisão, que cria pequenos sulcos, canais, caracterizando a linha pelo desnível (ver fig. 1).
} 

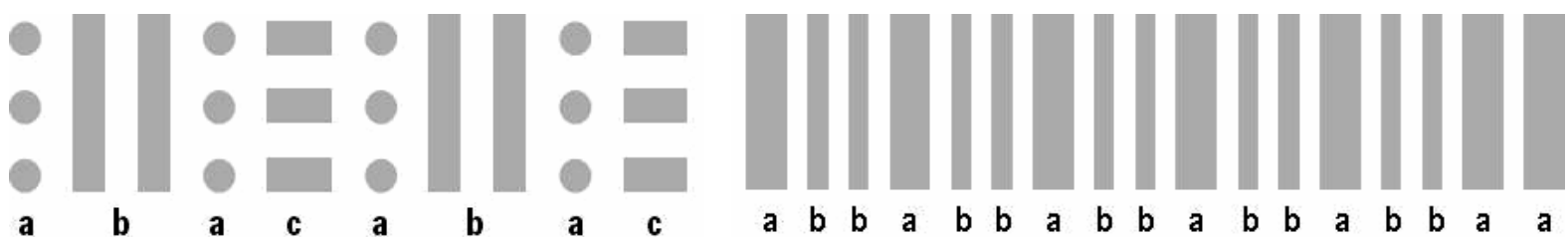

Esquema 1. Ritmos gráficos. À esquerda ( $a-b-a-c)$ o ritmo é conferido pela repetição de formas diferentes (linha pontilhada vertical, linha longa vertical e traços curtos horizontais); à direita ( $a-b-b-a-b-b-a-b-b-a-b-b-a-b-b-a-a), 0$ agrupamento de linhas com espessuras diferentes confere a estrutura rítmica (nesse caso, ela é idêntica à do hexâmetro dactílico, presente, por exemplo, nos versos homéricos [se $a$, para longos e $b$, para breves]). Ambas as estruturas seguem uma repetição que pode ser organizada de tal forma a informar ritmos de natureza diversa. Percebe-se por exemplo, nos códigos de barra, no código Morse de comunicação e na organização binária do meio digital (0-1) essa mesma estrutura, e de forma conceitual, em expressões artísticas como a poesia e a música.

As abordagens acadêmicas freqüentemente distinguem a dimensão estética da temática, privilegiando uma ou outra, às vezes por circunscrição pensada de um problema, ou por adesão acrítica a algum modelo de interpretação corrente. A questão é que os problemas envolvidos na dinâmica forma-conteúdo elucidam grandemente a análise conceitual do gráfico, sobretudo no que se refere ao contraste como elemento comunicativo. Porém, se a forma está ligada necessariamente ao conteúdo, a análise gráfica mostrará que, por vezes, há um descompasso entre essas duas dimensões, promovendo, por exemplo, a continuidade de um conteúdo através de formas estéticas diferentes, e vice-versa.

As formas gráficas pautam-se em um grande grau conceitual, pois não propõem uma cópia exata do que foi desenhado, tendo como elemento compositivo essencial a linha, que pode indicar tanto restrição e contenção (o que está dentro e o que está fora, ou seja, o que faz parte do desenho e o que não faz); ou simplesmente marcar a idéia de uma forma. Por exemplo, todos reconhecem as figuras humanas que as crianças fazem: uma linha pode resumir todo um segmento corporal (os braços, as pernas etc.), a caracterização da espessura, nesse caso, é irrelevante. A idéia de restrição e contenção pode ser combinada à linha puramente conceitual, como no caso das cabeças, que geralmente são formas arredondadas que contém olhos, nariz, boca (ver fig. 2). A linha conceitual e delimitativa, ambas, são peças chave na geometria, onde, como no exemplo da criação gráfica infantil, têm um valor imaginário ou real.

Na história humana, quando se buscou uma racionalização "naturalista", geralmente se afastou do gráfico. Não por acaso, os esforços racionalistas da arte renascentista privilegiaram os volumes extremamente elaborados (na escultura e pintura), e no caso das gravuras dessa mesma época, técnica que guarda um grande grau gráfico, a apresentação da tridimensionalidade persiste, mesmo que a sombra fosse criada a partir de inúmeras linhas enfileiradas (ver fig. 3). 

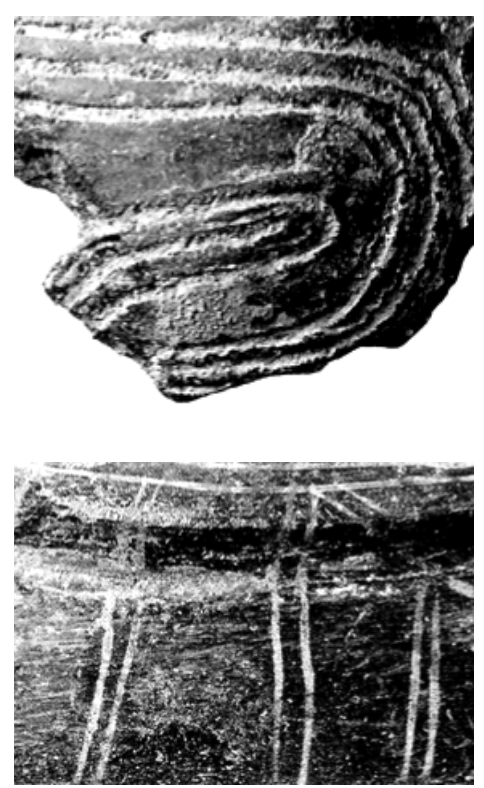
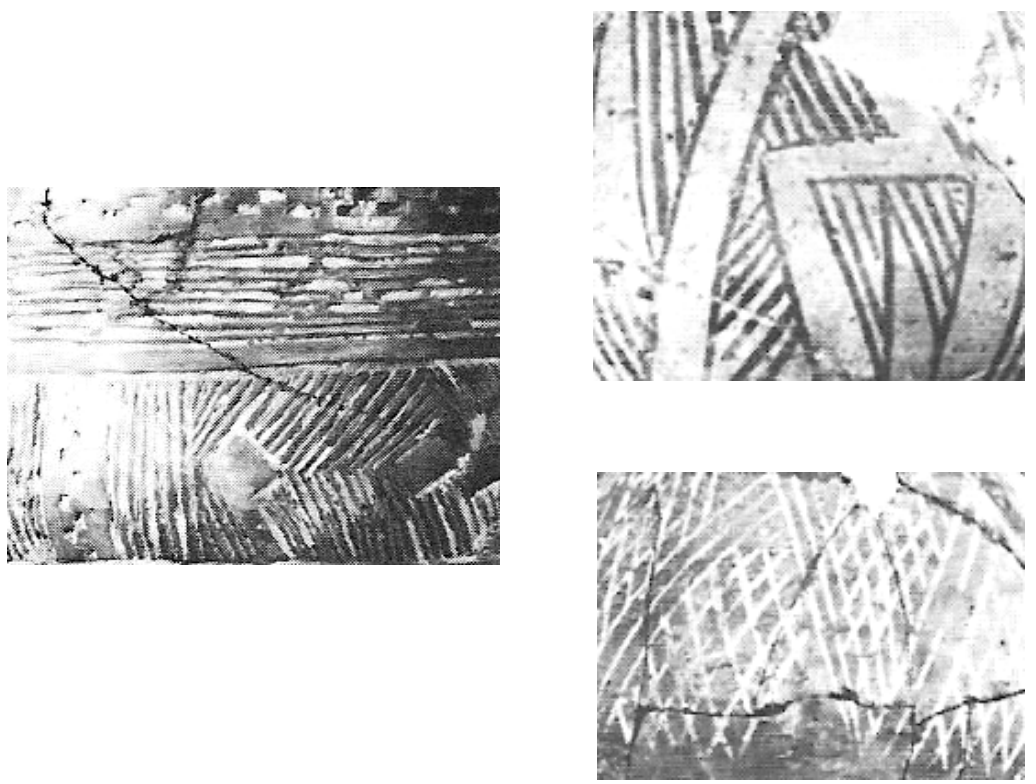

Fig. 1. (à esquerda) Detalhe de fragmentos de cerâmica de Dikili Tash, Grécia, Neolítico, MAE-USP (ornamentação incisa [acima] e pintada [abaixo]); (meio) detalhe de vaso da região da Romênia (Boian culture), V milênio a.C. (ornamentação incisa); (à direita) detalhe de cerâmica da região da Albânia, IV milênio a.C. (ornamentação pintada).
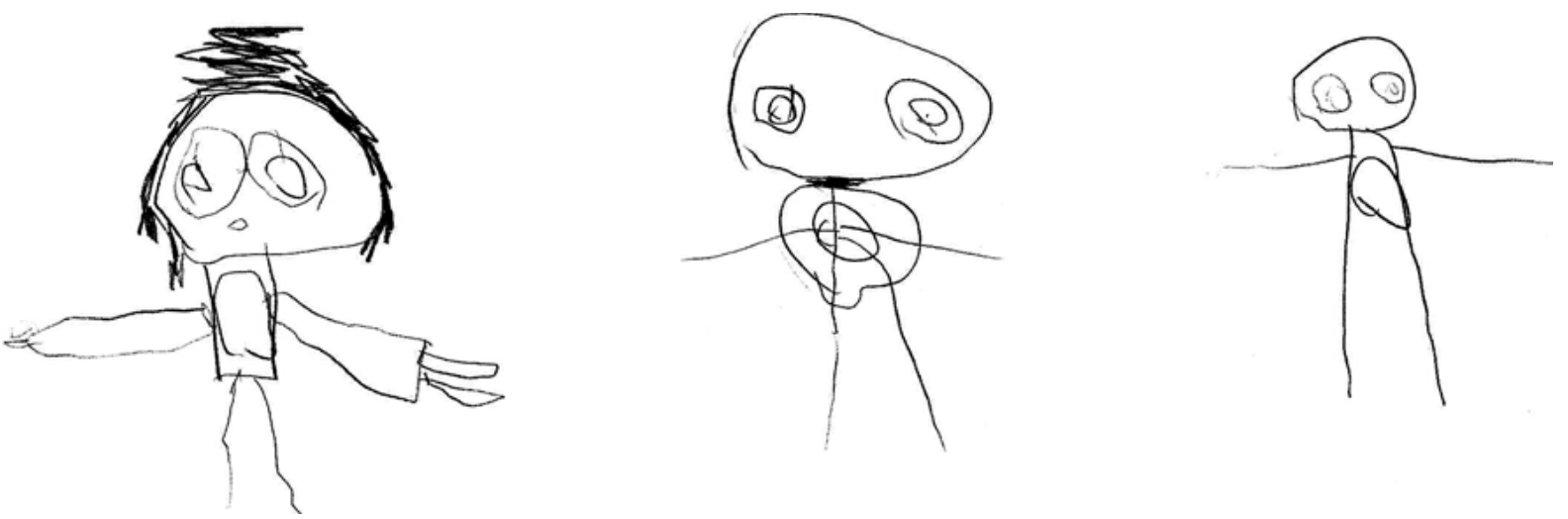

Fig. 2. Desenho de criança em processo de alfabetização.
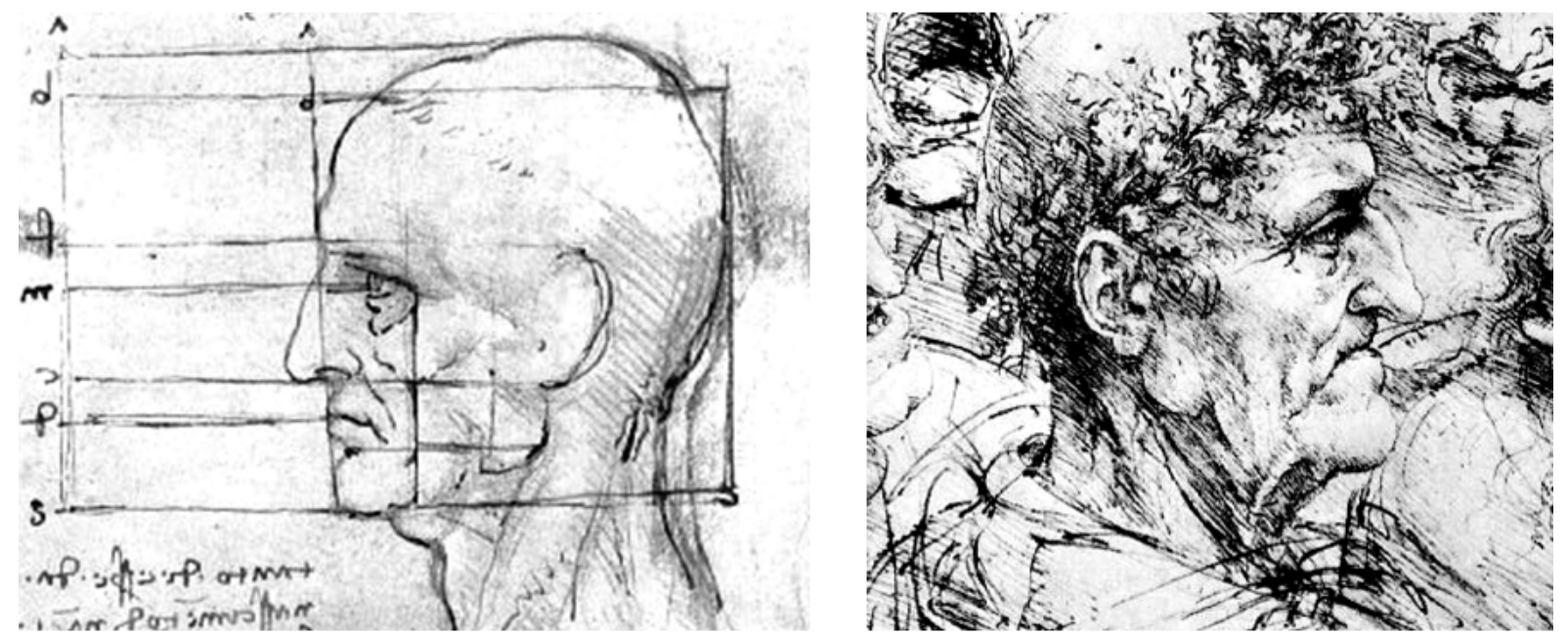

Fig. 3. Gravuras de Leonardo da Vinci: (à esquerda) Estudo de proporção entre cabeça e corpo (detalhe), Windsor Castle, Royal Library, London ; (à direita) Estudo de cabeças grotescas (detalhe), The Royal Library, Windsor Castle, c. 1490. 
A característica conceitual da linha tem a ver, certamente, com a sua utilização no desenvolvimento da escrita. De início, deve saber-se que a criação dos tipos, as letras, fonemas ou ideogramas que resumiam em si uma idéia, nem sempre tiveram composição gráfica. A observação dos hieróglifos egípcios, por exemplo, apresenta uma variedade de criação, dentre elas a técnica do relevo. Entretanto, o abandono das características ideográficas e o processo de abstração da escrita impeliu, em vários casos, a criação gráfica desses tipos. Acredita-se, aqui, que esse grau conceitual envolvido na linha serviu em grande parte para esse processo brevemente explicitado; isso, pois se na escrita ideográfica é importante a caracterização do paralelo com a natureza (certa iconicidade com o objeto ou idéia apresentados), no caso da escrita fonética ou a alfabética, a entonação está mais ligada à fala. ${ }^{2}$

Escrita e desenho são linguagens ligadas intimamente desde a origem. Qualquer obra que se ocupe da história da escrita, de forma generalista, acaba por apresentar indícios importantes dessa relação constante ao longo do tempo. Na maioria dos casos, ignora-se essa relação, buscando simplesmente compreender o desenvolvimento da escrita, numa apreensão freqüentemente evolutiva. Essa "evolução", portanto, é atestada com maior firmeza, quanto mais a forma da escrita abandona sua natureza pictográfica, estabelecendose caracteres de valor abstrato e reduzindo consideravelmente o número de caracteres envolvidos no sistema de escrita ${ }^{3}$, como no caso do alfabeto grego. ${ }^{4}$ Não é pretensão, nesse sentido, clamar por uma revisão urgente das "histórias da escrita" com essa entonação. Para tanto, deve se tratar mais profundamente as relações entre escrita e figuração, extrapolando as explicações da origem pictográfica da escrita, ou então, no caso de coexistência entre escrita e figuração plenamente desenvolvidas, análises dessa relação calcadas apenas no conteúdo de uma e outra. As características materiais dessa interação também devem ser tratadas, para além das preocupações temáticas; ou seja, mesmo quando o tema não aproxima ambas linguagens.

\footnotetext{
${ }^{2}$ Cabe dizer que a escrita hieroglífica não se pauta somente na caracterização de uma idéia-figura, mas há indícios de que escritas hieroglíficas, como a egípcia, desenvolveram-se também em torno de uma estrutura fonética.

${ }^{3}$ Os sistemas alfabéticos, que possuem o número de caracteres em torno de vinte, também se distinguem dos sistemas mais antigos, como o pictográfico, por essa "economia" de caracteres, levando-se em consideração, por exemplo, que o sistema pictográfico mesopotâmico (IV milênio a.C.) compunha um conjunto de, "(...) aproximadamente, 1500 pictogramas repertoriados (...)" (Pozzer, 2004, p. 68); ou o ainda existente sistema de escrita chinesa, que tem em torno de 47.201 ideogramas, conforme indica o Dicionário de K'anghsí, de 1716 (Del Val, J. Nota sobre la escritura y la lengua china. In: Franke, H. \& Trauzetel, R. El imperio chino. $8^{a}$ ed., México D-F: Siglo Ventiuno, 1989. p. 366); ou seja, há um desnível quantitativo considerável de tipos entre um tipo de sistema para outro.

${ }^{4}$ É interessante, nesse sentido, lembrar que os nomes das letras gregas guardavam uma experiência pictorial que os próprios gregos desconheciam. O alfa, por exemplo, referia-se, nas línguas semíticas ocidentais, ao touro; e a própria forma da letra, de cabeça para baixo ( $\forall$ - como ainda registravam inscrições da Beócia dos séculos VIII e VII a.C. - Healey, J. F. O primeiro alfabeto. In: Hooker, 1996, p. 283), era a indicação da cabeça de tal animal. No processo de abstração dos sistemas de escrita, essa compreensão pictórica perde-se.
} 
A reflexão evolutiva da escrita segue também uma direção geográfico-cultural do Oriente para o Ocidente; tendo como ponto de origem a Mesopotâmia, seguindo para a costa oriental do Mediterrâneo (dos vários cuneiformes ao alfabeto consonântico fenício) e Egito (os hieróglifos), Grécia (o alfabeto grego) e região da Península Itálica (com a criação do etrusco e principalmente do alfabeto latino). Assim, entre avanços (como com o expansionismo romano) e recuos (como com a restrição da cultura letrada no seio do clero no período "medieval"), o ápice é freqüentemente apresentado como a invenção da imprensa em época moderna, e a ampla difusão da cultura letrada dado o movimento expansionista europeu (as grandes navegações), consolidando a abrangência letrada (alfabética) no chamado "mundo ocidental"; e em contextos mais recentes, uma "universalização" desse cenário, através dos meios digitais de difusão e armazenamento de conhecimento.

Esse caminho, aparentemente normal, pressupõe uma visão calcada numa idéia de aquisição e exclusão que não aconteceu necessariamente. Um exemplo disso é a importante persistência da escrita silábica de influência cretense em Chipre; um sistema de escrita criado na Idade do Bronze na região do Mar Egeu, e que persistiu até o século III a.C., o que em periodização da história grega equivale à época helenística. Apesar de o uso tardio ser bastante restrito (a permanência dá-se, sobretudo em Chipre), pode falar-se numa abrangência de mais de mil anos do uso desse sistema, ou seja, atravessou o próprio período de criação, desenvolvimento e desagregação da pólis grega.

Outro exemplo é a utilização do cuneiforme (cuja época de criação remonta o final do IV milênio a.C.) ainda no final do séc. I a.C. (as últimas inscrições em cuneiforme datam de 75 e 40 a.C., já numa época de ampla substituição do cuneiforme pelo aramaico - Hooker, 1996, p. 37), uma persistência muito grande, é claro, baseada em algumas adaptações e mudanças (além das várias adaptações locais do cuneiforme, cabe dizer, as últimas inscrições são bastante cursivas). Por fim, nessa mesma linha, a escrita hieroglífica egípcia possui exemplares de c. 3100-3000 a.C. (os mais antigos são "curtos textos inscritos sobre a pedra e objetos de cerâmica encontrados em vários sítios arqueológicos") até 394 d.C. (os últimos exemplos datáveis são de uma inscrição num templo na ilha de Filae) ${ }^{5}$; uma permanência de quase 3500 anos.

Todos esses são fortes exemplos de que a linha que trata a história da escrita do ponto de vista da aquisição e exclusão é insuficiente. O cuneiforme que influenciou a criação de várias escritas regionais, inclusive a consonântica fenícia, não desapareceu tão cedo; ${ }^{6}$ nem mesmo o silabário cretense desapareceu logo após sua muito provável contribuição na

\footnotetext{
${ }^{5}$ Davies, W. V. Os hieróglifos egípcios. In: Hooker, 1996, p. 103.

${ }^{6}$ Existe registro de coexistência, no mesmo suporte, de inscrições em cuneiforme babilônico e em grego, ainda no período helenístico (Dalley \& Reyes, 1998, p. 112). Ver Heródoto, IV 87, sobre o paralelismo entre estelas com inscrições em grego e em assírio.
} 
introdução de vogais no alfabeto grego (Sarian, 1998-1999, p. 163). Essas contribuições não significaram ganho e conseqüente abandono.

A compreensão da origem da escrita, como visto, passa necessariamente pela sua acepção figurativa, mas o abandono dessa situação não significa que esse fosse o único caminho possível a se tomar. A escrita chinesa apresenta um grau ideográfico grande (apesar do amplo desenvolvimento formal) e não se pode, por isso caracterizá-la como inferior à alfabética. Dito de outra forma, não se pode estabelecer o alfabeto com auge na história da escrita, e tudo o que veio antes ou que teve desenvolvimento diferente, como necessariamente "defeituoso".

Nessa linha de raciocínio, parece que a escrita veio a agregar junto ao desenho e outras formas figurativas um conjunto de referências no quadro da linguagem humana; mas essa é uma conclusão óbvia. De início, vale dizer que a natureza desses registros era freqüentemente gráfica, e assim permaneceu durante muito tempo. Entretanto, a natureza gráfica é mais complexa, e pode ser inferida a partir da interação entre homem e natureza, mesmo antes das marcas deixadas pelo homem.

Para entender essa origem deve abranger-se à sua dimensão indiciária; ou seja, um elemento visual, registrado e processado mentalmente; não necessariamente produzido pelo homem, mas simbolizado por ele. Um indício, no sentido mais básico do termo: se há fumaça, provavelmente há fogo; se no céu há nuvens cinzas, escuras, provavelmente choverá. Assim, os rastros no chão (sobre solo barrento, sobre a neve etc.) dos mais diversificados animais, inclusive o homem; esses sinais indicavam algo, como a direção de um transeunte do qual se poderia fugir ou seguir, exemplos de "leitura" antes do aparecimento da escrita. É dessa natureza a primeira apreensão das marcas que exemplifica bem a original realidade gráfica na mentalidade humana, e sua função comunicativa, já em épocas extremamente antigas ${ }^{7}$, "primeiro facto de uma sociedade que começa a estruturar-se em torno do visual, enquanto no mesmo caso os animais se reconhecem entre si pelo olfacto, e não pelos rastros". ${ }^{8}$ Emblematicamente, essa situação persiste no registro da origem da escrita, em casos como o surgimento da escrita chinesa:

Segundo a tradição, um alto funcionário, Cang Jie, que tinha quatro olhos e vivia há cinco mil anos no reino do imperador Huang Di, teria notado, nas margens de um regato, os vestígios

\footnotetext{
${ }^{7}$ Acredita-se que mesmo representantes evolutivos do homem atual, anteriores ao Homo Sapiens, como o Homo Ergaster, já podiam identificar e interpretar esses sinais gráficos.

${ }^{8}$ Barthes, R. \& Marty, E. Oral/escrito. In: ENCICLOPÉDIA Einaudi, 1987, p. 32.
} 
de patas de pássaros na areia. Daí lhe veio a idéia de reproduzir [alguns tipos] numa pequena tábua de madeira, com um pincel molhado em verniz negro: a escrita chinesa havia nascido. ${ }^{9}$

Ainda, conta o mito grego, que não as marcas no chão, mas a experiência da observação do movimento das aves no céu - "o vôo em formação triangular dos grous", teria inspirado a criação das letras em forma de cunha pelas três Parcas "nascidas da união entre Erebo e a Noite" (Idem).

Quanto à criação gráfica, cabe dizer, que o processo de evolução humana foi decisivo, sobretudo no que se refere à aquisição do porte ereto, desde o Australopitecus, possibilitando, num longo processo

uma diminuição da importância do sentido do olfato, em comparação com o da visão. Isso, juntamente com a liberação das mãos e o desenvolvimento do cérebro, estava intimamente associado à fabricação e manipulação de artefatos. (Clark, 1985, p. 27)

Ao homem, restringe-se a criação gráfica articulada, e apesar de alguns outros animais como variados primatas terem potencial para desenvolver alguma percepção gráfica, ou mesmo uma criação gráfica desorganizada (Idem, p. 38-9 e fig. 8), é na investigação sobre o homem, numa perspectiva histórica ou observando o desenvolvimento da criação gráfica nas crianças (Ibidem), que reside com grande viabilidade a compreensão das origens da prática da criação gráfica.

As marcas gráficas, no entanto, por mais que tivessem originalmente um componente comunicativo em sua percepção, não formavam um corpus organizado, sistematizado a se utilizar de forma recorrente, ainda eram aleatórias, esparsas; e o caminho que trilhariam até se tornarem uma escrita desenvolvida é bastante revelador da dimensão relacional entre escrita e figuração. De antemão, é preciso saber que os primeiros grafismos (datados de aproximadamente 30.000 anos) surgem mais ligados à idéia de ritmo que de figuração. ${ }^{10}$ São marcas, enfileiradas, com repetição regular, características presentes nos calculi mesopotâmicos, por exemplo, instrumentos de registro numérico (ver fig. 4 e 5).

A história da escrita apresenta um quadro em que, originalmente, um caractere, geralmente um desenho, indica uma palavra (uma idéia). Essa escrita pauta-se na "notação do sentido dos signos, e não de seu som: apela, portanto, a um reconhecimento visual e não

\footnotetext{
${ }^{9}$ Mac Kenzie, A. Le pavillon des caracteres traces. Paris: Pauvert, 1970. Apud Cazade, E. \& Thomas, C. Alfabeto. In: ENCICLOPÉDIA Einaudi, 1987, p. 175

10 "Particularmente interessante é o facto de o grafismo não ter começado por uma expressão 'servil' e fotográfica do real, mas organizando-se, numa dezena de mil anos, a partir de sinais que parecem ter exprimido primeiramente os ritmos e não as formas" (Leroi-Gourhan, 1990a, p. 190).
} 
auditivo..." (Barthes \& Mauriès, 1987, p. 149) - ver fig. 6, 7 e 8. Depois, num processo, chegaria até uma situação na qual teria havido uma abstração bastante grande, decompondo a idéia-palavra em fonemas, e mesmo em signos que, apenas em sua composição variada, criam fonemas e palavras (é o caso do alfabeto).

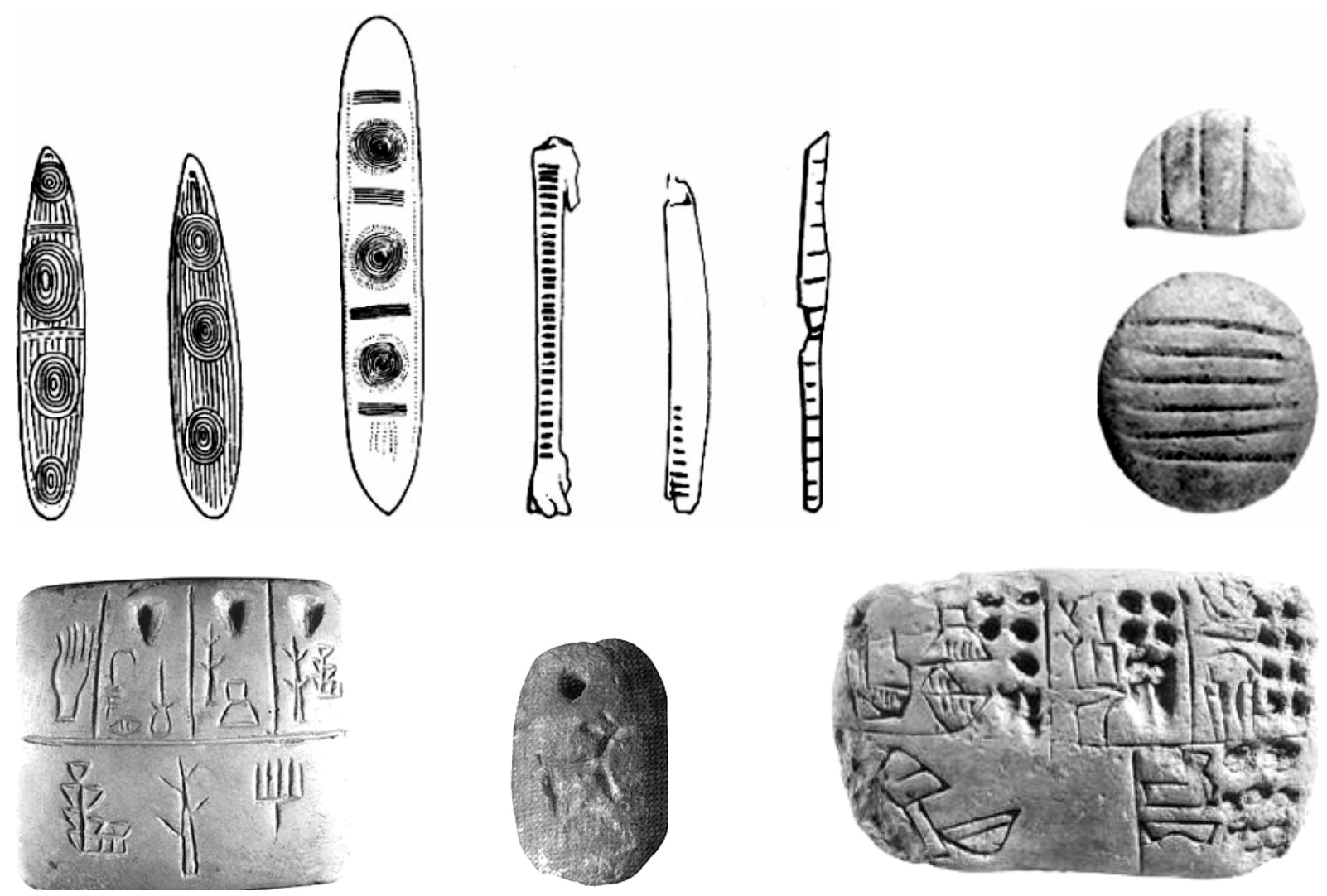

(Acima) Fig. 4. (à esquerda) Chiringas australianas, segundo Spencer e Gillen (Apud Leroi-Gourhan, 1990a, p. 188); Fig. 5. (à direita) Calculi neolíticos de Susa, Paris, Museu do Louvre; (Abaixo) Fig. 6. (à esquerda) Tablete do final do IV milênio a.C., Mesopotâmia, Museu do Louvre, Paris. ; Fig. 7. (meio) Tablete pictográfico de Tell Brak, final do IV milêncio a.C.; Fig. 8. (à direita) Tablete com inscrição pictográfica, pré-cuneiforme, final do IV milênio a.C. (larg.: 7,2 cm).

Sabe-se que este não é o único caminho possível, mas é amplamente observável no desenvolvimento de algumas escritas mediterrânicas e médio-orientais, como o mais antigo registro de escrita: o cuneiforme sumério-acadiano (originado em c. de 4000 a.C.), um tipo de escrita que surge em forma pictográfica, mas "sofre depois uma série de racionalizações" (Idem, p. 148); ou seja, afasta-se da formalização figurativa.

Interessa, neste momento, concentrar-se em dois sistemas de escrita anteriores ao alfabeto, amplamente difundidos na costa oriental do Mediterrâneo no período arcaico, mas também antes disso: trata-se do cuneiforme e do hieróglifo. O cuneiforme foi utilizado por culturas diversas do Oriente Próximo (o cuneiforme sumério-acadiano seria apropriado por outros povos da Ásia Menor originando-se assim o elamita, urarteano e o hitita). Os hieróglifos egípcios são pequenas figuras, ideogramas, mas se desenvolveu conjuntamente uma 
formulação fonética. Essa escrita também sofreria um processo de "simplificação" até o I milênio a.C., promovendo a criação da escrita "hierática" e do demótico, respectivamente. ${ }^{11}$ Entretanto, a grande popularidade que recaiu sobre os hieróglifos egípcios, desde os esforços decriptativos de Champollion (1822), não deve esconder que este não era o único tipo de escrita hieroglífica presente na região: pode citar-se, por exemplo, os hieróglifos hititas, e mesmo aqueles encontrados por Evans em Creta. O próprio termo hieróglifo é polêmico, pois a sua acepção "escrita sagrada" nem sempre é amplamente comprovada; bem como alguns traços de influência entre os hieróglifos citados.

Essa variedade de usos do cuneiforme e do sistema hieroglífico proporcionou uma grande diversidade de usos, inclusive nas constantes aproximações com imagens figurativas. Um estudo aprofundado requereria muito tempo e dedicação. Aqui serão tratados alguns aspectos materiais observados na interação entre escrita e figuração. O ambiente é circunscrito geograficamente como o Mediterrâneo (sobretudo a porção oriental), palco de variadas escritas no período arcaico grego, algumas com experiência milenar (como o cuneiforme e o hieróglifo), e outras relativamente recentes (como o alfabeto fenício e o grego). Quanto aos exemplares em que coexiste escrita e figuração, o cenário é o mesmo: de uma grande variedade.

São poucos os exemplares que se caracterizam pela redução da técnica criativa das duas linguagens (escrita e visual) à lógica gráfica (ver fig. 9), havendo, assim, geralmente textos criados a partir de linhas incisas, cunhas ou pintados, sobre ou associados a formas em relevo ou escultura plena. Essa é a forma mais comum de relação entre a linguagem verbal e não-verbal nesse contexto. É claro que, mesmo com isso, a variedade mantém-se, havendo exemplares nos quais escrita e figuração são apartadas fisicamente (espaços próprios para cada uma - ver prancha fig. 10 e 11), e outros onde a escrita interfere na imagem figurativa (ver fig. 12). A coexistência material e conceitual, como observada nos vasos áticos, que serão tratados com maior especificidade, não são comuns nas formas orientais e egípcias: não há discurso nem prática que aproxime tão fortemente as duas criações, submetidas à forma gráfica.

Se a lógica gráfica não aproxima as duas linguagens, por vezes, a criação pintada e tridimensional, sobretudo em relevo, aproxima mais freqüentemente escrita e figuração. Assim, são comuns exemplares, em papiro, de hieróglifos egípcios, nos quais as linguagens visual e escrita possuem a mesma técnica, e a sua diferenciação dá-se, sobretudo, pelas dimensões (os pequenos hieróglifos aproximados de figuras maiores, que não são exatamente hieróglifos); e essa mesma característica pode ser observada em alguns relevos esculpidos, bem como nos sinetes e selos (ver fig. 13-15).

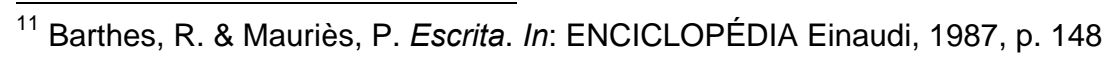




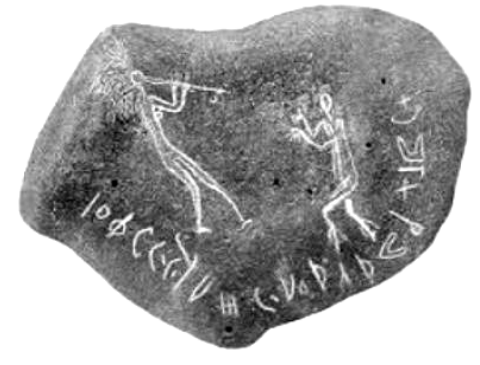

Fig. 9. Inscrição safaítica sobre basalto, IV milênio a. C., Amman, Jordânia. Fig. 10. (meio) Código de Hamurabi, século XVIII a.C., Museu do Louvre, Paris. Coletânea de leis inscritas sobre uma Estela de diorite. Uma versão foi depositada no templo de Samash (deus solar de Sippar) e outras cópias em várias cidades da Babilônia. A presente estela foi transportada como butim de guerra a Susa, onde os arqueólogos franceses a exumaram (alt.: $225 \mathrm{~cm}$ ). Fig. 11. (à direita) Estela do rei babilônico NabouAplaiddina representando 0 deus Sol Shamash sob o aspecto de um disco ou de uma roda em grandes traços incisos; entre eles, ondulam os raios que caracterizam a divindade solar. Sippar, Iraque, c. 870 a.C., Museu Britânico, Londres (alt. $29,5 \mathrm{~cm})$.
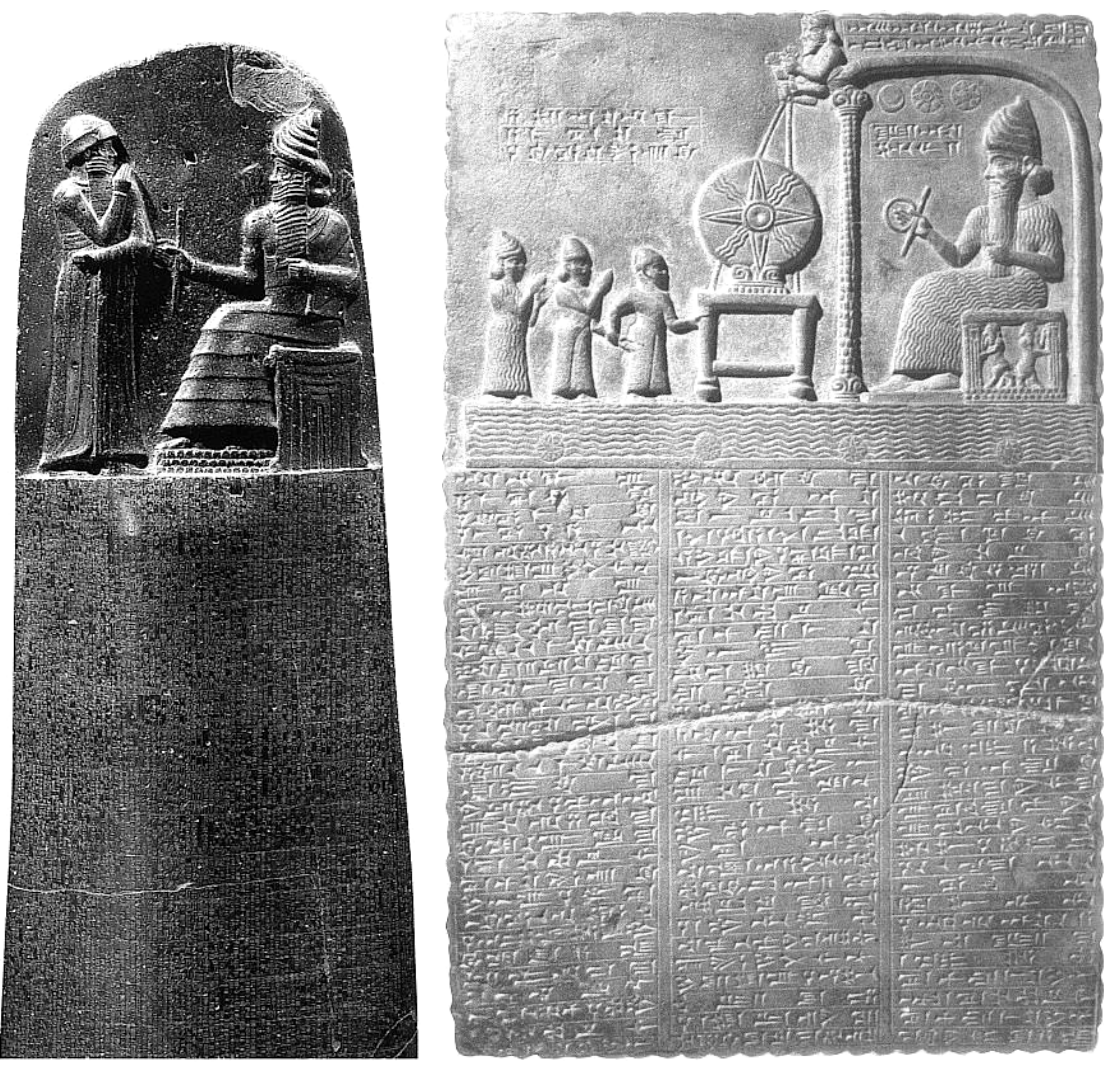
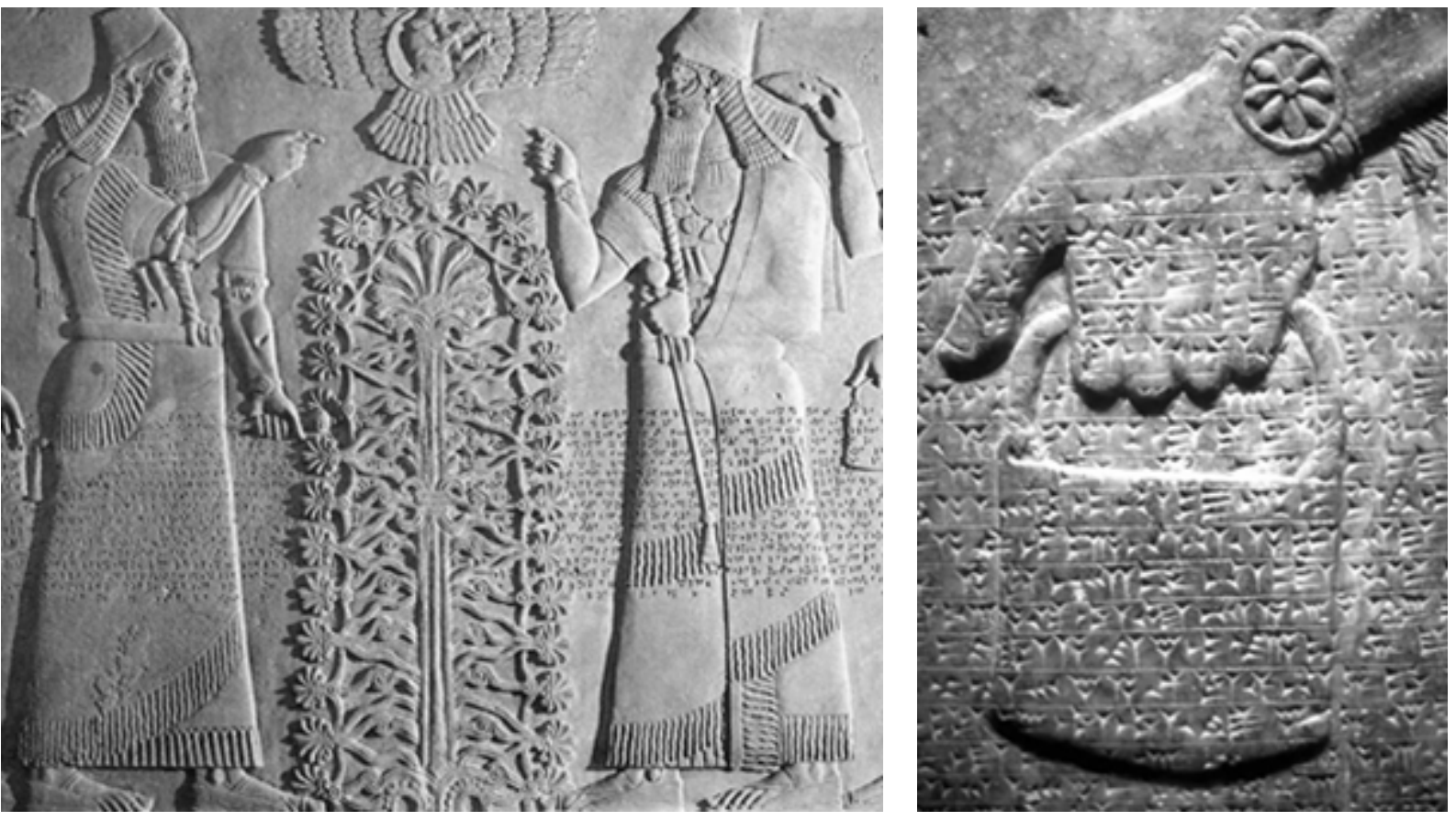

Fig. 12. Detalhes de relevo de Asurbanipal II junto à arvore da sabedoria (883-859 a.C.), Kalhu. 

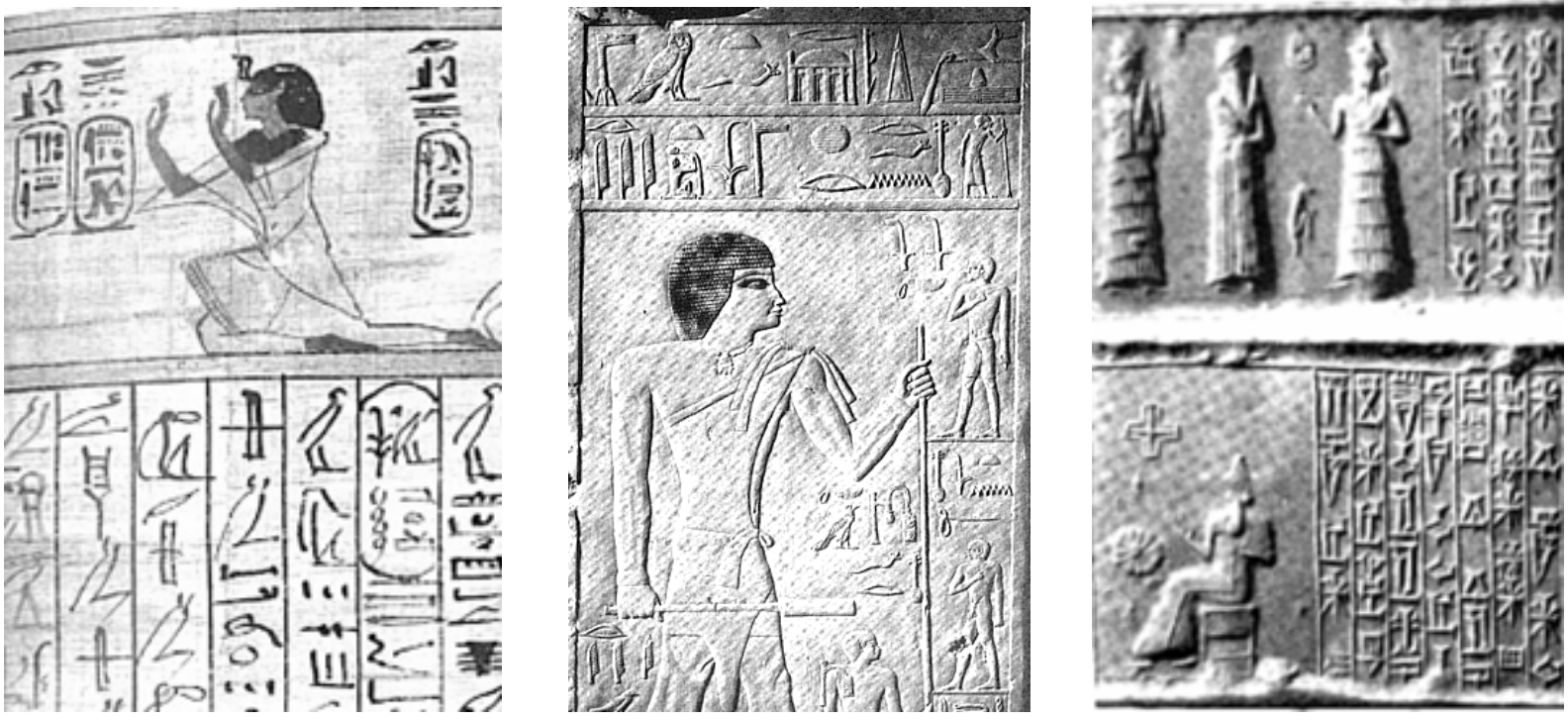

Fig. 13. (à esquerda) Livro dos mortos do reino de Mout-nedjemet, mencionando do faraó Hérithor; Paris, Museu do Louvre; Fig. 14. (centro) Mural de calcário decorado com figuras e hieróglifos, encontrado no túmulo de um homem chamado Iry, V Dinastia; Fig. 15. (à direita) Sinete cilíndrico do Babilônico antigo, e sinete cilíndrico do Período Cassita, III-II milênio a.C.

Essa leitura da relação entre escrita e figuração nos modelos orientais e egípcios é complicada, pois leva em conta um grande número de exemplares, distribuídos através de um longo recorte temporal. Entretanto, algumas dessas características são constantes, e podem ser observadas desde os mais antigos exemplares de coexistência das duas linguagens, estendendo-se até o período arcaico grego. De forma exemplar, é possível verificar que a estrutura básica de organização entre as informações escritas e figurativas numa estela do Código de Hamurabi (séc. XVIII a.C. - ver fig. 10) persiste, ao menos, até o séc. IX a.C, como indica uma estela produzida no governo do rei babilônico Nabou-Aplaiddina (ver fig. 12).

Apesar da verificação de alguns modos comuns de articular informação escrita e figurativa, a caracterização dessa ação entre orientais e egípcios não pode ser reduzida absolutamente, e apenas um estudo quantitativo poderia revelar as tendências mais sistemáticas e as menos comuns, os abandonos e as persistências etc., o que não confere a breve observação proposta. Aqui, basta dizer que a variedade e a ausência de um discurso e prática sobre a articulação gráfica da escrita e figuração num mesmo suporte marca a ampla produção oriental e egípcia. Ainda, cabe salientar que, apesar da importância dada ao texto escrito nesses grupos, muitas vezes observa-se certa subordinação do texto frente à imagem figurativa (ou a imagem é o suporte da escrita [ver fig. 16 e 17-21] ou a inscrição acomoda-se a espaços "livres", alguns vãos não ocupados pela figuração - fig. 22); mas, como visto, por vezes a escrita invade o campo da figuração (ver fig. 12), e também podem ser distinguidas espacialmente (cada uma ocupando um espaço determinado, sem interações físicas [marca isso, por vezes, a presença de faixas, linhas ou desníveis delimitatórios - ver 
fig. 10]). E, ainda, por vezes, o esquema pode inverter-se, sendo a imagem formalmente subordinada à estrutura imposta pelo texto (ver fig. 22).

Fig. 16. Esfinge de arenito: Inscrição em hieróglifos egípcios (a), e inscrição alfabética proto-sinaítica (b). Segundo Período Intermediário, originária de Serabit el-Khadim (cerca de 1700 a.C.) - alt.: $23,7 \mathrm{~cm}$. Inscrição: (I)b'lt,("Para a deusa Baalat").
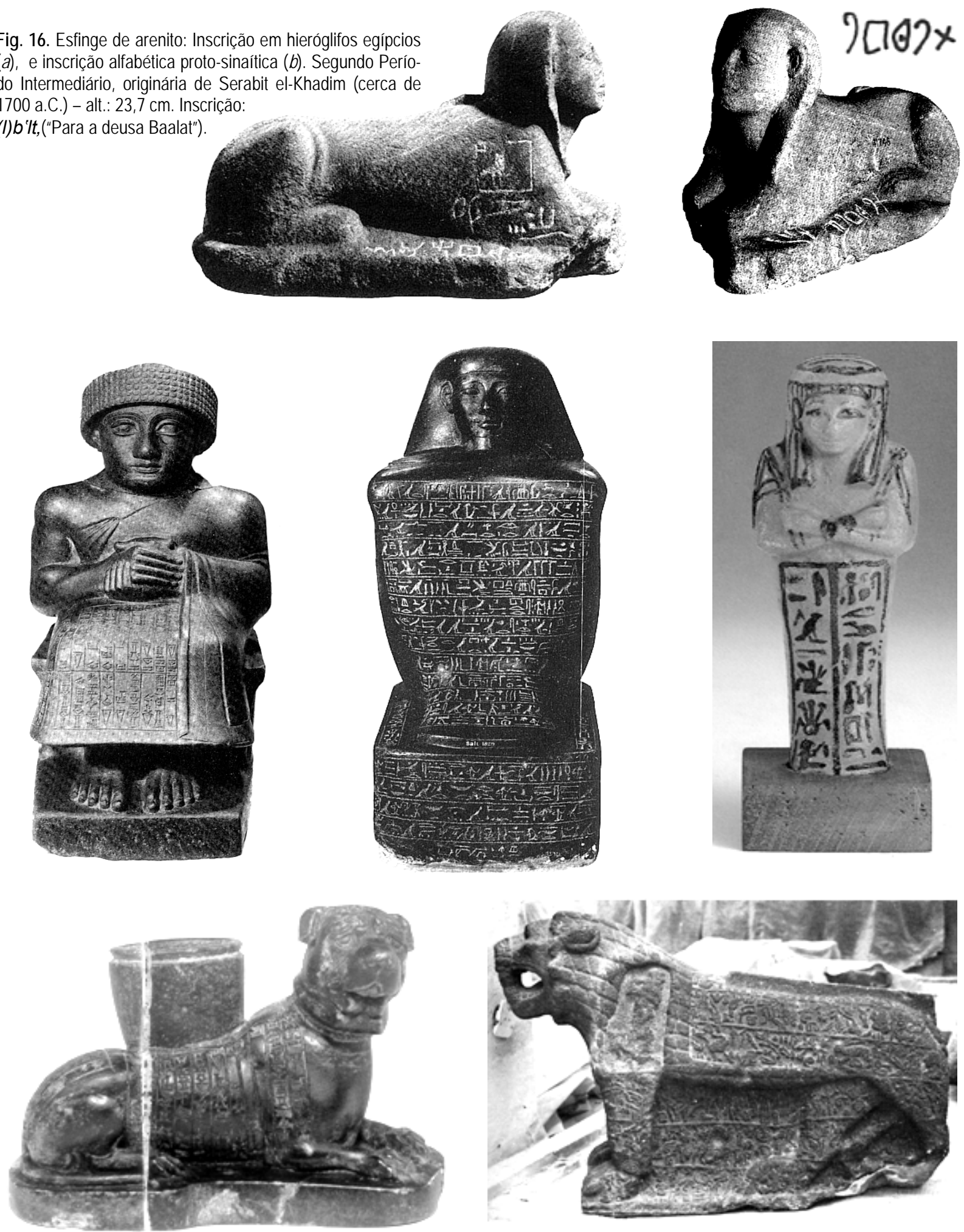

Fig. 17. (acima, à esquerda) Monumento de pedra neobabilônico que celebra Adad-etir e seu filho Marduk-balassu-iqbi, c. 2130 a.C. (alt.: $46 \mathrm{~cm}$ ); Fig. 18. (acima, cento) Escultura de granito representando Sennefer agachada. Tais estátuas, devido à sua forma peculiar em "bloco", foram consideradas veículos adequados para textos longos. XVIII Dinastia (alt.: $38,5 \mathrm{~cm}$ ); Fig. 19. (acima, à direita) Estatueta Ushabti de Haremakhbit, Tebas, XXI Dinastia, c. 1000 a.C., Museu Nacional, Rio de Janeiro (alt.: 12,5 cm); Fig. 20. (abaixo, à esquerda) Estatueta de cão com inscrições, dedicada à Ninisinna, c. 1900 a.C.; Fig. 21. (abaixo, à direita) Pequena estatueta de basalto em forma de leão, inscrições hieroglíficas, Maras, c. 800 a.C. (alt.: $62 \mathrm{~cm}$ ). 

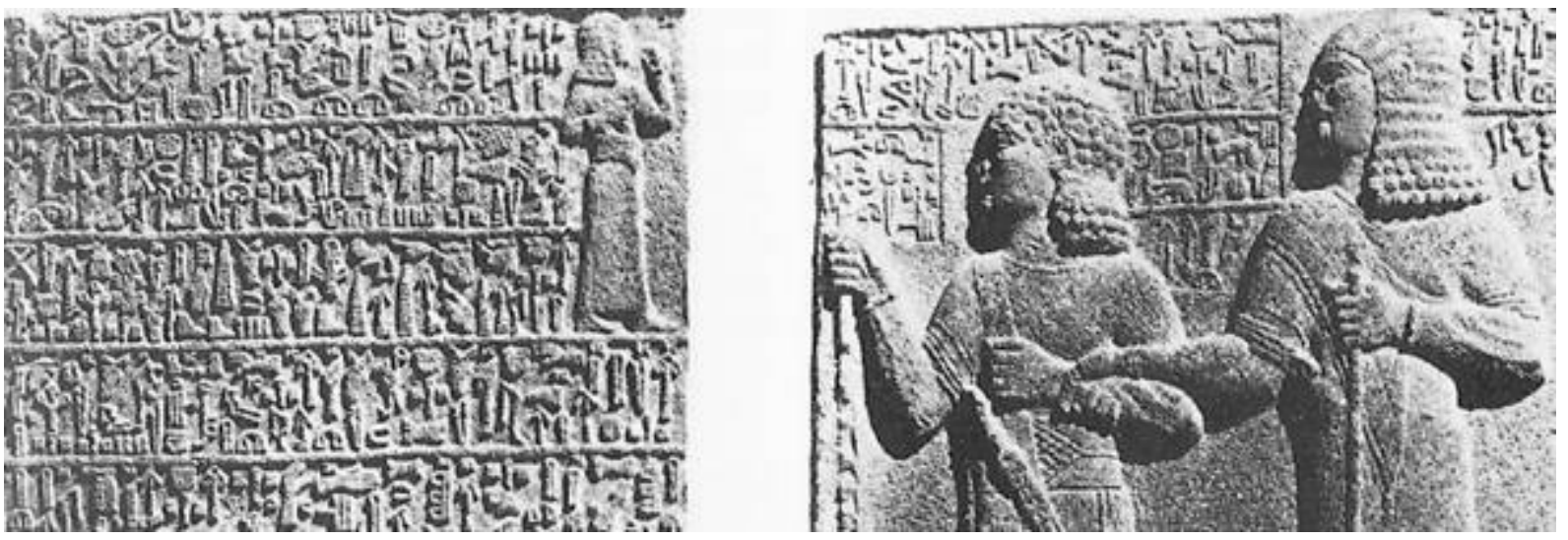

Fig. 22 e 23. (abaixo) Ortostatos hititas de basalto, Carchemish, início do séc. VIII a.C.

O distanciamento observado entre a produção escrita e figurativa, em vários casos, pode sugerir uma ampliação social da produção desses modelos: provavelmente, nem sempre o criador de imagens era o produtor de informações escritas. As sociedades orientais e o Egito, desde muito cedo, eram caracterizados pela criação de grupos privilegiados responsáveis pela produção escrita (escribas).

A variedade acima indicada pode estar ligada a essa prática; assim haveria a criação de uma imagem figurativa por um artesão, de origem diversa do escritor, e este, depois, ou melhor, em outro momento, aplicaria no mesmo suporte o texto escrito; interpretação viável em vários casos. Nesse sentido a subordinação não é necessariamente hierárquica, mas apenas cronológica, ou seja, uma ação depois da outra, o que pode ser observado claramente em alguns exemplares (ver fig. 12). Entretanto, em outros casos, essa distinção criativa não pode ser traçada (seria abusivo, por exemplo, estender esse tipo de interpretação à lógica da produção das imagens e inscrições dos sinetes mesopotâmicos). E, mesmo relativizando um pouco a grande distinção criativa acima citada, pode dizer-se que muito da criação em escultura ou relevo segue algo da linguagem gráfica (linhas incisas marcando alguns detalhes da figuração).

Por fim, vale dizer que o caminho que se trilhou até aqui mostrou uma relação quase absoluta entre escrita e arte figurativa; o que deve ser nuançado. Apesar da grande constância, essa relação é variada, havendo sociedades que dominaram as duas técnicas, sem ter estruturado qualquer coexistência sistemática entre o registro escrito e o figurativo. $\mathrm{O}$ histórico do fazer gráfico na região do Mar Egeu, que será apresentado a seguir, indicará bem essa situação. 


\subsection{Os grafismos gregos até o período arcaico}

Uma característica marcante de boa parte da cerâmica produzida na região da Grécia é sua ornamentação gráfica. Muitas obras sobre arte grega, e especificamente sobre cerâmica, recorrem a uma abordagem cronológica, buscando os inícios dessa atividade na região. A própria noção de origem, de começo, é complexa e, dessa forma, como se abandonou a perspectiva geral da criação gráfica, e busca-se um espaço específico (o Mar Egeu e Península Balcânica), será perseguido o desenvolvimento dos grafismos nessa região, numa linha cronológica mas não necessariamente evolutiva. Assim, cabe saber que termos consagrados como "pré-gregos" e similares, para designar parte dessa produção, perdem sua viabilidade analítica e, quando muito, dão uma vaga referência temporal.

É certo que se o período histórico que compreende as chamadas "Idade do Bronze" e "Idade Obscura" é, em grande parte, um enigma que vem sendo, aos poucos, desvendado por especialistas da área, ${ }^{12}$ para os gregos antigos ele era pouquíssimo conhecido; restando, para a compreensão dessa época, uma ampla gama de narrativas míticas que contavam, por exemplo, com figuras como Homero na situação de "guia", uma orientação que passava originalmente, sobretudo, pela oralidade, mas se estendeu à literatura escrita e à imagística.

Essa região, muito antes do desenvolvimento das póleis, foi palco de ampla experiência gráfica (inclusive sobre vasos de cerâmica), desenvolvida pelos minoanos e micênios. ${ }^{13}$ Motivos de escamas, florais e espirais conviveram com a figuração de animais como polvos, lulas, ostras, eqüinos, caprinos e cervídeos, dentre vários outros, e grande interesse também pela figuração humana. Ademais, houve a ocorrência de inscrições pintadas sobre vasos de cerâmica, e uma grande produção escrita sobre tabletes de argila. ${ }^{14}$

\footnotetext{
12 Sobre a Idade do Bronze, por exemplo, grande parte dos documentos escritos encontrados em Creta, e outros locais do Egeu (como os hieróglifos e o Linear A), ainda não foi decodificada; quanto à "Idade obscura", "no sentido de que somos nós que tateamos no escuro, e somente por causa desse sentido, é legitimo adotar a convenção que denomina de 'Idade das trevas' o longo período da história grega entre 1200 e 800" (Finley, 1990, p. 80).

${ }^{13}$ Temporalmente, podemos caracterizar essa experiência num grande recorte: desde c. de 1575 a c. de $1020-$ 1000, segundo Mountjoy (1993, p. 4).

${ }^{14}$ É sobre o Linear B que se dispõe de maiores informações. A orientação desta escrita micênica era invariavelmente da esquerda para a direita, como a nossa (conforme informações obtidas na palestra de Pierre Carlier, La bureaucracie mycénienne, ses méthodes et ses limites. Novas abordagens em Ciências da Antigüidade (DLCV/FFCH-USP, MAE-USP. 30 de agosto a 3 de setembro de 2004). Diferente dos hábitos gregos a partir da experiência alfabética, situação na qual havia diversas orientações da escrita, só uniformizada (da esquerda para a direita) como a organização da língua grega no período helenístico. Ainda, o grau prioritariamente administrativo do uso de tal escrita, não permitiu um uso amplo, ou seja, para várias outras criações como a literatura. Assim, em Linear B, nunca foram encontrados textos em estrutura narrativa. Ainda, Havelock (1996, p. 165-9) diz que o caráter "limitado" das escritas silabárias devia-se ao seu uso ostensivo na composição de lista de bens, trocas comerciais etc., havendo mesmo, várias teses de especialistas que legam a origem dessa tecnologia à dinâmica comercial. Dessa forma, narrativas extensas, a partir desses sistemas de escrita, seriam muito repetitivas (por conta de um vocabulário pequeno para fins literários), como indica Havelock, ao comparar quantitativamente a narrativa do dilúvio na Epopéia de Gilgamesh, escrita em sistema silabário (cuneiforme) e o dilúvio homérico, a partir da transcrição alfabética (enquanto este teria repetições de palavras em torno de 14\%, a narrativa em cuneiforme atinge repetições de $23 \%$ ).
} 
Não há registro de uma prática artesanal que propusesse de forma consistente a coexistência entre escrita e figuração num mesmo suporte; mas é necessário dizer que os hieróglifos cretenses, o Linear A e o Linear B eram caracterizados por um certo grau ideográfico, uma escrita em parte composta por caracteres correspondentes a pequenas imagens figuradas (ver fig. 24-26). Contra uma ausência quase absoluta da relação entre elemento figurativo e escrito num mesmo suporte, há alguns poucos exemplares cretenses, selos encontrados por Evans no início do século XX. Alguns desses exemplares, apesar do alto grau figurativo da escrita hieroglífica, apresentam escrita e figuração bastante definidas (ver fig. 27-30).

Entretanto, enquanto a figuração era mais amplamente desenvolvida em painéis ${ }^{15}$; a escrita privilegiou sistematicamente os tabletes de argila como suporte. Um indício desse distanciamento de suporte é a função da escrita no período micênico. Sabe-se que seu papel era importante no contexto da administração palaciana, e esses tabletes eram suporte de informações que deveriam, por vezes, ser arquivadas. Ainda, a escrita não era uma tecnologia disseminada, mas destinada à atividade de alguns funcionários dos palácios, e mesmo as inscrições pintadas sobre vasos, podem ser aproximadas às muito posteriores estampilhas prensadas sobre uma grande quantidade de vasos de transporte, que eram continentes de produtos amplamente comercializados no Mediterrâneo (ver fig. 31-35). ${ }^{16}$

Nesse contexto, se a escrita estava mais ligada ao ambiente burocrático administrativo, a criação figurativa, pelo menos no que tange à temática, estava altamente relacionada ao registro épico, ${ }^{17}$ paralelamente à oralidade. Porém, é necessário aqui explicar os limites de tal afirmação. O que se tem à disposição de exemplares suporte da escrita hieroglífica cretense, Linear A e B compõe um grupo relativamente pequeno de inscrições, que chegou aos dias atuais através de episódicos incêndios que preservaram alguns suportes dessas inscrições; enquanto a maior parte deles desapareceu (J.-P. Olivier, Les écritures crêtoises, In: Treuil, 1989, p. 238).

\footnotetext{
15 "A cultura minóico-micênica legou-nos um universo imagético extremamente rico. Esse universo está distribuído entre os mais diversos suportes: afrescos, relevos, selos, anéis de sinete, terracotas e, obviamente, cerâmica decorada" (Torralvo, 1996-1997, p. 35).

${ }^{16}$ As marcas que indicam informações relacionadas à dinâmica comercial no Mediterrâneo (geralmente informações sobre o conteúdo, local de emissão ou de destino) são bastante antigas e presentes em várias culturas da região, além dos gregos e micênios. Cabe dizer que tal prática, de formas diversas, persistiu amplamente, e há registros como os aqui indicados, que remontam à Idade do Bronze (inscrições em Linear B), até outras bastante posteriores, utilizadas no contexto da dominação romana no Mediterrâneo.

${ }^{17}$ Compreende-se, aqui, como registro épico, as referências ligadas, pela temática, à poesia épica (no caso, a homérica), muitas das quais se pode estabelecer paralelos entre práticas próprias da experiência micênica, até as posteriores na época de desenvolvimento das póleis gregas. Não se trata de dizer que as referências materiais tratadas sejam ligadas ao conteúdo épico de forma subordinativa, ou seja, como influência direta daquele. Entretanto, as referências literárias em Homero servem como guia para tal aglutinação documental.
} 

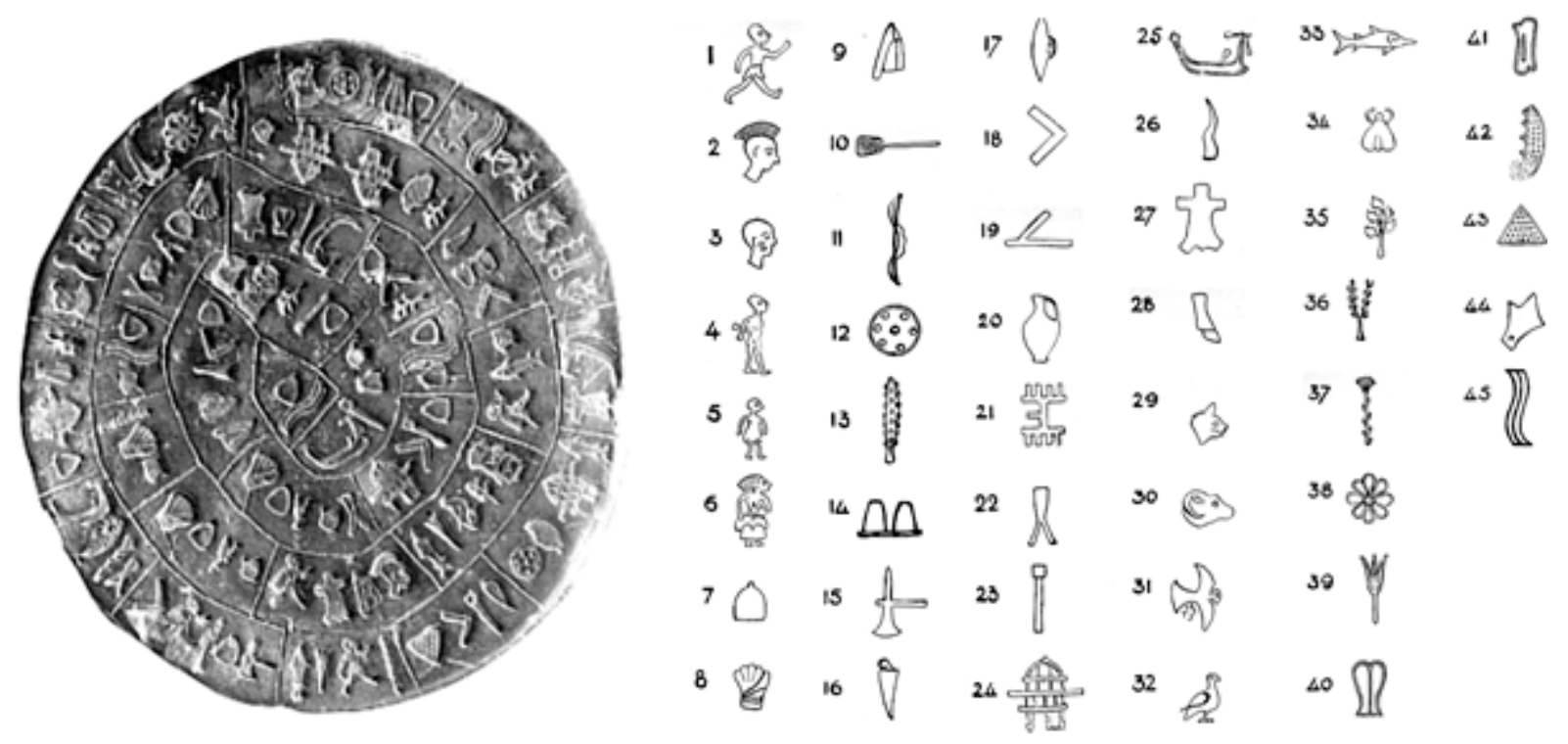

(De cima para baixo): Fig. 24. Uma face do Disco de Festo (c. 1700 a.C.) - diâm. máx.: $16,5 \mathrm{~cm}$ - e esquema com todos os caracteres presentes. O Disco de Festo é único, e muito se discute seu real significado no contexto dos achados arqueológicos e epigráficos em Creta; entretanto, distante disso, uma característica sua aproxima-o dos outros achados em Creta e alhures: trata-se do alto grau ideográfico dos tipos desse disco.
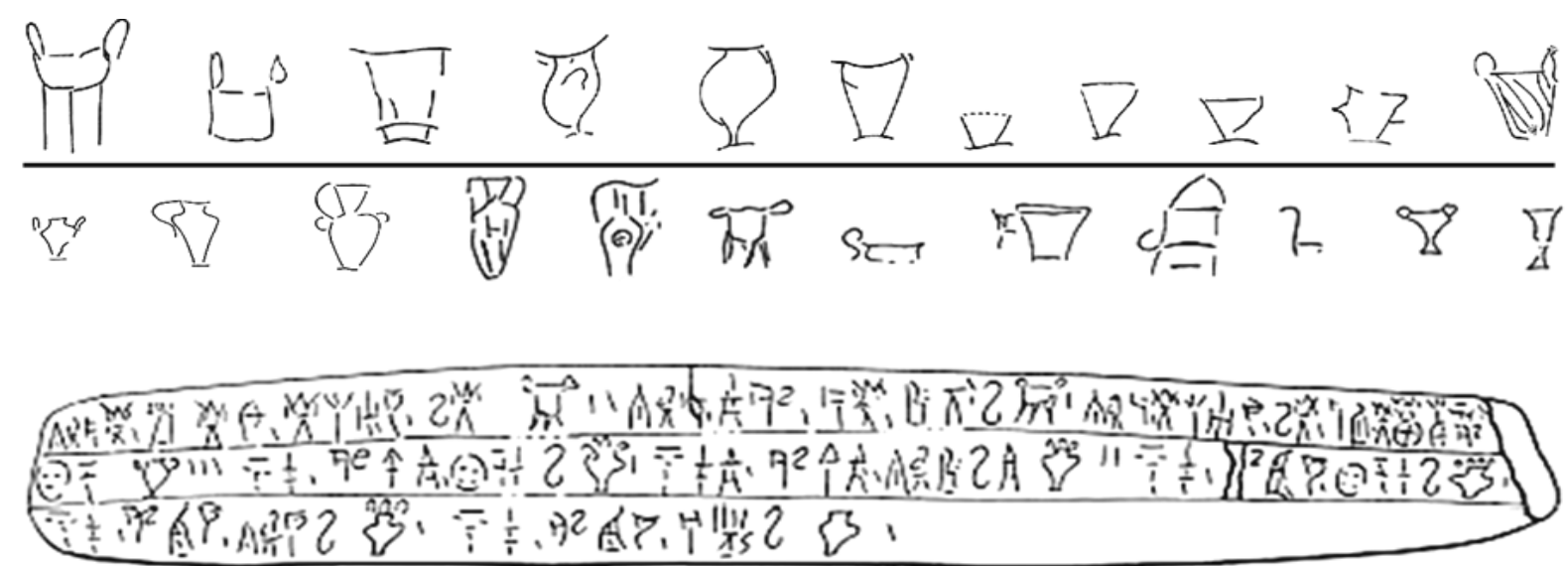

Fig. 25. Ideogramas (formas de vasos): a. (acima) em Linear A; $\boldsymbol{b}$. (meio) em Linear B; Fig. 26. (abaixo) Tablete com sistema fonético e ideogrmático combinado (larg.: $25 \mathrm{~cm}$ ): Linha 1. ti-ri-po-de ai-ke-u ke-re-si-jo we-ke TRIPOD 2 ti-ri-po e-me pó-de o-wo-we TRIPOD 1 ti-ripo ke-re-si-jo we-ke a-pu ke-ka-u-me-no ke-re-a2 no-[pe-re? TRIPOD 1]; Linha 2. qe-to WINE-JAR? 3 di-pa me-zo-e qe-to-ro-we POT ${ }_{1}$ dipa-e me-zo-e ti-ri-o-we POT 2 di-pa me-wi-jo qe-to-ro-we POT 1; Linha 3. di-pa- me-wi-jo ti-ri-jo-we POT 1 di-pa me-wi-jo a-no-we POT 1.; (Da esquerda para a direita).
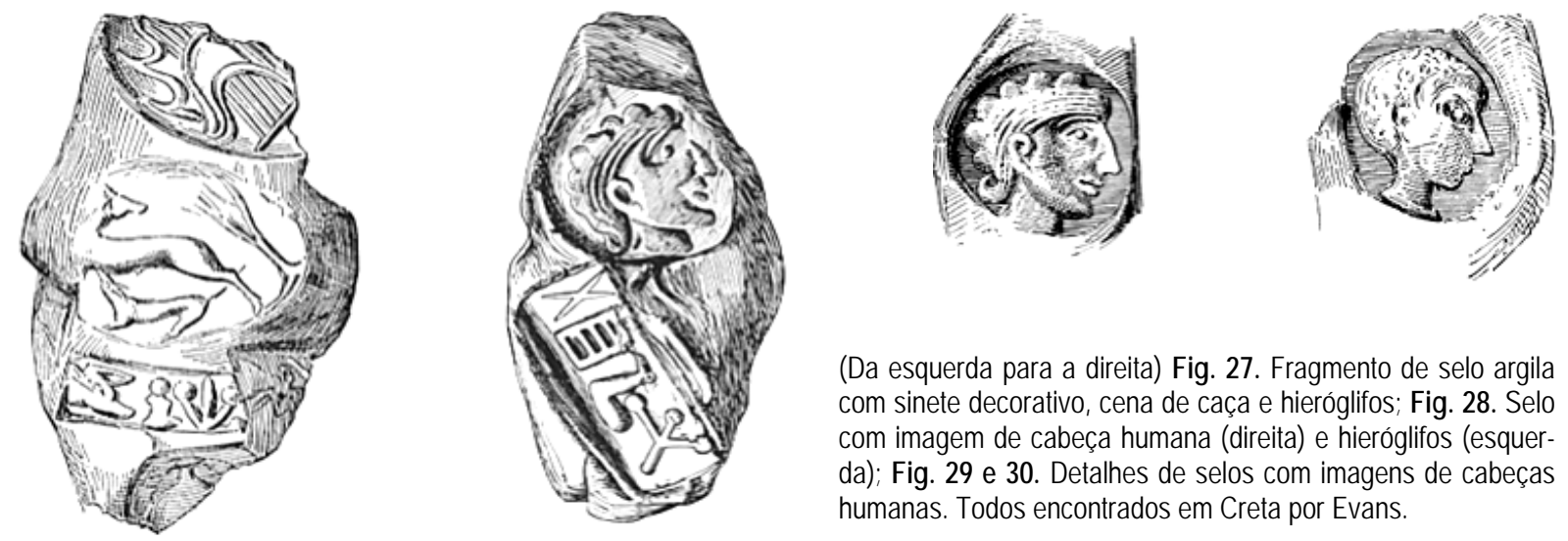

(Da esquerda para a direita) Fig. 27. Fragmento de selo argila com sinete decorativo, cena de caça e hieróglifos; Fig. 28. Selo com imagem de cabeça humana (direita) e hieróglifos (esquerda); Fig. 29 e 30. Detalhes de selos com imagens de cabeças humanas. Todos encontrados em Creta por Evans. 

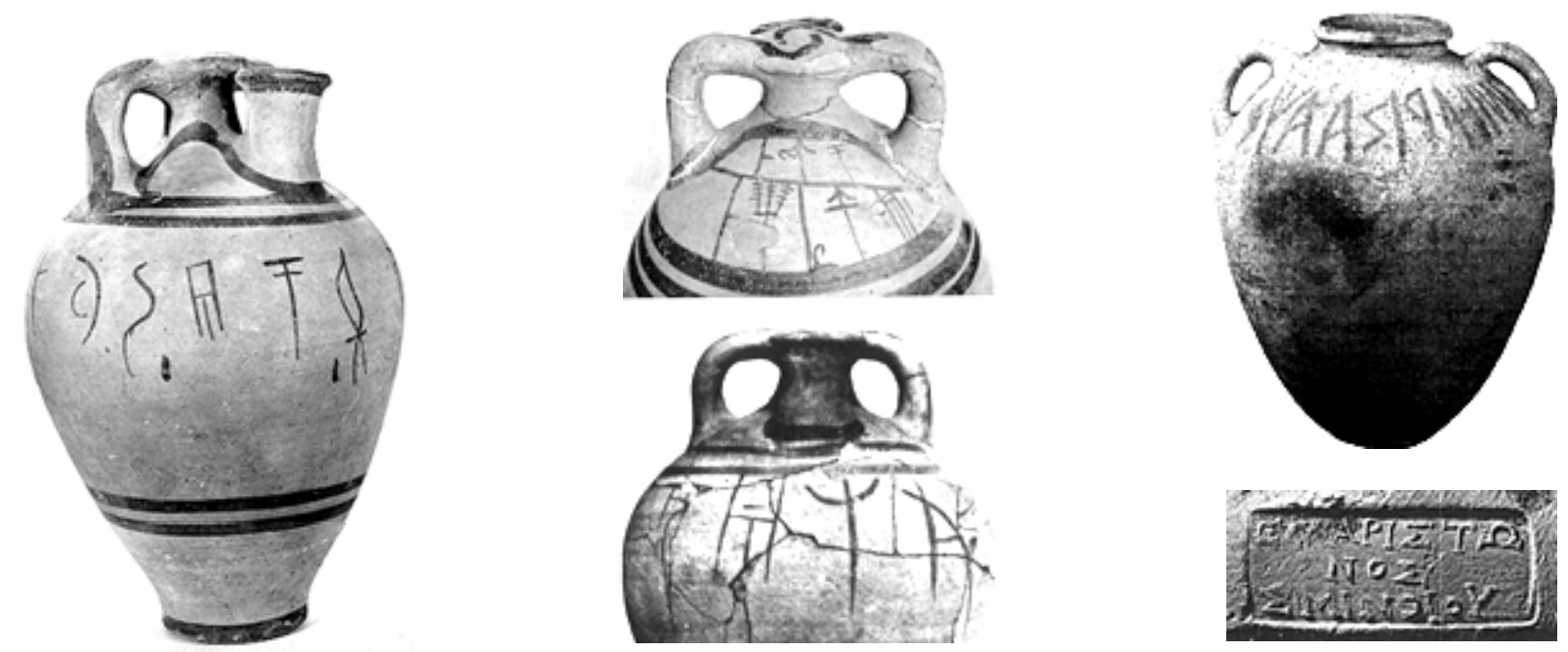

Fig. 31. Vaso inscrito (em Linear B) para transporte de vinho e óleo, c. 1300 - c. 1190, Kadmeion, Thebes - três nomes: dois nomes de pessoas e um nome de lugar, segundo Mountjoy, 2001, p. 74. Fig. 32 e 33. Detalhes de jarro de transporte (parte alta com inscrições em Linear B); (acima) encontrada em Eleusis, (abaixo) encontrada em Tebas - alturas: c. $40 \mathrm{~cm}$. Fig. $\mathbf{3 4}$. Vaso de transporte (inscrição em etrusco). Fig. 35. Estampilha de alça de ânfora grega de transporte.

Por exemplo, em Creta, foram encontrados 270 documentos em hieróglifo (1537 signos), 1427 em Linear A (7362 signos), 4765 em Linear B (57.398 signos); um total de 6.462 documentos, 66.297 signos (hieróglifos: $4 \%$ da documentação e 2\% dos signos, Linear A: $22 \%$ dos documentos e $11 \%$ dos signos, e Linear B: $74 \%$ dos documentos e $87 \%$ dos signos); “... o que equivale a pouco mais de 25 páginas deste livro", segundo Olivier, um número muito pequeno de documentos e signos, com os quais compara quantitativamente ao livro de que participou, que possui 633 páginas (Idem, p. 242; ver também Vernant, 1989, p. 15).

Essa rica experiência gráfica praticamente desapareceria (desde o século XII a.C.) sem vestígio de coexistência entre uma escrita que paulatinamente deixava de ser ideográfica, e a imagem figurativa. Esse distanciamento entre escrita e figuração, no que se refere ao suporte, indica alguns caminhos para se entender melhor o reaparecimento da escrita e da arte figurativa no período arcaico.

É importante dizer que o ato de articular informação escrita e figurativa num mesmo suporte não é algo naturalmente estabelecido, havendo variantes importantes, dadas as especificidades de cada sociedade. Neste caso, mesmo com uma ampla experiência em articular escrita e figuração em regiões muito próximas (Oriente Próximo e Egito), desde o IV milênio a.C., não houve registro de disseminação sistemática dessa prática entre minoanos e micênios.

Apesar de alguns claros traços de continuidade a partir da experiência artesanal micênica, o lapso que compreendeu uma época em que desaparece a escrita e a figuração (a "Idade Obscura") não favoreceu uma semelhante retomada do relacionamento entre a atividade de escrever e produzir imagens no período arcaico, já que, enquanto os gregos compreendiam essas duas atividades de forma análoga, os micênios, através de sua prática 
restritiva, não admitiam essa identidade tão forte. Nesse caso, procurar a "origem" da prática grega de articular escrita e figuração, propõe novos caminhos, além da pura e simples continuidade de uma experiência anterior na mesma região; relativizando posições como a de M. I. Finley (1990, p. 79), que disse:

Ao menos que a própria vida seja destruída numa região, sempre há algum tipo de continuidade. Nesse sentido, a história grega foi uma continuação de sua pré-história da Idade do Bronze.

É sob a égide da continuidade que o desenvolvimento da produção material, dentro disso a produção ceramista, em grande medida, vem sendo analisada. Dessa forma, o que é chamado de estilo "protogeométrico" é constantemente caracterizado a partir da influência micênica (Finley, 1990, p. 81; Cook, 1997, p. 9). Entretanto, mesmo Finley (op. cit., p. 79) vê problemas nessa ótica histórica unicamente pautada na continuidade.

O que se observa então nos vasos de cerâmica é caracterizado como uma ornamentação simples, baseada em linhas paralelas (sejam elas retilíneas ou sinuosas) e motivos em semicírculos ou círculos concêntricos; ou seja, ornamentos "poucos e simples (...) derivados do micênico", que compõem o chamado estilo "protogeométrico" (c. 1050 - c. 900 a.C. - Cook, 1997, p. 8-9) - ver fig. 36-39. A ornamentação da cerâmica nessa situação (entre o declínio micênico e a organização das póleis - a sub-micênica e protogeométrica), ao afastar-se de qualquer traço ornamental figurativo, compunha-se pelos elementos geométricos simples acima citados, mas é importante ressaltar que esses eram elementos e mesmo esquemas disponíveis no contexto da ornamentação ceramista desde o séc. XVI a.C. (ver fig. 40 e 41).

É notória a ausência de elementos figurativos, pelo menos até o século $X$ a.C., quando muito timidamente ressurge a figuração. Um exemplo disso é a figuração de um cavalo num vaso protogeométrico (ver fig. 42). ${ }^{18}$ A ornamentação desse vaso (caracteristicamente protogeométrica) é composta por linhas e faixas paralelas, semicírculos concêntricos e pescoço com pintura plena, tudo em verniz escuro.

\footnotetext{
${ }^{18}$ Além desse eqüino figurado, segundo Hurwit (1985, p. 59), há também a representação de dois pássaros num vaso ático exportado para Lefkandi: "Pelo início do séc. IX a.C., então, dois dos três temas mais importantes da arte geométrica ática - o cavalo e a ave - já haviam sido introduzidos. O terceiro - a figura humana - não apareceria sobre vasos áticos até o final do séc. IX a.C."
} 

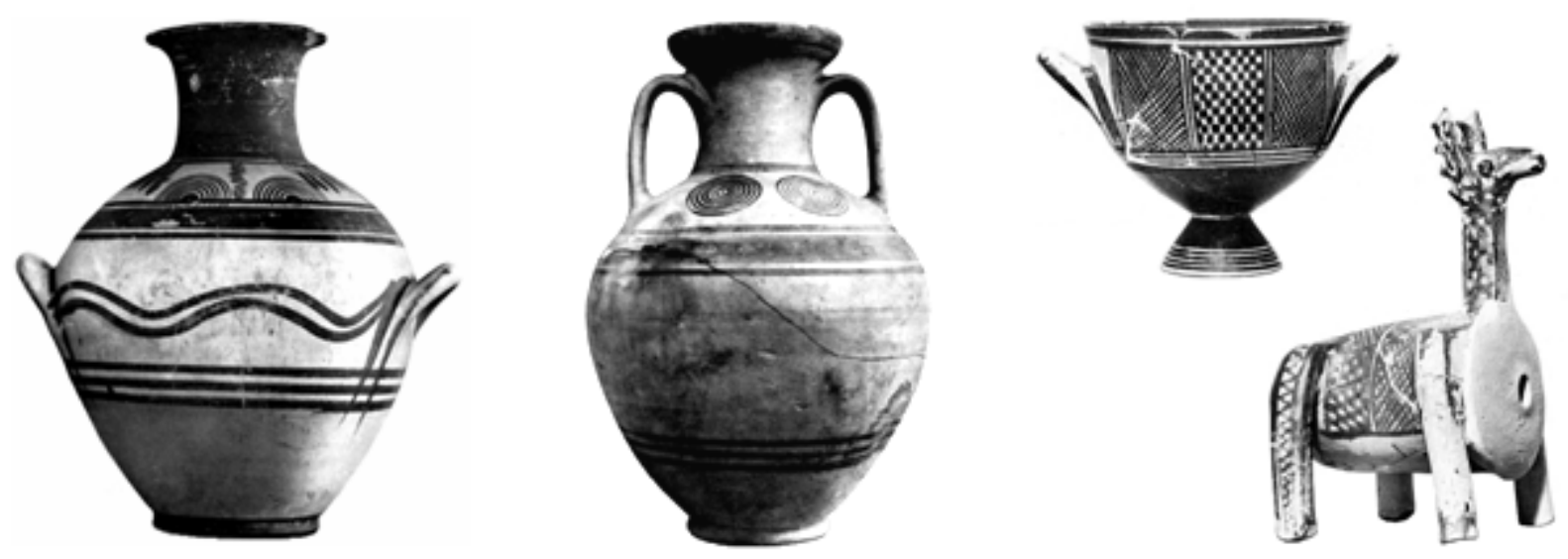

Fig. 36. Ânfora ática protogeométrica 544, século X a.C., Museu do Cerâmico, Atenas (alt.: 29,5 cm); Fig. 37. Ânfora ática protogeométrica 556, fim do século XI a.C., Atenas, Museu do Cerâmico (alt.: $40 \mathrm{~cm}$ ); Fig. 38. Taça ática protogeométrica 567, séc. X a.C., Atenas, Museu do Cerâmico; Fig. 39. Rhyton protogeométrico em forma de cervo 641, séc. X a.C., Atenas, Museu do Cerâmico.

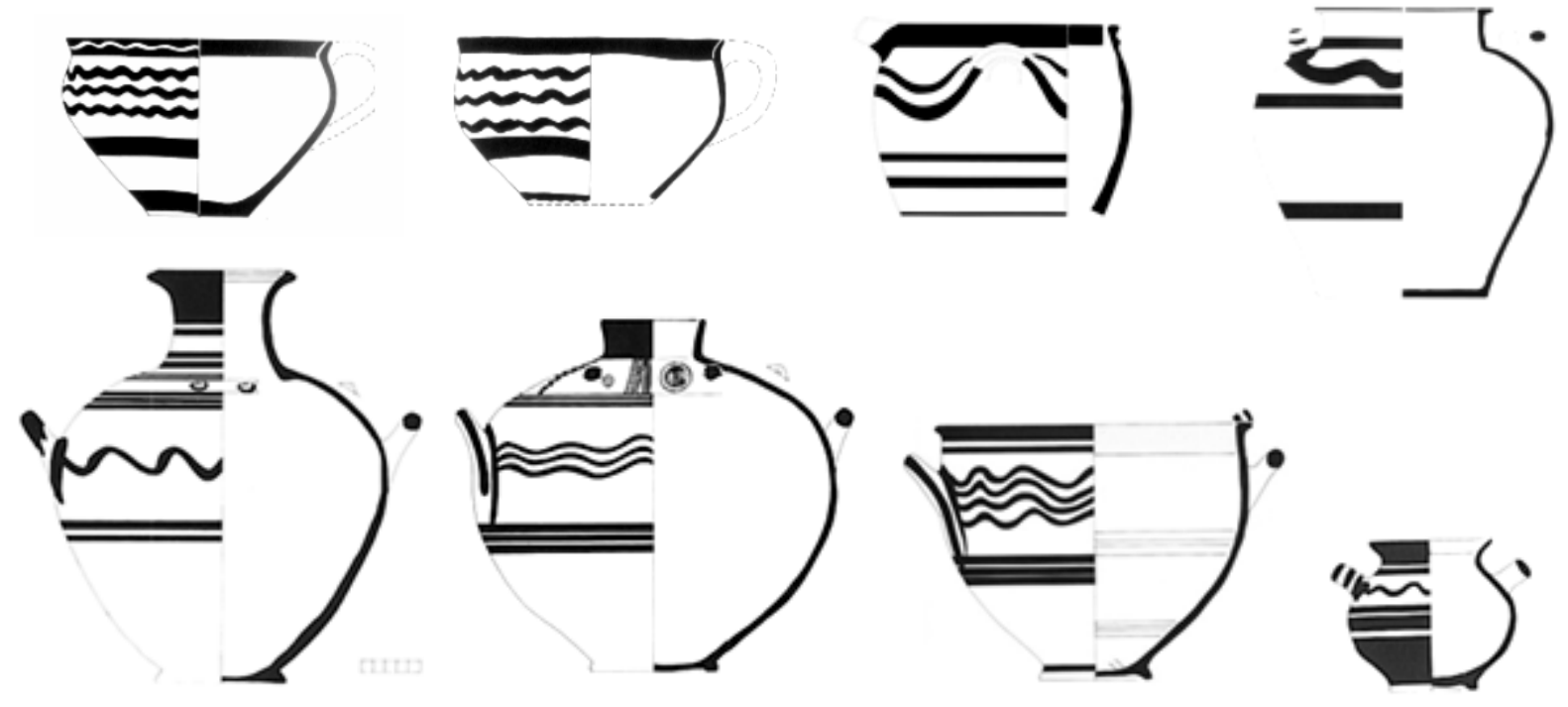

Fig. 40. (Linha acima, da esquerda para a direita) Vasos encontrados na região de Kommos, sul de Creta: $\boldsymbol{a}$ e $\boldsymbol{b}$. séc. XVI a.C.; $\boldsymbol{b}$ e $\boldsymbol{c}$. séc. XIV a.C.; Fig.41. (Linha abaixo, da esquerda para a direita): a-d. c. 1070 - c. 1050/30.

O elemento menos rígido é uma faixa na parte alta do bojo, composta por três linhas sinuosas feitas à mão livre ${ }^{19}$, enquanto as faixas formadas por linhas paralelas são feitas com o auxílio do torno (situação revelada pela regularidade delas), e os semicírculos associados feitos com compasso. À esquerda da composição, entre a faixa sinuosa (acima) e a faixa regular (abaixo, o "chão"), localiza-se um eqüino, que tem seu rabo voltado para a esquerda (próximo da alça do vaso, que marca o limite lateral da cena), tendo um grande espaço "vago" à sua frente. Este eqüino é apresentado de forma bastante esquemática (uma

\footnotetext{
${ }^{19}$ Apesar das significativas modificações, dado o declínio das estruturas micênicas, algumas permanências podem ser notadas. Se a ornamentação figurativa desapareceu, as suas áreas delimitativas (acima e abaixo), que submetiam a figuração a um esquema de faixa, ainda persistiria até o protogeométrico (ver fig. 36, 49 e 50). Não é surpresa, nesse sentido, notar que as linhas sinuosas, o elemento menos rígido da estrutura ornamental protogeométrica, ocupa exatamente o mesmo espaço conferido anteriormente à figuração, e é justamente nessa zona que a figuração ressurge (ver fig. 42), como será visto a seguir.
} 
silhueta), tendo longas patas (regulares, retilíneas, e espessura estreita), como o rabo. O tronco é proporcionalmente estreito em relação ao pescoço bastante largo, como observado em outros exemplos tridimensionais de terracota e bronze, da mesma época. Há também a indicação de sua crina.
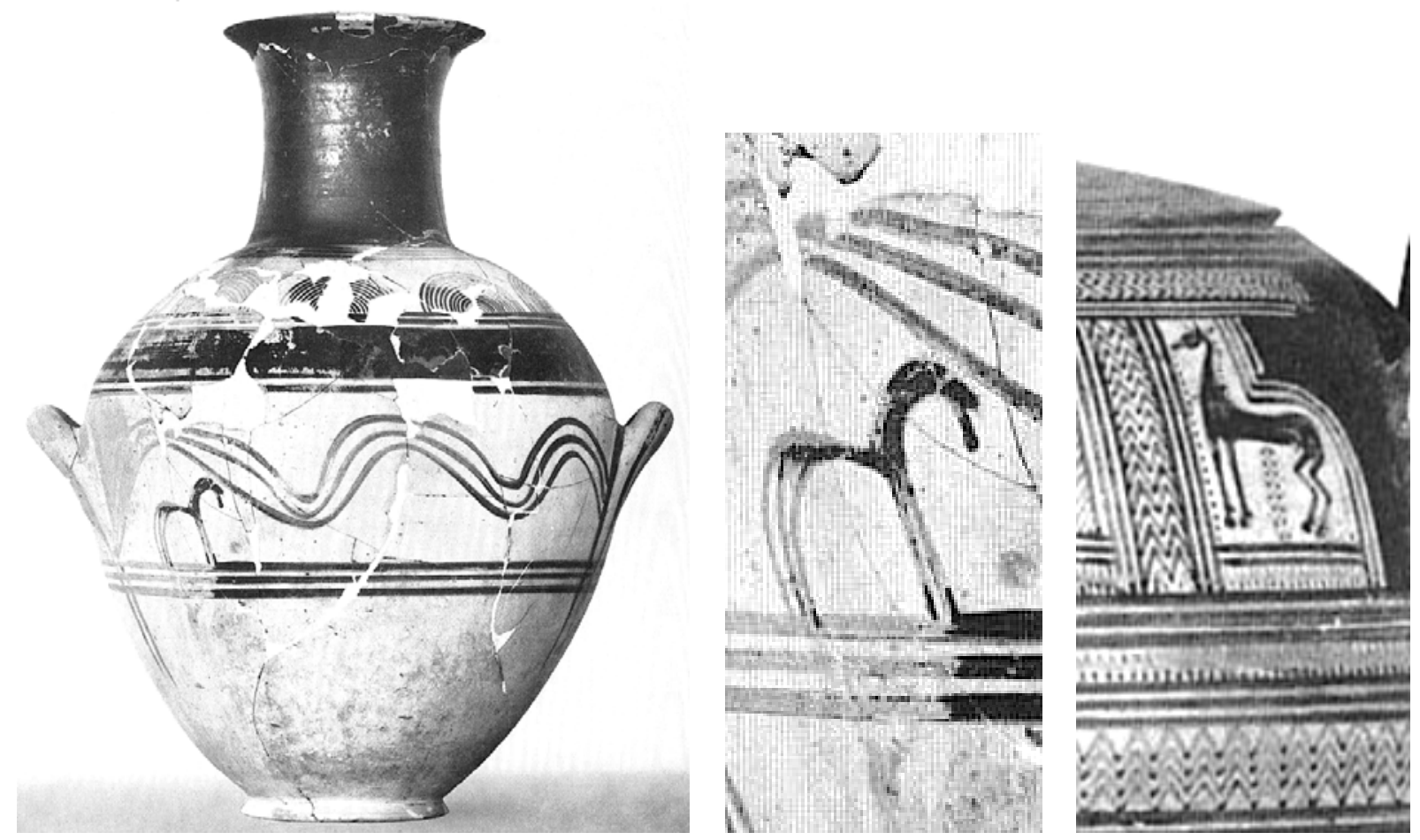

Fig. 42a. (à esquerda) Ânfora ática protogeométrica 560, século X a.C., Atenas, Museu do Cerâmico; Fig. 42b. (meio) Detalhe com imagem figurativa (cavalo) no bojo do vaso; Fig. 43. (à direita) Cratera ática geométrica A 514 (detalhe), final do século IX a.C., Paris, Museu do Louvre

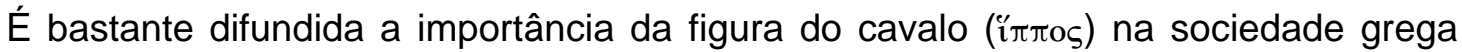
aristocrática; ${ }^{20}$ entretanto, longe de estabelecer paralelos ansiosos, pode indicar-se a ampla presença desse animal como elemento figurativo, dada a sua recorrente presença na ornamentação vascular, sendo um dos primeiros temas da figuração sobre a cerâmica (e mesmo a recorrente presença em outros suportes, desde épocas bem recuadas). ${ }^{21}$ Sua persistência é grande nos exemplares geométricos, nos quais a composição esquemática do eqüino ainda é presente, porém apresentando mais formas anatômicas (detalhamento das patas e dobras das pernas traseiras - ver fig. 43 e 44), características observáveis já nos séculos IX e VIII a.C., e mesmo em formas plásticas de cerâmica observa-se essa caracterização es-

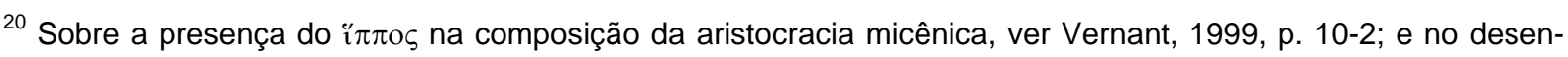
volvimento da pólis, p. 31-2.

${ }^{21}$ Venant (1989, p. 11) indica uma provável origem material para essa temática: "Os primeiros documentos gregos que nos esclarecem a esse respeito datam do século XVI: em estelas funerárias descobertas no círculo dos túmulos em fossas de Micenas (1580-1500), em cenas de batalha ou de caça figuram um guerreiro de pé em seu carro puxado por cavalos a galope".
} 
quemática em volume (ver fig. 45 e 46), e estes carregam ornamentação pintada a partir de motivos geométricos (é possível notar a marcação de detalhes anatômicos como o olho a partir dessa pintura). A imagem figurativa dos cavalos persiste mesmo no séc. VII a.C., ressaltando-se, cada vez mais, os detalhes anatômicos (ver fig. 47 e 48). No que se refere à ornamentação da cerâmica, este é um tema que só desaparece com a própria decadência da produção ceramista: a iconografia atlética, por exemplo, o caso das ânforas panatenaicas, registra o cavalo e as corridas até o período romano.
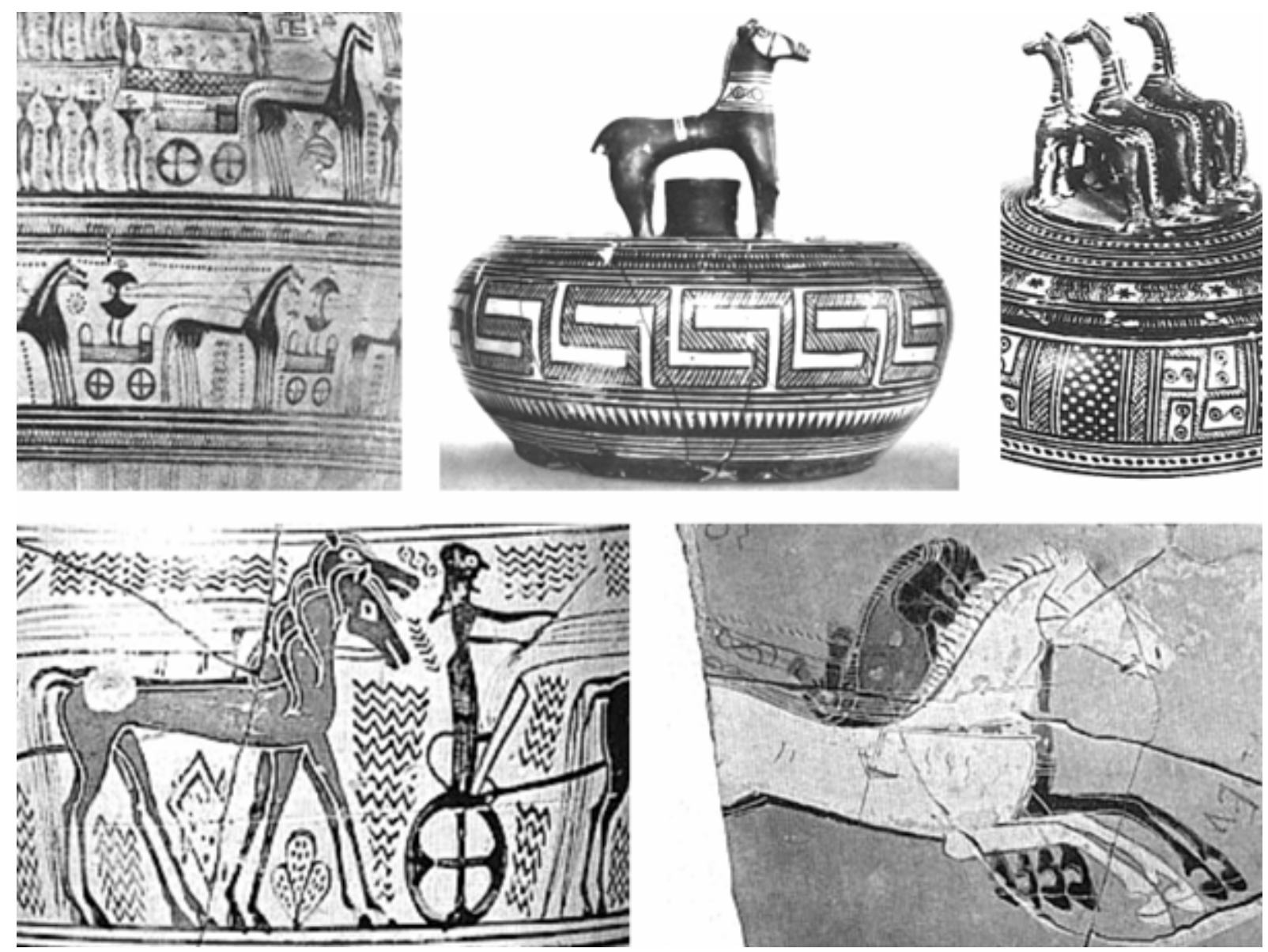

(De cima para baixo, da esquerda para direita) Fig. 44. Cratera ática geométrica 990 (detalhe do bojo), terceiro quartel do século VIII a.C., Atenas, Museu Nacional; Fig. 45. Pyxis geométrica 257 (tampa com forma plástica: cavalo), fim do século IX a.C., Atenas, Museu do Cerâmico; Fig. 46. Pyxis geométrica (detalhe), Atenas, Museu do da Agora; Fig. 47. Ânfora-loutroforo protoática CA 2985 (detalhe do bojo), primeiro quartel do séc. VII a.C., Paris, Museu do Louvre; Fig. 48. Fragmento de dinos de Sófilo 15499 (detalhe), c. 580-570 a.C., Atenas, Museu Nacional.

\subsection{Período arcaico. Memória, grafismos e oralidade}

A situação "favorável" dos atuais observadores do desenvolvimento histórico não deve contaminar a compreensão dos processos passados, entendendo-os como se houvesse um desenvolvimento "natural" (puramente linear, cíclico; ou seja, esquemático) das socieda- 
des humanas. O termo "período arcaico", muitas vezes, leva a isso: a entender esse recorte temporal como se fosse uma época "preparatória" ou simples "estágio preliminar"22 do "período clássico", que também carrega caracterizações ideológicas. ${ }^{23}$ É importante saber que estes são conceitos modernos, que permitem entender parcialmente processos passados, e mesmo compreendendo-o conceitualmente, e a seus "antecedentes" e "conseqüentes", é devido tratar desse período, o "arcaico", levando em conta a dinâmica própria da sociedade ática nessa época; pois todo o presente (mesmo o que não exista mais, que agora seja passado) tem sua autonomia de presente, e não simples ponto de partida para um desenvolvimento pré-estabelecido.

Uma compreensão linear, puramente conseqüente, leva a uma visão problemática. Um exemplo: se ela for utilizada no que se refere ao quadro das figuras humanas ou humanizadas na ornamentação da cerâmica, parece que há um desenvolvimento "natural" das esquemáticas figuras de exemplares como os vasos funerários do Dípilo, até as concebidas em figuras negras, nas quais há maior detalhamento das formas. Assim, do século VIII ao VII a.C. teria havido uma processual "naturalização" desse tipo de figuração. Ora, esse raciocínio, além de ingênuo, deixa de lado uma intrusão importante: as relações com a ornamentação da cerâmica coríntia, que por sua vez tinha paralelos com formas orientais como as que chegavam na Grécia através de objetos como marfins e metais, que eram ornamentados por meio de incisões (Boardman 1995, p. 9; Cook, 1997, p. 41; Shanks, 1999, p. 9). Dessa forma, esse processo histórico é mais complexo e indica as armadilhas de uma compreensão esquemática da história. Ainda, é importante ressaltar a presença da influência oriental no ramo da imagística, quando muitas vezes essa propriedade foi vista como pura originalidade grega. Nesse caso, reconstituir a produção dessas imagens no período arcaico passa também por uma extrapolação espacial até Corinto e Oriente próximo.

Essa visão esquemática que propôs durante muito tempo a originalidade grega, talvez não esteja relacionada somente a um puro desvio ingênuo da compreensão do tempo, mas a questões ideológicas mais amplas.

Verdadeiro tumulto foi levantado por um livro, Black Athena, que me parece colocar [questão fundamental:] (...) é saber se a constituição da Grécia clássica como modelo histórico ideal em face do Oriente egípcio e semítico deve algo ao racismo ou, mais modestamente, ao eurocentrismo, da ciência do final do século XVIII e do XIX. A esta questão, pode-se, creio, dar uma resposta positiva, com infinitas nuanças. (Vidal-Naquet, 2002, p. 217)

\footnotetext{
${ }^{22}$ Essa idéia de estágio preliminar, de anteriorioridade, relacionada à palavra arcaico, já encontrava eco na Antigüidade; por exemplo, a raiz grega ỏpxý- tinha acepção que remete à idéia de começo, origem, presente em

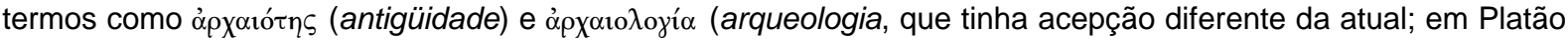
[Hippias maior 285 d], por exemplo, é algo próximo da "história ou lenda da antigüidade" [Bailly, verbete

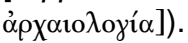

${ }^{23}$ Sobre as acepções e usos do termo "clássico" e correlatos, ver Pollitt, 1996, p. 1-2.
} 
Mark D. Fullerton participa da discussão:

Já foi demonstrado que os especialistas clássicos do século XIX preocupavam-se, pelo menos parcialmente, em construir um conceito de pureza cultural grega, pela clara demarcação da diferença entre os aspectos culturais gregos (ocidentais) e os do Oriente, e pela negação de qualquer influência dos orientais sobre os gregos (até mesmo as ignorando). (Fullerton, 2002, p. 72-3)

E Martin Bernal propõe, já no subtítulo de sua obra Black Athena, "raízes afroasiáticas" para a "civilização clássica" (Bernal, 1996 e 1999). Além disso, grande parte dos estudos recentes sobre a Grécia antiga que abordam a escrita alfabética (Jeffery, 1990, p.1; Coldstream, 1979, p.296), a arte figurativa (Vernant, 1990, p. 399-400) e a relação entre escrita e figuração (Hurwit, 1990, p. 180-1), tema privilegiado nesse estudo, indica essa influência oriental. ${ }^{24}$

Não se trata, entretanto, de abandonar completamente a discussão dos séculos XVIII e XIX sobre a Grécia e os gregos, mas de notar que a pura e simples adesão, sem crítica, apresenta armadilhas de que se deve fugir, seguindo um caminho mais sólido, preocupando-se, inclusive, com as novas interpretações. Pierre Vidal-Naquet salienta:

(...) que Atena tenha sido negra é uma idéia que atrai as simpatias populares nas universidades americanas. Trata-se de uma extravagância contemporânea que permitirá relativizar um pouco nossa indignação ao analisarmos as hipóteses do erudito sueco Olof Rudbeck, que estimava ter provado que a Atlântida de Platão era a Suécia e sua capital era Uppsala, sede da universidade onde Rudbeck atuava como reitor. (Vidal-Naquet, 2002, p. 218)

Essa colocação é importante, pois se preocupa com os antigos e os atuais usos ideológicos da compreensão do passado. A necessidade de apresentar a diversidade como fator positivo no desenvolvimento histórico teve como objetivo principal, em vários casos, dar respostas a projetos homogeneizantes, como os fascismos europeus. Já no final da década de 20 do século XX, Sir John Linton Myres, numa apresentação conferida (série Sather Lectures, da Universidade da Califórnia, em 1927), discursava sobre uma conformação gre-

\footnotetext{
${ }^{24}$ Para além das questões das influências recíprocas entre Mundo grego, Oriente Próximo e Egito na Antigüidade, o próprio cenário das pesquisas contemporâneas, como as ligadas à decifração das línguas antigas, indicam essa antiga e intensa interação. Ora, para isso basta saber que os hieróglifos egípcios foram decriptados a partir de paralelismos com a língua grega (a empresa de Champollion (1822) tratava de estabelecer os paralelos a partir de uma estela com inscrição trilíngüe); tal como o "(....) primeiro estudioso a conseguir decifrar alguns caracteres do persa antigo, [que] foi Georges Grotefend, um professor alemão que, em 1802, conseguiu ler o nome dos reis Dario (pai) e Xerxes (filho) devido a um paralelo com o grego, o hebreu e a língua avestan" (Pozzer, 2004, p. 71). Ainda, conforme Dalley e Reyes (1998b), encontram-se, referente ao período helenístico, sobre o mesmo suporte, inscrições em grego e cuneiforme (p. 112, fig. 51 e 52) e grego e aramaico (p. 114-5, fig. 53 e 54), confirmando a continuidade de tal interação, além do período arcaico.
} 
ga baseada na diversidade, "Myres argumentava que a Grécia tinha sido habitada, desde a Idade do Bronze, por uma população mista" (Hall, 2001, p. 214). Entretanto, esse tipo de argumentação nasce num contexto específico e conseqüentemente propõe novas formas de ver o passado (e não apenas quanto à Grécia antiga) ${ }^{25}$; ou seja, a "variedade" vista de forma positiva na compreensão das Ciências Humanas é historicamente datada, ${ }^{26}$ e essa constatação serve mais para situa-la que para repeli-la. Assim, não se trata de dizer que é errado tomar a "variedade" para compreender o passado, nem de livrar-se dela e propor uma nova imparcialidade pura e simples, mas tratar a idéia de "pureza" (do séc. XVIII e XIX) e de "variedade" (do século XX), de forma crítica. Esse, acredito, é um caminho mais seguro para traçar-se qualquer caracterização de períodos da história grega na Antigüidade, neste caso, especificamente o período arcaico.

Existem algumas idéias consolidadas sobre o período arcaico, entre elas estão as suas balizas cronológicas, que, se parecem variadas, na verdade seguem uma linha que prioriza eventos políticos como referência. Um breve exemplo mostra isso: tomando-se algumas obras clássicas, outras nem tanto, que apresentam cartas ou indicações cronológicas, observa-se um pouco dessas escolhas. As épocas de produção e áreas de interesse são diversas, conforme tabela a seguir:

\begin{tabular}{|c|c|c|c|c|c|}
\hline \multicolumn{3}{|c|}{ Período Arcaico (a.C.) } & Autor & Obra & Data $^{27}$ \\
\hline Séc. VII & $\mathrm{e}$ & Séc. VI & Ch. Dugas & La céramique grecque & 1924 \\
\hline 720 & a & 480 & R. M. Cook & Greek painted pottery & 1960 \\
\hline Final do séc. VIII & a & 480 & R. M. Cook & Os gregos até Alexandre & 1961 \\
\hline $800-750$ & a & 500 & M. I. Finley & Os gregos antigos & 1963 \\
\hline 776 & a & 508 & M. I. Finley & Grécia primitiva: Idade do bronze e Idade arcaica & 1970 \\
\hline c. 700 & a & 480 & P. Cartledge & História ilustrada da Grécia antiga & 1998 \\
\hline c. $590^{28}$ & a & 480 & M. D. Fullerton & Arte grega & 2000 \\
\hline
\end{tabular}

Tabela 1. Algumas balizas temporais para o período arcaico.

Em Finley (1990), por exemplo, a delimitação da Idade Arcaica dá-se a partir de dois eventos políticos: 776 a.C. (instituição dos Jogos Olímpicos) e 508 a.C. (reforma da Constituição de Atenas por Clístenes); enquanto as épocas imediatamente anteriores (Idade das Trevas e Idade do Bronze) são caracterizadas pelo domínio de tecnologias, o que também

\footnotetext{
${ }^{25}$ Quanto à história do Brasil, por exemplo, digna de nota é a montagem de uma interpretação baseada na idéia de diversidade já em Gilberto Freyre, na sua Casa grande e senzala (1933); interpretação que é das mais correntes, e reafirmada, em certa medida, por análises como a de Darcy Ribeiro, que apresenta a idéia do tripé cultural (as três matrizes) para a compreensão d'O povo brasileiro (1995).

${ }^{26}$ Mesmo nas Ciências Naturais observa-se um processo parecido. Por exemplo, as teorias de pureza biológica (racial) encontram no discurso da variabilidade genética um forte argumento contrariador (ver Lévi-Strauss, 1982 , p. 52-4); e na Física quântica, a idéia de variedade é apresentada como central, mas se pode mesmo retomar Albert Einsten e sua proposta Teoria da Relatividade, já em 1915, cuja estruturação tem a idéia de variedade como importante.

${ }^{27}$ As datas indicadas referem-se à publicação original.

${ }^{28}$ A época entre 700-600 o autor caracteriza como "orientalizante".
} 
acontece com a denominação Período Geométrico e Idade do Ferro. Essa prática tem mais a ver com os limites e fontes da pesquisa contemporânea, que com questões temporais propriamente antigas; já que, para os períodos anteriores à criação do alfabeto grego, e de seu uso sistemático, em práticas de escrita a caracterização de uma história eventual é impossível, e, dessa forma, há uma ênfase num tipo de história da arte e da técnica. Por isso, eras, idades ou épocas são caracterizadas pelo domínio de certas tecnologias.

Com o desenvolvimento de uma cultura letrada na Antigüidade, e conseqüentemente de uma oferta maior de documento escrito ao pesquisador atual, o mapeamento dos processos políticos é mais seguramente delineado, e por isso cronologias ligadas a alguns eventos eleitos como importantes são criadas. Reforça isso, o fato de as datas para essas épocas serem tão precisas, a maioria das vezes, em anos.

O problema colocado sobre a cronologia para o período arcaico é o seguinte: até que ponto a periodização tradicional serve à proposta analítica e interpretativa aqui colocada? Não basta pinçar-se uma divisão cronológica numa publicação ou outra. Finley (1988, p. 26) já atentava a esses limites de tais delimitações cronológicas:

É convenção aceite, hoje em dia, dividir a subseqüente história dos gregos antigos em vários períodos, cujos títulos são apenas formas estenográficas (que não devem ser tomadas literalmente ou mesmo como particularmente significativas).

É claro que as relações entre a produção ceramista e o universo administrativo da pólis existiam; mas o que efetivamente a instituição dos Jogos Olímpicos ou a reforma da Constituição ateniense ajuda na discussão gráfica aqui proposta? É válida a ampliação do termo arcaico, não apenas a uma época, mas a um estilo artístico inserido nessa época? ${ }^{29}$

O caminho mais interessante, parece, é procurar na criação gráfica relacionada à produção ceramista algo que the dê corporeidade, como já visto na discussão cronológica (ver cap. 2, item 2.1.1), e, dentro da lógica de uma sociedade "arcaica", buscar as relações, os pontos de junções; assim, o que de propriamente "arcaico" esses grafismos têm, e o que dessa criação gráfica alimenta a história dessa época.

As convenções são importantes. Cook (1997, p. 325) e Cartledge (2002, p. 494) caracterizam o período arcaico, retomando literalmente balizas "convencionais", entretanto, junto às convenções ("arcaico" para o período ou para o estilo), é necessário repensá-las à luz dos problemas colocados pela pesquisa específica, já que, muito dessa caracterização sobre o "arcaico" nasceu para responder questões específicas (por exemplo, para satisfazer uma história de cunho político, eventual), e foi estendida a outras áreas através de um uso tradicional. Essas tradições, convenções que permitem diálogos amplos, devem ser utiliza-

\footnotetext{
29 "Arcaico. O estilo e o período entre o Geométrico e o Clássico" (Cook, 1997, p. 325).
} 
das, mas não podem sufocar as questões específicas. Dar autonomias demasiadas aos contornos tradicionais do período arcaico pode, até inconscientemente, produzir uma reflexão sobre a cerâmica, na qual esta seja vista como produto de um contexto, de um arranjo político, econômico e social; enquanto a análise aqui proposta, rejeita essa única explicação, já que esses arranjos são em parte compostos por inúmeras ações, pensamentos, objetos etc., e, dentre eles, está a cerâmica e sua ornamentação gráfica.

O período arcaico é visto constantemente como a época em que se desenvolveu a pólis grega, instituição só amadurecida no período clássico, vista como instituição política essencial desta época. Ora, essa interpretação histórica esconde os variados projetos paralelos ao desenvolvimento da pólis, como, por exemplo, a própria manutenção da estrutura monárquica. A pólis democrática não era o único caminho a ser enveredado; ou seja, não houve uma natural "evolução" política. Esta constatação assume grande importância pois se pode observar que o arcaico tratou-se de um período de modificações, entretanto tenso, repleto de disputas; situação na qual a escrita teve papel central na reestruturação social, uma "nova" tecnologia que nasce no contexto da atividade comercial e artesanal, ambiente bastante diferente da restritividade dessa prática na Idade do Bronze. Alguns teóricos da linguagem legam à escrita alfabética papel definidor em situações como essa:

Séculos de emprêgo do ideograma em nada ameaçaram a trama inconsútil das sutilezas familiares e tribais da sociedade chinesa. De outra parte, uma simples geração de alfabetização na África, hoje - como na Gália há dois mil anos - é suficiente para desligar o indivíduo da teia tribal, pelo menos no início. Isto nada tem a ver com o conteúdo das palavras, mas é o resultado da súbita ruptura entre as experiências auditiva e visual do homem. Só o alfabeto fonético produz uma divisão tão clara da experiência, dando-nos um ôlho por um ouvido e liberando o homem pré-letrado do transe tribal, da ressonância da palavra mágica e da teia do parentesco. (McLuhan, 1974, p. 102-3)

Um problema central da análise gráfica, sobretudo no que se refere à linguagem escrita, é o texto como mediador social. Sabe-se que a escrita assumiria papel muito importante na cultura grega, mas essa importância deve ser em parte relativizada. Isso, pois no contexto do desenvolvimento da pólis, época em parte coincidente ao recorte temporal aqui proposto, a escrita ainda não era instrumento dos mais importantes na interação social entre cidadãos. Escrever, por exemplo, era atividade mais comum no meio comercial e artesanal, mas não na formação intelectual da elite cidadã, que era ainda mais ligada à oralidade. ${ }^{30}$

\footnotetext{
${ }^{30}$ Sobre isso, Eric Havelock (1996, p. 187) diz: a população de Atenas não se tornou letrada, no sentido que hoje damos ao termo, senão no último terço do século V a.C. (ver também Havelock, Preface to Plato, 1963, p. 40), e que "em 700 a.C., na altura em que o alfabeto pela primeira vez entrou em uso, as condições necessárias para
} 
O processo que se desenvolveria promovendo uma ampla utilização social da escrita ainda estava em curso. Em algum ponto entre a memória que se satisfazia com a oralidade e a memória que necessitava do registro material, escrito, para sua perenidade, haja vista colocações como a de Heródoto, em pleno século $V$ a.C., que abre sua História dizendo que exporia

(...) suas investigações para impedir que se apague a memória, com o tempo, o que os homens fizeram e para que as grandes e maravilhosas proezas executadas tanto pelos bárbaros como pelos heládicos não cessem de ser renomadas. $(I, 1)$

Exposição por escrito, vale dizer.

Os próprios gregos, na Antigüidade, refletiram sobre a origem da escrita. Ésquilo indica que Prometeu teria criado "a combinação de letras", o cálculo, e também atrelado os animais ao arado e aos carros, em benefício dos homens (Prometeu acorrentado, 461-471). Como hábil nas criações, de fato, Prometeu era visto, pois além dessas invenções listadas por Ésquilo, teria o deus criado o próprio homem misturando água e terra (Pausânias, VIII (XXII)-X e Apolodoro, I 7,1). Ainda, a tradição indica o herói argivo, Palamedes, como aquele que aperfeiçoa o alfabeto criado por Cadmo, inventando algumas letras (como o Y), inspirado pelo vôo dos grous (Grimal, 2000, p. 348). Além da criação mítica da escrita grega, a literatura antiga também registrou a contribuição oriental na origem do alfabeto grego (Heródoto, $V$, 58-61) ${ }^{31}$, informação amplamente reforçada pelas fontes arqueológicas: por exemplo, o conjunto de contribuições do Oriente, no qual o alfabeto está inserido, como visto, é seguramente comprovado. Ainda, o uso de caracteres muito próximos do fenício, originalmente, é atestado através de inscrições como a da enócoa do Dípilo e de um fragmento de Pitecussa (ver cap. 2, fig. 1 e 3, p. 60 e 63), aliadas às teses de que os gregos teriam a-

uma socialização da competência no ler e no escrever ainda estavam no porvir distante" (p. 98). Vale dizer que no quadro das mais antigas inscrições nos mais variados suportes, prevalecia a ação de artesãos na confecção da escrita (a maioria dos métodos pressupunham determinados conhecimentos artesanais). A escrita de cunho particular, intimista, como a indicada na utilização do papiro como suporte não era ainda amplamente desenvolvida, é o que indica o atual estágio do conhecimento arqueológico.

31 "Os fenícios vindos com Cadmos, entre os quais estavam esses gerifeus, introduziram numerosos conhecimentos entre os helenos quando se estabeleceram em seu território - entre outros o conhecimento do alfabeto, que os helenos, até onde vai meu conhecimento, não possuíam anteriormente; de início esse alfabeto (grifos meus) era o mesmo usado pelos fenícios; depois, com o passar do tempo, simultaneamente com a língua esses cadmeus mudaram também a forma das letras. As regiões circunvizinhas eram habitadas em sua maior parte por helenos de raça iônica; eles adotaram os caracteres aprendidos dos fenícios e passaram a usá-los com ligeiras modificações, e usando-os eles os divulgaram, como era justo - pois os fenícios haviam sido os seus introdutores na Hélade - sob o nome de 'fenícios'. Da mesma forma, os iônios chamavam os livros de díphtheroi por causa dos usos antigos, pois anteriormente, em decorrência da raridade do papiro para livros, eles usavam peles de cabra ou carneiro; ainda em minha época muitos bárbaros escrevem nessas peles." É importante saber que o termo "alfabeto" (para $\gamma \rho \alpha ́ \mu \mu \alpha \tau \alpha)$ usado convenientemente pelo tradutor Mário da Gama Kury, pode ser discutido. Por exemplo, a solução apresentada na tradução da Les Belles Lettres é diversa: "letras" (lettres). A questão é que o termo alfabeto, que remete à própria origem desse sistema de escrita, através da junção dos dois primeiros signos (alfa e beta), "só passou a existir na era cristã" (Havelock, 1996, p. 66). 
prendido o alfabeto em contato com os fenícios no Levante, mas há que se considerar também a passagem por Chipre (Sarian, 1998-1999a, p. 163). Heródoto, ainda, indica uma característica importante das inscrições gregas: as adaptações locais, o que é amplamente verificável nas coletâneas de inscrições gregas, como a de Jeffery (1990). Vale ressaltar a indicação de suportes de escrita, e da predileção do papiro, pelo autor, frente à pele de carneiro ou cabra, a qual ele relega ao uso por bárbaros, e aos gregos, apenas como prática antiga; ou seja, a indicação de um signo de etnicidade. $O$ ato de escrever e os materiais associados funcionam para Heródoto como delimitação de um grupo (o seu) frente a outros (os bárbaros), o que pode ser confirmado a partir de outras passagens de mesma natureza (IV 87, II 36).

Há, ainda, que se notar que a referência ao "aperfeiçoamento" do alfabeto por Palamedes, acima citado, junto às informações de Heródoto, indicam um conhecimento razoavelmente maduro dos percursos do alfabeto grego desde sua origem. Assim, além da fonte fenícia, operações originais como a introdução das vogais (ausentes no fenício) são características que se mantém na memória através do registro mítico.

Essas informações, aliadas à bastante diferente experiência da Idade do Bronze, que não articulou sistematicamente escrita e figuração no mesmo suporte, e à extensa atividade comercial dos gregos na porção oriental do Mediterrâneo, impele, talvez, a visualizar uma influência oriental sobre o gregos nos inícios da prática de articular escrita e figuração. ${ }^{32}$ Entretanto, na Idade do Bronze o comércio com o Levante também existia, e provavelmente a experiência entre articulação escrito-figurativa oriental era observada. ${ }^{33}$ Isso leva a crer que esse contato por si só não era definidor, pois deveria haver condições sociais para que a prática de articular escrita e figuração fosse desenvolvida, o que aconteceu no período arcaico, graças ao domínio das duas técnicas em parte do meio artesanal. Nesse sentido, a

\footnotetext{
${ }^{32}$ A observação desses modelos orientais é atestada, sobretudo em parte do período arcaico, também chamada de orientalizante. Boardman (1964) mostra como relevos em pedra e imagens em outros suportes eram adaptados em vasos protocoríntios e coríntios, aproveitando-se, por exemplo, de motivos como a Quimera (p. 96, fig. 24), o Tritão (p. 97, fig. 25), e motivos florais (p. 99, fig. 26); além de estabelecer paralelos entre máscaras de terracota de Ur e de Esparta (p. 94, fig. 22) e estatuetas de terracota do Oriente Próximo e de Corinto (p. 93, fig. 21). Apesar de serem informações antigas (1964), recentes reflexões (Dalley \& Reyes, 1998), ratificam a influência oriental sobre a produção ceramista, quanto à utilização de motivos florais (p. 99, fig. 46), e os motivos de leões (Idem, fig. 47); delineando, inclusive, outros traços de tal influência: por exemplo, o esquema iconográfico do período arcaico de Perseu decapitando a Górgona (como o encontrado na decoração de um escudo de bronze em Olímpia; e outro de uma escultura de Selinunte, na Sicília), teria como base original imagens como a verificada num selo cilíndrico, de Gilgamesh e Enkidu matando Humbaba; e o próprio aspecto frontal da Górgona, teria paralelo com uma figura, numa máscara da Idade do Bronze, de Humbaba, encontrada num templo em Tell al-Rimah (p. 102, fig. 48a-d).

${ }^{33}$ Vernant (1999, p. 6) diz que a experiência grega da idade do Bronze face ao Oriente era de "assimilação e imitação", situação diferente da experiência grega do período arcaico, e para esta o autor usa termos "renovação" e "melhor consciência de si próprios". A idéia de influência, baseada nas de assimilação e imitação não é perseguida aqui, pois ela carrega uma compreensão de um processo unidirecional, fora das linhas de interpretação aqui apresentadas. Ainda, sobre a aproximação Grécia-Oriente, Finley (1988, p. 14) diz que "o antigo mundo micênico (...) tinha sua mais estreita afinidade com os estados contemporâneos, altamente centralizados e burocráticos, situados mais a Leste, na Síria setentrional e na Mesopotâmia."
} 
organização social do trabalho auxilia a compreensão da prática de articular escrita e figuração, mais que a idéia de contato ou continuidade cultural.

A abordagem que privilegia a idéia de continuidade na história grega, e especificamente no tocante à sua experiência gráfica, não é a única. Há mesmo interpretações que se baseiam na idéia de ruptura, e de que as transformações mais efetivas teriam acontecido dados contatos interculturais, entre os gregos e culturas do Médio Oriente. Por exemplo, J. P. Vernant diz que

Sob a influência de modelos orientais, a constituição do que se pode chamar de um repertório de imagens, uma paleta de figuras e a elaboração de uma linguagem plástica na cerâmica, no relevo, na escultura plena, produzem-se, por volta do século VIII, como que a partir de uma tábua rasa. (...) Paul Demarque poderá observar que essa espécie de redescoberta da imagística pelos gregos opera-se, com relação ao período anterior, num despojamento tão absoluto que assume o valor - eu o cito - "de uma criação ex nihilo" (Vernant, 1990, p. 399-400).

Essa linha também é problemática, pois se baseia, prioritariamente, no afastamento ou oposição entre conteúdo lingüístico e estético. No caso referido, a estrutura visual foi composta por elementos propriamente orientais apropriados pelos gregos. Entretanto, essa interpretação afasta uma provável articulação entre oralidade e linguagem visual.

Como visto, o cavalo (e também o carro, associado a ele) como tema é presente na experiência gráfica grega desde o século $X$ a.C., sem interrupções. Mas mesmo antes disso a experiência gráfica micênica registrou várias vezes esse tema (ver fig. 49-52), ${ }^{34}$ e essa correspondência, talvez continuidade gráfica, pode ter a ver com a importância desse tema na oralidade, como indica a poesia épica. Tal conteúdo já era disseminado na região, e dizer que a arte figurativa grega nasce do "nada" parece desprezar a dimensão oral da experiência gráfica entre os gregos, reelaborada na imagística. Nesse caso, cabe dizer que esse tema, junto a outros ${ }^{35}$, compõe um acervo mnemônico que não é bruscamente interrompido no contexto do desaparecimento da estrutura palaciana micênica ${ }^{36}$, e sua manutenção dáse, sobretudo, relacionada ao registro oral (ver esquema 2).

\footnotetext{
${ }^{34}$ Há que se considerar, na fig. 51, que, apesar da mesma temática, o esquema visual é uma exceção, na medida que a figuração foi aplicada no espaço de forma mais livre, em comparação com os outros paralelos (ver fig. 49, 50 e 52), onde a figuração é subordinada a um esquema de faixa, dada a delimitação pelas linhas acima e abaixo.

${ }^{35}$ Além das corridas de cavalos, "os desfiles de guerreiros, as cenas de combate" (Sarian, 1989, p. 593). Ainda, "as representações de pugilato aparecem não só no período micênico, como também no geométrico e em Homero, comprovando uma continuidade na prática do esporte [ou, mais seguramente, persistência da figuração do esporte] desde a Idade do Bronze até o Período Arcaico, quando aparecem representações mais detalhadas" (Torralvo, 1996-1997, p. 38).

${ }^{36}$ Sarian, op. cit.
} 

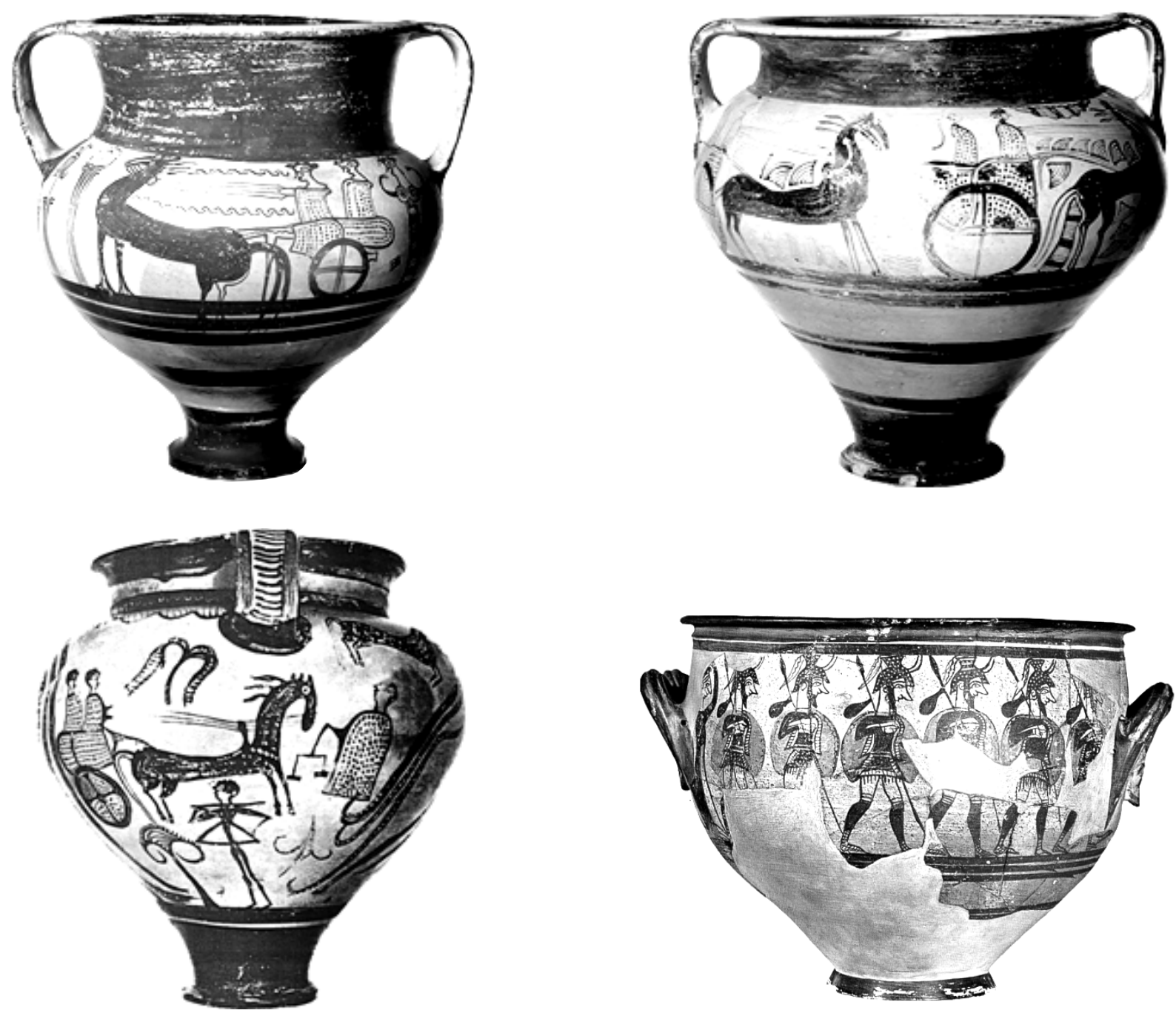

Temas heróicos em vasos micênicos: Fig. 49. Cratera anforóide, Primeira metade do séc. XIII a.C. Chipre (alt.: $41,6 \mathrm{~cm}) ;$ Fig. $\mathbf{5 0}$. Cratera anforóide, c. 1400-1370, The Cesnola Collection (alt.: 36,7 cm); Fig. 51. Cratera anforóide de Enkomi, Chipre (alt.: $37,5 \mathrm{~cm}$ ); Fig. $\mathbf{5 2 .}$ Cratera micênica (detalhe), fileira de guerreiros, séc. XIII a. C., Atenas, Museu Nacional (alt.: $41 \mathrm{~cm}$ ).

Se no período arcaico houve uma conjunção de linguagens (oral, escrita e visual) no registro épico, essa situação desde a Idade do Bronze apresenta uma novidade; já que, a partir da documentação à disposição hoje em dia, só se pode observar que até o período arcaico houve, inicialmente, interação entre o registro oral e visual, seguido de um isolamento da oralidade no registro épico (ver esquema 2).

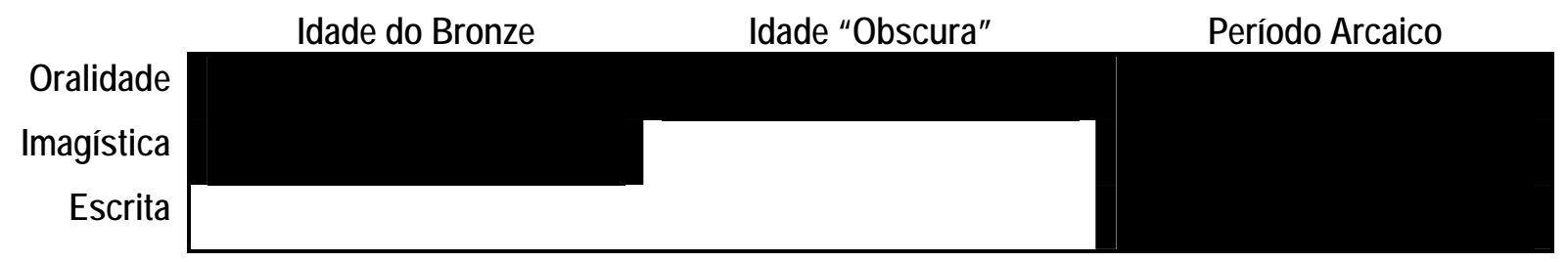

Esquema 2. A composição da memória: 1 - Oralidade e Imagística (período micênico); 2 - Oralidade (séc. XII-X a.C.); 3 - Oralidade, Imagística e escrita (o tripé que compõe a memória desde o período arcaico). 
Esse cenário indica diferentes composições da memória épica, e que a imagística, mesmo antes do registro escrito, já compunha, junto à oralidade, esse acervo de informações. Assim, a novidade do período arcaico, quanto ao registro visual, concentra-se nas novas formas (ou seja, num novo tratamento estético), mas não numa inédita composição figurativa do conteúdo épico, que, apesar do lapso da Idade "obscura", já existia antes, o que não aconteceu com a escrita.

Apesar de os textos em Linear B não comporem uma narrativa épica, algo do conteúdo épico-mítico pode ser observado nos tabletes, nunca em estrutura narrativa: geralmente são listas de cavalos, carros, rodas etc., relacionados a nomes (vendedores ou compradores, por exemplo), especificando quantidades (ver fig. 53).
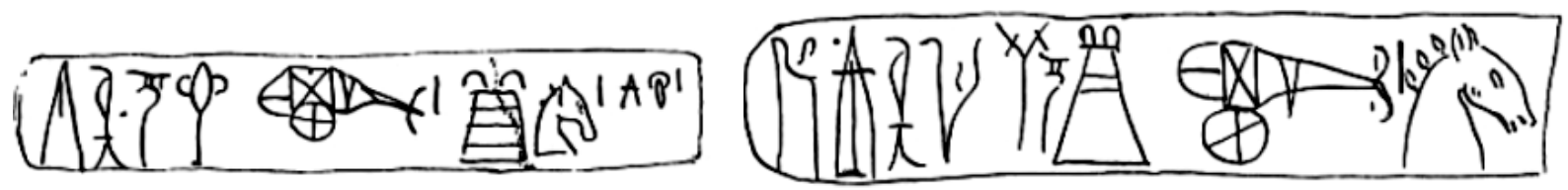

Fig. 53. Tabletes com inscrições em Linear B: um grupo de símbolos silábicos (nome de um homem) é seguido de ideogramas indicando cavalos e carros.

Alguns nomes de divindades também são encontrados. Segundo Carl Kerényi ${ }^{37}$, ocorre o nome Dioniso (di-wo-nu-jo ou di-wo-ni-jo - ver tabletes Pilos Xa 102 e Xb 1419). Esse autor ainda acredita que a referência "Eleuther, filho de Zeus", presente num tablete de Pilos (Cn 3.1-2), "só pode ser Dioniso" (p. 61-2), bem como pe-te-u (Pentheus) - Cnossos As 603 (p. 62-3). Ainda, haveria indicações de figuras associadas a Dioniso: si-ra-no - Silanos [Cnossos V 466.1]). Quanto ao nome Dioniso em Linear B, a interpretação não é conclusiva (se é efetivamente uma referência ao deus, ou não); e quanto às outras designações, todas elas têm interpretação provável, mas nenhuma absolutamente segura. Entretanto, alguns nomes de deuses aparecem em Linear B em estrutura de listas. John Chadwick apresenta um exemplo: um tablete (Tn 316 de Pilos) com inscrições referentes a oferendas dedicadas a divindades como "Zeus, Hera e Hermes, mas incluindo também outros nomes e títulos obscuros". ${ }^{38}$

Essas poucas informações, aliadas àquelas da própria estrutura da escrita préalfabética grega (ver nota 14, p. 92), reforçam o distanciamento entre o Linear B, como sistema de escrita da narrativa e o conteúdo épico-mítico, a despeito de algumas teses que

\footnotetext{
${ }^{37}$ Dioniso. Imagem arquetípica da vida indestrutível. São Paulo: Odysseus, 2002. p. 15.

${ }^{38}$ A Linear B e as escritas correlatas. In: Hooker, 1996, p. 219-221. Chadwick (1999, p. 88-9) dá outro exemplo, além do citado: é um tablete (Knos V52).
} 
legam o esforço de composição escrita da literatura homérica, mesmo antes do desenvolvimento da escrita alfabética na Grécia. ${ }^{39}$

\subsection{Espaço, inscrições e composição figurativa}

As especificidades espaciais (a Ática, como local de produção) e cronológicas (os séculos VII e VI a.C.) ainda apresentam um quadro variado no que se refere à ornamentação da cerâmica. O período é longo, e o que se categoriza como "figuras negras", assume formas diferentes nesse recorte temporal, e mesmo num único vaso, além dos grafismos que aqui se privilegiam (as informações escritas e figuradas) existem outros, aplicações gráficas que não podem ser absolutamente marginalizadas, pois, como será possível observar, elas indicam um pouco da origem da dinâmica entre escrita e figuração nos vasos áticos.

De início, é devido dizer que a significação que envolve a decoração é mais ampla, e não pode ser vista sob a ótica do puramente estético, abrangendo outras esferas como a da linguagem. A partir disso, uma questão relacionada à variedade dos grafismos "decorativos" dos vasos áticos vem à tona: pode estabelecer-se uma diferenciação tão grande entre os grafismos vistos como portadores de um conteúdo lingüístico (geralmente as imagens figuradas e as inscrições), e os vistos de forma puramente decorativa (ocupadores e (ou) delimitadores de espaço)?

Geralmente se tomam as imagens figurativas e as inscrições para tratar do potencial comunicativo presente na criação ornamental ática, em detrimento das faixas gregas, palmetas, pontos etc.; esses teriam papel menos importante, ou potencial comunicativo quase nulo. Entretanto esses elementos não são irrelevantes no que se refere à análise gráfica. Por exemplo, muitas vezes no estudo da "mão do artista", de seu estilo, utiliza-se cada detaIhe como referência, permitindo estabelecer a autoria de alguns objetos de cerâmica pintada a um único grafista, grupo ou oficina. Nesse caso, esses grafismos indicam algumas características individuais e mesmo coerência no quadro das regras canônicas na ornamentação da cerâmica.

Mais além, deve lembrar-se que esses elementos também compunham a sociedade ática arcaica, e devem ser vistos como formadores desse contexto. Um breve exercício pode indicar isso; ou seja, tomando esses elementos decorativos de uma cratera do Dípilo e de uma ânfora de Exéquias. É importante notar a diferença de época (século VIII a.C. para a primeira e séc. VI para a segunda), o que já apresenta que diferentes grupos as produziram,

\footnotetext{
39 "A tese de que os textos homéricos poderiam ter sido escritos em Linear B cerca de 1350 e sofrido transcrição alfabética cerca de 750 foi proposta em 1967 por G. Kahl-Furthmann, em Wann lebte Homer?, Meisenheim, 1967" (Havelock, 1996, p. 40, n. 17).
} 
mesmo que tenham relações "genealógicas"; e também considerar as dimensões do suporte, dadas as variadas estratégias de preenchimento da superfície do vaso, conforme suas dimensões (ver fig. 54).
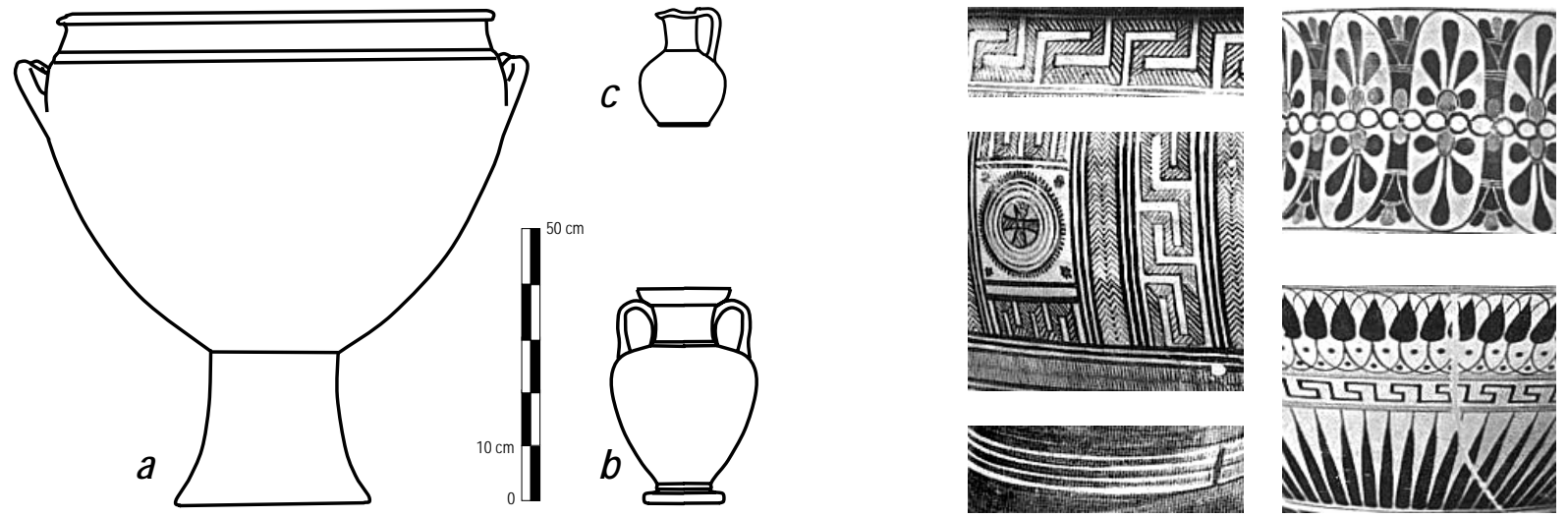

Fig. 54. Proporção dimensional entre a cratera geométrica do Dípilo (a), a ânfora de figuras negras de Exéquias (b) e uma enócoa geométrica (c - ver fig 63, p. 121). Fig. 55. (à esquerda) Detalhes de cratera geométrica do Dípilo, terceiro quartel do séc. VIII a.C. New York, Metropolitan Museum of Art (referente a fig. 54a); Fig. 56. (à direita) Detalhes de ânfora de Exéquias ornamentada com a técnica de figuras negras, C. 530 a.C., London, British Museum (referente a $54 \mathrm{~b})$.

No primeiro vaso, uma cratera de quase um metro de altura, nota-se a decoração geométrica (repetidas faixas em linhas preenchidas com traços oblíquos ou em ziguezague, algumas interrompidas formando outras faixas, chamadas "gregas", e motivos circulares concêntricos) que dominam grande parte do espaço, e as imagens figurativas restringem-se a uma faixa estreita e um quadro emoldurado por elementos geométricos, um em cada face do vaso. Linhas seqüenciais e grandes faixas em verniz escuro também são elementos constitutivos dessa decoração (ver fig. 55 ). ${ }^{40}$ No segundo vaso, as imagens figurativas dominam grande parte do espaço e a decoração que é feita com repetidas palmetas, aros, espirais, raios e folhas (mantendo ainda uma sutil faixa "grega" - ver fig. 56 e fig. 1, p. 38) limita a cena principal, dominada pela figuração humana (esta ocupa a maior parte do espaço mais visível do vaso - um painel). Entretanto, ainda se concentrou na importância da decoração figurativa. Nesse caso, é viável a seguinte questão: como a decoração "auxiliar" indica as transformações ocorridas nas sociedades que elas compunham?

Antes de tudo, é preciso deixar claro que se a figuração humana chama a nossa atenção, e deveria chamar também a do homem antigo, no caso da cratera do Dípilo, por sua apresentação em área de grande visibilidade, é notável a extensa presença de motivos geométricos articulados, que dessa forma é menosprezada se for chamada apenas de auxiliar.

\footnotetext{
${ }^{40}$ Em exemplares "geométricos" de menores dimensões, nos quais a ornamentação figurativa é proporcionalmente mais expressiva, é possível observar os mesmos elementos geométricos preenchendo inclusive o "espaço vazio" entre as imagens figuradas (ver fig. $54 \mathrm{c}$ e 63 , p. 121).
} 
Comumente se utiliza a ornamentação figurativa, que apresenta um processo de "naturalização" da figura humana, para indicar uma forte modificação na cultura grega, sobretudo numa situação idealizada que encontra, a partir do século $V$ a.C., um ambiente de rica discussão sobre o homem e o mundo em que vive: "naturalismo" grego, "antropocentrismo" etc. Esses grafismos "decorativos" também se inserem nesse processo. Nota-se que os elementos geométricos que antes dominavam o espaço, dão espaço à figuração humana, mas não apenas a ela, eles passam a ser cada vez menos presentes nessa decoração (deve lembrar-se de que na ânfora de Exéquias há apenas uma sutil faixa "grega"), abrindo espaço a uma decoração que tem como inspiração primeira elementos orgânicos (folhas, palmetas, espirais etc.). ${ }^{41}$ Assim, pode-se notar uma mudança na concepção de homem, da natureza e do espaço. Tratar-se-á aqui da questão espacial.

Como visto, os elementos geométricos que cobrem grande parte da superfície do vaso funerário do Dípilo contrastam com o papel delimitativo no vaso de Exéquias. A figuração humana amplia-se, como também outros elementos orgânicos. Essa grande modificação no tratamento espacial não acontece apenas na ornamentação vascular, a estatuária também segue um processo parecido, onde as linhas que marcavam segmentos anatômicos são substituídas por volumes que compõem essas formas, assim como o drapejamento dos tecidos (ver fig. 57). Um processo da constituição de formas corporais que, de início, pautavam-se na delimitação das formas pela incisão, ou seja, pela linha ( $a$ e $b$ ) - uma organização quase gráfica -, e uma gradual mudança já observada no século VI a.C. ( $c$ e $d$ ), onde a linha perde espaço para o volume, uma notável mudança no que se refere à produção de formas em suporte tridimensional, como com as kórai dos século VII e VI a.C., que foram produzidas invariavelmente vestidas, e essa indumentária também apresenta uma nova ação em relação à criação de formas a partir do espaço tridimensional. Note-se que a kóre de Auxerre $(e)$ possui formas bastante fixas, lineares, na sua indumentária não se percebe drapejamento, ou seja, dobras no caimento de seu manto e quíton. Apesar da rigidez formal ainda presente nos exemplos ático $(f)$ e no sâmio $(g)$, o drapejamento já é notado, e, neste último, vê-se um movimento no caimento. A kóre ática $(h)$ é caracterizada pelo drapejamento, e inclusive pela diferenciação de tecido do manto e do quíton (um mais pesado e outro mais leve, respectivamente).

\footnotetext{
${ }^{41}$ Mesmo com a introdução de elementos orgânicos, em detrimento dos geométricos, a composição esquemática, repetitiva e simétrica, mantém-se.
} 

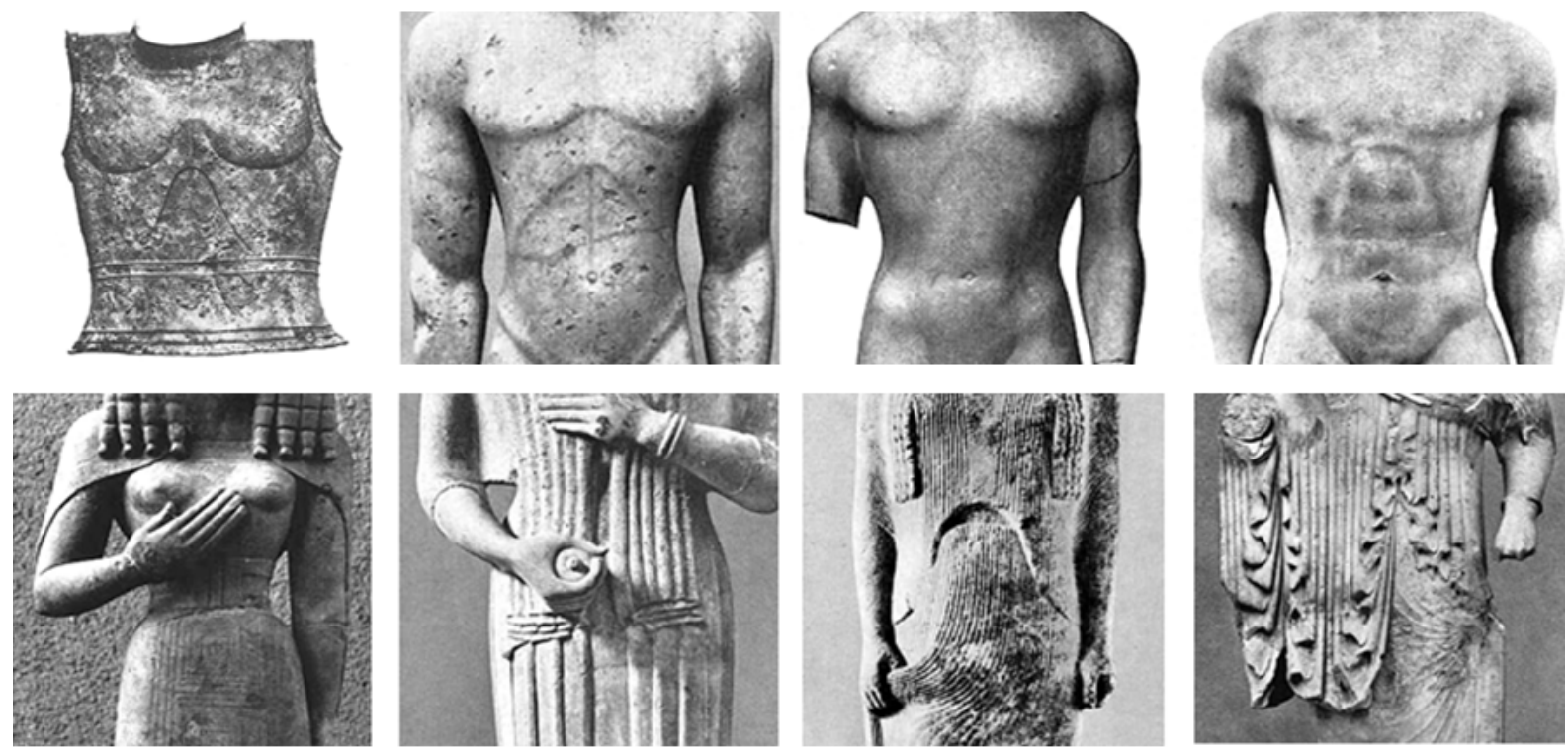

Fig. 57. Koûroi e kórai do séc. VIII ao VI a.C (detalhes do tórax e abdômen, e do drapejamento do manto e quíton): (acima, da esquerda para a direita) a. Armadura de bronze, encontrada em tumba geométrica de Argos, fim do séc. VIII a.C. (bastante próxima dos detalhes do abdômen dos gêmos "Cleóbis e Bíton", também argivos - como também nota Shanks [2004, p. 120, fig. 3.25]) , Museu de Argos (alt.: $50 \mathrm{~cm}$ ). b. Kouros ático, c. 620 a.C., Metropolitan Museum of Art, Nova lorque (alt.: $184 \mathrm{~cm}) ;$ c. Kouros coríntio, metade do séc. VI a.C., Glyptotèque, Munique (alt.: $153 \mathrm{~cm}) ; \boldsymbol{d}$. Kouros ático de Anavyssos, c. 520 a.C., Museu Nacional, Atenas (alt.: 194 cm). (Abaixo, da esquerda para a direita) e. Kóre de Auxerre, c. 650 a.C., Museu do Louvre, Paris (alt.: 65 cm); f. Kóre ática, início do séc. VI a.C., Museu Staatliche, Berlim (alt.: $193 \mathrm{~cm}) ;$ g. Kóre do Heraion de Samos, metade do séc. VI a.C., Museu de Samos (alt.: $168 \mathrm{~cm}$ ); $\boldsymbol{h}$. Kóre ática, c. 525-520 a.C., Museu da Acrópole, Atenas (alt.: $215 \mathrm{~cm}$ ).

Numa perspectiva mais ampla, pode inserir-se esse processo num quadro de profundas modificações na concepção espacial, que contou com a reorganização geográfica dada a instituição de várias póleis, e ainda uma ação colonizadora que propunha diferentes relações com espaços além da Península Balcânica. Assim, não se deve ver esses grafismos como mero reflexo dessa nova concepção espacial, mas parte integrante desse processo. As relações mais diretas entre a espacialização gráfica, territorial e mental não são tão claras, mas se pode dizer, de início, que esses grafismos, junto a outras ações sociais, revelam um novo ideal de espaço físico e mental entre os gregos antigos. Essa reestruturação fica clara quando se observa a própria concepção do que seria a Hélade do século VIII ao VI a.C. Nesse ponto Jonathan M. Hall ajuda:

O nome Helas é encontrado na llíada, mas a área à qual este nome se refere é extremamente limitada. No livro IX, o velho Fênix relembra as proezas de sua juventude e reconta como havia fugido da casa de seus pais em Helas e havia se dirigido para a corte do rei Peleu na vizinha Ftiótida. Esta e outras passagens tornam claro que Helas aqui define uma área relativamente pequena, ao redor do vale do rio Espérquio na Grécia central. Na Odisséia, entretanto, Helas parece ter sido imaginada como uma área já muito maior. (...) Uma ampliação da abrangência geográfica de 'Helas' aparece ao final do século VII a.C. quando o poeta espartano Alcmão descreve o troiano Paris como 'um mal para Helas, produtora de homens'. Mas, mesmo então, outros fragmentos poéticos do período sugerem que Helas pode ter indicado apenas uma porção principal da Grécia, com exclusão de muitas ilhas do Egeu. Teremos que esperar pela poesia de Xenófanes em meados do século VI a.C., para encontrar o primeiro 
emprego de Helas significando sem ambigüidades o que chamaríamos de Grécia - ou então para ser mais precisos - o Mundo grego. (Hall, 2001, p. 216)

É possível observar a partir disso uma notável reorganização no tocante a espacialidade, que não se restringe à geografia. A conformação física e mental da Hélade estendese à delimitação do que seriam os helenos; questões como a territorialidade, fronteiras, autoconsciência grupal, tratamento do outro, dentre muitas outras possibilidades analíticas vêm à tona, e os grafismos fazem parte desse instrumental a partir do qual se pode verificar isso.

Esse não é um evento exclusivamente grego. Um outro exemplo bastante claro pode ser visualizado nas passagens do período "medieval" ao "renascentista". É perceptível que a pintura "medieval" européia era caracteristicamente marcada pela proposta bidimensional de espaço, ou seja, um espaço "chapado". No Renascimento propôs-se uma concepção espacial bastante diferente em vários níveis. A pintura insere a apresentação da tridimensionalidade baseada na perspectiva geométrica. Pode-se observar de forma clara a diferente caracterização do espaço em duas pinturas exemplares. A primeira (fig. 58), executada a partir da técnica de têmpera sobre madeira, apresenta uma hierarquia formal (a estatura de Maria e Cristo menino é bastante grande em relação aos anjos que os rodeiam). Há uma tênue caracterização de perspectiva (como o desajeitado caso do trono), entretanto o espaço que compõe a cena é chapado, sem apresentação de profundidade. Já no segundo caso (fig. 59), além do tratamento diferente dos volumes, onde há um refinado e complexo jogo de luz e sombra, o espaço pauta-se pela tridimensionalidade, característica da formulação geométrica, como a técnica do ponto de fuga. A estatura das personagens é proporcional, e definida pela posição no esquema da perspectiva matemática.
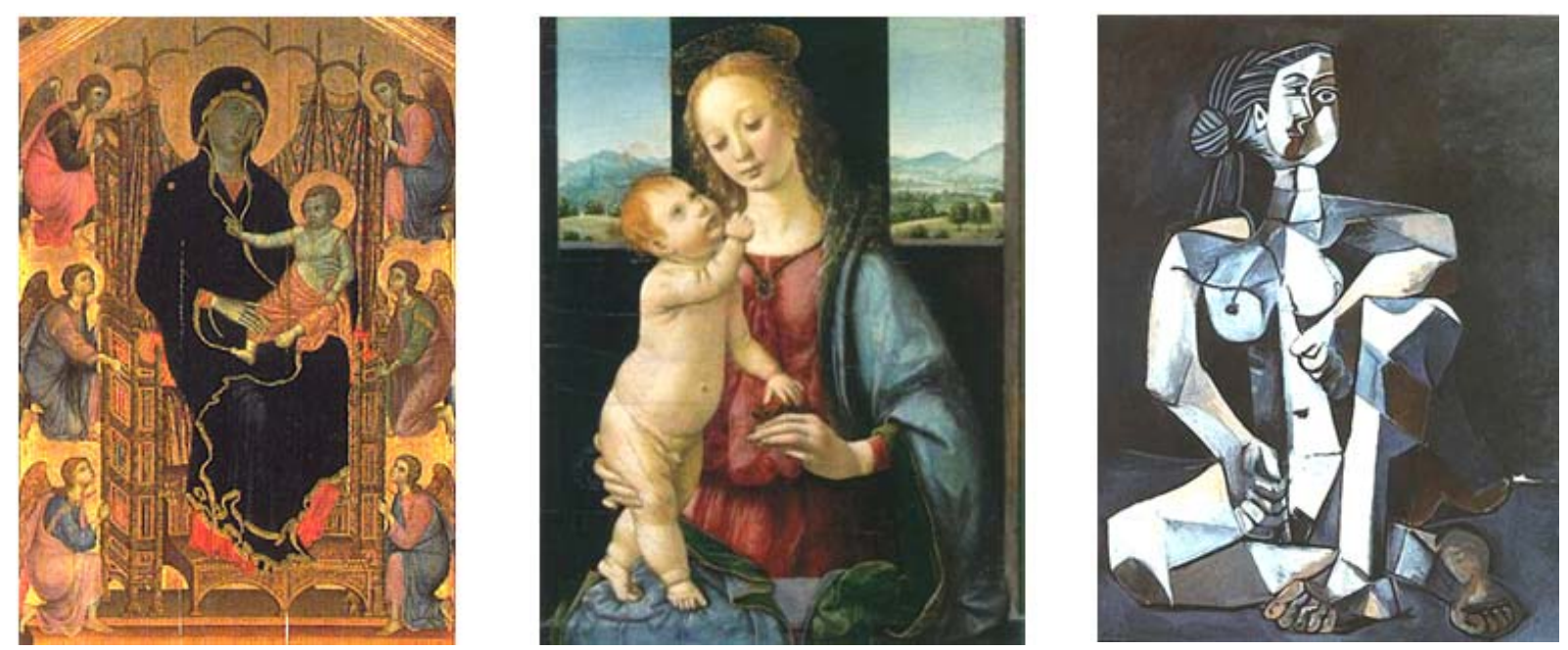

(Da esquerda para a direita): Fig. 58. Madonna Rucellai, Duccio di Buoninsegna, Itália, 1285. Têmpera sobre madeira, Galeria degli Uffizi, Florença; Fig. 59. Madonna com romã, de Leonardo da Vinci, Itália, c. 1469. Óleo sobre tela, National Gallery of Art, Washington; Fig. 60. Mulher sentada, Pablo Picasso, 9 de julho de 1953. Óleo sobre tela, Museu de Arte de Saint Louis, EUA. 
Esse desenvolvimento perde sua vitalidade analítica histórica quando observado do ponto de vista exclusivamente artístico, estético. Entretanto, quando ele é inserido num quadro mais amplo, percebe-se que a compreensão astronômica, que rejeitava a explicação teológica de um planeta plano, propondo-o esférico, e mesmo o desenvolvimento náutico e a chegada dos europeus em espaços como a América, a África e o estabelecimento de novas rotas para o Oriente, integram o quadro das profundas modificações (mental e física) do espaço, junto às novas técnicas e práticas artísticas, como no caso grego citado.

Numa outra situação, e reforçando essa discussão, novas tendências analíticas inserem obras de pintores cubistas como Pablo Picasso e Georges Braque num debate espacial mais amplo, aproximando-as, por exemplo, da Teoria da Relatividade de Albert Einstein (1915), que já no início do século XX rediscutia a concepção da relação entre espaço e tempo. O espaço, aliado ao tempo, apresenta na área plana da tela uma caracterização facetada da matéria (ver fig. 60). Assim, é possível ver, como no caso do rosto (e em outras regiões do corpo) da Mulher sentada, ao mesmo tempo parte em perfil e face frontal, propondo mais que um momento "fixado" pela pintura.

Quanto ao caso grego, os grafismos menos lingüísticos, não figurativos, analisados desse ponto de vista, indicam o preenchimento de espaço nas pinturas sobre a cerâmica, e, além disso, amplia-se ao tratamento abstrato, com relação ao espaço. Essa discussão da composição espacial assume papel importante também no que se refere à relação entre escrita e figuração na cerâmica grega antiga, pois é assumindo o papel de elementos ornamentais preenchedores de espaço que as inscrições aparecem, e paulatinamente abrangem seu desempenho, promovendo uma situação em que não ocorria mais a "concorrência" pela disposição na superfície do vaso entre as inscrições e os grafismos decorativos. Essa situação indica, inclusive, os procedimentos criativos gráficos sobre a cerâmica. Na confecção dos grafismos sobre a cerâmica existia uma certa subordinação (formal e cronológica) entre as inscrições frente às imagens figurativas, e a situação da introdução das inscrições sobre a cerâmica mostra essa ocorrência: elas preenchiam o espaço "vazio"42, adaptando-se aos locais a partir da confecção anterior das imagens figurativas. A discussão do espaço físico na superfície dos vasos de cerâmica e do espaço de forma mais ampla são importantes na compreensão da dinâmica escrito-figurativa, pois nesse cenário de profundas reestruturações quanto ao espaço que as inscrições são introduzidas na ornamentação da cerâmica ática.

\footnotetext{
42 O termo "vazio" ganha aspas, pois o espaço não figurado, não ornamentado, pode assim ser interpretado, haja vista as variadas estratégias de seu preenchimento na ornamentação da cerâmica ática, e mesmo grega, amplamente falando, em determinados períodos. Entretanto, esse espaço onde não há aplicação de grafismos, em outras situações, pode compor a cena como elemento fisicamente organizado na coerência da narrativa. Um exemplo disso são as cenas em que há indicação de interiores, como situações domésticas ou em oficinas variadas (ceramista, de escultura, dentre outras), onde o espaço não figurado pode ser caracterizado como uma parede onde são pendurados alguns objetos. Nesses casos, o espaço livre não pode necessariamente ser visto como vazio.
} 
A partir da discussão do preenchimento do espaço, ou seja, da superfície do vaso de cerâmica, uma observação geral no desenvolvimento da relação escrito-figurativa na ornamentação dos vasos áticos arcaicos impele a uma divisão em três fases mais ou menos distintas:

1) Em primeiro lugar, cronologicamente falando, as inscrições coexistiam com outros elementos ornamentais preenchedores de espaço "vazio", uma estrutura ainda próxima do esquema geométrico de ocupação de espaço, mas, sobretudo, dos modelos ornamentais orientalizantes. Assim, essas inscrições "disputavam" espaços com ziguezagues, rosáceas, cruzes estilizadas, dentre outros.

2) O momento posterior é marcado pelo desaparecimento desses elementos ornamentais geométricos, sendo estes substituídos por inscrições. Elas são bastante subordinadas à figuração, buscando vãos para se acomodarem, e nesse caso é comum o uso do estilo boustrophedon ou sinuoso de escrita. São inscrições esteticamente "desajeitadas", que não promoviam um equilíbrio visual na composição geral da cena.

3) Por fim, a inscrição insere-se na cena como elemento visual, ainda caracterizada por certa subordinação frente às imagens figuradas, mas a compreensão da narrativa da cena passa, em muitos casos, pela compreensão do papel (temático e material) da inscrição. Nesse ponto, quanto à natureza da composição visual, as inscrições acomodam-se de forma mais equilibrada.

Quando a inscrição atinge esse grau de equilíbrio na composição visual na cena, segue um movimento de diminuição de seu uso, sendo o estilo de figuras vermelhas caracterizado pelo uso menos sistemático de inscrições. Ainda, é possível observar um grau de crescimento da dimensão conceitual das inscrições, movimento paralelo às modificações no uso do alfabeto pelos gregos, que deixavam, pouco a pouco, as amarras da metrificação na escrita (característica da influência oral).

Os primeiros exemplares de cerâmica ática nos quais há a articulação gráfica original (já em meio artesanal) entre escrita e figuração datam do último quartel do século VII a.C., destoando de outras cidades (ou suas colônias, como o exemplo de Pitecussa - ver cap. 2, fig. 3 e 7, p. 63-4), cuja produção remontava, em alguns casos, ao final do século VIII e início do VII a.C. Mas se pode discutir essa cronologia em relação à Ática, deslocando para pouco antes da adoção do estilo de figuras negras nessa região; ou seja, um exemplo do 
estilo intitulado protoático. Especificamente, há uma base de cratera com a inscrição MENE $\Lambda \mathrm{A} \Sigma$ encontrada em Egina (ver fig. 61), cuja produção insere-se nas profundas similaridades entre o protoático ático e egineta. Como visto (cap. 2, item 2.1.1), a bibliografia indica que Atenas e Egina mantinham relações comerciais, e encontrar objetos de produção ática nesta ilha (ou vice-vesa) só confirmaria tal tese; por exemplo, segundo J. M. Cook (Apud Jeffery, 1949, p. 69), muito do estilo preto-e-branco (Black-and-White) médio protoático (c. 680-630 a.C.) era proveniente de Egina.
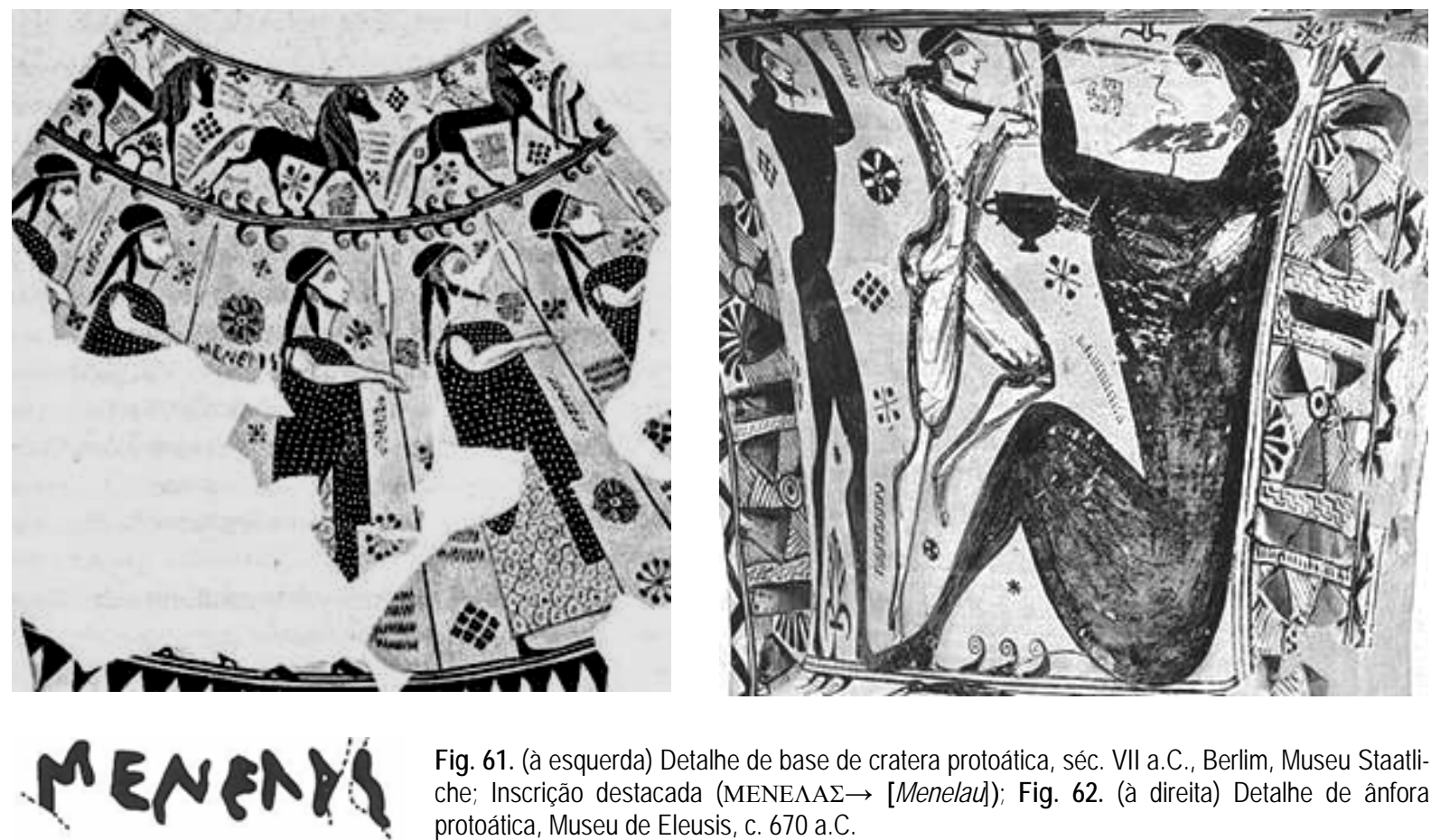

Fig. 61. (à esquerda) Detalhe de base de cratera protoática, séc. VII a.C., Berlim, Museu Staatliche; Inscrição destacada (MENE $\Lambda \mathrm{A} \Sigma \rightarrow$ [Menelau]); Fig. 62. (à direita) Detalhe de ânfora protoática, Museu de Eleusis, c. 670 a.C.

Alguns pontos relacionados ao estilo ornamental dessa base de cratera devem ser apresentados. Sua ornamentação é peculiar do estilo protoático, com a presença de rosáceas, cruzes estilizadas, quadros hachurados, entre outros, elementos encontrados em parte expressiva da cerâmica dessa época, na Grécia continental e no Egeu (ver fig. 61 e 62) ${ }^{43}$ o que não permite traçar maiores especificações quanto à produção ática ou egineta.

Outra característica importante dessa base é o seu aspecto figurativo. São duas regiões com esse tipo de ornamentação: na parte superior, esférica, uma fileira de homens montados a cavalo (?), abaixo, delimitado pela própria forma do vaso, e por um conjunto de três linhas com apêndices espirais, ocupa a maior parte da superfície desse objeto a apre-

\footnotetext{
${ }^{43}$ A ornamentação de estilo orientalizante, como os elementos citados, que também se inserem no estilo protoático, são encontrados em várias colônias gregas, tanto orientais como ocidentais. Além dos inúmeros exemplares encontrados na Grécia continental e Mar Egeu, há vários outros encontrados numa amplitude geográfica que abarca, por exemplo, desde o Mar Negro (Solovyov, 1999, fig. 28, 29 e 33.1) até a Península Itálica (La Genière, 1999, p. 124, fig. 2 [1-9]).
} 
sentação de uma fileira de cinco guerreiros (homens em perfil, com manto e quíton longos, cabelos longos [presos por uma faixa clara] e têm barbas, segurando, cada um deles, uma lança à sua frente). Entre dois deles, abaixo de uma rosácea, a inscrição MENE $\Lambda \mathrm{A} \Sigma$. É sobre esta última aplicação figurativa de que se tratará.

Alguns estudos aproximam essa imagem à de uma ânfora de Elêusis bastante conhecida: ela tem figurada em seu pescoço a cena de Odisseu cegando o Polifemo (ver fig. 62), e, no bojo, a decapitação da cabeça da Medusa por Perseu, em estado pouco fragmentado. Os elementos decorativos, preenchedores de espaço, peculiares do estilo protoático também compõem a ornamentação de tal ânfora.

Sobre a ornamentação figurativa, podem ser feitos alguns paralelos: as escamas presentes nas vestes dos guerreiros são parecidas com a do corpo da Górgona caída, a composição da face (branca) é bastante parecida, bem como o arranjo do cabelo, preso por faixas claras, e as suas barbas. Entretanto, se no exemplar egineta a apresentação dos corpos é uniforme (faces, cabelos, braços e vestimentas); não se pode dizer o mesmo do vaso eleusino: há dois corpos com cabeças brancas, e corpo silhuetado em negro, em uma figura é pintada de branco, com certa indicação de volume (um destaque à figura de Odisseu). Porém esses "descompassos" não comprometem inteiramente os paralelos e similariades.

Aqui, colocam-se duas questões pertinentes: A primeira é se a ausência de elementos figurativos que especifique um dos guerreiros (como acontece com o Odisseu no vaso de Elêusis, destacado pela pintura branca) permite que, associado à inscrição, um deles seja individualizado como Menelau; e a segunda (quase oposta) é se a inscrição MENE $\Lambda \mathrm{A} \Sigma$, por si só, individualiza um dos guerreiros, sendo desnecessário individualizá-lo a partir de elementos figurativos. A resposta ou encaminhamento dessas questões passa pela compreensão da natureza da inscrição, tanto no que se refere à sua relação com a imagem figurativa, quanto pelo seu uso dialetal em contextos específicos, como será visto a seguir.

Se os elementos ornamentais figurativos e não-figurativos aproximam os dois artefatos, a inscrição do vaso egineta pode distanciar; isso, pois ela é composta em forma dórica, peculiar da ilha de Egina, diferente de sua vizinha Ática, que utilizava na escrita a forma ática. A inscrição, assim, apresenta a maior disparidade, e afastaria a tese de uma produção ática para essa base de cratera. Cook (Apud Jeffery, 1949, p. 26) diz que o dialeto e a forma das letras da inscrição MENE $\Lambda \mathrm{A} \Sigma$ indicam que o pintor era egineta, pois o dialeto dórico "que era nativo entre os eginetas", caracterizava tal inscrição, enquanto a forma ática para tal

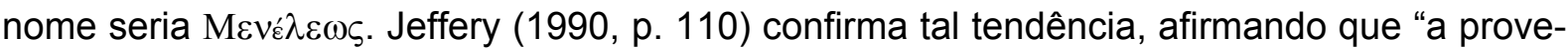
niência, a forma dórica do nome, o lâmbda não ático, tudo sugere que o pintor era egineta", mas a possibilidade de que tal suporte de cratera seja ático não é impossível (Idem). A favor disso, argumenta Ferrari (1988): Para ela, a tese de que o pintor da base de Menelau era egineta (seguida por vários especialistas), deve ser repensada (p. 180); sobretudo quando o 
maior argumento era o dialetal. Assim, o dórico, próprio de Egina, para Ferrari não atesta com firmeza a produção egineta, já que essa forma dialetal não-ática aparece em outros

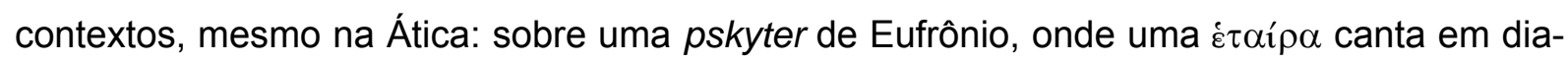
leto dórico; e mesmo no coro em Rhesus 257, de Eurípides, usa-se o mesmo recurso, indicando que o MENE $\Lambda \mathrm{A} \Sigma$ (dórico) da base da cratera, se for interpretado dessa forma, pode reverter o quadro, ou, ao menos, colocar alguma desconfiança na sugestão de Jeffery ( $p$. 181). Ainda, nessa linha, os "guerreiros", podem ser vistos como membros de um coral entoando uma poesia ou canção (Idem).

Minimamente desenvolvido o problema da interpretação da inscrição e imagens dessa base de cratera, as questões acima colocadas merecem atenção, pois a quase óbvia oposição delas apresenta uma compreensão importante da relação escrito-figurativa relativa ao estilo protoático. De um lado, a resposta afirma que a falta de elementos figurativos especificando Menelau seriam sanados pela inscrição que o individualiza; nesse sentido, o dialeto dórico só contribuiria para a confirmação da produção egineta dessa base. Além disso, tal visão indica que a inscrição, frente à imagem, apresenta uma nova forma de perceber a narrativa figurativa, deslocando-se parcialmente dos elementos figurativos para literários. De outra forma, a resposta reafirmaria que os próprios elementos figurativos fornecem elementos para a compreensão da narrativa (a regularidade visual dos guerreiros indicariam a tese de que seriam os "guerreiros" membros de um coral), e a inscrição de natureza nãoática reforça o uso nas situações da entoação do canto ou poesia. Assim, a inscrição não especificaria a produção egineta, mas seria indício de uma prática ática.

No fim, os indícios não são conclusivos, para uma interpretação ou outra, e a maior certeza que resta são as dificuldades de tratar essas fontes propostas até meados do século VII a.C., dada a diminuta produção ceramista que articulasse escrita e figuração. A base de cratera egineta, por sua unicidade, mesmo se fosse seguramente ática, só reforça a idéia de um ambiente que não pode ser caracterizado por um sistemático uso da articulação original entre escrita e figuração. Contemporâneos a essa base de cratera há alguns poucos exemplares áticos fragmentados onde ocorre a coexistência entre inscrição e figuração: em um deles, provavelmente um nome acompanhando uma figura masculina (ver fig. 67), e o outro, na boca de um esquifo, dividida em dois pequenos painéis, uma inscrição fragmentada, e separada pela estrutura do vaso, na região do pequeno ombro e do bojo, a figura de um peixe (ver fig. 68). Nos dois casos, inscrição e imagem são pintadas antes da queima. Esses são os exemplares áticos seguramente mais antigos, no que se refere à articulação original entre inscrição e figuração: protoáticos (ou seja, anterior às figuras negras), mas fragmentários e compõem um grupo muito pequeno (ver também na introdução, esquema 2, p. 16). Reforça-se, com isso, a idéia de que só em figuras negras essa prática consolida-se. Nesse sentido, um dos pioneiros é o chamado Pintor de Nessos. Entretanto, mesmo que um estilo 
ornamental diferente começasse a se difundir, junto à prática de inserir mais abundantemente entre as imagens figuradas inscrições, algumas permanências do estilo protoático podem ser observadas, como, por exemplo, a presença de elementos como rosáceas e ziguezagues, ocorrendo em torno da figuração preenchendo o espaço não-figurativo. Ora, como na base de cratera egineta, é concorrendo com esses elementos que a escrita insere-se na composição visual, atuando como elementos decorativos estilizados, observados na produção ceramista ática desde a ornamentação geométrica de cerâmica (ver fig. 61, 69 e 70).

A ornamentação dos vasos do Pintor de Nessos indica tal de transição de forma clara: de um lado, as similaridades ornamentais acima citadas, e mesmo a grande dimensão do vaso; de outro, a técnica de figuras negras (no protoático, a composição das figuras não é feita a partir de incisões, recurso peculiar do estilo de figuras negras). Se o Pintor de Nessos é o "pioneiro" na organização ornamental na qual se utilizam inscrições, além dessa restrição quanto à escrita, ampliando-se ao quadro geral das figuras negras, esse pioneirismo (termo utilizado por Boardman [1995, p. 14]) deve ser dividido com o chamado Pintor de Berlim A34 (ver introdução, esquema 2, p. 16). Nota-se em alguns vasos desse pintor a mesma forte herança do protoático, mas já a utilização da incisão em algumas das figuras (Idem, p. 20).

Uma das características marcantes no esquema visual criado pelo Pintor de Nessos é o já citado uso de elementos decorativos que preenchem o espaço "vazio" em torno da figuração. Como no caso da base de cratera egineta, a escrita, nos vasos do Pintor de Nessos (fig. 70), concorre com rosetas, ziguezagues e pequenas faixas estilizadas. Esse recurso de preenchimento espacial, que deve certa relação com o protoático, caracteriza-se, também, pela influência da ornamentação da cerâmica coríntia. De fato, esse tipo de recurso era generalizado na Grécia continental e Mar Egeu, a partir de formas diversas (ver fig. 63-66 e 69), e o que se percebe na transição das formas orientalizantes ao estabelecimento de uma estrutura ornamental própria, como se deu no desenvolvimento das figuras negras na região da Ática, é um distanciamento gradual de seu uso.

A criação artesanal contemporânea do Pintor de Nessos apresenta esse mesmo recurso de preenchimento espacial (sem a generalização do uso de inscrições), como nos vasos do Pintor de Berlim A34, Pintor do Pireu, Pintor de Górgona, Pintor do Cerâmico, KX Painter, entre outros; e, de forma bastante variada, até um dos primeiros a utilizarem as inscrições de forma bastante ampla: trata-se de alguns vasos executados por Sófilo, que insere a segunda fase acima caracterizada. 

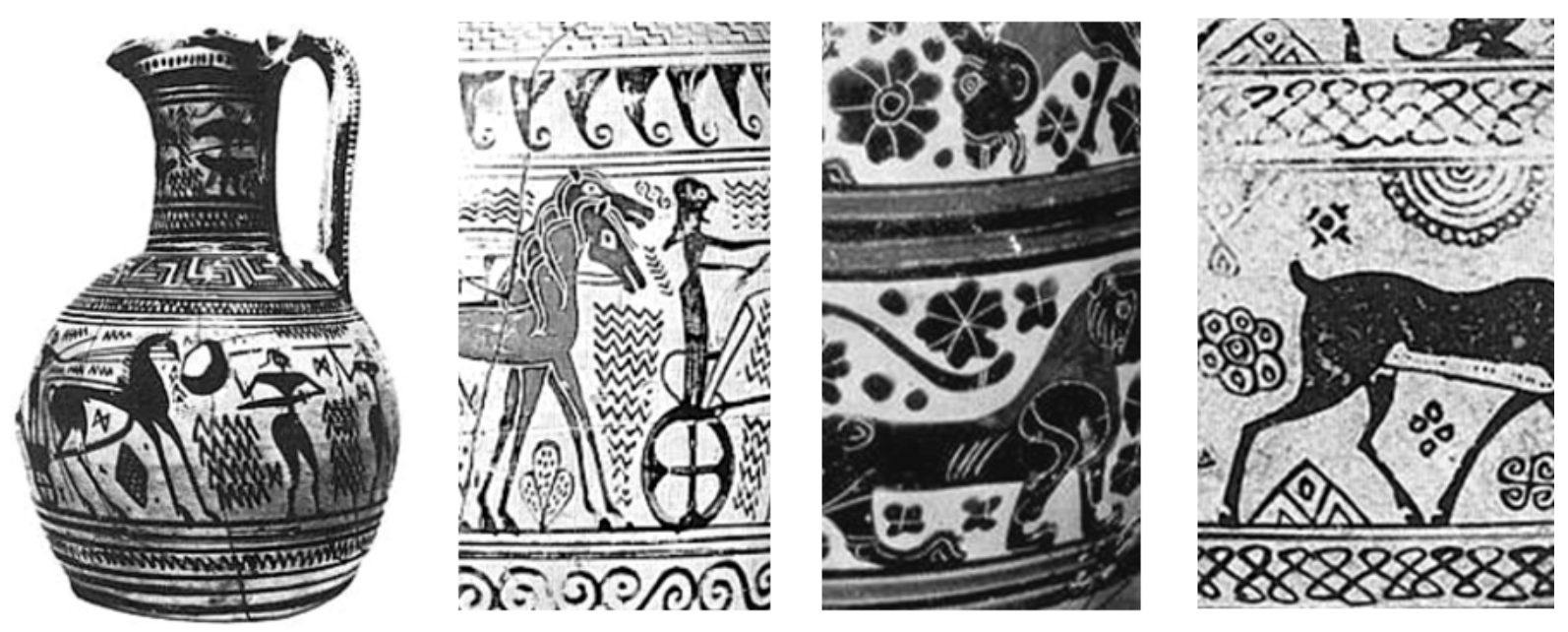

Diversas estratégias de preenchimento do espaço "vazio" (da esquerda, para a direita): Fig. 63. Enócoa geométrica ática, c. 700 a.C., Atenas, Museu da Agora (alt.: 22,8 cm); Fig. 64. Detalhe de ânfora-lutróforo protoática, início do século VII a.C., Paris, Museu do Louvre; Fig. 65. Detalhe de olpe coríntia, séc. VII a.C.; Fig. 66. Detalhe de enócoa ródia, c. 630-620 a.C., Munique, Staatliche Antiken Sammlungen.
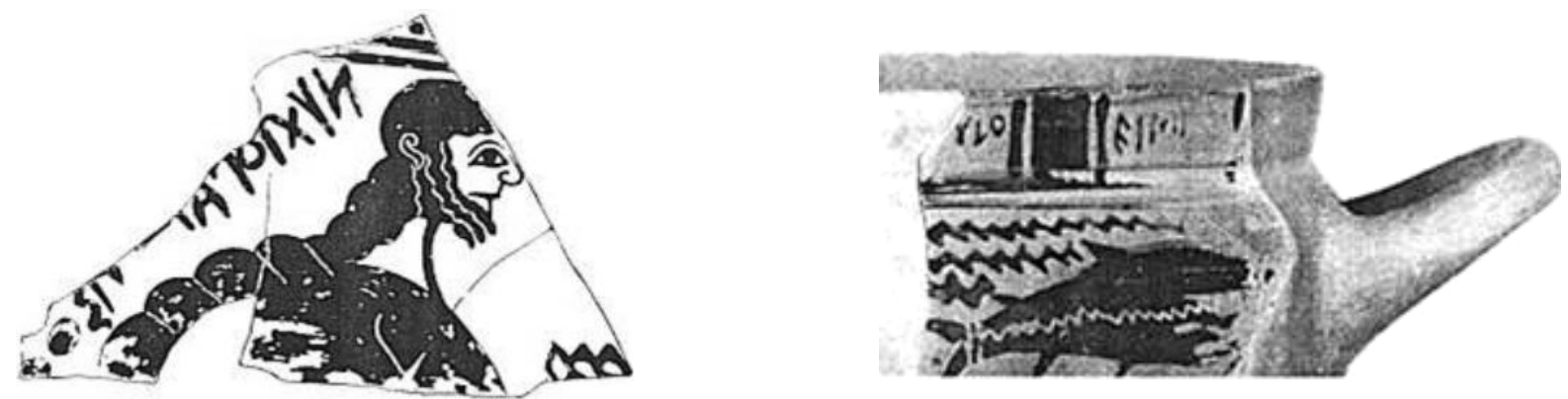

Fig. 67. Fragmento de ânfora protoática, terceiro quartel do século VII a.C., inscrição: NYXTIOПАI $\triangle \mathrm{IA} \Sigma \leftarrow$ (parcialmente fragmentada); Fig. 68. Fragmento de esquifo protoático, C. 650 a.C., inscrição: [- - - ]Y $\Lambda \mathrm{O}$ EIMI $\rightarrow$.

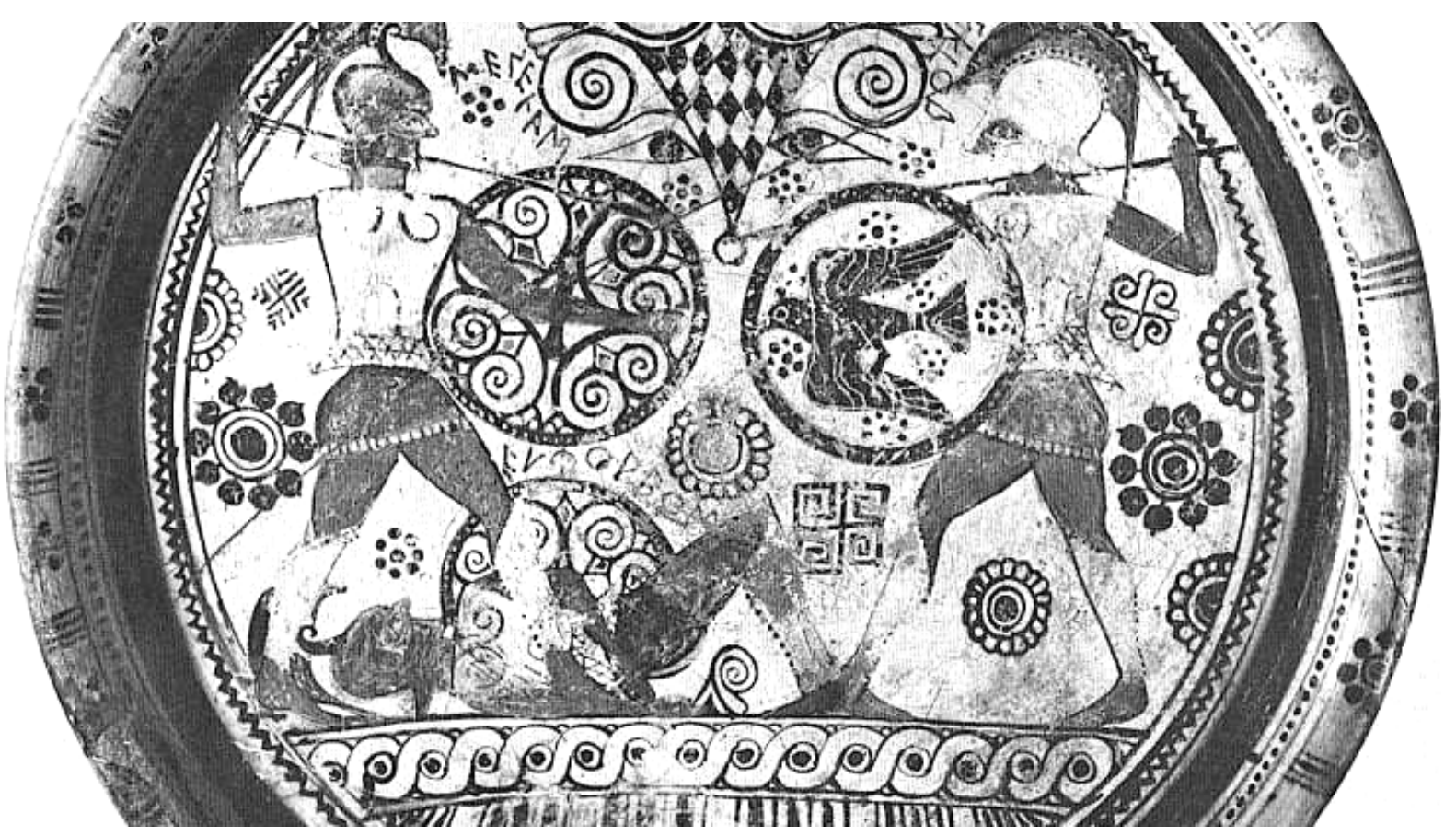

Fig. 69. Detalhe de prato ródio (combate entre Menelau e Heitor por Eufórbio), final do séc. VII a.C., Londres, Museu Britânico (diâm.: $38,5 \mathrm{~cm})$. 

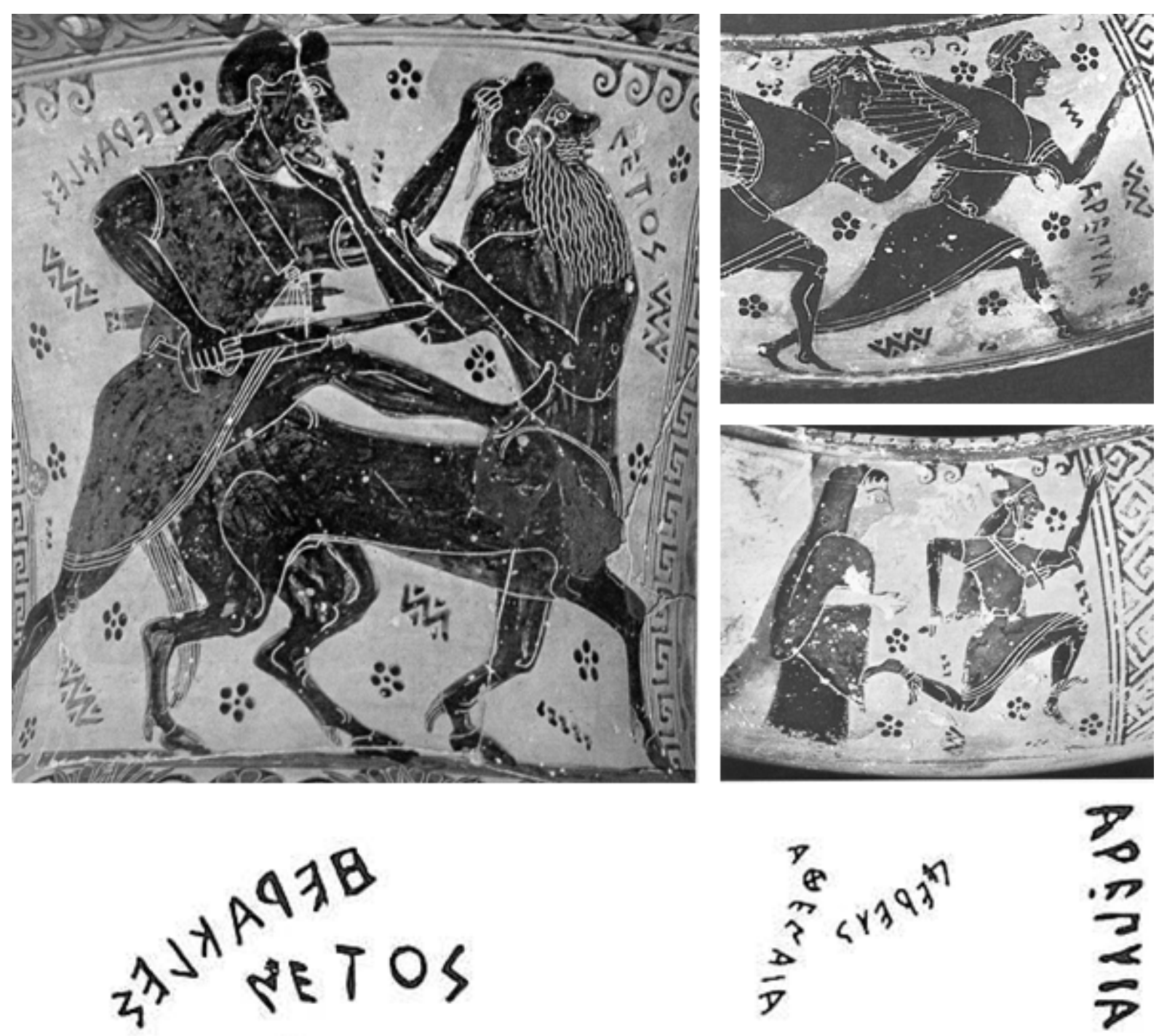

Fig. 70. Detalhes de dois vasos do Pintor de Nessos, e destaque das inscrições, último quartel do séc. VII a.C.; (à esquerda) Atenas, Museu Nacional; (à direita) Berlim, Museu Staatliche.

Apesar de em alguns de seus vasos ainda haver elementos ornamentais preenchendo espaço, este artesão inicia um uso sistemático das inscrições sobre seus vasos, uma escrita que não mais concorria com rosetas, ziguezagues etc. Entretanto, além do crescimento quantitativo do uso de inscrições, houve, associado a ele, um crescimento qualitativo. $^{44}$

\footnotetext{
${ }^{44}$ Serão utilizados como exemplares vasos produzidos por Sófilo (ver fig. 71-73), e o bastante conhecido vaso François (ver fig. 74-77). De início, cabe saber que um único fragmento, como um executado por Sófilo (ver fig. 71), poderia conter inscrições de autoria $\left(\Sigma \mathrm{O} \Phi\left[\imath \lambda \circ \mu^{\prime} \varepsilon \gamma \rho \alpha \psi \varepsilon v\right]\right)$, do tipo legenda (ПАТPO $\Lambda$ YY $\left.\mid \mathrm{AT} \Lambda \mathrm{A}\right)$ e nominativa (AXIAEY) - ver fig. 69; e mesmo o vaso François possui 129 inscrições identificadas. Tanto o exemplar de Sófilo como o de Ergotimo e Clítias (o vaso François) apresentam novidades, ou seja, um uso ostensivo de inscrições até então inexistente (cer fig. 73 e 75a).
} 
A grande maioria das inscrições presentes nos vasos de Sófilo e no vaso François são nominativas, mas há também inscrições de autoria (no caso do vaso François duas do oleiro e duas do grafista - ver fig. 76), a indicação da cena (pouco comum) - ver fig. 71, e o exercício de escrita vai até a caracterização de objetos inanimados (é o caso da fonte [KPENE] e da hídria [HY $\triangle \mathrm{PIA}$ ], no vaso François - ver fig. $75 b$ e $c$ ). O aspecto visual das inscrições, então, caracteriza-se pela abundância que busca preencher os variados espaços não figurativos, havendo alguns poucos indícios de preocupação visual (procurando, por exemplo, um equilíbrio estético) da utilização dessas inscrições nas cenas figuradas (ver fig. 77).

O estágio do desenvolvimento da relação escrito-figurativa na cerâmica ática, no qual há substituição de elementos decorativos variados por inscrições preenchendo o espaço "vazio", pode ser relacionado, certamente com a produção coríntia (ver fig. 72), que também passava por um processo de reestruturação. Até esse ponto, todos os exemplares onde existe a aproximação escrito-figurativa aproveitam esquemas variados já difundidos no mundo grego e outras regiões adjacentes: trata-se do protoático, que utilizaria modelos orientalizantes, e, mesmo no início dessa prática articuladora de linguagens dada a prática do Pintor de Nessos, o débito com o protoático ainda pode ser traçado, como visto. A independência da inscrição no espaço, ainda aproveita uma forma exterior à Ática, a ornamentação peculiar de Corinto, que foi apropriada na produção artesanal ática, como já visto. ${ }^{45}$

Ora, essas apropriações indicam o caminho nada natural que o desenvolvimento que a produção ornamental da cerâmica ática tomou. Não se tratou de um linear progresso do geométrico às figuras negras, mas de um caminho sinuoso, que tem certamente a ver com as múltiplas relações entre a Ática, e outros espaços (cidades, colônias, entrepostos, mercados consumidores etc.). Nesse quadro, uma organização original da relação escritofigurativa, própria da cerâmica ática, só poderia ser observada num estágio mais avançado, ou seja, quando essas inscrições deixavam de ser usadas prioritariamente como recurso de linguagem (remetendo à cena, ao personagem, marcando autoria etc.), mas ampliando seu papel materialmente falando; ou seja, além da referência comunicativa explícita, a inscrição passa, em alguns casos, a tornar-se elemento estético importante, interferindo em variadas situações na compreensão da cena figurativa.

\footnotetext{
${ }^{45}$ As profundas aproximações entre a produção coríntia e ática do início do século VII a.C. indicam isso. As estratégias variadas da ornamentação em figuras negras (a utilização de incisões sobre o verniz negro, a utilização de tinta branca na diferenciação dos corpos, faixas delimitativas em esquemas de flores de lótus articuladas ou pétalas estilizadas paralelas) são muito semelhantes, e a organização das inscrições no espaço figurativo segue esse quadro de íntimas aproximações (ver fig. 71 e 72).
} 


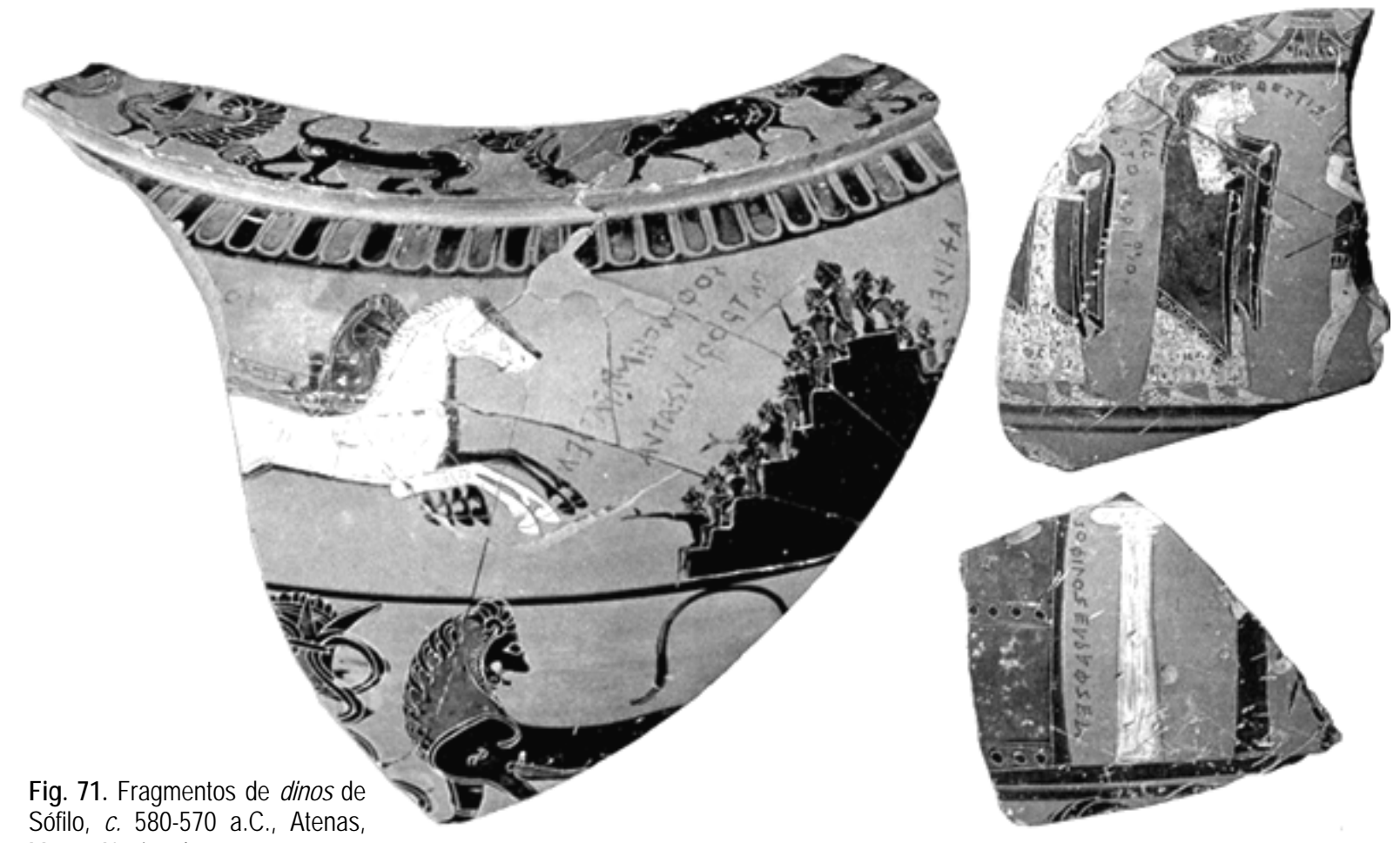

Museu Nacional.
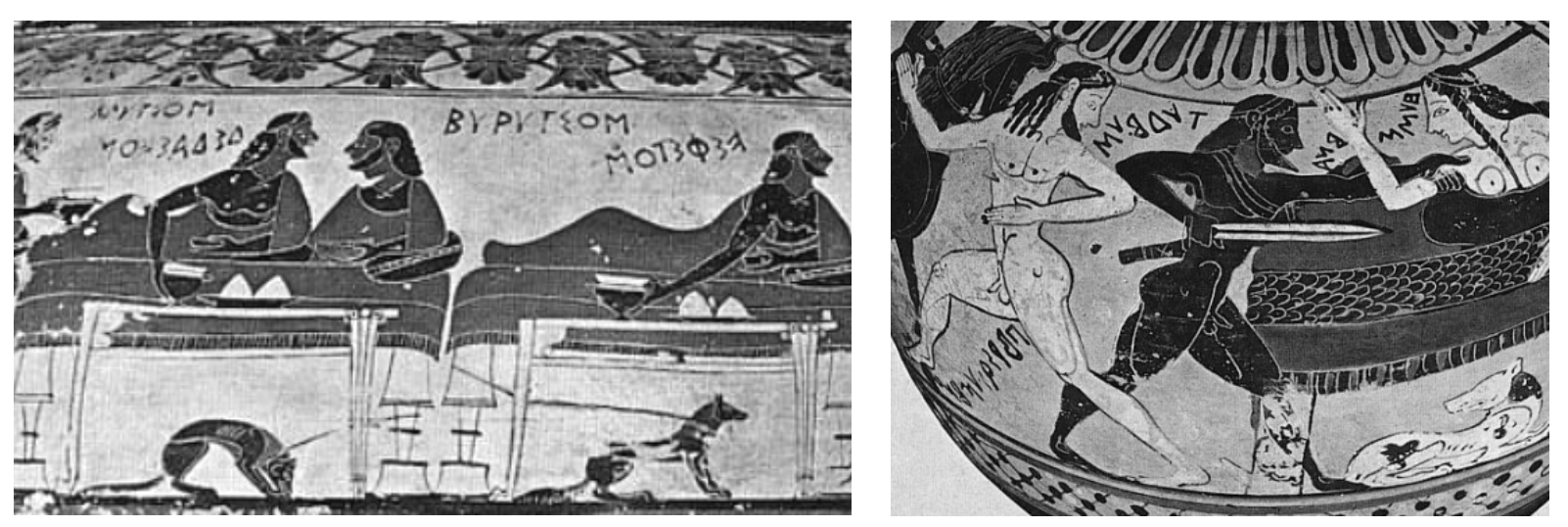

Fig. 72. a. (à esquerda) Detalhe de cratera com colunas coríntia, início do séc. VI a.C., Paris, Museu do Louvre; $\boldsymbol{b}$. (à, direita) detalhe de ânfora coríntia, c. 560-550 a.C., Paris, Museu do Louvre.

As inscrições, nesse contexto, ganham uma nova importância no que se refere à sua natureza compositiva, invertendo a situação orignal; isso, pois se o ato de escrever sobre a cerâmica introduz-se aproveitando os espaços preenchidos pela ornamentação geométrica, não figurativa, já no século VII a.C., e principalmente no VI a.C., os espaços não figurados eram preenchidos quase exclusivamente por inscrições. Assim, seguindo esse novo esquema, há exemplos de "imitações" de inscrições, desde inscrições sem sentido (gramaticalmente falando), porém com letras do alfabeto ático enfileiradas, passando por "invenções" de uma escrita inexistente (pseudo-inscrições - ver fig. 79), havendo, também, pontilhados que, com certa distância, dão a idéia de serem inscrições (ver fig. 80), retomando claramente modelos com inscrições efetivas (ver fig. 77 e 78). 

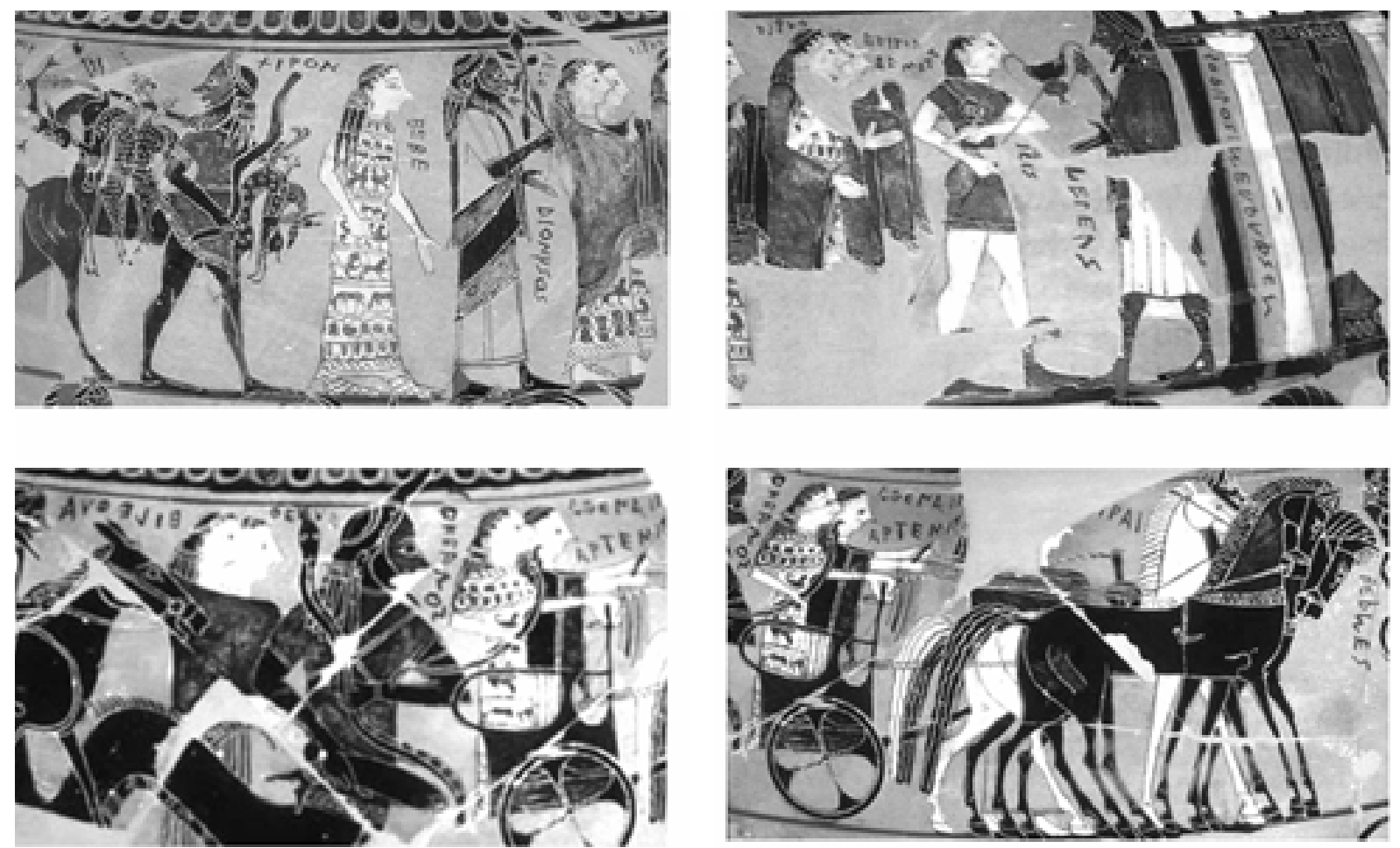

Fig. 73. Detalhes de íinos de Sófilo, Londres, Museu Britânico, c. 580 a.C.
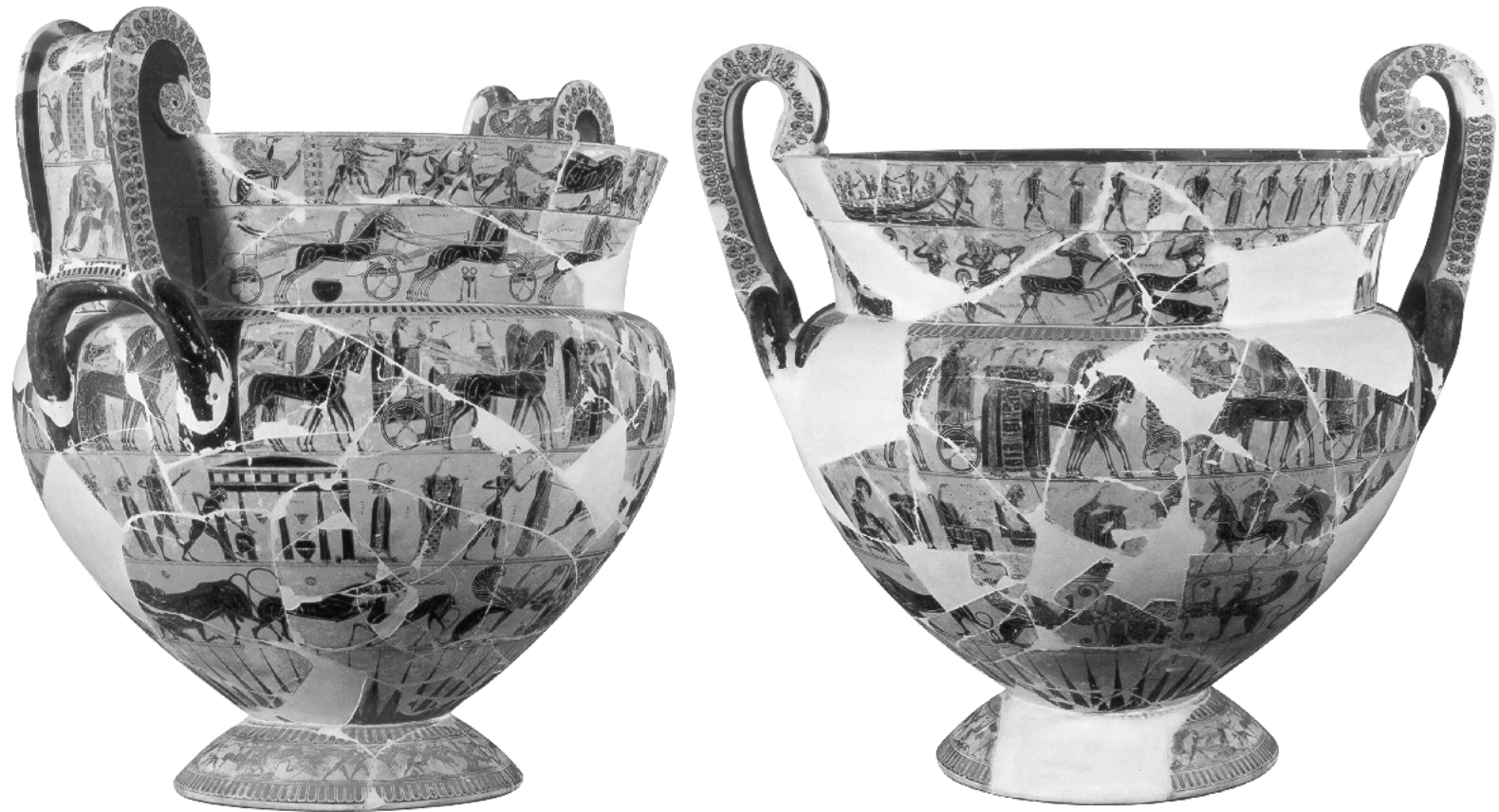

Fig. 74. Vaso François (cratera com volutas), c. 570 a.C., Florença, Museu Arqueológico (alt.: 66 cm). 

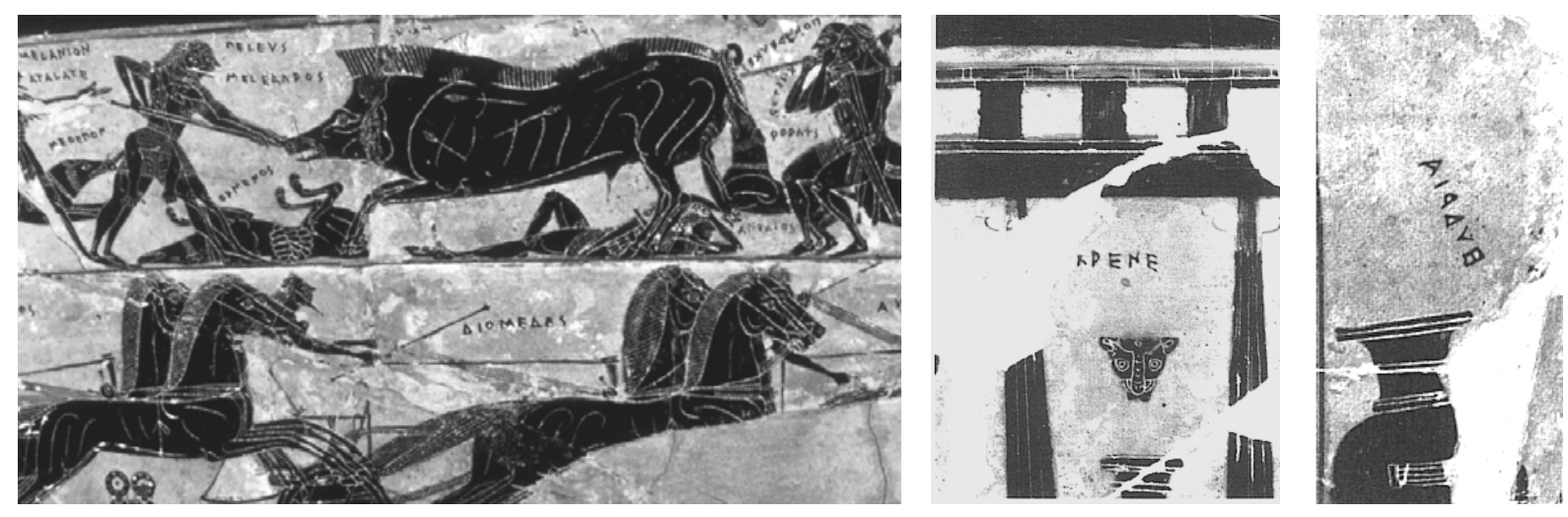

Fig. 75. Detalhes do vaso François: $\boldsymbol{a}$. As inscrições preenchendo o espaço; $\boldsymbol{b}$. A inscrição nominativa KPENE $\rightarrow$; $\boldsymbol{c}$. A inscrição nominativa HY $\triangle \mathrm{PIA} \leftarrow$.
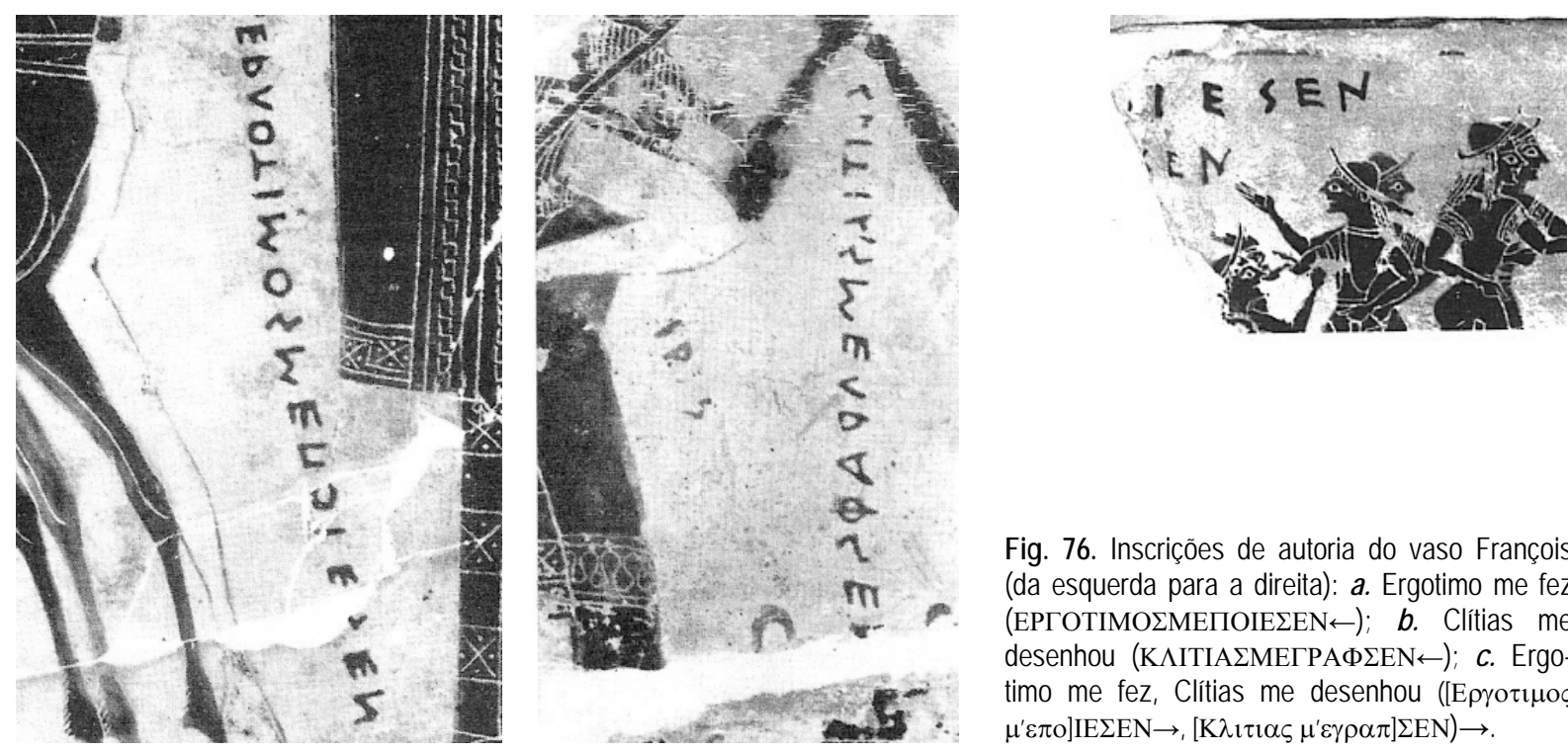

Fig. 76. Inscrições de autoria do vaso François (da esquerda para a direita): a. Ergotimo me fez (ЕРГОТIMO $M E \Pi O I E \Sigma E N \leftarrow) ; \quad \boldsymbol{b}$. Clítias me

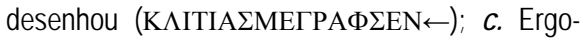

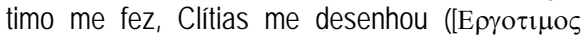
$\left.\left.\mu^{\prime} \varepsilon \pi \mathrm{o}\right] \mathrm{IE} \Sigma \mathrm{EN} \rightarrow,\left[\mathrm{K} \lambda \iota \tau \iota \alpha \varsigma \mu^{\prime} \varepsilon \gamma \rho \alpha \pi\right] \Sigma \mathrm{EN}\right) \rightarrow$.

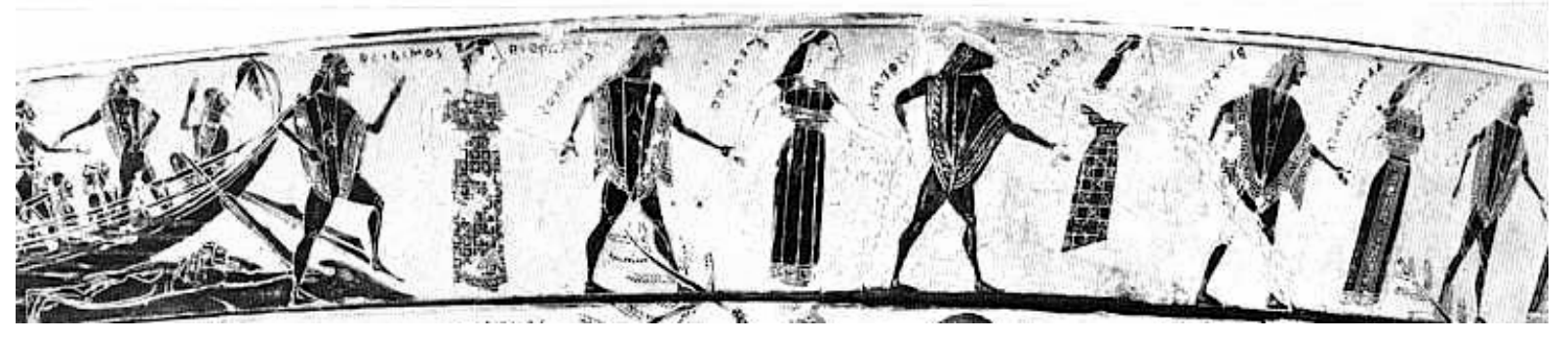

Fig. 77. Detalhe do vaso François com fileira de personagens com inscrições acompanhando. 


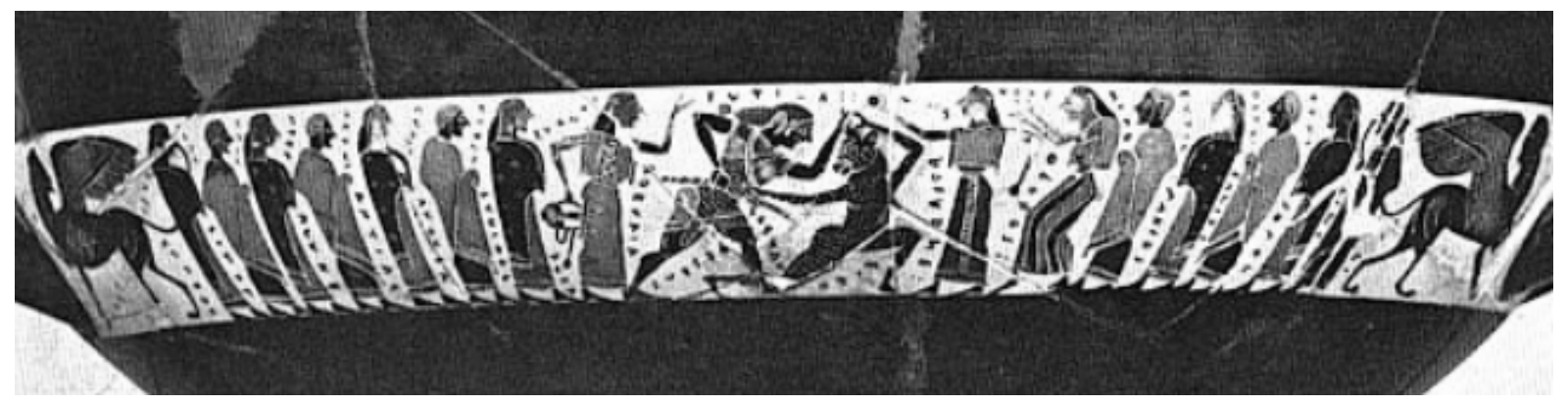

Fig. 78. Detalhe de taça com faixa (band cup) assinada por Archikles e Glukytes, Cena da luta entre Teseu e Minotauro ladeada por várias outras figuras (muitas inscrições preenchem os espaços entre as imagens figuradas), c. 540 a.C.

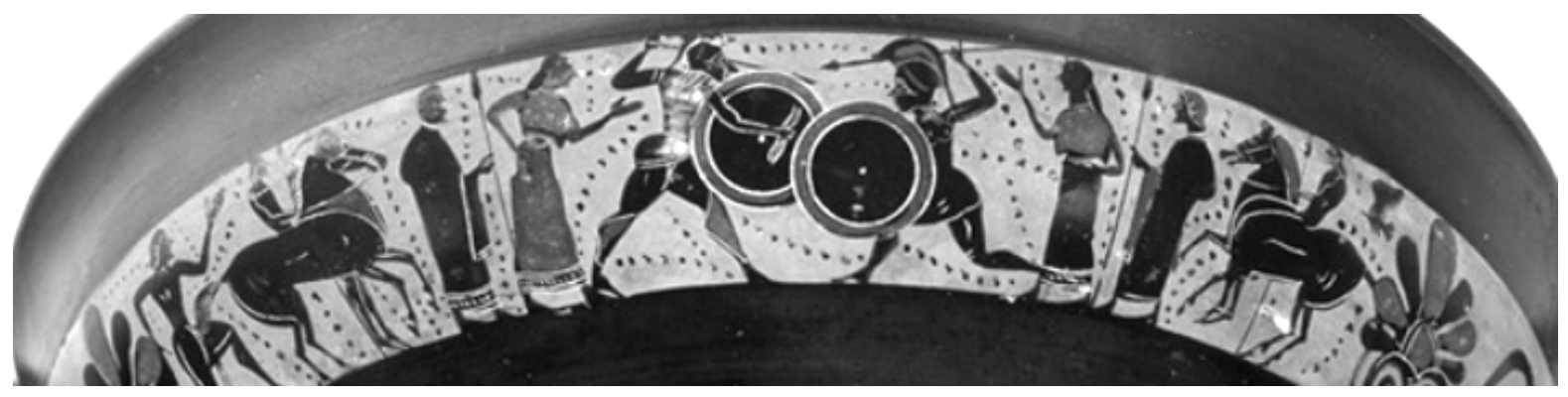

Fig. 79. Detalhe de faixa externa de uma taça ática (band cup), dois guerreiros lutando e várias pessoas ladeando-0s, c. 540 a.C., Museu da Universidade de Melbourne.

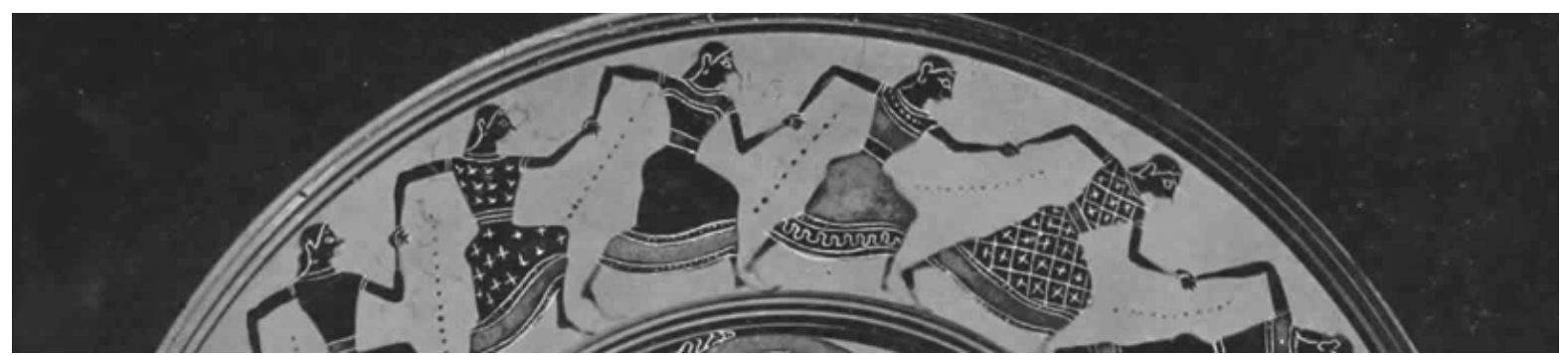

Fig. 80. Detalhe de tondo interno de taça ática (lip cup), dançarinas de mãos dadas, entre elas, linhas pontilhadas; Tarqüínia, meados do século VI a.C.

É claro o processo de inversão, no qual a inscrição compõe um esquema visual que não precisaria ser necessariamente preenchido por inscrições efetivas, ou seja, em alfabeto ático e com conteúdo que tivesse sentido. As inscrições agregam a atividade gráfica ceramista, nesse ponto, já como um elemento visual a qual pudesse se recorrer. Não se tratava apenas de escrever o nome de uma personagem, caracterizar uma cena, autoria ou homenagem, mas de compor um esquema no qual a inscrição em sua apreensão visual era viável.

Desse ponto de vista, perde a vitalidade a sua caracterização como inscrições "sem sentido" (nonsense inscriptions); que só podem assim ser chamadas pela falta de uma apreensão temática e lógica gramatical. Entretanto, como foi possível observar, elas ganham 
novo significado na produção gráfica ceramista: seu "sentido" é outro; o que só pode ser compreendido quando se extrapolam as amarras do conteúdo temático das inscrições, buscando entender suas múltiplas relações com as imagens, estendendo-se às questões de sua fisicalidade. ${ }^{46}$

Sobre as inscrições que nomeiam as figuras, Jeffery (1990, p. 47) diz que "o nome será naturalmente escrito o mais próximo possível de seu possuidor, como se estivesse saindo dele", o que certamente liga-se, como especula Havelock (1996, p. 196), à importância do nome dito (falado, mas também escrito, como neste caso) na composição da identidade do indivíduo, e "sem ele a pessoa seria um 'ninguém', como Odisseu, ao encontrar com estranhos". A questão é que para além dessa verificável característica, as inscrições posicionam-se junto das figuras, mas não de qualquer forma. Como visto, o caminho da inscrição, desde sua introdução na arte figurativa sobre a cerâmica, apresenta um alto grau visual. Pode exemplificar-se isso, claramente, a partir da abordagem de um exemplar: trata-se de um vaso já tratado aqui, cuja ornamentação foi executada por Exéquias (ver fig. 81).

Sobre essa ânfora há a figuração, numa face $(\mathrm{a} \mathrm{A})^{47}$ da luta entre Aquiles e Pentesiléia (fig. 81a), em que se nota a imagem do combate e inscrições que nomeiam as personagens. Esse parece um exemplo de uma simples relação temática antiga entre escrita e imagem figurada; ou seja, há informações imagéticas adicionadas de outras inscritas, AXI $\Lambda \mathrm{EY} \rightarrow$

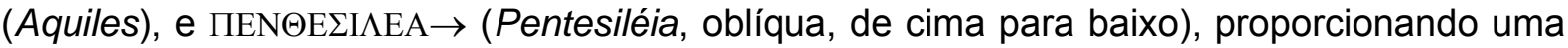
identificação específica do episódio mitológico (não seria ele confundido com outro). A inscrição que denomina Aquiles está à frente de sua cabeça, horizontal, da direita para a esquerda, e indica a ação do herói sobre a figura de Pentesiléia. E a inscrição desta personagem aparece numa diagonal, da esquerda para a direita, indicando a queda da rainha das Amazonas diante da força física de Aquiles, que leva vantagem no combate. ${ }^{48}$

Porém, despojadas das inscrições, as imagens apresentariam elementos para a identificação do episódio? A figura de Pentesiléia, rainha das Amazonas, é facilmente reconhecida: características como sua indumentária feita a partir de pele de animal pouco trabaIhada, denunciando um afastamento da arte e artesanato das cidades, da civilização, eram recorrentes elementos na apresentação iconográfica das Amazonas, no período tratado.

\footnotetext{
${ }^{46}$ As inscrições "sem sentido" abrem, cada vez mais, novas perspectivas nos estudos dos vasos áticos. Por exemplo, Annie Bélis (1984) mostrou como algumas inscrições tradicionalmente interpretadas como "sem sentido", na verdade eram notações musicais (ver cap. 4, fig. 11-2, p. 159); e Cécile Jubier (1998), indica que algumas repetições nessas inscrições podem ser importante elemento norteador na atribuição de autoria, e mesmo ser interpretadas como "marcas" peculiares de alguns grafistas ou oficinas.

${ }^{47}$ A caracterização de uma face A e outra B dá-se de forma arbitrária, e sem qualquer hierarquia implícita. Este é um recurso usual, mas nem sempre essa divisão é possível, e em alguns casos a própria interação entre as duas faces é produtiva na interpretação de suas imagens. Entretanto, a análise gráfica identifica claramente divisões, delimitações criadas já na Antigüidade. Partes de um vaso (como as alças) podem indicar faces opostas e isso poderia ser reforçado com faixas negras, grupos espirais ou de palmetas, dentre outros, que, associados àqueles elementos formais do vaso, delimitavam e orientavam uma cena (ver cap. 4, item 2.3.3.).

${ }^{48}$ Para uma discussão sobre as inscrições que orientam o olhar ver Lissarrague, 1992.
} 

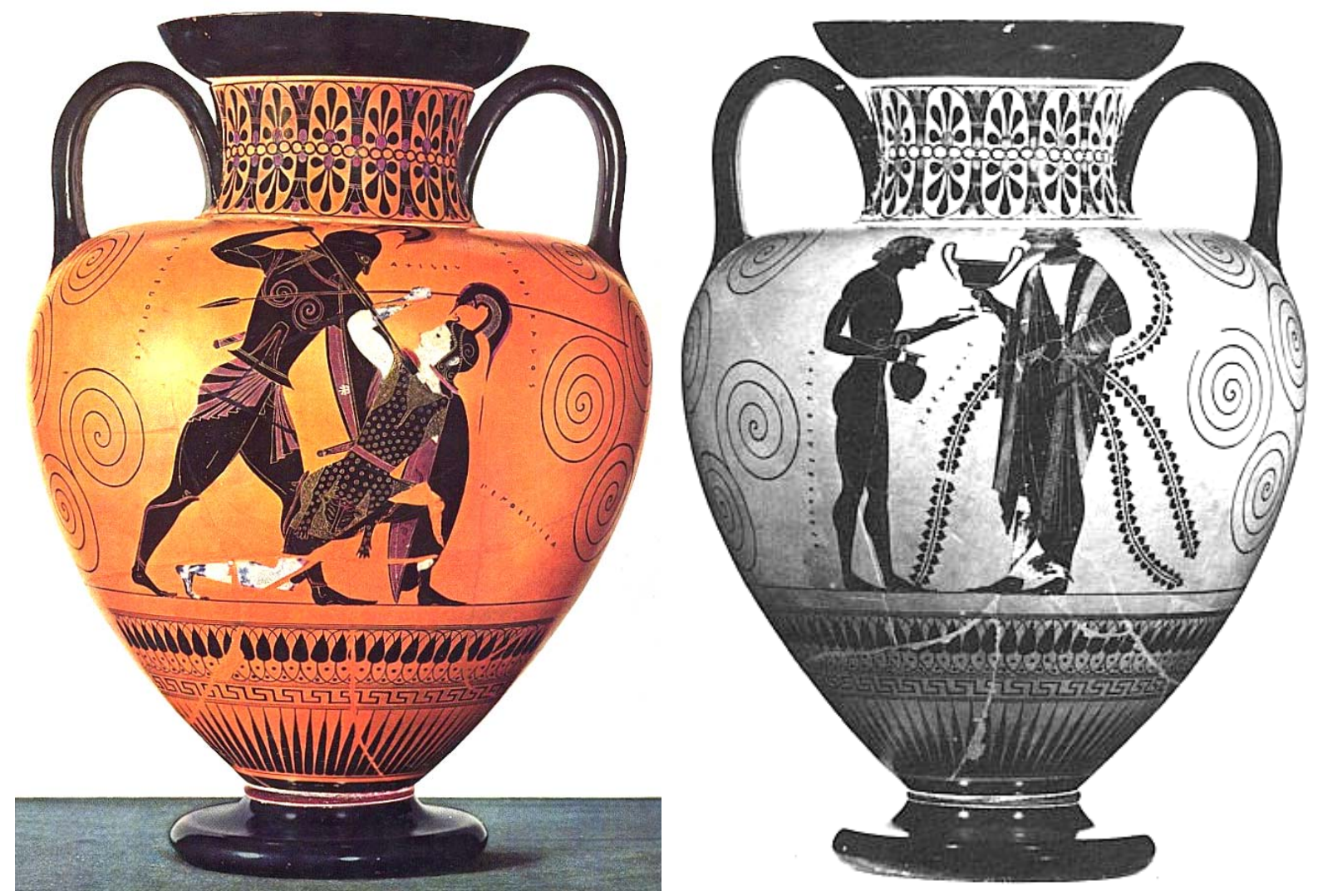

Fig. 81. Ânfora executada por Exéquias, c. 530 a.C. British Museum, London (alt.: 41,6 cm): a. Luta entre Aquiles e Pentesiléia EX $\Sigma E K I A \Sigma E \Pi O I E \Sigma E \leftarrow \quad$ (Exéquias fez); ONETOPI $\triangle \mathrm{E} \Sigma \mathrm{KA} \Lambda \mathrm{O} \Sigma \rightarrow \quad$ (Onetorides é belo); AXI $\Lambda$ EY $\rightarrow$ (Aquiles); $\Pi E N \Theta E \Sigma I \Lambda E A \rightarrow$ (Pentesiléia); $\boldsymbol{b}$. Encontro entre Dioniso e Oinópio: OINOחION $\rightarrow$ (Oinópio); $\Delta \mathrm{IONY} \Sigma \mathrm{O} \Sigma \leftarrow$ (Dioniso); $\mathrm{EX} \Sigma \mathrm{EKIA} \Sigma \mathrm{E} \Pi \mathrm{OIE} \Sigma \mathrm{E} \rightarrow$ (Exéquias fez).

Talvez se poderia confundir com outro combate entre um herói e uma amazona: trata-se do episódio de um trabalho de Héracles, no qual ele teria lutado contra Hipólita. Porém, a caracterização desse herói passava longe da apresentada na figura identificada como Aquiles na época tratada. A iconografia de Héracles teve um desenvolvimento que contava com a presença de alguns elementos como a aljava, a pele de leão que o cobria, dentre outros. Dificilmente, na Antigüidade, confundir-se-ia o combate entre Aquiles e Pentesiléia com o entre Héracles e Hipólita. Entretanto a inscrição reforça a identificação exata.

Essa fórmula, aparentemente simples, encontra uma nova variante: uma inscrição de homenagem, ONETOPI $\triangle \mathrm{E} \Sigma \mathrm{KA} \Lambda \mathrm{O} \Sigma \rightarrow$ (Onetorides belo, levemente oblíqua, de cima para baixo) e uma de autoria, EX $\Sigma E K I A \Sigma E \Pi O I E \Sigma E \leftarrow$ (Exéquias fez, levemente oblíqua, de cima para baixo), que compõem claramente um esquema visual composto pela aproximação entre escrita e imagem figurada: as inscrições cercam lateralmente a cena tratada limitando-a, formando dois arcos (impressão dada ao olho pela curvilínea superfície do vaso). A partir disso, não se pode simplesmente adicionar essas novas informações às primeiras já citadas: para a análise da escrita e da imagem na cerâmica é preciso levar em consideração a natureza específica de ambas, para que se compreenda qualquer tipo de interação. Seria 
ingênuo dizer que a relação dessas últimas inscrições citadas com as imagens cumpre a mesma função das primeiras vistas. ${ }^{49}$

$\mathrm{Na}$ outra face (a B) vê-se o encontro entre Dioniso (à direita) e seu filho Oinópio (fig. 81b). Se o tema mitológico aproxima as cenas figuradas nas duas faces do vaso ${ }^{50}$, a composição é diferente. A cena vista anteriormente apresenta um conflito (a luta entre Aquiles e Pentesiléia), já esse lado apresenta uma cena harmoniosa: Dioniso, perfeitamente reconhecível pela composição da imagem (manto longo, barbado, com coroa e quatro longos ramos - três caem arqueados, e um sobe - que agarra com uma das mãos, a outra segura um grande cântaro pouco abaixo de sua cabeça), ele está de frente a um jovem imberbe, nu, de cabelo longo, que carrega uma enócoa, que sortirá (ou já sortiu) o cântaro de Dioniso. A harmonia não se dá apenas pela ausência de uma luta, mas se percebe que a ação é desenvolvida com concordância mútua: Oinópio no ato de servir seu pai, Dioniso, que calmamente recebe a oferta.

Como visto, a figura de Dioniso é perfeitamente identificável, mas não a de Oinópio, que é apresentado como efebo, e só sua relação com Dioniso nessa cena poderia, palidamente e com muitas dúvidas, levar a essa interpretação. Mas as inscrições nomeiam tanto o identificável $\triangle \mathrm{IONY} \Sigma \mathrm{O} \Sigma \leftarrow$ (Dioniso, oblíqua, de cima para baixo), como OINOחION $\rightarrow$ (Oinó-

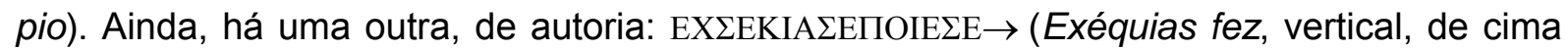
para baixo). A posição da primeira inscrição de autoria (face $A$ ) compõe um arranjo simétrico com a cena e a inscrição de homenagem (Onetorides belo); na face B, é colocada verticalmente, atrás da figura de Oinópio, de forma quase desajustada no que se refere à composição estética geral; e há variadas orientações da escrita, que ora é da direita para esquerda, e ora vice-versa. Com isso, percebe-se que a articulação dos grafismos num único vaso propõe esquemas variados. Existem alguns padrões, mas eles não controlam completamente a relação entre escrita e figuração, por isso cada caso deve ser olhado com atenção. En-

\footnotetext{
49 "(...) pode observar-se que ele [Exéquias] utiliza freqüentemente os nomes das personagens de modo dinâmico, para sublinhar as linhas de força da imagem, e as inscrições do tipo assinatura ou aclamação para enquadrar suas pinturas". Idem, p. 194.

50 Tem-se nesse vaso a aproximação, numa face, entre um tema tradicional do Ciclo troiano, no qual figura o grande herói grego, Aquiles; na outra, o deus Dioniso. Essa aproximação era comum nessa época, e estava relacionada à valorização, proporcionada pela autoridade da pólis ateniense, da figura do deus Dioniso, que já era bastante popular dentre as camadas "inferiores". Um paralelo interessante pode ser feito com dois vasos em que há a representação de Dioniso e Mênade numa face, e na outra a representação de um trabalho de Héracles (vaso do MAE-USP, ânfora do The Red Line Painter), ou Posidão e Atena (vaso do Museu do Louvre, ânfora de Amasis), ambos do século VI a.C., como a ânfora de Exéquias aqui tratada. Num esquema diferente, é possível identificar Dioniso introduzindo Hefesto no Olimpo (ver Sarian, 1999b, p. 167 e Vernant, J.-P. \& Frontisi-Ducroux, F. Figuras de máscara na Grécia antiga. In: Vernant \& Vidal-Naquet, 1999, p. 174), numa das faixas do "vaso François" (Museu Arqueológico de Florença). Para uma discussão sobre essa prática ver Sarian, 1999b. Excetuando-se a ânfora do MAE-USP (que não possui inscrições), todos os outros vasos (o de Exéquias - Museu Britânico -, o de Amasis - Museu do Louvre -, e o de Clítias e Ergotimo, o "vaso François" - Museu Arqueológico de Florença) são assinados nas duas faces; ocorrendo, no "vaso François", duas assinaturas do oleiro e duas do grafista. Ainda, semelhanças estilísticas permitem traçar alguns traços gerais na ornamentação ceramista da época. Excetuando-se o "vaso François", os outros usam o recurso de áreas delimitatórias verticais das cenas (na região logo abaixo das alças), não uma linha reta vertical que se torna arqueada a linha reta na superfície dos vasos, mas a delimitação é composta por elementos orgânicos (espirais e palmetas).
} 
tretanto a orientação da escrita pode apresentar um quadro diferente. Isso parece indicar o encontro entre Oinópio e Dioniso, e mais um elemento da cena: seria o momento imediatamente anterior ao abastecimento do cântaro do deus, pois a posição da inscrição de Dioniso (inclinada), junto ao sentido dela $(\leftarrow)$, esboça o descimento de seu cântaro até as mãos de Oinópio (ver fig. 82). Com isso, o papel das inscrições identificando personagens perfeitamente reconhecíveis parece chegar perto de uma resposta: seria a indicação da ação, além da simples denominação (Lissarrague, 1992, p. 193-4). ${ }^{51}$
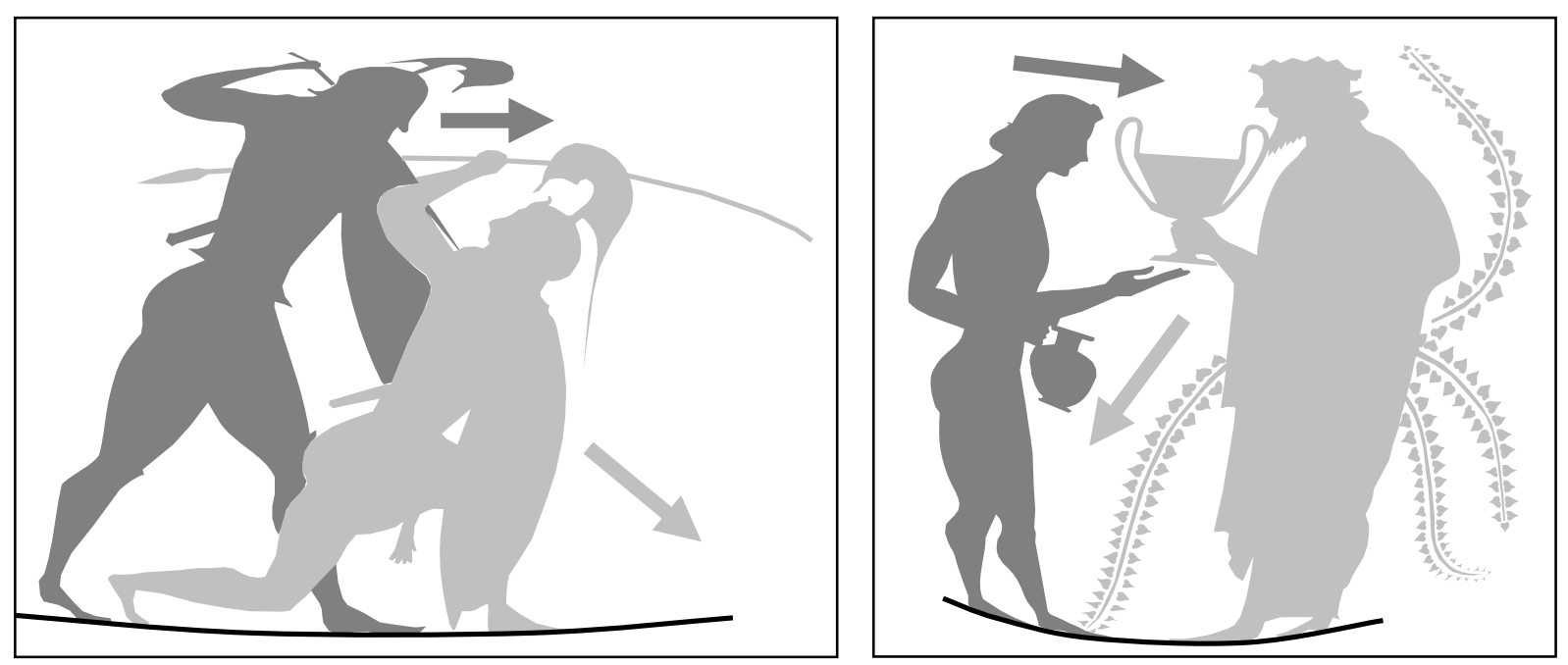

Fig. 82. Vetores das inscrições que denominam as personagens na ânfora de Exéquias. Na face A (à esquerda), as inscrições já indicam a vitória de Aquiles sobre Pentesiléia, que está prestes a capitular caindo no chão; na face B (à direita), as inscrições indicam o momento exato do encontro de Dioniso e Oinópio

É importante saber que essa breve análise não contempla as várias categorias de vasos produzidos no período arcaico (numa ânfora panatenaica, por exemplo, a relação entre escrita e imagem é bastante diferente e outro esquema interpretativo, baseado na natureza do próprio documento, deve ser pensado). Um outro exemplo indica essa situação: é uma ânfora de Amasis (ver fig. 83), cujo esquema compositivo é diferente do apresentado por Exéquias (por exemplo, não se notam as inscrições como vetores da ação). A especificidade desse vaso será observada a partir de uma restauração antiga e uma outra proposta mais recente.

\footnotetext{
${ }^{51}$ Endossa essa tese, vários outros vasos de Exéquias sobre os quais se observa a mesma dinâmica entre escrita e figuração (Lissarrague, op. cit.).
} 

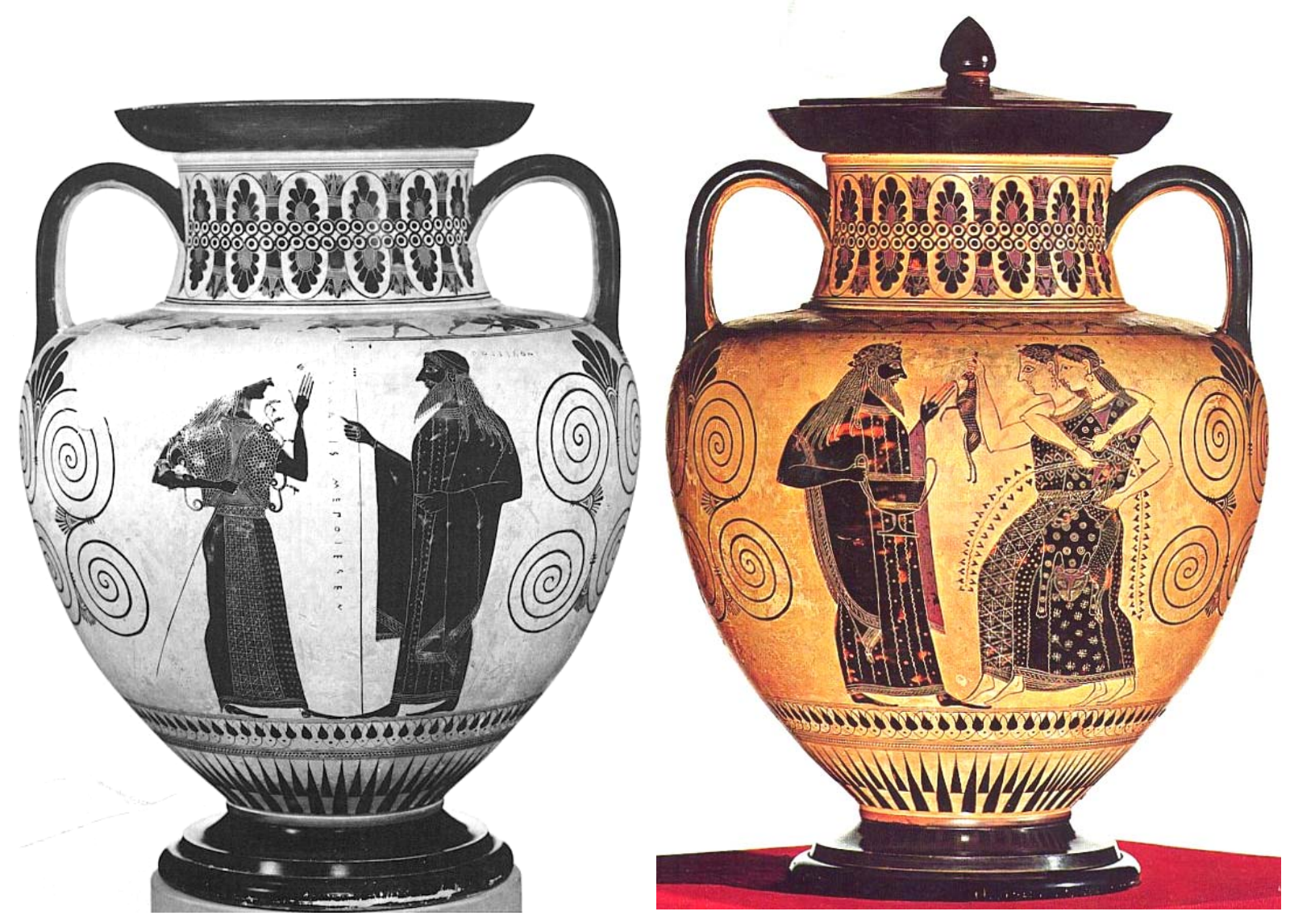

Fig. 83. Ânfora de Amasis, c. 540 a. C., Biblioteca Nacional da França, Paris (alt.: $33 \mathrm{~cm}$ ): a. Encontro de Atena e Posidão: AMA $\Sigma I \Sigma$ MEПOIE $\Sigma E N \rightarrow($ Amasis me fez); $\Pi \mathrm{OO} \Sigma \mathrm{EI} \Delta \mathrm{ON} \rightarrow$ (Posidão); $\quad \boldsymbol{b}$. Dioniso e Mênades: $\Delta \mathrm{IONY} \Sigma \mathrm{O} \Sigma \rightarrow$ (Dioniso); $\mathrm{AMA} \Sigma \mathrm{I} \Sigma \mathrm{ME \Pi OIE \Sigma EN} \rightarrow($ Amasis me fez)

$\mathrm{Na}$ face $\mathrm{A}$, à esquerda, há uma mulher com quíton longo, lança inclinada (ponta para cima), capacete com plumas, gorgoneion, pele com vestígios de tinta branca. Ela olha para um homem à sua frente (à direita na cena); este usa manto longo, cabelo e barba longos, segura em uma das mãos um tridente ereto com as pontas para cima. Olham-se frente a frente. Atrás da cabeça do homem a inscrição "Posidão". A face em questão é em parte fragmentada, sobretudo em parte da cabeça da figura feminina, identificada por seus atributos (lança, gorgoneion etc.): seria Atena. Supõe-se, baseado no esquema geral do vaso, que houvesse logo atrás de sua cabeça uma inscrição que a nomeasse (já que há uma atrás da cabeça de Posidão, bem como atrás da cabeça de Dioniso, na face oposta do vaso). O esquema bastante vertical é rompido pela lança oblíqua carregada por Atena. As inscrições adaptam-se ao esquema, realçando sua simetria. Como um eixo (entre Posidão e Atena) uma inscrição vertical de autoria (AMA $\Sigma I \Sigma$ MEПOIE $\Sigma E N \rightarrow$ [Amasis me fez]) ao lado do tridente de Posidão. Uma proposta inscrição ao lado de Atena (ver fig. 84 e 85), realçaria essa simetria: logo atrás da cabeça de cada um dos deuses uma inscrição nomeando-os $\left(\mathrm{A \Theta ENAIA} \rightarrow{ }^{52}\right.$ (Atena) e $\Pi \mathrm{O} \Sigma \mathrm{EI} \Delta \mathrm{ON} \rightarrow$ [Posidão]).

\footnotetext{
${ }^{52}$ Da esquerda para a direita, já que todas as inscrições do vaso seguem essa orientação da escrita (ver fig. 85).
} 

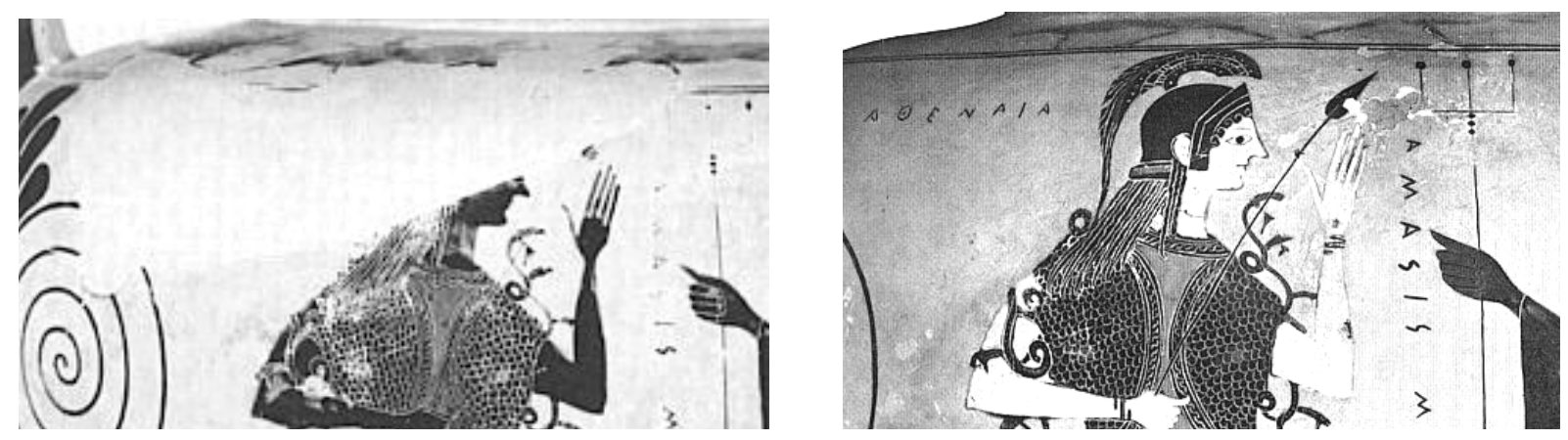

Fig. 84. Detalhes: à direita, solução de restauração apresentada por Arias \& Hirmer (1962, prancha 56); à esquerda, 0 estado atual da restauração da peça.
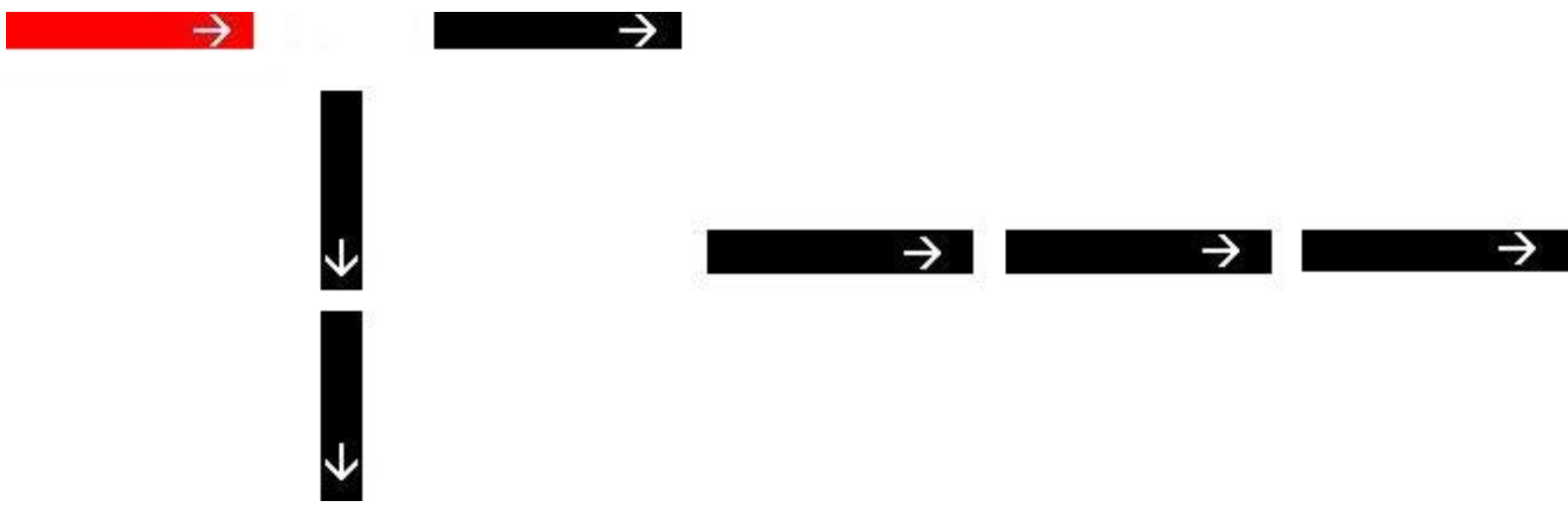

Fig. 85. Esquema das inscrições da ânfora de Amasis (fig. 83): em vermelho, a inscrição inexistente, mas provável (todas as inscrições são da esquerda para a direita).

No outra face (B), à esquerda, um homem veste manto e quíton longos, cabelos e barba são longos. Usa coroa de hera, e segura com uma das mãos um cântaro, e com a outra, está prestes a receber uma lebre. Ele olha para duas mulheres à sua frente (à direita na imagem). Estas usam quíton longo, uma delas é coberta com pele de animal. Abraçamse, ensaiam passo compassado, e carregam em uma mão um ramo longo (um cai à direita e outro à esquerda). Uma delas entrega uma lebre ao homem para quem olham. Usam brincos e coroa de hera. Enquanto a cútis do homem é constituída a partir da técnica de figuras negras, a das mulheres é apenas delineada por uma linha. Há detalhes nas roupas em tinta rubra. Sobre a cena (logo acima das cabeças das figuras), há uma inscrição "Amasis me fez".

É comum encontrar na ornamentação vascular a caracterização da pele feminina diferente da masculina; ou seja, freqüentemente se apresentam homens em figuras negras, e as mulheres caracterizando suas peles pintando-as com tinta branca. Esse vaso apresenta um curioso desvio dessa prática. A diferenciação da coloração da pele continua (tanto no caso de Atena e Posidão, quanto no de Dioniso e das Mênades); entretanto, num mesmo vaso, há, em um lado, a caracterização da pele feminina pintada com tinta branca, e, no 
outro, a pele mantém a coloração de fundo, ou seja, o alaranjado da cerâmica (ver fig. 8688). Essas informações indicam as estratégias de distinção do عُ $\theta$ vo $\zeta$, ao menos uma categoria dele, que é a diferenciação de gênero. ${ }^{53}$ Não eram apenas as formas ou detalhes característicos que marcavam tal distinção, mas elementos gráficos associados com o uso de cores simples apresentam uma estratégia própria da ornamentação da cerâmica nessa delimitação. ${ }^{54}$
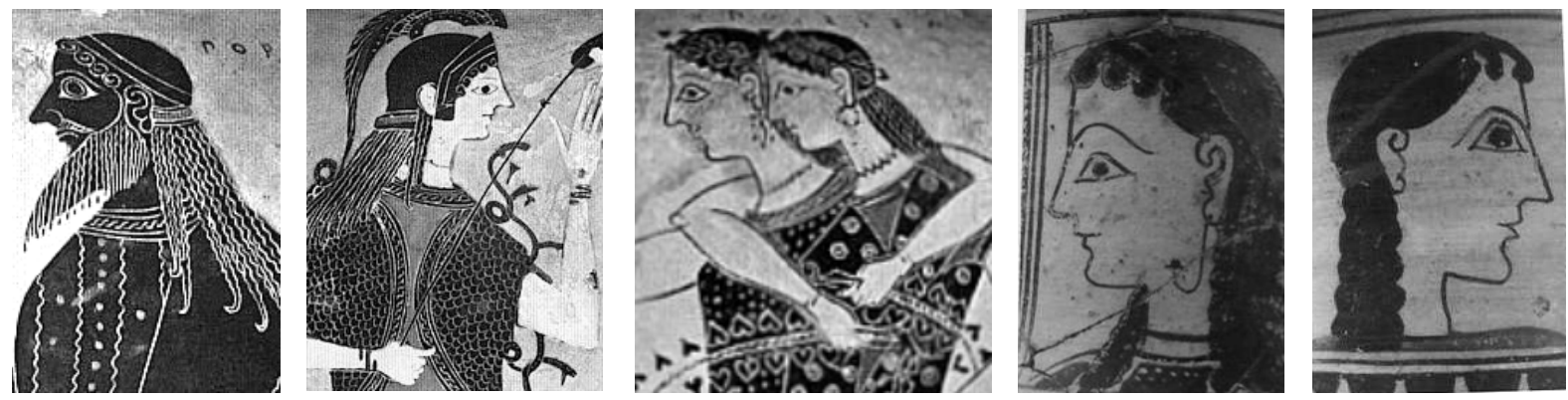

Fig. 86. Diferentes estratégias de caracterização da cútis no vaso de Amasis (fig. 83): $\boldsymbol{a}$. Posidão em verniz negro; $\boldsymbol{b}$. Atena com pele pintada de branco (restauração a partir de vestígios de tinta branca); $\boldsymbol{c}$. Mênades com cútis delineada, ressaltando-se 0 fundo da cor da argila; Fig. 87. Cabeças femininas: recurso comum nos pescoços de vasos de Paros do período arcaico: mesmo recurso técnico da fig. $86 c$.

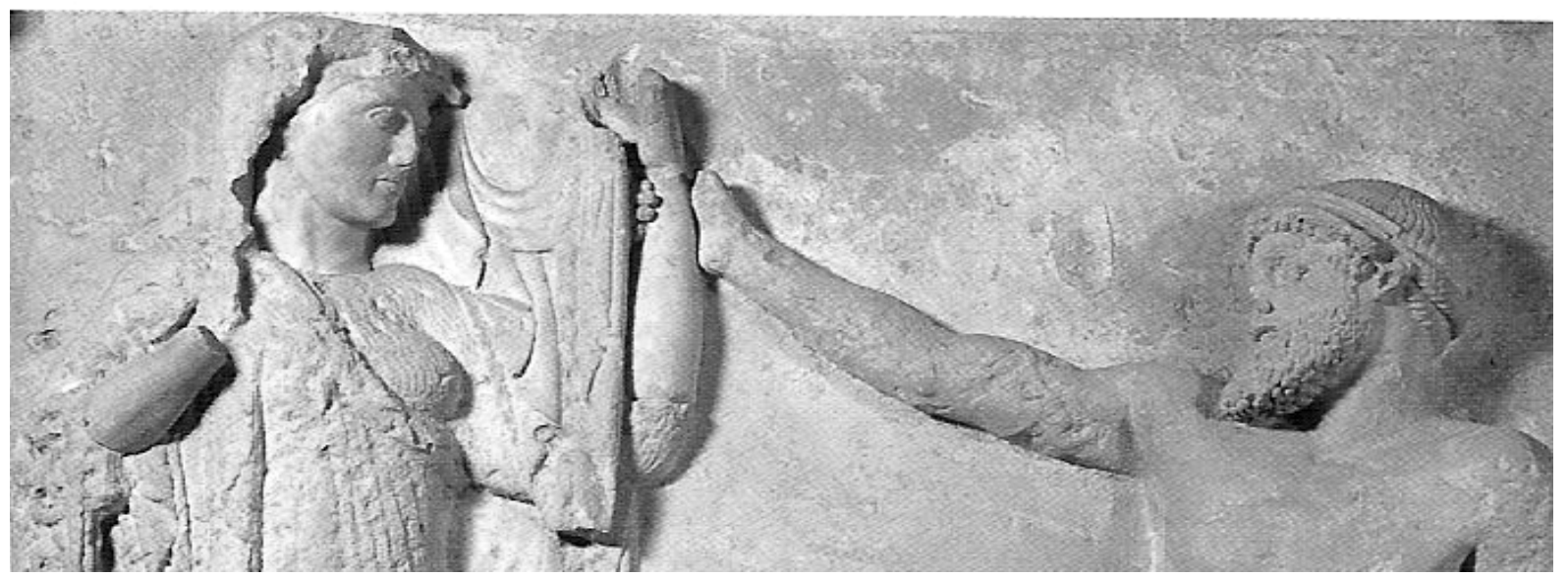

Fig. 88. Detalhe de métopa com Zeus e Hera do templo E em Selinunte, Sicília, c. 460 a.C. (relevo em pedra calcária, incrustado com mármore, que compõe a pele da figura feminina), Palermo, Museu Arqueológico.

\footnotetext{
${ }^{53}$ A caracterização do $€$ " $v o \zeta$, na Antigüidade, era mais ampla que a caracterização do "étnico" na atualidade, e se baseava também na delimitação de gênero-sexo (ver Píndaro, Píticas, 4, 252 e Xenofonte, Econômico, 7, 26) - ver Bailly, verbete عُधvos.

${ }^{54}$ A distinção entre o feminino e o masculino é amplamente observada entre os gregos, desde as fontes literárias até as materiais. Cabe lembrar que, na narrativa mítica, enquanto os homens já conviviam com os deuses, a mulher (Pandora) só seria criada como um presente ambíguo dado por Zeus, que marcava o fim da convivência harmoniosa entre deuses e homens (Hesíodo, Os trabalhos e os dias, 42-105). Ainda, contígua às conhecidas distinções sociais, havia inúmeros recursos em meio artesanal na distinção entre o masculino e o feminino: as kórai vestidas e os koûroi nus, as comuns diferenciações a partir de colorações diferentes, como observado no vaso de Amasis (ver fig. 86), recurso também utilizado em escultura (a pele feminina composta com material diferente da pele masculina - ver fig. 88). Todos claros exemplos das estratégias de diferenciação do ๕̌ $\theta$ vo próprios da ação artesanal.
} 
É importante saber que a cútis feminina nem sempre era representada a partir dessas distinções materiais, havendo grande número em figuras negras; e, além disso, as figuras masculinas também poderiam ser apresentadas em tinta branca (como o exemplar de Corinto demonstra - ver fig. 72b). Essa diversidade criativa coloca uma questão importante, mais ampla que a própria diversidade gráfica apresentada: a figuração humana poderia ser apresentada a partir de formas diferentes; ou seja, a técnica gráfica a partir da incisão sobre verniz escuro, com a ajuda do recurso tonal (a tinta branca), e a linha pintada, todas eram elementos possíveis na caracterização do ser humano, e nas delimitações internas (como as de gênero). A experiência criativa relacionada ao elemento humano, na ornamentação ceramista, não é circunscrita apenas a uma forma.

Essa variedade no tocante à figuração humana não caracteriza a produção das inscrições que eram invariavelmente pintadas (fala-se das produzidas em contexto original). A variedade localiza-se em outros pontos. No vaso de Amasis (fig. 83), as inscrições são maiores, comparadas às de Exéquias, mantendo uma tradição que remonta a uma prática antiga, como observável nas inscrições da ânfora de Nessos, vasos (e fragmentos) de Sófilo, ou a inscrição egineta "Menelau"; e essa prática era comum nas inscrições dos vasos coríntios (ver fig. 72).

Ainda, diferente de Exéquias, Amasis separa as palavras nas inscrições que com-

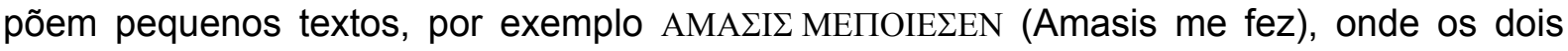
núcleos são separados nas duas faces. Na face $B$, essa separação poderia compor um esquema visual: acima da cabeça de Dioniso, horizontalmente a inscrição $\Delta \mathrm{IONI \Sigma O \Sigma}$; entre ele e as duas Mênades (no mesmo alinhamento) a inscrição AMA $\Sigma I \Sigma$; e, acima da cabeça das

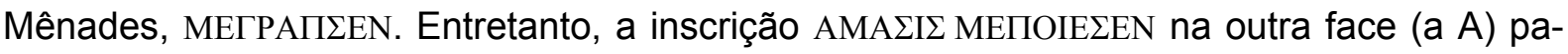
rece refutar a idéia da separação do núcleo como simples composição visual, já que, acompanhando a verticalidade do esquema, não há nenhuma interrupção nas figuras, mas mes-

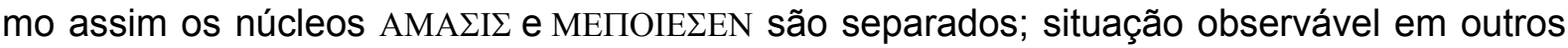
vasos do mesmo pintor (ver fig. 89).

Cabe lembrar que já em vasos de Sófilo com as mais antigas inscrições áticas de autoria encontradas (num dinos e num fragmento) aparecem separações desses núcleos ( mas três pontos verticais, o que também acontece no texto ПАТРОQ $\Lambda$ Y $\mid \mathrm{AT} \Lambda \mathrm{A} ;$ mas essa não pode ser considerada uma prática sistemática, já que o mesmo pintor, assinava mantendo o texto de autoria sem nenhuma separação. Confirmando essa variedade, Clítias, no

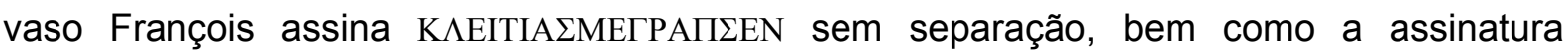
ЕРГОТІМОГМЕПОIЕ 2 EN; mas em uma base de cerâmica, onde também ocorrem as duas assinaturas, elas são separadas pelos três pontos verticais (ver cap. 4, fig. 22, p. 189). 


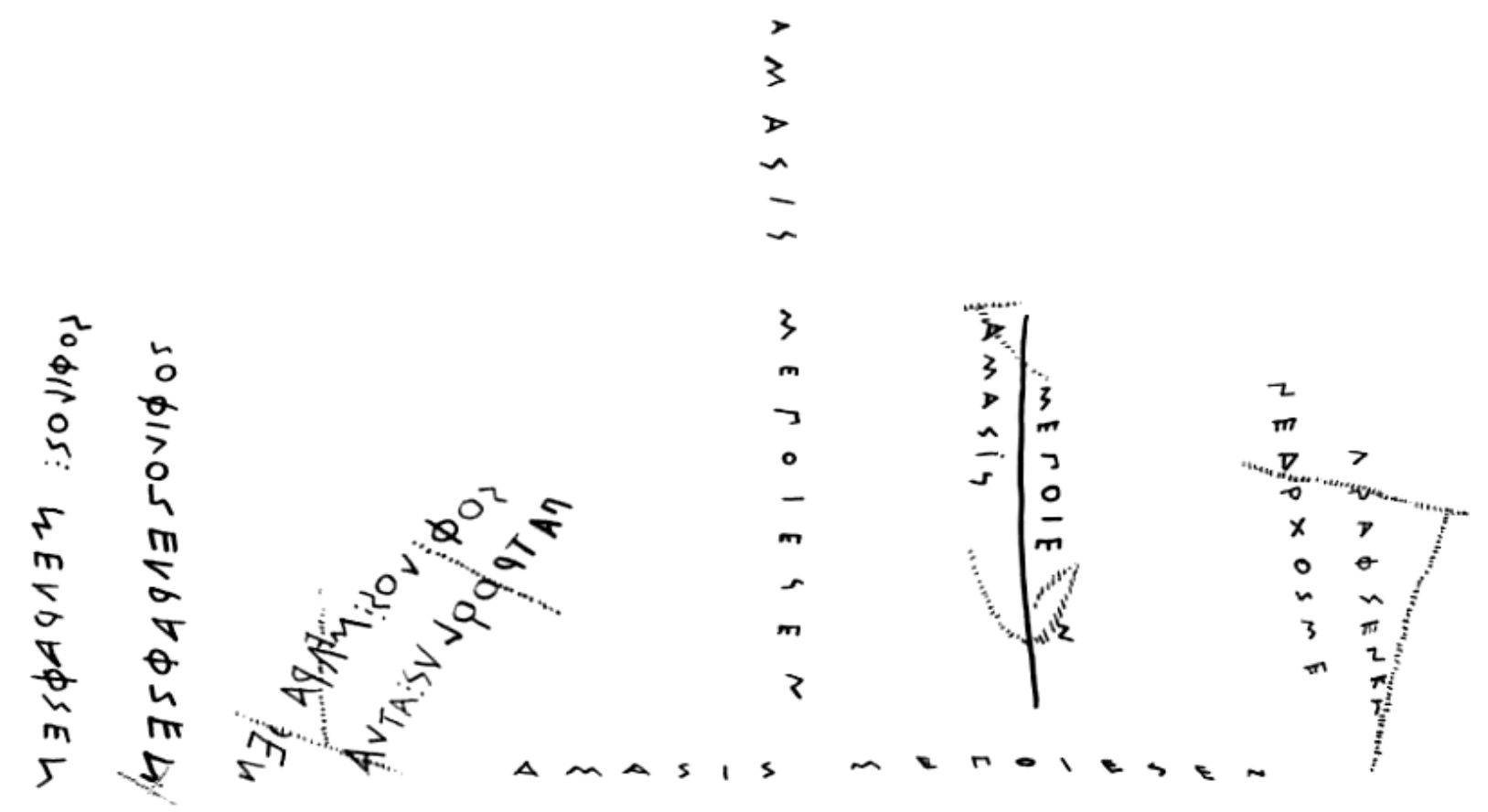

Fig. 89. Inscrições de autoria de Sófilo, Amasis e Nearco.

A aplicação dessas inscrições, nesse sentido, só pode ser caracterizada por uma certa variedade de usos, tanto no que se refere à escrita (o ato de escrever não era absolutamente regular (quanto à orientação da escrita, a relação entre as palavras etc.), como à composição dos esquemas visuais.

Assim, como no vaso de Exéquias acima tratado (onde, claramente, numa face a inscrição de autoria compõe de forma equilibrada o esquema visual; e do outro, ajusta-se a um canto do enquadramento, sem maiores funções estéticas), as várias assinaturas de Amasis sobre vasos de cerâmica são diversificadas: ora sinuosas (ver fig. 92), reforçando o ritmo da cena; ora acompanham visualmente arcos ou outras formas das imagens figurativas (ver fig. 90), ora ajustam-se a algum canto (ver fig. 91)...

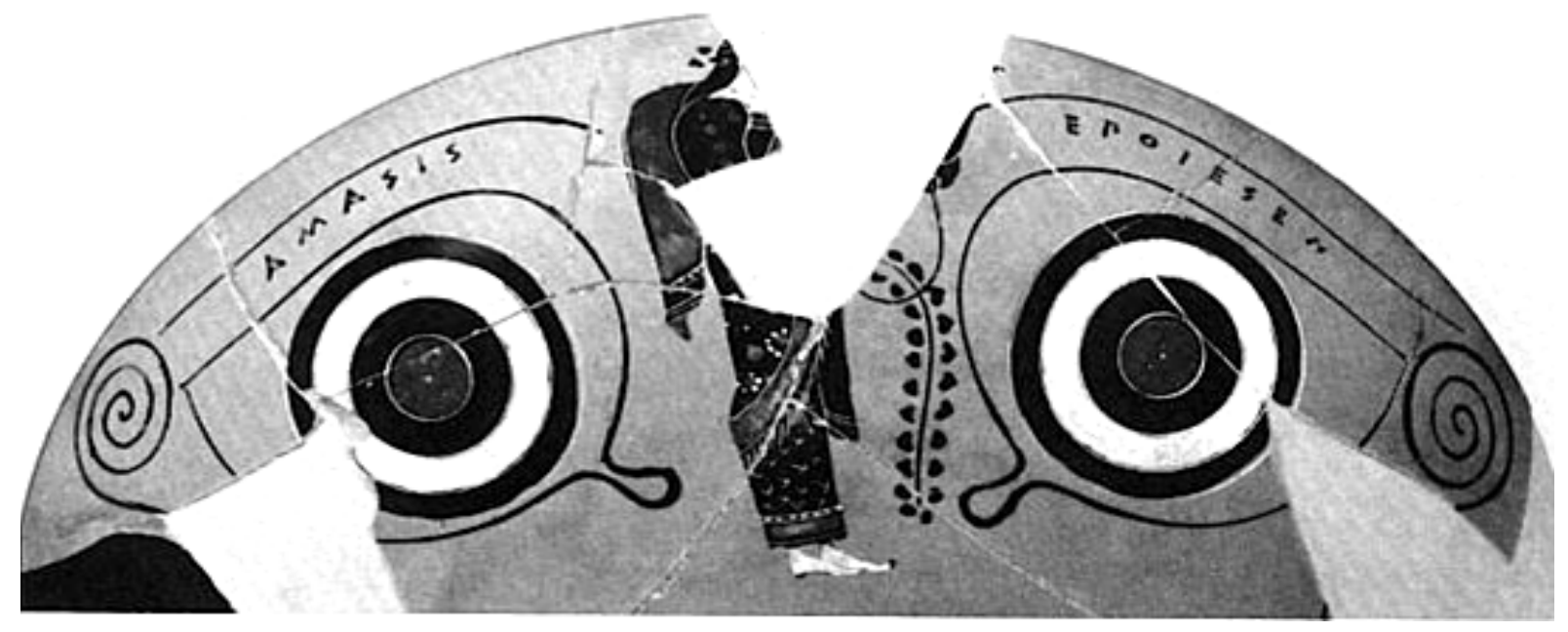

Fig. 90. Detalhe de taça de Amasis, Museu do Vaticano. 

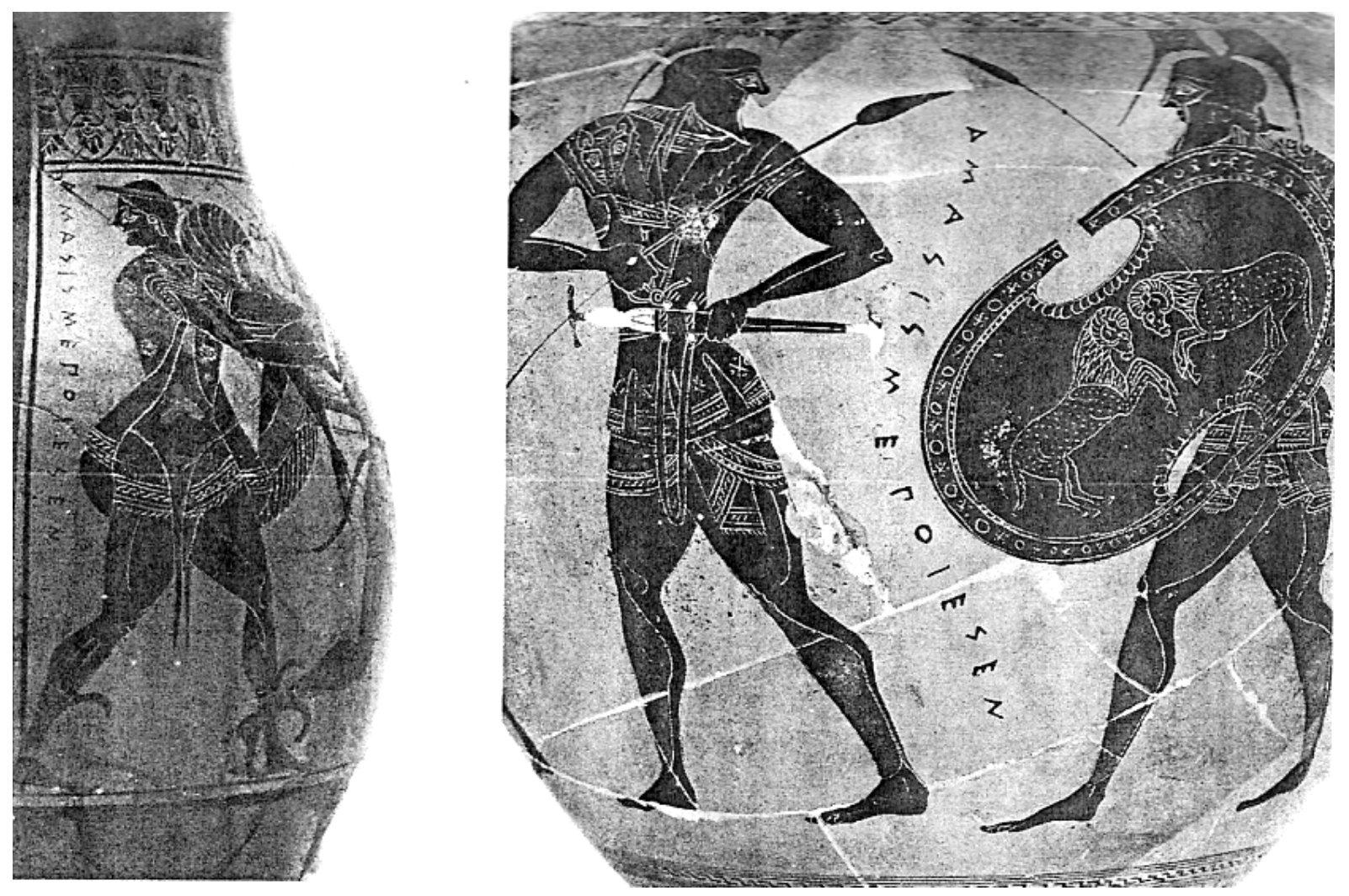

Fig. 91 e 92. Detalhes de vasos de Amasis (Londres, British Museum [à esquerda] e Boston, Museum of Fine Arts [à direita]).

Neste ponto, é possível traçar um quadro cronológico, levando em conta as competências na articulação entre inscrição e imagem no contexto da produção ceramista ática:

1) séc. VIII a. C.: Ausência de articulação original em contexto artesanal; ${ }^{55}$

2) séc. VII a. C.: Tímida aproximação em poucos exemplares do protoático (inscrições "disputam" espaço com elementos ornamentais [palmentas, cruzes estilizadas, quadros hachurados etc.) - Do protoático (base da cratera de Menelau) até o Pintor de Nessos;

3) Séc. VI a.C.: Figuras negras (substituição dos elementos decorativos por inscrições) De Sófilo, Vaso François até Amasis;

4) Séc. VI a.C.: Inscrições compondo esquema figurativo maior (Amasis, Exéquias até o aparecimento das figuras vermelhas);

5) Séc. V a.C.: Figuras vermelhas (diminuição da incidência de inscrições).

${ }^{55} \mathrm{O}$ que se tem, até essa data, é a inscrição da enócoa do Dípilo, em que a inscrição e imagem figurativa têm processos criativos diferentes. 
O delineamento das formas gráficas interativas do séc. VII ao VI a.C., acima apresentado, é bastante parcial e contou com algumas ausências. Privilegiaram-se os tipos mais comuns da interação escrito-figurativa, e uma apresentação mais detida ainda será feita; levando-se em conta o universo da produção gráfica ceramista, mas não apenas ele. A linha aqui apresentada foi introduzida pela discussão das modificações espaciais, de forma genérica, e essa não é a única possibilidade de observação desse desenvolvimento geral dos grafismos nessa época. Por exemplo, tratá-los a partir do viés da política e do simbolismo que assumem nesse quadro é também possível, e será desenvolvido na análise das ânforas panatenaicas.

Essa análise ampla é importante, pois, quando se fala do desenvolvimento de uma compreensão de linguagens, como o processo indicado acima, fala-se também de pessoas pertencentes a um grupo, inseridas nesse universo de mudanças; assim, os grafismos mudam por que estão inseridos num contexto de mudanças, ao menos em alguns aspectos, contexto que eles mesmos formam.

Tais balizas cronológicas, além de aguçarem a visão para as modificações materiais ocorridas, indiciam outras mais amplas que o próprio desenvolvimento gráfico. O crescimento da importância da cultura letrada no contexto da Ática no período arcaico é um indicador disso. Assim, observar o quadro cronológico acima apresentado, pode promover uma compreensão que não tem unicamente o desenvolvimento gráfico como paradigma. É possível falar no percurso de uma sociedade que, já dominando parcialmente a escrita, não a articulava sistematicamente à linguagem visual, e que a articulação dessas linguagens só se deu num processo longo, e que sofreu interferências de produções exteriores (como a coríntia). Ainda, pode-se dizer que a sociedade ática só alcançaria uma maturidade no ato de articular linguagem escrita e visual em meados do século VI a.C., quase cem anos depois dos inícios dessa prática. Também se deve considerar que a produção, por variados motivos, aumenta substancialmente na Ática, e que esse crescimento é também relacionado ao crescimento do número de artesãos. O esquema 2 (cap. 2, item 2.1.1, p. 71) apresenta isso com clareza, ou seja, um constante aumento de profissionais envolvidos nesse meio produtivo. ${ }^{56}$ Nesse sentido, além do desenvolvimento no tempo, que proporcionaria as mudanças acima identificadas no quadro da produção gráfica ceramista, a variedade de profissionais também é elemento explicador. De início, basta indicar a variedade formal gráfica, numa mesma época.

\footnotetext{
${ }^{56}$ Retomando as informações desse esquema 2 (cap. 2, p. 71), o crescimento do número de profissionais envolvidos no meio artesanal ceramista pode ser reduzido da seguinte forma: de $c$. de 625 a 600 , dois profissionais identificados; de 600 a 575, três profissionais; de 575 a 550, oito profissionais identificados e dois grupos; de 550 a 525 , doze profissionais e um grupo; de 525 a 500, doze profissionais; de 500 a 475 , oito profissionais envolvidos.
} 
Por fim, vale dizer que nesse quadro de mudanças pode-se observar uma característica constante na articulação entre linguagem escrita e visual: uma relação quase necessária entre inscrição e imagens na produção da cerâmica ática; mas isso deve ser brevemente discutido. Ora, é amplamente sabido que a maior parte da cerâmica ática ornamentada não era inscrita. Nesse sentido, a aplicação da imagem figurativa aparece de forma mais autônoma, pois pode ocorrer isoladamente ou acompanhada de inscrições; e o quadro muda bastante no que se refere ao aparecimento de inscrições nesses vasos, pois a grande maioria dos vasos que as possuem, aplicadas em contexto original (criadas pelo grafista) apresentam também imagens figurativas. Assim, o uso da escrita nesses vasos é quase sempre relacional, diferente do uso das imagens figurativas que é mais independente. Disso se pode inferir, de forma generalista, que um vaso ornamentado poderia 1) não possuir imagem figurativa ou inscrições; 2) possuir imagens figurativas, e 3) possuir figuração e inscrições (ver esquema 3$)^{57}$

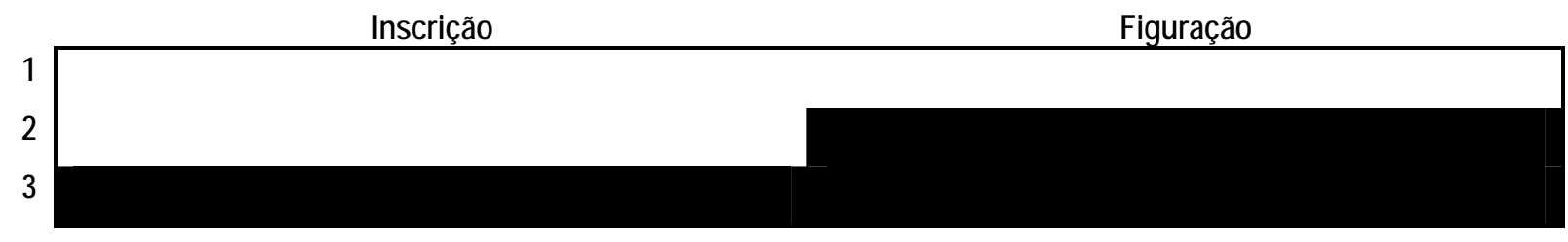

Esquema 3. Quadro geral de ocorrências de inscrições e imagens figurativas no vasos áticos.

A explicação desse comportamento passa por dois pontos: o primeiro refere-se à própria introdução da escrita e da figuração nos vasos áticos: como visto, a experiência do uso de imagens figurativas na produção ceramista ática remonta, de forma muito tímida, ao séc. X a.C. (ver fig. 42, p. 98), mas se intensificando já no período geométrico. Já a escrita como elemento compositivo é posterior, e em meio original, só em meados do século VII a.C., com os poucos usos na cerâmica protoática, é que seriam usadas como elemento viável na ornamentação dos vasos de cerâmica; e, é importante lembrar, em condições pouco autônomas (ver fig. 61, 67 e 68).

A segunda linha da resposta passa pela compreensão do uso da escrita em outros suportes. Houve um crescente uso de inscrições sobre pedra, bronze etc., no início do séc. VII a.C., tanto dividindo espaço com imagens visuais (variadas esculturas, por exemplo), mas também de forma independente. É nesse contexto que o uso mais sistemático das inscrições se estrutura com maior autonomia. É claro que o problema dos objetivos e da organização social do trabalho são importantes: ora, as grandes inscrições em pedra (que só desenvolveriam depois dos variados exemplos da cerâmica, já em período geométrico, prin-

\footnotetext{
${ }^{57}$ O recurso visual do esquema 3 mostra que, no quadro da ornamentação da cerâmica ática arcaica, enquanto a imagem figurativa (portanto o ato de produzir imagens) afirma-se pela grande presença; a inscrição (o ato de escrever) caracteriza-se pela maior ausência.
} 
cipalmente fora da ática), são produzidas por artesãos diferentes, e que deveriam ter uma outra aptidão para escrever, tanto no que se refere à técnica (inscrições lapidadas e não pintadas como as dos vasos), às dimensões físicas (geralmente maiores que as dos vasos), à extensão dos enunciados (desde pequenas mensagens, até algumas que tomavam toda a extensão da pedra-suporte), e à complexidade das mensagens (destoando das comuns mensagens simples dos vasos de cerâmica). Cabe dizer, ainda, que o universo do grafista relacionado ao artesanato cerâmico, tinha a inscrição como elemento subsidiário, a que poderia, mas não necessariamente deveria, recorrer; já o lapicida, pela natureza de sua criação, tinha a escrita como elemento primordial. Assim, é nesse contexto que a escrita se desenvolve com maior autonomia; e no que se refere à produção gráfica ceramista, seu uso mantém-se subordinativo, apesar de bastante viável em alguns casos.

Ainda, é importante saber que essas diferentes inscrições eram também diferentes mediadoras sociais: o impacto da mensagem escrita do vaso, vinha freqüentemente apoiado pela criação figurativa associada (sendo ela referente ao tema da inscrição ou não); e o uso privado desses grafismos pode indiciar uma discussão sobre a relação entre o grafista e o que faz a encomenda (por exemplo, mensagens de homenagem, muito específicas, indicam isso), destoando do caráter prioritariamente público das inscrições lapidadas sobre a pedra. Assim, ao menos, se pode colocar uma questão: que as inscrições de caráter privado, no contexto tratado, desenvolveram-se menos independentemente que as de natureza pública, mas a resposta passaria por amplos levantamentos e interpretação dessas inscrições, o que destoa da proposta aqui colocada; mas inscrições como as das ânforas panatenaicas, de encomenda pública, e as sobre estelas funerárias relativizam qualquer delimitação ou oposição bruscas. 


\subsection{Fonte material, fonte textual e a noção de documento}

Antes da apresentação de alguns aspectos básicos sobre os grafismos dos vasos de cerâmica áticos, discutir-se-ão dois pontos centrais no tratamento e compreensão desse tipo de fonte: o primeiro, a própria noção de documento no cenário das pesquisas arqueológicas (e não uma discussão geral sobre o termo); e, depois, os próprios limites do acesso, em grande parte indireto, da documentação selecionada. Dois aspectos que extrapolam em certa medida os contornos do tema aqui proposto, mas de aproveitamento importante para a continuidade da discussão mais específica.

Neste item, tratar-se-á de um ponto de tratamento pouco rígido na bibliografia em geral: o significado do termo documento e outros termos relacionados no campo da pesquisa arqueológica. Tal questão só é levantada dada a grande heterogeneidade incidente sobre ela, e acredito que seja necessária uma breve explanação da situação e da posição aqui tomada, sobretudo no tocante às fontes materiais, já que utilizar um arsenal conceitual inadequado pode levar a análises e interpretações equivocadas.

Essa apresentação mostra-se viável, dada a importância da organização específica e interativa entre fonte material e textual, nesse caso, a partir do exame da lógica semântica e as propostas subjacentes a ela. Assim, acredita-se aqui, que o debate do significado dos termos é também um debate histórico e não apenas lingüístico; dadas, além das perceptíveis posições de caráter político, ideológico, cultural etc. que o discurso guarda, as próprias limitações discursivas frente à caracterização do passado, e a própria simbolização dos vestígios em tempos atuais (por exemplo, caracterizá-los como documentos).

O quadro que se encontra é o seguinte: desde a caracterização de "(...) documento [que] foi definido tradicionalmente como um texto escrito (grifo meu) à disposição do historiador" (Funari, 2003, p. 14), até a abstrata caracterização de Leroi-Gourhan, que aplica esse termo à discussão pré-histórica, chegando mesmo a falar em "documento pré-histórico (...), documento efêmero, amálgama de poeira, pedras, restos de ossos, cujo valor fundamental reside apenas nas relações mútuas dos elementos que o compõe". Documento que quando é "lido" é "inexoravelmente destruído" (Leroi-Gourhan, 1995, p. 92). Uma utilização do termo documento que ultrapassa os limites da escrita como parâmetro, sobretudo quando

(...) não temos nenhum repertório escrito, e bem poucas noções sobre o lugar dos diferentes lotes de documentos no tempo, sobre o número de anos, séculos ou milênios que os sepa- 
ram. (...) ignoramos os nomes desses povos, de seus chefes, de seus deuses. Nada nos chegou de sua língua, de suas idéias, de sua música. (Leroi-Gourhan, 1983, p. 28) ${ }^{1}$

É entre esses dois pólos que se deve caminhar para compreender a variedade das propostas do que seja documento. ${ }^{2}$

Inicialmente, Moses I. Finley apresenta uma cena bastante distinta quanto ao tratamento do termo documento. Ele se refere a "documento" como algo diverso "das fontes arqueológicas", das quais exclui "papiros, inscrições, rolos de couros", que considera, estes sim, documentos (Finley, 1994b, p. 90). ${ }^{3}$ Essa posição foi apresentada no artigo Arqueologia e História, no qual, ao discutir os limites das fontes e relações entre Arqueologia e História, Finley acaba dizendo o que acredita ser documentação propriamente dita, e o que não é, e em certos casos hierarquizando-as:

Por exemplo, sabemos, através da preservação casual dos relatos na pedra, que o mais delicado entalhe feito em pedra no templo em Atenas, conhecido como Erecteion, foi criado no fim do século $V$ a.C. por homens livres e escravos trabalhando lado a lado. Nada no material que chegou até nós (o próprio entalhe) poderia nos ter dito isso. Por outro lado, os relatos de que dispomos sobre o templo de Apolo em Epidauro, construído trinta ou quarenta anos depois, são de uma natureza tal que a força de trabalho não está especificada. Como imagina Binford ser possível descobrir se foram ou não empregados escravos, de alto grau de habilidade, nesse templo? (Idem, p. 93)

A distinção marcada que ele faz entre documento e fonte material acaba por diminuir as possibilidades interpretativas a partir do objeto material, já que, é claro na citação acima, Finley perguntava à fonte material coisas que ela não poderia responder (não seria o caso de adaptar as questões, a algo que o templo de Apolo pudesse responder?) E mais, restringir essa explicação à História da arte ou da técnica, como o autor sugere (Idem, p. 17), parece restringir o próprio papel dessas criações no contexto em que foram produzidas.

Esse autor volta a discutir os problemas das fontes históricas e arqueológicas em História antiga, testemunhos e modelos, e mesmo no âmbito do texto escrito ele faz distinções entre documento e fontes literárias, evocando Momigliano (Finley, 1994a, p. 12 e 43). ${ }^{4}$

\footnotetext{
${ }^{1}$ Ainda, uma bela analogia é construída por Leroi-Gourhan: segundo ele, as camadas pré-históricas sãs as páginas do "livro da terra", e as escavações, a decifração do manuscrito pré-histórico (Idem. p. 18). Para uma visão crítica a essa proposta, ver Bruneau, 1974.

${ }^{2}$ A seguinte coletânea de opiniões e usos relacionados ao termo documento é propositadamente variada. A diversidade é de época de publicação, centros acadêmicos e países diferentes; isso, já que é o cenário que o pesquisador encontra. A disposição das idéias, vale dizer, não é necessariamente cronológica, mas segue uma lógica referente ao paulatino desenvolvimento do termo documento na discussão arqueológica e afim.

${ }^{3}$ Publicado originalmente em 1971.

4 Publicado originalmente em 1985.
} 
Delimitando conceitualmente o termo documento, divide-o em dois grupos: os das fontes primárias e secundárias, criticando a utilização de fontes antigas, porém de épocas bastante diferentes como primárias - um problemático agrupamento, levando em conta unicamente a sua produção antiga -, já que ser produzido na Antigüidade pode significar ser produzido num espaço de tempo muito amplo, e por várias culturas diferenciadas (Idem, p. 15-6). Finley atenta perspicazmente a esse problema: não se pode utilizar ao mesmo tempo Homero e Pausânias como fontes primárias sem conseqüências que beiram, em muitos casos, o anacronismo na pesquisa histórica. ${ }^{5}$

É possível observar, a partir das propostas de Finley, que ele utiliza o termo documento de forma não tão específica, e com certas variações: numa primeira proposta (1971), a rigidez é menor que na segunda (1985), onde o termo torna-se mais delimitado; parecendo algo que não seja fonte material e nem mesmo texto literário, algo mais próximo do que se conhece como "documento voluntário", ou seja, um texto produzido para registrar algo, geralmente em caráter oficial. ${ }^{6}$ É nesse grupo de testemunhos restritos que Finley acredita com afinco:

Essa é a triste conseqüência de nossa escassez de fontes históricas primárias. A menos que tenha sido captado por um relato histórico mais ou menos contemporâneo, a narrativa fica perdida para sempre, independente de quantas inscrições e papiros possam ser descobertos. Basta lembrar a História de Atenas e do Império Ateniense durante os quase cinqüenta anos que se estendem entre as guerras persas e do Peloponeso, um período rico em testemunhos epigráficos, mas sobre o qual Tucídides preferiu não escrever um relato sistemático. Não podemos sequer datar algumas das batalhas que Tucidides obviamente julgava importantes. (...) As exceções estão, por um lado, na História das idéias, especificamente na História da filosofia e das ciências, da retórica, da poesia e da historiografia, e, por outro lado, da História da arte e da tecnologia. Na primeira, a distinção entre fontes literárias e documentais perde a maior parte de seu significado; na segunda, as "fontes documentais" constituem os próprios objetos. (Finley, op. cit., p. 17) - grifos meus

Além da pia crença na absoluta importância das fontes históricas, os documentos escritos, e da mais absoluta "desgraça", na falta deles; esse autor apresenta uma nova visão

\footnotetext{
${ }^{5}$ Não é impossível articular textos produzidos em épocas e realidades sociais tão díspares, haja vista que a experiência dos textos homéricos ainda era persistente na época de Pausânias, e, como se sabe, Pausânias referia-se ao universo homérico constantemente. Entretanto, há que se observar as realidades específicas próprias da época de produção imediata desses textos, e operar numa aproximação desses universos tão diferentes sem uma declarada abordagem metodológica e verificação da viabilidade dessa interação é complicado.

6 “É comum se distinguirem pelo menos duas categorias de documento como suporte de informação: documento voluntário e involuntário. (...) 'Documento voluntário' seria o documento no seu sentido original, aquele que, no seu contexto primário, já teria por função própria ser suporte de informação. Seriam, então, objetos cuja função natural, - que lhes dá existência - é registrar e conservar informação. (...) Ao inverso dos documentos voluntários, os 'involuntários' seriam aqueles que não tivessem como função primária registrar e conservar informação, mas que, apesar disso, poderiam convenientemente também fornecer certa informação" (Meneses, 1980, p. 2-3).
} 
sobre as fontes que não considera documentação stricto sensu: no caso das fontes materiais, elas estariam legadas a uma História da arte, tecnologia, afastando-se de uma narrativa histórica mais ampla. É emblemático que o autor usa aspas quando se refere a essa documentação, indicando que elas, apenas de forma restrita e com certo esforço epistemológico, podem ser assim chamadas, como ele próprio diz, em caráter de exceção. ${ }^{7}$

Distante dessa delimitação e afastamento da fonte material ao termo documento, UIpiano T. B. de Meneses apresenta o "documento como suporte físico de informação" (Meneses, 1980, p. 1). Essa caracterização documento-suporte físico, que aproxima o termo documento do campo de elementos da cultura material não se dá à toa, a própria etimologia do termo apresenta essa possibilidade:

A palavra documento tem a mesma raiz latina do verbo doceo, que significa ensinar. Ensinar, sobretudo, não no sentido de formar, mas no sentido de transmitir informação, de comunicar informação já consolidada. Documentum, portanto, significa modelo, no sentido de que esta informação parte de paradigmas pré-fixados. É dessa noção que se desenvolveu a idéia de testemunho, de prova, a idéia de que o documento é um veículo de informação que eu obtenho. É corrente, entre os historiadores, conceituar documento como sendo todos aqueles traços que permanecem da atividade humana ou do pensamento humano. É nesse sentido, inclusive, que se considera o problema das fontes, para o conhecimento da História. (Idem, p. 2) $)^{8}$

Há, nessa conceituação de documento, um pouco de otimismo, já que, como visto, há ainda a defesa desse termo como algum tipo específico de produção textual, e não "todos aqueles traços que permaneçam da atividade humana"; entretanto o quadro vem mudando bastante, e o significado realmente abrange essa possibilidade. ${ }^{9}$ Entre as novidades apresentadas pela "Nova História" inserem-se as ampliações das fontes, e por conseqüência a do termo documento, propondo discursos como o de Michel Vovelle, dizendo que o

\footnotetext{
${ }^{7}$ Aqui, a visão opositiva à de Finley concentra-se, sobretudo, na questão da hierarquia das fontes, e de sua articulação. Cabe lembrar que esse autor apresenta importantes críticas no tocante a algumas interpretações arqueológicas ideologicamente orientadas, como no caso da "Deusa Mãe" (por Jackqetta Hawkes) ou o "Culto do Minotauro" (por Grahme Clark, em Analytical Archaeology). Vale ainda dizer que, apesar das limitações da língua inglesa com relação ao termo documento, que é invariavelmente ligado à formulação escrita, Finley estrapola essa limitação, tratando da adequação do termo, indicando a necessidade de discutir a sua natureza, mesmo que ele opte muito fortemente pela aproximação entre a idéia de documento e a formulação escrita do discurso.

${ }^{8}$ É interessante o fato de que Marie-Anne Chabin, ao rediscutir a noção de documento frente à tecnologia digital, busca, de início, a compreensão etimológica do termo documento (p. 146), como Meneses, acima. A pesquisadora francesa, acaba concluindo que a noção de documento é flexível, e os novos meios não apresentam uma abolição de tal conceito, mas as mudanças consolidam mais profundamente uma nova noção de suporte. Chabin, M.-A. Document trace et document source. La technologie numérique change-t-elle la notion de document? Information-Interaction-Intelligence, Vol. 4, $\mathrm{n}^{\circ} 1$, pp. 141-57. Não se pode esquecer aqui da caracterização, em termos mais gerais, do termo documento atrelada à do termo monumento, empreendida por Jacques Le Goff; que também inicia pela etimologia dos dois termos (Le Goff, 1997, p. 95-105).

${ }^{9}$ Por exemplo, basta consultar a obra História: novos objetos, organizada por Jacques Le Goff, que se percebem essas novas possibilidades "documentais", uma compreensão bem mais ampla que o texto escrito oficial.
} 
"escrito não é mais o único documento histórico" (Vovelle, 1990, p. 78). Essa tendência tratou-se de um movimento que continha desde 1929, com a publicação do primeiro número da revista Annales d'histoire économique et sociale, um grupo de historiadores que não se contentava com os limites impostos à categoria documento; situação que teve desenvolvimento lento e contínuo (Febvre [1949], Bloch [1941-2] e Samaran [1961], por exemplo, conforme Le Goff, op. cit., p. 98). Dizia Bloch

Que historiador das religiões se contentaria em consultar os tratados de teologia ou as recoIhas de hinos? Ele sabe bem sobre as crenças e as sensibilidades mortas, as imagens pintadas ou esculpidas nas paredes dos santuários, a disposição e o mobiliário das tumbas, têm pelo menos tanto para Ihe dizer quanto muitos escritos. (Bloch, Apologie pour l'histoire ou métier d'historien. Apud Le Goff, Idem)

\section{E precisa Samaran:}

Há que tomar a palavra 'documento' no sentido mais amplo, documento escrito, ilustrado, transmitido pelo som, a imagem, ou qualquer outra maneira. (Samaran, L'histoire et ses méthodes. Apud Le Goff, op. cit.)

Essa nova visão sobre as fontes estava longe de se tornar hegemônica, e mesmo quando Le Goff (op. cit.) fala de uma revolução na noção de documento, concentra-se na sua apreensão de monumento, ou seja, a consciência de que o documento não é algo "puro", apenas selecionado pelo historiador; longe disso, há inúmeras triagens, conscientes ou não, que permitem sua chegada até o pesquisador, e isso também deve ser levado em conta. Apesar de usar termos como documento arqueológico e documento iconográfico, e discutir muito brevemente o papel da Arqueologia na recomposição da História, no contexto do avanço do tratamento quantitativo das fontes e mesmo da discussão sobre a seriação delas, essa importante reflexão não deixava de ser parte de um todo ainda resistente a certas ampliações, como é claramente demonstrado nas proposições de M. I. Finley. Também evidencia isso a grande sorte de reflexões bastante recentes sobre o estatuto documental de fontes "alternativas", como as fontes audiovisuais, e mesmo diversas categorias do texto escrito como cartas, diários e textos digitalizados; ${ }^{10}$ e, o campo aqui tratado, a Arqueologia.

\footnotetext{
${ }^{10}$ Essa é uma das grandes discussões a que tive acesso a partir do curso Documentos e arquivos, ministrado pela professora Ana Maria Camargo, no Departamento de História da FFLCH-USP, $2^{\circ}$ semestre de 2005 . É digno de nota que grande parte dos textos tratados no curso apresentava uma necessidade de debater o estatuto documental das fontes chamadas alternativas (na verdade, fontes que quase sempre foram rejeitadas ou sub exploradas), e aliado a isso, a reunião de esforços para criar um aparato teórico-metodológico levando em conta a especificidade de cada tipo de fonte. É emblemático que a maioria dos textos são de publicação recente (a partir do ano de 2000), e a indicação do estágio, em certos casos bastante inicial, desse tipo de discussão. Vale, nesse sentido, a indicação de alguns desses textos: Chabin, op. cit.; Moreland, J. Archaeology and text. Avon: Duckworth, 2001; López, E. L. L. La fotografia como documento histórico-artístico y etnográfico: uma epistemolo-
} 
O cenário é variado: desde uma das principais obras de síntese de Arqueologia brasileira, Arqueologia brasileira (Brasília, DF: Editora UnB, 1992), onde o autor, André Prous, utiliza o termo documento (e similares) sem maiores especificações, para tratar das fontes materiais, mesmo "pré-históricas"; até a utilização aparentemente restritiva de Charles E. Orser Jr., em Introducción a la Arqueologia histórica, onde, ao apresentar as várias fontes para a Arqueologia histórica, indica documento como fonte escrita, propriamente histórica (junto aos mapas e História oral), ao contrário dos "artefatos, estruturas, contextos do sítios", próprios do campo da Arqueologia (p. 46). Entretanto, nessa mesma obra, tal autor chega abranger o uso do termo documento, dizendo que a fotografia "documenta" (p. 45), e mesmo especificando o termo documento com os complementos "escrito" e "histórico" [p. 33 e 35]). ${ }^{11}$

Haiganuch Sarian, no seu artigo A cerâmica como documento arqueológico, não trata conceitualmente do termo documento, mas de sua adequação ao campo da Arqueologia: define-o como instrumento através do qual se possa "chegar à reconstituição de uma certa maneira de pensar, de confeccionar, de criar e de se relacionar (...)" (Sarian, 1984, p. 196); como Hélène Balfet, de quem Sarian tira inspiração para seu título, em La céramique comme document archéologique, diz que esse título serve para

indicar claramente o que é para nós a ceramologia: disciplina auxiliar à Arqueologia, ela tem por objetivo a exploração sistemática de todos os recursos ofertados pelos documentos cerâmicos (que não é exagerado dizer, são geralmente sub explorados). ${ }^{12}$

Philippe Bruneau, em Fontes textuais e vestígios materiais: reflexões sobre a interpretação arqueológica, discute a articulação e o relacionamento entre fontes materiais e textuais, o que permite, inclusive, tratar de algumas especificidades da "Arqueologia histórica", no tocante à problemática do documento, e suas restrições epistemológicas. Bruneau diz que

gia. Revista de Antropologia Experimental, Jaen, n. 5, texto 10, 2005; Delmas, B. Donner à l'image et au son le statut de l'écrit: por une critique diplomatique des documents audiovisuels. Bibliothèque de l'École des Chartes, Paris, t. 161, p. 553-601; Jones, A. The many uses of newspapers. Richmond: University of Richmond, s. d. (Reports); Djick, J. V. composing the self: of diaries and lifelogs. Ibreculture, Australia, n. 3, 2004; Zen, M. W. Íntimo e pessoal: a agenda como um espaço de constituição de si. Anais do XXIII Simpósio Nacional de História, Londrina, jul. 2005. CD-ROM; Vonderau, P. Historiography and film: a dangerous liaison? In: Vonderau, P. (ed.). Film as history I History as a film. Berlin, 1999. (Working Papers "Gemenskaper Gemeinschaften", 1); Falbe-Hansen, R. The filmmaker as historian. P. O. V.: a Danish Journal of film studies, Aarhus, n. 16, December 2003; Duranti, L. Pour une diplomatique des documents életroniques. Bibliothèque de l'École des Chartes, Paris, t. 161, p. 603-23, juillet-décembre 2003; Schwartz, J. M. "We make our tools and our tools make us": lessons from prhotographs for the practice, politics, and poetics of Diplomatics. Archivaria, Ottawa, n. 40, p. 40-74, Fall 1995.

${ }^{11}$ Orser Jr., C. E. Instroducción a la Arqueologia histórica. Trad. Andrés Zarankin, Buenos Aires: Asociación Amigos Del Istituto Nacional de Antropologia, 2000

${ }^{12}$ Balfet, H. La céramique comme document archéologique. Bulletin de la Société Préhistorique Française, 63, 1966. p. 279. 
O tratamento dos dados arqueológicos, com efeito, consiste essencialmente numa convergência da linguagem: os vestígios materiais, objeto da Arqueologia, contêm informações virtuais, mas elas devem ser decriptadas e traduzidas num enunciado verbal; elas só existem pela formulação. As fontes textuais, ao contrário, se situam por definição no nível da linguagem. Portanto, os vestígios materiais são heterogêneos em relação à formulação do arqueólogo, enquanto os textos são homogêneos em relação ao comentário do filólogo. (...) Esta etapa intermediária de enunciação verbal que intervém no tratamento dos dados arqueológicos para fazê-los existir como documentos, cria uma diferença entre eles e os textos: uns e outros não se situam no mesmo nível de abstração. (Bruneau, 1974, p. 2)

Para esse autor, não há grandes impedimentos na caracterização da fonte material como documento, entretanto, em si, ela não é documento (no máximo é fonte), o que a distingue da fonte textual, que é documento pela formulação verbal que tem. Dessa forma, a potencialidade lingüística da fonte material, como não está no nível de linguagem do pesquisador acadêmico, que tem o texto escrito como mediador, deve adaptá-la às suas necessidades: eis, então, a fonte material caracterizada como documento! Para Bruneau, há um caminho de transformação a se trilhar para que se considere a fonte material como documento; em outras palavras, ela não é "naturalmente" documento.

A aproximação conceitual entre os dois tipos de fonte foi proposto, por exemplo, pelas autoras Pauline Schmitt-Pantel e Françoise Thelamon, na comunicação Image et histoire. Ilustration ou document, ${ }^{13}$ onde ocorrem os termos documento literário (p. 10), documento escrito (p. 12) e documento textual (p. 14), pois as autoras têm em vista uma ampliação de sentido do termo documento, falando em documento iconográfico (p. 14), ao se referir às imagens figurativas sobre os vasos áticos, e criticando o uso tradicional, restritivo, do temo documento:

O mais freqüente discurso do historiador é construído inicialmente a partir de fontes escritas às quais ele dá prioridade, como se apenas a elas seja reconhecido o estatuto de documento (p. 10)

Para Schmitt-Pantel e Thelamon, as fontes materiais, no caso a iconografia vascular ática, devem alçar o estatuto de documento, ou seja, deixar de ser utilizadas apenas como ilustração, entretanto tal uso deve ser precisamente pensado: elas criticam o uso como fotografias, seu uso pontual (sem levar em conta a coesão interna das cenas, ou sua inserção em séries), e o uso indireto (notas obtidas apenas através de estudos de especialistas). So-

\footnotetext{
$\overline{13}$ In: Lissarrague \& Thelamon, 1983, p. 9-20.
} 
bre o termo documento, na proposta das autoras, se se rompem as amarras do registro escrito, mantém-se o domínio histórico como referência (é nesse campo que as autoras pensam): "imagens como documentos para a História" (p. 14); de certa forma, "desobedecendo" a lição de N.-D. Fustel de Coulanges, que dizia "o melhor historiador é aquele que se mantém o mais próximo possível dos textos". É claro que ele falava de manter-se fiel, o máximo possível, ao que o texto diz, mas sua caracterização de documento indica igualmente a proximidade, que tal autor considerava salutar ao historiador. Seriam categorias de documento as "leis, cartas, fórmulas, crônicas e histórias"; ainda, esse pesquisador não deveria esquecer nunca que "a História se faz com textos" (Fustel de Coulanges, La monarchie franque. Apud Le Goff, op. cit., p. 96).

O mais importante para esta discussão é que não há nada, desde a compreensão etimológica do termo documento, que impeça sua utilização de forma mais ampla, ou seja, que a fonte material seja também assim categorizada a partir de sua função informativa. Entretanto, há uma prática, que coibiu semanticamente esse uso, e parece que se deve atentar a ela. Uma definição que legue apenas ao texto escrito, caracteristicamente voluntário, o estatuto de documento parece insuficiente, sobretudo repousante numa tradição da pesquisa histórica que o utilizou restritivamente. Essa tradição criou um aparato teóricometodológico em torno de si, e usar o termo documento de forma ampla, como parece viável, deve passar pela ampliação teórico-metodológica conseqüente, e não se fixar unicamente numa prática que serve ao exercício da pesquisa histórica que têm o texto escrito como fonte principal. O problema não está no termo em si, mas nas propostas subjacentes a ele, amplamente perceptível através da análise do discurso historiográfico, arqueológico e afim. Pode-se, então, chamar de documentos os objetos de cerâmica com que se trabalha aqui, pois a fonte material não perde sua especificidade quando é assim caracterizada, porém tomando os devidos cuidados: não é permitido esquecer que se restringiu (e ainda se restringe) seu uso a esse tipo de fonte, e isso levou a limitar as suas possibilidades interpretativas; situação da qual se deve fugir. 


\subsection{Limites e possibilidades da documentação}

Um problema central relacionado à utilização de documentação específica é a sua adequação aos problemas propostos, bem como os limites informativos que toda documentação oferece. Essas questões próprias dos limites e interpretações serão tratadas em vários momentos, quando necessário, mas antes é preciso concentrar-se em um ponto importante: o acesso à documentação que, no caso de inúmeros estudos sobre a Antigüidade clássica realizados no Brasil, especialmente sobre cultura material, é, em grande parte, indireto, o que apresenta um cenário diferente do que compõe o pesquisador instalado em centros acadêmicos na Europa ou Estados Unidos da América. ${ }^{14}$ Para tratar dessa questão, serão apresentados alguns exemplos de como o acesso indireto pode atrapalhar a pesquisa, mas também de como isso pode revelar novos caminhos interessantes. O ponto de partida é uma breve nota sobre a enócoa do Dípilo.

Sobre ela, Jeffery (1990, p. 68) diz: "Todo levantamento das antigas inscrições áticas deve começar com a enócoa do Dípilo". Entretanto, o que se observa é que a maioria dos estudos (incluindo Jeffery) segue em parte essa lição, já que se ocupa de compreender a sua inscrição, mas não necessariamente o vaso (seu suporte). A enócoa do Dípilo, como visto (ver cap. 2, item 2.1), figura como um importante objeto para o estudo da Epigrafia grega, posto que possui um grafite que compõe o grupo das mais antigas inscrições em alfabeto grego. Nesse sentido, muitos estudos utilizaram tal documento, entretanto de forma sumária. Ou seja, é costume haver a apresentação da inscrição citada apenas ou prioritariamente em esquemas, transcrita ou ainda em fotografias que privilegiam a informação escrita no vaso. Quanto ao seu suporte, ele é freqüentemente indicado, mas não de forma suficiente: limitando-se ao comentário sobre a sua natureza (um vaso cerâmico), e, episodicamente uma ou outra informação sobre a ornamentação. Já em 1939, Rodney S. Young (1939, p. 228) denunciava tal problema, dizendo que a ornamentação da enócoa do Dípilo era constantemente mal apresentada, impedindo qualquer possibilidade de real discussão sobre a cronologia do vaso baseando-se no estilo ornamental. ${ }^{15} \mathrm{~A}$ situação, apesar das grandes possibilidades técnicas, parece ter avançado pouco (ver fig. 1 e 2).

\footnotetext{
${ }^{14}$ É claro que algo das condições sócio-econômicas e mesmo a distância geográfica colocam alguns limites e impõem, em certa medida, restrições na ação de pesquisadores que atuam longe do Mediterrâneo, espaço privilegiado de suas pesquisas; entretanto, mesmo especialistas que têm maior acesso a esses espaços recorrem, inúmeras vezes, a interpretações correntes, privilegiando-as, muitas vezes, em relação à observação mais direta. Nesses casos, ocorre, obviamente, um distanciamento que também é severamente marcado por tais limitações que serão tratadas a seguir.

${ }^{15}$ Por exemplo, Colstream (1979, p. 298) insere essa enócoa na categoria LG lb, e apresenta a inscrição sem se preocupar com outras informações do vaso; dessa forma, a ornamentação é submetida à informação de classificação ("late geometric lb").
} 


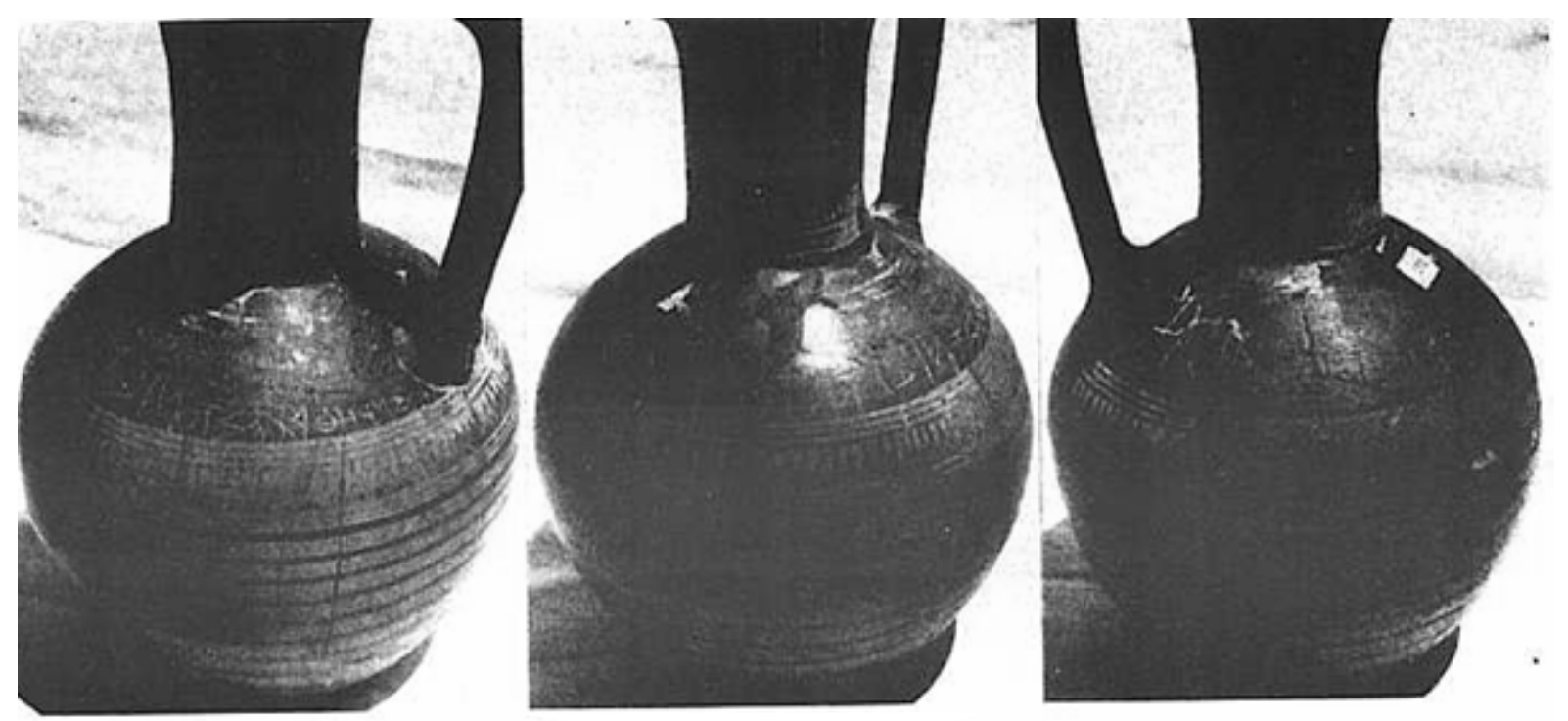

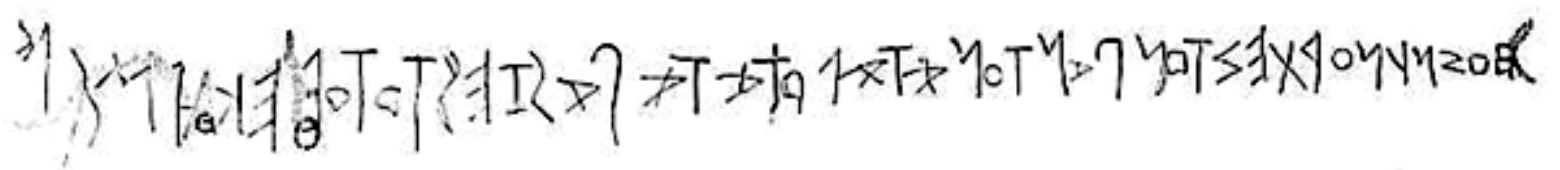

Fig. 1. Enócoa do Dípilo em Jeffery (1990, pr. 1, fig. 1) - esquema da inscrição, também utilizado por Copete (1999, p. 77)
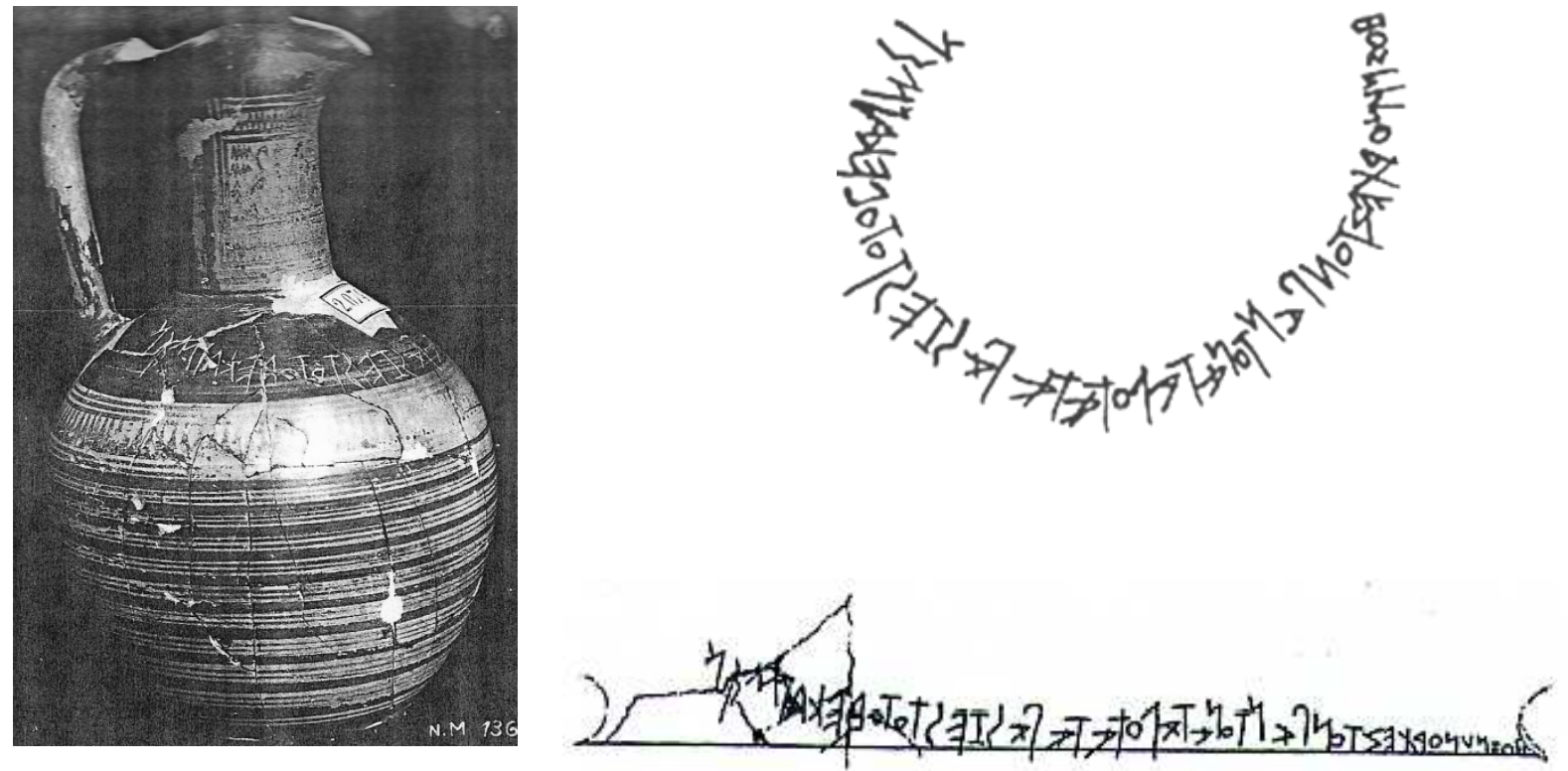

Enócoa do Dípilo e esquemas da inscrição: Fig. 2. À esquerda, fotografia de Immerwahr, 1990, pr. 1, fig. 1; Fig. 3. À direita, acima, Esquema da inscrição em Coldstream, 1979, p. 298; Fig. 4. À direita, abaixo, esquema da inscrição em Powell, 1999, p. 158.
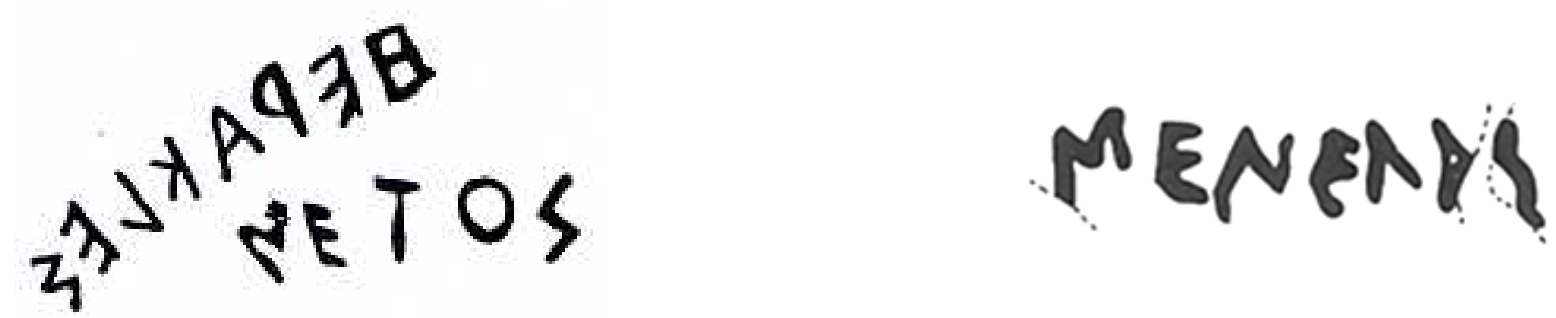

Fig. 5. Inscrições de ânfora do Pintor de Nessos em Jeffery (1980, pl. 1, fig. $6 a$ - aqui, ver cap. 3, fig. 70, p. 122); Fig. 6. Inscrição da base de Menelau em Jeffery (1949, fig. 3 - aqui, ver cap. 3, fig. 61, p. 117). 
Uma interessante experiência pessoal, no que se refere à interpretação desse vaso baseando-me nas informações visuais, é bastante revelador dessa situação, e, mais além, dos próprios limites que o estudo baseado prioritariamente em reproduções fotográficas, esquemas, desenhos etc. (ou seja, distante da observação do original), pode apresentar. ${ }^{16}$ Ao tratar da enócoa do Dípilo como documento, a partir publicações de renome como a de Jefferey (1990) e Immervahr (1990), as informações visuais obtidas não indicavam com clareza a presença de alguma imagem figurativa; e a consulta de várias outras obras, só revelava a própria inscrição em variados esquemas, quando muito uma descrição da ornamentação. Por exemplo, em Homer and the origin of the Greek alphabet, Barry B. Powell faz uma descrição da enócoa, e sobre sua decoração diz:

(...) é decorada sobre o corpo com uma combinação de linhas concêntricas interrompida por uma serra dentada desenhada próxima do ombro. Uma sólida ornamentação em negro cobre o vaso, acima do ombro, exceto por um painel decorado, limitado por ziguezagues, abaixo do bico (Powell, 1999, p. 158).

A ornamentação geométrica é descrita, e o "painel decorado" é apenas citado sutilmente. Como o objetivo de Powell é traçar linhas entre a prova epigráfica e a poesia homérica, a imagem figurada que não se comunica com a inscrição no tocante ao conteúdo é quase desprezada. A imagem apresentada pelo autor guarda da materialidade do vaso apenas a característica pouco fragmentar que tem e a linha que orienta a escrita (ver fig. 4).

Assim, esse vaso não se mostrava como documento viável para a discussão aqui proposta, pois a verificação da relação escrito-figurativa não era possível (ver fig. 1 e 2): além das fotografias pouco reveladoras da integral natureza do vaso, privilegiam-se, constantemente, os esquemas de tal inscrição, como no caso de outras inscrições importantes (ver fig. 3, 5 e 6); indicando que em boa parte dos estudos epigráficos e afins há uma concentração nas informações temáticas, e, materialmente falando, privilegiam-se as formas (estilo) das letras, mas não seu suporte.

Somente depois da observação direta do vaso, em exposição no Museu Nacional de Atenas, verifiquei que ele comportava sim informações escritas e figurativas, e, portanto, deveria compor este estudo, não apenas como traço subsidiário, mas de forma central (importante elemento na discussão cronológica). Ora, só a observação direta pôde esclarecer certos pontos obscuros que o contato indireto colocava. Das obras clássicas sobre Epigrafia grega que consultei apenas a de M. Guarducci (1967) apresenta, de forma clara, o painel

\footnotetext{
${ }^{16}$ A observação do original não se restringe ao "olhar com os próprios olhos" (situação usada para conferir autoridade ao que foi dito desde a produção de histórias na Antigüidade), já que o próprio "olhar" é subjetivo, e assim, esse exercício deve ser renovado sempre que possível. Entretanto, esse contato direto trata-se também da possibilidade de aferição de informações anteriormente divulgadas, de execução de análises físico-químicas etc.
} 
com a ornamentação figurativa da enócoa do Dípilo. Vale dizer, essa obra não existe em bibliotecas brasileiras (encontrei-a na biblioteca da Escola Francesa de Atenas). ${ }^{17}$

O desapego às informações do suporte pode provocar um "efeito em cascata", ocasionando desvios dado o uso indireto desse vaso como documento. Um exemplo disso é a caracterização feita por Francisco Marshall ${ }^{18}$ : este autor baseia-se, para comentar a inscrição da enócoa do Dípilo, num esquema oferecido por David Diringer ${ }^{19}$, onde aparece apenas a inscrição. O suporte é caracterizado por Marshall da seguinte forma: a "famosa ânfora do dipylon, encontrada em Atenas em escavação antiga, pouco rigorosa no registro e, portanto, de datação imprecisa" (p. 150). Há, nessa apresentação do vaso, duas imprecisões: quando se diz que o vaso é uma ânfora e as conjecturas sobre a situação de seu achado. Tal engano impele a uma outra referência: a realmente famosa ânfora do Dípilo, do Museu Nacional de Atenas, bem maior nas dimensões físicas comparada à enócoa do Dípilo, e aquela não apresenta inscrições ${ }^{20}$ (ver fig. 7 e 8).

Sobre as condições de achado da enócoa do Dípilo, Marshall (op. cit.) não indica precisamente a fonte de informação, mas se trata certamente da leitura a partir de Havelock (1996). Este, por sua vez, consultou Jeffery (1990). Ora, quando Jeffery explicita as condições de achado do vaso (baseada em S. A. Koumanoudes, Athenaion ix, 1890, p. 50, Apud Jeffery, op. cit.), ela indica que tal vaso foi encontrado em escavação ilícita, e só depois entregue à Sociedade de Arqueologia Grega, sem haver possibilidade, já naquele momento, de recuperar as informações contextuais específicas do vaso.

\footnotetext{
${ }^{17}$ É na produção de artigos em periódicos sobre Arqueologia e Epigrafia gregas que se encontram informações mais específicas; como, por exemplo, um artigo de Powell (1988) sobre a enócoa do Dípilo, onde informações mais amplas e fotografias mais claras são apresentadas.

${ }^{18}$ A escrita da civilização grega. In: Bakos, M. M. \& Pozzer, K. M. P. (orgs.) III Jornada de estudos do Oriente Antigo. Línguas, escritas e imaginários. Porto Alegre, 22 a 24 de maio de 1997. Porto Alegre: EDIPUCRS, 1998. p. $145-56$.

${ }^{19}$ Writing. New York: F. Praeger, 1962, p. 150.

${ }^{20}$ Uma outra equivocada caracterização do vaso pode ser observada na tradução de Literacy and orality in ancient Greece (Cambridge: Cambridge University Press, 1995), de Rosalind Thomas, por Raul Fiker (ver Thomas, 2005), em que a caracterização de tal vaso em inglês como Dipylon vase e jar (p. 58, no original em inglês), foi traduzida como "ânfora do Dípylon" e "ânfora" (ver Thomas, 2005, p. 81). Ainda, na tradução de Homero e os artistas. Texto e pintura na arte grega antiga, de Anthony Snodgrass, feita por Luiz Alberto Machado Cabral e revisada por Ordep Trindade Serra, o nome do vaso em inglês (jug, conforme Snodgrass), é traduzido como "cântaro", repetido várias vezes (ver Snodgrass, 2004, p. 86-7 e 89), apesar de a legenda da imagem trazer o nome oinócoe, o que revela que a tradução é bastante literal, e que dialoga pouco com a ceramologia grega. Por exemplo, o dicionário Michaelis traz como correspondentes em português para jug, as palavras jarro, cântaro e moringa, o que revela tal possibilidade; mas, no que se refere à nomenclatura dos vasos gregos, cântaro é um tipo de vaso bem definido, não correspondente à forma do vaso em questão, uma enócoa. Tal tradução é marcada pela repetição de tal problema. Outras enócoas são caracterizadas como "cântaro" (p. 45 e 47, fig. 7; p. 5961, fig. 11; p. 65, fig. 14; p. 104, fig. 26; p. 148-9, fig. 39), e há a caracterização de um dínos (relativo ao famoso fragmento de Sófilo, sobre os Jogos fúnebres a Pátroclo) como "oínos" (p. 172-3, fig. 45), e uma enócoa como "cratera" (p. 198, fig. 53 - "corinthian krater", já mal caracterizada no original em inglês). Todos esses erros comprometem sensivelmente a qualidade da tradução, justamente no tocante à documentação privilegiada pelo autor.
} 


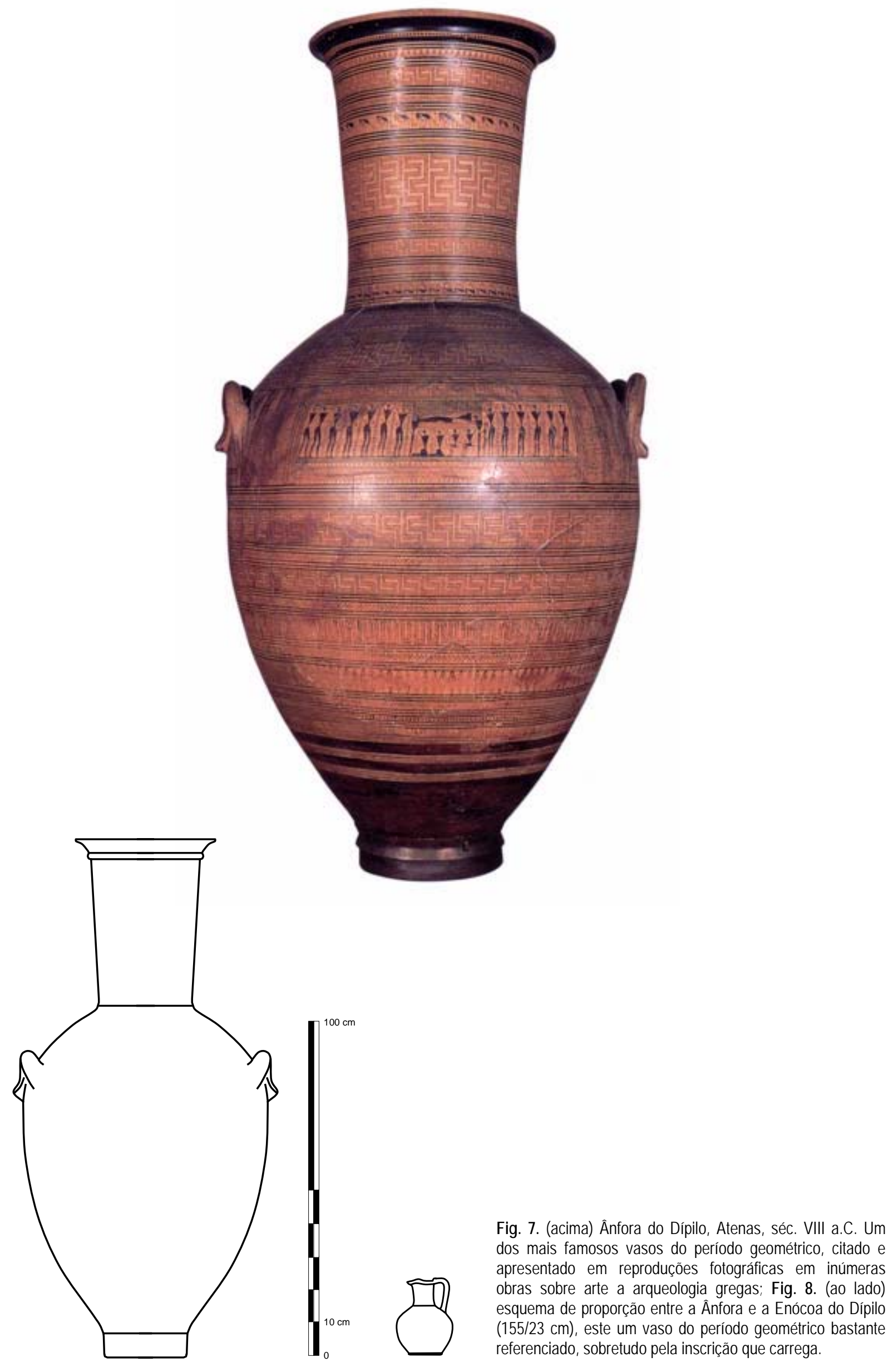


Havelock (1996, p. 197), sobre essa situação, diz o seguinte:

O famoso vaso do Dípylon foi encontrado num cemitério do período geométrico, além da Porta do Dípylon, em Atenas. Foi exumado ilicitamente em 1871, antes que a arqueologia se tornasse uma ciência disciplinada por controles legais, e o conteúdo da tumba em que estava enterrado, se é que existia, dispersou-se e permanece desconhecido.

A esse relevo que Havelock dá ao caráter indisciplinado da Arqueologia daquela época, unicamente a ele, que Marshall dá importância, sem citar o caráter ilícito da situação específica, o que muda significativamente o cenário. Ora, mesmo com práticas cientificamente comprometedoras (do ponto de vista atual), muitas informações das escavações antigas ainda são referências. Um exemplo disso é o relativo esforço de controle estratigráfico. Graças a isso, muito da cronologia dos materiais antigos, como aqueles com escrita não decritptada até o momento, foi estabelecida; é o caso, por exemplo, do Disco de Festo (c. 1600 a.C.) - ver cap. 3, fig. 24, p. 94 -, que teve cronologia dada por Evans, a partir de informações relacionadas ao depósito em que foi encontrado tal objeto (no estrato M. M. III, associado a tabletes de Linear A); isso já no início do século XX (Evans, 1909, p. 273-4).

Quanto à enócoa do Dípilo, a falta da verificação de informações básicas sobre o suporte pode comprometer a interpretação mais profunda sobre o documento e dos aspectos sociais que ele poderia revelar; e usar tal estudo como referência, sem verificar as informações apresentadas, só prolongaria a série de equívocos na interpretação arqueológica.

Também há que se ressaltar a dificuldade de acesso mesmo de reproduções fotográficas que indiquem com maior clareza algumas características do suporte. Quando procurei um outro objeto importante para a Epigrafia grega, um fragmento de cratera encontrado em Pitecussa, portando uma inscrição que é a mais antiga pintada e de autoria (...inos m'epoiesen), até agora encontrada, já na publicação original (o relatório dos achados em Ísquia de 1965-1971 - Buchner, 1971) apresentava-se um desenho da peça, que foi utilizado de forma recorrente por publicações posteriores, provavelmente pela maior clareza na visualização da ornamentação (ver cap. 2, fig. 6 e 7, p. 64). Quanto à sua fotografia, só tive acesso entrando em contato com o Museu Arqueológico de Pitecussa (site www.pithecusae.it/ materiali/rimandi1.htm, consultado em 09/01/2005).

Um outro claro exemplo é a dificuldade encontrada na observação dos aspectos gráficos da ornamentação dos vasos de cerâmica no que se refere a vários volumes da série internacional Corpus Vasorum Antiquorum. Os exemplares mais recentes apresentam um bom tratamento de reproduções fotográficas, preocupando-se com detalhes, várias vistas do mesmo vaso etc. Entretanto, essa abordagem do que se compreende como tratamento cien- 
tífico na apresentação dos vasos nessa série mudou ao longo do tempo (deve levar-se em conta que o projeto CVA data originalmente da década de 1920, quando foram publicados os primeiros exemplares); ${ }^{21}$ e o tratamento é idêntico ao do catálogo de vasos de cerâmica do Museu Nacional de Atenas ${ }^{22}$ : imagens pequenas, completamente dependentes das informações do volume escrito (ver fig. 9). ${ }^{23}$

A questão é que o pesquisador preocupado com o tratamento gráfico característico desses vasos não tem em toda a publicação do CVA um bom recurso técnico para basear a pesquisa, ressaltando que o conteúdo do volume de texto, na maioria das vezes, se restringe a informações gerais sobre as personagens figuradas, e, em vários casos, mesmo quando há inscrições ilegíveis nas reproduções fotográficas, não há a transcrição delas. A resolução de tal problema poderia estar na disposição digital de grande parte dos volumes do CVA (http://www.cvaonline.org); já que existe a possibilidade de ampliar consideravelmente as imagens, mas em muitos casos o original digitalizado fornece, em meio digital, imagens amplas cujas informações visuais ainda continuam ilegíveis (ver fig. 10).

Um último exemplo mostra bem como o acesso direto à documentação material, mesmo quando já houve publicação com boas reproduções fotográficas anteriormente, pode ser bastante fecundo. Trata-se do artigo de Annie Bélis, onde esta autora indica uma fonte relativamente nova de notações musicais: um epinetron de cerâmica, ornamentado com técnica de figuras negras ${ }^{24}$ e inscrições até então interpretadas como "sem sentido".

Tal objeto já havia sido publicado por Caroline E. Haspels (1931, pr. 34), e a reprodução fotográfica é bastante boa. Isso não impediu Bélis de estudar pessoalmente os fragmentos desse epinetron, fotografando-o sob autorização do Museu de Eleusis. Essa nova experiência permitiu que a autora identificasse um vestígio material até então despercebido:

um exame atento do epinetron mostrou a existência de uma letra suplementar entre o ômicron e o êta, na fissura; distinguindo-se pela barra horizontal; a reconstituição mais realista é um tau (Bélis, 1984, p. 102) - ver fig. 11.

\footnotetext{
${ }^{21}$ O primeiro exemplar do CVA é França 1, Museu do Louvre 1, editado por Edmond Pottier, em Agosto de 1922 (Para as bases do projeto, ver Pottier, E. Préface au premier fascicule du Corpus Vasorum Antiquorum. In: Corpus Vasorum Antiquorum - France I, Musée du Louvre I. Paris: Librairie Ancienne Édouard Champion. p. i-vii, 1922).

${ }^{22}$ Collignon, M. Catalogue des vases peints du Musée National d'Athenes. Paris: Albert Fontemoing, 1904.

${ }^{23}$ As imagens apresentadas são do volume França 3, Compiègne 1, de 1924.

${ }^{24}$ A peça é do início do séc. V a.C., atribuído, por Haspels, ao Pintor de Sappho (Bélis, 1984, p. 99).
} 


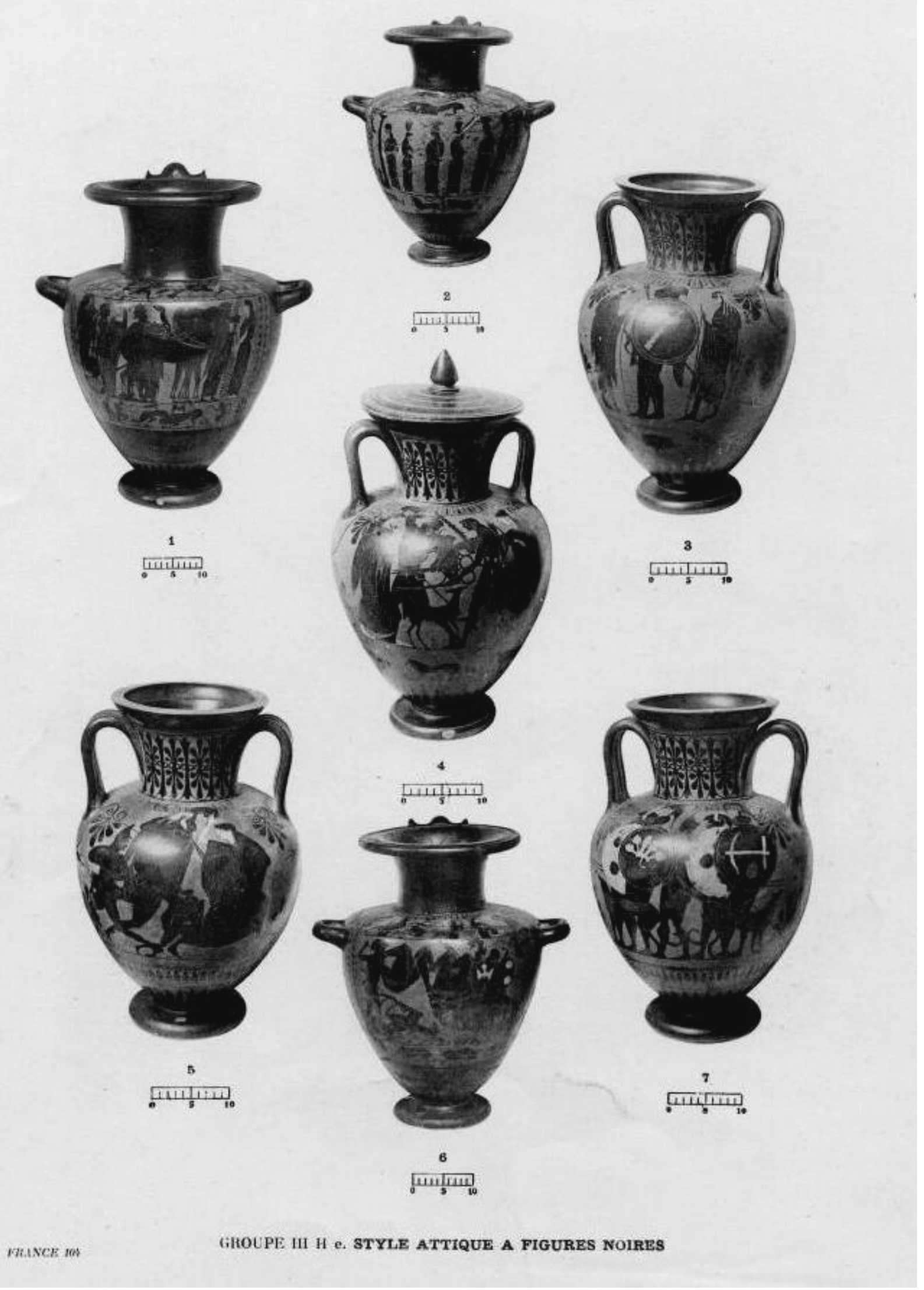

Fig. 9. Prancha 6 do CVA França 3, Compiègne 1 (a escala da prancha é 1:1, e foram cortadas as margens para 0 ajuste aqui apresentado. Deve-se, ainda, saber que a digitalização em scanner e a impressão não modificaram tanto a imagem, que é bastante similar à da prancha original). 

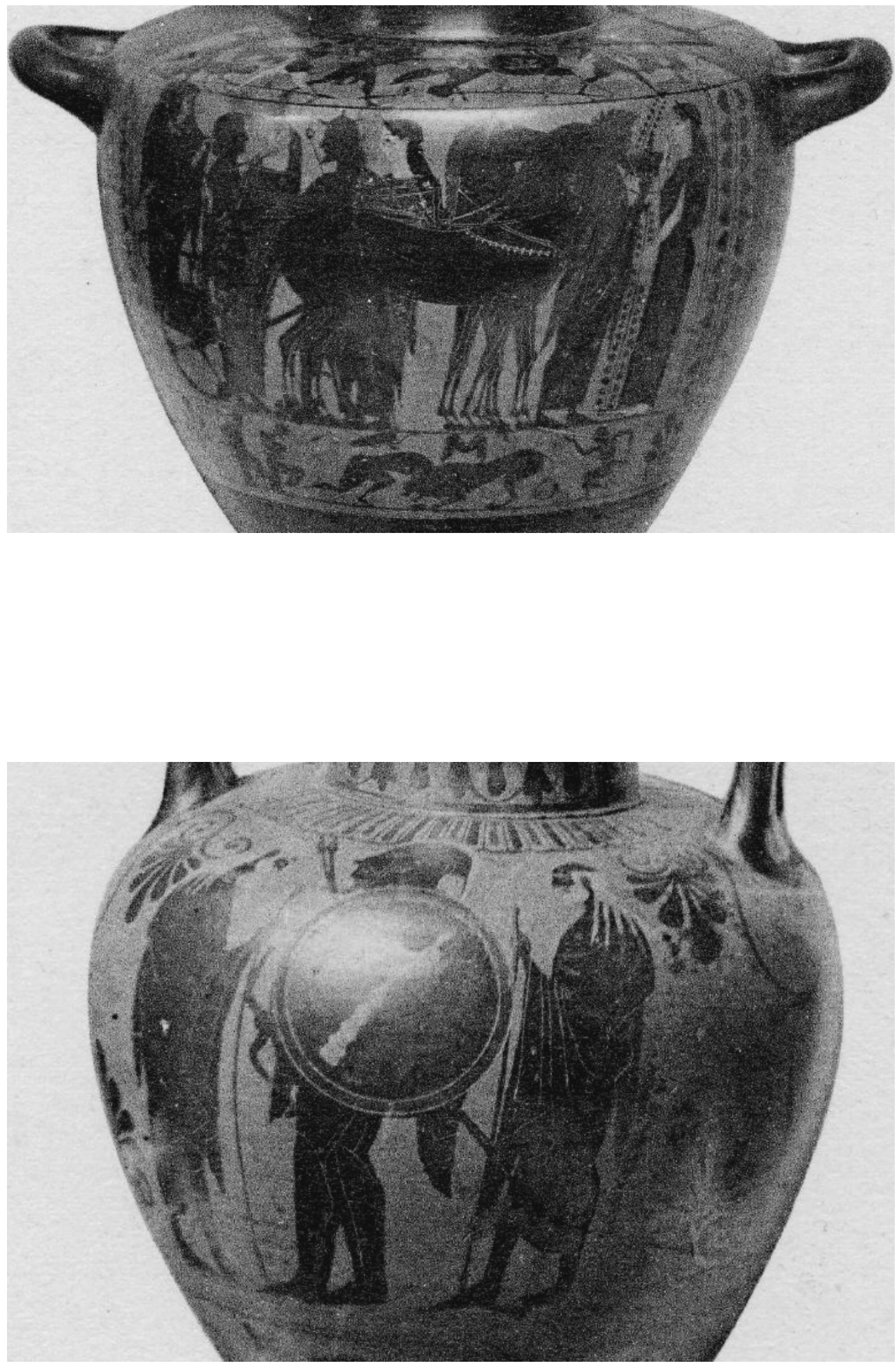

Fig. 10. Detalhes da prancha 6 (ver fig. 9) ampliação de 3 vezes. 

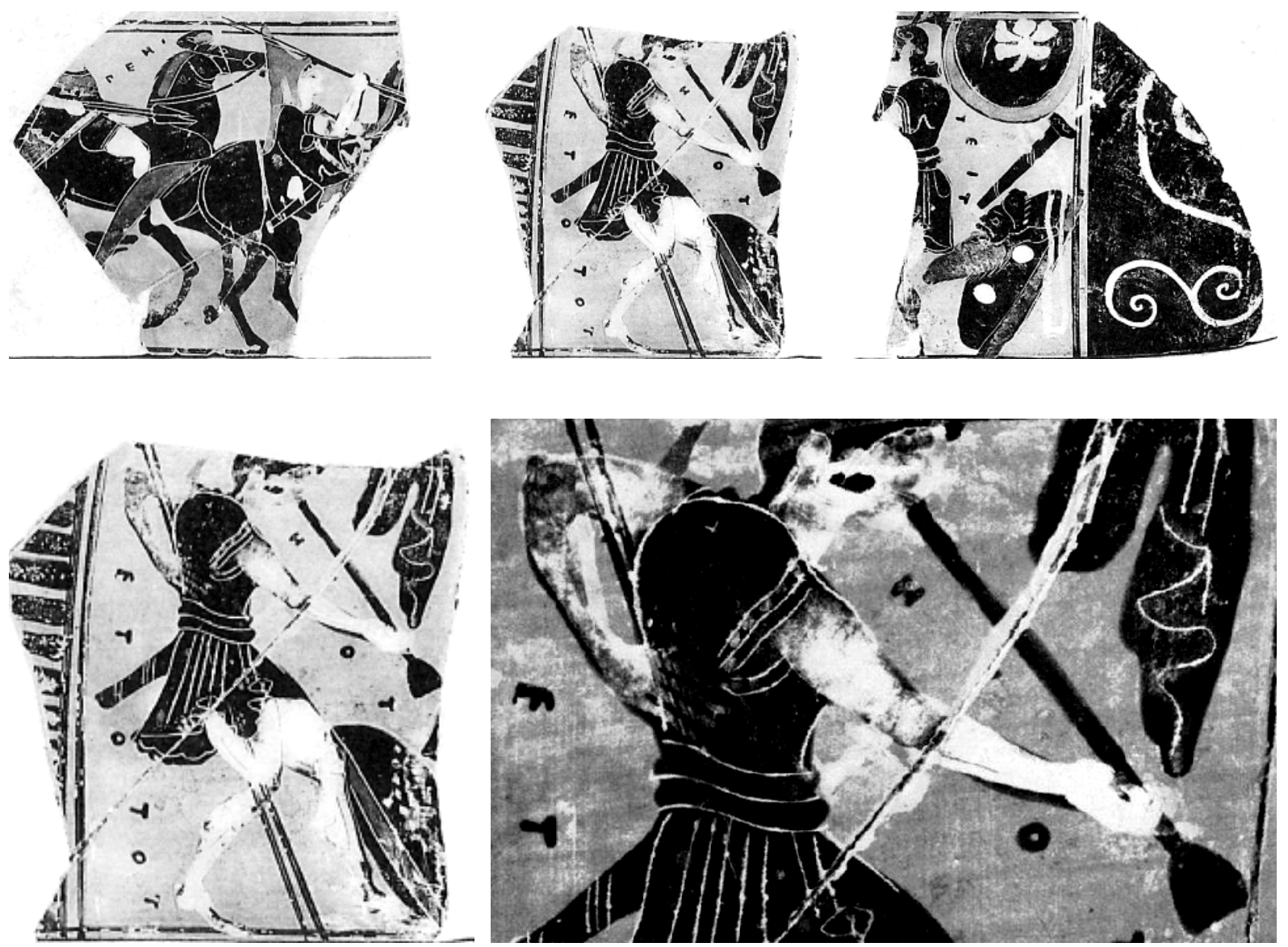

Fig. 11. Fragmentos do epinetron publicados por Haspels (acima e abaixo, à esquerda); detalhe publicado por Bélis (abaixo, à direita).

\begin{tabular}{|c|c|c|c|c|}
\hline $\begin{array}{c}\text { Tétracorde des } \\
\text { Hypates }\end{array}$ & $\begin{array}{l}\text { Tétracorde } \\
\text { des Mèses }\end{array}$ & $\begin{array}{l}\text { Tétracorde } \\
\text { des Conjointes }\end{array}$ & $\begin{array}{l}\text { Tétracorde } \\
\text { des Disjointes }\end{array}$ & $\begin{array}{c}\text { Tétracorde des } \\
\text { Hyperbolées }\end{array}$ \\
\hline
\end{tabular}

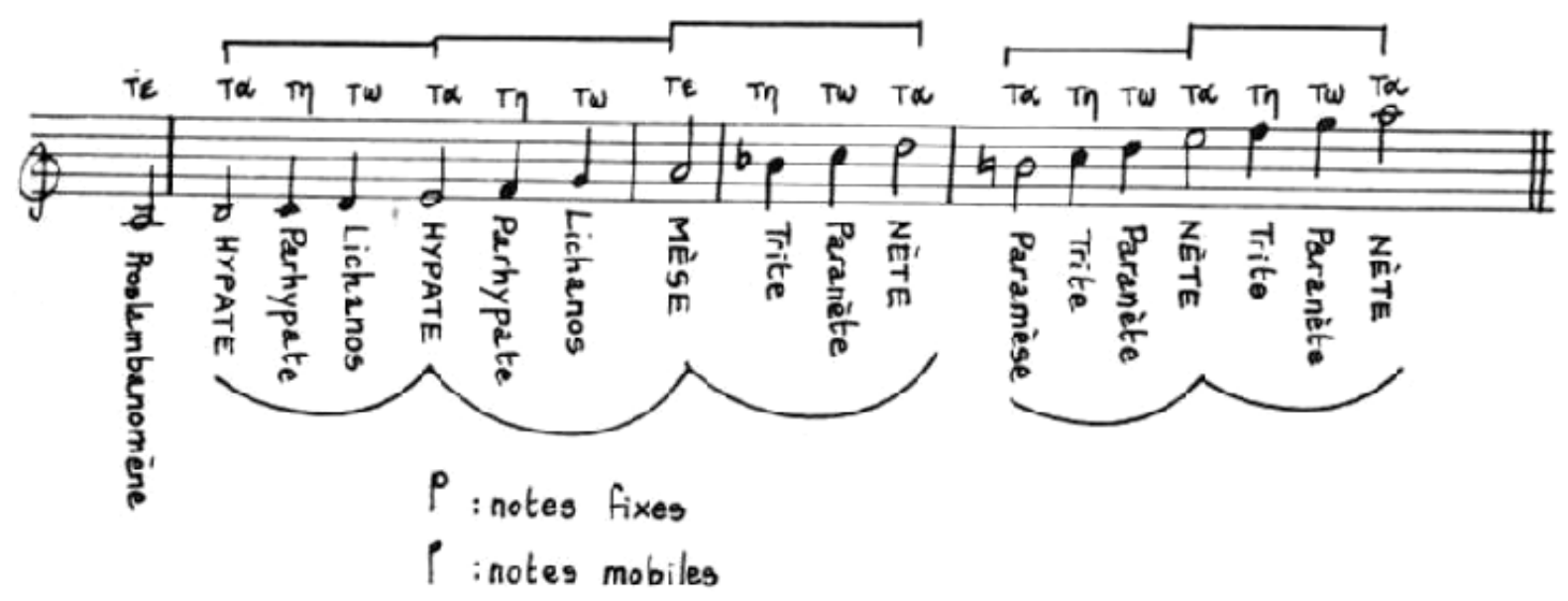

Fig. 12. Esquema de antigas notações musicais gregas. 
Assim, a seqüência de letras que antes era interpretada como TOTOTЕ ТОН $\leftarrow$, transformou-se em TOTOTE $\mathrm{TO}<\mathrm{T}>\mathrm{H} \leftarrow$, perfeitamente adaptável à interpretação da seqüência

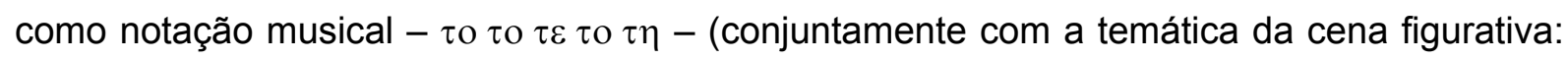
uma Amazona tocando um instrumento). Ora, apenas o acesso direto à peça proporcionou essa observação que se converteu em interpretação que inovaria em grande medida a gama de possibilidades dos usos das inscrições nos vasos gregos, e, ainda, apresentou o que seria a mais antiga notação musical grega conhecida (Idem, p. 107) - ver fig. $12{ }^{25}$

Por fim, ainda vale ressaltar a dificuldade em lidar com a falta de informações técnicas sobre os objetos, como, por exemplo, suas dimensões lineares; pois não é sempre que o interesse específico propõe uma análise dimensional, e, dessa forma, tais características não são apresentadas. ${ }^{26}$

Entretanto, esse cenário de dificuldades não compromete absolutamente a utilização desses objetos como documentos, mesmo que o contato seja indireto. Vale lembrar que o estudo dos textos antigos se desenvolveu em torno de documentação cujo acesso é indireto. O que os especialistas têm consigo (afora os registros estudados pela Epigrafia e a Papirologia) não são manuscritos de Aristóteles, Platão ou Sócrates; mas o produto de transmissão através da ação de copistas, o que não impede que, pensando nesses limites, se desenvolvessem importantes estudos. O mesmo vale para a fonte material. Para tanto é necessário que se estabeleçam bem os objetivos da análise e os limites das informações indiretas; assim, acredito, o uso indireto não desvia a possibilidade de um estudo coerente e profundo sobre objetos arqueológicos, mas defasa, em certa medida, algumas possibilidades de análise e interpretação.

Delimitação idêntica deve ser pensada quando são tratados objetos que, em grande parte, têm suas informações contextuais perdidas. Ou seja, mesmo que sejam desconhecidas as situações específicas do achado desses vasos (relações com outros objetos, com o espaço etc.) algo de sua materialidade pode indicar importantes traços de sociedades e contatos interculturais no Mediterrâneo; ora, quanto a isso, basta lembrar que a cerâmica ática é muito bem identificada (através do estilo e de análises químicas) ${ }^{27}$, e saber que foi achada

\footnotetext{
${ }^{25}$ Ainda, sobre o acesso indireto, e fora do campo da ceramologia, vale citar dois estudos: 1) Sarian (2005, p. $195)$ indica como o uso de gravuras renascentistas influenciou equivocadas interpretações sobre um relevo de Mitra Tauróctono; 2) Meneses (1998, p. 71-5) apresenta alguns problemas da utilização da descrição de Pausânias sobre a perdida Arca de Cípselo.

${ }^{26}$ Aqui, para uma relativa observação dimensional entre os vasos, ver o esquema 5 , p. 182 , das formas dos vasos áticos dos séculos VI e V a.C., com escala; o que, a despeito das pequenas variações entre um vaso e outro de uma mesma forma, indicam certas recorrências proporcionais e formais.

${ }^{27}$ É importante saber que mesmo objetos descontextualizados podem ser aferidos, quando for conveniente, sob métodos de datação como a termoluminescência (mesmo sem o sedimento associado, o que, é bem verdade, diminui a qualidade do controle dos resultados), e o Carbono 14 (Informações a partir de anotações do curso "Técnicas nucleares não destrutivas aplicadas ao estudo de objetos arqueológicos e de arte"; ministrado pelo Prof. Dr. Carlos Roberto Appoloni [24 a 26 de maio de 2006]). Ainda, vale ver Sarian, 1996.
} 
fora da Ática, mesmo que não se conheçam as condições exatas, isso pode elucidar, por exemplo, questões sobre o alcance das relações comerciais, ou trocas de outra natureza, em que estavam envolvidos tais vasos.

Novamente, trata-se de delimitar bem os objetivos de análise e entender os limites das informações obtidas. No caso deste estudo, então, as questões do uso indireto das fontes, bem como do desconhecimento das informações contextuais do objeto, devem ser levados em conta; propondo-se linhas de análise e interpretação coerentes a esse quadro que não impede a pesquisa, mas coloca novos limites e práticas.

Quanto às informações contextuais, elas são apenas parte do problema deste estudo; mas não devem ser rejeitadas. Ora, se se conhecem bem as formas e funções práticas dos vasos áticos, sabe-se que seu uso extrapola tais amarras, havendo, por exemplo, a utilização de vasos para misturar vinho com água (as crateras), como objeto encontrado em contexto funerário (é o caso do vaso François [ver cap. 3, fig. 74, p. 125], cujas informações contextuais são conhecidas). Nesse sentido, o problema da forma e função não é seguramente tratado a partir do corpus aqui constituído (ou seja, a partir de informações de cada peça e seu contexto arqueológico), mas se pode ampliar a análise usando algumas informações gerais. Um único vaso pode ser analisado dentro desse quadro amplo de possibilidades. Além disso, existem traços materiais que o objeto descontextualizado pode carregar consigo, como resquícios do conteúdo (vestígios de vinho, óleos, corantes etc.), marcas de uso (desgaste em uma determinada região, fragmentação, remontagem etc.), adições (inscrições riscadas em vaso de cerâmica etc.) dentre muitos outros.

Dizer, portanto, que o objeto no museu (cujas informações contextuais foram perdidas) não é apto à uma análise arqueológica é verdade apenas em parte; ou seja, se não se conhecem os contextos, importantes elementos da análise arqueológica, novas questões podem ser colocadas: a inserção em séries cujos contextos são bem conhecidos, o histórico da constituição da coleção, as novas funções de tais objetos nos tempos atuais, dentre outras possibilidades. A ação científica, neste caso, especificamente a arqueológica, vem, durante muito tempo, justificando a composição de acervos em instituições variadas, e pensar sobre essa dimensão da Arqueologia nos tempos atuais mostra-se indispensável. O arqueólogo não deve ser aquele que pensa apenas na instrumentação tecnicista ou num passado distante, mas também no impacto de sua ação no presente e perspectivas de futuro. Essa questão é das mais relevantes no tocante ao debate relativamente recente sobre patrimônio arqueológico, tendo em vista que a escolha do arqueólogo é decisiva na conformação de coleções, restauração e conservação de artefatos que sofrerão intervenções de cunho preservacionistas, e várias vezes assumindo valores de dimensão ideológica, política, propagandística etc. Contra uma visão-ação passiva, pensar sobre o próprio papel nesse cenário é imprescindível. 
A questão colocada é bastante pungente no campo da pesquisa de cunho histórico, e, no limite, trata da própria problemática do acesso à documentação, que nunca se trata de um acesso direto e integral, mesmo no caso de escavações (já que essa atividade arqueológica responde também a questões ideológicas, e tem limites físicos [nem tudo será escavado!]); assim, essas escolhas e percursos devem ser objeto de atenção do arqueólogo. No caso do acesso indireto, além das próprias questões relacionadas à pesquisa acadêmica, ele deve da mesma forma refletir sobre as escolhas do outro, daquele de quem retira informações. Por exemplo, deve-se saber que se as relações materiais entre escrita e figuração não foram amplamente estudadas, sendo objeto de alguns artigos, grande parte da documentação à disposição, indiretamente, foi adaptada de estudos que, originalmente, tinham outros objetivos, como obras de Arqueologia, Epigrafia e mesmo de História da Arte.

Essa breve discussão abre, inclusive, a possibilidade de verificação de certos "vícios" da bibliografia geral, pois, no que tange a vários dos manuais de arte e Arqueologia gregas, apresenta-se o que se considera uma produção "elevada" da Antigüidade, relevando obras, num intuito mais próximo do sentido de "grande arte" dos museus de arte contemporâneos. A produção subsidiária, de menor qualidade artesanal e afim, esta dificilmente aparece, e se não for dada atenção a essa situação, parece ao pesquisador que a produção artesanal grega era uníssona. Esses são documentos-monumento, como sugeria Le Goff (1997), e o percurso de "monumentalização" é de compreensão indispensável; no caso do pesquisador que obtém a documentação indiretamente, de forma dupla.

Ainda, esse uso indireto coloca a questão do pesquisador afastado dos grandes centros de pesquisa europeus ou norte-americanos. Não se trata de dizer que estes são necessariamente piores, menos informados ou que esse acesso indireto inviabilize sua atuação científica, mas que ele (sobretudo no que tange aos Estudos Clássicos relacionados à cultura material) deve ter maior atenção na sua constituição e interpretação documental.

A discussão sobre esses limites peculiares ao acesso e das próprias fontes aqui tratadas implica, num momento seguinte, na caracterização da interferência desses limites impostos às estratégias teórico-metodológicas antes apresentadas. Ora a adoção da linha contextualista da Arqueologia não se deu à toa, ela se justifica pela própria natureza da documentação, e o acesso tido, propondo-se estratégias interessantes de interpretação a partir da organização de um acervo num grupo relativamente coeso (os vasos áticos e seus grafismos), o que permite uma seriação e comunicação interna, mesmo que as informações específicas estejam perdidas. É a própria tarefa que Michael Shanks (1996; 2004) opera na análise dos vasos protocoríntios (por meio das modificações iconográficas), integrando-os num universo maior que o da própria cerâmica, alçando esferas como a política e a cultura.

Essa escolha não significa uma rejeição a priori dos ensinamentos importantes deixados pela Nova Arqueologia. Entretanto, as questões ambientais mais amplas (Lewis R. 
Binford ${ }^{28}$ ), e o próprio registro de formação dos sítios, através da compreensão dos contextos sistêmicos e arqueológicos (Michael B. Schiffer [1972 e 1976]), poderiam ser de grande ajuda, mas como utilizar tais instrumentos quando o acesso indireto impõe limites às vezes bastante severos?

Outro problema é a própria proposta de acompanhamento da trajetória complexa, inspirada na idéia de cadeia operatória. Bem, se se conhece bem a região de origem, e de produção desses vasos de cerâmica ornamentados (as oficinas áticas), e mesmo alguns locais de achado (a deposição em inúmeras tumbas estruscas, por exemplo), grande parte desses objetos chega até os dias atuais já como objeto de coleção, sem informações contextuais registradas. Muito do registro específico da difusão e deposição desses vasos não existe. Nesse cenário, como tratar das especificidades da recepção?

Contra isso, poder-se-ia observar a lógica da recepção desses vasos através de textos escritos, mas a tradição escrita guardou pouquíssimas informações sobre a cerâmica na Antigüidade; e os vasos per se não indicam necessariamente o gosto de quem os recebia na Ática, na Grécia ou em outros espaços do Mediterrâneo. Há, assim, algumas informações indiretas como certas recorrências (por exemplo, a grandíssima quantidade de vasos áticos encontrados na região da Itália, e uma posterior organização de oficinas ceramistas altamente influenciadas pelas formas iconográficas da cerâmica ática, tudo isso pode indicar algo sobre o gosto da população desse local); mas quando as informações de contexto são perdidas, esse tipo de análise dificulta-se ainda mais.

\subsection{Algumas características dos grafismos}

A documentação aqui selecionada trata-se de vasos de cerâmica ornamentados produzidos na região da Ática; sobre os quais será observado, no detalhe, um aspecto especial: a relação escrito-figurativa. A apresentação a seguir centrar-se-á em alguns pontos importantes no que se refere a essa dinâmica de articulação gráfica; mas sem perder de vista aspectos mais amplos, como a própria integridade dos vasos, e os universos variados em que estavam inseridos. Essas questões serão orientadas a partir de sua relevância quanto à articulação gráfica, escrito-figurativa. Seguem, então, três pontos para discussão: os cenários de inserção desses vasos; os tipos mais comuns de inscrições, de figurações e de articulações; e, por fim, as características formais dos vasos e grafismos, e as estratégias de comunicação interna, e, em certa medida, externas.

\footnotetext{
${ }^{28}$ Ver New perspectives in archeology. Chicago; New York: Aldine: Atherton, 1972; e For theory building in archaeology: essays on faunal remains, aquatic resources, spatial analysis, and systemic modeling. New York: Academic Press, 1977.
} 
Os pontos anteriormente tratados não devem ser esquecidos. Assim, deve-se esclarecer que o que se entende aqui como documentação privilegiada são os vasos de cerâmica, vistos como uma unidade, que podem ser observados a partir de uma seriação. ${ }^{29}$ Dadas as especificidades dos achados arqueológicos, muito do que se tem à disposição são fragmentos, em grande parte aptos a informarem algo de sua materialidade integral perdida; é, por exemplo, a partir disso que se estrutura a tarefa de reconstituição das formas. Entretanto, o fragmento deve ser observado como tal, ou seja, como objeto lacunar, o que não o inviabiliza como documento, mas as limitações devem ser tratadas. Os grafismos não são a documentação, mas apenas um aspecto dela; dessa forma, trata-se aqui, privilegiadamente, de uma dimensão específica desses vasos ornamentados, que, claramente, devem ser observadas com atenção à sua materialidade integral; ou ao menos, mais ampla.

Por fim, a observação da documentação apresentada, e as conseqüentes interpretações, serão feitas atentando-se nos limites peculiares ao acesso à documentação; o que impele, em alguns casos, a uma reflexão abstrata, mas sem uma apresentação sistemática dos dados relacionados, o que será anunciado convenientemente.

\subsubsection{Os cenários: produção, difusão, consumo e deposição/rejeição}

Anteriormente, foram indicadas algumas mudanças quanto à relação escritofigurativa, que se inserem, sobretudo, no quadro das modificações do próprio estilo ornamental da época (ver cap. 3, item 3.4); e o desenvolvimento das figuras negras foi observado sob o ponto de vista prioritariamente temporal. Algumas diferenciações, já ali, não se explicavam por questões cronológicas, já que em épocas coincidentes havia estratégias diversas no cenário dessa ornamentação. Para isso, basta lembrar que o uso da inscrição como elemento que "direcionasse o olhar" ou vetorial da cena, peculiares da ação criativa de certos vasos confeccionados por Exéquias, não incidem na criação ornamental de um contemporâneo seu: o Pintor de Amasis, que, na organização visual de suas inscrições, utilizava-se de outros meios. Nesse cenário, observa-se que mesmo um único grafista poderia criar "fórmulas" bastante diferentes de articulação escrito-figurativa.

As mudanças ao longo do tempo, ou a caracterização de diferenças numa mesma época, respondem também a outras situações: a que será tratada agora é a da aparentemente intencional diferenciação qualitativa; ou seja, cerâmica com diferentes qualidades de ornamentação para diferentes usos sociais, comerciais etc. Essa caracterização, que pode

\footnotetext{
${ }^{29}$ Cabe dizer que mesmo a idéia de série pode ser relativizada, tanto no que tange aos contornos de sua constituição antiga, ou mesmo os critérios de seriação na pesquisa atual. Por exemplo, séries de vasos áticos são estabelecidas, mesmo que esses tenham sido encontrados em locais de achado ou contextos muito diferentes, assim, em vários casos, a idéia de série submete outras importantes questões arqueológicas.
} 
parecer óbvia, serve, de início, à compreensão de um cenário bastante diversificado na produção de vasos ornamentados na Ática, e da absorção também variada; destoando de uma produção de altíssima qualidade, que buscasse características de originalidade artística, situação que permeia a interpretação em muitos manuais de arte e Arqueologia da Grécia antiga.

Essa discussão mostra-se bastante pertinente, pois a cerâmica com inscrições criadas em contexto original de produção, ao menos grande parte dela, provavelmente era socialmente bem avaliada no seio de uma sociedade onde a maioria das pessoas não era letrada. ${ }^{30}$ Vasos bem decorados e com inscrições formam um grupo que representa uma quase exceção no quadro da produção ceramista ática. Além deles, havia outros com ornamentação rápida (pinturas combinadas a incisões de forma esquemática), bem como vasos sem ornamentação figurativa (pintados com verniz, com faixas decorativas etc.); mas onde a figura humana, humanizada ou animais não apareciam. Ainda, nesse quadro diminuto, as estratégias de articulação com as imagens figurativas são bastante variadas.

Os motivos dessas diferenciações são discutíveis, e, no estágio atual do conhecimento, pouco conclusivos, permitindo encaminhamentos das questões através de interpretações indiretas; já que a experiência pessoal do artesão (os aspectos psicológicos), e sua relação com o mercado (encomendas, adesão a estilos bem aceitos etc.) têm difícil caracterização, dadas as poucas fontes, além dos próprios vasos, sua compreensão dentro de séries (continuidades e mudanças) e mesmo o mapeamento geográfico dos espaços de achado.

Os dados quantitativos relacionados ao comportamento desses grafismos são de grande importância, mas, dadas as limitações do acesso à documentação, eles só poderão ser inferidos também de forma indireta. Para melhor compreensão geral do quadro dos vasos que contêm inscrições e imagens no universo de vasos áticos decorados com a técnica de figuras negras, o levantamento quantitativo deveria sustentar-se em dois pontos básicos:

a) tal levantamento deveria ter três objetivos: o primeiro é verificar, quantitativamente, na produção ceramista ática do período arcaico, qual é a proporção entre os vasos ornamentados apenas com imagens e os vasos com inscrições e imagens. Depois, dentro do quadro dos vasos que contenham inscrições e imagens figuradas coexistentes, verificar qual o comportamento delas; por fim, entender em exemplos particulares qual a relação dessas articulações entre uma e outra face do vaso, e em outras regiões deles;

\footnotetext{
${ }^{30}$ Sobre a inserção da escrita e a prática de ler e escrever na Grécia do período arcaico, apóia-se, aqui, nas teses de Havelock (1996); ver também o capítulo 3, nota 30 (p. 104-5) desta dissertação.
} 
b) Seriam utilizadas apenas vasos inteiros nesse levantamento. Não por um fetiche pelo objeto integral, mas porque tratar os fragmentos nessa atividade específica pode indicar informações quantitativas equivocadas. Se, por um lado, haveria uma considerável redução do número de peças analisadas, por outro, há maior certeza de não tratar de forma errada as informações quantitativas; pois um fragmento com inscrição apenas revela a existência de uma inscrição e a dúvida da coexistência com imagem. De forma parecida, um fragmento que contenha apenas imagem figurada, revela exclusivamente a existência da imagem e a dúvida da coexistência com inscrição: um fragmento sem inscrição ou imagem, por sua característica lacunar, não revela absolutamente sua natureza. Apenas o fragmento com inscrição e imagem forneceria uma melhor noção no quadro geral, mais ainda assim haveria problemas, pois uma questão importante para se compreender é o comportamento das inscrições num mesmo vaso, o que o objeto lacunar, fragmentário, não responde. Assim, se a utilização de fragmentos, num estudo específico, pelo menos em sua grande parte, fornece informação quantitativa imprecisa, havendo a opção pelo levantamento a partir de vasos inteiros (mesmo que essa escolha seja até certo ponto arbitrária), isso não impede, na dinâmica da pesquisa, que se considerem fragmentos (alguns, como o de um dínos de Sófilo (ver cap. 3., fig. 71, p. 124), que apresenta uma inscrição do tipo legenda ao lado de imagens figuradas, têm sua importância).

A natureza das publicações não permite cumprir esses pontos básicos, havendo informações insuficientes mesmo em programas como o CVA. Quanto aos grandes manuais, vale lembrar, muitas das imagens dos vasos são apresentadas em detalhes ou apenas uma face ou região do vaso.

É relevante aqui a indicação de um relato da experiência em visitas a alguns museus, nos quais há vasos áticos de cerâmica nas exposições. Deve-se, entretanto, levar em conta que tais observações não levam em conta, por exemplo, todo o material que se encontra nas reservas técnicas desses museus; e mesmo a dinâmica muitas vezes arbitrária da aquisição desses objetos pelos museus.

Em primeiro lugar, permanecendo no Brasil, há uma expressiva coleção do MAEUSP (aproximadamente 200 peças, dentre vários vasos e alguns fragmentos), a que tive acesso, além da exposição permanente Formas de Humanidade (Mediterrâneo - Grécia e Roma), aos exemplares da reserva técnica, ${ }^{31}$ dos quais seis exemplares são de figuras negras (69/1 [vitrine 04], 76/3.122, 64/11.38 [vitrine 04, gaveta 03], 64/11.39 [vitrine-cenário],

\footnotetext{
${ }^{31}$ A experiência como integrante do projeto Corpus Vasorum Antiquorum, ministrado pela pesquisadora Haiganuch Sarian, de 2002 a 2004, proporcionou-me relacionamento direto com esses vasos, desde as atividades de medição, tiragem de coloração, descrição etc., até a organização das informações desses vasos e de sua bibliografia em banco de dados.
} 
64/11.42, 64/11.12 [vitrine 06]), nenhum deles contém inscrição, mas não apenas esses de figuras negras, não há um único vaso pertencente ao acervo do MAE-USP que contenha inscrições. Decerto, para uma experiência efetiva com vasos gregos que contenham inscrições, expostos em instituições no continente americano, é necessário visitar os Estados Unidos da América; mas, aqui, vale indicar a importante coleção de vasos gregos do Museu Nacional de Belas Artes de Havana (Cuba), que possui cerca de duzentos vasos gregos, dentre eles dez vasos com inscrições, inclusive uma ânfora panatenaica (ver Olmos, 1993).

É notória a inserção da atividade científica nas questões ideológicas. Por exemplo, a Arqueologia americana discute seriamente a primazia do homem na América, e apresentarse como "berço do homem americano", muitas vezes suplanta a pura pesquisa acadêmica e alcança as esferas de poder e submissão. No caso grego, deve-se considerar que se constituiu conhecimento intelectual profundo sobre a Antigüidade, em grande parte relacionado à atuação imperialista de alguns países como França, Inglaterra e Alemanha, que detêm (parcialmente hoje) várias áreas de escavação na Grécia, junto aos norte-americanos que entram nessa disputa já no século $X X{ }^{32}$ Nesse quadro, parece que possuir vasos inscritos representa fator "positivo".

Em alguns museus gregos, por exemplo em Atenas (o Museu Nacional, o da Ágora, o Goulandris e o Benaki), Eleusis, Délos e Míconos -, nota-se claramente grande desproporção entre vasos sem inscrição alguma, e os que as possuem (estes incidem em número bem menor, havendo exposições que não apresentam um único vaso inscrito). ${ }^{33}$ Isso indica, pelo menos inicialmente, que esses vasos com que se trabalha aqui, eram objetos menos incidentes. Charles Dugas (1924, p. 41) diz que

Os vasos assinados [portanto inscritos] que formam o orgulho de nossos museus, os vasos de Eufrônio ou de Brygos, constituem artigos de luxo cuja venda era insuficiente para fazer viver uma indústria (...).

Duas informações da inserção social desses vasos são apresentadas. A primeira é a do estatuto desses vasos gregos, sobretudo os que contêm inscrições, na contemporaneidade; assim, são eles objeto de grande interesse, o seu valor simbólico e de mercado são

\footnotetext{
32 Não é à toa que as línguas modernas essenciais no ramo da pesquisa sobre a Antigüidade clássica são o inglês, alemão, francês e italiano. Note-se que quase nunca é preciso consultar, para uma profunda pesquisa, as obras sobre a Antigüidade produzidas pelos gregos contemporaneamente; e inclusive sua citação em estudos variados sobre o tema é quase exceção.

${ }^{33}$ Essa observação deu-se em visita à Grécia nos anos de 2004 e 2006, nas quais participei diretamente de trabalhos de classificação e descrição de fragmentos e vasos de cerâmica, nos Museus de Delos, além das visitas às exposições de alguns museus de arqueologia, cujos acervos cerâmicos mais expressivos são os dos museus acima citados.
} 
diferentes dos da época de sua produção ${ }^{34}$ e sua atual inserção social também - hoje são objetos de arte e (ou) documentos. ${ }^{35}$ Depois, indica que a situação de menor representação desses vasos que chama "de luxo" não satisfazia na Antigüidade o comércio (eles eram a minoria dos vasos produzidos), e junto a eles era necessária uma produção menos luxuosa, cujo acesso era maior, de que não se tratará amplamente nesse estudo, o que indica alguns limites de penetração social desse tipo de vaso que suporte inscrição e figuração na sua ornamentação. Dugas não apresenta como chega a tal caracterização tão segura da produção de vasos assinados frente o quadro geral de vasos ornamentados (os dados quantitativos, por exemplo); entretanto, a observação mais generalizada (como a experiência pessoal acima citada), já indica isso. Ainda, para considerar com maior segurança a colocação desse autor, é importante saber que era ele um especialista em cerâmica, grega, inclusive a ática. $^{36}$

Nesse sentido, se há limites consideráveis na observação quantitativa desses grafismos, o apoio da discussão sobre a trajetória desses objetos, sobretudo concentrando-se nas questões da produção, pode elucidar um pouco do quadro relativo da produção desses

\footnotetext{
${ }^{34}$ Sparkes (1996, p. I) inicia sua obra indicando o grande valor monetário dos vasos gregos decorados na Contemporaneidade. Entretanto, na Antigüidade, seu custo não era tão alto, havendo teses que legam a esses objetos o papel de substituto menos nobre que os similares em metal (ver Vickers \& Gill, Artful crafts: ancient Greek silverware and pottery. Oxford: Clarendon, 1996; ver também Shanks, 1999, p. 38-9). O caso é que se pode traçar um relativo quadro de como eram avaliados esses vasos na Antigüidade. Dugas (1924, p. 40) dizia que "alguns textos e sobretudo inscrições gravadas nos dão uma idéia dos preços sob os quais os vasos eram vendidos. Eles variavam de um óbulo (cerca de 0 fr. 15 - quinze centavos de franco), que representa o valor de um lécito, provavelmente de pequenas dimensões, até quatro óbulos, que representa o preço de uma cratera". Dugas, quando informa isso, não apresenta a metodologia para a conversão do óbulo (dividendo do dracma) para o franco (que deve ser atualizado para os dias atuais, já que sua obra é de 1924). Quanto às fontes, ele cita uma inscrição sob um vaso, cujo o proprietário seria Képhisophon; e a peça A Paz, de Aristófanes (Idem). Sparkes (op. cit., p. 140-5) apresenta as fontes de forma mais clara, e ainda uma base antiga para comparação do valor relativo dos vasos: Aristófanes, em 405 a.C., n'As rãs (v. 1236), diz que um lécito (lekythos) cheio de óleo vale um óbulo. A base para se estabelecer uma idéia do valor relativo desses vasos advém de informações de inscrições fragmentárias de uma estela de Eleusis, de c. 414-413 a.C., na qual se observa, por exemplo, o valor monetário de uma escrava estrangeira (150 dracmas) e de uma ânfora panatenaica (três óbulos), sendo um dracma equivalente a seis óbulos. Há ainda algumas poucas indicações dos artesãos, inscrições riscadas nos próprios vasos, às vezes, sob sua base, apresentando o seu preço (ver fig. 13).

35 "Nas coleções, justamente, tem-se o esvaziamento total das funções originais das coisas, de maneira que, por exemplo, um tapete deixa de ser uma cobertura de solo, uma arma de ser um artefato de ataque e defesa, em suma, um vaso deixa de ser um vaso, um relógio deixa de ser um relógio e tudo isso se transforma em 'objetos de coleção'. O museu é o lugar privilegiado em que esse esvaziamento se institucionaliza, em que se promove essa espécie de exílio do objeto de seu campo próprio, em que se dá, vamos dizer, essa alienação das coisas. É preciso pois ter em mente que transformar um objeto em documento é quase sempre uma violência feita à sua natureza original de objeto" (Meneses, 1980, p. 5); vale, ainda, uma citação de Vidal-Naquet (2002, p. 195), sobre a mudança do estatuo desses vasos: "De qualquer forma, a Antigüidade resiste, e Eufrônio, um pintor e oleiro do final do século $\mathrm{VI}$, do qual nenhum texto jamais nos falou e de quem um contemporâneo de Platão certamente jamais teria ouvido pronunciar o nome, está sendo exposto neste momento no Louvre, o que teria surpreendido muito Isócrates, que se indignava só em pensar que um 'sofista' pudesse compará-lo com um copista, e Fídias com um pintor de pequenas cenas, como era Eufrônio. De qualquer forma, viu-se mesmo em Paris, no metrô, uma exposição que se chama 'a cidade das imagens', uma expressão que nem Eufrônio, nem Ésquilo e nem Péricles teriam seguramente compreendido (e essa observação não sai da minha boca como uma crítica)."

${ }^{36}$ Numa listagem de títulos produzidos por esse autor, apresentada na coletânea póstuma Recueil Charles Dugas (Dugas, 1960), de 65 títulos listados, pelo menos 24 são sobre vasos de cerâmica.
} 
vasos de cerâmica ornamentados. ${ }^{37}$ Nessa trajetória, a questão da especialização das tarefas (no caso, a da atividade artesanal ceramista e as variadas tarefas que a integravam) deve ser considerada, bem como a sua comunicação com um universo mais amplo. Geralmente as questões que propõem uma análise mais ampla, que se interessa pela relação entre a ação artesanal e a sociedade que integra, dá-se na fase do uso ou da produção imediata que precede esses uso; mas essa não precisa ser uma regra rígida.
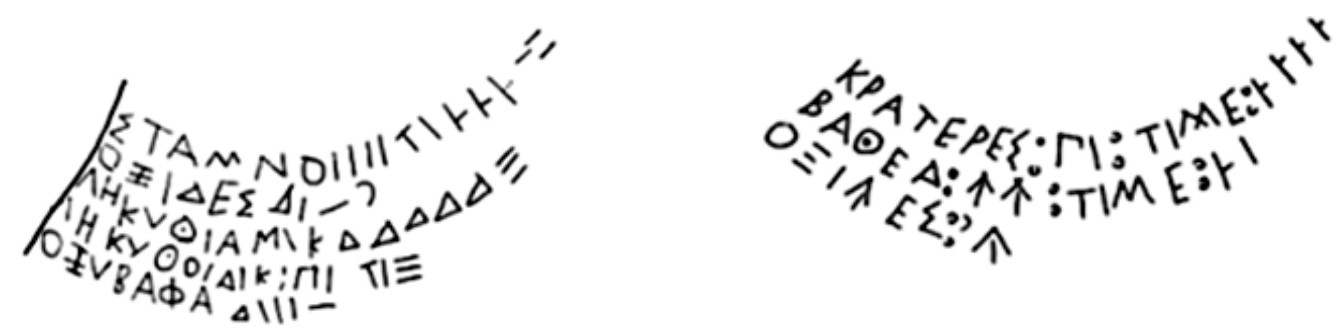

Fig. 13. (à esquerda) Graffiti sobre uma pélike ática de figuras vermelhas (Nikias Painte[?]): Stamnoi 3; preço 3 dracmas, 3 óbulos. Oxides 11; 1 1/3 óbulos. Lekhitoi, small 50; 3 óbulos. Lekhitoi, normal 6; preço 3 óbulos. Oxybapha 13; 1 óbulo . Metade do século V a.C.; (à direita) Graffiti sob base de uma cratera em sino de figuras vermelhas (Kadmos Painter): Crateres 6; preço 4 dracmas. Bathea 2; preço 1 dracma, 1 óbulo. Oxides 12.

Mesmo numa análise gráfica, pode-se começar pelas atividades anteriores ao ato de aplicar a ornamentação no suporte, ou seja, a própria articulação produtiva desse suporte (desde questões ligadas ao dispêndio de energia envolvido nessa situação, até as formas e os modelos de composição do suporte). Nesse contexto, a análise ampla, que integra questões do meio artesanal e a sociedade, deve ser empreendida. Ou seja, é preciso considerar que a quantidade de esforço gasto na captura de matéria-prima, seu transporte e produção básica desses objetos estão ligados, em algum nível, com as demandas sociais envolvidas no processo. Captura-se argila o suficiente para cumprir determinadas necessidades, e mesmo quando se armazena, a idéia de uma provável demanda futura coloca-se. A quantidade de trabalho (profissionais variados ou o número de repetição de uma tarefa), se existe uma equação viável para alcançar tal dado, ela deve ser analisada levando-se em conta essas variantes sociais importantes. Além disso, o tratamento da cerâmica atendia a um número grande de necessidades (a cerâmica ornamentada, a de transporte, objetos feitos no torno, à mão, ou em moldes etc.). Assim, cada uma dessas categorias necessitava, em algum nível, de um tratamento específico da matéria-prima; e essa variedade de objetos servia a um mercado que impunha, em parte, esse ritmo e variedade produtiva.

\footnotetext{
${ }^{37}$ Compreender a trajetória desses objetos não significa estabelecer uma biografia do objeto por si mesma; o intuito é observar as ações humanas que a estruturam. Desse ponto de vista, a compreensão será sempre relacional (objeto-homem/sociedade [homem-homem]). A tendência de criar "biografias de objetos" não se restringe a um esforço antiquarista, mas a própria discussão arqueológica, em tempos recentes, pautada em uma entonação biografista (ver Holtorf, 2002). Ver também Schiffer (1976, p. 28-9 e 34-6) sobre a seqüência de comportamentos (Apud Holtorf, op. cit., p. 51), sobretudo quanto a passagem do sistema arqueológico para o sistêmico $(A \rightarrow S)$.
} 
A partir desse cenário, vê-se que não é apenas sob o ponto de vista do uso, ou da situação da encomenda que se estrutura essa cadeia de atividades, bem esquematizada pelo modelo de cadeias operatórias ou mesmo o esquema do ciclo de elementos "duráveis" (Schiffer, 1972, p. 158-9), mas a partir de demandas, projetos, probabilidades e um cenário tradicional que se impunha sobre a sociedade ática, a atividade artesanal ceramista, e mesmo um mercado consumidor. Propõe-se, então, pensar em quatro campos definidos e interdependentes, que não serão tratados profundamente um a um, mas que devem ser considerados, direta ou indiretamente, na análise:

1) Produção: não somente o momento da produção dos vasos, mas o universo amplo relacionado e essa tarefa; ou seja, uma dinâmica bastante complexa de tarefas que envolve desde a captura de argila até o acabamento do vaso;

2) Difusão: tratamento das realidades espaciais que vão da distribuição local (Ática, Grécia) até o quadro regional (Mediterrâneo - tratado de forma geral e selecionandose alguns exemplos específicos). Há que se considerar também, neste ponto, as relações entre tais realidades geográfico-espaciais;

3) Consumo: lógica do consumo, sua diversificação: desde a utilização prática desses vasos em situações variadas, e especificamente a recepção dos grafismos;

4) Deposição/rejeição: afastamento das dinâmicas de consumo primário, por imobilização ou descarte.

Observar os grafismos sob o ponto de vista de sua trajetória complexa, coloca algumas questões importantes, sobretudo no cenário do que se compreende como Arqueologia Clássica ou Arqueologia Histórica. Como visto, muito do contexto (as condições de achado) dos suportes desses grafismos, os vasos de cerâmica, foram perdidas. ${ }^{38}$ Observando os estudos específicos que utilizam abundantemente esses instrumentos metodológicos, notase que as informações contextuais são importantíssimas. Entretanto, a preocupação com a compreensão do objeto em sua trajetória complexa busca relacioná-lo em determinada situação a um quadro bem mais amplo. Ora, as informações sobre os espaços de captura de matéria-prima, de produção, de utilização nem sempre são tão claramente observáveis a partir da materialidade da relação objeto-ambiente, e muito dessas informações são constru-

\footnotetext{
${ }^{38}$ É importante lembrar que mesmo quando se registrou informações contextuais em escavações ao longo do século XX, muitas informações importantes foram perdidas (e mesmo hoje, perde-se), já que existem limites na pesquisa arqueológica concernente à própria prática científica de sua época.
} 
ídas sob interpretações prováveis. Assim, a procura de uma fonte de argila pode funcionar como informação arqueológica para se estabelecer elos entre o local de produção, uso, deposição e de captura da matéria-prima.

$\mathrm{Na}$ situação específica dos vasos áticos, as informações sobre o espaço (e mesmo as condições) de sua produção são amplamente conhecidas. Tem-se um importante dado (seguro) na composição do cenário de sua trajetória. Mesmo que esses vasos em grande parte sejam descontextualizados, as informações do seu pólo produtivo remetem a um contexto histórico bem delineado. Entretanto, deve-se discutir mais essa informação, não no que se refere ao espaço simplesmente, mas no tocante à situação da produção ceramista, focando-se exclusivamente (por questões de delimitação temática aqui proposta) na produção dos vasos ornamentados.

Falar em produção e a grande variedade de tarefas que a compõe, impele, pelo menos brevemente, a comentar as questões sobre o desenrolar do tempo, tendo como referência as mudanças já delineadas do período arcaico. De início, de forma generalista, colocamse duas situações diferentes relacionadas à produção:

a) uma produção relativamente estranha, que integra a sociedade como novidade, ou seja, é apresentada num contexto em que é desconhecida, e onde as mudanças formais são mais expressivas;

b) uma produção que responda a demandas específicas, bem delineadas (objetos já conhecidos no seio de sua sociedade), e onde as modificações formais são menores.

Essas duas situações apresentam cenários bem distintos: num primeiro momento, uma maior diversificação (em um curto espaço de tempo) e busca de adaptação; e depois um cenário de estagnação. Observar a produção a partir dessas duas balizas (e do processo que vai de uma à outra) coloca questões importantes sobre os modos de produção; ou seja, a quantidade de argila que deve ser capturada, de pigmentos para a ornamentação, e o mais importante, a quantidade de energia humana dispensada nesse processo. Os diferentes cenários apresentam, certamente, situações diferentes no contexto das oficinas ceramistas.

Neste ponto, é viável situar a produção desses grafismos nesse cenário. As atividades relacionadas à produção ceramista são variadas, e nem todas têm relação direta com a confecção dos grafismos. De outra forma, pode-se dizer que tais grafismos localizam-se no estreitamento de um "funil" que tem como cenário amplo as criações mais variadas (materialmente articuladas ou não). É claro que algo desse cenário acaba sendo diretamente ligado à criação desses grafismos, mas muitas situações são distantes, e não se pode estabelecer 
relações tão claras de início (ver esquema 1). O artesanato cerâmico era bastante variado, dando origem a objetos também variados, muitos deles com formas, funções e usos completamente diferentes dos vasos de cerâmica ornamentados. Ainda, vale dizer, que no grupo concernente aos vasos de cerâmica ornamentados há certa variedade no que se refere ao tipo de ornamentação, e ao comportamento dela nos vasos. Assim, mesmo no diminuto grupo de vasos com inscrições e imagens coexistentes, pode-se encontrar vasos em que, na confecção original, houve apenas preocupação com a produção de imagens, e inscrições foram inseridas posteriormente. Privilegia-se neste estudo ambas as criações em contexto original, ou seja, aqueles vasos que possuam inscrições e imagens confeccionas pelo mesmo autor, o grafista.

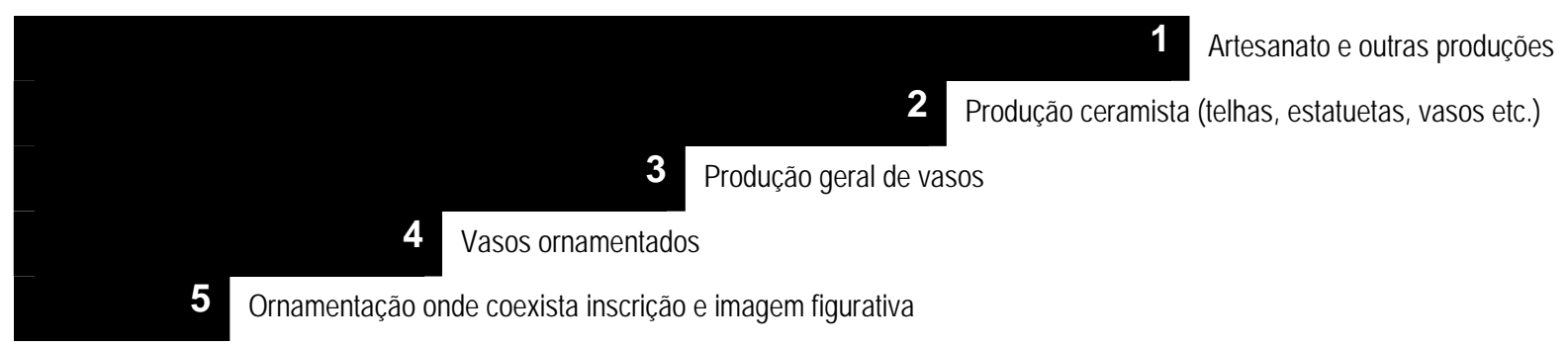

Esquema 1. Grafismos sobre a cerâmica, relacionados a outras produções mais amplas.

Além da criação dos grafismos, frente a uma produção ceramista maior, este esquema indica um ponto importante da documentação: a sua seleção. Ora, se se preocupa aqui com uma entonação específica da experiência dos homens antigos que tinham algum tipo de contato com esses vasos, ela é apenas uma faceta de um todo bastante complexo. Preocupar-se com qualquer entonação específica é devido, tendo-se em vista uma observação contígua de sua inserção num contexto mais amplo.

De início, deve-se dizer que dentro do quadro artesanal, mesmo especificamente o ceramista, a produção caracterizada por grafismos escritos e figurativos (coexistindo ou não) é apenas um aspecto; e quando se trata da existência de inscrições, essa produção torna-se ainda mais delimitada. Entretanto, isso que apresentaria uma séria limitação pode apresentar uma linha contrária, ou seja, a observação pela ausência. Nesse caso, a ausência de uma ampla produção ceramista que articulasse escrita e figuração num mesmo suporte apresenta um determinado cenário no âmbito da produção artesanal ceramista e mesmo no que se refere ao universo bem mais amplo: o dos consumidores desses grafismos.

Depois de caracterizadas, em parte, algumas dinâmicas da inserção dos vasos de cerâmica ornamentados, partir-se-á para a caracterização específica; ou seja, as formas gráficas presentes nos vasos, tendo-se em mente que elas devem ser observadas retomando as questões acima apresentadas sobre seu contexto. Assim, nesse quadro, o que signifi- 
ca realmente nomear uma figura com uma inscrição ou propor diálogos nas superfícies dos vasos ou entre vasos; ou seja, desde a produção e fruição dessas mensagens? As respostas passam, certamente, pela compreensão material desses grafismos, mas também de sua inserção social.

\subsubsection{Tipos de imagens, de inscrições e de articulações gráficas}

A ornamentação gráfica (escrito-figurativa) presente na cerâmica ática possui algumas tendências que é preciso situar. De um lado, alguns tipos de imagens recorrentes tratadas por alguns especialistas a partir de agrupamentos como imagens da "realidade" e do "cotidiano"; de outro, as inscrições formam grupos organizados quanto ao conteúdo, nos termos de Boardman (2003, p. 110):

(...) [as] inscrições sobre vasos áticos designam uma das figuras na cena, ou elas saem de uma boca como uma verdadeira 'legenda', ou elas são assinaturas de artistas, ou livres menções elogiando a beleza de garotos em geral (ho paîs kalós) ou de um rapaz em particular (Leagros kalós, etc.), ou não têm sentido, ou permitem que o vaso fale por ele mesmo, ou são dedicatórias, e há um ou dois títulos de cenas.

E complementa Cook (1992, p. 241-8), quanto à sua técnica, que elas poderiam ser feitas antes ou depois da queima (para ele, a distinção material mais significativa, em torno do que organiza algumas outras distinções: pintadas, incisas ou estampadas). Cabe, ainda, lembrar que elas, inicialmente, seguiam modelos coríntios já razoavelmente estabelecidos, e que um maior grau de originalidade dar-se-ia apenas em meados do século VI a.C.

Essa caracterização aborda as inscrições que compunham a ornamentação no contexto original de produção. Pode-se, então, assinalá-las como inscrições pré-queima, mas é importante saber que essa determinação é prioritariamente técnica e ligada a uma organização seqüencial. Diferente disso, dizer que são inscrições feitas em contexto original de produção propõe ressaltar as características da ação artesanal de forma mais abrangente. Assim, por oposição, ou melhor, pela diferença, pode-se pensar no quadro das inscrições pósqueima, ou seja, produzidas fora do contexto original de produção. Essa distinção é mais aguda e quase exclusiva no que tange a criação gráfica (pré ou pós-queima) das inscrições, e não quanto às imagens figurativas. Assim, ao se falar no quadro das intervenções gráficas depois do vaso finalizado, deve-se pensar prioritariamente na produção de inscrições.

Esses grupos (o das imagens figurativas e o das inscrições) são geralmente analisados de forma específica, deixando-se de lado as variações num mesmo vaso. Nesse senti- 
do, há inúmeros estudos sobre imagens mitológicas, e como informam algo sobre a constituição e organização da personagem ou cena mitológica; ou mesmo das fórmulas peculiares de inscrições como as de autoria (epoiesen [fez] e egrapsen [desenhou]), e sua complexidade (ver Beazley, 1949; Cook, 1971; Eisman, 1974 e Seeberg, 1994), estudos próprios da linha filológica da Epigrafia (as questões formais e dialetais das inscrições, sobretudo das mais antigas - Powell, 1999; Ferrari, 1987); e, por fim, os estudos que mais aproximam os dois domínios são os de iconografia mitológica, que lançam mão da relação entre inscrição e imagem figurativa para a caracterização de determinadas figuras mitológicas; e os de autoria, combinando as inscrições de autoria às peculiaridades estéticas próprias da criação de determinados artistas, oficinas ou grupos.

Aproveitando essa discussão, e ampliando-a em alguns aspectos (procurando articular as discussões isoladas) que se desenvolverá este item. O ponto de partida é a relação básica que existe entre escrita e figuração: a aproximação num mesmo suporte a partir da criação do artesão da Antigüidade.

Uma comum dicotomia relacionada à temática das cenas figuradas nos vasos áticos pauta-se em situações tratadas como opostas ou extremamente distantes, as "cenas da realidade" e "cenas mitológicas". ${ }^{39}$ Nesse sentido, as "cenas da realidade" representariam atividades do cotidiano (colheita, artesanato, prática funerária, o simpósio, a guerra etc.); e as "cenas mitológicas", as mais variadas histórias relacionadas às narrativas de mitos. Deuses, monstros, heróis, dentre outros, povoariam esse grupo de imagens. Um claro discernimento estabelece-se então.

É possível compreender uma delimitação temática e até formal entre elas, mas levando em conta que as várias estruturas relacionadas às sociedades gregas confundiam-se, interagiam de forma bastante densa; não é possível levar em frente qualquer discussão sobre os gregos antigos sob um ponto de vista particularmente atual e contemporâneo; distinções tão precisas entre esferas como a cultura, política, economia etc., mais comuns à perspectiva liberal, e que não faziam parte da vida dos antigos. Essa impossibilidade passa pela própria caracterização do que seja, conceitualmente, mito e realidade entre os gregos. ${ }^{40}$

\footnotetext{
${ }^{39}$ O grande banco de dados disponível na Internet, The Beazley Archives, divide a temática dos vasos da seguinte forma: "Deuses", "Heróis e Mito" e "Vida Privada"; correspondente, de certa forma, a essa noção delimitativa. Vale dizer, esse tipo de levantamento privilegia a formação de agrupamentos iconográficos, preocupando-se menos com o suporte e as informações que ele poderia oferecer.

${ }^{40}$ Como aconselha Jan Bažant (1981, p. 14), a linha que se deve tomar é a da compreensão das condições históricas em que está inserida a idéia de realidade entre os gregos antigos. Isso permite observar elementos da concepção antiga da realidade, presente tanto nas caracterizações do mito ou do cotidiano. Inicialmente, é necessário saber que "o que nós chamamos de mitologia era, para os gregos, a antiga história de seu próprio povo" (Shapiro, 1997, p. 1). A narrativa literária mostra uma aproximação entre esses mundos: por exemplo, "os casamentos entre deuses e mortais é uma prática bem ilustrada por Homero" (Idem).
} 
Vale dizer que a figuração de qualquer divindade, mesmo com a inserção de elementos animais, carrega consigo um definidor elemento da realidade: o próprio corpo humano; seja ele idealizado ou esquemático, a referência é clara. Observando esse fundamental traço da realidade humana é incoerente caracterizar dois grupos com tanta exclusividade. Traçar diferenciação entre cenas da mitologia e do cotidiano não significa separar o mito da realidade, estando esta mais próxima do cotidiano. Ambas as expressões relacionavam-se com uma concepção de realidade entre os gregos. Só se pode fazer uma categorização cotidiano/realidade ou mitológico se ela for abertamente generalista, levando em conta os próprios limites. Adicione-se a isso, a possibilidade de encontrar-se nas "cenas do mito" elementos históricos como, por exemplo, a indumentária dos gregos e dos não-gregos (caracterização bastante comum nas representações de batalhas mitológicas como a Gigantomaquia, Amazonomaquia etc.). Nos termos de B. A. Sparkes (1996, p. 133):

(...) [essa] dicotomia, como eu disse, é falsa. Aquiles é cada filho de mulher pronto para a batalha, Alceste é uma esposa ateniense aprontando-se para seu marido. As cenas heróicas fornecem como a indumentária atual da época do pintor, como se os pintores soubessem como alcançá-lo. (...) os deuses e heróis eram mais reais na experiência humana que algum companheiro humano; eles estavam diariamente presentes no culto e em imagens que povoavam santuários e locais públicos. ${ }^{41}$

Nessa mesma linha, é interessante o caso apresentado por F. Lissarrague acerca da temática da ornamentação de taças utilizadas no simpósio (Lissarrague, 1990a). Ele analisa algumas taças de figuras vermelhas nas quais há uma aparente divisão temática: numa face das taças, a própria caracterização de cenas do simpósio, na outra, geralmente uma cena mitológica. O importante é indicar que essa divisão pura e simples não atende à compreensão da inserção desses objetos e suas imagens no simpósio. A mensagem que fica é a que ambas figurações estão ligadas à moralidade do evento (o simpósio) e uma divisão muito restritiva não é possível.

Mesmo J. Boardman, que acredita na eficácia dessa divisão, confessa que, em alguns casos, "requerem-se apenas inscrições nomeando heróis para traduzir (...) [um guerreiro figurado] ao mundo do mito" (Boardman, 1995, p. 205); ou seja, duas imagens figuradas, praticamente idênticas, podem ser interpretadas como representante "do mito" ou "da realidade", contando apenas com a especificidade de uma inscrição que a nomeia. Assim,

\footnotetext{
${ }^{41}$ Vale ainda apresentar alguns pontos dessa discussão. Meneses acredita que "a narração pura e simplesmente histórica não tinha voga entre os gregos, que sempre a transpunham para um plano dramático ou da reflexão moral do mito. (...) Mas, muitas vezes, a transposição para esse plano mítico partia de elementos realistas observados com bastante acuidade. (...) Em suma, mesmo quando a arte grega 'idealiza', ela emerge de uma realidade vivida em todas as suas dimensões" (1965, p. 260). Numa outra proposta, Boardman vê esse grande potencial nas "cenas da realidade", que dariam "uma valiosa imagem da vida em Atenas e da zona rural" (1995, p. 205).
} 
qual a verdadeira fronteira entre a figuração do mito e da realidade: uma inscrição, um atributo?

A necessidade de especificação revela uma base comum, que só pode ser delimitada a partir de adições, intrusões, que discriminarão o comum (o que responde pela generalidade) do herói, do deus ou de outra entidade específica. Nesse ponto, a própria discussão gráfica aqui proposta apresenta viabilidade; isso, já que as inscrições relacionadas a uma imagem podem mudar definitivamente a sua compreensão e seu estatuto; ou seja, confere a uma imagem figurada valor diferenciado (ver esquema 2). Há elementos que aproximam e que distanciam a natureza das cenas figurativas sobre os vasos aqui tratados; e é importante entender essa dupla dimensão antes de estabelecer uma diferenciação a priori, a partir de conteúdos "mitológicos" ou "realistas"...

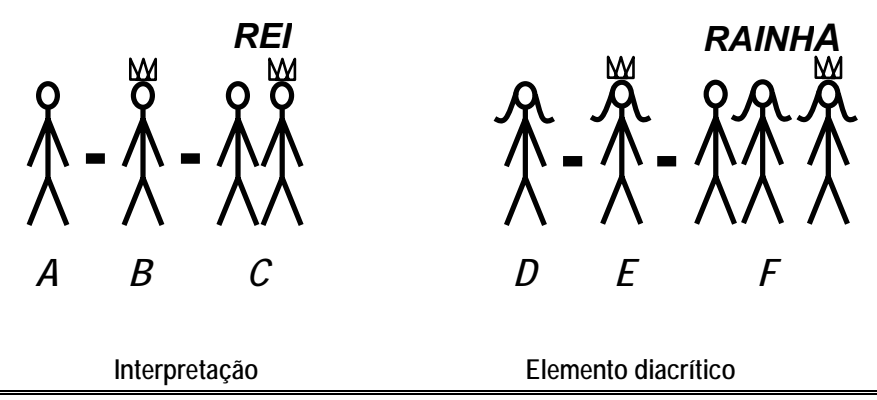

Ser humano (representa- Não há, a interpretação dá-se pela conceitual A ção geral), homem (sexo articulação proporcional entre cabeça, tronco e masculino) membros

B Rei

C Rei

D Mulher (sexo feminino)

E Rainha

F Rainha
Representação de coroa sobre a cabeça

Legenda "REl", que pode ser combinada à coroa sobre a cabeça para a interpretação

Representação de cabelos longos

Combinação do cabelo longo, com a coroa sobre a cabeça

Inscrição "RAINHA", que pode ser combinada à representação do cabelo longo e (ou) à da coroa
Esquema 2. Imagens e inscrições (interpretações)

Sem a especificidade da legenda escrita, pode haver interpretação diversa. A coroa, atributo que identifica o rei, pode ser, por exemplo, um chapéu de palhaço ou um cocar, e mesmo os cabelos longos que permitem interpretar que seu portador seja uma mulher, pode ser apenas a indicação de uma pessoa, homem ou mulher, de cabelos longos (sabe-se, por exemplo, que na Grécia antiga, em determinado contexto, os cabelos longos não marcavam signo de delimitação sexual, mas a cidadania).

Nesse sentido, a interpretação deve levar em conta os significados desses vários elementos e suas articulações possíveis em determinadas culturas e épocas, já que, como visto, o que para nós pode ser um rei e uma rainha, em outros contextos pode ter interpretação diversa.

Cabe salientar, que $B, C, D, E$ e $F$, mesmo imbuídos de elementos diacríticos que os distingam do quadro geral "ser humano", ainda assim se referem genericamente a um grupo. Apenas inscrições como, por exemplo, "REI LUÍS XIV" ou "RAINHA ELISABETE", ou atributos muito mais específicos, poderiam caracterizar uma atestada individualidade.

Aproveitando as informações do esquema 2, é importante pensar no que se chama de nomeação de determinada figura. Ora, materialmente falando, isso significa uma aproximação entre uma imagem figurativa e uma inscrição. É essa proximidade que vem sendo chamada de nomeação, mas não apenas isso: é preciso levar em conta que deve haver certa correspondência lógica entre a figuração e a inscrição. Assim, se uma imagem, caracteristicamente interpretada como Atena, estiver próxima de uma inscrição "Héracles", isso não significa que a imagem figurada seria de Héracles. Observando a figura 14, nota-se a inscrição HEPAK $\Lambda \mathrm{E} \Sigma$ entre duas figuras: uma masculina, em luta contra um leão, e outra, feminina, com escudo e capacete. Fisicamente, a inscrição está próxima das duas imagens 
figurativas de forma equivalente; entretanto, do ponto de vista de sua composição lógica, é uma inscrição que caracteriza a figura masculina (lutando contra um leão) e não a feminina, Atena. No que se refere à mentalidade do grafista, isso significa que a inscrição, por si só, não é o bastante para caracterizar determinada figura; e que as características figurativas ainda são um "teste" que coloca à prova interpretações atuais da caracterização da figura pela inscrição.

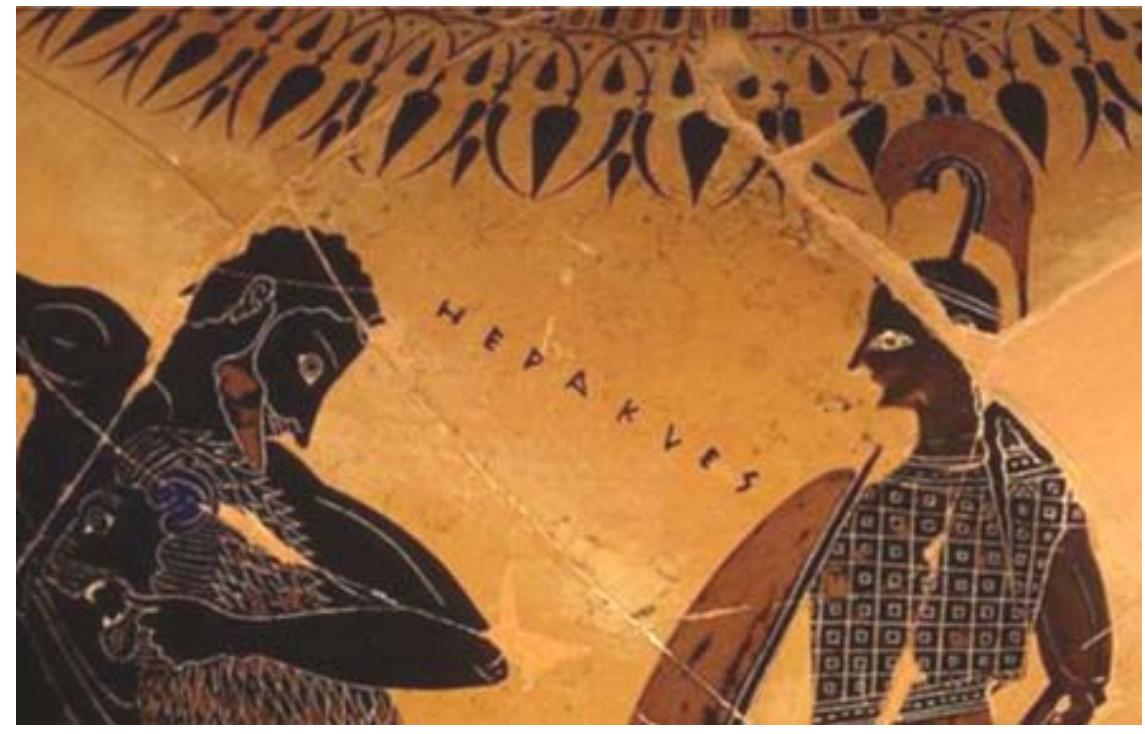

Fig. 14. Detalhe de ânfora ática assinada por Exéquias, c. 545-540 a.C., Berlin, Antikenmuseen.

A inscrição, nessa linha de interpretação, é compreendida, freqüentemente, como um atributo da imagem figurativa. Ora, mesmo quanto aos atributos figurativos, adverte Berárd (1983) que as caracterizações das figuras mitológicas, feitas no seio dos estudos iconográficos, não podem ser absolutamente diretas. Uma figura feminina com elmo, escudo e lança não é necessariamente Atena. A observação da organização da cena (a lógica figurativa) deve ser pensada. Assim, além de Atena, tais atributos podem identificar, por exemplo, uma Amazona. Nesse sentido, o atributo não caracteriza diretamente uma figura, e o mesmo deve-se pensar sobre as inscrições nominativas; e a composição da cena, a disposição das inscrições, devem ser pensadas tanto do ponto de vista material como de sua articulação lógica.

Pode-se mesmo, observar essa situação do ponto de vista da comunicação entre "emissor" e "receptor": tanto na produção como na fruição, a correspondência lógica entre a imagem figurativa e inscrição era necessária para uma efetiva comunicação. ${ }^{42}$ Nesse sentido, o não reconhecimento de alguns códigos iconográficos (como a caracterização de uma

\footnotetext{
42 Trata-se da caracterização de um cenário ideal, ou seja, da crença em um emissor (no caso, o grafista), que teria como paradigma um consumidor-fruidor que compreendesse absolutamente suas mensagens. É claro que há descompassos entre esses dois "atores", mesmo quando se pensa que essa relação poderia ser mediada pela situação da encomenda. Especificidades da experiência social de cada um deles, por exemplo, poderiam comprometer sensivelmente o quadro comunicativo; isso, se se pensar que havia realmente um interesse comunicativo mais forte que o estético nessa produção de imagens e inscrições.
} 
figura por meio da articulação lógica entre ela e seus atributos) ou da mensagem escrita (seja por desconhecimento do sistema de escrita, ou por variações dialetais), diminui sensivelmente a possibilidade de compreensão da mensagem, fruto da interação escritofigurativa. Entretanto, não se pode deixar de lado o caráter amplamente estético dessa relação, no caso das inscrições "sem sentido" ou pseudo-inscrições; isso, mesmo quando o grafista cria imagem e inscrição a partir do sistema lógico acima explicitado, pois se o receptor de sua mensagem não é apto a reconhecê-la, não se impede o reconhecimento básico dessa da proposta colocada: até aquele que não conhecia o referente e referencial; ou seja, as figuras e inscrições áticas, e o universo específico (mitológico e não mitológico) a que elas remetiam, poderia facilmente reconhecer que se tratava de informações escritas e figurativas a que não se podia interpretar com mais profundidade.

O caso da nomeação das figuras é apenas uma forma de relação entre inscrição e figuração, onde a articulação dá-se pela logicidade e aproximação física. Entretanto, há múltiplas possibilidades, pois há várias categorias de imagens e de inscrições. Como exemplo disso, retomar-se-á a ânfora de Exéquias (ver cap. 1, fig. 1, p. 38 e cap. 3, fig. 81 e 82 , p. 129 e 131), a partir do seguinte quadro:

\section{Face A}

\begin{tabular}{|c|c|c|}
\hline Imagens & $\begin{array}{l}\text { Luta entre Aquiles* e Pentesiléia (inter- } \\
\text { pretação a partir de aspectos iconográfi- } \\
\text { cos e de inscrições nomeando) }\end{array}$ & $\begin{array}{l}\text { Encontro entre Dioniso e Oinópio (inter- } \\
\text { pretação a partir de aspectos iconográfi- } \\
\text { cos e de inscrições nomeando) }\end{array}$ \\
\hline Inscrições & $\begin{array}{l}\text { AXI } \Lambda \text { EY } \rightarrow \text { (Aquiles) } \\
\Pi E N \Theta E \Sigma I \Lambda E A \rightarrow(\text { Pentesiléia }) \\
\text { EX } \Sigma \text { EKIA } \Sigma E \Pi O I E \Sigma E \leftarrow \text { (Exéquias me fez }) \\
\text { ONETOPI } \triangle E \Sigma K A \Lambda O \Sigma \rightarrow \text { (Onetorides é belo) }\end{array}$ & $\begin{array}{l}\text { OINOПION } \rightarrow \text { (Oinópio) } \\
\Delta \mathrm{IONY} \Sigma \mathrm{O} \Sigma \leftarrow \text { (Dioniso) } \\
\mathrm{EX} \Sigma \text { EKIA } \Sigma \text { EПOIE } \Sigma \mathrm{E} \rightarrow \text { (Exéquias me fez) }\end{array}$ \\
\hline
\end{tabular}

*Em negrito, as repetições.

As interpretações especificando a cena de luta entre Aquiles e Pentesiléia e o encontro entre Dioniso e Oinópio são, em parte, fundamentadas na relação com as inscrições que nomeiam as personagens (deve-se, então, tomar por nomear, a aproximação física e lógica entre uma determinada inscrição com um teor específico [um nome] e uma figura desenhada). Assim, essas inscrições nomeiam as figuras próximas delas. Cabe lembrar, que a única conexão de conteúdo paralelo dá-se nesse caso; ou seja, apesar de produtores de habilidades cognitivas diferentes, o significado (tema) da inscrição que "nomeia" e das imagens figurativas é o mesmo. Fala-se aqui de um significado imediato: o sentido básico de ambas as expressões. É claro que esse sentido pode ser estendido: a utilização dessas inscrições como vetores da ação da cena (ver cap. 3, fig. 82, p. 131), por exemplo, é indicador disso; bem como uma provável especificação no episódio do encontro entre Dioniso e Oinópio, cuja interpretação independente da inscrição seria bastante difícil. Assim, a figuração de um 
homem com determinadas características (no caso, a caracterização como efebo) adicionado de uma informação escrita torna-se Oinópio.

Quanto às inscrições de autoria, não é necessário que estejam ao lado de alguma imagem figurativa, basta apenas constar no vaso. Há vários casos de inscrições de autoria em espaços isolados no vaso (são os casos, por exemplo, das inscrições de autoria nas band cups). No vaso de Exéquias, vale lembrar, a única repetição de sentido na mesma linguagem dá-se com as inscrições de autoria (ver quadro acima). A partir de fórmulas repetidas (o mesmo conteúdo, a mesma direção da escrita, a mesma posição [à esquerda, no esquema estético geral nas duas faces do vaso]).

É claro, então, que existe articulação entre imagem figurativa e inscrição de forma variada, e, como visto, pode ser observado do ponto de vista temático, material e conceitual; o que impele a observação dos pontos de aproximação e distanciamento entre essas duas ações distintas do artesanato cerâmico: o ato de figurar e de escrever. Deve-se lembrar que o discurso literário compreende as duas atividades de forma análoga, resumindo à lógica gráfica. Entretanto, a observação da materialidade desses vasos pode indicar distinções importantes, uma delas, é a estrutura básica do elemento gráfico: a linha e o contraste. Escrita e figuração eram criadas a partir desses dois elementos básicos, mas com diferenças significativas.

Enquanto a apresentação gráfica se dava, sobretudo, pela linha riscada (anterior à queima), que efetivamente organizava o desenho sobre a silhueta negra, as inscrições eram produzidas em linhas pintadas. A prática do grafite, caracterizada pela a linha riscada após a queima, não era peculiar da criação original na atividade ornamental dos vasos áticos. No que se refere à criação das figuras, a estruturação do desenho dava-se, sobretudo, pela linha riscada. A variação de cores era quase irrelevante nos tons da figuração. É claro, a cor poderia ser apresentada em algumas variações com a aplicação de branco, e púrpura; entretanto, na composição geral das figuras, os contrastes mais relevantes eram entre a coloração escura do verniz e a vermelhada da cerâmica, que era reencontrada, com certas modificações tonais (mais clara). O contraste mais marcante era entre o avermelhado e o negro, o que foi estendido (de forma oposta) à apresentação da figuração em figuras vermeIhas. Assim, havia dois tipos de linhas (a riscada e pintada), e dois tipos de contrastes (a linha mais clara sobre o fundo mais escuro e a linha escura sobre o fundo mais claro - preto e avermelhado).

A compreensão intelectual da idéia de grafismo é importante, pois, aproximando-se do discurso sobre o ato de figurar e escrever da própria criação gráfica; há um refinamento, que não se dá, nesse caso, pela aquisição de novas fontes literárias. A prova, nesse caso, aparece de um novo tipo de vestígio bastante adequado à temática em questão (os próprios grafismos); o que propõe um novo dado sobre a história da composição dos grafismos no 
contexto tratado. Retomando então a idéia, o discurso que aproxima, não o faz absolutamente. Essa situação pode ser ainda observada na continuidade da ação gráfica além do período arcaico, como a criação gráfica em figuras vermelhas, em que uma diferença é excluída, pois as linhas da figuração e da escrita são ambas pintadas. Entretanto, a linha da figuração é negra sobre o verniz avermelhado, e a da escrita é púrpura sobre o negro; ou seja, dois contrastes tonais diferentes, quase opostos.

Outras especificidades ainda podem ser traçadas. Uma delas é a maior liberdade no traço figurativo e o menor no inscrito, quando se leva em conta o quadro geral. Isso, pois a figuração, apesar de alguns padrões gráficos, poderia ser constituída por linhas mais soltas, se se considerar que essas imagens não eram criadas a partir de gabaritos pré concebidos. E, mesmo nesse caso, os gabaritos de cada grafista ou oficina poderia ser diferente. ${ }^{43}$ Quanto à escrita, o conjunto de traços era bastante específico, pouco aberto a diferenciações gráficas. É claro, como visto, que poderia haver distinções de dimensão nas inscrições (um pintor poderia produzir letras maiores que outras), mas a criação das letras era razoavelmente rígida (ver esquema 3).

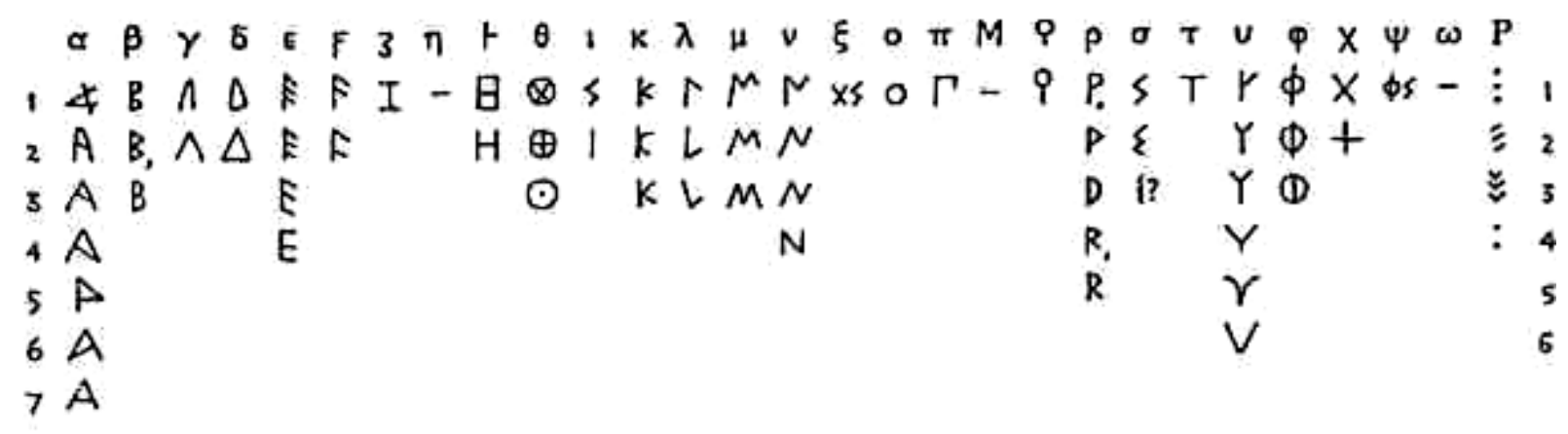

Esquema 3. Carta de inscrições áticas do período arcaico (Jeffery, 1990, p. 66, fig. 26). Note-se que na maioria dos usos das letras, as variações formais são bem pequenas.

Nesse sentido, os esforços de atribuição de autoria, empreendidos tradicionalmente a partir de Beazley, concentram-se na análise de pequenos detalhes anatômicos (como cada linha organiza a orelha, olhos, pés etc. [ver Boardman 2001, p. 128-38]), indicando que cada pintor ou grupo provavelmente tinha especificidades gráficas nessa composição. Quanto às inscrições, elas só contribuem decisivamente nesses estudos quando seu conteúdo indica um pintor ou oleiro; e existem, em algumas novas tendências de análise, inscrições "sem sentido" que poderiam, em alguns casos, por sua recorrência, indicar a autoria de

\footnotetext{
${ }^{43} \mathrm{O}$ estudo das linhas incisas previamente à pintura indica essa "liberdade" gráfica. Há inúmeros exemplares de cerâmica ática em que se percebe essas linhas, e certa fuga (pequena, média ou grande) do projeto inicial. Essa é uma tendência de estudo recente, mas vem sendo motivo de preocupação de especialistas de cerâmica desde o século XIX, mas de forma bastante isolada. Veja-se, por exemplo, Collignon $(1885$, p. 267) que indica alguns vasos onde ainda são visíveis os traços de esboço.
} 
um pintor ou oficina; ${ }^{44}$ mas essa também é uma caracterização a partir do conteúdo, mesmo que ele não seja gramaticalmente lógico. Assim, percebe-se que nessa linha que prioriza o estabelecimento de indivíduos ou grupos individuais, o traço gráfico que distingüe mais adequadamente é o figurativo e não o próprio da escrita.

\subsubsection{Suporte e ornamentação: questões de limite e comunicação}

Um vaso pode ser considerado uma unidade. É claro que a análise no campo dos estudos arqueológicos considera a inserção em contextos variados, desde a produção até seu uso e situação de descarte. Entretanto, ele é uma unidade e essa dimensão não pode ser esquecida; e acreditar nisso não significar dizer que ela seja indivisível; já que é um objeto composto de partes que, em si, não podem ser caracterizadas como unidades, pois a alça, o pé, e qualquer outra parte de um vaso, são um projeto de vaso; ou seja, uma parte projetada para integrar um todo. Por conseqüência, um vaso é o projeto concluído, pensado como um todo, a despeito de suas relações de similaridade com os vasos produzidos numa mesma oficina ou na ampla rede de produção ceramista ática na Antigüidade.

Essa composição de partes apresenta uma estrutura física cheia de pontos de junções, ângulos abertos e fechados, desníveis, descontinuidades etc., elementos físicos importantes na compreensão da distribuição dos grafismos na superfície dos vasos. Assim, de início, deve ficar claro que as questões físicas do suporte são elemento central para a discussão sobre as escolhas do grafista; isto é, escolhas de espaços para figurar e escrever (ver esquema 4). Identificar essas estratégias de figuração coloca a importante questão do papel do oleiro na organização gráfica da ornamentação. Em certa medida, ele era um coautor, pois era a partir das formas criadas por ele que se desenvolviam, pelo menos inicialmente, várias disposições gráficas. É claro que as formas criadas não eram tão variáveis, o que permite mapear com bastante eficácia as formas dos vasos (ver esquema 5 ), ${ }^{45}$ mas mesmo essa disponibilidade grande de recorrentes formas, suportes para figuração, pode ser observada considerando tal idéia de parceria. ${ }^{46}$

\footnotetext{
$\overline{{ }^{44} \text { A combinação das letras } \Lambda, T, I}, \Sigma$ e O, em organização variada, ou mesmo sua organização em $\Lambda \mathrm{TI} \Sigma \mathrm{T}$, por sua persistente utilização nos vaso do Pintor de Sappho, são um dos critérios de atribuição de autoria a favor desse pintor (Jubier, 1998, p. 63).

${ }^{45}$ Cabe dizer que tais regularidades já foram exploradas sob a ótica de estudos de proporção matemática; por exemplo, J. Hambidge (Dynamic symmetry. The Greek vase. London: Geoffrey Cumberlege, Oxford University Press, 1920), o pioneiro nessa linha de interpretação, e L. D. Caskey (Geometry of greek vases. Boston: Museum of Fine Arts, 1922).

${ }^{46}$ Tal parceria pode ser observada já na coexistência de assinaturas de autoria (do oleiro e do grafista) num mesmo vaso; ou então em situações onde o oleiro e o grafista eram um só.
} 


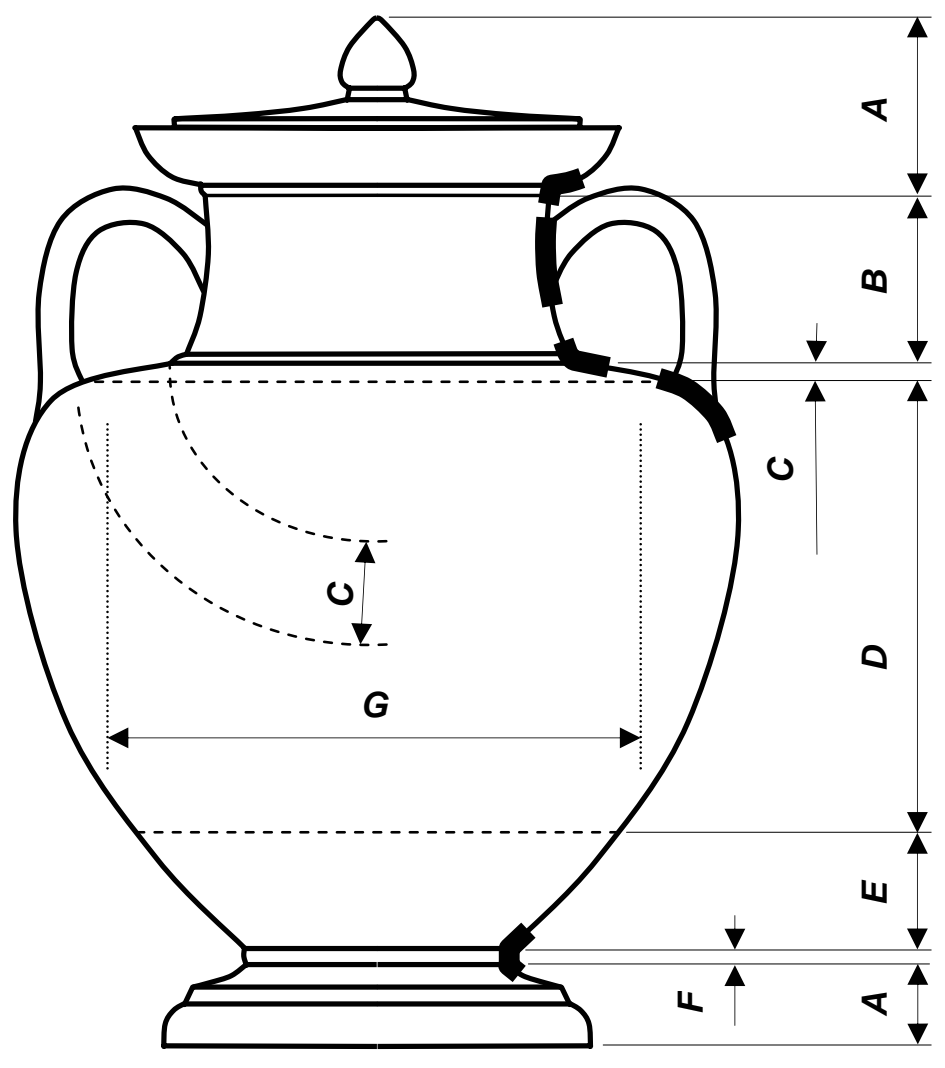

Esquema 4. Descontinuidades superficiais na constituição formal de uma ânfora ática (ânfora de Amasis - ver cap. 3, fig. 83, p. 132). As estratégias de ornamentação estão ligadas à estrutura formal do vaso: $\boldsymbol{A}$. Espaço pintado com verniz negro: tampa, boca, alças e pedestal do vaso (bem delimitados formalmente e pela pintura); $\boldsymbol{B}$. Ornamentação em palmetas estilizadas simétricas restrita à bem delimitada área do pescoço; $\boldsymbol{C}$. Área figurativa em faixa delimitada pelo fim do ombro e início do pescoço (parte alta), mudança da curvatura da superfície aliada à altura em que a alça liga-se ao ombro (parte baixa); D. Painel figurativo delimitado pela mudança da curvatura da superfície aliada à altura em que a alça liga-se ao ombro (parte alta), e estreitamento da conicidade (parte baixa). Ainda, lateralmente, respeitando a posição das alças, há dois motivos espirais simétricos delimitando as laterais (ver $\boldsymbol{G}$ ); $\boldsymbol{E}$. Conjunto de elementos geométricos organizados de forma repetitiva e em faixas acompanhando 0 estreitamento da conicidade do corpo do vaso até a ruptura entre corpo e pé (parte baixa); $\boldsymbol{F}$. Anel pintado em cor púrpura (liga 0 corpo e 0 pedestal). As passagens entre uma parte a outra do vaso são indicadas por cordões ou pequenas reentrâncias e saliências como entre a boca e o pescoço, entre o pescoço e 0 ombro, e $(\boldsymbol{F})$ entre o corpo e o pedestal.

superficiais.

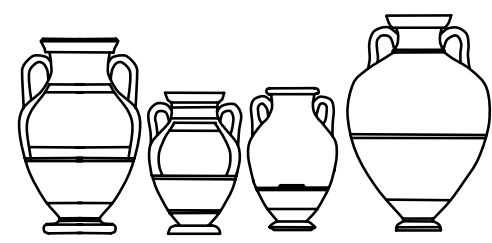

Ânforas: tipo A, B, C e Panatenaica

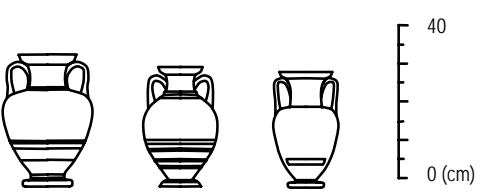

Ânforas com pescoço (Neck-amphorae): Padrão (Standard), Ovóide e Nolan
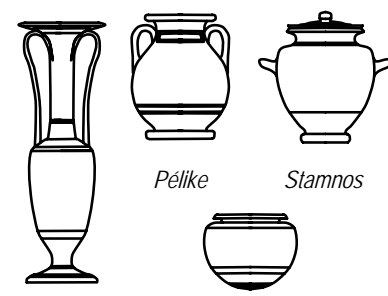

Pélike Stamnos

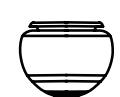

Dinos/Lebes
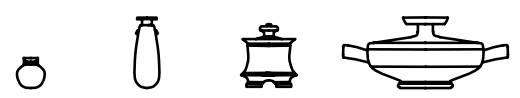

Aríbalo, Alabastro, Pyxis, Lekanis
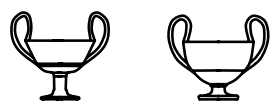

Cântaro (Kantaroi): Tipo A, C e D
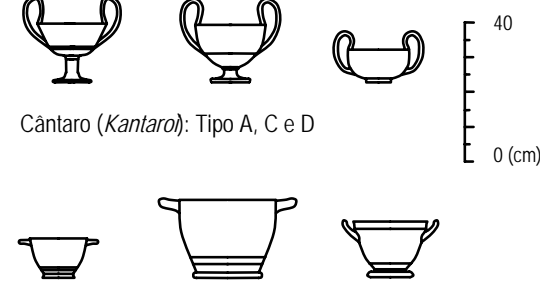

Skyphoi: Coríntio e Tipo ático, Cup-skyphos

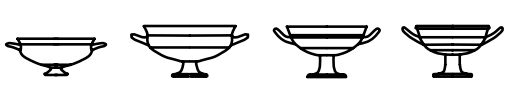

Taças (Cups): Komast, Lip e Band
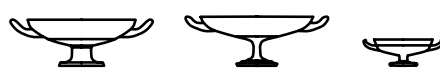

Taças (Cups): Tipo A, B e C

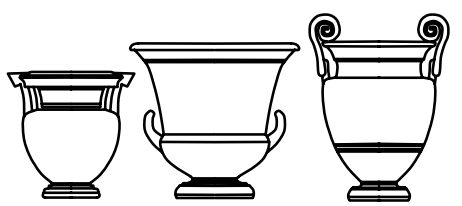

Crateras: Com Coluna, Em Cálice e Com Volutas

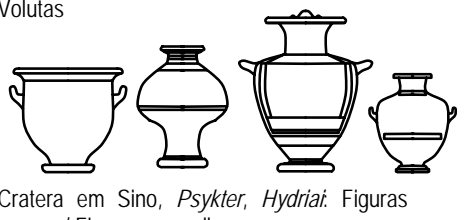

negras / Figuras vermelhas

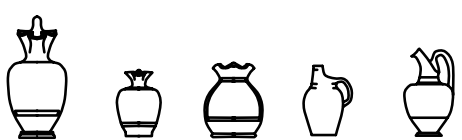

Enócoas (Oinochoai): Forma 1, 2, 3, 7 e 10

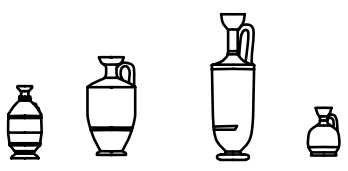

Lécitos (Lekythoi): Deianeira, Shoulder Cylinder e Squat

Esquema 5. Formas dos vasos áticos no século VI-V a.C. (Sparkes, 1996, p. 168-70). 
Os grafismos da enócoa do Dípilo (ver cap. 2, fig. 1, p. 60) indicam bem como a interação entre a ornamentação gráfica e as características formais do suporte são importantes. Tanto no contexto de produção original do vaso (a ornamentação pintada) e no da adição posterior (a inscrição riscada) há a articulação da lógica suporte-ornamentação. Quanto ao quadro figurativo (a ave e o cervídeo) ele se opõe à alça e se distribui abaixo do bico do vaso. Assim, uma compreensão de orientação (frente e traseira) bem delineada pelo pintor, aproveitando as formas previamente produzidas pelo oleiro. No que se refere à inscrição, além de ser aproveitada a ornamentaçao original do vaso (a linha caracterizada pela descontinuidade entre as linhas concêntricas repetidas e o verniz pleno no ombro) a alça funciona como parâmetro (ponto de começo e finalização) para a inscrição (ver esquem(2ess)sa forma, dizer que a inscrição começa e termina na alça é, mesmo indiretamente, reconhecer a estratégia de escrita daquele que a produziu. Da mesma forma, dizer que o quadro figuartivo ocupa a parte da frente do vaso, é reconhecer essa mesma estratégia de distribuição da ornamentação e organização das informações. Essas "leituras" podem indicar, inclusive, algo da recepção desses grafismos, pois para "lê-los" seria necessário compreender sua materialidade. É como dizer que a fruição de um quadro impressionista deve ser feita de uma certa distância, pois com proximidade demasiada só se pode ver borrões.
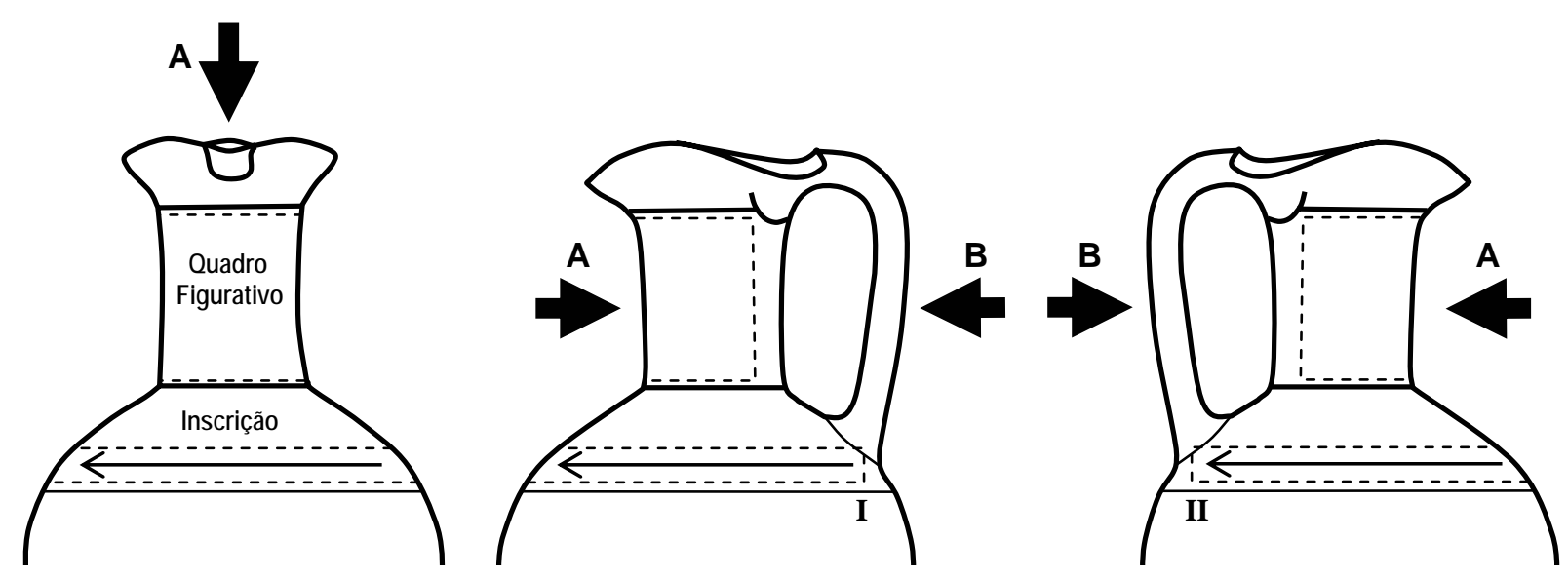

Esquema 6. Relação ornamentação-suporte na enócoa do Dípilo: A - Frente, B - Traseira; I - Início da inscrição, II - Fim da inscrição.

Essa importante interação entre suporte e ornamentação nem sempre pode ser observada, já que a ação seletiva presente em várias obras privilegia painéis figurativos, e não múltiplas vistas de um mesmo objeto. Para isso, basta dizer que nunca encontrei em nenhuma publicação as vistas "traseiras" de algumas renomados vasos como o píthos de Míconos, do qual a preferência recai sobre a ornamentação do pescoço, com a figuração do episódio do Cavalo de Tróia (ver fig. 15 e 16); e o mesmo pode ser dito das famosas ânforas, a de Elêusis com Odisseu cegando o Polifemo (ver fig. 17), e a do Pintor de Nessos 
com o episódio de Héracles lutando com o centauro Nessos. ${ }^{47}$ A compreensão integral da superfície externa desses vasos, e da aplicação da ornamentação, seguem as reflexões sobre suporte-ornamentação acima citadas, mas apenas conhecendo o objeto de forma mais completa é que se pode dizer que nos três casos há um claro discernimento, por parte dos artesãos, do que seria um lado "a ser visto" e outro "ocultado".
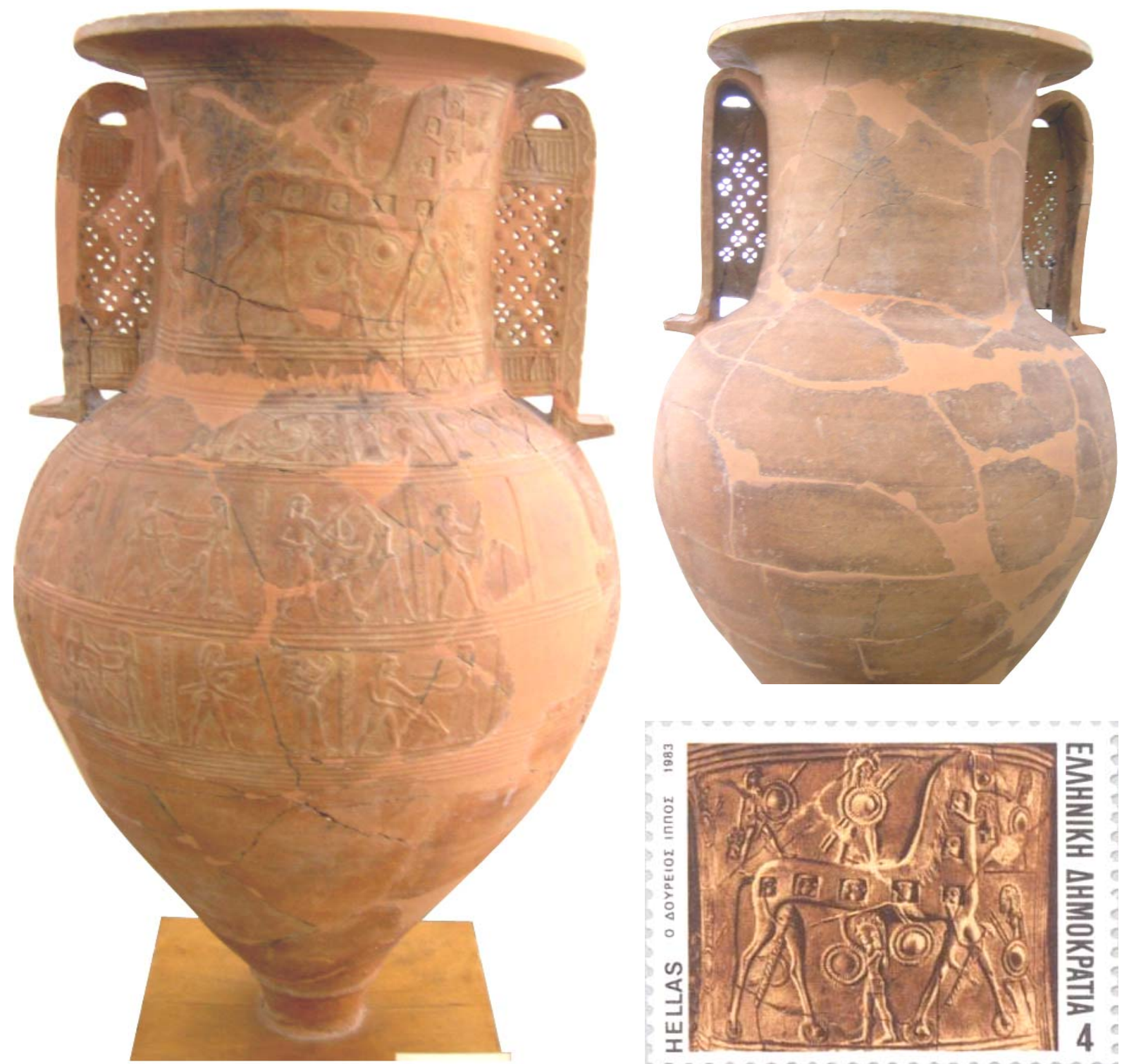

Fig. 15. Ânfora (píthos) de Míconos (alt:: $135 \mathrm{~cm}$ ): Vista de frente (à esquerda) e face oposta (à direita, acima), segundo quartel do século VII a.C., Museu de Míconos. A grande popularidade da figuração do pescoço é indicada pela Fig. 16, um selo emitido pelo governo grego com o detalhe do píthos de Míconos, figurando o episódio do Cavalo de Tróia.

\footnotetext{
${ }^{47}$ Quanto à ânfora de Elêusis, é clara a mudança de qualidade da ornamentação de uma face para a outra, como indica a transição da faixa em corrente na boca do vaso, atrás da alça; e mesmo as linhas articuladas na parte traseira do pescoço, tendo-se a parte dianteira como referência. Quanto à ânfora de Nessos (ver fig. 26, p. 193), uma referência no $A B F$ (p. 5): Beazley indica que a parte traseira (nomeada como "face B") é negra.
} 

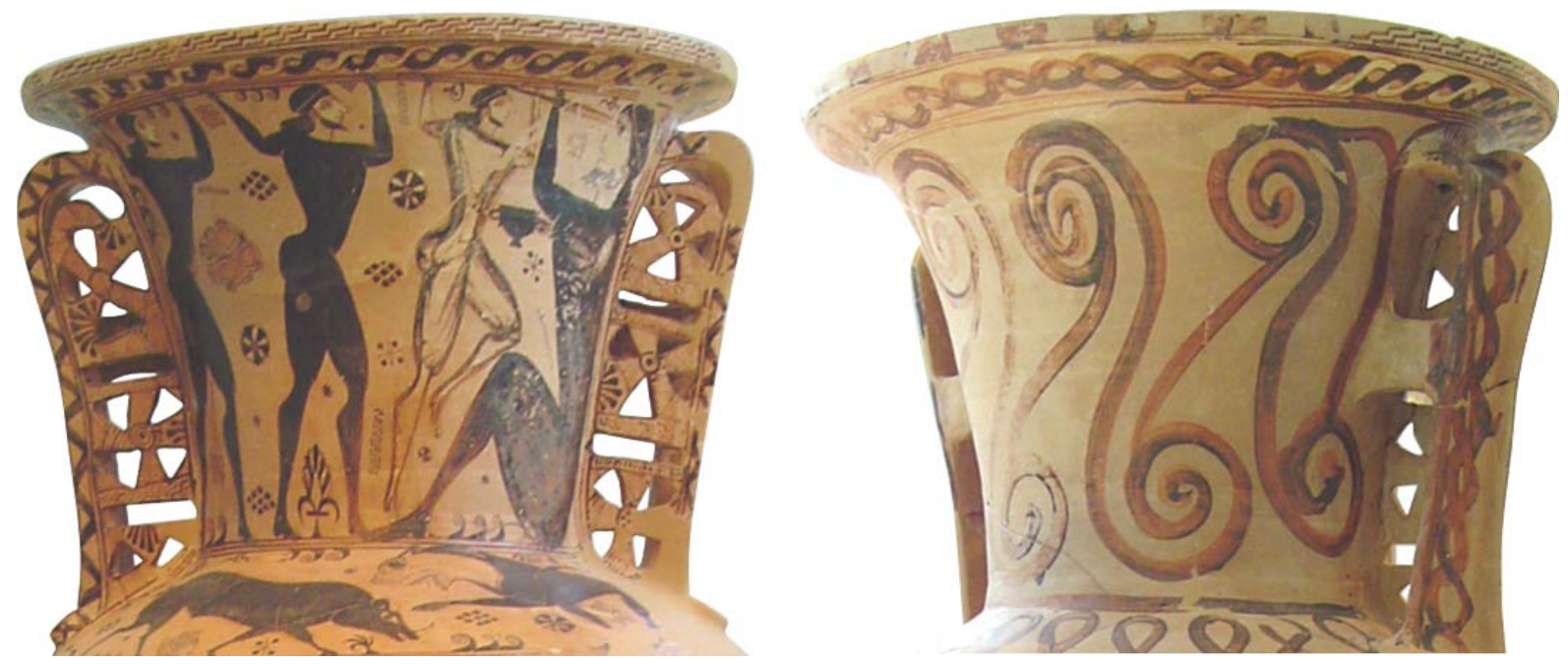

Fig. 17. Pescoço, em duas faces, da ânfora protoática de Elêusis, com Odisseu cegando o Polifemo, c. 670 a.C.; Elêusis, Museu de Elêusis (alt.: $144 \mathrm{~cm}$ ).

Compreender essas estratégias é ação indispensável na análise da interação entre inscrições e imagens figurativas por dois motivos básicos: primeiro, porque esses grafismos ocorrem em áreas geralmente delimitadas, as que aqui se chama de painéis ou faixas; e depois, porque compreendendo tais delimitações, pode-se interpretar as interações entre tais grafismos, mesmo quando ocorrem em regiões diferentes. Assim, as aproximações e distanciamentos entre os grafismos devem ser compreendidos, de início, já na dinâmica da aplicação da ornamentação sobre o suporte. Qualquer idéia do grafista deveria considerar aquele espaço disponível, que era, cabe lembrar, curvo, com alguns desníveis, intrusões e algumas interrupções bruscas.

Os grafismos sobre os vasos áticos distribuem-se de forma variada. É necessário, então, antes de tratar dos significados dessa variedade, compreender como se organizavam materialmente tais aplicações. Para isso, tratar-se-á das questões de limite e comunicação na cerâmica ática. O ponto de partida são os limites impostos à figuração, ou seja, o estabelecimento de faixas ou painéis adequados para aplicar as figuras. ${ }^{48}$ Assim, de início, notam-se dois tipos peculiares de organização das imagens: a faixa, que propiciava com

\footnotetext{
48 Já foram indicadas aqui algumas distinções entre o ornamental e o figurativo, mas sua validade deve ser discutida. Discursos sobre a pintura na Antigüidade são geralmente tardios e não tratam das especificidades da pintura sobre a cerâmica. Quanto à cerâmica, a apresentação freqüente do verbo $\gamma \rho \alpha \varphi \tilde{\imath} v$ nas assinaturas de autoria permite, por extensão, dizer que a ação ornamental pautava-se pela idéia do gráfico como organizador das formas; seriam, então, propriamente grafismos. Qualquer outra especificidade não foi registrada nas fontes literárias que chegaram aos tempos atuais. Entretanto, a observação de certas recorrências na produção gráfica permite falar em algumas distinções gráficas (como o ornamental e o figurativo). Assim, é a partir da observação de aspectos gráficos da cerâmica que se pode apresentar distinções mais específicas no fazer ornamental: existiam faixas com elementos repetitivos como palmetas organizadas simetricamente, aros, espirais, flores de lótus, raios etc. todos elementos que tinham como função principal a delimitação de espaços reservados à figuração. Além disso, apesar de haver certa busca pela simetria, a organização da figuração nem sempre se pautava por isso, sendo a caracterização figurativa uma ação mais dinâmica na ornamentação, enquanto as faixas delimitativas eram recorrentes em séries de vasos de várias oficinas. Dessa forma, cabe dizer, que tal distinção serve a interpretação aqui proposta, e é indiciada por elementos gráficos observados, mas não se constitui a partir de um discurso antigo sobre a questão.
} 
maior viabilidade um desenvolvimento mais longo, ou repetitivo da temática; e o painel, caracterizado preponderantemente por um maior espaço figurativo em área, mais menor em estensão horizontal para a organização da cena. Há, então, um tipo de figuração mais horizontalizada e outra menos; o que indica que a própria organização das figuras no espaço impõe certos modos figurativos, inclusive quanto ao desenvolvimento do conteúdo.

A organização em faixas ou painéis deve ser observada junto às questões da fisicalidade do vaso, ou seja, os espaços próprios para a figuração em faixa e em painel são, em certa medida, sumetidos à estrutura física do vaso: regiões baixas na altura e largas em diâmetros (como pescoços de certas crateras, ou ombros de algumas ânforas, são bons espaços para a figuração em faixas; enquanto a região do bojo, ou largos ombros são espaços ideiais para a figuração em esquema de painel. Entretanto, essas regras não são absolutas, e grandes bojos como o do Vaso François (ver fig. 74, p. 125) poderia ser dividido em várias faixas, e os painéis, nesse mesmo vaso, são observáveis nas largas alças.

Observa-se, com isso, que os limites da figuração eram criados tanto a partir de características físicas do vaso, respondendo à ação mais imediata do oleiro; bem como da aplicação de verniz, aliada ou não à estrutura física do vaso. Dessa forma, tem-se que as estratégias de delimitação superior e inferior da cena são, geralmente, materializadas de forma mais regular que as laterais; ou seja, enquanto acima e abaixo os limites são linhas retas bem delineadas, por vezes marcando um desnível superficial do vaso; os limites laterais ocorrem em região onde a curvatura é grande, e a delmitação nessa área é mais diversa. Há duas formas bastante recorrentes: a linha reta, que delimita dois campos, um de verniz negro e outro de coloração reservada da argila (ver fig. 18); ou então elementos vegetais estilizados, como espirais e palmetas articuladas (ver fig. 19). Os painéis das cenas figuradas em figuras negras enquadram-se quase invariavelmente dessa forma. ${ }^{49}$ Entretanto, vale salientar, esses limites não apresentam uma rigidez delimitativa absoluta; e a compreensão da extrapolação espacial pode indicar uma característica importante das mensagens escrito-figurativas na cerâmica ática: as possibilidades de comunicação. Mas, para isso, ainda é preciso comentar mais algumas características formais desses vasos.

Em busca de espaços viáveis para a figuração, como visto, em vários casos, optouse pela oposição entre faces, o que não significa oposição temática necessariamente. Tal caracterização deve, em grande parte, a avaliação de espaços físicos aptos a figurar, e outros não tão aptos. Para isso, basta dizer que as alças (que interrompem fragmentos da grande área do ombro ou bojo de vasos) frequentemente, marcam as laterais. Assim, é ori-

\footnotetext{
${ }^{49}$ Essas são as formas principais de enquadramento das cenas figurativas, mas não as únicas. As várias formas dos vasos promoviam uma série de estratégias diferentes de estruturação das cenas e outras formas de delimitação. Por exemplo, taças e pratos, formas bem abertas, tinham o interior ornamentado, e as figuras adaptavamse a limites circulares; e há casos em que a distinção das cenas em faces delimitadas não é observável.
} 
entando-se pela posição das alças que inúmeras vezes se constituíram as faixas laterais que delimitam as cenas. ${ }^{50}$
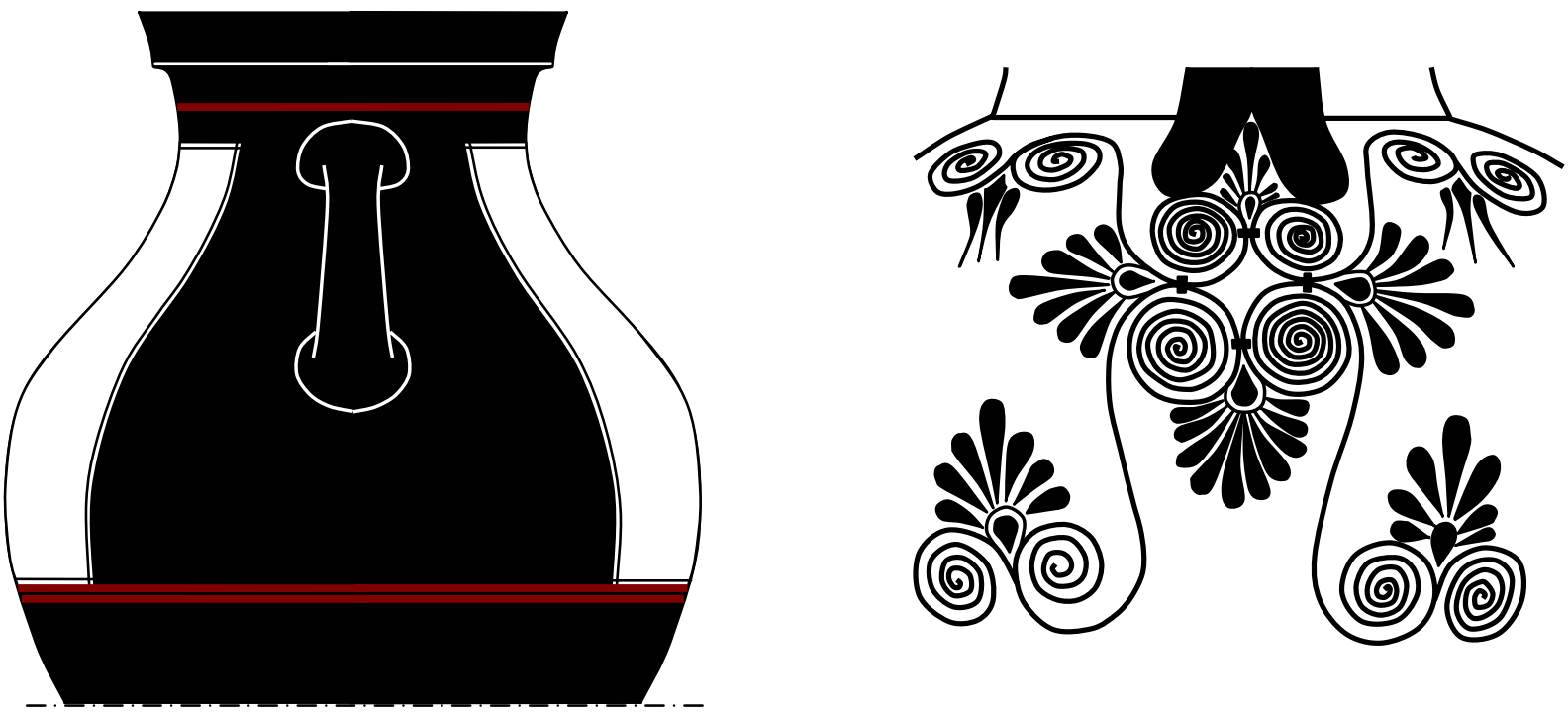

Estratégias de delimitação lateral: Fig. 18. Ânfora tipo A, faixa negra (à esquerda) - note-se que a passagem entre o negro e a coloração da argila é feita, em vários casos, através de uma linha fina como elemento de transição; Fig. 19. Ânfora confeccionada por Exéquias, Staaliche Museum, Berlim, ornamentação floral na delimitação lateral.

Esses limites eram constituídos a partir de características físicas do vaso e gráficas, e da ornamentação; e essa organização conjunta dos espaços é bastante observável (por exemplo, a alça como referência espacial); e, inúmeras vezes, os limites físicos eram marcados pelo grafista, denunciando que ele os reconhecia. A partir disso estruturava-se, então, o que seria espaço figurativo, e o que não seria. Espaço figurativo, pois as estratégias de produção de painéis, faixas ou medalhões eram sobretudo ligadas ao enquadramento das figuras; enquanto as inscrições adaptavam-se aos espaços disponíveis, quando já estavam bem dispostas as imagens figuradas. Ora, observa-se aí uma seqüência relacionada à organização gráfica: a produção do suporte, a avaliação de espaços viáveis para a figuração, a criação das delimitações levando-se em conta características do suporte, a criação das figuras e a aplicação de inscrições; e toda essa avaliação e aplicação gráfica acontecia entre uma primeira queima e a queima posterior que promovia a estruturação final da orna-

\footnotetext{
${ }^{50}$ Cabe comentar, aqui, os constantes paralelos feitos entre a estrutura ornamental de vasos e da organização figurativa em templos. Assim, os painéis e as faixas são frequentemente aproximados das formas de frisos e métopas, onde a estrutura formal também indica certa subordinação ao tipo de estrutura narrativa. $O$ mesmo ocorre com a idéia de oposição entre as faces de um vaso e dos frontões de um templo, conforme M. Denoyelle (Le cratère des Niobides. Paris: Editions de la Réunion des Musées Nationaux - Louvre, Service Culturel, 1997, p. 10), ao comentar a cratera de Nióbides, "As faces da cratera são compostas de modo bastante distinto; como os frontões de templo grego, oferecem, um, uma cena 'calma', o outro, uma cena 'agitada'”. Entretanto, se essa caracterização segue frequentemente uma linha que vê na produção figurativa ceramista um "reflexo" da arquitetural, aqui se repudia tal idéia como pressuposto, já que essas relações devem ser mais profundamente discutidas.
} 
mentação, e mesmo a clara marcação das diferenças dos contrastes; já que, antes disso, o verniz sobre a argila não era tão negro. Ainda, mesmo algumas intrusões posteriores como alguns grafites poderiam aproveitar o esquema gráfico original do vaso, bem como sua estrutura física. É dessa forma, como visto, que a inscrição da enócoa do Dípilo se estende no vaso (o "escritor" aproveitou uma linha, produto da ornamentação pintada do vaso; bem como a alça como parâmetro), e um interessante grafite num aríbalo ático, imitando uma inscrição de autoria: "Nearco me fez" (ver fig. 20); o que propiciou, segundo G. Richter (1932), um debate sobre a real autoria do vaso, dada a característica bastante incomum dessa inscrição (seria uma tentativa de partilhar um pouco do prestígio de $\mathrm{Nearco}$, assinando seu nome, mesmo nessas condições?).

A caracterização de espaços figurativos não impedia a criação de espaços específicos para as inscrições, e em alguns vasos a aplicação de inscrições e figuras em áreas diferentes era comum. As lip cups, por exemplo, eram constantemente ornamentadas com inscrições em uma parte (a baixa) da taça, enquanto as figuras (miniaturas) em outra (a alta) ver fig. 21. A diferenciação dos espaços dá-se pela articulação entre o desnível da superfície (uma mudança entre o bojo e a boca que é levemente extroversa) e uma linha que marcava a região mais aguda desse desnível (a passagem de uma curvatura para outra). Num outro esquema, uma base confeccionada pelo oleiro Ergotimo e o grafista Clítias apresenta a figuração na parte alta, e as inscrições de autoria abaixo (no pedestal); uma clara diferenciação espacial entre uma linguagem e outra (ver fig. 22).

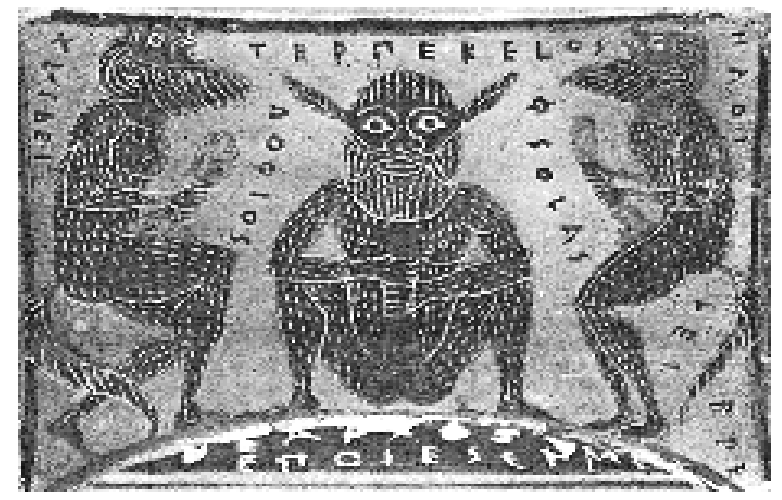

Fig. 20. Aríbalo ático, c. 570 a.C., New York, Metropolitan Museum of Arts (alt.: $8 \mathrm{~cm}$ ). Abaixo das figuras dos três sátiros (na alça), a inscrição riscada (já no ombro): NEAPXO $\Sigma$ EПOIE $\Sigma$ ENME $\rightarrow$ (Nearco me fez). Grafites (inscrições riscadas após a queima) são incomuns no que se refere às inscrições de autoria sobre a cerâmica, produzidas em contexto original. Isso propiciou um debate (ver Richter, 1932, p. 272-5), havendo autores que não acreditam que seja esta uma original inscrição de autoria.

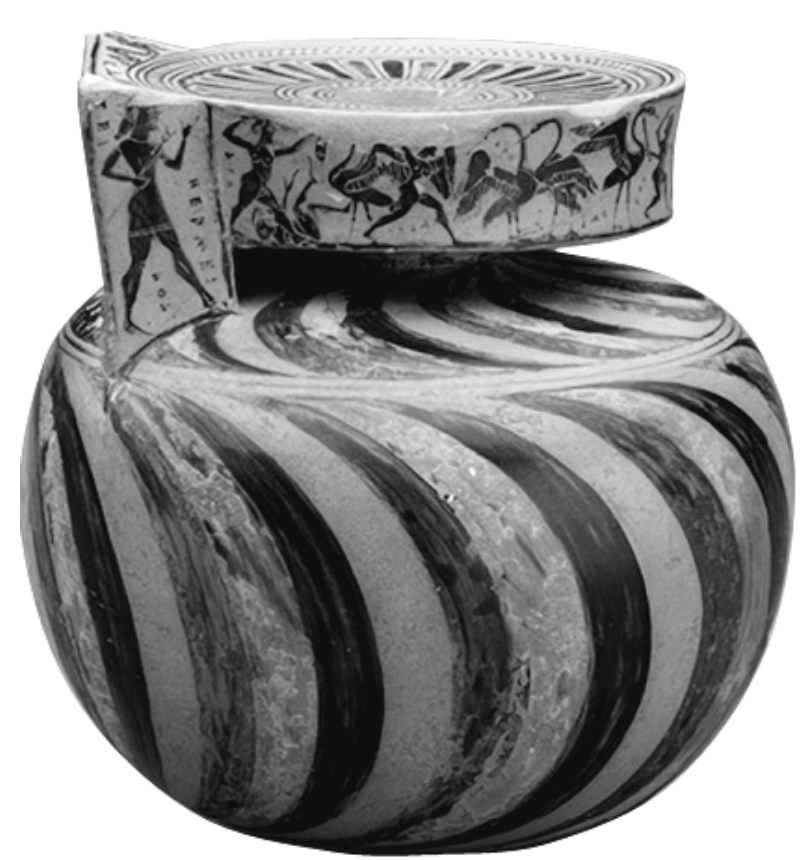



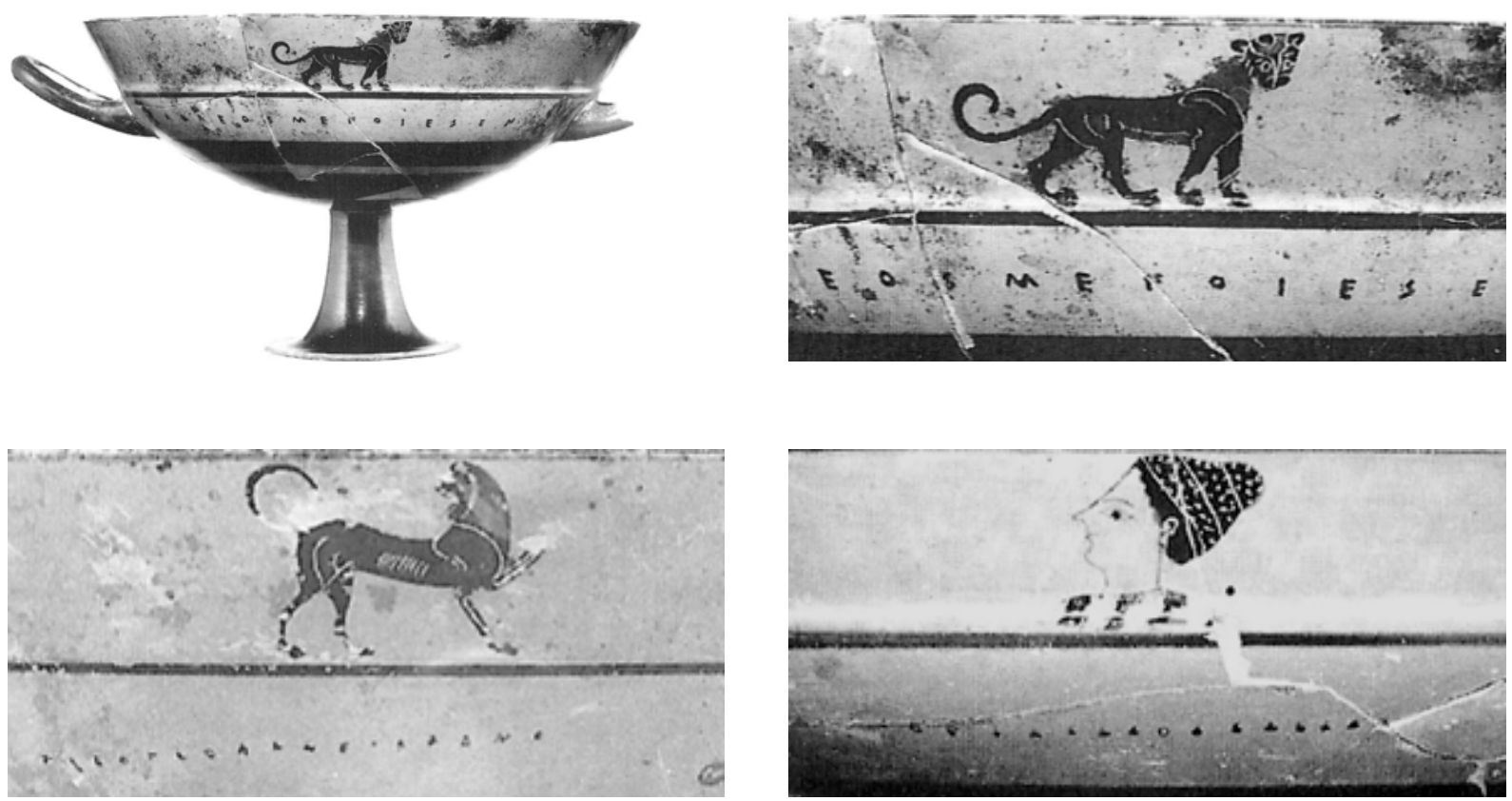

Fig. 21. Detalhes de taças áticas (Lip cups) do terceiro quartel do século VI a.C., Coleção De Marchesi Guglielmi, Vulci (acima, taça de $11,5 \mathrm{~cm}$ de altura).
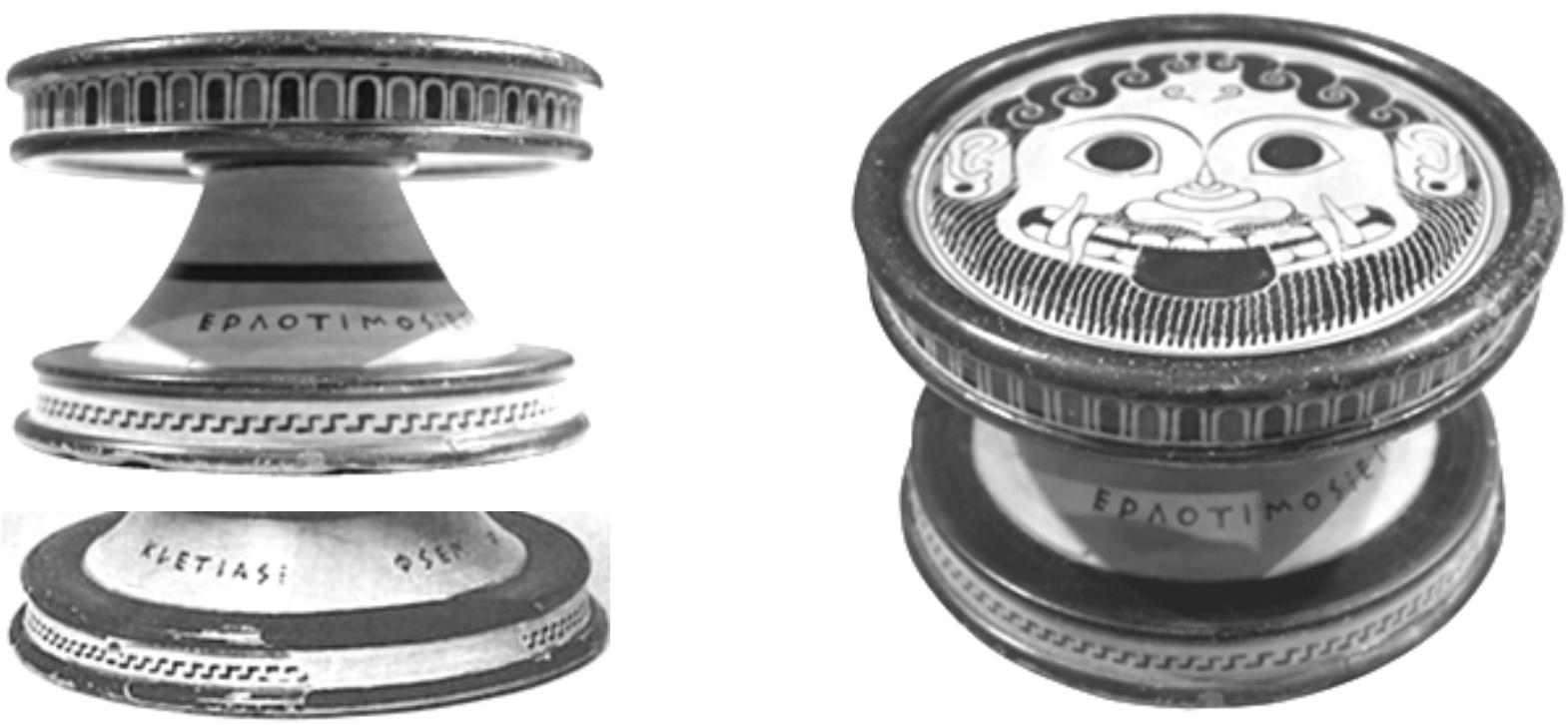

Fig. 22. Base confeccionada por Ergotimo e Clítias, c. 570 a.C., Metropolitan Museum of Arts, New York. Inscrições: (Ergotimo fez)

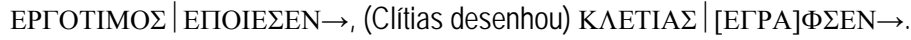


Observa-se, aí, um tipo de cisão entre imagem figurativa e inscrição, por um lado, e uma aproximação, por outro, num mesmo vaso. Essa estrutura comum nas lip cups poderia apresentar algumas variações, como uma produzida por Tleson, que assinava como "filho de Nearco". Tleson assinou na superfície externa do vaso (nas duas faces), respeitando o espaço determinado para as inscrições nessas taças (ver fig. 21); entretanto, acima, onde geralmente haveria uma pequena imagem figurativa, não há nada. A figuração, então, restringe-se nesse vaso à parte interior, um medalhão; mas ali há inscrições que nomeiam as figuras (Minotauro e Teseu) - ver fig. 23.
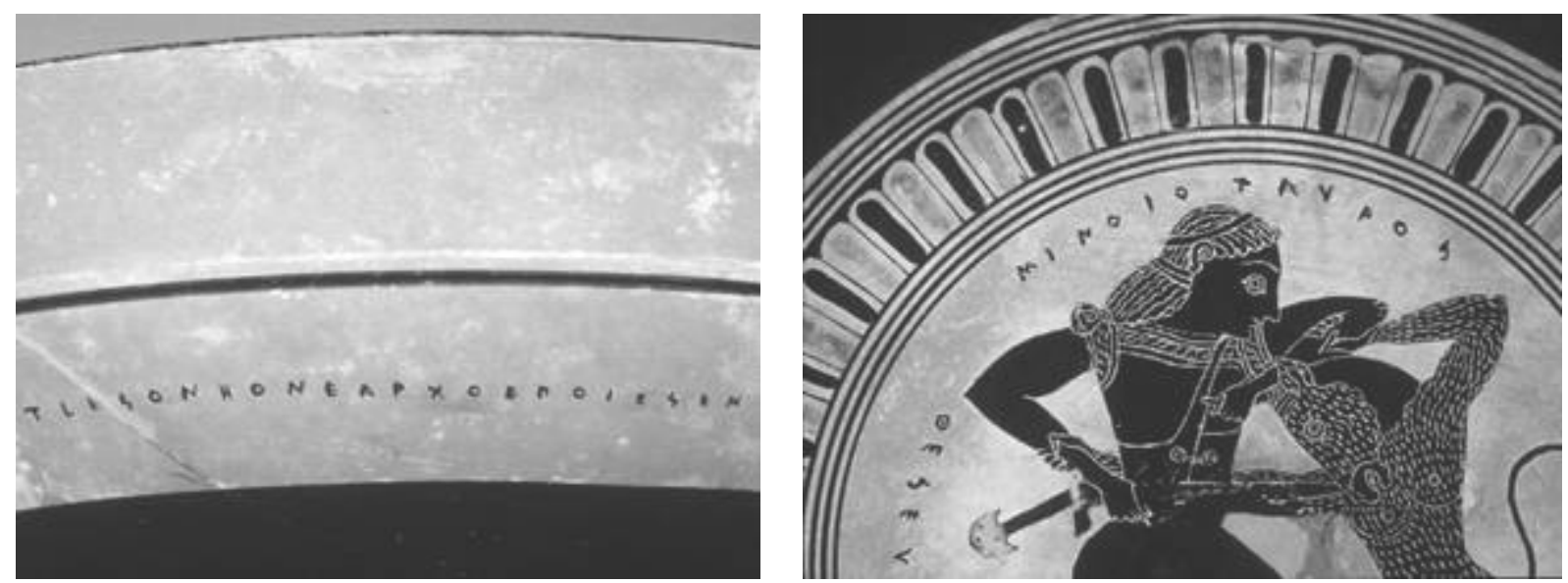

Fig. 23. Detalhes de taça (lip cup), Pintor de Tleson, c. 550 a.C.; Toledo, Museu de Arte: (à esquerda) superfície externa, assinatura $\mathrm{T} \Lambda$ E $\Sigma$ ONHONEAPXOEחOIE $\Sigma$ EN $\rightarrow$ (Tleson, o [filho] de Nearco, fez); (à direita) medalhão interno, inscrições MINOIOTAYPO $\Sigma \rightarrow$

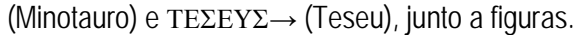

Tal situação pode indicar uma característica material importante quanto à disposição dessas inscrições no vaso; uma entonação comum da relação escrito figurativa: as inscrições de autoria são mais independentes, e poderiam mesmo ocorrer tanto compondo um esquema visual junto às imagens figurativas, como em espaços próprios (é o caso das figuras 21, 22 e 23). Já as inscrições do tipo nominativas, estas eram menos autônomas, e sua incidência estaria condicionada à imagem figurativa.

A partir disso, percebe-se, que os elementos gráficos e físicos do vaso, por vezes, eram conjuntamente utilizados pelos grafistas para organizar a disposição dos grafismos, e, inclusive poderia apartá-los. Entretanto, a pesar da verificação de algumas disposições restritivas, a dinâmica entre os grafismos escrito-figurativos e os limites apresentados é abrangente; ou seja, propõe, a partir de sua materialidade e de seu conteúdo, inúmeras formas de burlar qualquer delimitação muito rígida. 
As figuras esquemáticas do período geométrico, rigidamente enquadradas nos limites, marcam um cenário diferente das formas de figurar a cerâmica desde o protoático. Logo após a reestruturação no quadro ornamental da cerâmica, quando se optaram por figuras com detalhes anatômicos mais claros, a relação entre figuração e delimitação já não era tão rígida; e isso é indicado por uma característica constante na cerâmica ática, que é o "desrespeito" aos elementos delimitativos da cena. Pés de figuras, suas mãos, cabeças, capacetes etc., todos eles ultrapassaram, alguns milímetros ou centímetros, áreas delimitativas. Essa característica acompanha a produção ática durante muito tempo, e até nos exemplares mais tardios é possível observar tal situação. E pode-se, mesmo, especular sobre uma abordagem seqüencial na produção das cenas figurativas (ver esquema 7); já que, enquanto as delimitações laterais e superiores são freqüentemente "desrespeitadas", o limite inferior (o "chão" da cena) quase nunca é transposto.
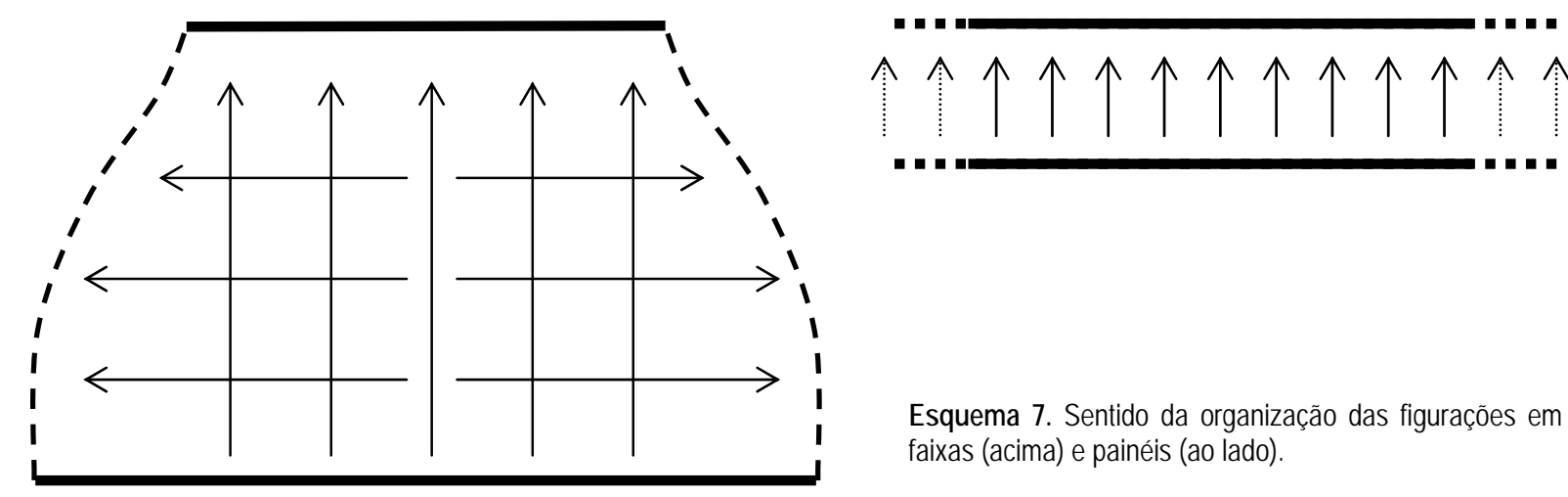

Esquema 7. Sentido da organização das figurações em faixas (acima) e painéis (ao lado).

Os mais antigos exemplares em figuras negras já apresentavam tal característica: alguns vasos do Museu Nacional de Atenas (fig. 24, 25 e 26) mostram isso: numa ânfora, a Quimera figurada no ombro, e caprino pescoço, todos eles ultrapassam os limites superiores (ver fig. 24). Num prato ático da mesma época, uma Górgona figurada, adapta-se a dois conjuntos de círculos que delimitam a figura, e suas asas transpassam um deles. E, ainda, numa ânfora executada pelo Pintor de Nessos, as figuras das Górgonas atingem levemente as três linhas que delimitam superiormente a cena, e as figuras no pescoço, Héracles e Nessos, de forma parecida, os limites laterais e superiores. A cena, claramente, é enquadrada ou na grande faixa no bojo, ou no painel no pescoço, entretanto, os ajustes que extrapolam levemente alguns limites não constituem grande problema; e uma perna de Heracles chega a transpassar o conjunto de três linhas que delimitam a cena (ver fig. 26). 


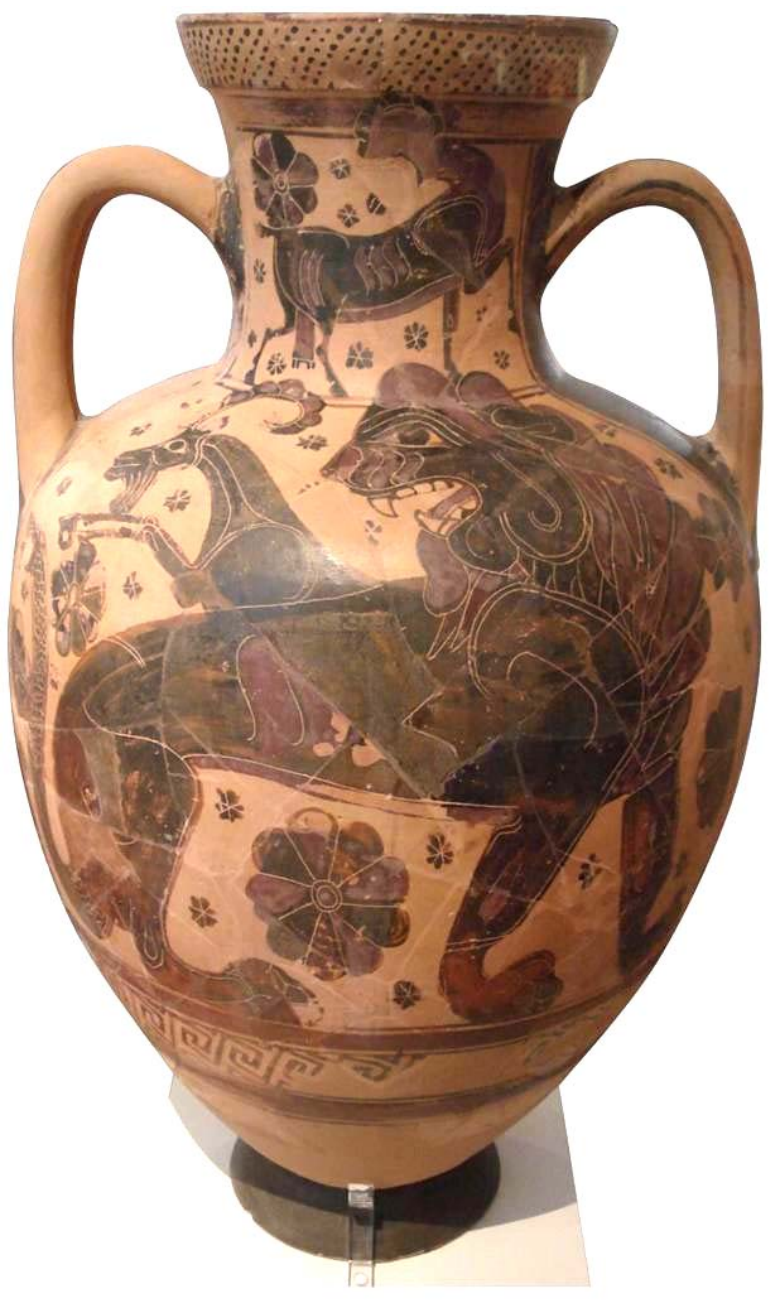

Fig. 24. Face de ânfora de figuras negras: Quimera (bojo ao ombro, alcançando o pescoço) e caprino (pescoço), 625-600; Atenas, Museu Nacional (Inv.16391). Fig. 25. Prato ático de figuras negras, Górgona correndo, Pintor Anagyrous, c. 600-575 a.C., Atenas, Museu Nacional (Inv. 19171)

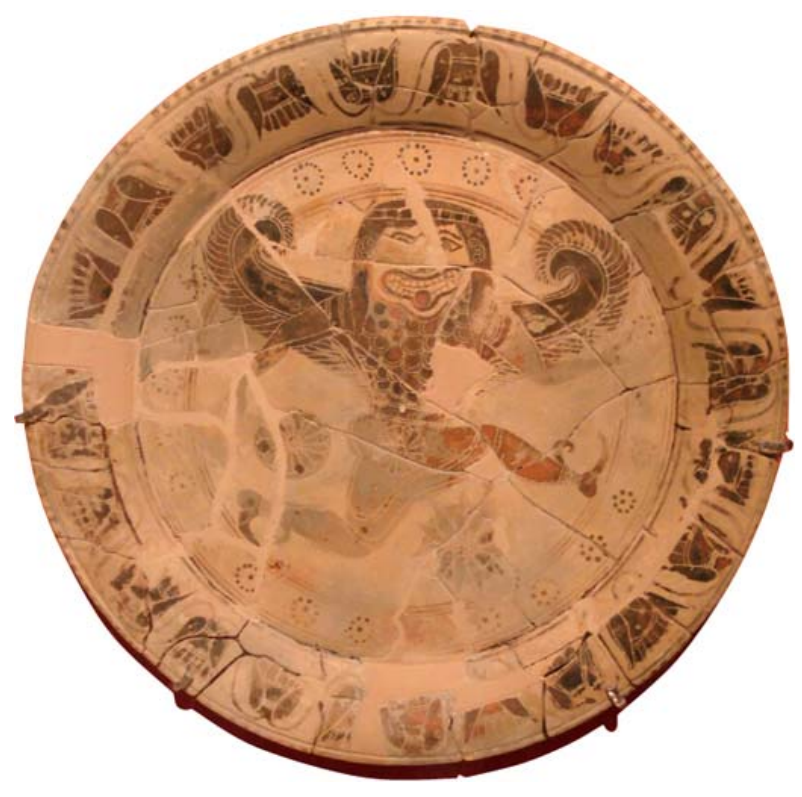

De forma menos sutil, a invasão de algumas figuras da ânfora anterior (fig. 24) não só ultrapassam as linhas delimitativas (acompanhada por uma mudança abrupta do ângulo entre o ombro e o pescoço), mas atingem (os chifres da cabra e a cabeça do leão que formam a Quimera) o campo figurativo da figura do pescoço. Tem-se, então, já desde o século VII a.C., na produção de cerâmica ática, figuras que extrapolam em certa medida os limites que as enquadram, indicando que, materialmente falando, esses limites não são tão severos.

Dessa forma, há um primeiro elemento de interesse para a compreensão da interação entre figura e inscrição: ora, em muitos casos, elas são separadas fisicamente, por mais que apareçam próximas; ou seja, a disposição de uma e outra em partes diferentes de um mesmo vaso. Nesse caso, então, separa-se absolutamente imagem figurativa de inscrição, ou mesmo os grafismos bem delimitados, num mesmo vaso?

Bem, seguindo as pistas dos próprios grafistas, não se pode caracterizar esses limites como empecilhos absolutos para uma comunicação maior. Assim, se a materialidade afasta, existe ainda a possibilidade de observar comunicações que extrapolam as amarras materiais. É esse o caso do estabelecimento de faces opostas, que são afastadas material- 
mente, mas, várias vezes, comunicam-se de forma intensa. A comunicação gráfica proposta pelo artesão, então, deve ser observada a partir de sua materialidade e significado dos grafismos. Entretanto, é preciso dizer que existem interações diferentes entre os grafismos e, conseqüentemente, alcances diferentes. Uma inscrição que nomeia uma figura enquadrada numa cena, geralmente refere-se à coesão gráfica daquele espaço específico. Enquanto inscrições de autoria referem-se ao vaso como um todo.
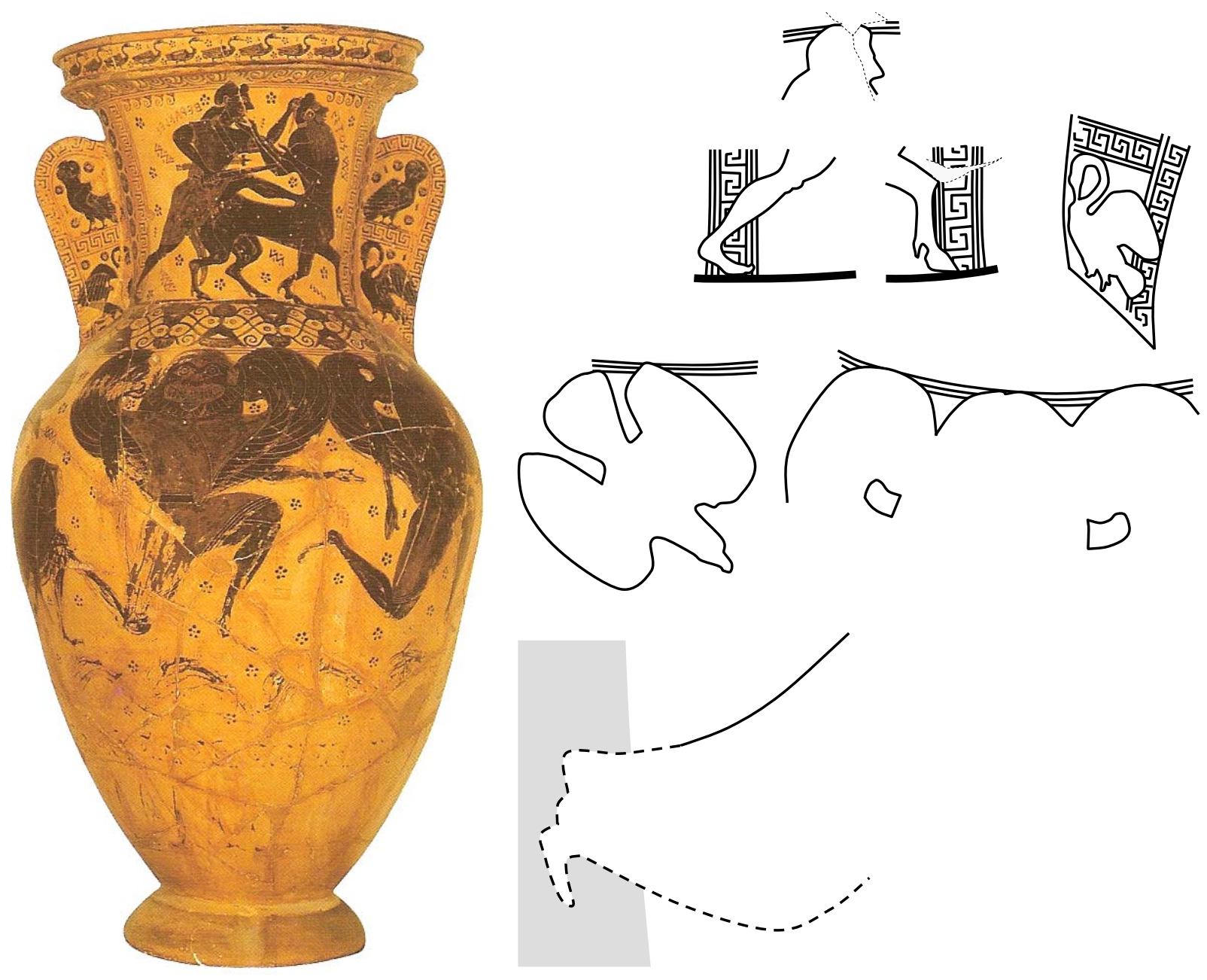

Fig. 26. Ânfora de Nessos (alt.: $122 \mathrm{~cm}$ ) e Esquema da figuração transpassando alguns limites: (acima) pescoço - cabeça e pé de Héracles, e pata dianteira de Nessos; e detalhe da alça - asa de cisne; (meio) bojo - ave e cabeça de Górgona alcançam o limite superior; (abaixo) parte do corpo da Górgona decapitada ultrapassa o limite lateral (alcança a parte traseira do vaso, quase toda pintada com verniz escuro).

Como foi possível observar, a compreensão da dinâmica da materialidade gráfica não serve apenas como exercício de interpretação de sua fisicalidade, mas também de seu conteúdo e alcances das mensagens. Nessa perspectiva, não é absurdo dizer que algumas dessas inscrições poderiam extrapolar o próprio suporte e propor uma comunicação no âmbito da produção ceramista. Esses grafismos possuíam um potencial comunicativo que suplantava as questões gráficas relacionais; isso significa que além dessas possibilidades de comunicação aqui delineadas, havia outras menos restritas. As inscrições de autoria poderi- 
am conectar-se e, já na Antigüidade, serem compreendidas como um grupo: por exemplo, vários vasos assinados poderiam ser observados ressaltando-se essa declarada característica comum de produção. Contra essa idéia de observação de conjunto, há a distribuição bastante variada desses vasos no Mediterrâneo; o que não permitia uma visão de conjunto dos que recebia tal vaso. Assim, tal observação é mais seguramente observável no campo produtivo.

Da mesma forma, é nessa perspectiva ampla de comunicação gráfica que se pode

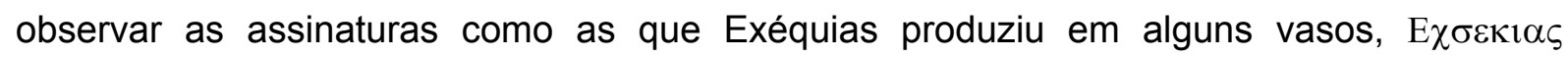

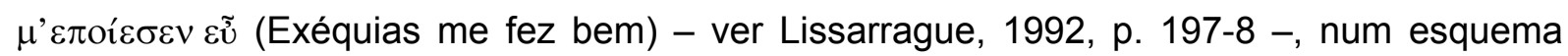
bastante parecido com o de Tleson, ${ }^{51}$ ou seja, apartando na superfície exterior num campo, informação escrita, e no outro, informação figurativa, promoviam também uma comunicação que extrapolava a faixa que enquadrava a inscrição; e se estendia para uma qualificação da ornamentação do vaso como um todo. São dignas de atenção, assim, assinaturas desse mesmo Tleson, filho de Nearco. Ora, tal oleiro colocava inúmeras vezes o nome do próprio pai, um artesão bastante atuante na geração anterior, no próprio vaso. Tleson provavelmente procurava tirar proveito do prestígio que o pai poderia ter tido, em certa medida calcado pelos grafismos que produziu. ${ }^{52}$ A perspectiva, nesse sentido, é também comparativa.

Um outro exemplo apresenta claramente esse tipo de possibilidade mais ampla no que tange à comunicação gráfica. Trata-se de uma inscrição do pintor Eutímedes, que operava no final do século VI a.C., um momento de grandes mudanças no quadro da produção ceramista. Numa ânfora de sua autoria, já em figuras vermelhas, ele propõe um diálogo

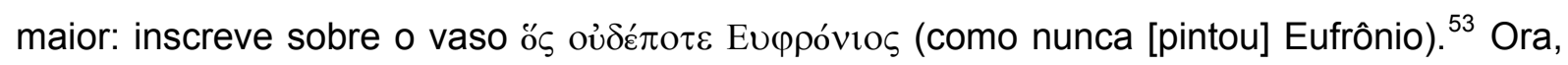
essa mensagem refere-se às suas imagens figurativas, à qualidade ornamental de seu vaso, mas a perspectiva é relacional, e, é nesse ponto que se dá a abrangência. ${ }^{54}$ Eutímides coloca em perspectiva comparativa sua criação gráfica com a de outro, seu concorrente. Assim, tal inscrição pedia a atenção às imagens contíguas a ela, mas também as da criação de um outro grafista. Essa mensagem para ser bem compreendida requeria certo grau de conhecimento da produção de forma mais geral; isto é, conhecer as figuras de Eutímides e as de

\footnotetext{
${ }^{51}$ Exéquias e Tleson, dentre outros, são classificados como Little master cups, já que produziram sistematicamente taças com esquema ornamental bem parecido (ver Beazley, 1932).

${ }^{52}$ A estrutura de nomes com patronímicos não era incomum entre os gregos, ao contrário (ver Shapiro, 1987; sobre as inscrições de homenagem em estrutura patronímica); mas nas assinaturas de autoria nos vasos áticos não era abrangente. Assim, o nome de Nearco constantemente relacionado ao de Tleson não remete a uma situação comum da caracterização de certos indivíduos; e, nesse sentido, propor a busca de parte do prestígio de Nearco, por intermédio da ação de seu filho, Tleson, baseando-se nessas constantes assinaturas, mostra-se viável.

53 Tradução de Sarian, 1993, p. 116.

${ }^{54}$ Tal prática de Eutímides revela um diálogo interessante, uma ampliação a ponto de ele colocar num vaso de sua produção o nome de outro grafista contemporâneo, o que não era absoluta novidade. Dugas [1960, p. 13-7] indica algumas inscrições com o nome Amasis em vasos atribuídos a Exéquias; mas sem esse paralelo comparativo.
} 
Eufrônio. A relação escrito-figurativa, nesse caso, não se resume a uma referenciação do que está ao lado, ou então distante num mesmo suporte; mas a inscrição de um vaso, relacionada aos grafismos dele, que se conecta, também, a outras imagens figurativas, a outra forma de ornamentar (específica de outro grafista, e cabe dizer, pior qualitativamente na perspectiva de Eutímides), e a relação escrito-figurativa é de uma complexidade diversa.

Em síntese, tem-se que existiam limites, e que eles eram responsáveis pela delimitação de espaços figurativos (às vezes espaços de inscrições), mas tais demarcações não eram tão severas; entretanto, é importante observar a sua eficácia. Essas faixas, linhas, conjunto de aros e palmetas, além dos desníveis na superfície do vaso, serviam como fronteira importante para a figuração, e são elementos essenciais na compreensão da relação escrito-figurativa. Se, de um lado, observam-se os constantes trespasses, por outro, há um grandíssimo número de cenas perfeitamente enquadradas. A partir disso, pode-se concluir que a lida com esses limites era diversa; havendo mesmo a possibilidade, em um único vaso, de haver o transpasse de limites importantes, o ajuste dentro do espaço figurativo enquadrado e o corte de parte de alguma figura que não se encaixaria nos limites. E mais, essa diversidade quanto à adaptação do espaço acompanharia a ornamentação ceramista ática até a época de seu declínio; ou seja, é um elemento característico da produção em figuras vermelhas e das figuras em fundo branco.

Mas, em alguns casos, pode-se mesmo dizer que ultrapassar tais limites era mais que comum; mas indispensável. As figuras portadoras de capacete freqüentemente alcançam e ultrapassam os limites superiores; e esse é um recurso iconográfico sistemático, por exemplo, na caracterização da Atena promachos nas ânforas panatenaicas (ver cap. 5, esquema 3, p. 202). Conter ou não conter as imagens nesses espaços indica, então, certa variedade da compreensão desses limites. A variedade persiste quando se refere à relação escrito figurativa; já que é o tipo específico de inscrição e de imagem que fundamentará a interpretação. As inscrições nominativas junto às imagens figurativas enquadram-se (materialmente e logicamente) muito bem aos espaços delimitativos: geralmente, elas não promovem diálogos maiores que a lógica interna da cena enquadrada poderia oferecer. Já as inscrições de autoria, essas poderiam ultrapassar com facilidade a lógica interna do quadro e mesmo de seu suporte, propondo comunicações amplas no quadro da produção da cerâmica ornamental ática tanto de forma relacional contemporânea (o paralelo com os outros vasos produzidos por um mesmo oleiro, grafista ou oficina; ou então, a comparação qualitativa proposta por Eutímides); ou então buscando uma comunicação entre gerações (como no caso de Tleson, referenciando seu pai). 
UM ESTUDO DE CASO: AS ÂNFORAS PANATENAICAS 


\subsection{Caracterizando a ânfora panatenaica}
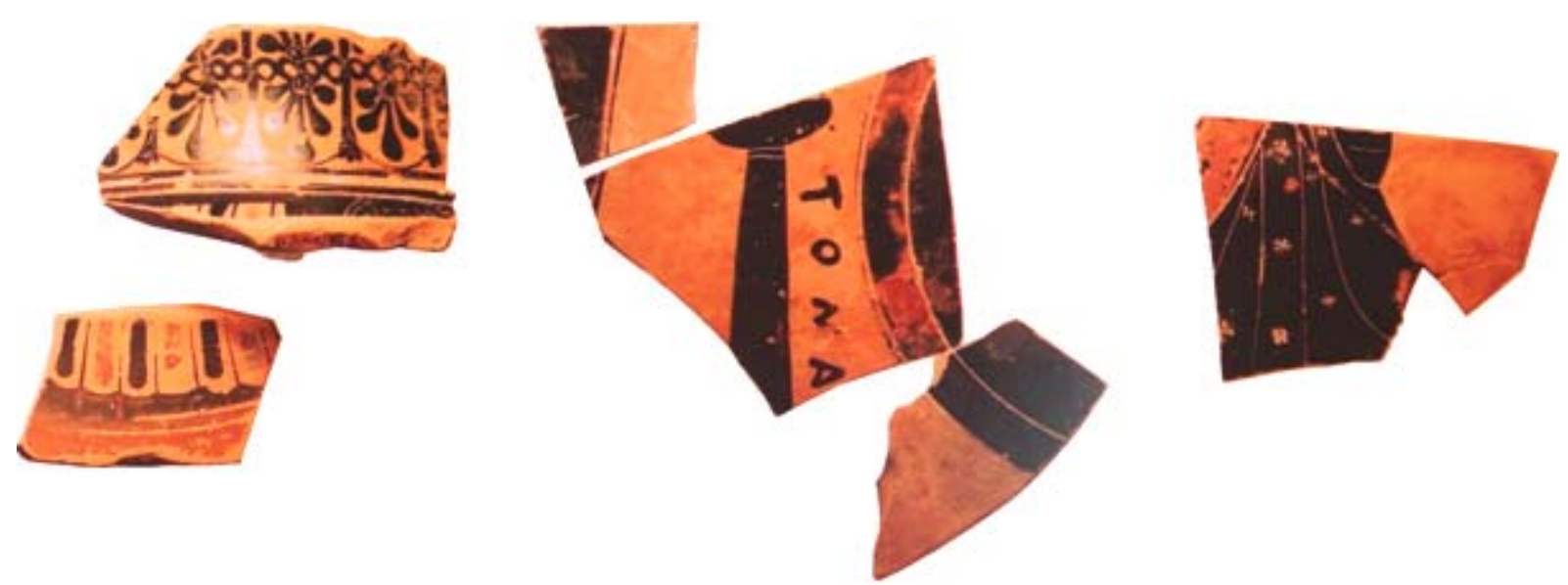

Fig. 1. Fragmentos de ânfora panatenaica atribuída ao Pintor Eufileto, c. 530-510 a.C., Gela, Museu de Gela.

A figura 1 apresenta fragmentos de uma ânfora panatenaica. A asserção tão segura dá-se pela possibilidade de observar, mesmo a partir de sua característica lacunar, formas bastante claras referentes a esse tipo de vaso. Um elemento é definidor; ou, ao menos é isso que a erudição acadêmica vem dizendo desde o século XVIII: trata-se da inscrição. Isso apresenta uma justificativa central para a escolha dessa categoria de vaso para um estudo de caso; ou seja, uma observação mais profunda. É um tipo de vaso caracterizado pelos especialistas, sobretudo pela inscrição que possui.

Na figura 1, como o objeto, a inscrição é também lacunar: TONA[- - ] $\rightarrow$; de onde se

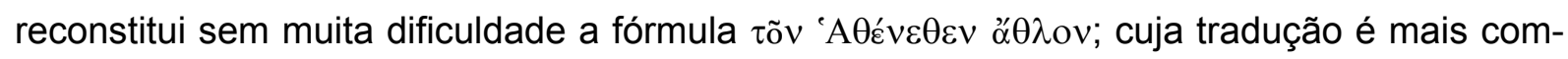
plexa do que parece; e, assim, será discutida com mais profundidade em breve. Por enquanto, deve-se saber que é ela o elemento escolhido como definidor da caracterização desse tipo de vaso; desde as discussões mais antigas. Por exemplo, Thomas Burgon, mercador turco e descobridor da mais antiga ânfora panatenaica (ver fig. 2), ${ }^{1}$ em correspondência com P. O. Bröndsted, tentando comprovar a autenticidade de "sua" ânfora, concentra-se

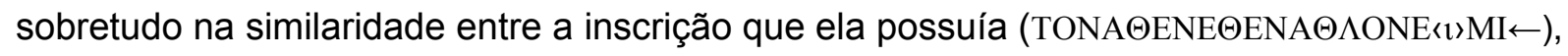
e outras que vinham sendo descobertas na Itália (Corbett, 1960, p. 52-4); época que ainda se discutia se a produção seria efetivamente grega ou etrusca (ver Sparkes, 1996, p. 59). Entretanto, há uma gama grande de elementos formais que contribuem para uma determinação com segurança, e, nesse momento, é importante conhecê-los bem. Para isso, é preciso saber que foram produzidos vários outros objetos relacionados, alguns muito similares

\footnotetext{
${ }^{1}$ A ânfora em questão e outros vasos, encontrados numa tumba em Atenas em 1813, foram agrupados (hoje, no British Museum) e caracterizados como pertencentes ao Burgon group.
} 
às ânforas panatenaicas; aos quais é dado o nome de vasos "pseudo-panatenaicos". A distinção dá-se, em grande medida, pela "ausência" da ocorrência de inscrição, embora tenham dimensões e formas físicas e ornamentais às vezes idênticas.
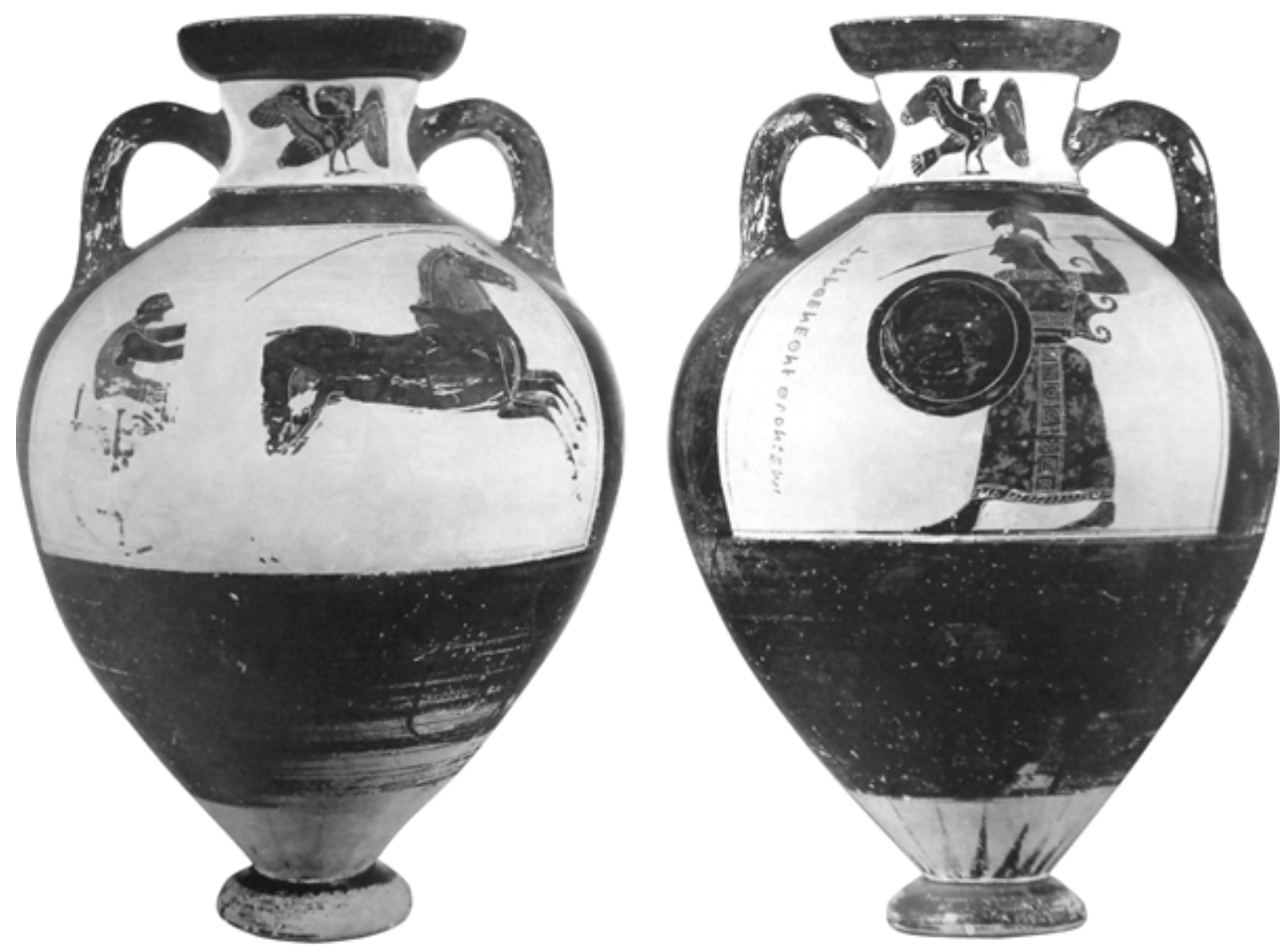

Fig. 2. Ânfora Panatenaica (Burgon Group), c. 560 a.C., London, British Museum (alt.: 61, $3 \mathrm{~cm}$ ).

As condições históricas que envolveram a produção e difusão das ânforas panatenaicas ainda serão apresentadas; entretanto, neste momento algumas informações básicas são importantes. Esses vasos possuíam forma física e ornamentação bastante regular, e mesmo as mudanças podem ser bem delineadas, tanto no que se refere a eventos históricos específicos ou ao longo do tempo; como a própria estrutura do vaso. Ainda, sua cronologia é bastante incomum. Trata-se de uma forma que se matém com certa rigidez do período arcaico (época de modelação e consolidação do esquema ornamental) até o período romano; compondo um conjunto de criações chamadas de arcaizante (ver Havelock, 1965). Ainda, sua produção estava ligada originalmente à premiação nos Jogos Panatenaicos, onde esses vasos eram oferecidos aos ganhadores, repletos de óleo provenientes das oliveiras sagradas de Atenas (as Mopíaı); e não apenas um deles: a premiação variava, sendo o máximo 140 de ânforas panatenaicas, dependendo da prova, ou da colocação que o partici- 
pante alcançava. $^{2}$ Tal situação coloca um problema aos pesquisadores desse tipo de vaso. Em primeiro lugar, seu caráter de exceção no quadro geral da produção ceramista, já que sua produção estava ligada a um evento quadrienal, cujo número de vencedores era prédefinido. Depois, o verdadeiro papel simbólico que tais vasos carregavam, pois eles eram continentes do valioso óleo sagrado de Atenas, certamente uma forma de premiação dos Jogos Panatenaicos; mas, nesse sentido, o vaso é um complemento do prêmio, ou apenas o invólucro dele? Ou seja, sua simbolização dependia de sua estreita relação com o óleo que carregava (ou teria carregado - dependendo do contexto de uso de tais vasos); ou havia uma simbolização específica?

Tal questão é importante no que se refere ao grau simbólico dedicado aos objetos. Um frasco de perfume, um Chanel $n^{\circ} 5$, por exemplo, ganha certo prestígio relacionado com seu conteúdo; e podem se tornar objetos de colecionadores. E mais, esses continentes em vários casos apresentam o produto, eles são a sua "cara". Assim, um valor que estaria ligado originalmente ao conteúdo que carregava, pode desvincular-se e mesmo extrapolar essa dependência original. Entretanto, essas questões anunciadas só podem ser mais profundamente discutidas a partir de informações externas, além da própria estrutura física do vaso, o que deve ser bem caracterizado.

Ainda, algo da cronologia das ânforas panatenaicas deve ser apresentado. A dimensão transecular de sua produção proporcionou uma série de mudanças formais importantes; mas também notáveis permanências. A questão é que a série extrapola em grande medida as propostas balizas temporais já discutidas (capítulo 2, item 2.1); o que não apresentará grandes complicações, pois a grande presença temporal desses vasos na realidade social grega antiga, e mesmo de vários outras culturas do Mediterrâneo, guarda, em grande medida, formas que foram estruturadas no período arcaico; ou seja, a compreensão da estrutura formal das ânforas panatenaicas e suas permanências, passa, em grande medida, pela observação atenta da formulação de tal modelo no período arcaico; e, em certa medida, uma percepção dessa própria época posteriormente. Assim, a observação da dinâmica suporteornamentação deve atentar às modificações formais ao longo do tempo.

Os grupos mais abundantes de ânforas panatenaicas, concentram-se na produção do período arcaico até o helenístico, ${ }^{3}$ e de uma época para a outra, as mudanças formais são significativas. As ânforas panatenaicas helenísticas têm o corpo mais alongado, a boca

\footnotetext{
${ }^{2}$ Sua capacidade era de cerca de 39 litros de óleo (Noble, 1996, p. 13), entretanto poderia haver certas modificações na quantidade de óleo e nas dimensões das ânforas. Em épocas menos propícias, por exemplo, contextos de guerras, essa quantidade poderia diminuir.

${ }^{3}$ M. Bentz, autor do catálogo mais sistemático sobre as ânforas panatenaicas (Bentz, 1998), restringe sua documentação entre o período arcaico ao helenístico, justamente argumentando que é a partir desses exemplares que se constitui um grupo mais consistente.
} 
é extroversa, as alças mais altas, dentre outras variações, levando-se em conta a matriz arcaica, como por exemplo a organização e junção das formas do vaso (ver esquema 1).
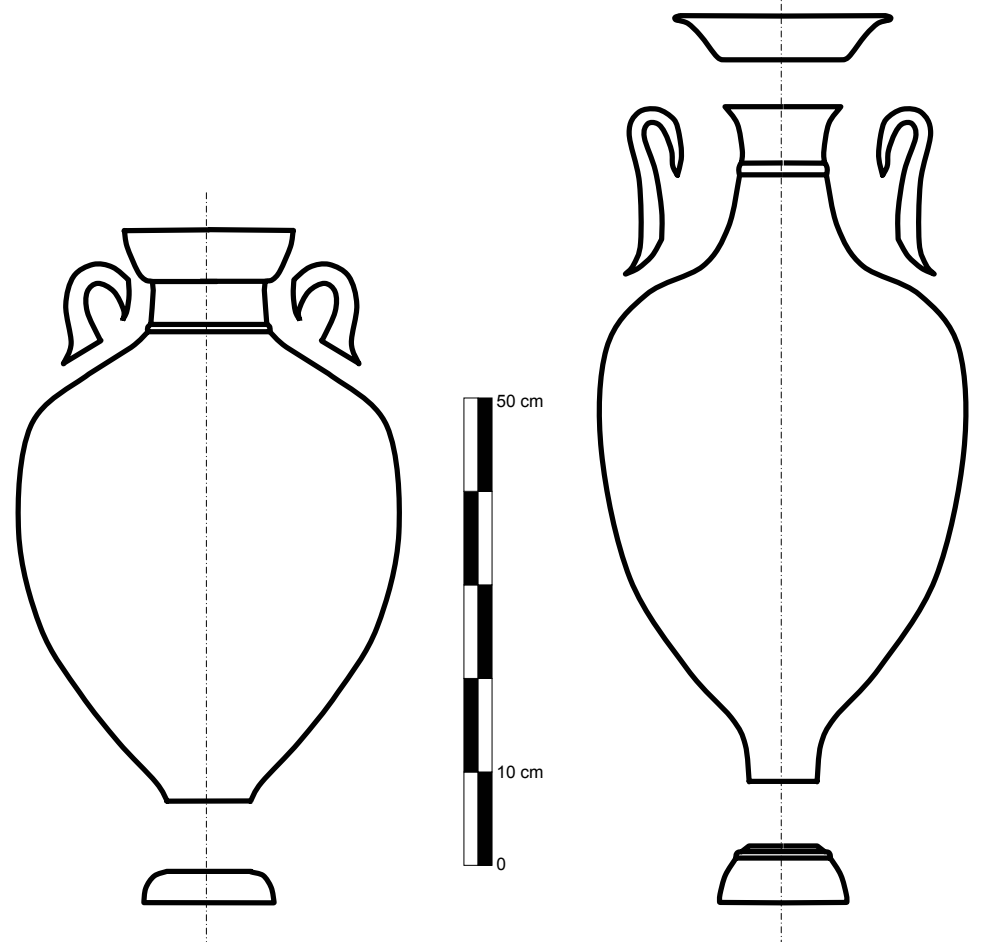

Esquema. 1. (à esquerda) ânfora panatenaica do período arcaico: corpo, pescoço e boca numa só peça, alças e pé confeccionados separadamente; (à direita) ânfora panatenaica do período helenístico: corpo e pescoço formam uma peça; enquanto alças, boca e pé são produzidos separadamente (Noble, 1996, p. 13).

A pesar desse cenário de mudanças, algumas permanências são marcantes; por exemplo, o bojo largo, o gargalo estreito, alças robustas. ${ }^{4}$ Do ponto de vista iconográfico o quadro é parecido. Nesse sentido, é preciso antes caracterizar a formulação arcaica do esquema panatenaico; para posteriormente verificar as permanências e mudanças.

As primeiras ânforas panatenaicas datam do segundo quartel do século VI a.C., época de reestruturação das Panatenéias, quando se organizam as festividades quadrienais, além das anuais. É nesse cenário que surgem as ânforas panatenaicas. Os primeiros exemplares não registravam um esquema rígido (do ponto de vista físico e ornamental). Entretanto, em meados do século VI a.C., consolida-se o esquema ornamental (ver esquema 2); uma organização que pode ser observada na produção dos vasos panatenaicos de forma sistemática, e inclusive nos exemplares relacionados.

As inúmeras mudanças ocorridas respeitam em grande medida este esquema, com raras exceções. Do período arcaico para o clássico, a faixa com palmetas (2, no esquema

\footnotetext{
${ }^{4}$ Essas características das ânforas panatenaicas remetem aos vasos de transporte extremamente comuns no Mediterrâneo antigo; e em certa medida, elas eram vasos de transporte. A forma dessas ânforas é originada, segundo especialistas, nas ânforas de transporte "SOS"; um tipo de vaso sub-geométrico, da primeira metade do século VII a.C.; mas de experiência visual corrente no período arcaico. Para isto, basta observar que o Dioniso de Ergotimo e Clítias, na cratera François (c. 570 a.C.), carrega nas costas uma ânfora do tipo "SOS". Entretanto, há quem remeta a origem da forma à ânfora do tipo "à la brosse" (Valavanis, 1986, p. 454)
} 
2), diminui em relação à faixa com lingüetas contornadas (3), adaptando-se à nova articulação entre alça e pescoço. A faixa com raios (5), não aparece em alguns vasos, sendo, às vezes reservada a coloração da argila, ou então, a região é pintada de negro; entretanto, a seqüência de elementos é bastante recorrente, inclusive em alguns vasos da Magna Grécia inspiradas nesse modelo. Esses elementos não eram exclusividade dos vasos panatenaicos, e muitos remontavam à produção ceramista coríntia. As faixas ornamentais, as delimitações dos painéis, tudo isso era presente na produção corrente; entretanto é nos vasos panatenaicos que eles ocorreram sistematicamente nessa seqüência.

Face $A$

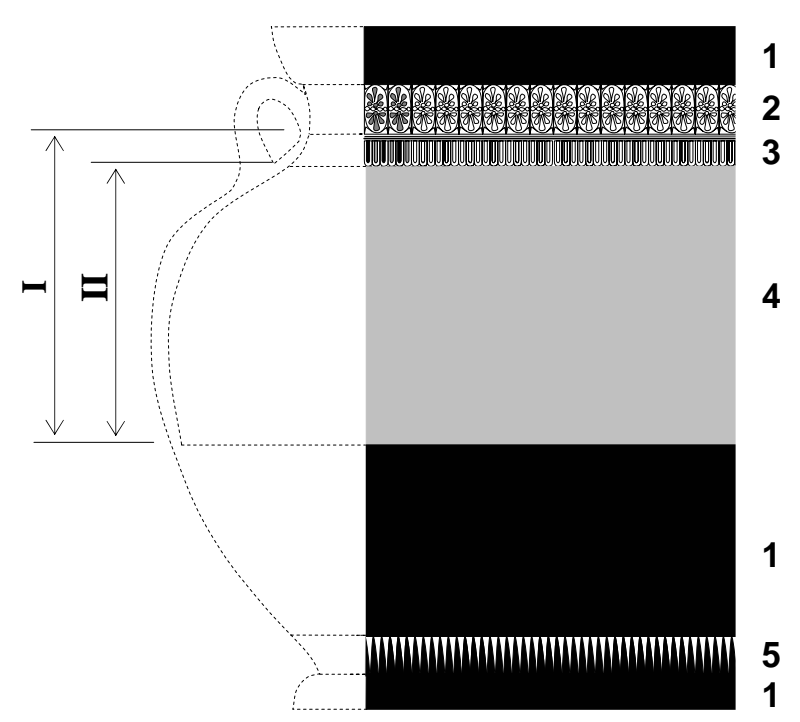

Face $B$

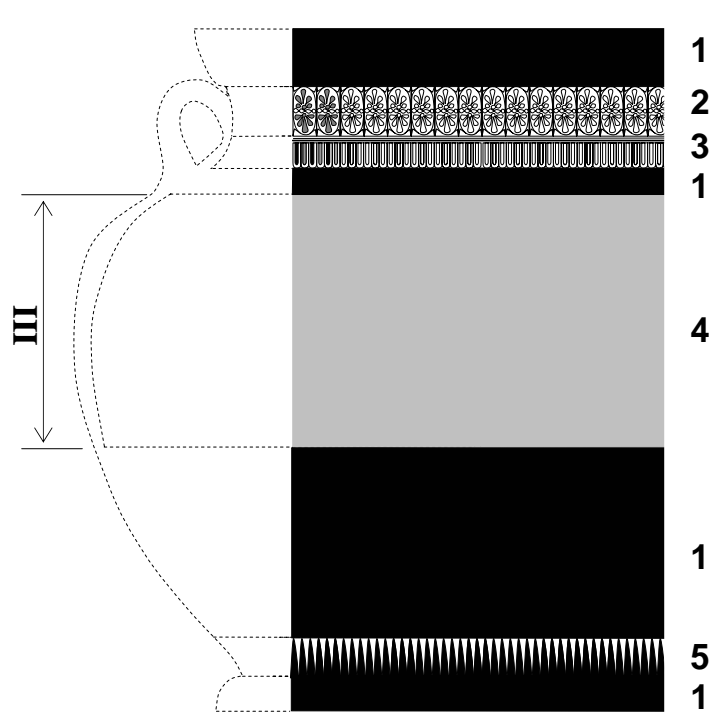

Esquema 2. Estrutura geral da ornamentação das ânforas panatenaicas: 1. Preenchimento com verniz negro; 2. Faixa ornamental 1; 3. Faixa ornamental 2 (na face $\mathrm{A}$, funciona como delimitação superior da cena); 4. Espaço dedicado à figuração; 5. Faixa ornamental 3. I e II. Alturas relativas à figuração na Face A; III. Altura relativa à figuração na Face B. (Esquema baseado em ânfora panatenaica típica do século VI a.C.)

A articulação desses elementos, então, organiza em grande medida os espaços em que ocorriam os grafismos. As figuras e as inscrições ocorriam em painéis bem delimitados, seguindo a estrutura geral do vaso em duas faces. As alças e o recorte que guarda um painel em argila reservada delimitam tais espaços; mas, há certas sutilezas que diversificam a adaptação dos grafismos. Do ponto de vista seqüencial, observado no esquema 2, há uma "dessimetria" entre uma face e outra: o quadro figurativo da face $A^{5}$ tem como delimitação superior imediata a faixa com lingüetas contornadas; já o quadro da face B é completamente cercado pelo recorte em verniz negro. Ou seja, o espaço figurativo da face A é maior que o da B. Essa que parece uma informação sem importância, indica algumas formas próprias da

\footnotetext{
${ }^{5}$ Caracterizar as faces como A e B não apresenta prioritariamente uma hierarquização entre elas. É certo que a bibliografia escolhe freqüentemente uma face "principal", "anverso" etc. de forma hierárquica; entretanto, esse é um problema a ser discutido.
} 
adaptação da figuração numa face e na outra; duas estratégias bem diferentes. Assim, na face $\mathrm{A}$, a figura da Atena promachos (que guerreia à frente) ultrapassa invariavelmente o limite superior; sendo esse, inclusive, uma indicação cronológica; ou seja, quanto mais recente for o vaso, mais a figura da Atena se estende sobre a faixa delimitativa superior (ver esquema 3). Na outra face, a figuração da prova atlética nunca ultrapassa o limite superior. Dessa forma, percebe-se que a organização figurativa nas duas faces é diferente em alguns aspectos; e é apenas em uma delas que ocorre a aproximação entre inscrições e figuras; o que não impede, como visto (capítulo 4, item 4.3.3), alguma possibilidade de comunicação entre as faces.
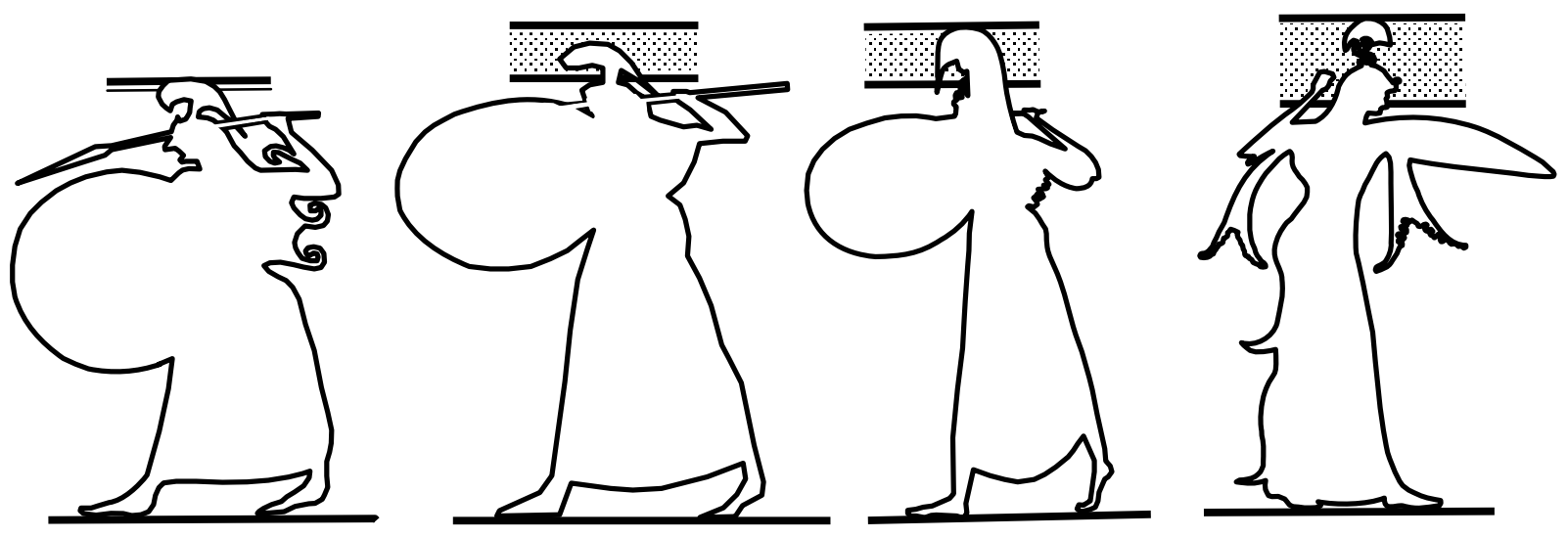

Esquema. 3. Iconografia panatenaica (esquema do desenvolvimento da imagem de Atena): (da esquerda para a direita) a. Burgon group, $2^{0} 1 / 4$ do séc. VI a.C.; b. atribuída ao pintor de Cleofrades, c. 525-500 a.C.; c. Kuban group, c. 400 a.C.; d. Ânfora da série de Nicômaco, 340-339 a.C.

A caracterização desses elementos essenciais na composição das ânforas panatenaicas indica outros meios de identificação do objeto fragmentar, além da inscrição. Voltando à figura 1, vê-se, sobre o pescoço e início do ombro, a seqüência das faixas em palmeta e em lingüetas contornadas (em uma parte da faixa, praticamente ilegível na figura, há a interrupção com o que parece ser o capacete de Atena); além deles, nos fragmentos do bojo, a parte de uma coluna e da Atena portando o escudo. Entre estes, o fragmento de inscrição.

Os fragmentos do pescoço, isoladamente, não apresentariam categoricamente elementos para a verificação de sua natureza (se um vaso panatenaico ou não). Além disso, coloca-se uma questão interessante: se apenas uma informação específica (a inscrição) define com certeza se um vaso é panatenaico ou não, materialmente falando, é sobre a inscrição que residiria o ônus da autenticidade de tal objeto. Assim, boa parte dos fragmentos encontrados com esse tipo de ornamentação peculiar, mas sem inscrição, não são bons guias para a observação da produção de ânforas panatenaicas em termos quantitativos. 
A inscrição como elemento-guia tem vários pontos a favor. Por exemplo, parte dos vasos sem inscrição, na face que figura a prova atlética, em vez delas, apresenta um concurso musical (ver fig. 3); competição que não era premiada com ânforas panatenaicas. ${ }^{6}$ Com isso, tem-se que esses vasos sem inscrição eram menos constantes no que se refere à rigidez formal, mesmo que em vários casos a única diferença entre eles e as ânforas panatenaicas seja a falta de inscrição.
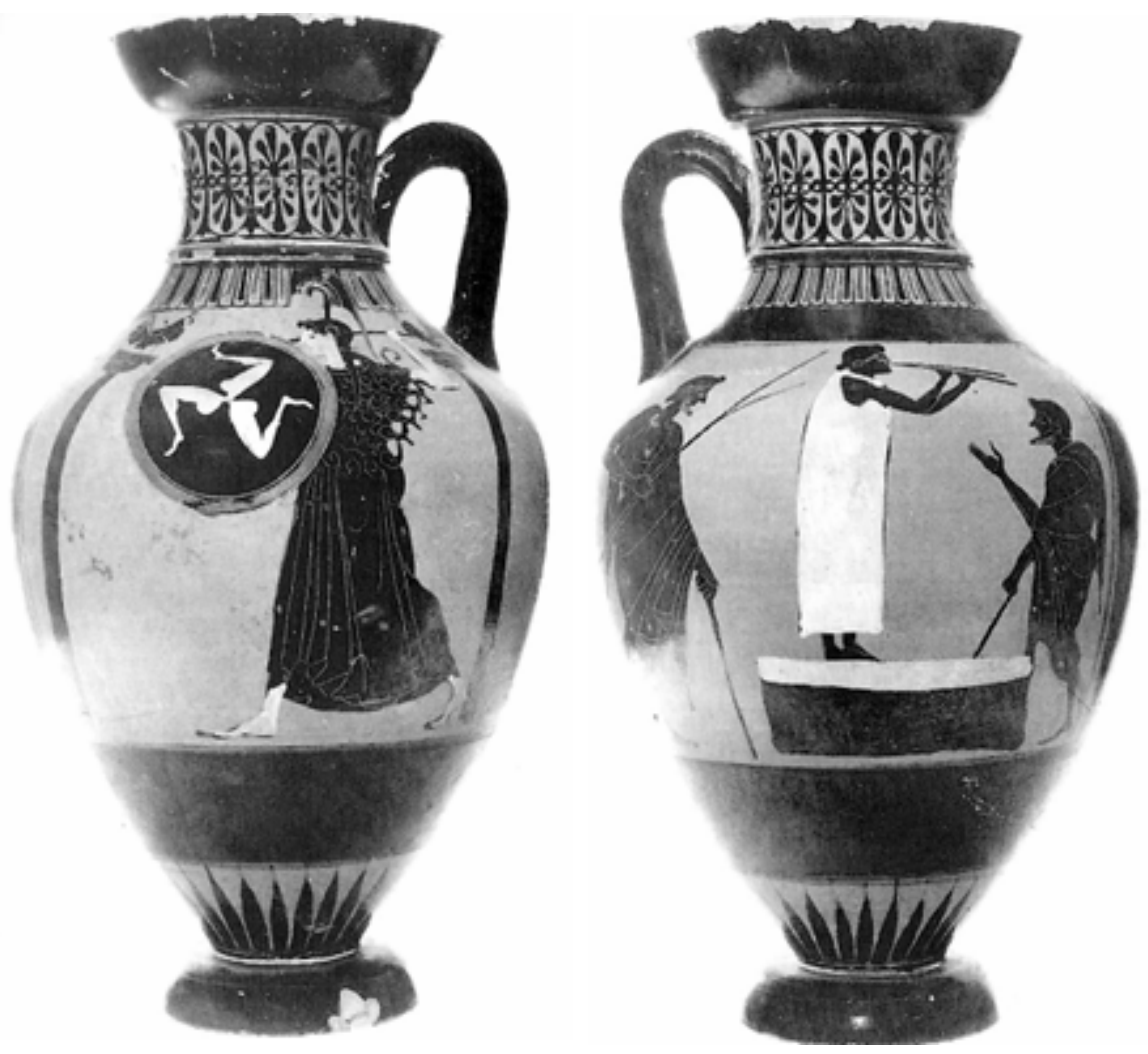

Fig. 3. Ânfora "pseudo-panatenaica", c. 500-490 a.C., Museu Gregoriano Etrusco (alt.: $34,1 \mathrm{~cm})$.

Há uma concordância ampla na bibliografia sobre esse tema, de que esses vasos sejam relacionados, mas não propriamente panatenaicos; ou seja, aqueles oferecidos aos vencedores das competições atléticas. Nesse sentido, algumas imprecisões são feitas. Bentz, por exemplo, acredita na eficácia dessa distinção; mas, como observa Hamilton (1999, s/p), ele utiliza fragmentos pouco conclusivos, ou seja, aqueles que não possuem inscrições, como correspondentes a ânforas panatenaicas. ${ }^{7}$ Outro problema são as propostas de reconstrução quantitativa do quadro geral da produção de vasos áticos baseados na observação das ânforas panatenaicas. Assim, se se sabe com certa clareza a quantidade de

\footnotetext{
${ }^{6}$ Aristóteles, Constituição ateniense, 60, 3.

${ }^{7}$ Ainda, Marx (2003) trata alguns fragmentos sem inscrição (fig. 4 e 5, prancha 3) como ânforas panatenaicas, entretanto, um vaso inteiro sem inscrição (fig. 3, prancha 4) como "imitação".
} 
vasos que era produzida a cada Grande Panatenéia, ${ }^{8}$ e o quanto deles permaneceu, poderia estender-se ao quadro mais amplo da produção ceramista, e se estipular números para ela. Entretanto, a falta de clareza de muitos fragmentos (se são ou não panatenaicos) complica sensivelmente tal proposta. Isso, pois grande parte dos objetos encontrados são fragmentos que não informam definitivamente sua natureza. Dessa forma, a quantificação fica baseada num chão pouco seguro. Esses não são os únicos problemas, e parece que a aceitação da inscrição como elemento conclusivo não seja absolutamente seguro, mas provável. Alguns autores (como Hamilton, op. cit.) propõem cautela nessa caracterização ansiosaAinda, além da distinção entre vasos panatenaicos e os relacionados, a inscrição pode indicar um outro problema complicador, mas este pouco tratado pela bibliografia. Trata-se de seu significado e como ele pode contribuir para a compreensão da dimensão simbólica das ânforas panatenaicas.

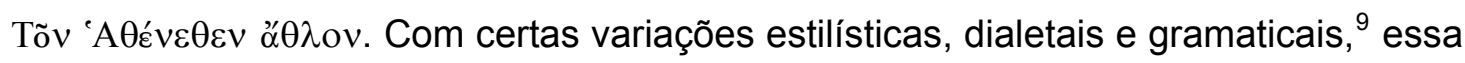
era a mensagem escrita mais constante nesses vasos; não a única; mas é sobre ela que agora se concentrará. A tradução é complexa, por mais que sua apresentação em inúmeras obras que tratam das ânforas panatenaicas não indique nenhum problema. Existem variações significativas de tradução, e elas podem indicar caminhos diferentes de compreensão da inserção social desses vasos. As propostas de tradução mais recorrentes são as seguintes:

1) “Um prêmio de Atenas" (Cook, 1997, p. 86);

2) "Um dos prêmios de Atenas" (Nicholson, 2005, p. 13; Bentz, 2003, p. 112; Marx, 2003, p. 16; Boardman, 1995, p. 167; Noble, 1996, p. 13);

3) "Um prêmio dos jogos de Atenas" (Collignon, 1885, p. 288; ${ }^{10}$ Beazley, 1986, p. 81 ;

4) "Dos jogos de Atenas" (Tracy, 1991, p. 143; Neils, 1992, p. 29; Hamilton, 1992, p. 130);

As variações são significativas, e repousam sobre três pontos básicos: a noção de prêmio, dos jogos, e a filiação ou a sediação em Atenas. Tais traduções são apresentadas na maioria das vezes sem se discutir seu significado, retomando-se alguma tradição de in-

\footnotetext{
${ }^{8}$ Acredita-se que cerca de 1500 vasos (números relativos ao século IV a.C.) eram produzidos por ocasião dos jogos panatenaicos (Bentz, 2003, p. 112).

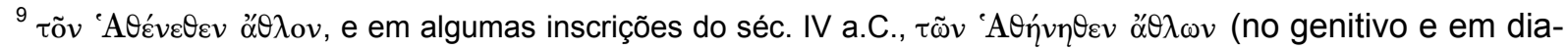
leto dórico).

${ }^{10}$ Essa é uma das mais antigas propostas de tradução do conteúdo das ânforas panatenaicas; entretanto, seu conteúdo já era apresentando, em grego, em obras anteriores, como Pottier, 1882, p. 168, e De Witte, Ann. D. Inst., 1877 (Apud Ducati, 1922).
} 
terpretação (como a de Beazley); mas há, em poucos casos, discussão de seu teor. Por exemplo, Hamilton (1992), apesar de ter citado a fórmula de Beazley, opta pela "dos jogos de Atenas", pois considera um problema interpretar tal vaso naturalmente como um "prêmio" (como Immerwahr [1990, p. 183]). A questão é que o termo $\tilde{\alpha} \theta \lambda \mathrm{ov}$, o centro do problema de tradução, era polissêmico já na Antigüidade. Seu uso na produção literária indica três significados básicos inter-relacionados: $\tilde{\alpha} \theta \lambda \mathrm{ov}$, como prêmio de um combate, uma recompensa; como a competição (o combate, a luta); e, por fim, como o próprio espaço do combate. ${ }^{11}$ Porém, se parece que as variações de interpretação quanto a inscrição dos jogos não apresentam grande prejuízo, a opção por uma delas revela a adesão a um modelo de interpretação mais amplo. Dessa forma, a compreensão da inscrição, mais do que uma discussão puramente filológica, depende de uma compreensão do próprio significado do vaso no contexto em que era criado; ou seja, na situação em que os grafistas aplicavam tal inscrição. Dar relevo à sua dimensão sígnica, caracterizando-o naturalmente como prêmio, significa interpretar tal vaso como um objeto valioso socialmente falando. Ao contrário, pode-se mesmo ressaltar sua filiação à pólis ateniense e a importância de seu conteúdo, o óleo sagrado das oliveiras sagradas de Atenas. Assim, mesmo antes de compreender o real significado da inscrição, pode-se observar que essas traduções interpretativas pautam-se em visões diversas sobre a inserção social de tal vaso; revelando um debate constante no tocante às ânforas panatenaicas: seriam elas importantes objetos, imbuídos de um alto grau simbólico; ou apenas o invólucro de um produto realmente valioso: o óleo ateniense? Pender para uma ou outra interpretação da inscrição, nesse sentido, significa tomar partido nesse quadro de interpretações. Dessa forma, a caracterização mais segura, deve esperar uma discussão mais precisa das questões internas e contextuais sobre tal vaso. Entretanto, de início, é possível situar tal prática histórica entre os gregos.

Vasos de cerâmica como premiação não era algo incomum. Porpõe-se freqüentemente que estes seriam substitutos dos objetos de metais, inclusive vasos, cuja experiência como dons na Antigüidade era constante, como indica a poesia homérica (ver Bažant, 1981, p. 8). No torneio em honra de Pátroclo (Ilíada XXIII, 741-3; 748-50), Aquiles anuncia entre os prêmios:

uma cratera, prata bem lavrada, seis

medidas, que no mundo a todas excedia

em beleza (...).

(...) Aquiles põe-na

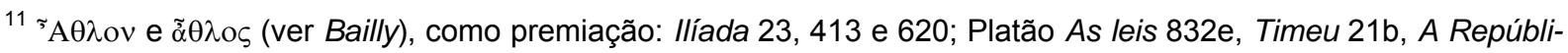
ca 613c; Xenofonte Hiéron 9, 4; Heródoto 8, 26; 9, 101; Aristóteles Política 4, 11, 17; como combate, luta: Odisséia 8, 160; 24, 89; Sófocles Antígone 856, Philoctète 508, El 49, 682; Ésquilo Prometeu 708, 752; As suplicantes 1034; Heródoto 1, 126; como espaço para o combate, arena: Platão As leis 868a, 965b.
} 
como prêmio, em tributo ao amigo dileto,

ao corredor mais ágil. ${ }^{12}$

A substituição desses objetos de metal pelos de cerâmica é amplamente observável. Já no século VIII a.C., por exemplo, a ocorrência da inscrição na enócoa do Dípilo (ver capítulo 2, fig. 1, p. 60) a qualifica como prêmio. São comuns as relações apresentadas entre as ânforas panatenaicas e a enócoa do Dípilo, buscando certos comportamentos originais (ver Neils, 1992, p. 29). Realmente, é possível estabelecer paralelos no tocante às inscrições como elemento definidor do objeto como prêmio; entretanto, a lógica da estrutura formal desses vasos não permite mais aproximações, já que, enquanto para a enócoa do Dípilo é a informação escrita, unicamente ela, que a caracteriza como prêmio, os vasos panatenaicos, já em sua forma, eram reconhecidos como ou relacionados ao prêmio, como revelam figuras desse tipo de vaso em outros suportes, que guardam, em vários casos, apenas a forma e nenhuma referência à sua ornamentação.

Ainda, diferente das ânforas panatenaicas (onde o caráter prático da premiação deve ser também considerado, pois eram oferecidas dezenas de vasos repletos de óleo), este era um único objeto encontrado em contexto funerário. A inscrição atesta com certa segurança a natureza desse vaso como prêmio. Assim, vasos como premiação eram viáveis. Além disso, é devido lembrar que sobre a superfície de vasos de cerâmica ornamentada foram produzidas inúmeras inscrições de homenagem. Parece, com isso, que não haveria grandes impossibilidades em se utilizar vasos como prêmio ou presente (dom); mas os vasos panatenaicos tinham inserção bastante específica, o que ainda será tratado.

Outra possível fonte para comparação é a inscrição ПАТРОQ $\Lambda \mathrm{Y} \Sigma \mid \mathrm{AT} \Lambda \mathrm{A} \leftarrow$ num dínos de Sófilo (ver capítulo 3, fig. 71, p. 123). A tradução mais comum é "Os jogos em honra de Pátroclo" (Snodgrass, 2004, p. 172-3), subtendendo disso, que $\tilde{\alpha} \theta \lambda \alpha$ seja algo como "jogos em honra"... Ora, vê-se aí que é a dimensão da competição, e não da premiação, a privilegiada na interpretação. E esse tipo de tradução segue, em grande medida, os prováveis paralelos entre a cena produzida por Sófilo e o canto XXIII da llíada. Entretanto, a comparação deve considerar as diferenças marcantes; já que a inscrição nesse fragmento não o qualifica, mas indica a temática da cena (uma legenda), diferente da inscrição de caracterização do objeto presente nas ânforas panatenaicas. Assim, a avaliação do sentido da inscrição no fragmento de Sófilo passa sobretudo pela sua correspondência com a cena figurada e os paralelos com a provável matriz homérica. ${ }^{13}$

\footnotetext{
${ }^{12}$ É também uma cratera, o presente de Menelau a Telêmaco (Odisséia IV, 570).

${ }^{13}$ Snodgrass (2004) faz um exame dos paralelos entre a iconografia grega geométrica e arcaica, comumente estabelecidas na discussão acadêmica como quase natural. Nesse caso, a imagem com inscrição, parece apontar um exemplo de variação imagética de um tema propriamente homérico; tendo em vista, por exemplo, os indícios de "uma versão poética mais antiga, na qual esses jogos teriam sido realizados, na realidade, para o próprio
} 
A compreensão da inscrição panatenaica, então, parece merecer atenção maior, já que sua interpretação imediata pode transferir à observação de sua inserção contextual certas formas de apropriação e reflexão desses objetos que não correspoderiam à sua real natureza na Antigüidade. Nesse sentido, apenas posteriormente, depois das questões da lógica escrito-figurativa e dos contextos relacionados às ânforas panatenaicas que será retomada a questão do significado de tal informação escrita.

\subsection{Uma observação interna: a relação escrito-figurativa}

As faces das ânforas panatenaicas, algumas estratégias de adaptação figurativa (ver esquema 2) e os elementos de sua temática já foram apresentados de forma rápida. Neste item, contígua à observação da relação escrito-figurativa nos vasos panatenaicos, haverá uma caracterização mais detalhada. Retomando, é abusivo tratar de antemão qualquer uma das faces como hierarquicamente superior. Marx (2003, p. 14), ao comentar a importância da composição complexa de vistas da figura de Atena, traço, segundo a autora, praticamente esquecido, opta por uma hierarquização, chamando a face relacionada à imagem figurativa de Atena de "lado A" e também de "frente" (p. 16), como Bentz (2003, p. 112); e, vale dizer, esses são apenas dois exemplos de uma prática generalizada. Falar em frente e verso significa dizer que eles assim eram pensados o que não é absolutamente claro; ou seja, aceitar a caracterização de duas faces bem delimitadas, não significa aceitar de antemão qualquer oposição absoluta ou desequilíbrio da importância de uma sobre a outra. Em muitos casos, hierarquizar as faces do vaso significa atribuir um valor a essa delimitação, sem saber se (ou como) ela existia; e ainda isso poderia ser variado, pois tais vasos alcançavam contextos diversos. Assim, as hierarquizações ou devem partir de uma compreensão antiga desses objetos, como eram eles integrados socialmente; ou, então, de uma opção contemporânea, que serve a determinadas posições metodológicas, mas isso deve ser anunciado. É, neste sentido, então, que se denomina aqui uma face como A e outra como B.

As propostas de oposição entre as faces das ânforas panatenaicas são variadas: feminino e masculino (a apresentação da deusa Atena contrastando com a apresentação das provas exclusivamente masculinas), estático e dinâmico (enquanto a figuração da deusa Atena e as inscrições são invariavelmente apresentadas na face $A$; na face $B$, há a figuração de variadas provas atléticas), extrapolante e contido (a figura de Atena alcançando a faixa superior delimitativa, o que nunca ocorre com as figuras das provas), mítico e não-mítico (a

Aquiles. Se essa opinião estiver correta, então a associação estritamente homérica de 'Os jogos em honra de Pátroclo' não consiste apenas no interesse especial do poeta pelo caráter do herói morto: o episódio inteiro teria sido uma das contribuições pessoais de Homero à lenda grega antiga." (Snodgrass, op. cit.) 
Atena promachos, muitas vezes relacionada à Atena que compunha o grupo de deuses na Gigantomaquia; e a apresentação de uma prova esportiva regular), pólis e indivíduo (numa face, referências explícitas à pólis ateniense, como a inscrição dos jogos ou do arconte, e a deusa padroeira da cidade - o objeto de culto nas Panatenéias -; e, na outra, a premiação do vencedor em uma prova), dentre outras; nenhuma delas absoluta, mas que explicariam, em certa medida, a dinâmica da interação entre as faces das ânforas panatenaicas. Partindo da distinção das faces, que, como visto, é viável em alguns pontos, procurar-se-á, aqui, tratar também das interações.

Ainda, grande parte dos estudos sobre as ânforas panatenaicas que se volta para a compreensão de sua dimensão figurativa opta por uma clara diferenciação: ou trata-se de uma face, a de Atena promachos entre as duas colunas e inscrição; ou da outra, relacionada aos eventos atléticos. Estudos sobre atletismo na Antigüidade freqüentemente apresentam a iconografia atlética, referente à face B (ver Poliakoff, 1987 e Golden, 1998); outros se concentram nas questões da inscrição e composição iconográfica da deusa Atena (ver Marx, 2003). A distinção é tão grande que mesmo estudos como Bentz (1998), que tratam dos vasos inteiros, optam por capítulos ou itens específicos para tratar da iconografia de Atena e a das competições; e, cabe lembrar, o que caracteriza de fato uma ânfora panatenaica, segundo as proposições acadêmicas, é a conjunção de determinados aspectos formais, figurativos e sobretudo as inscrições. Nessa linha, basta observar a face comumente chamada de A, ou principal, que já se interpreta um vaso ou fragmento como panatenaico. Aqui, a proposta é a de tratar o vaso de forma mais ampla, buscando as interações e mesmo a compreensão da viabilidade de tal cisão. De início, é importante notar que há diferenças marcantes entre as faces, mas que há aspectos comunicativos que não podem ser deixados de lado.

O esquema panatenaico compreendia na face $A$ uma estrutura bem organizada: No painel, no centro, a figura de Atena promachos ladeada por duas colunas encimadas por elementos variados como galos (os mais constantes no período arcaico), Vitórias aladas, estatuetas etc. $O$ tipo de coluna também varia: inicialmente um predominância de colunas dóricas, mas haveria, já no período helenístico, colunas em acanto. Entre a figura de Atena e as colunas ocorria, na maioria das vezes, a inscrição dos jogos (à direita), e a do arcontado ou de autoria (à esquerda). A posição poderia variar em poucos casos, e a inscrição ocorrer no lado externo da coluna; ou, ainda, a inscrição dos jogos no lado esquerdo. Entretanto, essas são exceções, e mesmo essa fuga mantém a proximidade comum entre inscrição e a coluna no esquema panatenaico. Apesar das variações numa mesma época ou ao longo do tempo, pode-se reduzir esquematicamente essas ocorrências (ver esquema 4). 

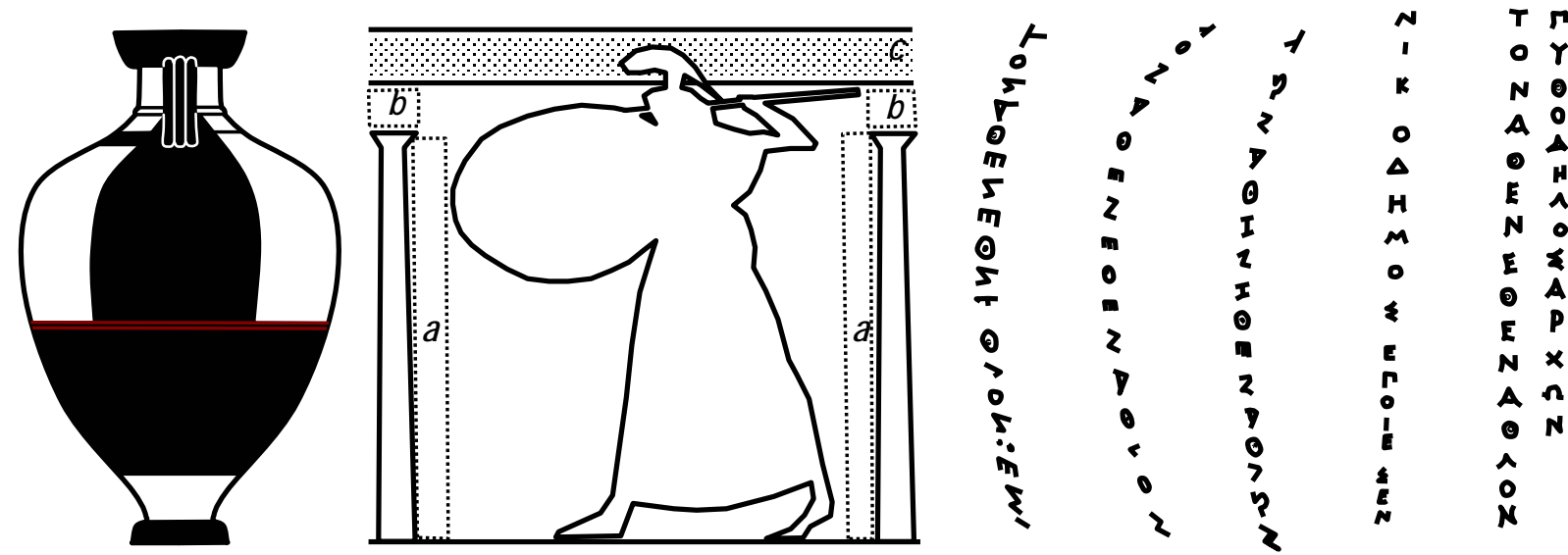

Esquema 4. (à esquerda) lateral de ânfora panatenaica - a divisão em duas faces e dois painéis dá-se com orientação da posição da alça e a espessa faixa lateral; (meio) apresentação esquemática dos grafismos da face A, onde a. campo da inscrição (dos jogos, dos arcontes e de autoria - em poucos casos a isncrição pode ocorrer do outro lado da coluna); $\boldsymbol{b}$. elementos que encimam as colunas (galos, Vitórias aladas etc.), c. Faixa ornamental que delimita a cena; Inscrições de ânforas panatenaicas: d. 575-550 a.C.; e. 520-500 a.C.; f. c. 400 a.C.; g. 363-362 a.C., "Nicodemos fez"; $\boldsymbol{h}$. 336-335 a.C., "Pithodelos arconte".

Os elementos peculiares dessa face indicam um conjunto de fortes referências propriamente atenienses. Em primeiro lugar, a própria deusa Atena, reverenciada especialmente na ocasião das Panatenéias. Discute-se amplamente a natureza de sua figura: seria ela a "representação" da estátua de culto, ou a própria Atena pronta para o combate, como a que lutou contra os Gigantes? Longe de definir a discussão, a presença maciça da deusa, invariavelmente, inclusive na maioria das imitações, reforça essa forte referência. Outro elemento importante é a inscrição dos jogos. Ela referenciava os jogos em algum nível e ocorria em dialeto ático, com algumas exceções. As ânforas do século IV a.C., apresentam um outro elemento específico: as inscrições de arcontado, aquelas que apresentavam sob a égide de qual administração o festival teria sido promovido, e também pode se especular sobre o controle do conteúdo. Por fim, as assinaturas de autoria parecem restringir mais ainda o conjunto de referências, agora não propriamente à pólis, mas o indivíduo ou oficina responsável pela produção. ${ }^{14}$

A outra face, a B, apresenta um esquema bastante diferente. Nela eram figuradas as variadas provas atléticas: corrida (à pé), de cavalo, de carro, pugilato e outros eventos do pentatlo (corrida, arremesso de disco, lançamento de dardo, salto e luta). A caracterização era mais livre, e pode-se mapear uma variação grande no que se refere à figuração do mesmo esporte (ver fig. 4).

\footnotetext{
${ }^{14}$ Há quem diga que as imagens nos escudos passam, em determinado período, a remeter símbolos utilizados pelas oficinas, assim, seriam outro elemento especificador presente na face $\mathrm{A}$.
} 

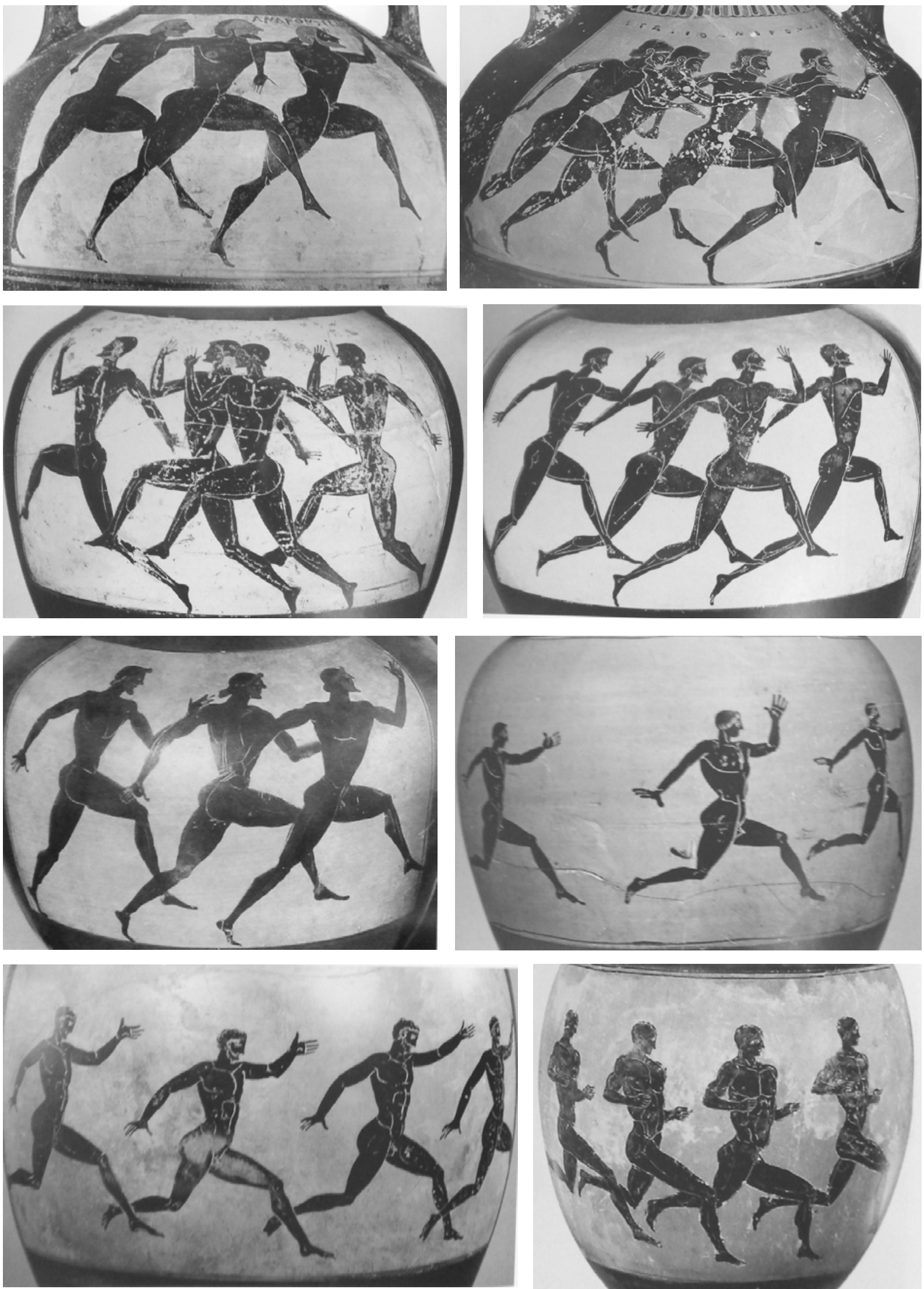

Fig. 4. Detalhes da face $B$ de ânforas panatenaicas refrentes à prova de corrida à pé : (de cima para paixo, da esquerda para a direita) $C$. 566-530 a.C., New York, Metropolitan Museum of Arts; c. 566-530 a.C., München, Staaliche Antikensammlungen; c. 480-460 a.C., Berlin, Staatliche Museen; c. 480-460 a.C., Karlsruhe, Landesmusem; c. 500-450 a.C., Frankfurt, Liebieghaus - Museum alter Plastik; c. 450-410 a.C., Atenas, Museu da Acrópole; 380-370 a.C., Detroit, Detroit Institut of Arts. 
A observação material da interação escrito-figurativa indica a constante dependência das inscrições frente às imagens; o que também acontece com as ânforas panatenaicas. Para isso, basta dizer que elas ocorrem numa estrutura bastante recorrente (entre uma coluna e a figura da deusa Atena, mas quase colada à coluna, o que orienta as inscrições de uma forma linear - situação observável, mesmo quando o espaço não era suficiente para cumprir o projeto da inscrição - ver fig. 5). Existe uma acomodação da inscrição frente à figuração, e quando há certa fuga do esquema tradicional (por exemplo, quando ocorrem duas inscrições) ambas se acomodam de forma idêntica (especular), o que leva a concluir que a inscrição é confeccionada após a figuração completada; ou seja, o ato de escrever é posterior, e nesse caso dependente, do ato de figurar.
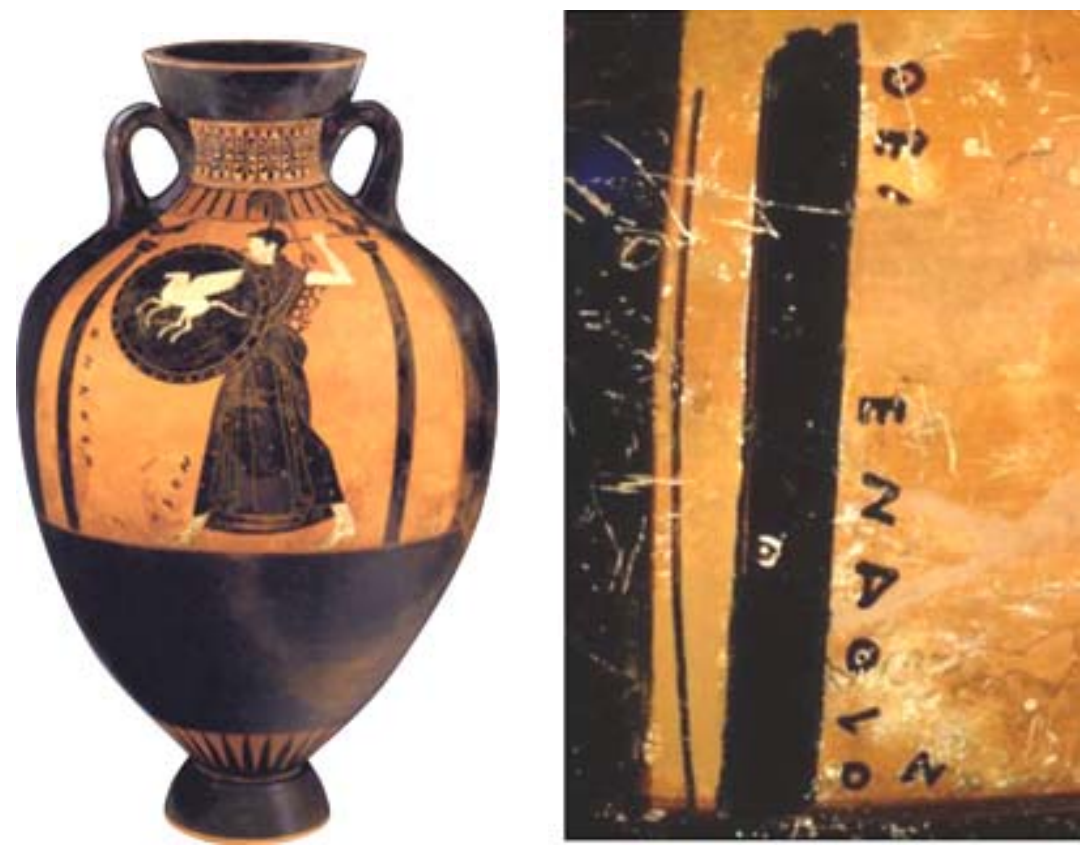

Fig. 5. (à esquerda) Ânfora panatenaica, Pintor Cleofrade, c. 490 a.C., Christie's, Antiquities (alt. : $65 \mathrm{~cm}$ ); Fig. 6. (à direita) Ânfora panatenaica (detalhe), c. 500 475 a.C., atribuída ao Pintor Cleofrades, Yale University Art Gallery.

A pesar da delimitação entre as faces (ver esquema 2, p. 201), sua organização diferente, e até oposições aceitáveis, algumas possibilidades de comunicação podem ser observadas. O teor das inscrições, por exemplo, não é do tipo que responde a uma lógica interna ao painel. Tanto a inscrição dos jogos, as do arcontado, como as de autoria podem remeter ao objeto todo. Assim, a informação escrita dizendo que aquele vaso tinha inserção nos jogos panatenaicos remetia também à figuração das provas atléticas. Apesar da dependência material frente à organização esquemática (figurativa) da face $\mathrm{A}$, ela se comunicava com as imagens da face B. E, pode-se dizer que a figuração da face B completava ou especificava o sentido abrangente (no que se refere ao evento) da inscrição dos jogos: assim, se se tratava de um prêmio da corrida a pé ou de carro, pugilato ou outra prova qualquer, só a figuração da face B poderia confirmar. 
Quanto à inscrição dos arcontes, elas também têm esse potencial comunicativo que se estende ao vaso amplamente. Ela remete não só a uma possibilidade de controle do conteúdo, mas de seu continente, haja vista que a rigidez observada no esquema panatenaico segue, em certa medida, a relação de encomenda entre pólis e oficina ceramista. Assim esses grafismos, todos eles, deviam ser passíveis de certo controle da autoridade administrativa; e sua permanência em figuras negras, mesmo em época de ampla produção e consumo de outros estilos ornamentais indica isso.

Essa interação, entretanto, pode ser observada de outra forma: como visto, a face A é a que apresenta mais explicitamente referências propriamente áticas; enquanto a face $B$ apresenta um repertório mais generalista. Essa generalidade, provavelmente, conecta-se ao quadro amplo das competições atléticas na Grécia; situação fortemente representada pelos grande eventos panelênicos como os jogos olímpicos, délficos, nemeanos e do Ístmo de

Corinto. É emblemático, nesse sentido, que justamente na época que Atenas reestruturou suas festividades e promoveu participação mais ampla nos jogos, que se desenvolveu a figuração panatenaica. Parece, então, que uma face remete a própria especificidade local, a conexão com a origem de Atenas e da reunião da Ática; enquanto a outra face remete com maior sucesso o repertório mais amplo, panelênico, ao qual Atenas procurava se inserir, inclusive como sede de um evento atlético de grandes proporções. A comunicação entre as duas faces, assim, indica a própria interação entre a realidade local e a regional, mais ampla.

Essa interpretação pode parecer pouco sustentável, mas como será visto a seguir, algumas informações de contexto arqueológico parece indicar algo nessa direção; ou seja, as ânforas panatenaicas, propriamente áticas, remetendo a um conjunto de referências mais gerais. Seriam, assim, os vasos panatenaicos, um elemento bastante indicativo da ideologia ateniense (mais que isso, eles a constituem); entretanto essa colocação deve observar mais acuradamente as possibilidades de inserção desse objeto em contextos diversos. Mas, de início, é possível dizer que o esquema panatenaico consolida-se no seio desse universo político e cultural.

\subsection{Uma observação contextual: historicidade e contexto arqueológico}

Como visto, as ânforas panatenaicas eram oferecidas por ocasião dos jogos panatenaicos; e é viável, neste ponto, caracterizar com mais clareza a inserção desses vasos no contexto do evento: as Panatenéias. 
As origens das festas panatenaicas são obscuras, os textos antigos registram, na maioria dos casos, informações gerais sobre a festa e pouco de sua origem. Apolodoro (séc. II d. C.) dizia que

Erictônio, que havia sido criado pela própria Atena dentro de um bosque sagrado, depois de expulsar a Anfiction se converteu em rei de Atenas; erigiu na acrópole uma estátua de madeira de Atena e instituiu a festa das Panateneas. (Apolodoro, Biblioteca mitológica III, 14, 6)

Porém, opondo-se a essa versão, Plutarco (séc. I-II d.C.) atribui tal feito ao herói Teseu. ${ }^{15}$ A chave, talvez, esteja no próprio nome da festa. Diz-se que Erictônio teria elevado à acrópole um xoanon (estátua) de Atena e teria fundado os festejos chamados Atenaicos. Teseu, teria tornado a festa oficial na Ática, quando reuniu suas cidades sob a hegemonia de Atenas (sinoikismo); dessa forma, as festas atenaicas tornar-se-iam panatenaicas. ${ }^{16}$

Pode-se intuir que o sentido original dessa festa estivesse ligado de alguma forma com a própria origem mítica da cidade; dadas as referências entre as figuras de Atena e Erictônio. Este é um herói ligado à fundação da cidade de Atenas (ele é identificado como um dos primeiros reis da cidade); e suas correspondências com a deusa Atena são grandes, como registra o mito em torno dele. A mitologia conta que, numa tentativa de relação sexual forçosa contra Atena, Hefesto derramou na perna da deusa seu esperma; enjoada, ela limpou sua pele com lã, jogando o sêmen na terra. Disto nasceu Erictônio ou Erecteu. ${ }^{17}$ Relatos mitológicos indicam que Atena teria cuidado de Erecteu (ou Erictônio), filho de Hefesto e da Terra, como se fosse seu próprio filho. ${ }^{18}$ Ainda, Erecteu é indicado como aquele que teria instituído os Jogos Panatenaicos. Um estudioso das Panatenéias (A. Mommsen, Heortologie) diz que

o ciclo de festas em honra de Atena é um ciclo de festas agrárias: Atena desempenhou para os camponeses da planície da Ática, antes de Deméter, o papel de divindade da vida do campo. (Daremberg \& Saglio, 1877-1919, p. 303)

Assim, o primeiro sentido da festa estaria ligado ao nascimento de Erecteu; o segundo, à homenagem a Atena, deusa agrária. Erecteu é visto aí como protetor de Atena, e insti-

\footnotetext{
${ }^{15}$ Theseus, 24 (Apud Grimal, 2000, p. 143).

${ }^{16}$ Daremberg \& Saglio, 1877-1919, p. 304. Pausânias (séc. II d.C.) comenta esse evento mitológico: "Eu defendo que o Festival Panatenaico não foi fundado antes do de Licáon. O mais antigo nome para aquele festival foi Atenéia, que foi mudado para Panatenéia na época de Teseu, porque ele os estabeleceu para todo o povo ateniense reunido numa única cidade." (Arcadia, II, 1)

${ }^{17}$ A genealogia deste aproxima-o daquele: Ora Erecteu é neto de Erictônio, ora ambos são identificados numa só pessoa. (ver Grimal, 2000, verbetes "Erecteu" e "Erictônio")

${ }^{18}$ Apolodoro, op. cit.
} 
tuidor do culto em sua homenagem, e já que ele era ancestral comum de todos os atenienses a festa deveria ser comum a todos (uma festa de unificação). Num terceiro momento o papel de Atena cresce e se esquece de Erecteu; nele, as Panatenéias comemoram as vitórias da deusa, o poder e o império de seu povo.

Além dos traços peculiares do mito e da organização política ático-ateniense, essas informações indicam algumas características bastante comuns no quadro dos eventos panalênicos gregos: a consolidação sobre temas míticos de fundo heróico. A instituição dos jogos, e mesmo dos santuários relacionados a eles, passou, na maioria dos casos, por essa identificação. Foi assim em Olímpia, Neméia, Corinto e Delfos. Foi nesse contexto de referências locais e regionais que são criadas as Panatenéias.

Aqui, por ocasião da documentação selecionada, concentra-se mais fortemente numa dimensão dos festejos panatenaicos, as provas atléticas; entretanto, esse era um evento bem mais amplo. Pode-se destacar, por exemplo, a grande procissão panatenaica, que transitava em regiões como o Dípilo, contíguo à região da necrópole do Cerâmico, a Ágora e a Acrópole, respectivamente. Todos espaços importantes na organização política ateniense.

A dimensão dos jogos nas Pantenéias é em grande parte responsável pela popularidade do evento fora da Ática. Ora, era nesse momento do evento que a maior abertura se dava. E, nesse caso, não é espantoso observar que vasos produzidos especificamente para as demandas panatenaicas assumissem grande simbolismo mesmo fora desse ambiente; e, pode-se mesmo dizer que o grande valor simbólico que envolvia tal premiação (grandes quantidades de óleo ateniense em vasos ornamentados), poderia ser entendido e materializado no próprio vaso; mas o óleo tinha um valor especial. Segundo Aristóteles (Constituição de Atenas LX, 2-3), ela era "obtido de árvores sagradas", óleo cujo uso era bem restrito:

Então o Arconte coleta o tributo de óleo neste ano, e repassa-o ao Tesouro da Acrópole, e a ele não é admitido ir ao Areópago antes que ele conduza toda a quantidade aos Tesoureiros. Eles têm que o manter sempre na Acrópole, exceto nas Panatenéias quando eles distribuem aos Diretores dos Jogos e estes aos competidores vitoriosos.

É claro o valor simbólico relacionado a tal premiação, e ao vaso, por extensão, tanto por suas características próprias, como por ser continente e elemento de apresentação material do óleo. Entretanto, aliado a isso se deve lembrar das grandes quantidades de óleo oferecidas. Eram dezenas de vasos a apenas um único vencedor. Assim, além do valor simbólico, parece, imopõe-se uma dimensão prática a essa premiação, sobretudo quando se lembra da importância comercial do óleo na região; e que esse não era um óleo comum, mas obtido nas oliveiras sagradas de Atenas para fins específicos. 
A discussão sobre a produção paralela reside na própria estrutura das provas relacionadas às Panatenéias: a competição não se dava apenas no campo atlético. "Havia nas Panatenéias três concursos principais: o concurso musical, o concurso de ginástica, e o concurso hípico". ${ }^{19}$ Esse concurso musical dividia-se numa parte de poesia com lira, e outra de música propriamente dita. A premiação não era feita com as ânforas panatenaicas, mas com "uma soma de prata, mais uma coroa ao primeiro; por exemplo, o vencedor do concurso de cítara recebia 500 dracmas de prata e uma coroa de 1000 dracmas; o do concurso de flauta era pouco menos bem pago, dava-se a ele uma coroa de 300 dracmas" ${ }^{20}$ Isso é o que indicam algumas fontes antigas, entretanto, como visto (ver fig. 3), alguns autores defendem que a figuração de concursos musicais nas ânforas sem inscrição indicaria uma premiação (talvez menos prestigiosa) nesse campo. Além disso, essas ânforas sem inscrição poderiam suprir a premiação dos jogos infantis, que também eram premiados com vasos (Bentz, 2003, p. 111). A real natureza desses vasos oferecidos às crianças (com inscrição ou não) não é bem definido; e resta, como síntese, a própria relatividade do termo panatenaico utilizado com exclusividade para as ânforas com inscrição, já que ainda se está por definir com clareza as distinções criadas na Antigüidade.

Esse era o cenário de inserção imediata dos vasos panatenaicos. Eles eram produzidos em oficinas áticas, por encomenda da pólis ateniense, para suprir demandas das festividades, mais especificamente, alguns eventos competitivos. Entretanto, a história desses vasos apresenta inúmeros exemplos de usos e alcances variados, e é preciso organizar melhor esse quadro. De início, é importante observar o grau de excepcionalidade dos vasos panatenaicos na quadro da ceramologia grega. Grande parte dos estudos indica que, por várias razões, estes eram vasos "especiais": sua freqüência produtiva era específica, a rigidez ornamental era única, a relação entre encomendante e as oficinas era diferente, e o traço mais lembrado pelos autores: tratava-se de uma produção em figuras negras que ultrapassa a própria época de preponderante produção com essa técnica (período arcaico e início do clássico). Por exemplo, em pleno século V a.C., o Pintor de Aquiles, que produziu muitos vasos com a técnica de fundo branco e figuras vermelhas, foi responsável por uma expressiva produção de ânforas panatenaicas; ou seja, tal artesão dominava as três técnicas de ornamentação.

Retomando, a distribuição desses vasos no Mediterrâneo era diferente do restante da produção de vasos áticos. As ânforas panatenaicas tinham como elemento motivador

\footnotetext{
${ }^{19}$ Daremberg \& Saglio, op. cit., p. 308.

${ }^{20}$ Lavedan, 1938, p. 728. Aristóteles também ajuda nesse ponto: "A respeito dos prêmios são para os vitoriosos de música dinheiro em prata e vasos de ouro, (...) e para aqueles na competição ginástica e corrida de cavalo óleo de oliva." (Constituição ateniense LX, 3)
} 
para sua produção o suprimento das premiações nas provas atléticas nas Panatenéias. É claro que se deve considerar os usos posteriores, mas a sua produção estava condicionada, em primeiro plano, a uma demanda bastante específica. Assim, se eram vasos encontrados em várias cidades do Mediterrâneo, a produção original não respondia (quantitativamente ou qualitativamente) a esses interesses. Nesse ponto, então, cabe uma discussão sobre as trajetórias possíveis envolvendo as dinâmicas sociais em que esses vasos se inseriam (ver esquema 5).

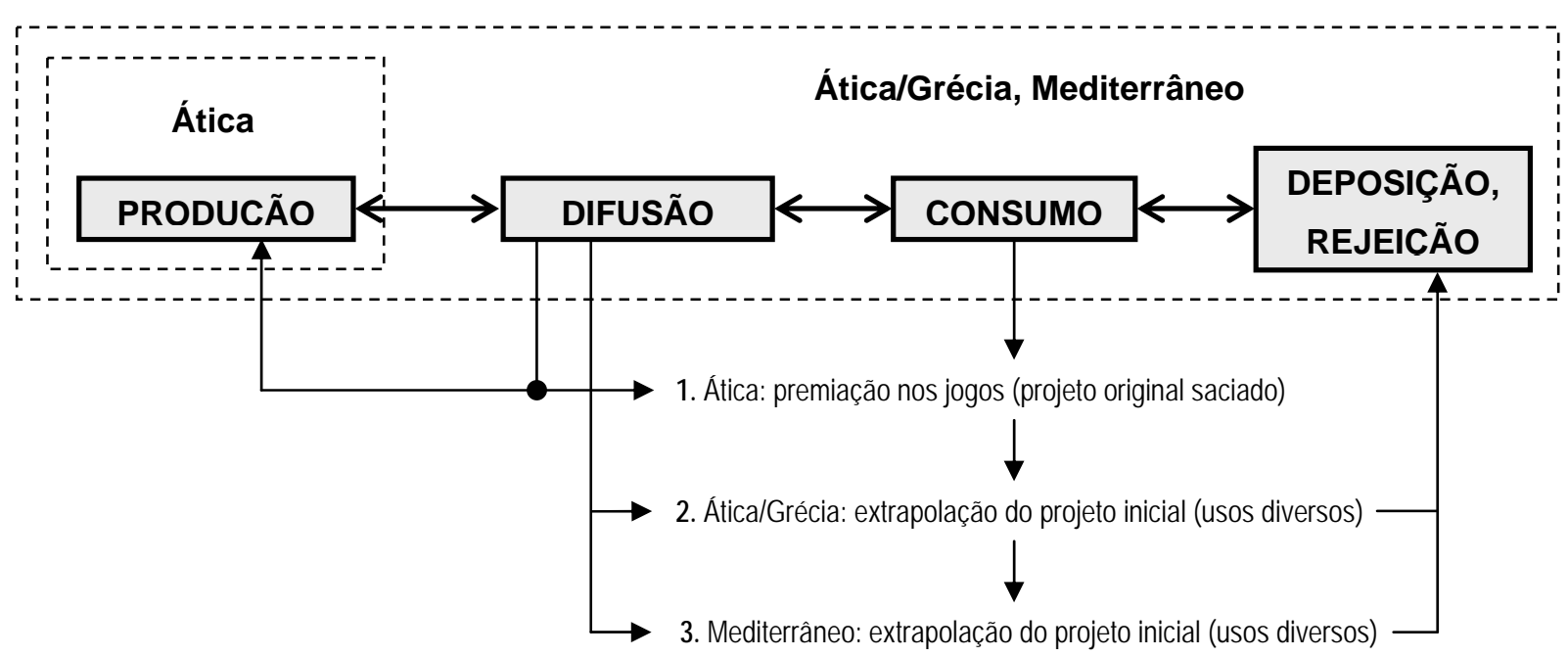

Esquema 5. Possíveis trajetórias das ânforas panatenaicas.

Algumas considerações sobre essa observação da trajetória desses vasos devem ser apresentadas. Em primeiro lugar, ela é uma redução considerável de propostas de observação de trajetória de objetos em contexto. As reduções devem-se tanto ao interesse específico, como a questões de adaptação à documentação e temática aqui tratada. Depois, cabe dizer que tal esquema pode ser compreendido de duas formas, não necessariamente excludentes entre si: de forma cronológica (PRODUÇÃO $\rightarrow$ DIFUSÃO $\rightarrow$ CONSUMO $\rightarrow$ DEPOSIÇÃO, REJEIÇÃO), ou de forma relacional (PRODUÇÃO $\leftrightarrow$ DIFUSÃO $\leftrightarrow$ CONSUMO $\leftrightarrow$ DEPOSIÇÃO, REJEIÇÃo). O prejuízo de observar tal trajetória de forma cronológica, é a inevitável caracterização desses percursos de forma prioritariamente seqüencial: a produção precede a difusão, que precede o consumo, que precede a deposição ou rejeição. Ora, nem sempre esse processo é tão linear, e ainda há que se considerar que a tarefa de produção, que aparentemente dá origem ao processo, está invariavelmente ligada a demandas sociais, a realidade de consumo que envolve todo o sistema. Nesse sentido, levando em conta as questões seqüenciais do processo, ele será observado sobretudo de forma relacional.

Os pontos "1", "2" e "3" apresentam os grandes contrastes relacionados à inserção social desses vasos. Em "1", vê-se uma espécie de ciclo fechado; ou seja, o intuito de utili- 
zar vasos relacionados ou sendo a própria premiação num evento competitivo tem seu desfecho no momento da premiação. Os pontos "2" e "3" podem ser decorrências do "1"; isto, já que se dá a extrapolação do projeto original, o que não era necessariamente previsto no contexto produtivo. É claro que por sua natureza, essas ânforas eram vasos de transporte, e esse poderia ser um elemento que já considerava a sua transitoriedade.

Assim, tal esquema acaba por indicar que as questões relacionadas ao projeto original (1) não oferecem contexto arqueológico bem definido ao pesquisador; e são as fontes literárias que esclarecem sobremaneira, junto aos próprios vasos; e que, por extensão, a maioria deles compunham posteriores experiências sociais diferentes (aí, sim, os contextos arqueológicos mais passíveis de observação pelo pesquisador). Se o contexto da produção era relativamente rígido (o que revela os cânones iconográficos e formais observados nos vasos), e mesmo o óleo contido neles (que era obtido das oliveiras sagradas de Atenas e levado para a acrópole, exceto por ocasião das Panatenéias); o mesmo não se observa nas trajetórias posteriores, tanto na Grécia (mesmo na Ática) como em outros espaços do Mediterrâneo.

O cenário é diversificado. Por exemplo, ânforas panatenaicas foram encontradas da Criméia à Etrúria, da Cirenaica à Síria. Dois terços das ânforas panatenaicas do século VI a.C., encontradas fora da Ática, provém de tumbas etruscas; já no século posterior, há um crescimento em outros sítios, e uma manutenção na Etrúria; e, no século IV, cresce o número no norte da África e diminui na Etrúria (Valavanis, 1986, p. 458). A variedade mantém-se quando se refere aos tipos de sítios: tanto tumbas de Tarento, Creta, Cirenaica e Etrúria, dentre outros espaços fora da Ática, como habitações em Olinto, Rodes e Eritréia (Idem). Os achados se dão em contexto sagrado (santuários, por exemplo - 40\%), locais públicos (36\%), tumbas (16\%) e habitações (8\%) - Bentz, 2003, p. 114-5.

E a situação pode ficar mais complexa, pois mesmo em ambientes considerados similares, como a imobilização desses vasos em contexto funerário, há grandes variações. Thomas Burgon comenta que a ânfora que encontrou era uma "urna cinerária", já que foram encontrados em seu interior, relacionados, ossos queimados, e vários outros vasos menores (Cobertt, 1960, p. 53). Já Boardman \& Kurtz (1971, p. 315) falam sobre uma tumba de Taranto, interpretada como de um atleta (já que os achados de seu interior eram quase todos relacionados à atividade atlética), havendo quatro ânforas panatenaicas, uma em cada quina da câmara. Assim, não se pode pressupor uma trajetória única para essa produção; meIhor que isso, pode-se observar os casos e ponderar sobre sua variedade.

Por fim, a própria interpretação atual, fundamentada em certas expectativas anacrônicas, acabam influenciando em grande medida a compreensão dessa variedade na Antigüidade, reduzindo-a. Por exemplo, Bentz, como desfecho de seu artigo Les amphores panathenaïques: une étonnante longévité (2003), apresenta a ânfora panatenaica como uma 
predecessora dos troféus atuais; o que, em certa medida, pode ser interpretado; entretanto, como rejeitar o caráter prático relacionado a esse tipo de vaso, situação observável a partir das disposições comerciais em que estavam envolvidas; ou mesmo sem estar bem definido na discussão acadêmica se realmente eram, no contexto dos jogos, objetos de alto grau simbólico? Ainda, por muitas vezes há certa valorização desses vasos, nem sempre equivalente ao seu uso antigo. Por exemplo, numa necrópole dell'Osteria, em Vulci, não se exitou em chamar uma tumba encontrada de La tomba della panatenaica, mesmo que a sorte dos achados fosse bastante diversa. ${ }^{21} \mathrm{~A}$ análise e interpretação deve também observar essa entonação da interpretação atual.

Todos esses são elementos importantes na observação da dinâmica em que estava envolvida a interação escrito-figurativa nas ânforas panatenaicas. Apesar de uma lógica e comunicação interna, em grande medida explicada pelas estratégias consolidadas em ambiente artesanal; há um componente essencial da trajetória que é a situação em que eram recebidos esses grafismos. A grande diversidade apresentada, impele a interpretar uma conseqüente diversidade na recepção dessas mensagens articuladas. Essa é a matéria o próximo item.

\subsection{Os múltiplos contextos e os múltiplos significados}

O ponto de partida para a discussão dos significados dos grafismos das ânforas panatenaicas é uma produção paralela, e a interpretação incidente sobre ela. Assim, é necessário recuperar as interpretações sobre o grau de simbolismo incidente sobre esses vasos, que vai, como visto, da importância atribuída ao vaso, a despeito de seu conteúdo; até a dependência absoluta desse objeto, visto como mero continente. Os limites são extensos, e, nesse meio, pode-se encontrar algumas explicações viáveis.

Além da grande variedade peculiar da produção dos vasos panatenaicos e paralelos; havia referenciação das ânforas panatenaicas em vários outros suportes ao longo do tempo: relevos, esculturas plenas, moedas, pinturas, mosaicos etc. Um deles, neste ponto, interessa especialmente: é um mosaico encontrado na ilha de Delos (ver fig. 7 ). ${ }^{22}$

\footnotetext{
${ }^{21}$ Além da ânfora panatenaica, foram encontrados um vaso com "cariátides", um cântaro de bucchero e uma ânfora (neck amphora) ática de figuras negras, todos do século VI a.C. Para La tomba della panatenaica, ver Ridgway, D. (1967) Archaeology in Central Italy and Etruria, 1962-67. Archaeological Reports.

${ }^{22}$ A escolha desse mosaico de produção tardia, se se lavar em conta o período aqui tratado, deu-se pela possibilidade de encontrar em Delos farta e variada documentação sobre a recepção dos vasos panatenaicos. Assim, concedeu-se uma licença cronológica e de suporte, levando-se em conta as possibilidades de interpretação.
} 

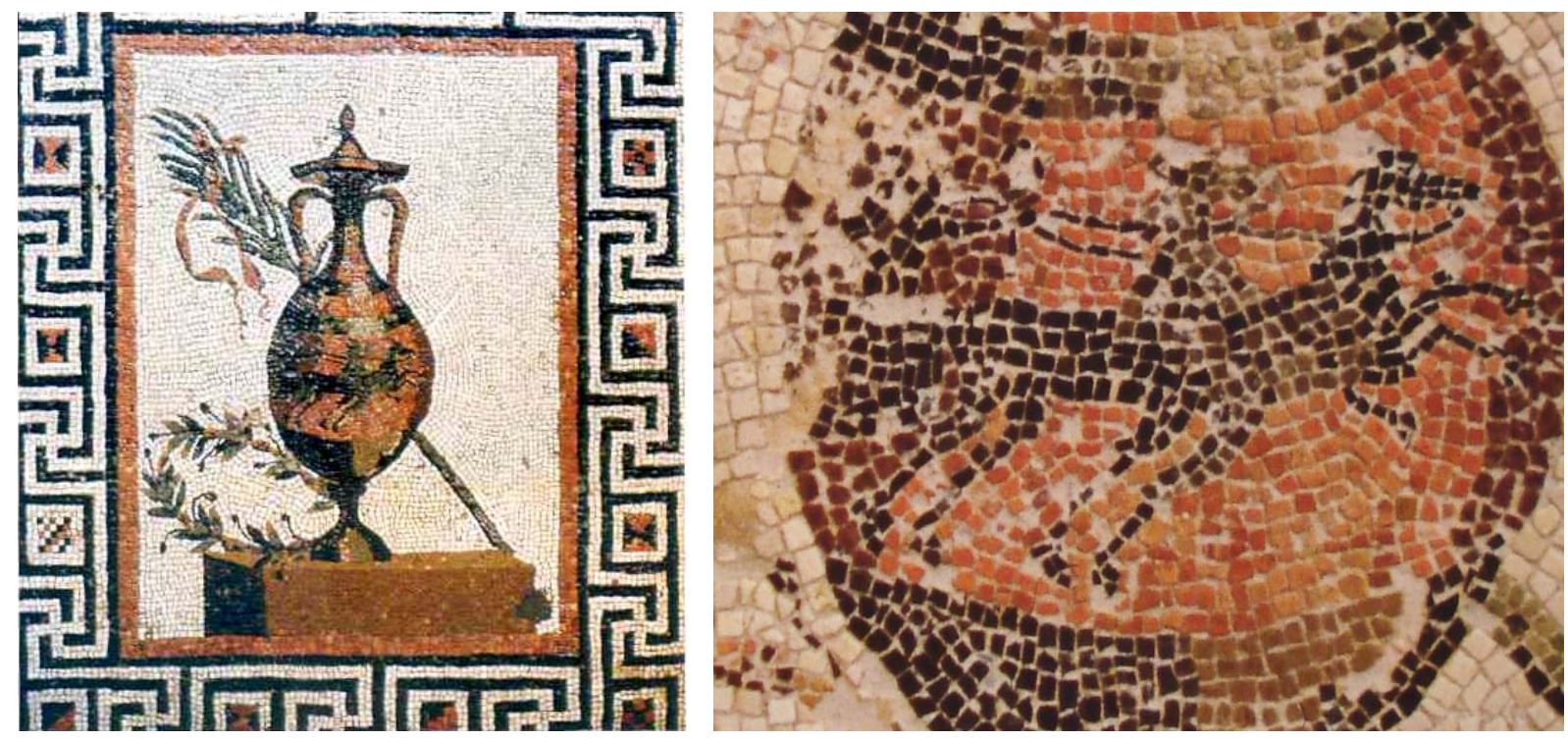

Fig. 7. Ânfora panatenaica figurada em mosaico (detalhes), Casa do Tridente (sala I), Delos, século II a.C.

Ele compõe um conjunto de mosaicos na intitulada Cada do Tridente (Maison du Trident), habitação do século II a.C., época de dominação ateniense na ilha (de 167 a 69 a.C.). O mosaico tem figurada uma ânfora panatenaica em face, onde o painel com um corredor de biga é apresentado. O esquema ornamental é bastante similar ao modelo panatenaico em iconografia e forma física, havendo poucos desvios. Ela é posicionada sobre um pequeno tablado (em perspectiva), e associada a uma coroa de ramos de oliveira (à direita do vaso, ao seu pé) e uma palma que atravessa obliquamente o painel (atrás da ânfora). O fundo é branco sem indicação de profundidade, ao contrário do vaso, que é organizado com indicação de volume. Ele é o elemento central da figuração, que é emoldurada imediatamente por um enquadramento em faixa vermelha, e, mais exteriormente, por um arranjo de motivos geométricos em preto, branco e vermelho. A situação contextual, entretanto, não apresenta um destaque tão grande. Assim, se no cômodo que encerra tal mosaico, ele é expressivamente grande (ocupando boa parte da área total) - ver fig. 8, na casa, a posição não é privilegiada, levando-se em consideração as entradas e circulação do edifício; havendo outros mosaicos de constituição iconográfica mais simples (monocromáticos, sem indicação de tridimensionalidade - ver fig. 9 e 10); ou mesmo outros sem figuração alguma, expostos em espaços com maior visibilidade. ${ }^{23}$

\footnotetext{
${ }^{23} \mathrm{~A}$ visibilidade desses mosaicos é um elemento para se estabelecer em algum grau a hierarquização entre eles, junto a sua composição iconográfica. Entretanto, o espaço menos visível pode, também, oferecer elementos importantes para a interpretação. Por exemplo, um espaço mais reservado poderia ser de utilização mais restrita aos habitantes da casa e seus próximos, e vedado ao público externo. Nesse sentido, a interpretação segura deve andar junto à compreensão do contexto arqueológico, que poderia oferecer dados sobre os usos dos espaços.
} 


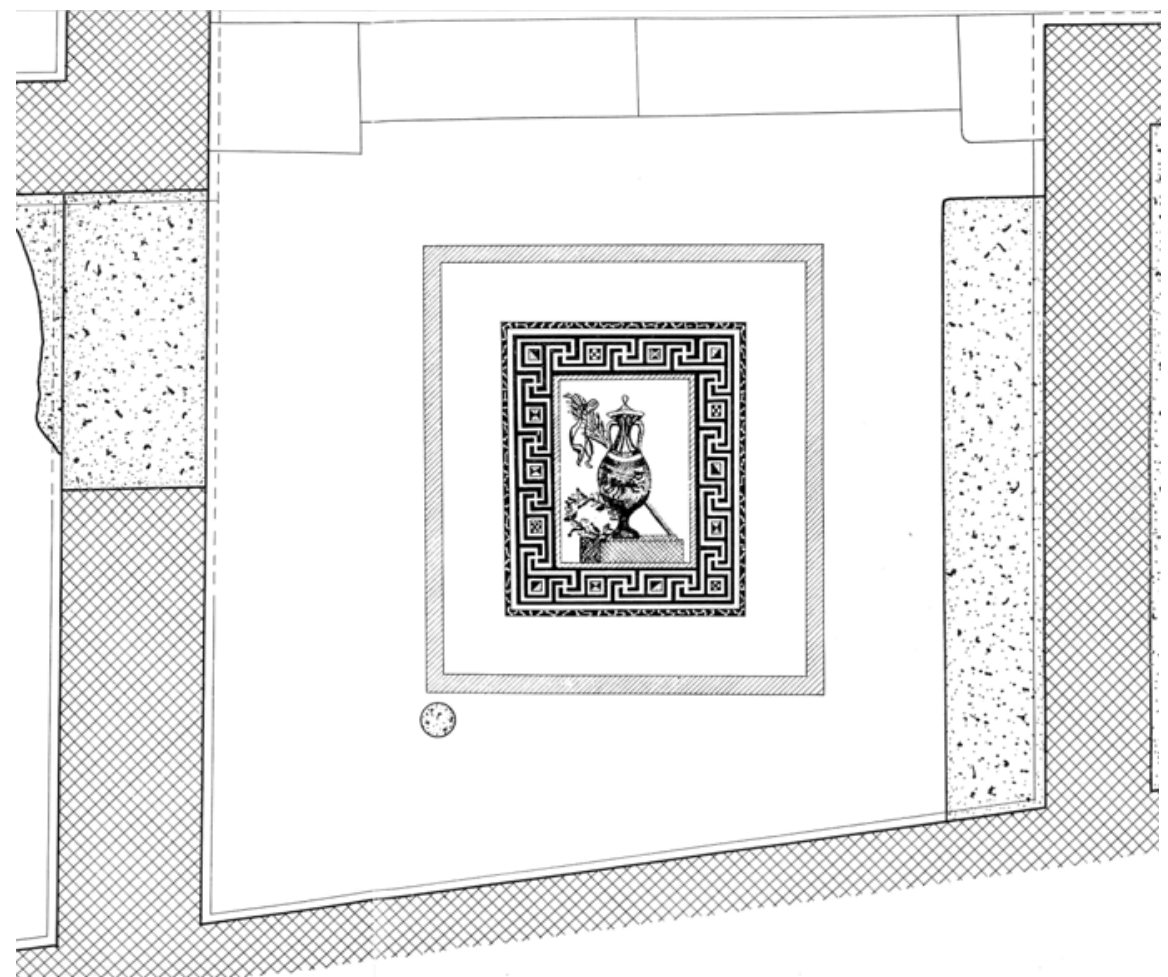

Fig. 8. Planta da Casa do Tridente (Sala I), Delos, século II a.C.
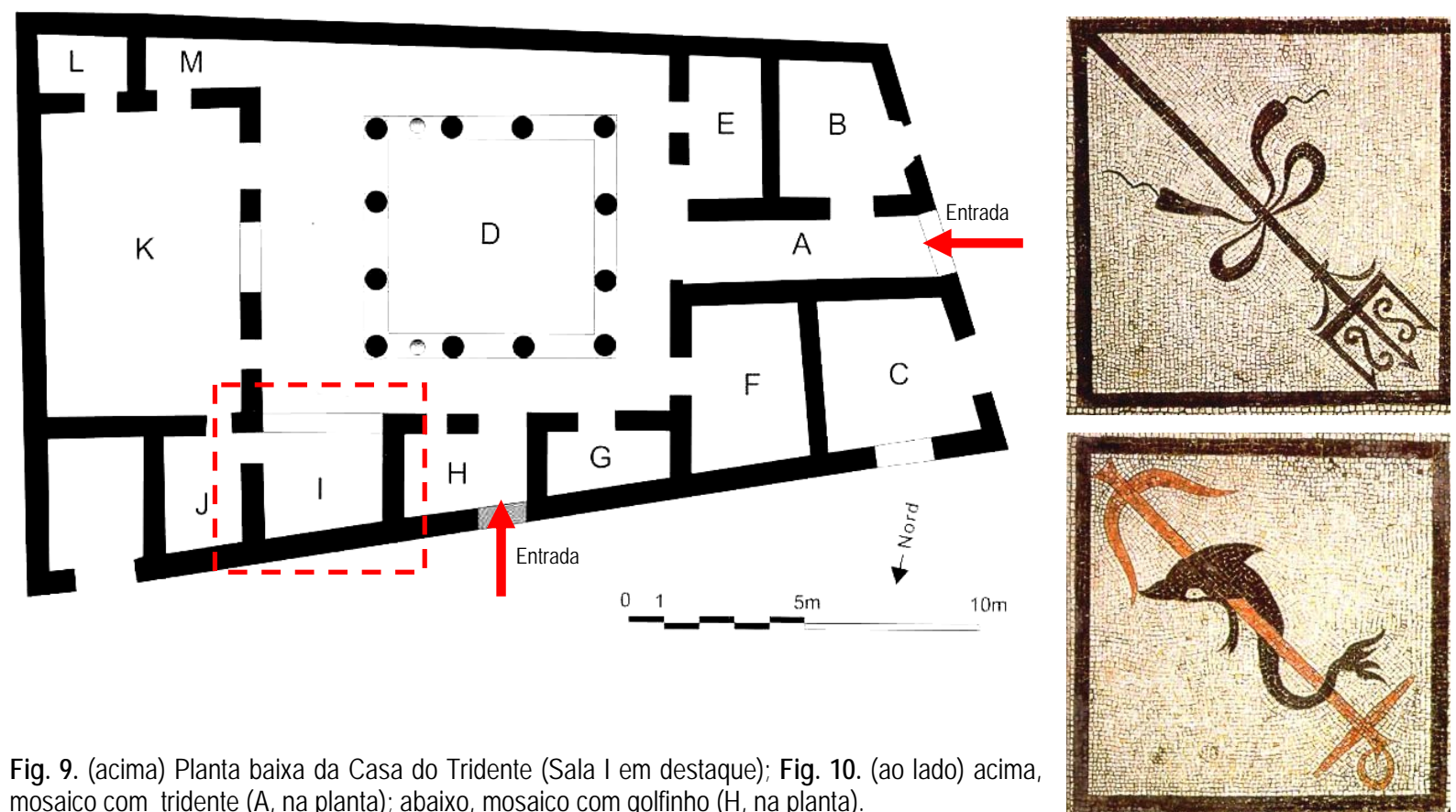

Fig. 9. (acima) Planta baixa da Casa do Tridente (Sala I em destaque); Fig. 10. (ao lado) acima, mosaico com tridente (A, na planta); abaixo, mosaico com golfinho ( $H$, na planta).

Sobre esse mosaico, sem se levar em conta as informações contextuais, já foram traçadas algumas linhas de interpretação sobre seu simbolismo e ao que deve ao universo propriamente ateniense. Bentz (2003, p. 116) diz que tal mosaico exposto na casa de colonos atenienses seria "como signo de sua origem, [e] deveria ser igualmente observado co- 
mo um símbolo de Atenas". ${ }^{24}$ Essa interpretação parece confirmar o potencial altamente simbólico que o esquema panatenaico poderia ter; assim, mesmo destituído de sua materialidade e convertido em figura, remeteria simbolicamente à sua origem.

A favor dessa interpretação, há a existência de um outro mosaico em habitação contemporânea à Casa do Tridente: um mosaico com a figura de uma ânfora panatenaica na Casa das Máscaras (Maison des Masques) (ver fig. 11), em esquema bem parecido (ânfora panatenaica, com palmeta oblíqua atrás), mas esta não apresenta nenhuma figuração no painel da ânfora; e é ladeada por duas grandes rosáceas. Em outro esquema compositivo e suporte, há, ao menos, duas ânforas panatenaicas figuradas em painéis pintados dessa mesma época (ver Meneses \& Sarian, 1973, p. 94, fig. 24; e Meneses, 1981, v. I, p. 45-7, v. II, fig. 40). Há, ainda, algumas miniaturas de ânforas panatenaicas encontradas no Complexo da Casa dos Atores (L'ilôt de la Maison des Comédiens), e os achados na ilha de Renéia: algumas ânforas panatenaicas do século II a.C. em contexto funerário, e no santuário de Héracles. Todos eles indicam uma experiência comum da presença desses vasos na região.
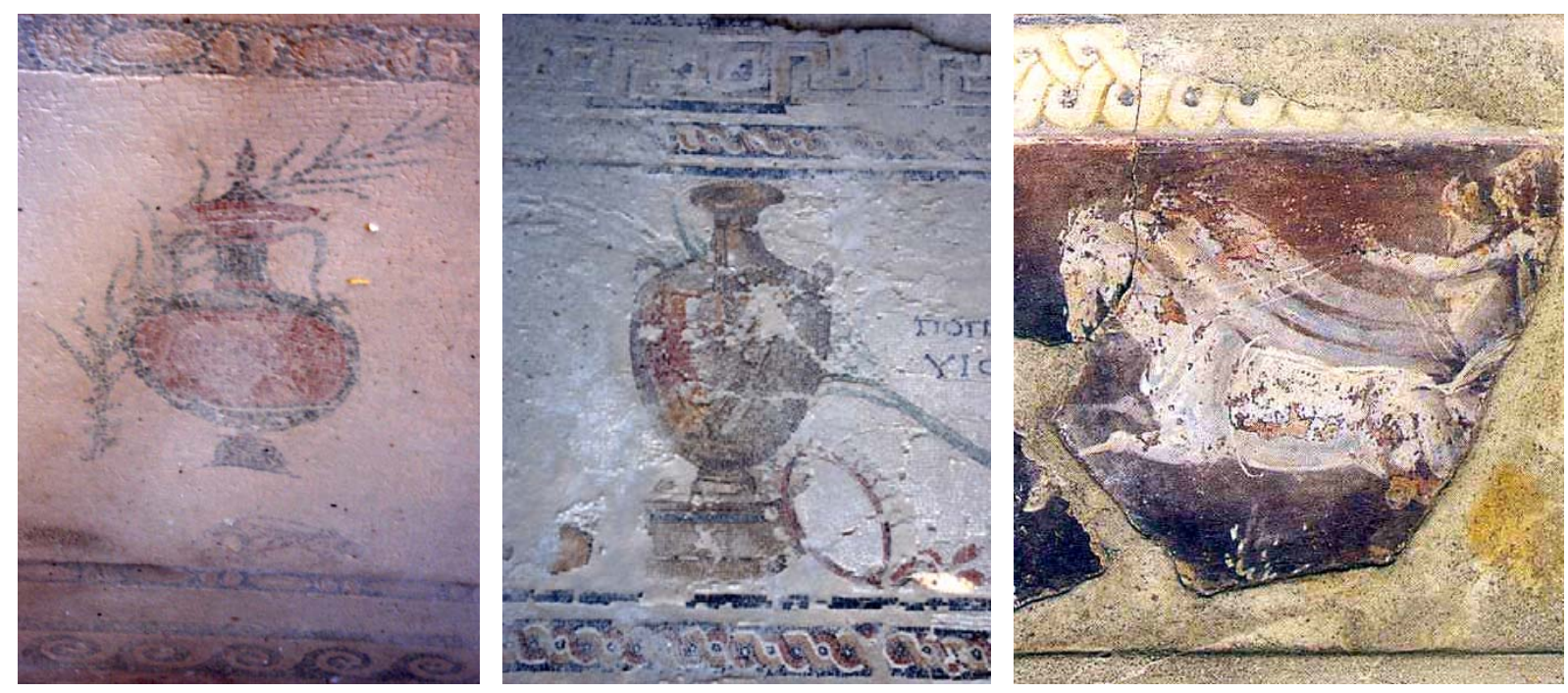

(Da esquerda para a direita) Fig. 11. Detalhe de mosaico com ânfora panatenaica da Casa das Máscaras (século II a.C.); Fig. 12. Detalhe de mosaico com hídria, coroa e palmeta da Agora dos Italianos (século II-I a.C.); Fig. 13. Detlahe de frisa pintada na Palestra de Granito (século II a.C.).

Entretanto, pode-se dizer que, ao contrário de restringir-se as referências ao universo ático (à sua origem), a proposta ali é de comunicação entre a forma propriamente ática e o universo mais amplo. Nesse sentido, há em estrutura também similar, entre os vários mosaicos da Agora dos Italianos (século II-I a.C.) - ver fig. 12, um com a figura de uma hídria ao lado de uma coroa e uma palma vertical atrás dela; e a figuração atlética em outras regi-

\footnotetext{
${ }^{24}$ Ver também Valavanis, 1998, p. 111.
} 
ões da ilha, como uma frisa pintada na Palestra de granito (século II a.C.) - ver fig. 13. Ou seja, elementos figurativos comuns, entretanto fugindo ao esquema panatenaico. ${ }^{25}$

Todas essas referências apresentam elementos importantes para a interpretação do simbolismo da presença de uma ânfora panatenaica no mosaico em Delos. Como visto, a organização das faces de uma ânfora panatenaica pode aproximar-se mais do universo específico ou do mais generalista. A composição gráfica da face A, com Atena figurada, apresenta elementos estritamente áticos, que podem ser comunicados a um universo mais amplo. Nesse sentido, a escolha da figuração da face com a corrida de carro no mosaico coloca algumas questões interessantes. Não haveria grandes impedimentos técnicos para caracterizar a face com a figura de Atena entre as colunas; visto que mesmo o esquema complexo da corrida de carro é bem organizado no mosaico. Assim, escolher essa cena (imobilizá-la como motivo), e não a de Atena, que apresenta uma ligação mais direta à "origem" como evoca Bentz, pode indicar, em vez de uma referenciação ao universo exclusivamente ático, a busca de aspectos mais amplos. Ora, a corrida de carro, e mesmo o cavalo como elemento agregador da elite grega é antigo, e pode-se mesmo remeter à experiência micênica na região (ver capítulo 3, item 3.2). Ou seja, a escolha de um tema tão tradicional no universo helênico, em detrimento de uma referência propriamente ática, coloca a possibilidade de uma abrangência do uso simbólico da imagem figurativa da ânfora panatenaica.

É complicado seguir um caminho único de interpretação. Uma ânfora panatenaica como referência exclusivamente ática, conforme interpretação tradicional, pode ser observada como tentativa de comunicar-se com o mais amplo; assim, reforçar ser ela a premiação num concurso (conjuntamente com a hídria da Agora dos Italianos), e a referenciação da mais tradicional das provas (a eqüestre). Nenhuma das duas possibilidades é exclusivamente ática.

A figura sobre um mosaico, então, é um bom exemplo, pois diferente das próprias ânforas panatenaicas, que poderiam ser observadas de forma articulada, face a face, no mosaico houve uma escolha que tende à permanência; ou seja, escolheu-se uma imagem figurativa que persistiria ali. A referência propriamente ática poderia ser buscada, e é esse o caso de figuras inspiradas na Atena promachos em moedas do período helenístico cunhadas em locais diversos; e, apesar das especificidades de suporte, tais figuras remetem provavelmente ao esquema panatenaico (ver fig. 14 e 15$)^{26}$, mas no caso do mosaico deliano optou-se pela corrida de carro.

\footnotetext{
${ }^{25}$ Para uma observação da situação geográfica dessas habitações na ilha de Delos, ver Bruneau \& Ducat, 2005.

${ }^{26}$ Existe um debate sobre a formulação original dessas imagens: se provenientes da figura da Atena promachos panatenaica, ou de uma estátua de culto macedônica. A posição aqui tomada baseia-se na argumentação de Havelock (1980).
} 

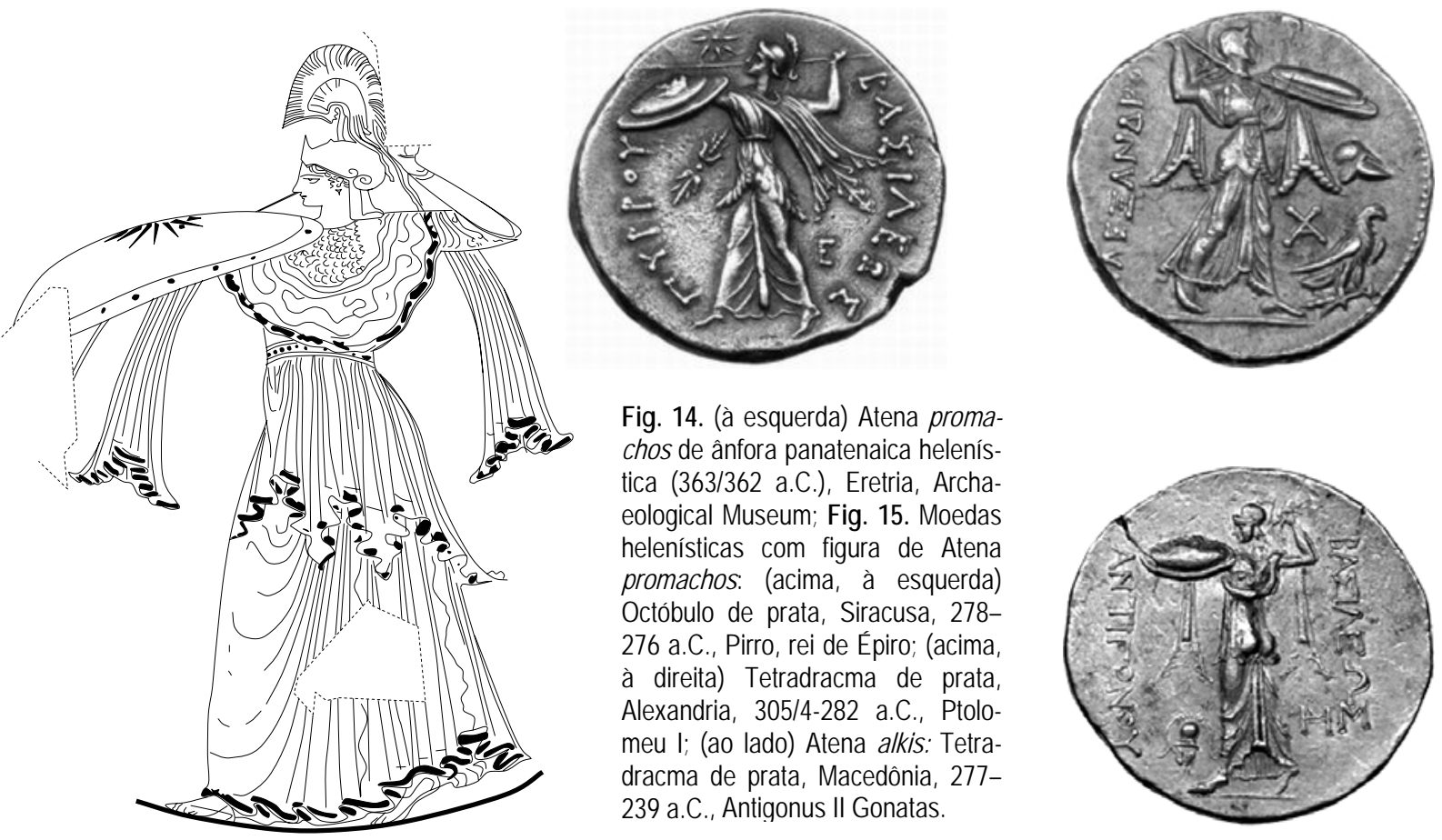

Fig. 14. (à esquerda) Atena promachos de ânfora panatenaica helenística (363/362 a.C.), Eretria, Archaeological Museum; Fig. 15. Moedas helenísticas com figura de Atena promachos: (acima, à esquerda) Octóbulo de prata, Siracusa, 278276 a.C., Pirro, rei de Épiro; (acima, à direita) Tetradracma de prata, Alexandria, 305/4-282 a.C., Ptolomeu I; (ao lado) Atena alkis: Tetradracma de prata, Macedônia, 277239 a.C., Antigonus II Gonatas.

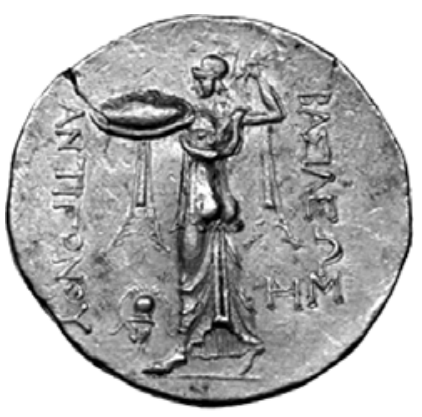

Numa casa de colonos atenienses, onde os elementos que remetiam à sua terra original seriam bem conhecidos, promove-se uma comunicação mais ampla que Delos (local onde moravam) e Atenas (cidade de origem), e pode-se falar em Delos, Atenas e outros espaços onde a cultura grega seja minimamente desenvolvida. A corrida de quadriga era um elemento bastante reconhecível, e poderia ser vista em outros tipos de vasos e moedas, por exemplo, objetos que alcançavam grandes distâncias no Mediterrâneo; nesse sentido, uma ilha onde a circulação de pessoal era bastante grande (um forte pólo comercial da época) a comunicação entre o específico e o mais geral poderia ser bem visto e facilmente reconhecido por vários outros, além do próprio proprietário. Assim, parece que a referência buscada era outra, não simplesmente a origem ática, ou a referência simbólica de uma presença ateniense. No quadro das produções delianas, como visto, há algumas reelaborações (em mosaico e pintura) das ânforas panatenaicas. É emblemático, nesse cenário, que nenhuma delas apresente a Atena promachos entre as colunas e a inscrição, ou, ao menos, uma redução esquemática dessa tradicional composição gráfica (o mosaico da Casa do Tridente apresenta a corrida de carro; o da Casa das Máscaras, nenhuma figuração. Quanto às pinturas, uma apresenta o pugilato e outra uma corrida de carro). Ao contrário, parece que se buscou, conscientemente, integrar o quadro das referências atléticas bastante difundido, por exemplo, nas variadas pinturas parietais da ilha, das quais a corrida de quadriga na Palestra de granito (ver fig. 13) é apenas um exemplar.

As referências propriamente áticas, aqui, não ofereceriam bom elemento comunicador, e, por extensão, pode-se dizer que elas seriam quase "perdidas" em contextos diversos; 
ou seja, o significado identificado, sobretudo marcado pela relação escrito-figurativa concebida em meio artesanal para suprir as necessidades dos jogos panatenaicos, talvez não alcançasse as grandes distâncias e se perdesse; e assim se consumasse no contexto do próprio evento. Como visto, esse era um tipo de vaso ático, reconhecivelmente ático, entretanto, a possibilidade de identificá-lo ao universo mais amplo era consideravelmente grande. Assim, mesmo quando um ateniense se utiliza do motivo, não é seguro dizer que a referência é exclusivamente ática. A relação escrito-figurativa nas ânforas panatenaicas, que marcava tão claramente a correspondência ao universo de referências áticas, sobretudo no contexto dos jogos, fora dessa situação parece atenuar-se, cedendo espaço à dimensão panelênica que os grafismos, como um todo, poderiam remeter. Nesse sentido, a proposta de hierarquização entre as faces, privilegiando a face de Atena com as inscrições, perde seu vigor. O exemplo do mosaico deliano parece mostrar que esse significado poderia até ser invertido.

É bastante complicado tratar da recepção desses grafismos. Não há nenhuma informação altamente segura; e a interpretação fundamenta-se sobretudo nos paralelos disponíveis. Nesse sentido, observou-se que mesmo atenienses poderiam ressignificar o simbolismo que envolvia esses objetos; em situações alheias, como a grande utilização de ânforas panatenaicas por etruscos, imagina-se que as referências específicas tornem-se ainda mais diluídas. Bem, se sabe que entre os etruscos a presença maciça da produção ceramista ática era constante desde o período arcaico, e foi em tumbas estruscas que se encontrou grande parte dos vasos áticos com que hoje se constitui conhecimento sobre a ceramologia grega. Exemplares como o Vaso François (ver capítulo 3, fig. 74, p. 125) foram encontrados nessa situação. Fixando-se por um momento nesse vaso, percebe-se que era uma cratera com amplo espaço figurativo; que foi preenchido com inúmeras figuras, grande parte delas com inscrições relacionadas. Ora, as referências são áticas; locais, no que tange ao universo da produção, mesmo assim tal vaso foi utilizado como mobiliário funerário em contexto etrusco.

Fala-se muito da influência da cultura grega sobre a etrusca, inclusive ressaltandose, além desse comércio de cerâmica ornamentada, o próprio desenvolvimento de temáticas (ou melhor, formas iconográficas) propriamente áticas ressignificadas quando inseridas na experiência etrusca. Deve-se lembrar também das contribuições inversas, das quais, em meio artesanal ceramista, destaca-se a inserção de formas propriamente etruscas no universo ático (a ânfora do tipo "nicostênico" e o "cântaro" são exemplos disso.). Assim, tem-se que as trocas entre atenienses e etruscos eram fortes e de mão dupla. Mais que isso: eram relações dinâmicas, e as pesquisas sobre esse tema indicam que a recepção dos objetos gregos ali, como em outros espaços, nunca foi estática. É nesse contexto de trocas que se inserem as ânforas panatenaicas. 
Se havia grande troca entre gregos e etruscos, o caso das ânforas panatenaicas coloca uma questão importante: no caso específico de aquisição, eles só poderiam obtê-las de forma indireta. As ânforas panatenaicas encontradas em Renéia, evocadas acima, estavam relacionadas à experiência de atenienses na região; ou seja, poderiam ter chegado ali, através de aquisição direta; já que o ateniense, como os membros de outras várias cidades gregas poderiam participar desses jogos. Assim, ao menos, tomavam parte do significado original de inserção daqueles vasos. Não era o caso dos etruscos que não tinham direito de participar dos jogos panatenaicos (Valavanis, 1986, p. 457). Mas, mesmo com isso, a quantidade de ânforas panatenaicas nas tumbas etruscas é muito grande (como visto, compõe os achados mais substanciais fora da Ática).

Esse afastamento do ambiente original impele a interpretar a recepção dos grafismos como se remetessem, nesse universo, a características gerais, e não as específicas. Não seriam, então, as informações mais ligadas ao universo ático que interessariam. Sobre isso, comenta Spivey (1991, p. 143) que a inserção dos inúmeros vasos panatenaicos encontrados na Etrúria, estariam ligados, por sua temática atlética, aos ritos funerários de passagem, como indicam as pinturas nas paredes das tumbas. Entretanto, tal explicação não parece tão simples como sugere o autor. É devido lembrar que se foram encontradas muitas ânforas panatenaicas, cujo tema de parte da ornamentação é atlético, foram também encontrados inúmeros outros tipos de vasos de ornamentação com temática diversa daquelas. Nesse caso, um esforço de quantificação dos temas iconográficos seria necessário para sustentar tal inferência. Depois, é importante lembrar que na pesquisa arqueológica muitas vezes ressaltou-se o achado de ânforas panatenaicas, vasos muito populares na atualidade, em tumbas, santuários etc. Ou seja, é necessário aferir tais colocações, mas a presença maciça de ânforas panatenaicas em tumbas etruscas, obtidas de forma indireta, já indicam um distanciamento do projeto original, e a probabilidade de um uso que valorizasse com maior ênfase os temas atléticos.

Diante desse quadro, o que se pode comentar sobre a recepção das mensagens escritas e figurativas desses vasos? Muito pouco se sabe do cenário detalhado, mas algumas inferências podem ser feitas. Em primeiro lugar, situando as ânforas panatenaicas no quadro geral da produção e distribuição de vasos áticos no Mediterrâneo, pode-se dizer que as mensagens propriamente áticas (em dialeto ático, versões de mitos específicas, estilo ornamental peculiar etc.) nunca foram empecilho para a difusão dessa produção em ambiente não ático ou não grego. Desde o século VI a. C., mesmo antes da produção de ânforas panatenaicas, vasos com essas mensagens já eram difundidos em larga escala, e no caso desses vasos-prêmio, a situação parece reforçar esse cenário. É claro que essa caracterização pode ser atenuada, quando se observa que muito do interesse residia no óleo contido nos vasos, ou ainda sobre referências a algum evento dos jogos; nesse sentido, a mensa- 
gem escrito-figurativa perde um pouco de sua eficácia, muito fortemente apresentada desde o contexto da produção à entrega do prêmio ao vencedor dos jogos. Pode-se mesmo falar numa ressignificação ou modificação de interesses; pois não era a referência específica aos jogos áticos que interessava sobremaneira, mas a própria referência ao evento competitivo de forma mais geral. Depois, pode-se dizer que as especificidades indicadas pela relação escrito-figurativa encontram nesse cenário um interesse mais antigo: trata-se das referências heróicas, constantemente relacionadas aos eventos competitivos. O específico cede espaço a uma tradição mais ampla, que inclusive o integrava. Basta lembrar que muito da organização original dos jogos panatenaicos, bem como outros importantes jogos, estava inserida numa lógica que remontava a temas heróicos.

Essa situação coloca interessante questão, a saber, a multiplicidade de inserções que um objeto pode assumir em contextos próprios. Assim, a vida política em Atenas, suas regras, dinâmica das oficinas ceramistas, a complexidade que envolvia a preparação e o desenvolvimento dos eventos esportivos, e sua trajetória posterior, devem ser observados, tanto de forma independente, mas, sobretudo, relacional. É inegável que as referências apresentadas na superfície do vaso, bem como o próprio vaso, são particularmente áticos. A manutenção multicentenária do esquema ornamental escrito-figurativo ratifica essa linhagem ática; entretanto, na observação de sua trajetória, não há nada que comprove um natural ou universal interesse específico no objeto como essencialmente ático, ou remetendo à referências propriamente áticas.

Voltando ao tema da inscrição dos jogos como definidora do vaso panatenaico, mais que dar fim a discussão, é devido observá-la em perspectiva relacional. Ora, a definição a partir da inscrição, mesmo se eficaz, concerne a apenas um segmento da trajetória desses vasos panatenaicos. Sua caracterização como prêmio ou não, tendo a inscrição como guia, encerra um período apenas da experiência social (experiência entre homens!) em que esses vasos estavam inseridos. As situações variadas que eles integravam poderiam mesmo atenuar amplamente sua importância.

Caracterizar, então, tais vasos a partir da inscrição não define a natureza múltipla das ânforas panatenaicas, ou ao menos o potencial para essa multiplicidade. A inscrição como guia é o começo e não o fim do caminho; aliás, é o ponto de partida para uma grande quantidade de veredas que poderão ser trilhadas. 
CONCLUSÃO 
É de comum aceitação, apesar de práticas opositivas, que a compreensão de uma experiência histórica deve considerar as mais variadas fontes. Retomar as críticas de Finley sobre as fontes materiais (Finley, 1994b), então, parece reavivar uma questão já resolvida. Entretanto, há ainda que se ponderar sobre isso. Por exemplo, num reconhecido manual de teoria da História ( $A$ escrita da História: novas perspectivas), Peter Burke retoma, com firmeza, Finley, cobrando uma contribuição original da Arqueologia (Burke, 1994, p. 26), sobretudo àquela que trata de sociedades com farta documentação textual. Ora, a despeito da interação das fontes, existem traços peculiares da documentação material, que só ela, ou de forma mais adequada, ela pode responder: questões adequadas para cada tipo de fonte, esse parece ser o desafio. Os anseios por uma contribuição original da Arqueologia, frente a uma farta documentação textual, pode ser respondido, assim, observando essa adequação. A questão gráfica aqui colocada ao longo desta dissertação procurou seguir esse caminho, observando as questões já respondidas, aprender com elas, avaliar a real viabilidade das respostas e a proposição de algo que simplesmente não duplicasse o estado atual do conhecimento.

Quanto ao gráfico na experiência grega, parece, as fontes materiais são as mais aptas a uma análise profunda no que se refere à sua proposta de articulação entre o ato de escrever e figurar. Como visto (já na Introdução), as fontes literárias não tratam dessa articulação, e, no tocante à amplitude do gráfico, ou seja, sua polissemia, os usos isolados que indicam a variada compreensão antiga sobre o universo gráfico. Dessa forma, o afastamento das fontes escritas como articuladoras de um discurso sobre a articulação escritofigurativa deu-se nesse sentido, e não por uma hierarquização acadêmica entre fontes.

O tratamento privilegiado de um tipo de fonte, a material, não significa uma adesão a um tipo de história específica: história da técnica, história do fazer produtivo, história dos materiais... Essas "histórias" só forneceram, aqui, elementos para a compreensão do problema do gráfico, bem delimitado em alguns níveis: produção, difusão, recepção; e as fontes tratadas foram a linha condutora para a compreensão de relações humanas.

Retomando, esses significados não estão restritos a uma história da técnica ou da arte; apesar de a abordagem tecnicista e mesmo descritiva serem essenciais predecessoras do discurso que se interessa pelas questões sociais. Voltando-se à exemplar figura da capa, observemos a interação escrito-figurativa. A figura da esquerda tem fisicamente relacionada 
a ela três inscrições. Ora, a disposição delas no suporte, o tipo de pigmento, as formas estéticas, e sua coesão no quadro geral, de certa forma, são questões específicas, mas nenhuma delas remete unicamente ao universo da técnica. No que tange à relação escritofigurativa, tem-se um importante exemplo da sutileza do discurso gráfico: uma figura e três inscrições; entretanto, a aproximação material similar não impede o reconhecimento da diversidade discursiva: uma inscrição diz que aquela figura é Aquiles, uma outra sai de sua boca como uma fala, e a outra informa a autoria (ver fig. 1). Três propostas bastante diferentes do discurso, materializadas de forma parecida. Esse é um refinamento da compreensão do discurso gráfico que vai além de sua caracterização técnica.

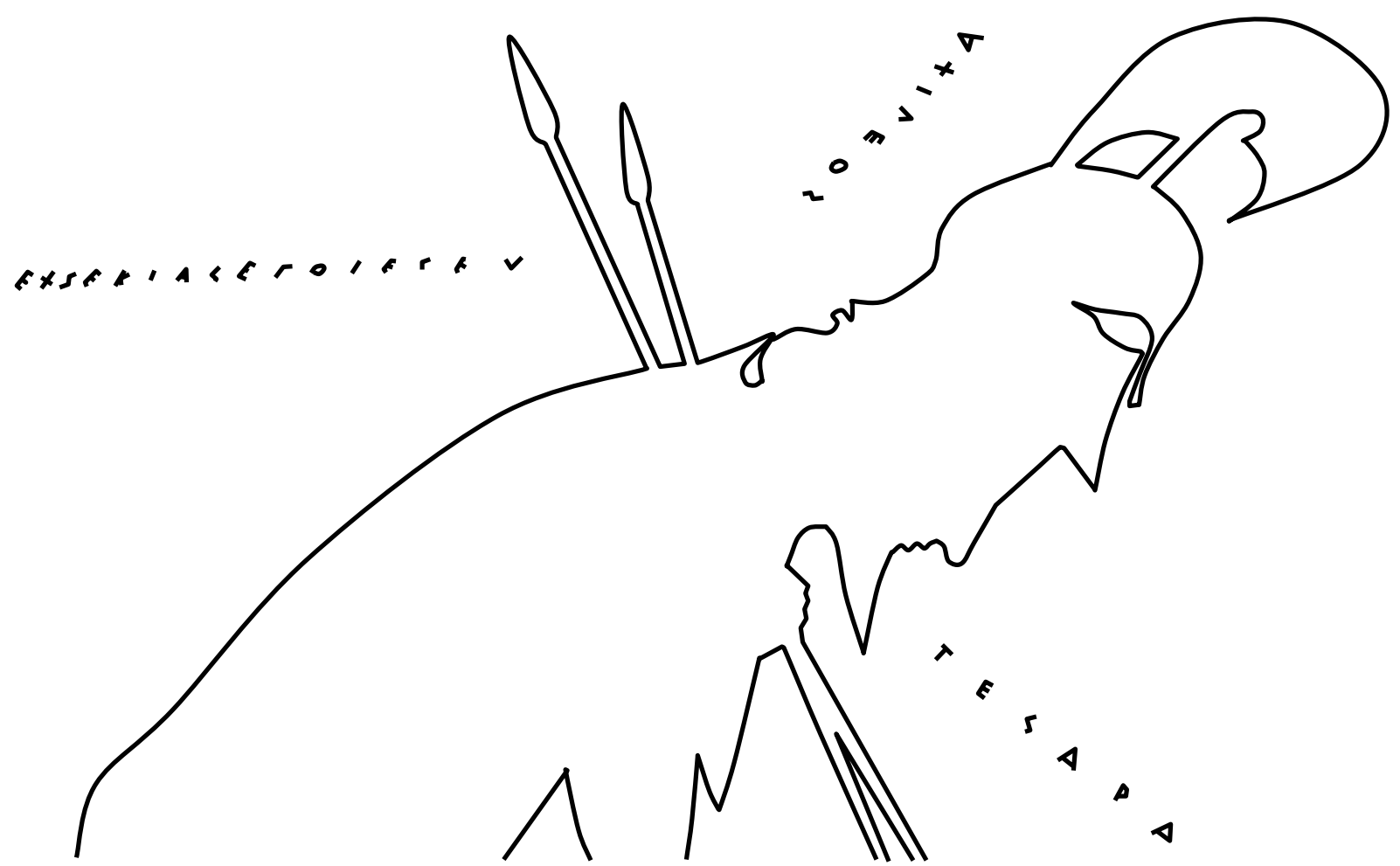

Fig. 1. Ânfora de Exéquias (detalhe - ver capa e introdução, nota 1, p. 10).

Mesmo ao observar a importância do espaço na composição escrito-figurativa, vê-se que as características técnicas não respondem absolutamente à questão. A disposição desses grafismos no espaço (superfície) de um vaso, pode ampliar-se a uma dimensão mais larga sobre o espaço, que organizou vários setores da ação dos gregos no período arcaico. Assim, se o espaço figurativo era algo altamente restrito no período geométrico, e essa relação muda bastante, mas não sozinha: ela formava um contexto histórico onde as mudanças no que tange à organização espacial, em vários níveis, se reestruturava. E é nesse cenário que a inscrição passou a dividir espaço com as figuras. 
Além de informar algo já relativamente conhecido (as amplas mudanças na noção de espaço dadas no período arcaico), a discussão sobre a natureza da interação escritofigurativa nos vasos áticos indicou especificidades nesse quadro amplo. Especificidades que não estavam restritas ao campo da criação em meio artesanal (as oficinas ceramistas áticas), mas a um conjunto de ações inter-relacionadas.

A principal contribuição à já tão retomada narrativa de uma história da Grécia antiga parece residir em alguns aspectos sobre o gráfico, desde sua organização técnica, até a sua sociabilidade. Retomando a idéia do gráfico como um discurso articulador, em certa medida, do escrito e do figurativo, trataram-se, aqui, de inúmeras nuances que refinam, razoavelmente, essa acepção do termo. Mas não o termo em si, isoladamente, mas como elemento de uma prática materializada nos vasos, e nas relações sociais em que estavam inseridos. Assim, escrita e figuração aproximam-se intimamente, mas essa aproximação é variada.

Essas diferenças são marcadas, em vários casos, por uma subordinação maior ou menor das inscrições à organização figurativa. De início, sabe-se que o gráfico como elemento articulador deve considerar certa hierarquia entre tais linguagens. Hierarquia que remete, em alguns aspectos, à própria história da inserção desses grafismos nos vasos de cerâmica: enquanto as imagens já no século $X$ a.C. ensaiavam uma presença na ornamentação vascular; as inscrições aparecem, em contexto original, apenas no século VIII a.C., e o uso sistemático, somente no século VI a.C.

Mostrou-se claro, nesse sentido, certa subordinação formal das inscrições frente às imagens figurativas, mas pode-se falar também numa subordinação temática; ou seja, inscrições que completavam as informações apresentadas de forma mais consistente pelas imagens figurativas. Mas essa não é a única possibilidade de aproximação. Existiam aquelas que, apesar da subordinação material (ou seja, adaptavam-se a espaços posteriormente à organização figurativa), pautavam-se pelo conteúdo mais independente; que se relacionava à imagem figurativa inclusive: são os casos das inscrições de autoria.

Outro refinamento do discurso gráfico encontra-se na idéia de comunicação. Se os grafismos dos vasos áticos tinham alto grau comunicativo, é preciso considerar os agentes da comunicação entre os quais tais vasos, por meio desses grafismos, faziam a intermediação. O comunicador pode ser um cidadão (encomendante) e não-cidadão (o artesão). Mas qual seria seu interlocutor? A variedade que a resposta de tal questão colocaria indica a própria dificuldade de falar de uma inteligibilidade comum, ampla e natural. O quadro não é definido. Nesse sentido, o próprio valor que esses grafismos imporiam aos vasos é relativo.

Considera-se, freqüentemente, a grande probabilidade de esses vasos que contivessem escrita e figuração serem objetos de luxo; mas não há nenhuma prova definitiva. Com isso, o seu valor simbólico é incerto, dada a variedade de recepção e mesmo o desconhecimento de informações específicas. Mas esse não é um problema restrito a essa documen- 
tação, e reside sobre boa parte das fontes materiais; ou seja, o que se sabe sobre o valor atribuído (aquele que nem sempre o objeto guarda materialmente, mas é construído socialmente) é muito pouco e geralmente as proposições sobre essa matéria são indiretas. Um dos poucos objetos sobre o qual se sabe com maior certeza o grau de simbolismo envolvido é aquele que, paradoxalmente, não existe (Snodgrass, 2004, p. 163): trata-se da Arca de Cípselo. Apesar de sua ausência material, mesmo com as constantes recriações, denominadas "reconstituição", guardaram-se informações preciosas, como o grau simbólico referente a esse objeto. $O$ fato de ser uma arca de ouro, cedro e marfim (materiais valiosos) poderia explicar, em parte, a sua situação privilegiada no Santuário de Zeus em Olímpia na época de Pausânias; mas é sobretudo sua inserção no mito que esclarece a situação. A despeito de ser ou não real a experiência contada é a narrativa que tal objeto compõe, que dá, em grande medida, sua valorização, situação denunciada pelos guias de Pausânias enquanto este visitava o local. Perdeu-se o objeto, manteve-se, em narrativa convertida em informação na pesquisa acadêmica, o valor que lhe era atribuído e o motivo disso.

Não há nada parecido no que se refere aos usos desses vasos aqui tratados, e a compreensão da recepção dos grafismos só pôde ser feita a partir de generalizações, aproximações e a observação de contextos mais bem delineados, como aquele que o mosaico deliano oferece. Trata-se, nesse caso, não de um discurso verbalmente articulado sobre as ânforas panatenaicas, mas de um "discurso visual", figurativo, e essa recriação em inúmeras peças, bidimensional e fixadora de uma face do vaso, informa algo sobre a recepção e possível leitura desses objetos.

Assim, na observação da trajetória dos grafismos, vê-se que se existem informações mais seguras sobre sua produção (espaço produtivo, fases, mentalidade do artesão etc.), o outro extremo dessa linha, a recepção, é pouco detalhada, quase nebulosa. Entretanto, a observação da trajetória, mesmo com esses limites, mostra-se importante, já que se trata de grafismos com potencial comunicativo, e esse grau de comunicação só pode ser mais bem compreendido se se remete a quem recebia as informações, e a própria manutenção ou reversão da hierarquia gráfica, constatada em meio artesanal.

Como avaliação do quadro geral, neste desfecho, tem-se que a observação da dinâmica gráfica, expressa na interação entre escrita e figuração nos vasos áticos arcaicos é mais clara no contexto produtivo. É sobre esse universo que se pode falar com mais certeza. Entretanto, não se pode estender naturalmente questões próprias da mentalidade dos artesãos envolvidos nessa experiência às várias situações em que esses vasos formavam. Conseqüentemente, é impossível descrever um quadro simples e linear de comunicação entre emissor e receptor. A expressão do gráfico, então, era objetivamente variada. Na hierarquização entre os tipos gráficos, na organização material, e na multiplicidade de inserção. 
Como "conclusão", ou melhor, avaliação das interpretações, vê-se que o gráfico era polissêmico (referia-se ao ato de escrever, desenhar, rabiscar...); mas na cerâmica, o discurso articulador aproximava estabelecendo certas hierarquias.

A compreensão desses desníveis é importante sobretudo quando se pensa que a apreensão de muitos conteúdos foi feita a partir dessas imagens e inscrições. A compreensão da organização material e os valores socialmente adquiridos estende-se a uma dinâmica importante no Mediterrâneo antigo. Ou seja, as relações entre sociedades, e mesmo internamente, eram, em certa medida, estabelecidas tendo como mediadoras as informações graficamente articuladas aqui tratadas.

Avaliar a importância ou extensão social desses mediadores é uma outra questão; entretanto é relevante saber que muito do conhecimento sobre a experiência antiga reconstituiu-se também os tendo como mediadores (documentos) que, na contemporaneidade, foram altamente valorizados. A referência gráfica como organizadora do discurso e meio de comunicação mostra-se indispensável como problema histórico e elemento a ser considerado teórico-metodologicamente. 


\section{Abreviaturas}

ABF - Beazley Attic Black-Figure Vase-Painters.

Add. - Beazley Addenda. Additonal references to ABV, ARV2 \& Paralipomena.

AION - Annali Sezione di Studi del Mondo Classico e del Mediterraneo Ântico.

AJA - American Journal of Archaeology (Archaeological Institute of America).

Bailly - Le grand Bailly. Dictionnaire Grec-Français.

BCH - Bulletin Correspondance Hellenique (École Française d'Athenes).

Classica - Classica: Revista da Sociedade Brasileira de Estudos Classicos.

CVA - Corpus Vasorum Antiquorum (União Internacional Acadêmica Intenacional - Bruxelas

-, Comissão Internacional de Filosofia e Ciências Humanas, Unesco).

CR - The Classical Review

Dev. - Beazley The development of attic black-figure.

ECA-USP - Escola de Comunicações e Artes da Universidade de São Paulo.

FFLCH-USP - Faculdade de Filosofia, Letras e Ciências Humanas da Universidade de São Paulo.

IG - Inscriptiones Graecae.

JHS - The Journal of Hellenic Studies (The Society for the Promotion of Hellenic Studies).

LIMC - Lexicon Iconographicum Mythologiae Classicae (Zurich: Artemis Verlag).

MAE-USP - Museu de Arqueologia e Etnologia da Universidade de São Paulo.

Mètis - Revue d'anthropologie du monde grec ancien. Philologie-Histoire-Archéologie (Paris, Athènes: Daedalus).

OJA - Oxford Journal of Archaeology (Institute of Archaeology, Oxford).

Para. - Beazley Paralipomena. Additions to Attic black-figure vase-painters and to Attic redfigure vase-painters.

RChD - Recueil Charles Dugas (Paris: Éditions E. de Boccard. Publications de la Bibliotèque Salomon Reinach).

RevMAE - Revista do Museu de Arqueologia e Etnologia da Universidade de São Paulo. 


\section{Texto original das citações traduzidas}

\section{Introdução}

p. 11, nota 2 “(..) two other sources, to be used with caution: our knowledge of human nature; and analogies drawn from what is know about the ways of crafstmen in other ages." (Beazley, 1949, p. 5).

p. 11, nota 3 "Ecriture et dessin, dans le code visuel grec, sont (...) étroitement liés (...). La langue grecque en porte témoignage, qui designe les deux activités, écrire et dessiner, du même mot : graphein." (Lissarrague, 1992, p. 191).

p. 12 "Ecrire et dessiner sont identiques em leur fond." (Lissarrague, 1992, p. 189).

p. 12, nota 6 "Le rapport de la lettre et de l'image a souvent été étudié depuis le texte inaugural de $M$. BUTOR, Les Mots dans la peinture (1969)." (Lissarrague, op. cit., p. 189).

p. 17, nota 14 “(..) on the body, is the head and neck of a man, and to the right of him the beginning of an inscription, A $\gamma \ldots$. Professor Karo has recently published fragments of another large Attic vase found in Aegina, the stand of a krater somewhat earlier than our (26tes Hallisches Winckelmannsprogramm pl. 1 and pp. 10-14): it is decorated with a procession of heroes, one of

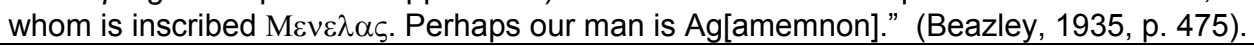

\section{Capítulo 1. Aspectos teórico-metodológicos}

p. 32

p. 33

p. 33

p. 33 , nota 4

p. 35 , nota 8

p. 37 , nota 15

p. 43 , nota 20

p. 50 , nota 26
"(...) différent de celui que nous présent la mémoire de l'intelligence sur la réquisition de notre volonté." (Proust, M. La petite Madeleine. In: À la recherche du temps perdu. Galimard, Vol. I, p. 701).

"Do you belive that the Athenian women were like the stately dignified figures of the Parthenon frieze, or like those marvellous goddess who sat in the triangular pediments of the same building? If you judge from art, they certainly were so. But read an authority, like Aristophanes, for instance. You will find that Athenian (...) were exactly like any silly fashionable or fallen creature of our own day. The fact is that we look back on the ages entirely through the medium of art, and art, very forntunately, has never once told us the truth." (Wilde, O. The decay of lying. An observation. Apud Bažant, 1981, p. 13).

"non-literate:literate", "barbarism:civilisation", "primitive:advanced" (Funari, Hall \& Jones, 1999, p. 3 e 5$)$.

"Las fuentes históricas convencionales sólo comienzan com el nacimiento del documento escrito, que se produjo em Asia Occidental en el 3000 AC aproximadamente, y bastante más tarde em lãs restantes partes del mundo (en Australia, por ejemplo, no existió hasta el 1788 DC). Por esta razón, es bastante común la distinción que se hace entre prehistoria - el período anterior a la escritura - e historia em sentido estricto, que supone el estúdio del pasado a través de la evidencia escrita." (Bahn \& Renfrew, 1993, p. 10).

“(...) l'agriculture naît au cours d'une phase récente correspondant à $2 \%$ de cette durée; la métallurgie à $0,7 \%$, l'alphabet à $0,35 \%$, la physique galiléenne à $0,035 \%$ et le darwinisme à 0,009\%." (White, L. A. The science of culture, p. 356, Apud Lévi-Strauss, 1997, p. 408).

"Je voudrais (...) montrer qu'il existe une tradition graphique autonome, indépendante de la tradition litéraire. Le plus souvent de la tradition graphique est parallèle à la tradition littéreire, ella la doublé, la complete, en dérivant évidemment de la même forme poétique des thème. Mais, en d'autres cas, elle n'est pas seulement indépendante de la tradition littéraire, elle y est opposée, et elle nous donne une variante de la légende incompatible avec la variante conservée par les textes." (Dugas, 1937, p. 59).

"(...) the case of Small's approach, where he emphasizes that material and written evidence constitute independent sets of data, produced by different social process, and Johnson's argument that they are product of the same social process." (Funari, Hall \& Jones, 1999, p. 10).

"(...) the study of inscriptions engraved on stone or metal in Greek letters." (Roberts, 2005, p. 263). 

p. 50 , nota 27
“(...) the study of Latin texts inscribed on durable objects, usually of stone or bronze.” (Idem, p.
$264)$.
p. 51
“L'épigraphie grecque est l'étude des inscriptions grecques antiques." (Rougemont, 1996-1997, p. 265).
"L'épigraphie grecque est donc une discipline auxiliaire de l'histoire, comme la papyrologie ou la numismatique. L'épigraphiste est un historien, spécialisé dans l'étude d'une des catégories de documents (en l'ocurrence, les inscriptions) grace auxquelle on écrit l'histoire du monde antique." (Idem, p. 266).
p. 53 "(...) the chaîne operatoire aims to describe ans understand all cultural transformations that a specific raw material had to go through. It is a chronological segmentation of the actions and mental processes required in the manufacture of na artifact and in its maintenance into techni- cal system of a prehistoric group. The initial stage of the chain is raw material procurement, and the final stage is the discard of the artifact." (Sellet, s/d, p. 106).
p. 53, nota $31 \quad$ "(...) pour signifier une méthode de structuration des actes techniques (...) elle a été adaptée par les préhistoriens aux études technologique d'industries prehistoriques." (Vialou, 2004, p. 422).
p. 54 "Son utilisation permet de definir des stratégies de production lithique au sein de contextes sócio-économiques quelles que soient les périodes de la préhistoire concernées (Perlès 1991). Cette notion de chaîne opératoire a progressivement conduit au développment d'une notion plus large que le seul processus de réalisation. A celui-ci s'ajoute largement l'amont et l'aval de la production et sur plusiers registres. La notion de système technique designe dans ce cas le cadre sócio-économique general des opérations techniques." (Geneste, 1991, p. 9).
p. 55, nota 33 "Context has long been recognised as vital in establishing an artifact's significance. It has righ- tly been stressed that context should be taken to refer not only to date, place and material loca- tion, but also to social context. 'Contextual archaeology' (Hodder 1987, 1991) makes much of associations, holding that meanings of thing can only be ascertained if contexts of use are considered. I am arguing that these possible dimensions of context should indeed be noted, but not defined a priori. The artifact, as assemblage, may define its own context through the inter- pretative encounter (Shanks \& Hodder, 1995, p. 14-17)." (Shanks, 2004, p. 28).

\section{Capítulo 2. Balizas espaço-temporais}

p. 65

p. 63 , fig. 4

p. 64 , fig. 6

p. 65

p. 65

p. 68 , nota 17
"The Athenian case is slightly weakened by some negative evidence: after the Dipylon oinochoe, no more Attic inscriptions are known until the graffiti from the Hymettus sanctuary on Subgeometric vessels around and after 700 B.C.., and these might appear to inaugurate a fresh start with upright $\alpha$, straight $\mathrm{l}$, and rectilinear $\pi$; it has even been doubted whether the Dipylon oinochoe was inscribed by a local man." (Coldstream, 1979, p. 299).

"[The Dipylon oinochoe] (...) was found during ilicit digging of tombs in or near the Kerameikos in 1871, and was offered to the Greek Archaeological Society with other material, after much had been already scattered; the rest of the grave-contents which accompained this oinochoe, if there were any, are therefore unknown." (Jeffery, 1990, p. 68).

"Epistamon, son of Luson, dedicated..." (Powell, 1991, p. 147).

"Jeffery has made much of the differences between this and later Attic inscriptions; she thinks that the inscription is not Attic, but perhaps close to the primitive Greek alphabet, which she derives from Al Mina." (Immerwahr, 1990, p. 7).

"(..) is unique $(\ldots)$, is unique $(\ldots),(\ldots)$ occurs in $(\ldots)$ and very rarely later $(I G \mathrm{i} 2,487) . "$ (Jeffery, 1990 , p. 66).

"The paucity of inscriptions before $700 \mathrm{BC}$ is probably due to the backwardness of Attica rather than to chance. (...) note especially the painted inscriptions on a local pot from Ithaca and two graffiti of a developed style (...) from Pithecussae, (...) from Corinth, all trhee rather well dated to the later eighth century." (Immerwahr, 1990, p. 8). 


\begin{tabular}{|c|c|}
\hline p. 72 & $\begin{array}{l}\text { "Cuando se refiere a los sitiadores de Troya, Homero emplea, diríase que indistintamente, tres } \\
\text { nombres: aqueos, dánaos (descendientes de Dánao, uno de los reyes míticos que crean Gre- } \\
\text { cia) y argivos." (Vidal-Naquet, 2001, p. 32). }\end{array}$ \\
\hline p. 72, nota 21 & $\begin{array}{l}\text { "For them there were no 'Greek' heroes, but Argive, Theban, Athenian, Corinthian, Cretan } \\
\text { heroes (...)." (Shapiro, 1997, p. 2). }\end{array}$ \\
\hline p. 73 & $\begin{array}{l}\text { "Athens or Attica? The common practice of calling Athenian vases Attic disguises the possibility } \\
\text { that there were potteries producing figure decorated vases elsewhere in Attica than in Athens' } \\
\text { potters' quarter." (Boardman, 1995, p. 182). }\end{array}$ \\
\hline p. 73, nota 26 & $\begin{array}{l}\text { "(...) was divided in the historical period into } 139 \text { demes. Many of these demes were districts or } \\
\text { neighborhoods within the city itself, but others were separate settlements scattered throughout } \\
\text { the countryside. Each had its own administration and civic organizations (...)." (Camp, 2001, p. } \\
271) \text {. }\end{array}$ \\
\hline p. 74 & $\begin{array}{l}\text { "Athens is not Greece. There are, for instance, rich and earlier series of myth scenes in Pelo- } \\
\text { ponnesian art on bronze reliefs and Corinthian vases. Sometimes Athens' debt to this tradition } \\
\text { can be traced, sometimes her independence of it. The stylistic and technical influence of East } \\
\text { Greek artists in Athens in sixth century is clear, and we may suspect iconographic influence } \\
\text { too." (Boardman, 1995, p. 215). }\end{array}$ \\
\hline p. 74 & $\begin{array}{l}\text { "(...) we need not take Athens as the model for all Greek behavoiur and taste in this craft. (...) } \\
\text { Athens' influence in Attica was propably the most extensive, but there was Argos and its Argo- } \\
\text { lid (...) Corinth with wide influence in the north-easr Peloponnese (...)." (Boardman, 2001, p. } \\
24) \text {. }\end{array}$ \\
\hline
\end{tabular}

\section{Capítulo 3. Os grafismos, da origem às especificidades gregas}
p. 79
“ll remonte à un thème indo-européen *gerbh, que l'on retrouve par exemple dans l'allemand kerben et dont le sens premier est écorcher, érafler, entailler." (Holtazmann, 1993, p. 3).
p. 95 “(..) ce qui équivaut à peu pres à 25 pages de ce livre (...).” (J.-P. Olivier, Les écritures crêtoi- ses, In: Treuil, 1989, p. 242).
p. 96
“(...) few and simple (...) derived from Mycenaean." (Cook, 1997, p. 8).

p. 96 , nota 18

"By the begining of the ninth century, then, two of three most important objects of Attic geometric art - the horse and the bird - were already introduced. The third - the human figure would not appear on Attic vases until later in the ninth century." (Hurwit, 1985, p. 59).

p. 100, nota 22 “(...) légende ou histoire de l'antiquité.” (Bailly, verbete $\alpha \rho \chi \alpha ı \lambda_{\text {ogxí }}$, p. 280).

p. 107, nota $35 \quad$ “...) les défilés de guerriers, les scènes de combat.” (Sarian, 1989, p. 593).

p. 118 “(..) that he was himself an Aeginetan." Cook (Apud Jeffery, 1949, p. 26).

p. 118 “(..) the provenance, the Doric form of the name, and the non-Attic lambda all combine to suggest that the painter was Aeginetan." (Jeffery, 1990, p. 110).

p. 128 "The name will naturally be written as close as possible to is owner, as it were issuing out from him (...)." (Jeffery, 1990, p. 47).

p. 130, nota 49 “(...) on peut observer qu'il utilize fréquemment les noms des personnages de façon dynamique, pour souligner les lignes de force de l'image, et les inscriptions de type signature ou acclamation pour encadrer ses tableaux." (Lissarrague, 1992, p. 194). 
(...) ignorons le noms de ces peuples, de leurs chefs, de leurs dieux. Rien ne nous est reste de leur langue, de leurs idées, de leur musique." (Leroi-Gourhan, 1983, p. 28).

“(...) indiquer clairement ce qu'est pour nous la céramologie: discipline auxiliaire de l'archéologie, elle a pour objectif l'exploration systématique de toutes les ressources offertes par les documents céramiques (dont il n'est pas exagere de dire qu'ils sont généralement sous-exploités." (Balfet, H. La céramique comme document archéologique. Bulletin de la Société Préhistorique Française, 63, 1966. p. 279).

"Le plus souvent le discours de l'historien est construit d'abord à partir des sources écrits auxquelles il donne la priorité, comme si à elles seules était reconnu le statut de document." (Schmitt-Pantel \& Thelamon, Image et histoire. Ilustration ou document, In: Lissarrague \& Thelamon, 1983, p. 10).

“(...) images des documents pour l'histoire.” (Schmitt-Pantel \& Thelamon, op. cit., p. 14).

"Every survey of early Attic inscriptions must start wuth the Dipylon oinochoe." (Jeffery, 1990, p. $68)$.

“(...) is decorated on the body with concentric lines of black slip interrupted by a broader sawtoothed design near the shoulder. A solid black slip covers the vase above the shoulder except for a decorated panel, bordered by zigzags, beneath the spout." (Powell, 1999, p. 158).

“(...) un examen attentif de l'épinetron montre l'existence d'une lettre supplémentaire entre l'omicron et l'êta, dans la cassure ; on en distingue la barre horizontale ; la restituition la plus vraisemblable est un Tau." (Bélis, 1984, p. 102).

"Les vases signés qui font l'orgueil de nos musées, les coupes d'Euphronios ou de Brygos, constituaient un article de luxe dont la vente eût été insufffisante à faire vivre une industrie (...)." (Dugas, 1924, p. 41).

p. 168, nota 34 "Quelques textes, et surtout les inscriptions gravées sur certains exemplaires, nous donnent une idée des prix auxquels ils étaient livres. Ces prix varient d'une obole (environ 0 fr. 15), qui represente la valeur d'un lécythe, vraisemblablement de petites dimensions, à quatre oboles, qui représentent celle d'un cratère." (Dugas, op. cit., p. 40).

"Inscriptions on Attic vases designate one of the figures in a scene, or they issue from a mouth as a true 'legend', or they are artits' signatures, or they are loose remarks praising the beauty of boys in general (ho pais kalos) or of a particular boy (Leagros kalos, etc.), or they are nonsense, or they allow the vase to speak for itself, or they are bespoke dedications, and there are one or two scene titles." (Boardman, 2003, p. 110).

p. 174, nota 40 "What we call mythology was, for the Greeks, the early history of their own people (...). The intermarrying of gods and mortals is a practice well illustrated in Homer (...)." (Shapiro, 1997, p. 1).

p. 175 "(...) dichotomy, as I have said, is false. Achilles is every woman's son ready for battle, Alcestis is an Athenian bride arrayed for her husband. The heroic scenes are furnished with the actual dress and impedimenta of the time of the painting (...). The gods and heroes had as much reality in human experience as one's fellow men; they were daily present in cult and in the images that crowded the sanctuaries and public places." (Sparkes, 1996, p. 133).

p. 175 "It requires only inscriptions naming heroes to translate these to the world of myth." (Boardman, 1995, p. 205).

p. 175, nota $41 \quad$ "(...) scenes of reality (...) these give a valuable picture of life in Athens and the countryside (...)." (Idem).

p. 187, nota 50 "Les deux faces du cratère, comme les frontons du temple grec, offrent, l'une, une scène 'calme', l'autre, une scène 'agitée'." (M. Denoyelle, Le cratère des Niobides. Paris: Editions de la Réunion des musées nationaux - Louvre, Service culturel, 1997, p. 10).

\section{Capítulo 5. Um estudo de caso: as ânforas panatenaicas}
p. 204
“a prize from Athens” (Cook, 1997, p. 86). 

"um des prix d'Athènes", "One of the prizes from Athens" (Nicholson, 2005, p. 13; Bentz, 2003, p. 112; Marx, 2003, p. 16; Boardman, 1995, p. 167; Noble, 1996, p. 13).
p. 204
"from the games at Athens" (Tracy, 1991, p. 143; Neils, 1992, p. 29; Hamilton, 1992, p. 130).
p. 204
"prix des jeux d'Athènes", "a prize from the games at Athens" (Collignon, 1885, p. 288; Beazley, 1986, p. 81).
p. 213
"Erictonio, que había sido criado por la propria Atenea dentro de um bosque sagrado, trás ex- pulsara Anfictión se convirtió en rey de Atenas; erigió en la acrópolis una estatua de madera de Atenea e instituyó la fiesta de las Panateneas." (Apolodoro, Biblioteca mitológica III, 14. 6.).

p. 213

“(...) le cycle des fêtes en l'honneur d'Athena est un cycle de fêtes agraires: Athena a joué, pour les paysans de la plaine attique, avant Déméter, le role de divinité de la vie des champs." (Daremberg \& Saglio, 1877-1919, p. 303).

p. 214, nota 16 "I hold that the Panathenian festival was not founded before the Lycaean. The early name for the former festival was the Athenian, wich was changed to the Panathenian in the time of Theseus, because it was then establishe by the whole Athenian people gathered together in a single city." (Pausânias Arcadia, II, 1 - Trad.: W. H. Jones, Loeb).

p. 214

"(...) So the Archon collects the tribute of oil accruing in his year, and passes it on to the Treasures at the Areopagus before he has handed the full quantity over to the Treasures. These have it in their keeping in the Acropolis they dole it out to Directors of the Games and these to the victorious competitors." (Aristóteles, Constituição de Atenas LX, 2-3 - Trad.: H. Hackham, Loeb).

p. 215 “...) une somme d'argent, plus une couronne au premier ; par exemple, le vainqueur du concours de cithare recevait 500 drachmes d'argent et une couronne de 1000 drachmes ; celui du concours de flûte était beaucoup moins bien partagé, on ne lui donnait qu'une couronne de 300 drachmes." (Lavedan, 1938, p. 728).

p. 215, nota 20 "For the prizes are for the victors in music silver money and gold vessels, (...) and for those in the gymnastic contest and horse-race, olive-oil." (Aristóteles, Constituição de Atenas LX 3 - Trad.: H. Hackham, Loeb). 


\section{Fontes imagéticas}

Capa

p. 1, s/no Detalhe de uma ânfora de Exéquias (Aquiles e Ájax jogando), Museu do Vaticano. (Site da UNISA).

\section{Introdução}

p. 19; fig. 1 Alfabeto Figurativo, Peter Flotner, 1534. (Site Giornale Nuovo).

p. 16; esq. 2 Fragmento de cratera protoática (detalhe), Pintor de Berlim A 34, c. 650-625 a.C. Atenas, Museu Nacional. Três propostas de reconstituição da inscrição. (Produzido pelo autor). ${ }^{1}$

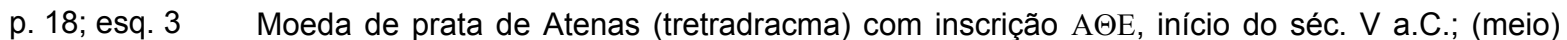
Alfa isolado: apresentação esquemática; (à direita) Desarticulação gráfica da letra alfa. Ao lado, formas do alfa em inscrições áticas do período arcaico (Jeffery, 1990, p. 66, fig. 26). (Produzido pelo autor).

p. 20, fig. 2 Trecho da segunda lição da cartilha Caminho Suave. Alfabetização pela imagem. (Lima, B. A. de L. (2005) Caminho Suave. Alfabetização pela imagem. Branca Alves de Lima, São Paulo: Caminho Suave Edições).

p. 20, fig. 3 Neues Nationen-Alphabet, Leporello, 1835; Nr. 97. Titelblatt. Lição das letras $A$ (Americaner) e $B$ (Berber). (Site da Goettingen University, Alemanha).

p. 21; fig. 4 Face de ânfora panatenaica (detalhe): corredores à pé e com escudos, o primeiro colocado carrega um escudo com uma grande letra alfa. (Olmos, 1993, fig. 52).

p. 22; fig. 5 (Detalhe) Taça ática de figuras vermelhas, Pintor Douris, c. 485 a.C., Berlin, Staatliche Museen. (Hurwit, 1990, p. 196, fig. 10).

p. 22; fig. 6 (Detalhe) Lécito ático de fundo branco, Inscription Painter, c. 475-450, Atenas, Museu Nacional. (Arquivo pessoal).

p. 22; fig. 7 (Detalhe) Lécito ático de figuras vermelhas, Klügmann Painter, c. 435-425 a.C., Paris, Museu do Louvre. (Arquivo pessoal).

p. 23; fig. 8 Kouros ("Apolo") de Mantiklos, procedente da Beócia, c. 700-675 a.C., Boston, Museum of Fine Arts. (Hurwit, 1990, p. 183, fig. 2).

p. 23; fig. 9 Koré de Nikandre, procedente de Delos, c. 650 a.C.; Atenas, Museu Nacional. (Arquivo pessoal).

p. 26; esq. $4 \quad$ Esquema de emblemas dos escudos dos sete guerreiros que vão assaltar Tebas (Vernant \& Vidal-Naquet, 1999, p.253).

\section{Capítulo 1. Aspectos teórico-metodológicos}

p. 39; fig. 1 Face de ânfora executada por Exéquias: Cena de luta entre Aquiles e Pentesiléia, c. 530 a.C. Londres, Museu Britânico. (Arias \& Hirmer 1962, pl. XVIII).

\footnotetext{
${ }^{1}$ Todos esquemas, croquis e tabelas foram criadas pelo autor desta dissertação, excetuando-se alguns que são apresentados com referência imediata. Ainda, além de várias reproduções fotográficas, algumas figuras (desenhos) foram produzidas pelo autor desta dissertação. Para estes, a referência na tabela será "produzido pelo autor".
} 
p. 45; fig. 2 Zeus fulminado gigante, ou titã. Frontão (e detalhe) do Templo de Ártemis, Iníco do séc. VI a.C., Corfou, Museu de Corfou. (Charbonneaux, Martin \& Villard, 1968, fig. 16; Boardman, 1996, pr. 84).

p. 45; fig. 3 Elemento de templo arcaico da Acrópole (pedra calcária), c. 550-540 a.C., Atenas, Museu da Acrópole. (Boardman, 1996, pr. 86 [adaptado]).

p. 45; fig. 4 Detalhe do friso norte do Tesouro de Sifnos, c. 525 a.C.- Delfos, Museu de Delfos. (Idem, pr. 118 [adaptado]).

p. 47; fig. 5 Detalhes de ânfora ática, Tarquínia, Museu Nacional; e detalhes de psykter ático, 530-520 a.C., Texas, Rice Museum. (LIMC, verbete "Gigantes”, v. 2, fig. 114 e fig. 153).

\section{Capítulo 2. Balizas espaço-temporais}

p. 61; fig. 1a Enócoa do Dípilo, Ática, 750-740 a.C., Atenas, Museu Nacional. (Site da University of Melbourne, Austrália; Guarducci, 1967, p. 135, fig. 28; Coldstream, 1979, p. 298).

p. 64; fig. 2 Inscrição de 'Izbet Sartah, c. séc. XI a.C. (Carrateli, 1996, p. 43).

p. 64; fig. 3 Inscrição sobre fragmento de cerâmica, Pitecussa. (Sarian, 1998-1999a, fig. 3d).

p. 64; fig. 4 Fíbula de ouro, Londres, Museu Britânico (Coleção Elgin). (Bandinelli, 1993a, prancha 13c).

p. 64; fig. 5 Enócoa do grupo do Dípilo (LG IIb), c. 725-700 a.C. Museu da Universidade de Melbourne. (Site da University of Melbourne, Austrália).

p. 65; fig. 6 Fragmento de placa votiva encontrada em Egina, c. 720-710 a.C. Museu Nacional, Atenas. (Powell, 1990, p. 147).

p. 65; fig. 7 Fragmento de cratera encontrada em Pitecussa, de tradição eubóica, último quartel do séc. VIII a.C., Ísquia, Museu Arqueológico de Pitecussa. (Buchner, 1971, p. 67).

p. 66; fig. 8 Kotyle de Nestor, 720-710 a.C., Ísquia, Museu Arqueológico de Pitecussa. (Site de The University of Texas at Austin).

\section{Capítulo 3. Os grafismos, da origem às especificidades gregas}

p. 81; fig. 1 Fragmentos de cerâmica de Dikili Tash, Grécia, Neolítico, MAE-USP (ornamentação incisa [acima] e pintada [abaixo]); vaso da região da Romênia (Boian culture), V milênio a.C. (ornamentação incisa); cerâmica da região da Albânia, IV milênio a.C. (ornamentação pintada). (FORMAS DE HUMANIDADE. Pré-história européia, Egito, Mesopotâmia, pr. 2; Boardman, 1984, fig. 5d, 11a e 11b).

p. 81; fig. 2 Desenho de criança em processo de alfabetização. (Desenho por Bruno de Jesus Francisco [4 anos de idade]).

p. 81; fig. 3 Gravuras de Leonardo da Vinci: Estudo de proporção entre cabeça e corpo (detalhe), Windsor Castle, Royal Library, London; Estudo de cabeças grotescas (detalhe), The Royal Library, Windsor Castle, c. 1490. (Site The Archive).

p. 86; fig. 4 Chiringas australianas, segundo Spencer e Gillen (Apud Leroi-Gourhan, 1990a, p. 188). (Leroi-Gourhan, 1990a, p. 188 e 190 [adaptado]).

p. 86; fig. 5 Calculi neolíticos de Susa, Paris, Museu do Louvre. (Jean, 1987, p. 12).

p. 86; fig. 6 Tablete do final do IV milênio a.C., Mesopotâmia, Museu do Louvre, Paris. (Christin, 2001, p. 22, fig. 2).

p. 86; fig. 7 Tablete pictográfico de Tell Brak, final do IV milêncio a.C. (Hooker, 1996, fig. 2, p. 23). 
p. 86; fig. 8 Tablete com inscrição pictográfica, pré-cuneiforme, final do IV milênio a.C. (Site Universidade de Siracusa - Maxwell School).

p. 88; fig. 9 Inscrição safaítica sobre basalto, IV milênio a. C., Amman, Jordânia (Jean, 1987, p. 11).

p. 88; fig. 10 Código de Hamurabi, século XVIII a.C., Museu do Louvre, Paris. (Christin, 2001, p. 25, fig. 7).

p. 88; fig. 11 Estela do rei babilônico Nabou-Aplaiddina representando o deus Sol Shamash, Sippar, Iraque, c. 870 a.C., Museu Britânico, Londres. (Boardman, 1984, fig. 29).

p. 88; fig. 12 Detalhes de relevo de Asurbanipal II junto à arvore da sabedoria (883-859 a.C.), Kalhu. (Idem, fig. 46).

p. 89; fig. 13 Livro dos mortos do reino de Mout-nedjemet, mencionando do faraó Hérithor; Paris, Museu do Louvre. (Christin, 2001, p. 48, fig. 5).

p. 89; fig. 14 Mural de calcário decorado com figuras e hieróglifos, encontrado no túmulo de um homem chamado Iry, V Dinastia. (Hooker, 1996, fig. 1, p. 94).

p. 89; fig. 15 Sinete cilíndrico do Babilônico antigo, e sinete cilíndrico do Período Cassita, III-II milênio a.C. (Idem, fig. 14-5, p. 49).

p. 90; fig. 16 Esfinge de arenito: Inscrição em hieróglifos egípcios. Segundo Período Intermediário, originária de Serabit el-Khadim (cerca de 1700 a.C.). (Idem, fig. 42, p. 164).

p. 90; fig. 17 Monumento de pedra neobabilônico que celebra Adad-etir e seu filho Marduk-balassu-iqbi, c. 2130 a.C. (Idem, fig. 16, p. 50).

p. 90; fig. 18 Escultura de granito representando Sennefer agachada. (Idem, fig. 12, p. 111).

p. 90; fig. 19 Estatueta Ushabti de Haremakhbit, Tebas, XXI Dinastia, c. 1000 a.C., Museu Nacional, Rio de Janeiro. (CERÂMICAS da Quinta da Boa Vista, p. 63).

p. 90; fig. 20 Estatueta de cão com inscrições, dedicada à Ninisinna, c. 1900 a.C. (Jean, 1987, p. 16-7).

p. 90; fig. 21 Pequena estatueta de basalto em forma de leão, inscrições hieroglíficas, Maras, c. 800 a.C. (Boardman, 1984, fig. 106).

p. 91; fig. 22 Ortostato hitita de basalto, Carchemish, início do séc. VIII a.C. (Idem, fig. 116).

p. 91; fig. 23 Ortostato hitita de basalto, Carchemish, início do séc. VIII a.C. (Idem).

p. 94; fig. 24 Disco de Festo, c. 1700 a.C. (Evans, 1919-1952, pr. XII e XXIV).

p. 94; fig. 25 Ideogramas (formas de vasos), em Linear A e Linear B. (Mountjoy, p. 81, fig. 187; Vandenabeele, 1974, fig. 2-12).

p. 94; fig. 26 Tablete com sistema fonético e ideogrmático combinado. (Stubbings, p. 81, fig. 65).

p. 94; fig. 27 Fragmento de selo argila com sinete decorativo, cena de caça e hieróglifos (encontrado em Creta por Evans). (Evans, 1909-1952, p. 22, fig. 11).

p. 94; fig. 28 Selo com imagem de cabeça humana (encontrado em Creta por Evans). (Idem, p. 272, fig. 123).

p. 94; fig. 29 Detalhe de selo com imagem de cabeça humana (encontrado em Creta por Evans). (Idem, fig. 124).

p. 94; fig. 30 Detalhe de selo com imagem de cabeça humana (encontrado em Creta por Evans). (Idem, fig. 125).

p. 95; fig. 31 Vaso inscrito para transporte de vinho e óleo, c. 1300 - c. 1190, Kadmeion, Thebes. (Mountjoy, p. 74, fig. 156). 
p. 95; fig. 32 Detalhe de jarro de transporte (parte alta co inscrições em Linear B) encontrado em Eleusis. (Christin, 2001, p. 200, fig. 5).

p. 95; fig. 33 Detalhe de jarro de transporte (parte alta com inscrições em Linear B) encontrado em Tebas. (Stubbings, 1973, p. 72).

p. 95; fig. $34 \quad$ Vaso de transporte (inscrição em etrusco). (Site Roma Sotterranea).

p. 95; fig. 35 Estampilha de alça de ânfora grega de transporte. (Biers, 1992a, p. 71, fig. 25).

p. 97; fig. 36 Ânfora ática protogeométrica 544, século X a.C., Museu do Cerâmico, Atenas. (Boardman, 1996, pr. 42).

p. 97; fig. 37 Ânfora ática protogeométrica 556, fim do século XI a.C., Atenas, Museu do Cerâmico. (Idem, pr. 41).

p. 97; fig. 38 Taça ática protogeométrica 567, séc. X a.C., Atenas, Museu do Cerâmico. (Idem, pr. 43).

p. 97; fig. 39 Rhyton protogeométrico em forma de cervo 641, séc. X a.C., Atenas, Museu do Cerâmico. (Idem).

p. 97; fig. 40 Vasos encontrados na região de Kommos, sul de Creta (séc. XVI e XIV a.C.). (Watrous, 1992, fig. 40, 50 e 65).

p. 97; fig. 41 Vasos encontrados na região de Kommos, sul de Creta (c. $1070-$ c. 1050/30). (Mountjoy, p. 104, fig. 277; p. 105, fig. 280; p. 113, fig. 318-25).

p. 98; fig. 42 a. Ânfora ática protogeométrica 560, século X a.C., Atenas, Museu do Cerâmico; b. Detalhe com imagem figurativa (cavalo) no bojo do vaso. (Boardman, 1996, pr. 44 e 47).

p. 98; fig. 43 Cratera ática geométrica A 514 (detalhe), final do século IX a.C., Paris, Museu do Louvre. (Idem, pr. 46 [adaptado]).

p. 99; fig. 44 Cratera ática geométrica 990 (detalhe do bojo), terceiro quartel do século VIII a.C., Atenas, Museu Nacional. (Idem, pr. 49).

p. 99; fig. 45

Pyxis geométrica 257 (tampa com forma plástica: cavalo), fim do século IX a.C., Atenas, Museu do Cerâmico. (Idem, pr. 47).

p. 99; fig. 46 Pyxis geométrica (detalhe), Atenas, Museu do da Agora. (Bandinelli, 1993a, fig. 6 [adaptado]).

p. 99; fig. 47 Ânfora-loutroforo protoática CA 2985 (detalhe do bojo), primeiro quartel do séc. VII a.C., Paris, Museu do Louvre. (Boardman, 1996, pr. IV).

p. 99; fig. 48 Fragmento de dinos de Sófilo 15499 (detalhe), c. 580-570 a.C., Atenas, Museu Nacional. (Idem, pr.XI).

p. 108; fig. 49 Cratera anforóide, Primeira metade do séc. XIII a.C., Chipre. (Arquivo pessoal).

p. 108; fig. 50 Cratera anforóide, c. 1400—1370, The Cesnola Collection. (Arquivo pessoal).

p. 108; fig. 51 Cratera anforóide de Enkomi, Chipre. (Higgins, 1997, fig. 133).

p. 108; fig. 52 Cratera micênica (detalhe), fileira de guerreiros, séc. XIII a. C., Atenas, Museu Nacional. (Arquivo pessoal).

p. 109; fig. 53 Tabletes com inscrições em Linear B. (Stubbings, p. 46, fig. 44).

p. 111; fig. 54 Proporção dimensional entre a cratera geométrica do Dípilo (a), a ânfora de figuras negras de Exéquias (b) e uma enócoa geométrica. (Produzido pelo autor).

p. 111; fig. 55 Detalhes de cratera geométrica do Dípilo, terceiro quartel do séc. VIII a.C. New York, Metropolitan Museum of Art. (Boardman, 1996, pr. 50 [adaptado].

p. 111; fig. 56 Detalhes de ânfora de Exéquias ornamentada com a técnica de figuras negras, c. 530 a.C., 
London, British Museum. (Arias \& Hirmer, 1962, pr. XVIII [adaptado]).

p. 113; fig. 57 Koûroi e kórai do séc. VIII ao VI a.C (detalhes do tórax e abdômen, e do drapejamento do manto e quíton): (acima, da esquerda para a direita) a. Armadura de bronze, encontrada em tumba geométrica de Argos, fim do séc. VIII a.C., Museu de Argos. b. Kouros ático, c. 620 a.C., Metropolitan Museum of Art, Nova lorque; c. Kouros coríntio, metade do séc. VI a.C., Glyptotèque, Munique; d. Kouros ático de Anavyssos, c. 520 a.C., Museu Nacional, Atenas. (Abaixo, da esquerda para a direita) e. Kóre de Auxerre, c. 650 a.C., Museu do Louvre, Paris; f. Kóre ática, início do séc. VI a.C., Museu Staatliche, Berlim; g. Kóre do Heraion de Samos, metade do séc. VI a.C., Museu de Samos; h. Kóre ática, c. 525-520 a.C., Museu da Acrópole, Atenas. (Boardman, 1996, pr. 79, 108, 117, 68, 81, 104 e 120).

p. 114; fig. 58 Madonna Rucellai, Duccio di Buoninsegna, Itália, 1285. Têmpera sobre madeira, Galeria degli Uffizi, Florença. (O LIVRO DA ARTE. São Paulo: Martins Fontes, 1999, p. 141).

p. 114; fig. 59 Madonna com romã, de Leonardo da Vinci, Itália, c. 1469. Óleo sobre tela, National Gallery of Art, Washington. (Site The Archive).

p. 114; fig. 60 Mulher sentada, Pablo Picasso, 9 de julho de 1953. Óleo sobre tela, Museu de Arte de Saint Louis, EUA. (Bois, Y.-A. (1999) Matisse e Picasso. São Paulo: Cia. Melhoramentos, p. 225, fig. 218).

p. 117 ; fig. 61

Detalhe de base de cratera protoática, séc. VII a.C., Berlim, Museu Staatliche. (Boardman, 1996, fig. 137; Jeffery, 1949, fig. 3).

p. 117; fig. 62 Detalhe de ânfora protoática, Museu de Eleusis, c. 670 a.C. (Boardman, 1996, pr. V).

p. 121; fig. 63 Enócoa geométrica ática, Atenas, Museu da Agora. (Bandinelli,1993a, fig. 16).

p. 121; fig. 64 Detalhe de ânfora-lutróforo protoática, início do século VII a.C., Museu do Louvre, Paris. (Boardman, 1996, pr. IV [adaptado]).

p. 121; fig. 65 Detalhe de olpe coríntia, séc. VII a.C. (Charbonneaux, Martin \& Villard, 1968, fig. 43 [adaptado]).

p. 121; fig. 66 Detalhe de enócoa ródia, c. 630-620 a.C., Munich, Staatliche Antiken Sammlungen. (Boardman, 1996, pr. 61 [adaptado)].

p. 121; fig. 67 Fragmento de ânfora protoática, terceiro quartel do século VII a.C. (Immerwahr, 1990, p. 8 e 9).

p. 121; fig. 68 Fragmento de esquifo protoático, c. 650 a.C. (Immerwahr, 1990, p. 8 e 9).

p. 121; fig. 69 Detalhe de prato ródio (combate entre Menelau e Heitor por Eufórbio), final do séc. VII a.C., Londres, Museu Britânico. (Boardman, 1996, pr. 75).

p. 122; fig. 70 Detalhes de dois vasos do Pintor de Nessos, e destaque das inscrições, último quartel do séc. VII a.C.; (à esquerda) Atenas, Museu Nacional; (à direita) Berlim, Museu Staatliche. (Charbonneaux, Martin \& Villard, 1968, fig. 50-2; Jeffery, 1990, pr. 1, fig. 6a e b).

p. 124; fig. 71 Fragmentos de dinos de Sófilo, c. 580-570 a.C., Atenas, Museu Nacional. (Idem, fig. 58-60).

p. 124; fig. 72 Detalhe de cratera com colunas coríntia, início do séc. VI a.C., Paris, Museu do Louvre; e detalhe de ânfora coríntia, c. 560-550 a.C., Paris, Museu do Louvre. (Boardman, 1996, pr. IX e X).

p. 125; fig. 73 Detalhes de dinos de Sófilo. (Site da University Wisconsin).

p. 125; fig. 74 Vaso François (cratera com volutas), c. 570 a.C., Florença, Museu Arqueológico. (Lissarrague, 1999).

p. 126; fig. 75 Detalhes do vaso François. (Idem e Cristofani, 1980, fig. 222 e 228).

p. 126; fig. 76 Inscrições de autoria do vaso François. (Cristofani, 1980, fig. 201, 208 e 160). 
p. 127; fig. 77 Detalhe do vaso François com fileira de personagens com inscrições acompanhando. (Boardman, 1996, pr. 94).

p. 127; fig. 78 Taça com faixa (band cup) assinada por Archikles e Glukytes, Cena da luta entre Teseu e Minotauro ladeada por várias outras figuras (muitas inscrições preenchem os espaços entre as imagens figuradas), c. 540 a.C. (Arias \& Hirmer, 1962, pr. 50).

p. 127; fig. 79 Detalhe de faixa externa de uma taça ática (band cup), dois guerreiros lutando e várias pessoas ladeando-os, c. 540 a.C., Museu da Universidade de Melbourne. (Site da Universidade de Melbourne).

p. 127; fig. 80 Detalhe de tondo interno de taça ática (lip cup), dançarinas de mãos dadas, entre elas, linhas pontilhadas. (Arias \& Hirmer, 1962, pr. XIV).

p. 129; fig. 81 Ânfora executada por Exéquias, c. 530 a.C. British Museum, London. (Idem, pr. XVIII; Dev. pr. 62, fig. 2).

p. 131; fig. 82 Vetores das inscrições que denominam as personagens na ânfora de Exéquias. (Produzido pelo autor).

p. 132; fig. 83 Ânfora de Amasis, c. 540 a. C., Biblioteca Nacional da França, Paris. (Dev. pr. 51, fig. 2).

p. 133; fig. 84 Detalhes: solução de restauração apresentada por Arias \& Hirmer para a ânfora de Amasis. (Arias \& Hirmer, 1962, pr. XV [adaptado]).

p. 133; fig. 85 Esquema das inscrições da ânfora de Amasis (fig. 83). (Produzido pelo autor).

p. 134; fig. 86 Diferentes estratégias de caracterização da cútis no vaso de Amasis. (Arias \& Hirmer, 1962, pr. XV [adaptado]).

p. 134; fig. 87 Cabeças femininas: vasos de Paros do período arcaico. (Hadjidakis, Delos).

p. 134; fig. 88 Detalhe de métopa com Zeus e Hera do templo E em Selinunte, Sicília, c. 460 a.C. (Fullerton, 2002, p. 150, fig. 95).

p. 136; fig. 89 Inscrições de autoria de Sófilo, Amasis e Nearco. (Produzido pelo autor).

p. 136; fig. 90 Detalhe de taça de Amasis, Museu do Vaticano. (Dev. pr. 59, fig. 3).

p. 137; fig. 91 Detalhe de vaso de Amasis, Londres. (Immerwahr, 1990, pr. 9, fig. 35).

p. 137; fig. 92 Detalhe de vaso de Amasis, Boston. (Idem, pr. 36).

\section{Capítulo 4. Sobre a documentação}

p. 151; fig. 1 Enócoa do Dípilo em Jeffery. (Jeffery, 1990, pr. 1, fig. 1).

p. 151; fig. 2 Enócoa do Dípilo em Immerwahr. (Immerwahr, 1990, pr. 1, fig. 1).

p. 151; fig. 3 Esquema da inscrição da enócoa do Dípilo. (Coldstream, 1979, p. 298).

p. 151; fig. 4 Esquema da inscrição da enócoa do Dípilo. (Powell, 1999, p. 158).

p. 151; fig. 5 Inscrições de ânfora do Pintor de Nessos em Jeffery. (Jeffery, 1980, pl. 1, fig. 6a).

p. 151; fig. 6 Inscrição da base de Menelau em Jeffery. (Jeffery, 1949, fig. 3).

p. 154; fig. 7 Ânfora do Dípilo, séc. VIII a.C., Atenas, Museu Nacional de Atenas. (Dev., pr. I).

p. 154; fig. 8 Esquema de proporção entre a Ânfora e a Enócoa do Dípilo. (Produzido pelo autor).

p. 157; fig. 9 Prancha 6 do CVA França 3, Compiègne 1. (Site do CVA). 
p. 158; fig. 10 Detalhes da prancha 6 (ver fig. 7) ampliação de 3 vezes. (Idem).

p. 159; fig. 11 Fragmentos do epinetron publicados por Haspels e Bélis. (Haspels, 1931, pr. 34, fig. 1a-c; Bélis, 1984, p. 101, fig. 2a).

p. 159; fig. 12 Esquema de antigas notações musicais gregas. (Bélis, 1984, p. 104, fig. 5).

p. 169; fig. 13 Graffiti sobre uma pélike ática de figuras vermelhas (Nikias Painter[?]), e graffiti sob base de uma cratera em sino de figuras vermelhas (Kadmos Painter). (Boardman, 2001, p. 157, figs. 182 e 183).

p. 177; fig. 14 Detalhe de ânfora ática assinada por Exéquias, c. 545-540 a.C., Berlin, Antikenmuseen. (Site Perseus Tufts).

p. 184; fig. 15 Ânfora (píthos) de Míconos: Vista de frente e face oposta, segundo quartel do século VII a.C., Museu de Míconos. (Arquivo pessoal).

p. 184; fig. 16 Selo emitido pelo governo grego com o detalhe do píthos de Míconos, figurando o episódio do Cavalo de Tróia. (Arquivo pessoal).

p. 185; fig. 17 Pescoço, em duas faces, da ânfora protoática de Elêusis, com Odisseu cegando o Polifemo, c. 670 a.C.; Elêusis, Museu de Elêusis. (Arquivo pessoal).

p. 187; fig. 18 Ânfora tipo A, faixa negra delimitativa. (Produzido pelo autor).

p. 187; fig. 19 Ânfora confeccionada por Exéquias, Staaliche Museum, Berlim, ornamentação floral na delimitação lateral. (Produzido pelo autor).

p. 188; fig. 20 Aríbalo ático, c. 570 a.C., New York, Metropolitan Museum of Arts. (Richter, 1932, pr. XIc).

p. 189; fig. 21 Detalhes de taças áticas (Lip cups) do terceiro quartel do século VI a.C., Coleção De Marchesi Guglielmi, Vulci. (Buranelli, 1997, p. 123, 126, 130; fig. 41-2, 44).

p. 189; fig. 22 Base confeccionada por Ergotimo e Clítias, c. 570 a.C., Metropolitan Museum of Arts, New York. (Immerwahr, 1990, pr. 5, fig. 20-1).

p. 190; fig. 23 Detalhes de taça (band cup), Pintor de Tleson, c. 550 a.C.; Toledo, Museu de Arte. (Site Perseus Tufts).

p. 192; fig. 24 Face de ânfora de figuras negras: Quimera (bojo ao ombro, alcançando o pescoço) e caprino (pescoço), 625-600; Atenas, Museu Nacional. (Arquivo pessoal).

p. 192; fig. 25 Prato ático de figuras negras, Górgona correndo, Pintor Anagyrous, c. 600-575 a.C., Atenas, Museu Nacional. (Arquivo pessoal).

p. 193; fig. 26 Ânfora de Nessos e Esquema da figuração transpassando alguns limites. (Fullerton, 2002, p. 75, fig. 41; esquema criado pelo autor).

\section{Capítulo 5. Um estudo de caso: as ânforas panatenaicas}

p. 197; fig. 1 Fragmentos de ânfora panatenaica atribuída ao Pintor Eufileto, c. 530-510 a.C., Gela, Museu de Gela. (R. Panvini \& F. Giudice. Ta Attika. Veder greco a Gela ceramiche attiche figurate dall'antica colonia. Roma: L'Erma di Bretschneider, 2004. p. 216, fig. 2).

p. 198; fig. 2 Ânfora Panatenaica (Burgon Group), c. 560 a.C., London, British Museum. (Bentz, 1998, fig. 6.001).

p. 203; fig. 3 Ânfora "pseudo-panatenaica", c. 500-490 a.C., Museu Gregoriano Estrusco. (Buranelli, 1997, p. 98, fig. 30).

p. 210; fig. 4 Detalhes da face $B$ de ânforas panatenaicas refrentes à prova de corrida à pé : (de cima para paixo, da esquerda para a direita) c. 566-530 a.C., New York, Metropolitan Museum of Arts; $c$. 566-530 a.C., München, Staaliche Antikensammlungen; c. 480-460 a.C., Berlin, Staatliche 
Museen; c. 480-460 a.C., Karlsruhe, Landesmusem; c. 500-450 a.C., Frankfurt, Liebieghaus Museum alter Plastik; c. 450-410 a.C., Atenas, Museu da Acrópole; 380-370 a.C., Detroit, Detroit Institut of Arts. (Bentz, 1998, fig. 6.007, 6.016, 5.071, 5.075, 5.094, 5.224, 4.004).

p. 211; fig. 5 Ânfora panatenaica, Pintor Cleofrade, c. 490 a.C., Christie's, Antiquities. (Site da Antiquities Christie's).

p. 211; fig. 6 Ânfora panatenaica (detalhe da isncrição), c. 500 - 475 a.C., atribuída ao Pintor Cleofrades, Yale University Art Gallery. (Site Perseus Tufts).

p. 219; fig. 7 Ânfora panatenaica figurada em mosaico (detalhes), Casa do Tridente (sala I), Delos, século II a.C. (Bruneau \& Ducat, 2005, p. 303, fig. 104).

p. 220; fig. 8 Planta da Casa do Tridente (Sala I), Delos, século II a.C. (Bruneau, 1972, p. 216).

p. 220; fig. 9 Planta baixa da Casa do Tridente (Sala I em destaque). (Bruneau \& Ducat, 2005, p. 302, fig. 102).

p. 220; fig. 10 Mosaico com tridente (A, na planta); e mosaico com golfinho (H, na planta). (Idem, p. 103).

p. 221; fig. 11 Detalhe de mosaico com ânfora panatenaica da Casa das Máscaras (século II a.C.). (Arquivo pessoal).

p. 221; fig. 12 Detalhe de mosaico com hídria, coroa e palmeta da Agora dos Italianos (século II-I a.C.). (Arquivo pessoal).

p. 221; fig. 13 Detlahe de frisa pintada na Palestra de Granito (século II a.C.). (Arquivo pessoal).

p. 223; fig. 14 Atena promachos de ânfora panatenaica helenística (363/362 a.C.), Eretria, Archaeological Museum. (Produzido pelo autor).

p. 223; fig. 15 Moedas helenísticas com figura de Atena promachos (Alkis): Octóbulo de prata, Siracusa, 278-276 a.C., Pirro, rei de Épiro; Tetradracma de prata, Alexandria, 305/4-282 a.C., Ptolomeu I; Tetradracma de prata, Macedônia, 277-239 a.C., Antigonus II Gonatas. (J. J. Pollitt, Art in the hellenistic age. Cambridge: Cambridge University Press, 1996. p. 27, fig. 15a-d).

\section{Conclusão}

p. 229; fig. 1 Detalhe de Ânfora de Exéquias. (Produzido pelo autor). 


\section{Textos antigos}

AESCHYLUS. Septem contra Thebas. Oxford: Clarendon Press.

APOLODORO. Biblioteca mitologica. MORENO, J. G. (trad. e introdução), Madrid: Alianza Editorial, 1993.

ARISTOTLE. Athenian constitution - Eudemian ethics - Virtues and vices. RACKHAM, H. (trad.), London, Massachusetts: William Heinemenn, Harvard University Press, The Loeb Classical Library.

ESCHYLE. Prométhée enchainé. In: Tome I. Les supplicantes - Les perses - Le sept contre Thèbes - Prométée enchainé. Texte établi et traduit par Paul Mazon. Versão bilíngüe (francês-grego). Paris: Société d'Édition "Les Belles Lettres", 1946.

ÉSQUILO. Prometeu acorrentado. Trad. Ramiz Galvão. In: ALMEIDA, G. de \& VIEIRA, T. Três tragédias gregas. p. 255-86.

Prometeu prisioneiro. Trad. Trajano Vieira. In: ALMEIDA, G. de \& VIEIRA, T. Três tragédias gregas. p. 143-76.

Os sete contra Tebas. Trad. Donaldo Schüler, L\&PM Pocket.

HERÔDOTOS. História. Trad. Mario da Gama Cury. $2^{\mathrm{a}}$ ed., Brasília: Ed. UnB, 1988.

HESIOD. The homeric hymns and homerica. Trad. Hugh G. Evelyn-White. The Loeb Classical Library, London, Cambridge, Massachusetts: William Heinemann Ltd., Harvard University Press, MCMLIX.

HOMER. The Iliad. I. Trad. A. T. Murray. The Loeb Classical Library, London, Cambridge, Massachusetts: William Heinemann Ltd., Harvard University Press, MCMLXXXVIII.

The Iliad. II. Trad. A. T. Murray. The Loeb Classical Library, London, Cambridge, Massachusetts: William Heinemann Ltd., Harvard University Press, LCL 71.

HOMERO. Ilíada. Trad. Carlos Alberto Nunes. $7^{\text {a }}$ ed., Rio d Janeiro: Ediouro, 2001.

. Ilíada de Homero. Volume I. Trad.: Haroldo de Campos. 5ª ed., São Paulo: Arx, 2003.

Ilíada de Homero. Volume II. Trad.: Haroldo de Campos. 3ª ed., São Paulo: Arx, 2002.

PAUSANIAS. Description of Greece. IV, Books VIII (XXII) - X. Trad. W. H. Jones. The Loeb

Classical Library, London, Cambridge, Massachusetts: William Heinemann Ltd., Harvard University Press.

Description of Greece. V. II, Trad. H. A. Omerod. The Loeb Classical Library, London,

Cambridge, Massachusetts: William Heinemann Ltd., Harvard University Press, 1955 [1926]. 


\section{Obras de referência e dicionários}

ARIAS, P. E. (1963) Enciclopedia Classica, Sezione III, vol. XI, t. Torino: Società Editrice Internazionale.

BAILLY, A. (2000) Le grand Bailly. Dicti onnaire grec-français. Paris: Hachette.

BEAZLEY, J. D. (1956) Attic black-figure vase-painters. Oxford: Clarendon Press.

. (1971) Paralipomena. Additions to attic black-figure vase-painters and attic red-figure vase-painters. $2^{\mathrm{a}}$ ed., Oxford: Clarendon Press.

BOARDMAN, J. (org.) (1984) Cambridge Ancient History. Plates to vol. III. The Middle East, the Greek World and the Balkans to the Sixth Century B.C. (New Edition) Cambridge, London, New York, New Rochelle, Melbourne, Sydney: Cambridge University Press.

CORPUS VASORUM ANTIQUORUM. Publicado desde 1922 pela Union Académique Internationale (mais de 300 fascículos com vasos de museus e coleções do mundo inteiro).

DAREMBERG, Ch.; SAGLIO, E. (dir.). (1877-1919) Dictionnaire des Antiquités Grecques et Romaines. Paris: Librairie Hachette.

ENCICLOPÉDIA Einaudi. (1987) Volume 11: Oral/escrito, Argumentação. Edição portuguesa, Imprensa Nacional - Casa da Moeda: BARTHES, R. \& MARTY, E. Oral/escrito. p. 32-57; BARTHES, R. \& MAURIĖS, P. Escrita. p. 146-172; CAZADE, E. \& THOMAS, C. Alfabeto. p. 173-183.

(1987) Volume 16: Homo-Domesticação. Edição portuguesa, Imprensa Nacional Casa da Moeda: BUCAILLE, R. \& PESEZ, J-M. Cultura material (verbete), p. 11-47.

GRIMAL, P. (2000) Dicionário de mitologia grega e romana. $3^{a}$ ed., Rio de Janeiro: Bertrand Brasil.

LAVEDAN, P. (1938) Dictionnaire illustré de la mythologie et des antiquités grecques et romaines. $3^{\mathrm{a}}$ ed., Librairie Hachette.

ROBERTS, J. W. (ed.) (2005) Oxford dictionary of the classical world. Oxford, New York: Oxford University Press. 


\section{Textos modernos}

ANDERSON, A. (1985) Interpreting pottery. Nova lorque: Pica Press.

ANDRÉN, A. (1998) Between artifacts and texts. Historical Archaeology in global perspective. New York, London: Plenum Press.

APPADURAI, A. (1998) The social life of things. Commodities in cultural perspective. Cambridge: Cambridge University Press.

ARIAS \& HIRMER. (1962) A history of greek vase painting. London: Thames and Hudson.

ARNOLD, D. E. (1985) Ceramic theory and cultural process. Cambridge: Cambridge Univestity Press, New Stuides in Archaeology.

BAHN, P. \& RENFREW, C. (1993) Arqueología. Teorías, métodos y práctica. Madrid: Ediciones Akal S. A.

BANDINELLI, R. B. et alli. (1993a) Storia e civiltà dei Greci. Origini e sviluppo della città (il medioevo greco). Milano: Gruppo Editoriale Fabri,Sonzogno, Etas S.p.A.

(1993b) Storia e civiltà dei Greci. Origini e sviluppo della città (l'arcaismo). Milano: Gruppo Editoriale Fabri,Sonzogno, Etas S.p.A.

BAURAIN-REBILLARD, L. (1998a) Des peintres linguistes? Mètis, Paris, Athènes: Daedalus. vol. XIII, p. 75-105.

(1998b) Les vases «communicants» à Athènes, des offrandes de l'Acropole aux premiers banquets sur l'Agora. Ktema, 23, p. 125-36.

BAŽANT, J. (1981) Studies on the use and decoration of athenian vases. Praha: Academia Nakladatelství Československé Akademie Vĕd.

BEAZLEY, J. D. (1927) Some Inscriptions on Vases. AJA, Vol. 31, № 3, p. 345-353, Jul. Sep.

. (1929) Some Inscriptions on Vases-II. AJA, Vol. 33, Nº 3. (Jul. - Sep., 1929), p. 361367.

(1932) Little-master cups. JHS, Vol. 52, p. 167-204.

(1935) Some Inscriptions on Vases III. AJA, Vol. 39, № 4, p. 475-488, Oct. - Dec.

(1941) Some Inscriptions on Vases IV. AJA, Vol. 45, N 4, p. 593-602, Oct. - Dec.

(1943) Two inscriptions on the attic vases. CR, Vol. 57, N 3, p. 102-103, Dec.

(1949) Potter and painter in ancient Athens. London: Geoffrey Cumberlege Amen

House.

. (1950) Some Inscriptions on Vases V. AJA, Vol. 54, N 4, p. 310-322, Oct. - Dec.

. (1954) Some Inscriptions on Vases VI. AJA, Vol. 58, N 3, p. 187-190, Jul.

(1957) Some Inscriptions on Vases VII. AJA, Vol. 61, No 1, p. 5-8, Jan.

(1960) Some Inscriptions on Vases VIII. AJA, Vol. 64, № 3, p. 219-225, Jul. 
(1986) The development of attic black-figure. Edição revisada, Berkeley, Los Angeles, London: University of California Press, Cambridge University Press. Sather Classical Lectures, Vol. 24.

BÉLIS, A. (1984) Un noveau document musical. BCH 108, 1984, p. 99-109.

BENTZ, M. (1998) Panathenaïsche preisamphoren. Eine sthenische vasengattung und hire funktion vom 6.-4. jahrhundert v. Chr. Antike Kunst, Achtzehntes Beiheft, 18.

(2003) Les amphores panathenaïques: une étonnante longévité. In: ROUILLARD, P. \& VERBANCK-PIÉRARD, A. Le vase grec et ses destins. München: Biering \& Brinkmann. BÉRARD, C. (1983) Iconographie-iconologie-iconologique. Études de Lettres. Revue de la Faculté des Lettres. Université de Lausanne, p. 5-37.

BÉRARD, C., BRON, C. \& POMARI, A. (1987) Images et société en Grèce ancienne. L'iconographie comme méthode d'analyse. Actes du Colloque Internacional de Lausanne (8-11 de fevereiro de 1984). (Cahiers d'Archéologie Roamnde, 36) Lausanne.

BÉRARD, F. et al. (2000) Guide de l'Épigraphiste. Bibliographie choisie des épigraphies antiques et médievales. $3^{\mathrm{a}}$ ed., Paris: Éditions Rue D'Ulm.

BERNAL, M. (1996). Black Athena. Les racines afro-asiatiques de la civilization classique. vol. I: L'invention de la Grèce antique 1785-1985. Paris: Presses Universitaires de France. (1999) Black Athena. Les racines afro-asiatiques de la civilization classique. vol. II: Les sources écrites et archéologiques. Paris: Presses Universitaires de France.

BERTRAND, J.-M. (1992) Inscriptions historiques grecques. Paris: Les Belles Lettres.

BIERS, W. R. (1992a) Art, artefacts, and chronology in classical archaeology - approaching the ancient world. Nova lorque: Routledge.

BOARDMAN, J. (1978) Exekias. AJA, 82, p. 11-25.

. (1964) The greeks overseas. Baltmore: Penguin Books.

. (1995) Athenian black figure vases. London: Thames and Hudson Ltd.

(1996) L' art grec. Jose Dörig, Werner Fuchs \& Max Hirmer (fotografias), München,

Paris: Hirmer Verlag, Flammarion.

(1998) Early greek vase painting. 11th-6th centuries BC. London: Thames \& Hudson Ltd.

(2001) The history of Greek vases. Potters, painters and pictures. Thames \& Hudson.

(2003) Reading' greek vases? OJA, 22 (1), p. 109-114.

BOARDMAN, J. \& KURTZ, D. C. (1971) Greek burial customs. London: Thames and Hudson. BRAUDEL, F. (1986) A longa duração. In: História e ciências sociais. $5^{\mathrm{a}}$ ed., Trad.: Rui Nazaré, Lisboa: Editorial Presença, p. 7-39.

BRON, C. \& KASSAPOGLOU. (1992) L'image en jeu. De l'Antiquité à Paul Klee. Yens-surMorges, Institut d'Archéologie et d'Histoire Ancienne de I'Université de Lausanne/Étitions Cabédita. 
BRUNEAU, Ph. et al (1970) L'îlot de la maison des comédiens. Exploration Archéologique de Délos. Paris: Éditions E. de Boccard.

BRUNEAU, Ph. (1972) Les mosaïques. Exploration Archéologique de Délos. École Française d'Athènes. Paris: Éditions E. de Boccard.

(1974) Fontes textuais e vestígios materiais: reflexões sobre a interpretação arqueo-

lógica. In: Mélanges G. Daux. Texto datilografado, tradução de Flávia Faleiros. Paris, 1974. Suppl. BCH, p. 4-42.

BRUNEAU, Ph \& DUCAT, J. (2005) Guide de Délos. $4^{\text {a }}$ edição, Paris: Éditions E. de Boccard.

BUCHNER, G. (1971) Recent work at Pithekoussai (Ischia), 1965-71. Archaeological Reports, 1970-71, No. 17, p. 63-7.

BURANELLI, F. (1997) La raccolta Gracinto Guglielmi. Parte I, a ceramica. Monumenti musei e gallerie pontificie, Museo gregoriano etrusco 4.

BURKE, P. (org.) (1994) A escrita da história: novas perspectivas. $2^{a}$ ed., Trad.: Magda Lopes, São Paulo: Editora da Unesp.

BUTOR, M. (1969) Les mots dans la peinture. Genève: Editions d'Art Albert Skira.

CAMP, J. M. (2001) The archaeology of Athens. New Haven, London: Yale University Press.

CARANDINI, A. (1984) Arqueología y cultura material. Barcelona: Ed. Mitre.

CARPENTER, T. H. (1986) Dionysian Imagery in Archaic Greek Art - Its development in black-figure vase painting, Clarendon Press, Oxford.

(1994) Art and myth in ancient Greece. London: Thames and Hudson.

CARRATELI, G. P. (1996) The greek world. Art an civilization in Magna Graecia and Sicily. New York: Rizzoli.

CHADWICK, J. (1999) The mycenaean world. Cambridge: Cambridge University Press.

CHARBONNEAUX, J; MARTIN, R \& VILLARD, F. (1968) Grèce archaïque: 620-480 avant J.C. Paris: Gallimard.

CHRISTIN, A. M. (org.) (2001) Histoire de l'écriture : de l'idéogramme au multimedia. Paris: Flammarion.

CLARK, G. (1985) A identidade do homem. Uma exploração arqueológica. Trad.: Álvaro Cabral, Rio de Janeiro: Zahar Editor.

COLDSTREAM, J. N. (1979) Geometric Greece. London, New York: Methuen.

COLLIGNON, M. (1985?) Manuel d'Archéologie grecque. Paris: A. Quantin.

COOK, B. F. (1980) Reading the past. Greek inscriptions. Berkeley, Los Angeles, London:

University of California Press, Britsh Museum.

COOK, R. M. (1971) ‘Epoiesen’ on greek vases. JHS, Vol. 91, p. 137-8. (1997) Greek painted pottery. $3^{\mathrm{a}}$ ed., Londres, Nova lorque: Routledge.

COPETE, J. M. C. (ed.) (1999) Epigrafía griega. Madrid: Cátedra.

CORBETT, P. E. (1960) The Burgon and Blacas tombs. JHS, Vol. 80, p. 52-60, pl. I-VII. 
COUËLLE, C. (1998) Dire en toutes lettres? Allusions et sous-entendus chez le Peintre de Meidias. Mètis, Paris, Athènes: Daedalus. vol. XIII, p. 135-58.

CRISTOFANI, M. (1980) Le iscrizioni. Bollettino d'Arte. Roma. P. 175-95.

DALLEY, S. \& REYES, A. T. (1998) Mesopotamian contact and influence in the Greek world I. To the Persian conquest. In: DALLEY, $\mathrm{S}$ et al. The leagacy of Mesopotamia. Oxford: Oxford University Press. p. 85-106.

. (1998b) Mesopotamian contact and influence in the Greek world II. Persia, Alexander, and Rome. In: DALLEY, S et al. The leagacy of Mesopotamia. Oxford: Oxford University Press. p. 107-124.

DEBIDOUR, M. (1998) Amphores, épigraphie et histoire. Epigraphie et histoire: acquis et problèmes. Paris: Diffusion De Boccard, p. 77-91.

DENOYELLE, M. (1998) Euphronios et Léagros: un couple impossible. Deux inscriptions euphroniennes à relire. Mètis, Paris, Athènes: Daedalus. vol. XIII, p. 7-15.

DETIENNE, M. (org.) (1992) Les savoirs de l'écriture em Grèce ancienne. Paris: Presses Universitaires de Lille.

DEVAMBEZ, P. (1961) Antiquité classique. In: Encyclopédie de la Plêiade Histoire de l’art, I. Le monde non-cretiene. Éditions Gallimard.

DUCAT, J. (1962) L'archaïsme à la recherche de points de repère chronologiques. BCH 86, 1962, p. 165-183.

DUCATI, P. (1922) Storia della ceramica greca. Firenze: Fratelli Alinari.

DUGAS, C. (1924) La céramique grecque. Paris: Payot. (1932) Note sur l'origine d'Amasis et des quelques peintres de vases. Mélanges Glotz, I, p. 335 sq. In: RChD, p. 13-17. . (1936) Decoration et imagerie dans la céramique grecque. REG, XLIX, p. 1 sq. In: RChD, p. 35-49. . (1937) Tradition littérarie et Tradition graphique dans l'antiquité grecque. L'Antiquité classique, VI, p. 5 sq. In: RChD, p. 59-74.

(1960) Recueil Charles Dugas. Paris: Éditions E. de Boccard. Publications de la Bibliotèque Salomon Reinach.

EISMAN, M. M. (1974) A further note on EPOIESEN signatures. JHS, Vol. 97, p. 172.

EVANS, A. (1909-1952) Scripta Minoa. The written documents of Minoan Crete, with special reference to the archives of Knossos. Oxford : Clarendon Press.

FERRARI, G. (1987) Menelas. JHS, Vol. 107, p. 180-182.

FINLEY, M. I. (1988) Os gregos antigos. Trad.: Artur Morão, Lisboa: Edições 70. (1990) Grécia primitiva: Idade do Bronze e Idade Arcaica. Trad.: Wilson Vaccari, São Paulo: Martins Fontes. 
(1994a) História antiga: testemunhos e modelos. Trad.: Valter Lellis Siqueira, São Paulo: Martins Fontes.

. (1994b) Uso e abuso da História. Trad.: Marylene P. Michael, São Paulo: Martins Fontes.

FORSDYKE, J. (1956) Greece before Homer. Ancient chronology and mythology. London: Max Parrish.

FRONTISI, C. (1992) L'image prise aux mots. BRON, C. \& KASSAPOGLOU. L'image en jeu. De I’Antiquité à Paul Klee. Yens-sur-Morges, Institut d'Archéologie et d'Histoire Ancienne de l'Université de Lausanne/Étitions Cabédita, p.205-221.

FRONTISI-DUCROUX, F. (2003) L'oeil du serpent. Jeux de mots, jeux d'images. Mètis, Paris, Athènes: Daedalus. N. S. 1, p. 111-8.

FULLERTON, M. D. (2002) Arte grega. Trad.: Cecília Prada. $1^{\text {a }}$ ed., São Paulo: Odysseus.

FUNARI, P. P. A. (1999) Lingüística e Arqueologia. Delta. [online] fev/jul 1999, vol. 15, n. 1, [citado 20 Fevereiro 2004]. P. 00-00. Sisponível na World Wide Web: <http://scielo.php?script=sci_artflex\&pid=S0102-44501999000100008\&Ing=pt\&nm=iso> (2003) Antigüidade clássica. A história e a cultura a partir dos documentos. $2^{\mathrm{a}}$ ed., Campinas: Ed. Unicamp.

FUNARI, P. P. A.; HALL, M. \& JONES, S. (eds.) (1999) Historical archaeology: back from the edge. London, New York: Routledge.

GENESTE, J.-M. (1991) Systèmes techniques de production lithique: variations technoéconomiques dans les processus de realization des outllages paléolithiques. Techniques et culture. 17-18, p. 1-35.

GOLDEN, M. (1998) sport and society in ancient Greece. Cambridge: Cambridge University Press.

GUARDUCCI, M. (1967) Epigrafia greca I. Caratteri e Storia della Disciplina. LA scritura greca dalle origini all'età imperiale. Roma: Istituto Poligrafico dello Stato, Libéria dello Stato. (1969) Epigrafia greca II. Epigrafi di carattere publico. Roma: Istituto Poligrafico dello Stato, Libéria dello Stato.

(1974) Epigrafia greca III. Epigrafi di carattere privato. Roma: Istituto Poligrafico dello Stato, Libéria dello Stato.

GUARINELLO, N. L. (2003) Cidades-Estado na Antigüidade Clássica. In: PINSKY, J. \& PINSKY, C. B. (orgs.). História da cidadania. $2^{\mathrm{a}}$ ed., São Paulo: Contexto, p. 29-47.

HALL, J. M. (2000a) Ethnic identity in Greek antiquity. Cambridge: Cambridge University Press.

(2001) Quem eram os gregos. RevMAE, São Paulo, n. 11, p. 213-225.

HAMILTON, R. (1992) Choes and Anthesteria. Athenian iconography and ritual. Michigan:

The University of Michigan Press. 
(1999) Martin Bentz, Panathenäische preisamphoren: eine athenische vasengattung und ihre function vom 6.4. jahrhundert v. Chr. Antike Kunst Beiheft 18. basel: Vereinigungder Freunde antiker Kunst, 1998. Pp. 240, 436 pl. Bryn Mawr Review 1999.11.15.

HASPELS, C. E. (1931) Attic black-figured lekythoi. Paris : E. de Boccard.

HAVELOCK, E. A. (1996) A revolução da escrita na Grécia e suas conseqüências culturais. Trad.: Ordep José Trindade Serra. São Paulo, Rio de Janeiro: Editora da Universidade Estadual Paulista, Paz e Terra.

HAVELOCK, C. M. (1965) The Archaic as survival versus the archaistic as a new style. AJA 69 , n. 4 , p. $331-40$, pr. $73-4$.

(1980) The archaistic Athena Promachos in early hellenistic coinages. AJA 84, n. 1, p. 41-50, pr. 7-8.

HIGGINS, R. (1997) Minoan and mycenaean art. London; New York: Thames and Hudson. HODDER, I. (1998) Interpretación em Arqueología. Corrientes actuales. Trad.: José Aubet. Barcelona: Editorial Crítica.

HODDER, I. \& PREUCEL, R. W. (1996) Contemporary Archaeology in theory. A reader. London: Blackwell.

HOLTZMANN, B. (1993) Le graphisme dans l'art grec. HistArt, 24, p. 3-11.

HOOKER, J. T. (org.). (1996) Lendo o passado: a história da escrita antiga do cuneiforme ao alfabeto. São Paulo: EDUSP, Melhoramentos.

HOLTORF, C. (2002) Notes on the life history of a pot sherd. Journal of Material Culture, vol. 7, London, University College, p. 49-71.

HURWIT, J. M. (1990) The words in the image: orality and literacy and early Greek Art, Word \& Image, 6, p. 180-97.

(1985) The art and the culture of early Greece, 1100-480 B.C. Ítaca, Londres: Cornell University Press.

IMMERWAHR, H. R. (1973) More book rolls on attic vases. Antike kunst, XVI, p. 143-7.

(1984) The signatures of Pamphaios. AJA, vol. 88, n. 3, p. 341-352.

(1990) Attic script. A survey. Oxford: Clarendon Press.

JEAN, G. (1987) L'écriture: mémoire des hommes. Paris: Gallimard.

JEFFERY, L. H. (1949) Comments on some archaic Greek inscriptions. JHS, Vol. 69, p. 2538.

(1978) Archaic Greece - the city-states c. 700-500 B.C. Londres: Methuen \& Co Ltd. (1984) The alphabet and Greece. In: The Cambridge Ancient History - Plates III (The Midle Est, The Greek World and the Balkans to the sixth century B.C.). Cambridge: Cambridge University Press, p. 290-9.

(1990) The local scripts of archaic Greece. A study of the origin of greek alphabet and its development from the eighth to the fifth centuries B.C. Oxford: Clarendon Press. 
JOUAN, F. (1996-1997) L'édition critique des textes grecs anciens. Classica, São Paulo, v. 9/10, n. 9/10, p. 275-90.

JUBIER, C. (1998) De l'usage des pseudo-inscriptions chez le peintre de Sappho, du signe au sens. Mètis, Paris, Athènes: Daedalus. vol. XIII, 1998, p. 57-73.

KIRCHNER, J. (1948) Imagines Inscriptorum Atticarum. Ein Bilderatlas Epigraphischer Denkmäler Attikas. Zweite Auglage, Durchgeschen Von Günter Klaffenbach. Berlin: Gebr. Mann Verlag.

LA GENIÈRE, J. de. (1999) De la céramique pour les mercenaires. In: LA COLONISATION GRECQUE EN MÉDITERRANÉE OCCIDENTALE. Actes de la rencontre scientifique en hommage à Georges Vallet organisée par le Centre Jean-Bérard. Rome, Naples, 15-18 novembre 1995. Rome: Ecole française de Rome.

LANE, A. (1948) Greek pottery. London: Faber and faber.

LANGDON, M. K. (1975) The Dipylon oinochoe again. AJA, vol. 79, n. 1, p. 139-40.

LARONDE, A. (1998) Épigraphie et histoire grecque. Epigraphie et histoire: acquis et problèmes. Paris: Diffusion De Boccard, p. 9-12.

LAZZARINI, M. L. (1999) Questioni relative all'origine dell'alfabeto Greco. In: CORDANO, F. \& GIANNI, G. B. (org.) Scritturi mediterranee trai I IX e il VII secolo a.C. Atti del seminário. Università degli Studi di Milano, Istituto di Storia Ântica, 23-24 Febbraio 1998. Milano: Università degli Studi di Milano, p. 53-66.

LE GOFF, J. (1997) Documento/monumento. In: Enciclopédia Einaudi, vol. 1 - MemóriaHistória. Edição portuguesa, Imprensa Nacional-Casa da Moeda. p. 95-105.

LEROI-GOURHAN, A. (1983) Les chasseurs de la préhistoire. Paris: Ed. A.-M. Métailié. . (1990a) O gesto e a palavra. 1 - Técnica e linguagem. Trad. Emanuel Godinho. Lisboa: Edições 70 .

. (1990b) O gesto e a palavra. 2 - Memória e ritmos. Trad. Emanuel Godinho. Lisboa: Edições 70.

(1995) Os caminhos da História antes da escrita. In: Le Goff, J. História: novos problemas. Trad.: Theo Santiago, $4^{\mathrm{a}}$ ed., Rio de Janeiro: Livraria Francisco Alves.

LÉVI-STRAUSS, C. (1982) As estruturas elementares de parentesco. Trad. Mariano Ferreira.

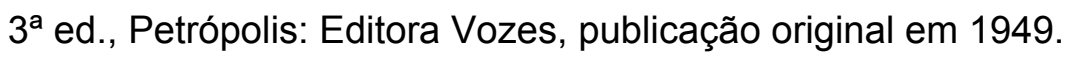

(1997) Vues perpectives. Saint-Amand: Impremierie Bussière.

LISSARRAGUE, F. (1988) La stele avant la letter. AION, X, Sezione temática: "LA Parola, L'imagine, La toma. Atti del Colloquio Internazionale di Capri. Napoli, p. 97-105.

(1990a) Epiktetos egraphsen: the writing on the cup. In: GOLDHILL, S. \& OSBORNE,

R. Art and text in ancient Greek culture. Cambridge: Cambridge University Press, p. 1227. 
(1990b) Une approche de l'imagerie attique. In: L'autre guerrier: archers, peltastes, cavaliers dans l'imagerie attique. Paris: Éditions la Découverte \& Rome: École Française de Rome \& Centre de recherches comparées sur les sociétés anciennes et l'École française de Rome - 3, p. 1-12.

(1992) Graphein: ecrire et dessiner. BRON, C. \& KASSAPOGLOU. L’image en jeu.

De I'Antiquité à Paul Klee. Yens-sur-Morges, Institut d'Archéologie et d'Histoire Ancienne de l'Université de Lausanne/Étitions Cabédita. p. 189-203.

. (1998) Les belles lettres: écriture et ornement sur une oenochoé de Charinos. Mètis, Paris, Athènes: Daedalus. vol. XIII, p. 123-33.

(1999) Artisans et artistes: signatures et atribuitions. In: Vases grecs. Les athéniens et leurs images. Ed. Hazan, p. 224-5.

LISSARRAGUE, F. \& THELAMON, F. (1983) Image et céramique grecque. Actes du Colloque de Rouen (25-26 de novembro de 1982). Rouen, Publications de I'Université de Rouen, n. 96.

MARX, P. A. (2003) Athena on early panathenaic amphoras. Antike Kunst 46, p. 14-30.

MATHESON, B. (1989) Panathenaic amphorae by Kleophades painter. In: Greek vases in J. P. Getty Museum. Vol. 4, Malibu, California.

MATSON, F. R. (ed.). (1965) Ceramics and man. Chicago: Aldine Publ. Comp.

MCCARTER, P. K. (1975) A Phoenician grafitto from Pithekoussai. AJA 79, p. 140-1.

MCLUHAN, M. (1972) A galáxia de Gutenberg. Trad. Leônidas Gontijo de Carvalho e Anísio Teixeira. Cia. Ed. Nacional, Editora da Universidade de São Paulo. Coleção Cultura, Sociedade, Educação, vol. 19.

. (1974) Os meios de comunicação como extensões do homem. Trad.: Décio Pignatari. São Paulo: Ed. Cultrix.

MENESES, U. T. B. (1980) O objeto material como documento. Texto datilografado, aula ministrada em curso sobre "Patrimônio Cultural: políticas e perspectivas". Condephaat, São Paulo.

(1981) Pintura na construção social da cidade: estudo de cultura material em Delos helenística. Vol. I (texto) e II (ilustrações). São Paulo, 1981; Tese (Livre Docência - FFLCHUSP - Faculdade de Filosofia, Letras e Ciências Humanas da Universidade de São Paulo). . (1983a) A cultura material no estudo das sociedades antigas. Revista de História, n. 115, Universidade de São Paulo, São Paulo, p. 103-17.

. (1998) As marcas da leitura histórica: arte grega nos textos antigos. Manuscrítica. Revista de crítica genética, São Paulo, n. 7, p. 69-82. (2002) A fotografia como documento. Robert Capa e o miliciano abatido da Espanha. Tempo, Rio de Janeiro, n. 14, p. 131-51. 
MENESES, U. T. B. \& SARIAN, H. (1973) Nouvelles peintures liturgiques de Délos. BCH. Suppl. I, p. 77-109.

MILNE, M. J. \& RICHTER, G. M. A. (1935) Shapes and names of the athenian vases. New York: The Metropolitan Museum of Art.

MINTO, A. (1960) I/ vaso François. Florença: Ed. Leo O. Olschki.

MOMIGLIANO, A. (2004) As raízes clássicas da historiografia moderna. Trad. Maria B. B. Florenzano. Bauru: EDUSC.

MORELAND, J. (2001) Archaeology and text. Avon: Duckworth.

NEER, R. T. (1998) Imitation, inscription, antilogic. Mètis, Paris, Athènes: Daedalus. vol. XIII, p. 17-38.

NEILS, J. (1992) Goddess and polis. The panathenaic festival in ancient Athens. New Jersey: Princeton University Press.

NICHOLSON, N. J. (2005) Aristocracy and athletics in archaic and classical Greece. Cambridge: Cambridge University Press.

NOBLE, J. V. (1960) The technique of attic vase-painting. AJA, 64, p. 306-18; pls. 84-88. (1965) The techniques of painted attic pottery. London, New York: Faber and Faber, The Metropolitan Museum of Art.

OLIVEIRA, M. K. de. (1992-1993) O verbal e o não-verbal. Revista USP. Dossiê Palavra/lmagem, (dez./jan./fev.), n. 16, p. 52-61.

OLMOS ROMERA, R. (1993) Catálogo de los vasos griegos del Museo Nacional de Bellas Artes de La Habana. Madrid : Ministerio de Cultura, Dirección General de Bellas Artes y Archivos, Instituto de Conservación y Restauración de Bienes Culturales.

PARIENTE, A. (1991) Les céramiques à partir de l'époque archaïque. In: PICARD, Ch. (org.) Guide de Delphe. Le Musée. Paris: Éditions E. de Boccard.

POLIAKOFF, M. B. (1987) Competition, violence, and culture. Combat sports in the ancient World. New Haven and London: Yale University Press.

POLLITT, J. J. (1996) Art and experience in classical Greece. Cambridge: Cambridge University Press, publicação original em 1972.

POTTIER, E. (1882) Amphore panathenaïque avec le nom de l'archonte Hégésias. BCH 6, p. 168-70.

POWELL, B. B. (1996) Art in the Hellenistic age. Cambridge: Cambridge University Press. . (1999) Homer and the origin of the Greek alphabet. Cambridge: Cambridge University Press.

POZZER, K. M. P. (2004) A palavra de argila e a memória histórica. In: KARNAL, L. \& FREITAS NETO, J. A. de (orgs.) A escrita da memória. Interpretação e análises documentais. São Paulo: Instituto Cultural Banco Santos. 
PREUCEL, R. W. \& HODDER, I. (1996) Contemporary Archaeology in theory: a reader. London: Blackwell.

PUIG, M.-C. V. (1998) A propos de quelques noms de ménades attiques inscrits. Mètis. Paris, Athènes: Daedalus. vol. XIII, p. 159-71.

RICE, P. M. (1987) Pottery analysis: a source book. Chicago, Londres: University of Chicago Press.

RICHTER, G. M. A. (1932) An aryballos by Nearchos. AJA, Vol. 36, № 3, p. 272-275 (Jul. Sep.).

ROCHA-PEREIRA, M. H. (1994) Estatuto social dos artistas gregos. RevMAE, São Paulo, n. 4, p. 95-101.

ROBERTSON, D. S. (1982) Uma breve história da arte grega. Trad.: Álvaro Cabral, Rio de Janeiro: Zahar Editores.

(1991a) A history of Greek art. 1. Cabridge, New York, Port Chester, Melbourne, Sydney: Cambridge University Press.

(1991b) A history of Greek art. 2. Cabridge, New York, Port Chester, Melbourne, Sydney: Cambridge University Press.

ROUGEMONT, G. (1996-1997) L'épigraphie grecque. Classica, São Paulo, v. 9/10, n. 9/10, p. 265-74.

SANTAELLA, L. (1992-1993) Palavra, imagem \& enigmas. Revista USP. Dossiê Palavra/Imagem, (dez./jan./fev.), n. 16, p. 36-51.

SARIAN, H. (1984) A cerâmica como documento arqueológico. Revista de Pré-História, n. 6, p. 196-204.

(1987) A expressão imagética do mito e da religião nos vasos gregos e de tradição grega. Cultura clássica em debate. Estudos de Arqueologia, História, Filosofia, Literatura e Lingüística greco-romana. Anais do I Congresso Nacional de Estudos Clássicos UFMG/CNPQ/SBEC, Vol. 6. p. 15-50.

. (1989) Civilization mycénienne; continuites et ruptures. In: TREUIL, R. et al. Les civilisations égéennes du Néolithique et de l'Age du bronze. Paris: Presses universitaires de France. p. 585-93.

. (1993) Poieîn-Graphein: o estatuto social do artesão-artista de vasos áticos. RevMA-

E, São Paulo, 3, p. 105-120.

(1996) Ceramografia e ceramologia: algumas reflexões. Cerâmicas Antigas da

Quinta da Boa Vista. Museu Nacional de Belas Artes (Catálogo de exposição, de 16 de novembro de 1995 a 16 de março de 1996) p. 31-38.

. (1998-1999a) A escrita alfabética grega: uma invenção da polis? A contribuição da arqueologia. Clássica, São Paulo. v. 11/12, n. 11/12, p. 159-177. 
. (1998-1999b) Corpus Vasorum Antiquorum (CVA). Clássica, São Paulo, v. 11/12, n. 11/12, p.349-363.

(1999a) Arqueologia da imagem: aspectos teóricos e metodológicos na iconografia de Héstia. RevMAE, São Paulo, n.3, p. 69-84.

. (1999b) Mito e imagística nos vasos gregos. Phoînix, Rio de Janeiro, n. 5, p. 163175.

(2005) Arqueologia da imagem. Expressões do mito e da religião na Antigüidade Clássica. Tese de Livre Docência em Arqueologia Clássica - MAE-USP.

SCHEFOLD, K. (1966) Myth and legend in early greek art. London: Thames and Hudson.

(1984) Texte et image à l'époque archaïque grecque. Texte et image. Actes du Col-

loque international de Chantilly (13 au 15 octobre 1982). Paris: Les Belles Lettres, p. 4152.

SCHNAPP, A. (1976) A Arqueologia. In: LE GOFF, J. (org.) História: novas abordagens.

Trad.: Henrique Mesquita. Rio de Janeiro: F. Alves, p. 1-20.

SCHIFFER, M. B. (1972) Archaeological context and systemic context. American Antiquity, vol. $37, \mathrm{n}^{\circ} 1$, p. 156-65.

. (1976) Behavorial Archaeology. New York, London, San Francisco: Academic Press.

SEEBERG, A. (1994) Epoiesen, Egrapsen, and the Organization of the Vase Trade. JHS, vol. 114, p. 162-164.

SELLET, F. (s/d) Chaine operatoire: the concept and its applications. Lithic technology, vol. 18 , n. 1-2, p. 106-12.

SHANKS, M. (1996) Style and the decoration of a perfume jar from an archaic greek city state.In: HODDER, I. \& PREUCEL, R. W. Contemporary Archaeology in theory. A reader. London: Blackwell, p. 364-93.

. (2004) Art and early Greek state. An interpretative Archaeology. Cambridge: Cambridge University Press.

SHAPIRO, H. A. (1987) Kalos inscription with patronymic. ZPE, 68, p. 107-18.

(1995) Literacy and social status of archaic attic vase-painters. RevMAE, São Paulo, 5, p. 211-22.

SHEPARD, A. O. (1971) Ceramics for the archaeologist. Carmegie Inst. Of Washington.

SIEBERT, G. (1981) Méthodologie iconographique. Actes du Colloque de Strasbourg, 2728 avril 1979. Groupe de recheche d'Histoire Romaine de I'Université des Sciences Humaines de Strasbourg. Strasbourg, p. 5-9.

SMALL, J. P. (2003) The parallel worlds of classical art and text. Cambridge: Cambridge University Press.

SNODGRASS, A. (1987) An Archaeology of Greece. The present state and the future of a discipline. Berkley: UCLA Press. 
. (2001) The uses of writing on early greek painted pottery. In: RUTTER, N. K. \& SPARKES, B. A. Word and image in ancient Greece. p. 22-34. . (2004) Homero e os artistas: texto e pintura na arte grega antiga. (trad.: Luiz Alberto Machado Cabral, Ordep Trindade Serra), São Paulo: Odysseus Editora.

SOLOVYOV, S. L. (1999) Ancient Berezan. The architecture, history and culture of the first Greek colony in the Northen Balck Sea. Leiden, Boston, Köln: Brill.

SPARKES, B. A. (1996) The red and the black: studies in Greek pottery. London, New York: Routhledge.

STRAWCZYNSKI, N. (1998) L'inscription comme élément de composition. Mètis, Paris, Athènes: Daedalus. vol. XIII, p. 107-21.

STUBBINGS, F. H. (1973). Prehistoric Greece. New York: John Day Co.

TEXTE \& IMAGE. (1984) Actes du Colloque Internacional de Chantilly (13-15 de outubro de 1982). Paris, Les Belles Lettres.

THOMAS, R. (2005) Letramento e oralidade na Grécia antiga. Trad.: Raul Fiker, São Paulo: Odysseus.

THREATTE, L. (1980) The grammar of attic inscriptions I. Phonology. Berlim, New York: Walter de Gruyter.

TORRALVO, A. C. (1996-1997) Competições e festivais na Grécia pré-helenica: as evidências minóico-micênicas. Classica, São Paulo, v. 9/10, n. 9/10, p. 34-44.

TRACY, S. V. (1991) The panathenaic festival and games: an epigraphical inquiry. Nikephoros, 4, p. 133-53.

TREUIL, R. et al. (1989) Les Civilisations égéennes du Néolithique et de l'Age du bronze. Paris: Presses universitaires de France.

TRIGGER, B. G. (2004) Uma história do pensamento arqueológico. Trad.: O. T. Serra, São Paulo: Odysseus.

VALAVANIS, P. (1986) Les amphores panathénaïques et le commerce athénien de l'huile. BCH, Suppl XIII, p. 453-60. (1998) Panathenäische amphoren auf monumenten spätklassischer, hellenisticher um römischer zeit. In: BENTZ, M. \& ESCHBACH, N. (orgs.) Panathenaïka. Symposion zu den Panathenäischen Presisamphoren Rauischholzhausen 25.11. - 29.11.1998. p. 165-74. VANDENABEELE, F. \& OLIVIER, J.-P. (1979) Les idéogrammes archéologiques du Linéaire $B$. Athènes: École Française d'Athènes.

VANDENABEELE, F. (1974) Les idéogrammes de vases sur les tablettes em Linéaire A de Haghia Traiada et Phaistos. BCH, 98 1974, p. 5-21.

VERNANT, J-P. (1989) As origens do pensamento grego. Trad.: I. B. B. da Fonseca. $6^{\text {a }}$ edição, Rio de Janeiro: Bertand Brasil. 
. (1990) Mito e pensamento entre os gregos: estudos de psicologia histórica. Trad.: H. Sarian, Rio de Janeiro: Paz e Terra.

VERNANT, J-P. \& VIDAL-NAQUET, P. (1999) Mito e tragédia na Grécia antiga I e II. Trad.: Anna L. A. de A. Prado et al, São Paulo: Perspectiva, Coleção estudos: 163.

VIALOU, D. (2004) Chaïne opératoire. In: VIALOU, D. (org.) La préhistoire - Histoire et Dicionnaire. Paris: Éditions Robert Laffout S. A. p. 422.

VIDAL-NAQUET, P. (2001) El mundo de Homero. Trad.: Daniel Zadunaisky, Buenos Aires: Fondo de Cultura Econômica de Argentina S. A.

. (2002) Os gregos, os historiadores, a democracia: o grande desvio. Trad.: J. B. Neto, São Paulo: Cia. das Letras.

VOVELLE, M. (1990) A História e a longa duração. In: LE GOFF, J. (org.) História nova. $1^{a}$ ed., Trad.: E. Brandão, São Paulo: Ed. Martins Fontes.

WACHTER, R. (1991) The inscriptions on the François vase. Museu Helveticum, 48, p. 86113.

WAGNER, C. (2000) The potters and Athena. Dedications on the athenian acropolis. In: PRAG, A. J. N. W. \& TSETSKHLADZE, G. R. (eds.). Periplous. Papers on classical art and archaeology presented to sir John Boardman. London: Thames \& Hudson Ltd, p. 383-7.

WATROUS, L. V. (1992) Kommos. Princeton, New Jersey: Princeton University Press.

WHOODFORD, S. (1997) An introduction to Greek art. Londres: Duckworth.

WHOODHEAD, A. G. (1992) The study of greek inscriptions. $2^{\mathrm{a}}$ ed., London: Bristol Classical Press.

WILLIAMS, D. (1995) Potter, painter and purchaser. In: VERBANCK-PIÉRARD, A. \& VIVIERS, D. Culture et cité. L'avènement d'Athènes, a l'époque archaïque. Actes du Colloque international organisé à I'Université libre de Bruxelles du 25 au 27 avril 1991 par I'instituti des Hautes Études de Belgique et Fondation Archéologique de I'U.L.B. Bruxelles, Paris: De Boccard, p. 139-60.

YOUNG, R. S. (1939) Late geometric graves and a seventh century well in the Agora. Hesperia, Suppl. 2. 


\section{Sites da Internet}

Site Christie's Antiquities (consultado em outubro de /2006)

http://www.thecityreview.com/

Site The Artchive (consultado em agosto de 2005)

http://artchive.com/

Site Beazley Archive Home Page (consultado em agosto de 2005)

http://www.beazley.ox.ac.uk

Site Corpus Vasorum Antiquorum (consultado em agosto de 2006)

http://www.cvaonline.org

Site Giornale Nuovo (consultado em abril de 2006)

http://www.spamula.net/blog/2005/08/

Site Goettingen University, Alemanha (consultado em abril de 2006)

http://webdoc.sub.gwdg.de/ebook/aw/2004/kinderbuch/html/Themen/02_Abecedarien/i ndex.html

Site Perseus Tufts (consultado em outubro de 2006)

http://www.perseus.tufts.edu/

Site Roma Sotterranea (consultado em setembro de 2005)

http://www.underome.com/

Site Universidade de Siracusa - Maxwell School (consultado em janeiro de 2006)

http://www.maxwell.syr.edu/hist/

Site University of Melbourne, Austrália (consultado em 30/10/2004)

http://vm.arts.unimelb.edu.au/tours/Gvases/muvindex/

Site UNISA - University of South Africa (consultado em outubro de 2005)

http://www.unisa.ac.za/default.asp?Cmd=ViewContent\&ContentID=15932

Site da University Wisconsin (consultado em setembro de 2004)

http://www.uwm.edu/Course/mythology/1100/twar1.htm 